GEOLOGICAL SURVEY OF DENMARK AND GREENLAND BULLETIN 39

Lithostratigraphy, geology and geochemistry of the volcanic rocks of the Vaigat Formation on Disko and Nuussuaq, Paleocene of West Greenland

Asger Ken Pedersen, Lotte Melchior Larsen \& Gunver Krarup Pedersen

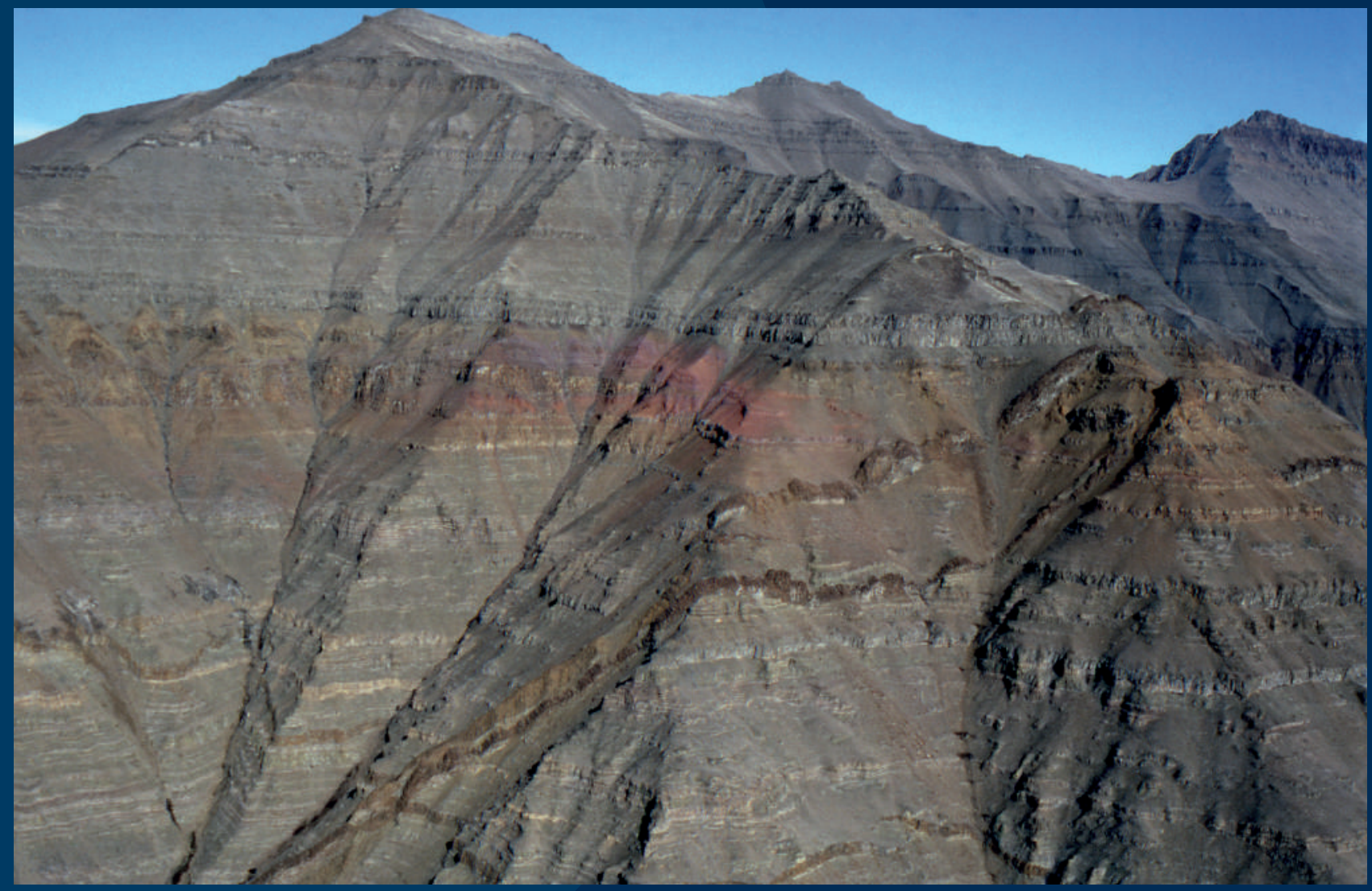





\section{Lithostratigraphy, geology and geochemistry of the volcanic rocks of the Vaigat Formation on Disko and Nuussuaq, Paleocene of West Greenland}

Asger Ken Pedersen, Lotte Melchior Larsen and Gunver Krarup Pedersen 


\section{Geological Survey of Denmark and Greenland Bulletin 39}

\section{Keywords}

Vaigat Formation, picrites, lithostratigraphy, crustal contamination, native iron, graphite, Nuussuaq Basin, Paleocene.

\section{Cover illustration}

Typical landscape formed in the Vaigat Formation. The volcanic succession consists mainly of numerous thin, grey, crumbling, olivine-rich (picritic) lava flows. The horizon of brown flows in the middle part of the succession is the basaltic andesites of the Kûgánguaq Member that were formed by contamination with sediments of the Nuussuaq Group in high-level magma chambers in the crust. One of the eruption sites for the Kûgánguaq Member is seen as a red area in the centre of the picture; this is the remains of a small volcano with brick-red crater deposits of oxidised, basaltic welded tuffs. Dark brown younger basalt dykes cut the whole succession. The contamination process removed nickel and precious metals from the magma; these elements may have accumulated in valuable deposits at depth, and the subsurface in the area has been explored by mining companies for deposits of these metals. East side of the Kuugannguaq valley, northern Disko.

\section{Frontispiece: facing page}

Helicopter refuelling at a coastal field camp at Nuuk Qiterleq, south coast of Nuussuaq. In the background lava flows and hyaloclastites of the Vaigat Formation (geological interpretation in Fig. 129). In the middle ground chaotic remains of one of the frequent landslides in the area. In the foreground to the right, an ice lens indicates the presence of a homothermal spring. The field work was based on transport by boat and helicopter. In addition, geological reconnaissance and photography by helicopter have been instrumental in the mapping of the mountainous terrain on Disko and Nuussuaq.

Chief editor of this series: Adam A. Garde

Editorial board of this series: John A. Korstgård, Department of Geoscience, Aarhus University; Minik Rosing, Geological Museum, University of Copenhagen; Finn Surlyk, Department of Geosciences and Natural Resource Management, University of Copenhagen Scientific editor: Adam A. Garde

Editorial secretary: Jane Holst

Referees: C.H. Emeleus and R. Wilson

Illustrations: Jette Halskov, Willy L. Weng, Susanne Rømer and Benny M. Schark.

Layout and graphic production: Henrik Klinge Pedersen and Carsten E. Thuesen

Printer: Rosendahls-Schultz Grafisk A/S, Albertslund, Denmark

Manuscript received: 17 January 2017

Final version approved: 21 September 2017

Printed: December 2017

ISSN (print) 1604-8156

ISSN (online) 1904-4666

ISBN (print) 978-87-7871-482-4

ISBN (online) 978-87-7871-483-1

\section{Citation of the name of this series}

It is recommended that the name of this series is cited in full, viz. Geological Survey of Denmark and Greenland Bulletin. If abbreviation of this volume is necessary, the following form is suggested: Geol. Surv. Den. Green. Bull. 39, 244 pp.

\section{Available from}

Geological Survey of Denmark and Greenland (GEUS)

Øster Voldgade 10, DK-1350 Copenhagen K, Denmark

Phone: +45381420 00, fax: +45381420 50, e-mail: geus@geus.dk

and at www.geus.dk/publications/bull (open access)

(C) De Nationale Geologiske Undersøgelser for Danmark og Grønland (GEUS), 2017

For the full text of the GEUS copyright clause, please refer to www.geus.dk/publications/bull 


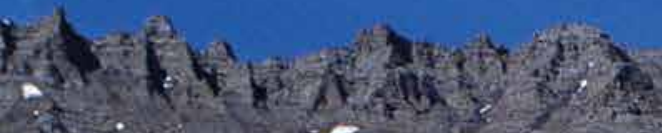

$x^{2}+y^{2}$ th

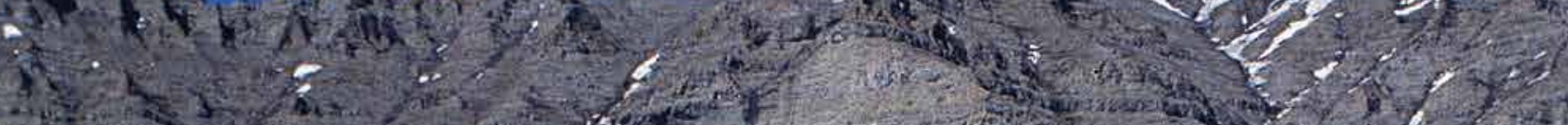

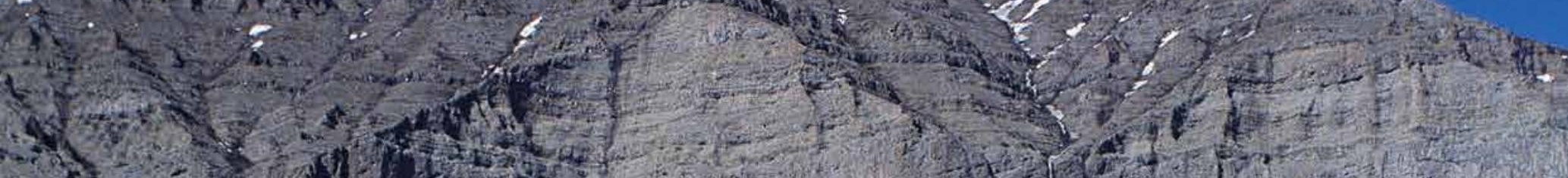

and

$(x+1)=1$

2,140 in in

$y^{3} \cdot 5$

$\rightarrow$

1.

${ }_{1} \operatorname{lit}^{2}$
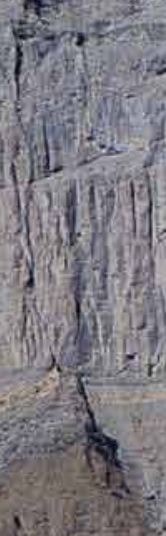

$x y$
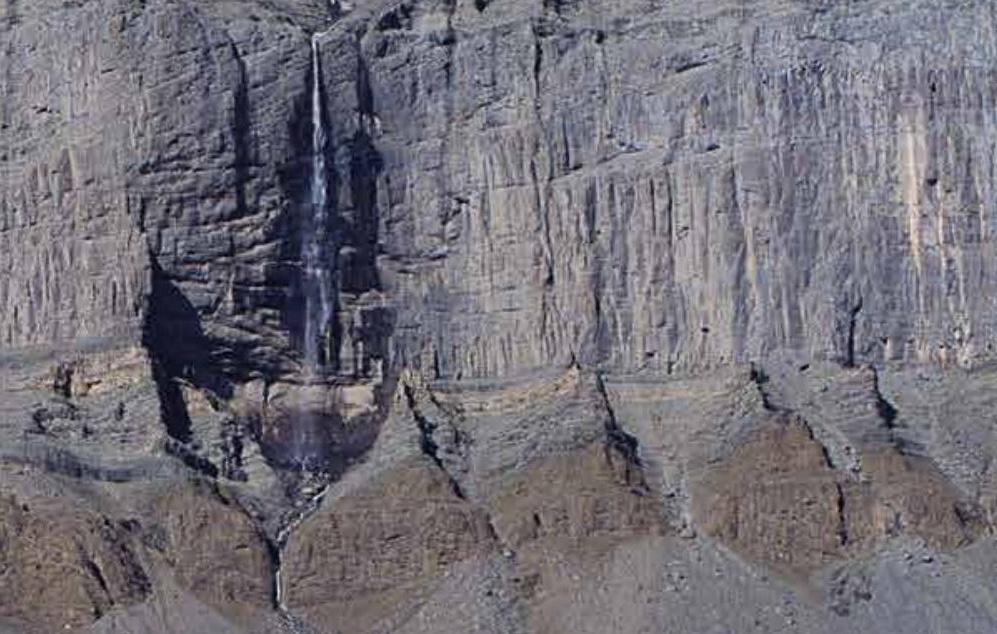

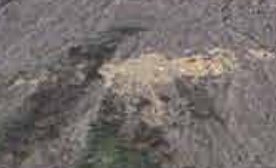

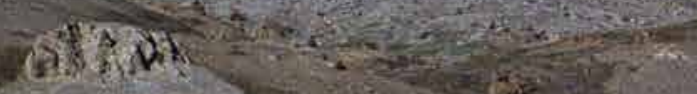

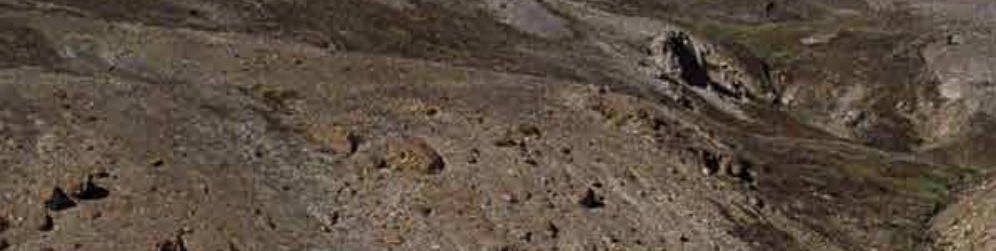

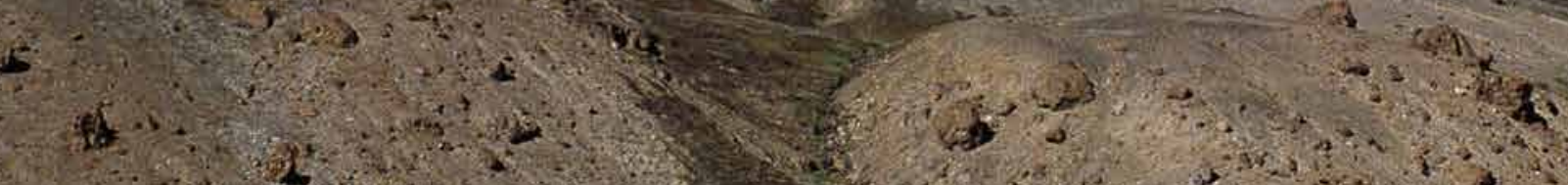

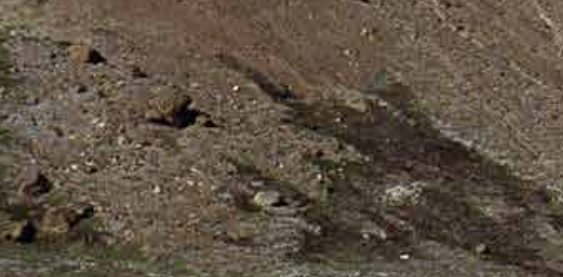

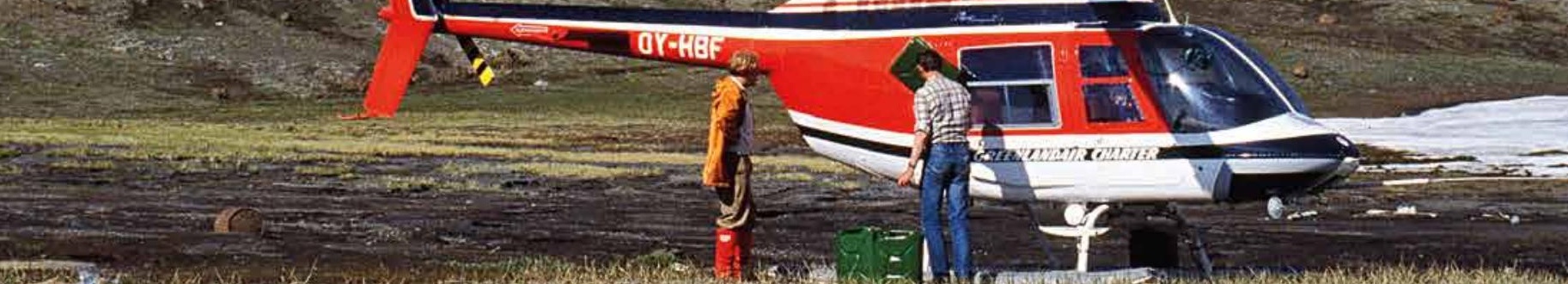

洒

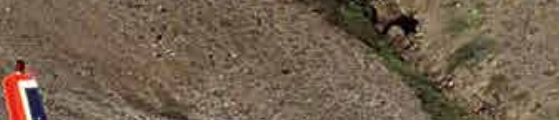

$\left.\rightarrow\right|_{1} ^{2}+3$

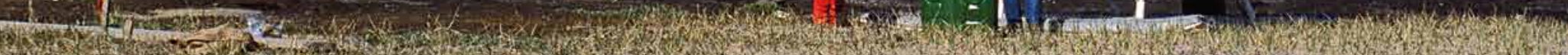

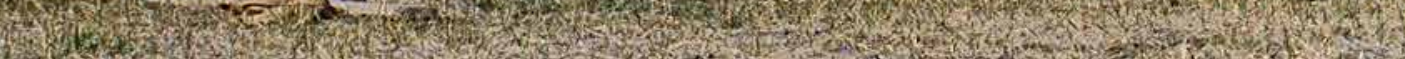

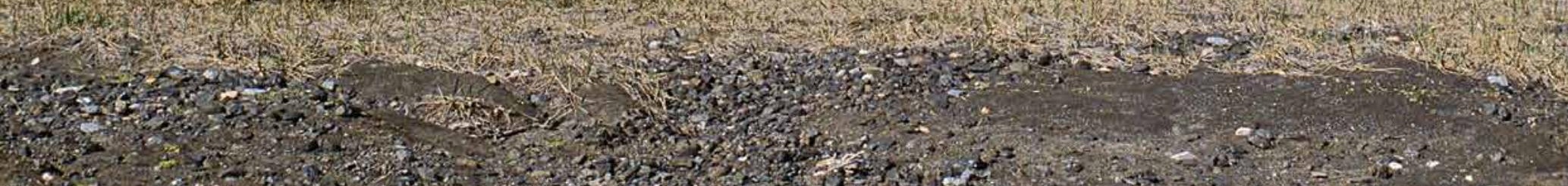




\section{Contents}

Abstract

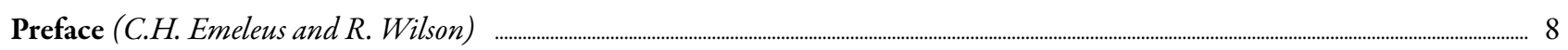

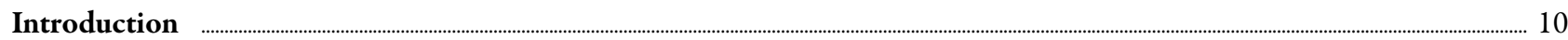

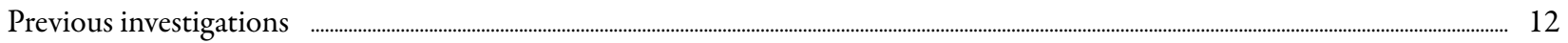

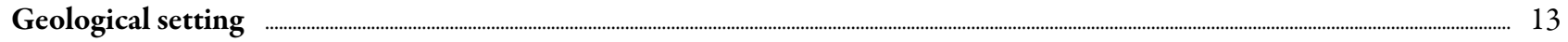

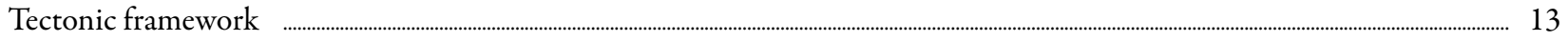

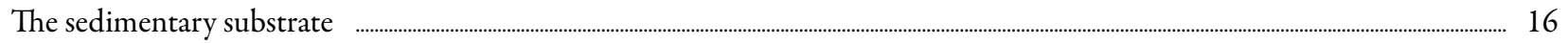

Deposition of the volcanic succession and equivalent sediments $\quad$........................................................................................................................................ 16

Palaeomagnetism, timing and duration of the volcanism

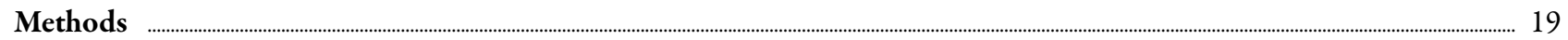

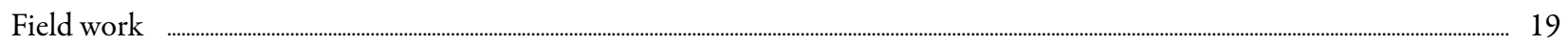

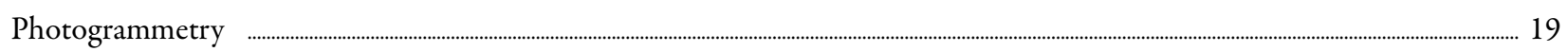

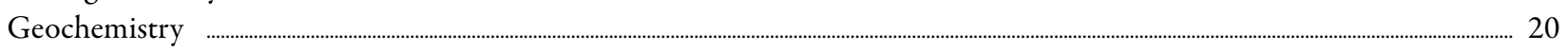

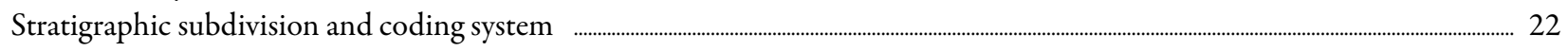

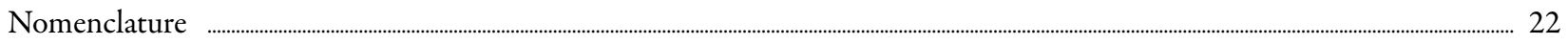

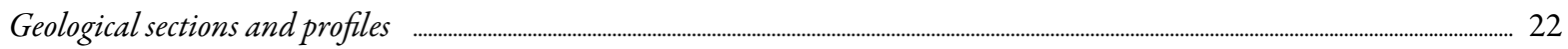

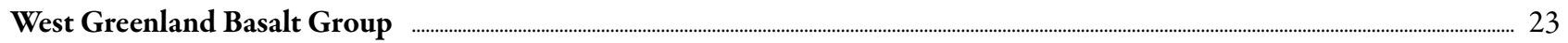

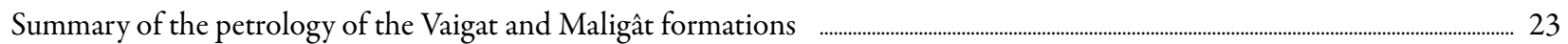

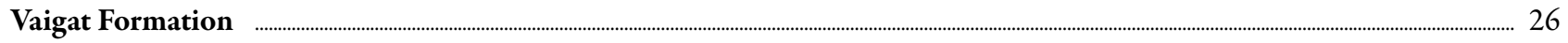

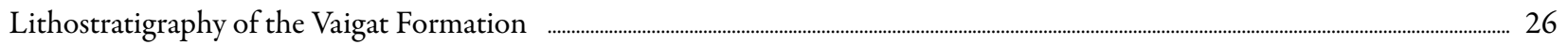

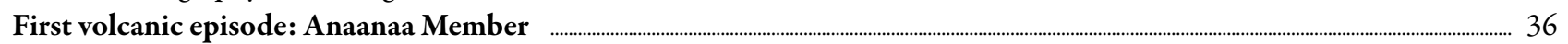

Summary of the main features of the Anaanaa Member ......................................................................................................................................... 36

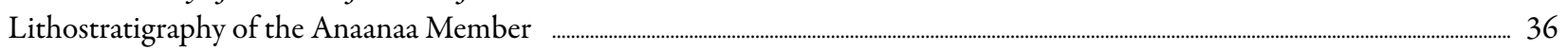

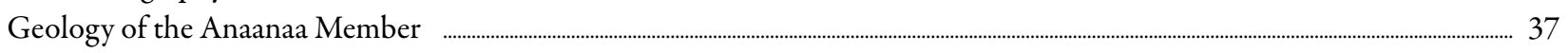

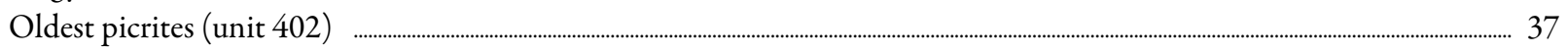

Ti-poor picrites (unit 403)

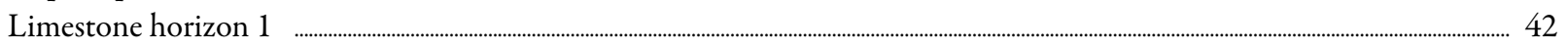

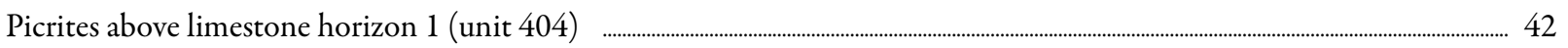

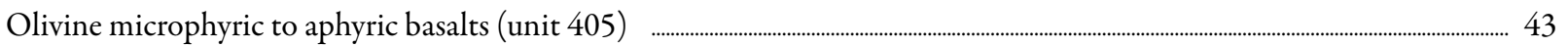

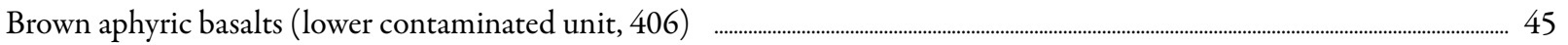

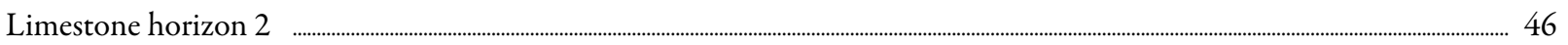

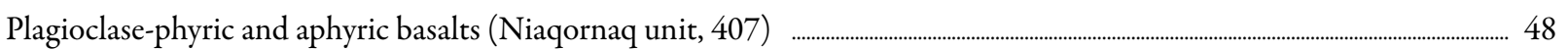

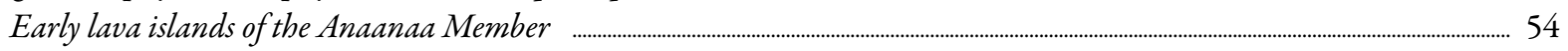

Brown aphyric basalts (Marraat unit or upper contaminated unit, 408) ................................................................................................................. 56

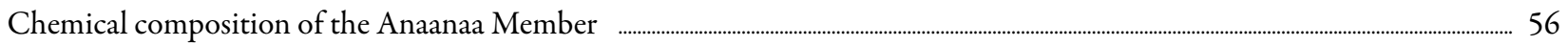

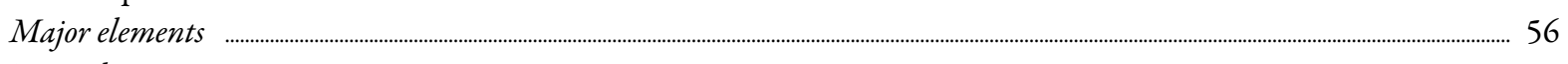

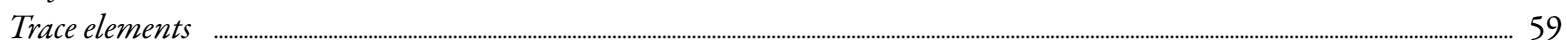

Second volcanic episode: Naujánguit Member and associated members $\quad$.......................................................................................................... 64

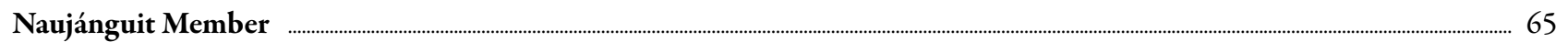

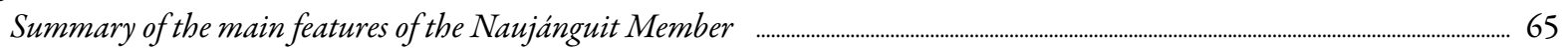

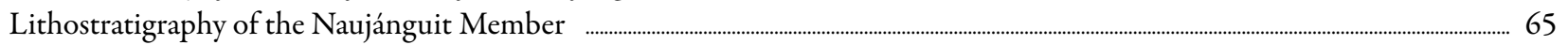

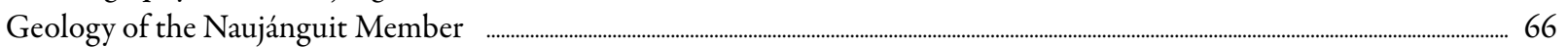

Uncontaminated Naujánguit Member below the Nuusap Qaqqarsua Member (unit 409) ...................................................................... 66

Uncontaminated Naujánguit Member between Nuusap Qaqqarsua Mb and Nuuk Killeq Mb (unit 413) ............................... 69

Uncontaminated Naujánguit Member between Nuuk Killeq Member and Asuk Member (unit 417) ........................................ 73

Uncontaminated Naujánguit Member above the Asuk Member (unit 423) ................................................................................................ 78

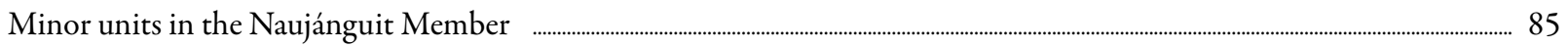


Henderson unit (unit 411)

Tunorsuaq a: Enriched contaminated basalts below the Saviaqqat level (unit 416) ..................................................................... 85

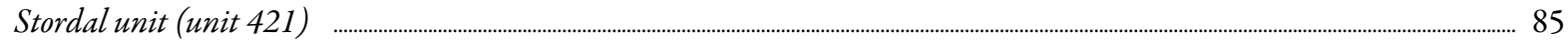

Tunorsuaq b: Enriched contaminated basalts above the Saviaqqat level (unit 425) .............................................................................. 88

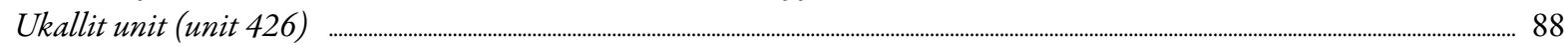

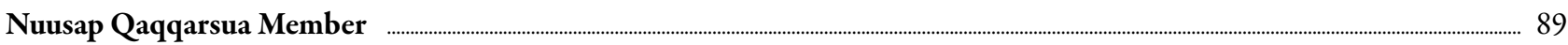

Summary of the main features of the Nuusap Qaqqarsua Member .............................................................................................................. 89

Lithostratigraphy of the Nuusap Qaqqarsua Member ……………………………....................................................................................................................... 89

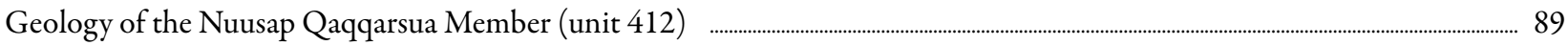

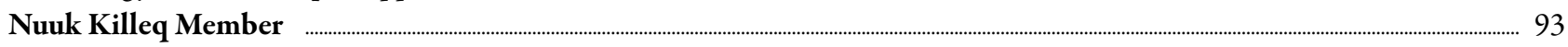

Summary of the main features of the Nuuk Killeq Member ............................................................................................................................. 93

Lithostratigraphy of the Nuuk Killeq Member ................................................................................................................................................................................ 93

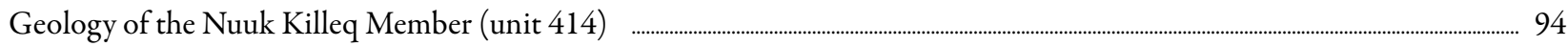

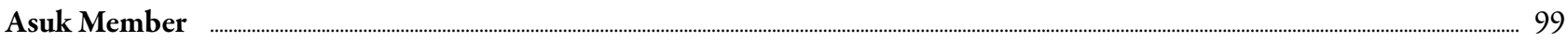

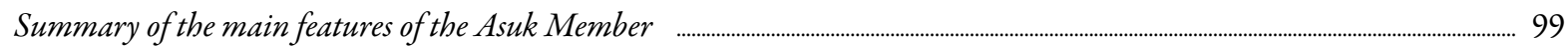

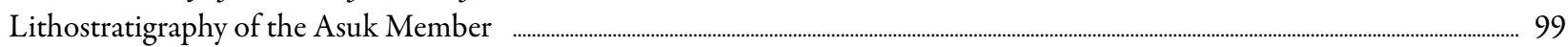

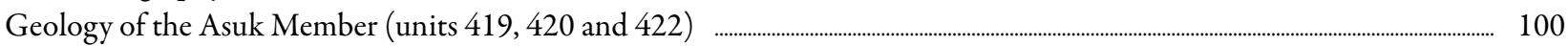

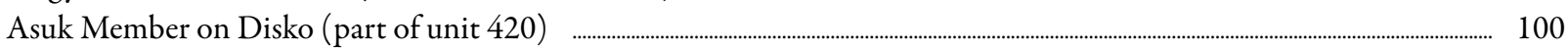

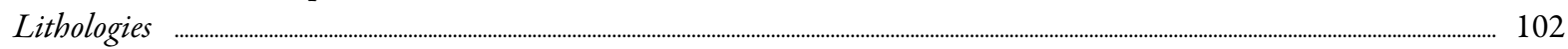

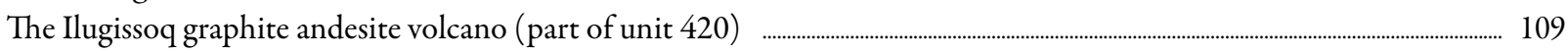

Graphite andesite tuffs in the Abraham Member in the Agatdalen area, central Nuussuaq $\quad$............................................................. 115

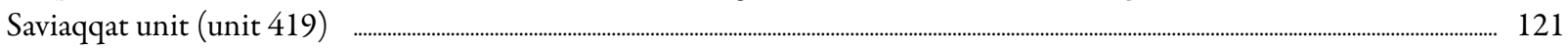

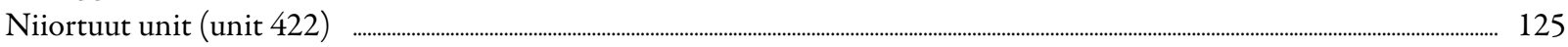

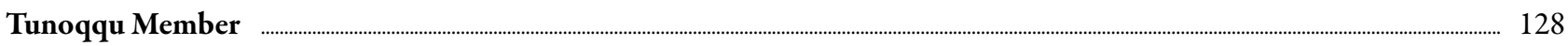

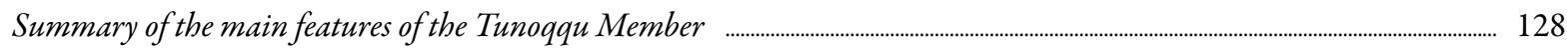

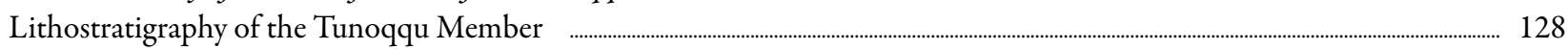

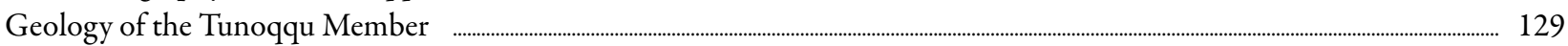

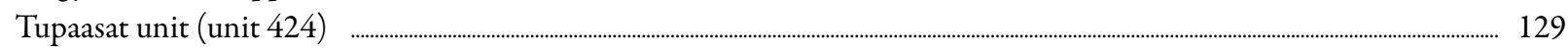

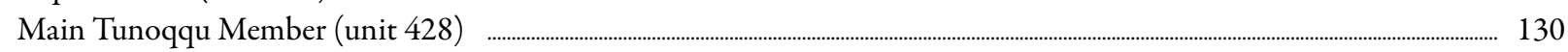

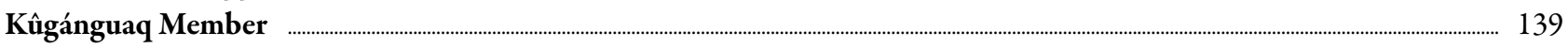

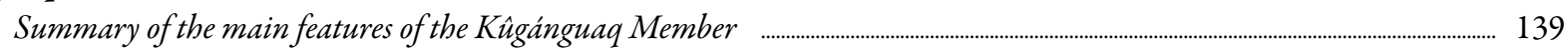

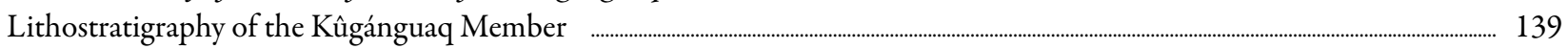

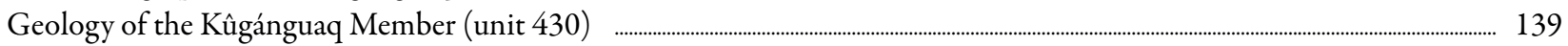

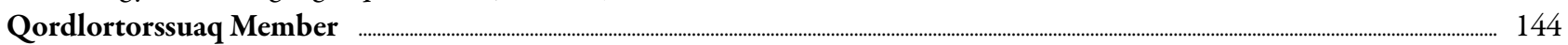

Summary of the main features of the Qordlortorssuaq Member ………................................................................................................ 144

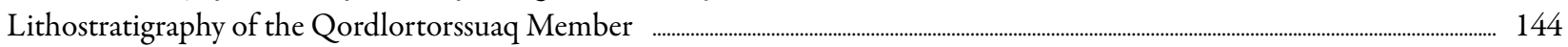

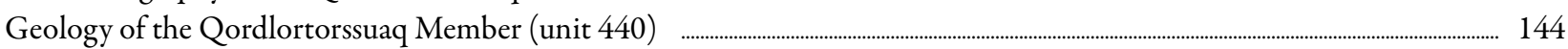

Chemical composition of the members of the second volcanic episode: Naujánguit Mb and associated members ............ 149 Summary of the main features of the geochemistry of the members of the second volcanic episode .............................................. 149

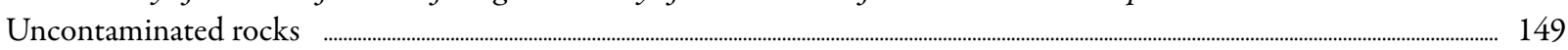

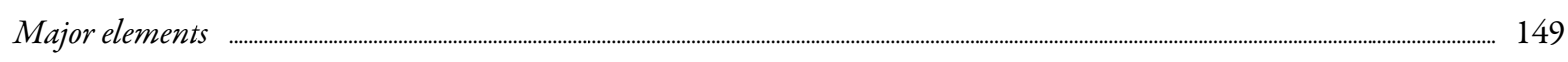

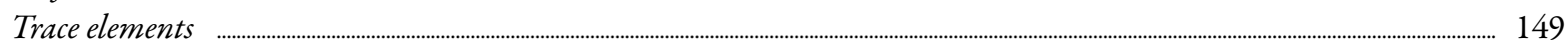

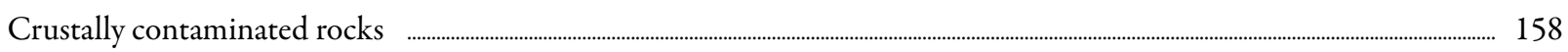

Henderson unit, Nuusap Qaqqarsua Member and Nuuk Killeq Member ................................................................................. 158

Asuk Member ......................................................................................................................................................................................................................... 162

Carbon, sulfur and native iron in the Asuk Member as evidence for the nature and location of the high-level magma

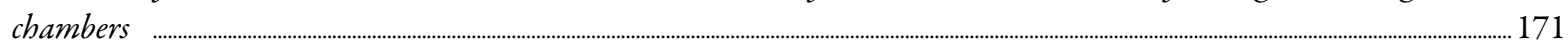

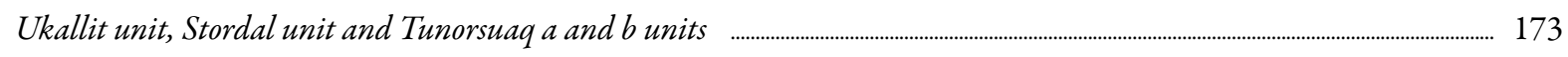

Kûgánguaq Member and Tunoqqu Member ............................................................................................................................................................ 173 
Summary of the main features of the Ordlingassoq Member ....................................................................................... 179

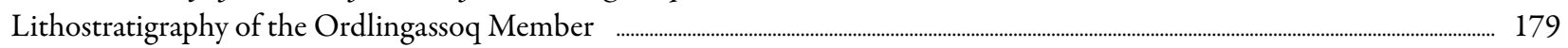

Geology of the Ordlingassoq Member .......................................................................................................................................... 181

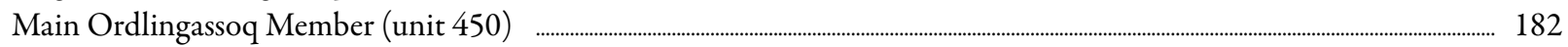

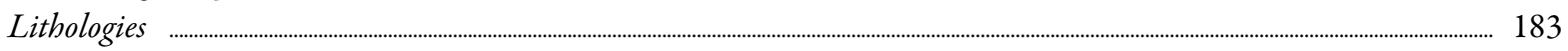

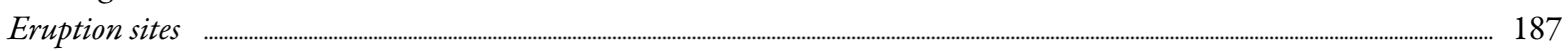

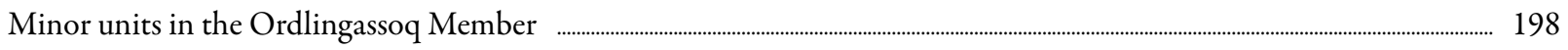

Crustally contaminated basaltic andesites and picrites in Stordal on Disko (unit 451) ......................................................... 199

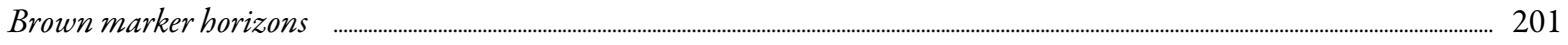

Volcaniclastic and quartzo-feldspathic sediments south of Qaarsut ............................................................................................. 206

Chemical composition of the Ordlingassoq Member …………............................................................................................................ 208

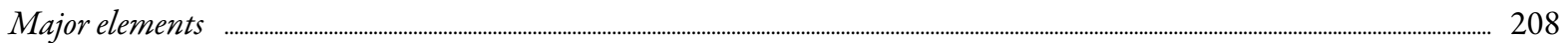

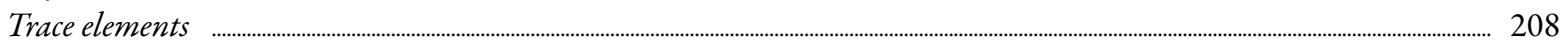

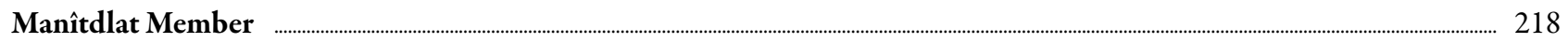

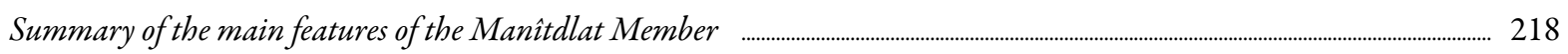

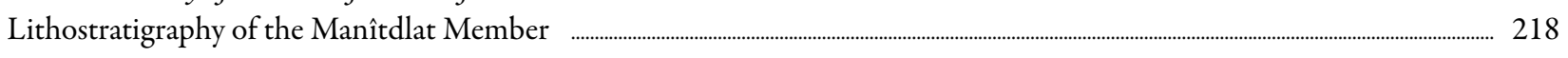

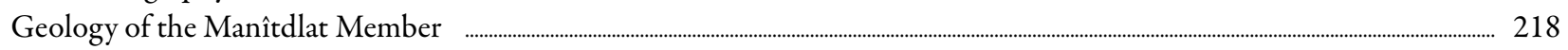

Alkaline picrites in the lower part of Ordlingassoq Member on Disko (unit 460, type 0) ........................................................ 219

Manîtdlat Member (units 461, 462, 463, 465; types 1a, 1b, 2, 3) .............................................................................................. 219

Units of the Manitdlat Member ....................................................................................................................................................................... 221

Non-alkaline rocks between the main alkaline succession and unit 465 (unit 464) ...................................................................... 224

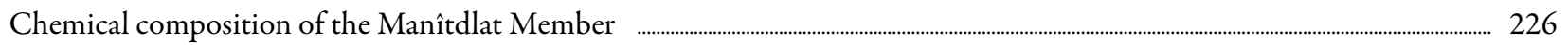

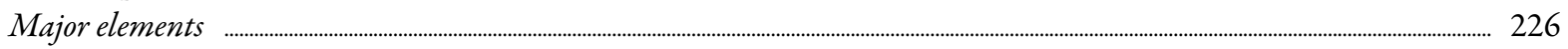

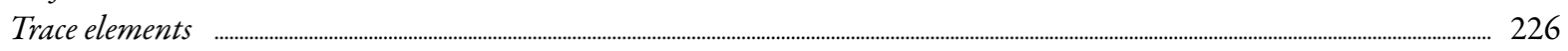

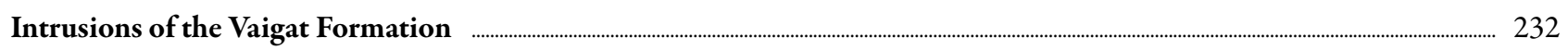

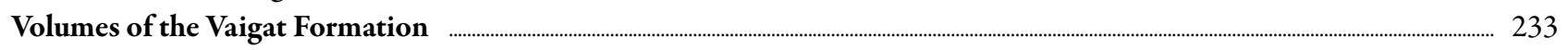

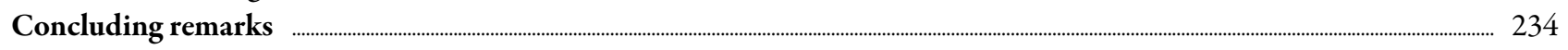

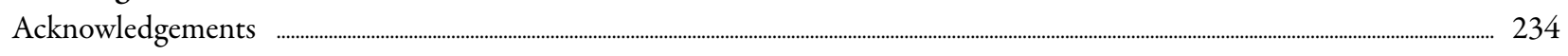

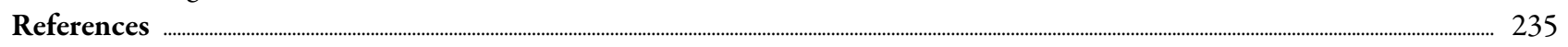

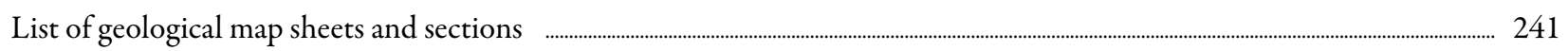

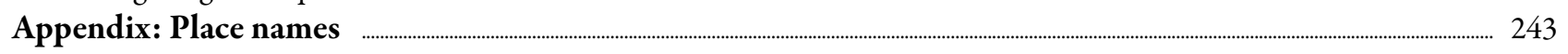




\section{Abstract}

Pedersen, A.K., Larsen, L.M. \& Pedersen, G.K. 2017: Lithostratigraphy, geology and geochemistry of the volcanic rocks of the Vaigat Formation on Disko and Nuussuaq, Paleocene of West Greenland. Geological Survey of Denmark and Greenland Bulletin 39, 244 pp.

The Paleocene volcanic rocks in the Nuussuaq Basin on Disko and Nuussuaq comprise the Vaigat Formation (c. 62-61 $\mathrm{Ma})$ and the Maligât Formation $(c .60 \mathrm{Ma})$. The Vaigat Formation in this area is $0-1600 \mathrm{~m}$ thick and is dominated by olivine-rich picrites. The formation was deposited during three volcanic episodes and is divided into 10 formally defined members and about 20 informal units. The first episode gave rise to the Anaanaa Member. The second episode gave rise to the Naujánguit Member which is intercalated with the minor, crustally contaminated Nuusap Qaqqarsua, Nuuk Killeq, Asuk, Tunoqqu and Kûgánguaq members and the uncontaminated Qordlortorssuaq Member. The third episode gave rise to the Ordlingassoq Member and the minor alkaline Manîtdlat Member. Contemporaneous sediments deposited during the first two episodes are the marine Eqalulik Formation, and during the third episode the nonmarine Atanikerluk Formation. During the second episode, the polarity of the geomagnetic field changed from normal (Chron C27n) via a transition zone to reversed (C26r).

The deposits of the first volcanic episode are situated on western Nuussuaq. During the second and third episodes, the volcanism gradually spread eastwards and southwards so that the Vaigat Formation now forms a domed structure, thickest in the north, thinning out on northern Disko and reaching eastwards to the high gneiss country on central Nuussuaq. The earliest eruptions took place on the sea floor and quickly built up a subaerial lava plateau. All three episodes gave rise to complicated facies changes between subaqueous and subaerial eruption products caused by the eastmoving volcanism, subsidence, volcanic aggradation and blockage of the sea connection against the elevated eastern gneiss country. Eruption sites are widespread for all three volcanic episodes. Within certain time periods, a number of contemporaneous high-level magma reservoirs developed within sediments of the Nuussuaq Group, and the crustally contaminated members formed in these reservoirs by reaction between $\mathrm{Mg}$-rich magmas and sediments.

The uncontaminated rocks in the Vaigat Formation are picrites with $12-31 \mathrm{wt} \% \mathrm{MgO}$ and subordinate basalts with 7-12 wt\% MgO. The crustally contaminated rocks range from silicic picrites with $12-16 \mathrm{wt} \% \mathrm{MgO}$ (Nuusap Qaqqarsua Member) to native-iron-bearing magnesian andesites with 6-10 wt $\% \mathrm{MgO}$ and up to $62 \mathrm{wt} \% \mathrm{SiO}_{2}$ (Asuk Member). The Asuk Member includes unique, strongly reduced rock types with native iron, graphite and sulfide. The contaminated units have individually distinct compositions, indicating individually different contamination events. The alkaline Manîtdlat Member contains an enriched lithospheric component.

Present-day seeps of migrated oil are widespread in the oldest part of the volcanic succession on western Nuussuaq. Some of the contaminated magmas in the Asuk and Kûgánguaq members have fractionated sulfides with $\mathrm{Cu}$ and $\mathrm{Ni}$ and have been explored for nickel and platinum-group elements.

A.K.P., Natural History Museum of Denmark, University of Copenhagen, Øster Voldgade 5-7, DK-1350 Copenhagen K, Denmark, and Geological Survey of Denmark and Greenland, Øster Voldgade 10,DK-1350 Copenhagen K, Denmark. E-mail: akp@snm.ku.dk

L.M.L., Geological Survey of Denmark and Greenland, Øster Voldgade 10, DK-1350 Copenhagen K, Denmark. E-mail: Iml@geus.dk

G.K.P., Geological Survey of Denmark and Greenland, Øster Voldgade 10,DK-1350 Copenhagen K, Denmark. E-mail: gkp@geus.dk 


\section{Preface}

\section{C.H. Emeleus and R. Wilson}

The island of Disko and the Nuussuaq peninsula in West Greenland comprise a succession of Paleocene lavas and hyaloclastite deposits overlying hydrocarbon-bearing Mesozoic sedimentary rocks and Precambrian gneisses. The topography is extreme and exposures are magnificent, especially in coastal sections and glaciated valleys where there is upwards of $1500 \mathrm{~m}$ of relief: they comprise some of the best displayed flood volcanic areas on Earth. This bulletin is the first of two volumes on these volcanic rocks published by the Geological Survey of Denmark and Greenland (GEUS) and is concerned with the lower portion of the volcanic succession, the Vaigat Formation. The descriptions are based on investigations by the authors over many years, using traditional field mapping, interpretation of vertical and oblique photographs, geophysical techniques and borehole data, supported by petrological and geochemical studies and radiometric age determinations. This work builds on earlier investigations dating back to the early years of the 19 th century: these are fully referenced.

The excellent exposure has allowed the architecture of the volcanic rocks to be determined with a degree of certainty rarely attained. Subaerial lava flows are intimately associated with, and pass into, subaqueous hyaloclastites, and numerous eruption sites have been recognised with accompanying feeder-dyke systems. Unusual geochemical features include the abundance of lavas and hyaloclastites very rich in magnesian olivine, indicative of high magma temperatures, and the presence of highly reduced lavas containing native iron, the result of reaction with and assimilation of Cretaceous shales.

This bulletin is notable in two ways. Firstly it provides a near-unique account of the development of a volcanic succession from initially largely submarine eruptions and deposits covering marine sediments, through to predominantly subaerial flows, lapping onto the edge of the adjoining continental crust. Secondly, for the clarity of the relationships between sedimentary rocks and later volcanic rocks on Disko-Nuussuaq, providing valuable information for the interpretation of other areas where submarine sedimentary hydrocarbon reservoirs are obscured by overlying volcanic rocks. The three-dimensional picture of the evolution of the volcanic succession that emerges is convincing and remarkable. Together with the accompanying volume on the Maligât Formation, this bulletin will be of considerable interest to both volcanologists and economic geologists. 

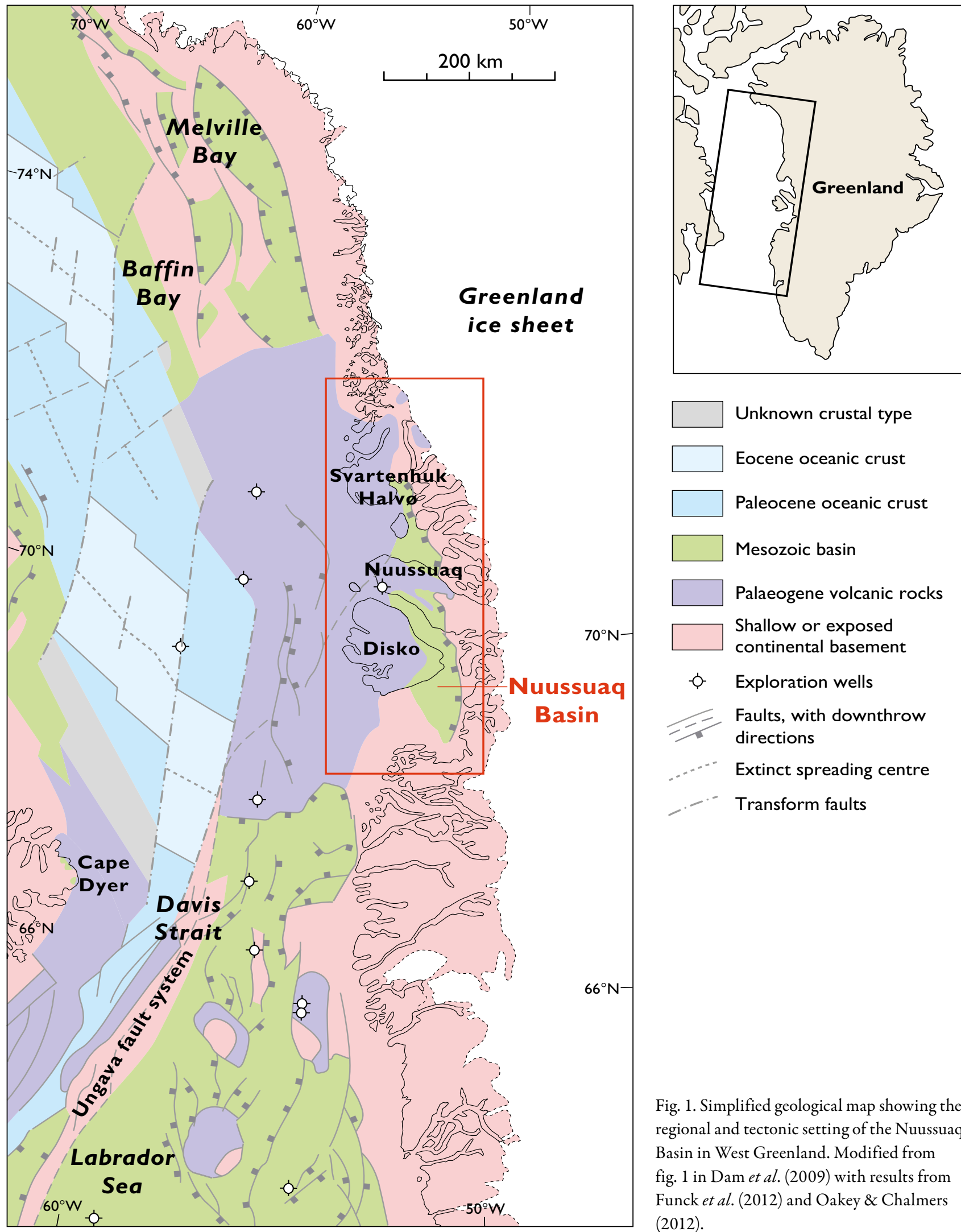

Unknown crustal type

Eocene oceanic crust

Paleocene oceanic crust

Mesozoic basin

Palaeogene volcanic rocks

Shallow or exposed continental basement

- - Exploration wells

Faults, with downthrow directions

..... Extinct spreading centre

,..- Transform faults

Fig. 1. Simplified geological map showing the regional and tectonic setting of the Nuussuaq Basin in West Greenland. Modified from fig. 1 in Dam et al. (2009) with results from Funck et al. (2012) and Oakey \& Chalmers (2012). 


\section{Introduction}

The Nuussuaq Basin is one of a series of linked basins that extend along the whole western continental margin of Greenland with a basin fill comprising Mesozoic to Tertiary sediments and Tertiary volcanic rocks (Chalmers \& Pulvertaft 2001; Fig. 1). The basins are partly situated in the offshore areas, but between $69^{\circ}$ and $73^{\circ} \mathrm{N}$ the rocks of the Nuussuaq Basin are exposed on Disko (Qeqertarsuaq), Nuussuaq, Ubekendt Ejland (Illorsuit) and Svartenhuk Halvø (Sigguup Nunaa; Fig. 2). The rocks have been studied since the mid-1850s because of occurrences of well-preserved fossils and coal, mainly in the sediments, and of native iron, and in later years discovery of hydrocarbons, in the volcanic rocks. The lithostratigraphy of the sediments in the Nuussuaq Ba$\sin$ (the Nuussuaq Group) was defined and described in Geological Survey of Denmark and Greenland Bulletin 19 by Dam et al. (2009).

The present work on the volcanic rocks may be considered a sequel to the sediment bulletin.

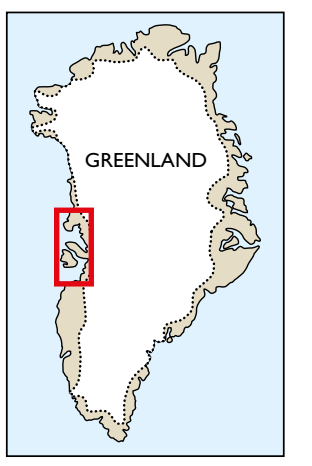

Neogene sediment cover

Saqqaata Qaqqaa central complex

Undifferentiated basalts offshore

Naqerloq Formation

Svartenhuk Formation

Maligât Formation

Paleocene picrites (Vaigat Formation)

Maastrichtian-

Paleocene sediments

Albian-Campanian

sediments

Precambrian basement

Extensional fault

- Fault with lateral or alternating displacements

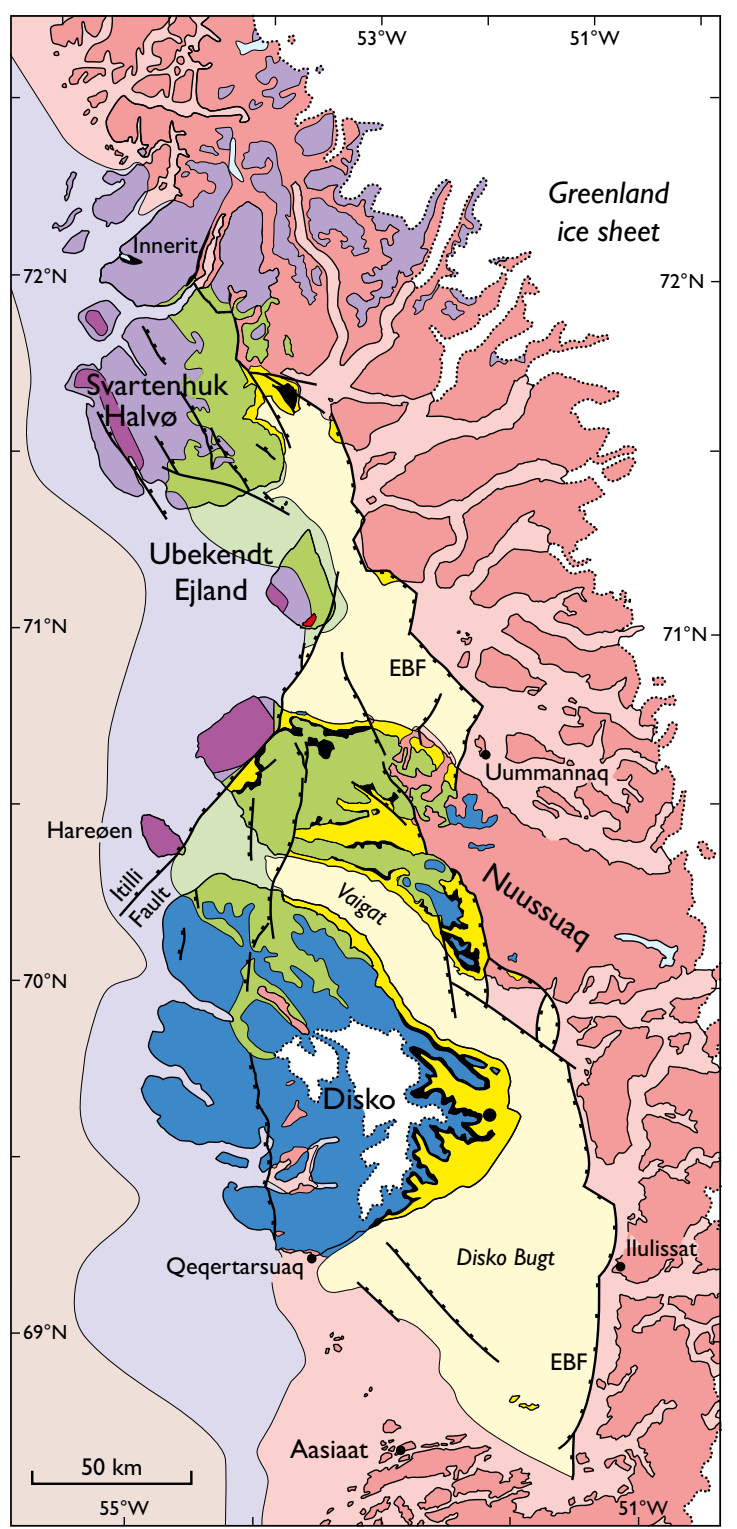

Fig. 2. Simplified geological map of the Nuussuaq Basin. Light colours: sea-covered areas. EBF: Eastern boundary fault system. 
The volcanic rocks in the Nuussuaq Basin crop out over $c .20000 \mathrm{~km}^{2}$ within a basinal area of $c .120 \mathrm{~km} \times 400$ $\mathrm{km}\left(c .50000 \mathrm{~km}^{2}\right)$; however, volcanic rocks extend over a total area of $c .200 \mathrm{~km} \times 550 \mathrm{~km}\left(c .110000 \mathrm{~km}^{2}\right)$, much of which is sea-covered (Chalmers et al. 1999a; Oakey \& Chalmers 2012). The volcanic rocks were erupted at highly variable rates into a tectonically very active environment, and there was a complex interplay between the volcanic, sedimentary and tectonic evolution of the basin which resulted in a highly complex architecture of the volcanic succession. Moreover, the range of magma compositions was large. West Greenland contains an unusually high proportion of primitive, $\mathrm{Mg}$-rich picritic rocks that represent almost unmodified mantle melts (Drever 1953, 1956; Clarke 1970; Clarke \& Upton 1971; Clarke \& Pedersen 1976; Holm et al. 1993; Larsen \& Pedersen 2000, 2009). However, repeated episodes of assimilation of crustal material, including organic-rich sediments, led to formation of units of silica-enriched rocks including native-iron- and graphite-bearing basalts, andesites and dacites and graphite-bearing rhyolites (e.g. Törnebohm 1878; Steenstrup 1883; Pedersen 1977a, 1981, 1985a; Pedersen \& Larsen 2006, Larsen \& Pedersen 2009).

The volcanic succession is divided into two major parts. The lower part is dominated by picrites and has been formalised as the Vaigat Formation, which is present from Disko and northwards to Svartenhuk Halvø (Hald \& Pedersen 1975). The upper part is dominated by basalts and has previously been referred to different formations in different areas; the most recent stratigraphy by Larsen et al. (2016) concluded that the basalts on Disko and Nuussuaq east of the Itilli Fault, and only these, belong to the Maligât Formation.

This bulletin on the Vaigat Formation and its companion on the Maligât Formation (Pedersen et al. 2018) describe the lithostratigraphy, geology and geochemistry of the volcanic succession on Disko and Nuussuaq east of the Itilli fault. They represent a synthesis of work that has been going on since 1968 and from which many results have been published. The two bulletins may be viewed as a comprehensive map description covering the Paleocene volcanic rocks in all the geological maps in the area, which is covered by seven geological maps on a scale of 1: 100000 , two geological maps on scales of 1:50 000 and 1:20 000, respectively, covering different parts of Nuussuaq, and five vertical geological sections on a scale of 1: 20000 across Disko and Nuussuaq (Fig. 3). An important task for the two bulletins has been the definition and documentation of the several volcanic units that appear on the published maps and sections but have not

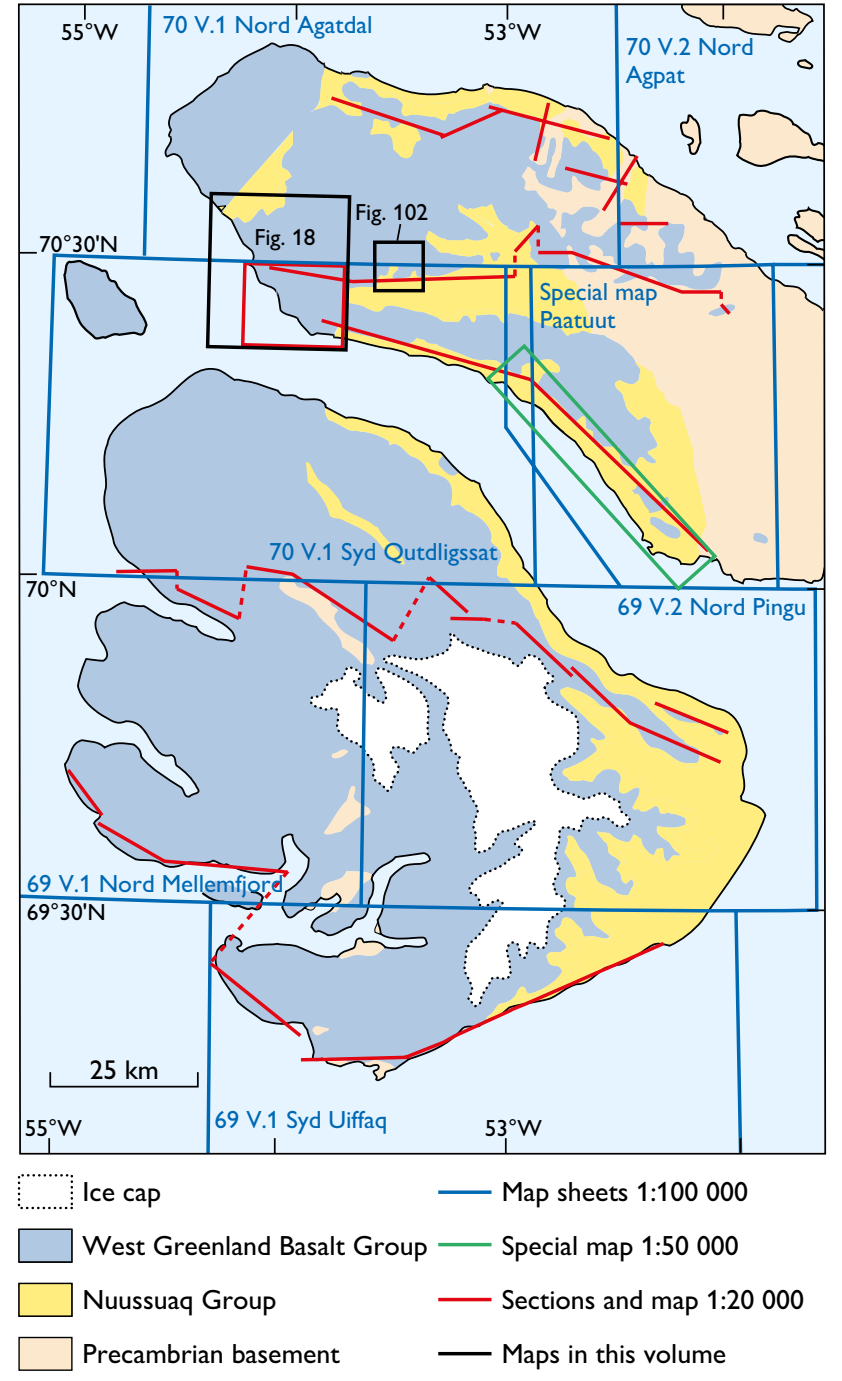

Fig. 3. Index map of published geological maps and photogrammetric sections covering Disko and Nuussuaq. Also shown are the locations of special geological maps that appear as figures in this bulletin. See also end of reference list.

been described before. The documentation includes geochemical data because chemostratigraphy is important in both formations and crucial for the Maligât Formation. Emphasis is placed on descriptions with illustrations of the variable lithologies in selected key areas and on geochemical descriptions and plots of the stratigraphic units, facilitated by a numerical coding system, data tables and a comprehensive electronic appendix with analytical data. The bulletins are therefore also intended to serve as guides for future field, geochemical and petrological studies.

The present bulletin on the Vaigat Formation on Disko and Nuussuaq contains detailed introductory chap- 
ters on previous investigations, geological setting and methods that also cover the Maligât Formation. Petrogenetic considerations have been published by Larsen \& Pedersen (2000, 2009) and Larsen et al. (2003) and the two bulletins therefore only give short summaries of the petrology of the rocks. However, the bulletin on the Maligât Formation (Pedersen et al. 2018) contains a final chapter on crustal contamination of the volcanic rocks, with descriptions of possible contaminants and discussion of contamination processes, that covers both the Vaigat and Maligât formations and is not found in this bulletin.

\section{Previous investigations}

The earliest scientific descriptions of the volcanic rocks in West Greenland were published by Giesecke (1821, [1910]) and Rink (1852) who used the terms "Floetztrap" or "Trap-formation" and distinguished between "Trap-tuff” (hyaloclastite), "Basalt-tuff" (pillow breccia), "amygdaloid Basalt" and "columnar Basalt". The first geological map was produced by Steenstrup (1883) and shows the distribution of basement, sediments, "Traptuf (Palagonit?)" and "Trap" between $69^{\circ} 10^{\prime}$ and $72^{\circ} 35^{\prime} \mathrm{N}$, with the major parts of the inland areas still unmapped. Steenstrup visited the region several times during the period 1871-1898 and made major contributions to the geology; in particular he provided the proof that the native iron occurs within the volcanic rocks and is telluric in origin (Steenstrup 1877, 1883, 1884, 1900) and not meteoritic as advocated by Nordenskiöld (1871). The native-iron-bearing rocks on Disko and Nuussuaq have been the subject of numerous papers, and the best introduction to the literature on the native iron is found in Bøggild (1953).
In the first half of the 20th century, the general geology and structure of the Disko-Nuussuaq-Svartenhuk region was described by Koch (1929), whereas more detailed studies on the volcanic rocks were published by Heim (1910) on the north coast of Nuussuaq, NoeNygaard (1942) on the geology of Svartenhuk Halvø (distinguishing for the first time older picrites ("oceanites") from younger plagioclase-phyric basalts), and Munck (1945) on intrusions on Nuussuaq.

After the Second World War, new expeditions to the area led to increased understanding and detailed knowledge of both the Nuussuaq Basin and the volcanic rocks. Early reviews on the stratigraphy, tectonics and structure of the basin are given by Rosenkrantz \& Pulvertaft (1969), Henderson (1973) and Henderson et al. (1981). Drever \& Game (1948) and Drever \& Johnston (1957), working on the picrites on Ubekendt Ejland, were the first to point out that the picrites must represent highly magnesian and very hot magmas. Clarke (1970) and Clarke \& Upton (1971), working on Baffin Island and Svartenhuk Halvø, supported this view which was disputed by Hart \& Davis (1978), as discussed by Larsen \& Pedersen (2000).

A comprehensive review of the volcanic rocks of West Greenland was published by Clarke \& Pedersen (1976). This summarised all the then existing knowledge of the volcanic rocks, much of which resided in numerous reports from GGU (Grønlands Geologiske Undersøgelse, the Geological Survey of Greenland), and even more was unpublished. This review stood its ground for about 30 years and is still essentially correct though many details have been added since then. In particular, the stratigraphy and geochemistry of the volcanic succession are now much better documented and understood. 


\section{Geological setting}

The Tertiary volcanic rocks in West Greenland form part of the North Atlantic Igneous Province. This province extends onshore from Baffin Island over West Greenland and East Greenland, Iceland and the Faeroe Islands to Ireland and Scotland; extensive volcanic rocks are also present in the offshore basins and make up the floor of the North Atlantic Ocean, and activity continues in presentday Iceland (Holmes 1918; Noe-Nygaard 1974; Upton 1988; Saunders et al. 1997). The magmatism started apparently simultaneously over large areas at around 64-62 $\mathrm{Ma}$, and this has been ascribed to the arrival of the proto-Icelandic mantle plume at the base of the lithosphere at that time (e.g. White \& McKenzie 1989; Eldholm \& Grue 1994; Chalmers et al. 1995; Saunders et al. 1997; Larsen \& Saunders 1998). At the same time, the North Atlantic continent began to break up. The splitting lines in many cases followed older, rifted sedimentary basins overlying attenuated and stretched parts of the lithosphere, and volcanic rocks were deposited in the basins on the nascent continental margins. The $c .20000 \mathrm{~km}^{2}$ of exposed volcanic rocks in West Greenland make it the second largest exposed volcanic succession on the continental margins of the North Atlantic, only surpassed by the central East Greenland basalt plateau.

The exposed rocks in the Nuussuaq Basin consist of Cretaceous to Palaeogene sediments and Palaeogene volcanic rocks. Both the deposition of the rocks and the present distribution of the various units, as seen on a geological map (Figs 2, 4), are strongly controlled by the tectonic framework of the basin which will therefore be described first. The following summary is to a large extent based on the review by Chalmers et al. (1999a) which should be consulted for more details and references.

Figure 5 presents a map with detailed place names used in this bulletin.

\section{Tectonic framework}

The three most important structural elements of the Nuussuaq Basin on Disko and Nuussuaq are the eastern boundary fault system (EBF), the Kuugannguaq-Qunnilik (K-Q) fault system and the Itilli fault system (Figs $2,4)$. These fault systems divide the basin into a central to eastern part where the volcanics are close to flat-lying and their substrate is well exposed, a western part where the substrate is rarely exposed and the volcanic succession is faulted and commonly tilted, and a westernmost part west of the Itilli fault system where, due to kilometrescale downthrow to the NW, a very different and mainly younger volcanic succession is preserved.

The eastern boundary fault system delimits the basin towards the elevated Precambrian basement in the east. The system consists of a number of fault segments with orientations from N-S to NW-SE. The basin boundary runs approximately $\mathrm{S}-\mathrm{N}$ along the eastern margin of Disko Bugt (which is floored by sediments, Fig. 2), then swings towards NW and NNW across southern and central Nuussuaq (Figs 2, 4). The main boundary fault runs across Nuussuaq from Saqqaq to Ikorfat, although on northern Nuussuaq the boundary fault system includes a sediment-covered ramp extending eastwards from the Ikorfat fault to the Kuuk fault (Fig. 4). Only few sediment exposures occur east of the Kuuk fault, but lavas step across it onto the elevated gneiss areas on southern and eastern Nuussuaq.

Within the basin, important faults run mainly N-S. A number of minor $\mathrm{N}-\mathrm{S}$-oriented faults occur between the eastern boundary fault system and the $\mathrm{K}-\mathrm{Q}$ fault system; they cut the sedimentary succession which is broken up into a number of tilted blocks, and to a much lesser extent such faults also cut the volcanic succession. The largest of these faults have been used in geophysical modelling and labelled 'P', 'M' and 'H' by Chalmers et al. (1999a).

The Disko Gneiss Ridge is a pre-basaltic fault block that is down-tilted towards the east, whereas to the west it is delimited by a N-S-running fault system that is an extension of the $\mathrm{K}-\mathrm{Q}$ fault system. The surface of the gneiss ridge is shaped by prevolcanic erosion (Bonow 2005); the later lavas have lapped onto the hilly landscape of the ridge and eventually covered it. The ridge stands up to $c$. $700 \mathrm{~m}$ a.s.l. on central Disko, lowers to $c .300 \mathrm{~m}$ a.s.l. on southern Disko and runs south, mainly below sea level, across Disko Bugt to the low-lying gneiss areas in the Aasiaat area. The ridge is not exposed at the north coast of Disko; this has been attributed to a NW-SE-trending fault on northern Disko (Chalmers et al. 1999a).

The K-Q fault system runs $\mathrm{S}-\mathrm{N}$ across both Disko and Nuussuaq, and pre-, syn- and postvolcanic movements have taken place along the faults. A clustering of volcanic eruption sites along the fault system demonstrates its deep-seated nature as a preferred pathway for magmas. West of the K-Q fault system no prevolcanic 


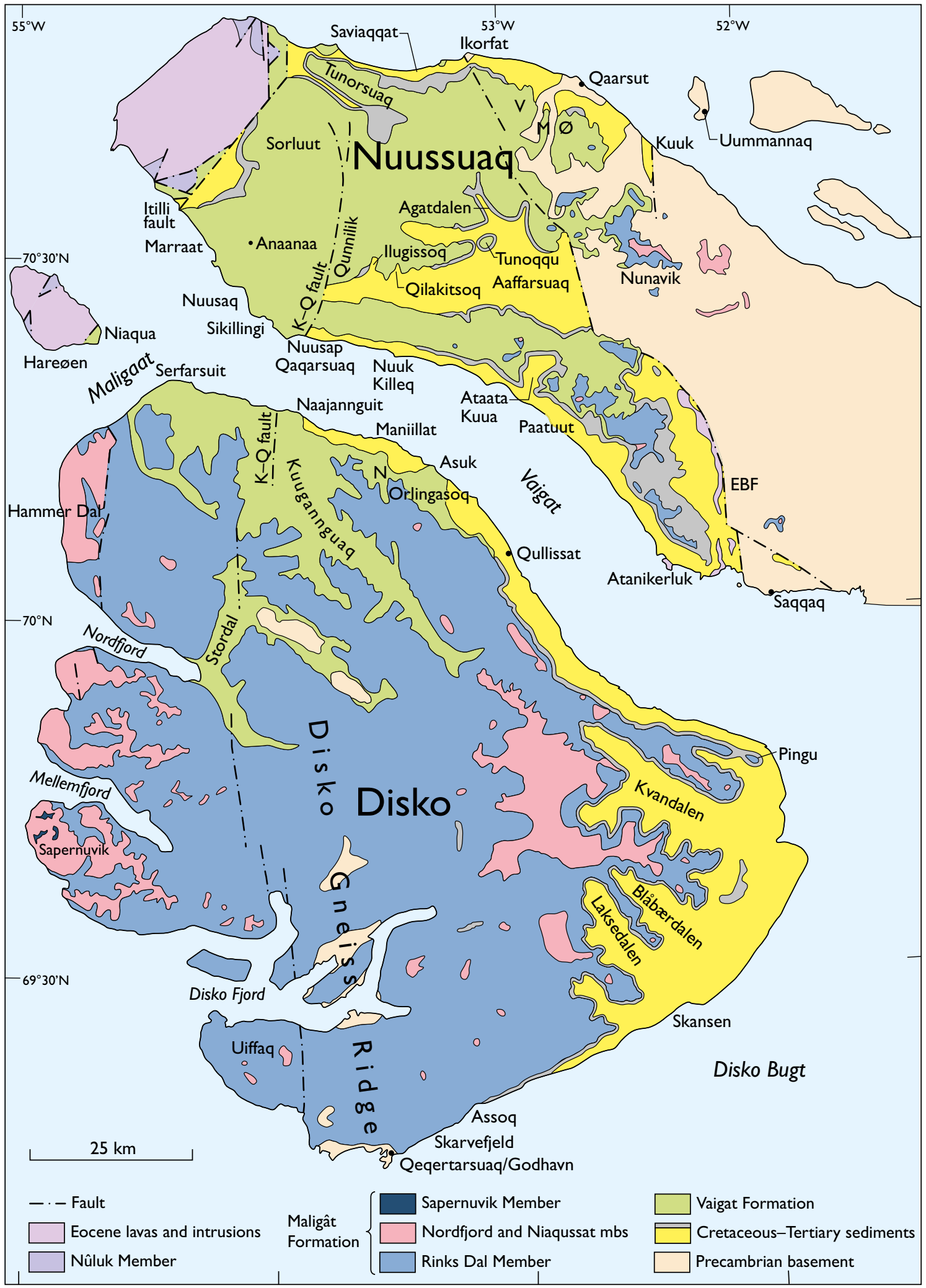

Fig. 4. Geological map of Disko and Nuussuaq. Ice caps are not shown (see Fig. 5). The extent of the Nordfjord and Niaqussat Members on central Disko is interpolated between many small exposures along the edge of the Sermersuaq ice cap. EBF: Eastern boundary fault system. K-Q fault: Kuugannguaq-Qunnilik fault. M: Mellemfjeld. N: Norddalen. Ø: Østerfjeld. V: Vesterfjeld. 


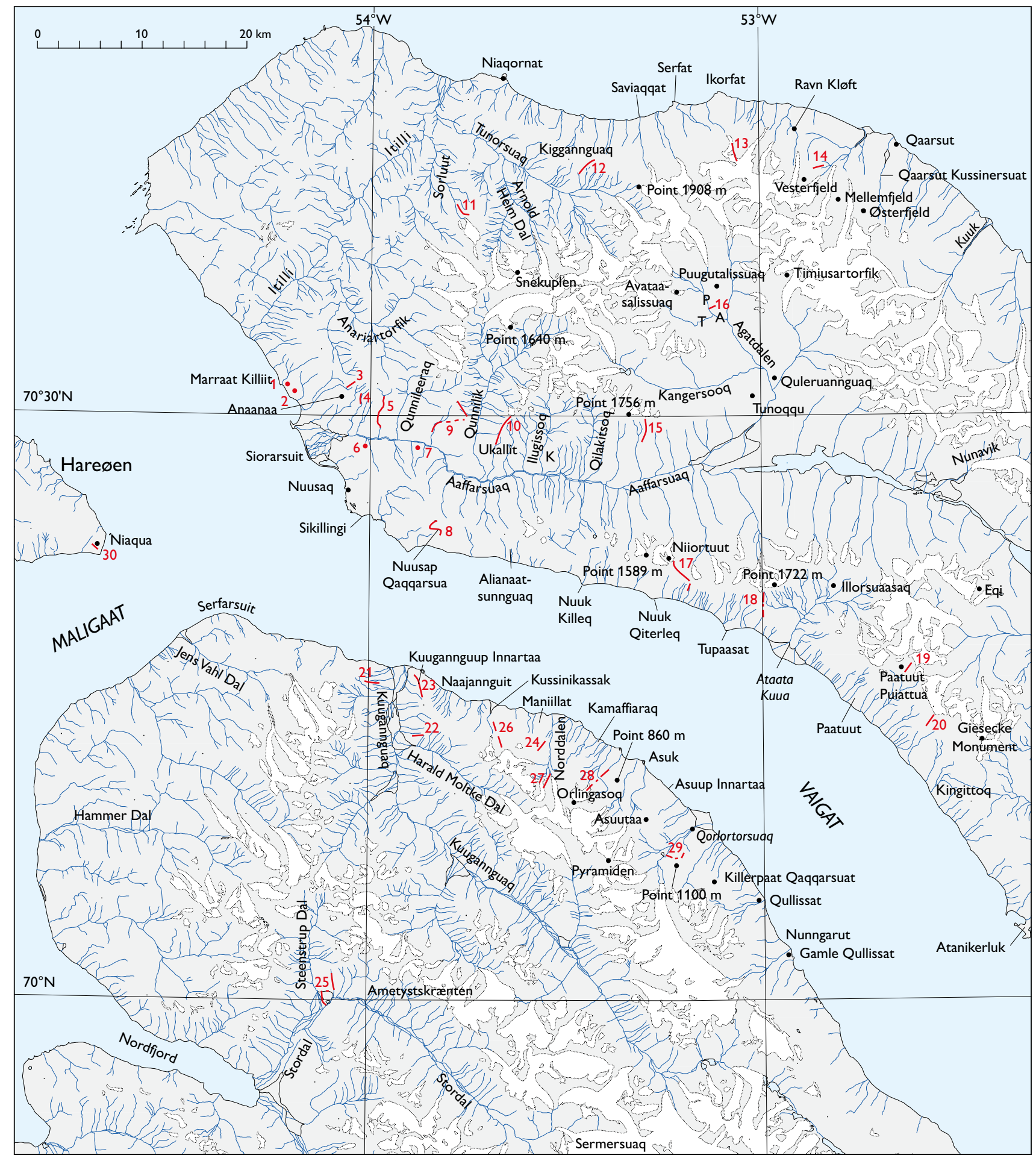

Fig. 5. Map with place names used in the text. Red lines and dots numbered 1-30 are the locations of the profiles shown in Figs 13-17. The ice caps (white) and the drainage pattern (blue) give an impression of the rugged topography and the many elevated areas of difficult access that do not appear from the other geological maps presented here. A: Agatkløft. K: Koralravine (at Ilugissoq). P: Pyramidedal. T: Turritellakløft. More place names for western Nuussuaq in Fig. 18. 
sediments are exposed on Disko, but sediment-contaminated volcanic rock units and sandstone and mudstone xenoliths in these attest to the presence of sediments at depth (e.g. Pedersen 1977a). Thick sedimentary successions are known from Nuussuaq west of the $\mathrm{K}-\mathrm{Q}$ fault system (Dam et al. 2009).

Western Disko west of the K-Q fault system is cut by several $\mathrm{N}-\mathrm{S}$-oriented post-Paleocene faults with steeply E-dipping fault planes. They divide the volcanic succession into a number of antithetic fault blocks in which the lavas dip $2-22^{\circ} \mathrm{W}$, thus exposing the youngest parts of the succession in the westernmost blocks. The offshore continuation of the lava succession has been conjectural (Geoffroy et al. 1998, 1999, 2001; Chalmers et al. $1999 \mathrm{~b}$ ), but recent geophysical work shows that the antithetic fault system does not continue offshore but rather has given rise to a monocline of limited width (Skaarup 2002; Skaarup \& Pulvertaft 2007; Gregersen \& Bidstrup 2008). According to refraction seismic data, Paleocene oceanic crust is situated $120 \mathrm{~km}$ west of Disko (Funck et al. 2012; Oakey \& Chalmers 2012; Fig. 1).

The structure of western Nuussuaq is different from that of western Disko. The area west of the K-Q fault and towards the Itilli fault is faulted but not antithetically, and sediments and volcanic rocks are arched up due to compression on the Itilli fault (Chalmers et al. 1999a), so that the oldest part of the volcanic succession and the underlying sediments are exposed just east of the Itilli fault. West of the Itilli fault, the fault pattern changes to become antithetic with consistently W-dipping lavas younging towards the west, as on westernmost Disko.

The Itilli fault system is a major structural boundary. It runs NE-SW across western Nuussuaq, skirts Hareøen (Qeqertarsuatsiaq) and runs into the Davis Strait where it links with the Ungava fault system (Figs 1,2; Chalmers $\&$ Pulvertaft 2001). Downthrow is to the NW, with net displacements of more than $1 \mathrm{~km}$ on Hareøen and Nuussuaq. As a result of this, the volcanic successions on either side of the Itilli fault system are fundamentally different. West of the fault system, in addition to Vaigat Formation picrites in some of the fault blocks, there is a succession of relatively young (latest Paleocene to early Eocene) volcanic rocks which are not present east of the fault system, and which are not included in this work.

\section{The sedimentary substrate}

The Nuussuaq Basin was a depositional area for clastic sediments for at least $40 \mathrm{Ma}$ since the Albian (Dam et al. 2009). Geophysical investigations have shown sediment thicknesses of at least $6 \mathrm{~km}$ and possibly up to $10 \mathrm{~km}$ in the western part of the basin (Christiansen et al. 1995a; Chalmers et al. 1999a); in the eastern part the sediments are only 1-2 km thick. Most of the exposed sediments were deposited in a large delta complex which fanned out from south-east of Disko towards the west and northwest; fluvial to deltaic environments therefore predominate on Disko and southern Nuussuaq, while marine deep-water environments are found on north-western Nuussuaq and on Svartenhuk Halvø (G.K. Pedersen \& Pulvertaft 1992). The Albian to Campanian nonmarine and marginally marine sediments are referred to the Kome, Slibestensfjeldet, Upernivik Næs and Atane formations (Dam et al. 2009) and comprise yellowish quartzo-feldspathic sandstones interbedded with mudstones and coal layers (Midtgaard 1996; G.K. Pedersen et al. 2006). Dark marine mudstones of the Itilli and Kangilia formations are exposed on north-western Nuussuaq. On western Nuussuaq the Itilli Formation is more than $2 \mathrm{~km}$ thick in the GRO\#3 well. The Itilli Formation comprises Upper Cretaceous turbiditic sandstones and mudstones deposited on a submarine slope west of the Kuugannguaq-Qunnilik fault (Dam \& Sønderholm 1994; Dam et al. 2009).

An early Campanian angular unconformity is observed on central Nuussuaq (Dam et al. 2000) and interpreted as a regional event (Gregersen et al. 2013). During the Maastrichtian and early Paleocene the basin was affected by faulting and changes in relative sea level. At least three phases of uplift during the Late Cretaceous and early Paleocene are interpreted from deeply incised submarine canyons with conglomerates, turbidites and mudstones, as well as an incised fluvial valley with pebbly sandstones as the dominant lithology (Dam \& Sønderholm 1994, 1998; Dam 2002; Dam et al. 2009). Faulting and tilting of the fault blocks is well displayed by the tilted, formerly horizontal erosional surface contacts between gneiss and Cretaceous sediments along the north coast of Nuussuaq between Ikorfat and Kuuk (Pulvertaft 1979; Pedersen et al. 2006a) and by angular unconformities between Atane Formation sediments and overlying Campanian to early Paleocene sediments (Dam et al. 2000, 2009).

\section{Deposition of the volcanic succession and equivalent sediments}

At the onset of the volcanism a marine embayment stretched from the open sea in the north-west (western Nuussuaq and beyond this) towards south and south-east where it was bounded by the Disko Gneiss Ridge in the 
west, an active delta depositing sediments in the south and south-east, and the gneiss highland in the east and north-east (Dam et al. 2009, fig. 12). Detailed studies of volcanic facies transitions have documented very high subsidence rates in excess of $20 \mathrm{~m} / \mathrm{ka}$ during the deposition of the early part of the Vaigat Formation (Pedersen et al. 2002b), making regional palaeogeographical reconstructions difficult. Deposition of the volcanic rocks started in the north-west and took place concomitantly with continued deposition of sediments in other parts of the basin, leading to a complex interplay between volcanic and sedimentary rock units. A lithostratigraphic scheme for both volcanic rocks and sediments is shown in Fig. 6. Lateral basin fill from west to east, shifting eruption sites with time and frequent facies changes between subaerial and subaqueous facies within most volcanic units resulted in an unusually complex stratigraphy of the volcanic succession.

In the volcanic succession, the Vaigat Formation is dominated by primitive, olivine-rich picritic rocks which in subaerial facies form thin, grey, crumbly lava flows. The overlying Maligât Formation is dominated by evolved, plagioclase-phyric to aphyric basalts which in subaerial facies form thicker, darker grey to brownish, massive lava flows. Both formations contain a number of lithologically and chemically distinct units; several of these form marker horizons and have been assigned member status (Fig. 6).

The Vaigat Formation forms a S-N elongate, $260 \mathrm{~km}$ long, shield-like feature in the Nuussuaq Basin. It is thickest, up to $c .5 \mathrm{~km}$, on Ubekendt Ejland north of Nuussuaq (J.G. Larsen 1977). In the Disko-Nuussuaq area, it is up to $1.6 \mathrm{~km}$ thick on central and western Nuussuaq and $1.5 \mathrm{~km}$ on northern Disko; it wedges out eastwards on eastern Nuussuaq and eastwards and southwards on eastern and north-central Disko. Its lower boundary towards the sediments is strongly diachronous and youngs towards the east because of progradation of the volcanic pile from west to east. It formed in three major episodes of activity which gave rise to its three main members, the Anaanaa, Naujánguit and Ordlingassoq members. The marine embayment with the mudstones of the Eqalulik Formation (Dam et al. 2009) was gradually filled in, and at the end of the second episode the advancing volcanic front reached the eastern gneiss highland on north-eastern Nuussuaq and blocked the connection to the sea so that the embayment was transformed into a freshwater lake, the Naajaat Lake (Piasecki et al. 1992; Pedersen $e t$ al. 1996), in which sediments of the non-marine Atanikerluk Formation were deposited (Koch 1959; Dam et

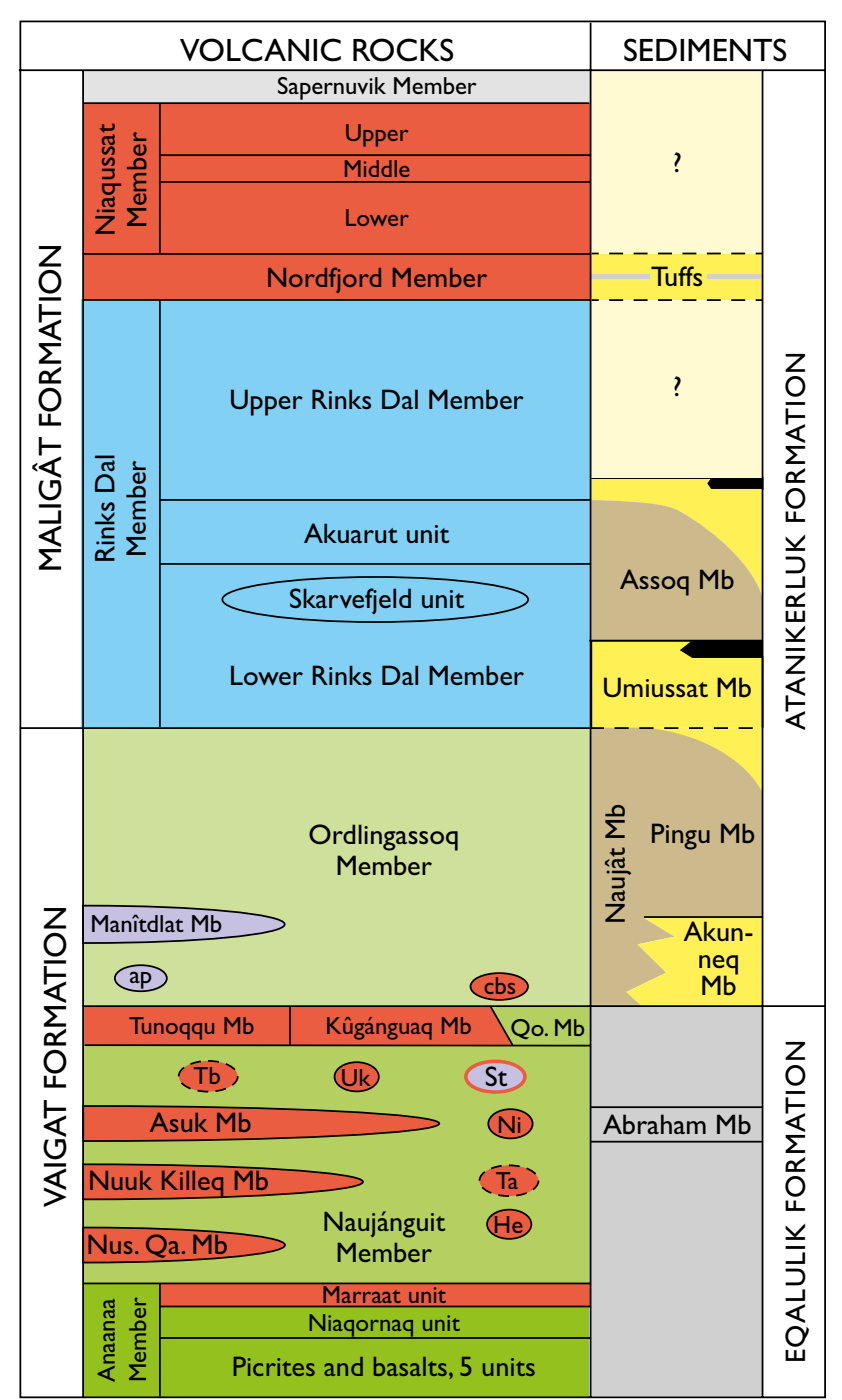

Fig. 6. Stratigraphic division of the Paleocene volcanic rocks and sediments on Disko and Nuussuaq. The thicknesses of the volcanic units in the diagram approximately reflect their volumes although this is not always possible. The units with elliptical outlines do not extend throughout the succession, and the small ones are distinctly local. Crustally contaminated units are shown in red, alkaline units in purple (with a red outline if crustally contaminated), and geochemically enriched units have dashed outlines. Ap: alkali picrites associated with the Manitdlat Member. Cbs: contaminated basalts in Stordal. He: Henderson unit. Ni: Niiortuut unit. Nus. Qa.: Nuusap Qaqqarsua. Qo. Mb: Qordlortorssuaq Member. St: Stordal alkaline unit. Ta: Tunorsuaq a unit. Tb: Tunorsuaq b unit. Uk: Ukallit unit. Sediments from Dam et al. (2009): marine mudstones: grey, non-marine mudstones: brownish-grey, sandstones: yellow and coal: black. 
al. 2009). This lake persisted through the third volcanic episode of the Vaigat Formation with deposition of the mudstones of the Naujât and Pingu members, but it was greatly diminished towards the end due to the combined infill by volcanic rocks and delta sands of the Umiussat Member (G.K. Pedersen et al. 1998; Dam et al. 2009).

The Maligât Formation is centred on Disko, and its oldest exposed part is found on south-central Disko. It is thickest on western Disko where its base is generally below exposure level; on southern and eastern Disko it rests on sediments, and in the north it laps onto the Vaigat Formation with increasingly younger lavas at the contact going north from Disko to Nuussuaq. Eastwards the Maligât Formation thins and interfingers with lake sediments of the Assoq lake basin and the sand-dominated delta deposits from a large north- to north-west-flowing river (Pedersen et al. 2003; Dam et al. 2009). As a result, the eastern fringes of the formation changed with time from subaqueous lava flows and hyaloclastites through invasive flows forming 'sills' in the wet sediments, to subaerial lava flows which finally covered much of the basinal area and stepped onto the gneiss highland on eastern Nuussuaq.

\section{Palaeomagnetism, timing and duration of the volcanism}

Palaeomagnetic work by Deutsch \& Kristjansson (1974), Athavale \& Sharma (1975), Hald (1977a), Riisager \& Abrahamsen (1999, 2000) and J. Riisager et al. (1999, 2003a, b, 2004) has shown that the lower part of the Vaigat Formation is normally magnetised, while its middle and upper parts and all of the overlying Maligât Formation are reversely magnetised. Based on ${ }^{40} \mathrm{Ar}-{ }^{39} \mathrm{Ar}$ radiometric dating (Storey et al. 1998), the two magnetic zones have been identified as C27n and C26r. The work of Storey et al. (1998) yielded ages of $c .62-61 \mathrm{Ma}$ for the
Vaigat Formation and 61-60 Ma for the Maligât Formation. The lowest dated sample is from immediately above the C27n - C26r transition; as C27n lasted for a total of only 0.33 million years at $62.55-62.22 \mathrm{Ma}$ (Vandenberghe et al. 2012), the lowermost exposed rocks of the Vaigat Formation cannot be older than 62.5 Ma. At the young end, one of the uppermost lava flows in the Maligât Formation was dated at $60.2 \pm 0.5 \mathrm{Ma}$ (Storey et al. 1998). Larsen et al. (2016) dated the younger volcanic evolution: the c. $2 \mathrm{~km}$ thick Kanísut Member west of the Itilli fault and on Hareøen is Eocene, 56-54 Ma. Consequently, the Kanísut Member should not be considered part of the Maligât Formation where it was originally placed (Hald \& Pedersen 1975), and Larsen et al. (2016) moved it to a new formation, the Naqerloq Formation.

Estimates of the volcanic productivity have been made by Storey et al. (1998) and Pedersen et al. (2002b). From volumes and age relations, Storey et al. (1998) estimated a minimum magma production rate for the Vaigat Formation and the lower and middle part of the Maligât Formation of $1.3 \times 10^{-4} \mathrm{~km}^{3}$ per year per kilometre rift, decreasing to $0.2-0.7 \times 10^{-4} \mathrm{~km}^{3} /$ year/ kilometre rift for the upper part of the Maligât Formation. The first figure is comparable with the productivity for postglacial lavas on Iceland (Pálmason 1981). Pedersen et al. (2002b) used the existence of $170 \mathrm{~m}$ of lavas erupted during the $c .5000$ year long period of reversal of the geomagnetic pole from $\mathrm{C} 27 \mathrm{n}$ to $\mathrm{C} 26 \mathrm{r}$ to estimate for that period a productivity of $1.2 \times 10^{-3} \mathrm{~km}^{3} /$ year $/$ kilometre rift, a volcanic aggradation rate of $c .33 \mathrm{~m} \mathrm{ka}^{-1}$ and a subsidence rate of $c .25$ $\mathrm{m} \mathrm{ka}^{-1}$. These extremely high rates cannot have been sustained continuously, and the volcanism must have had an intermittent character. This is also indicated by the complex geological record described here, with periods of erosion, soil formation and stagnation of magmas in crustal magma chambers. 


\section{Methods}

\section{Field work}

Field work started in 1968 and has been conducted during 23 full or partial field seasons, with the late Finn UlffMøller as an important contributor for many of the early years. With logistic support in the early years from boat, the work was first concentrated in the coastal areas of Disko, with additional trekking over long distances into the main valleys. Work on Nuussuaq started in 1986. Helicopter support became available in 1979, and work during several seasons in the 1980s and 1990s and later years filled in the inland areas of both Disko and Nuussuaq.

Sampling for mapping purposes was mainly done in stratigraphically well-controlled profiles, and flow-byflow sampling (or flow groups in case of thin pahoehoe lavas) was applied whenever possible. Additionally, special features of interest such as distinctive flows and eruption sites were sampled.

Mapping and location of samples were done on vertical and oblique aerial photographs on a scale of $c .1: 40000$ and, in later years, on paper copies of stereo pairs of colour diapositives taken with hand-held cameras and showing considerably greater detail. Sample coordinates were later digitised with high internal precision (better than $10 \mathrm{~m}$ for $\mathrm{x}$ and $\mathrm{y}$, and $5 \mathrm{~m}$ for $\mathrm{z}$ ) on a Kern photogrammetrical instrument (see below). In total, about 2100 samples were collected of the Vaigat Formation, 2400 of the Maligât Formation and 1000 of intrusions.

\section{Photogrammetry}

The volcanic formations on Disko and Nuussuaq are in general very well exposed, but a large part of the exposures are either inaccessible due to steep topography or it would demand very costly field work to map them in a conventional way. In such a region photogrammetry is a very useful tool, and the Nuussuaq Basin has therefore served as an experimental area for geological photogrammetry during the last 40 years.

Geological photogrammetry was first introduced to the Nuussuaq Basin by G. Henderson, who used a Hilgers \& Watts mirror-stereoscope on aerial photographs for structural studies (Henderson 1973) and compilation of the geological maps covering western Nuussuaq (Rosenkrantz et al. 1974, 1976).

The geological mapping of northern Disko by the first author led to a long-term collaboration with K.S. Dueholm at the Technical University of Denmark. The Disko part of the geological map sheet 1:100 000, Qutdligssat 70 V.1 Syd (Rosenkrantz et al. 1976) was compiled using aerial photographs and the stereo-measuring system AMIK (Dueholm 1976), which combined a Hilger \& Watt mirror-stereoscope with a computer system. This allowed much improved structural measurements and more accurate map compilations.

The next experiments were made on aerial photographs from western Disko (Dueholm et al. 1977) for which a Zeiss Planimat D-2, combined with an Ecomat-11 electronic recording unit, was used to compile an accurate geological map on a scale of 1:50 000 covering the lavas of the Mellemfjord area (Pedersen 1977b). A Zeiss Stecometer combined with a Wild Aviograph B8 was used to construct a block diagram showing the native iron and sulfide mineralised Hammer Dal complex (UlffMøller 1977).

A long series of photogrammetrical mapping experiments summarised by Jepsen \& Dueholm (1978) and Dueholm (1979) led to the establishment of the photogrammetrical laboratory at the Geological Survey of Greenland (GGU) in 1977, equipped with a KERN PG2 stereoplotter, an automatic flat-bed plotter and a minicomputer. The facilities of the laboratory were summarised by Hougaard et al. (1991). The GGU laboratory with the software by Pillmore et al. (1981) was used for the compilation of the map sheet 1:100 000, 69 V.1 Nord Mellemfjord (Pedersen \& Ulff-Møller 1987). The compilation was based on aerial photographs.

As geological work on the volcanic formations progressed, it became increasingly clear that compilations using the black-and-white, mainly vertical aerial photographs taken by the Geodetic Institute had severe limitations because of the steep geomorphology of the Disko and Nuussuaq region and the generally insufficient geological resolution in the photographs that also show a more extensive snow cover than today. A major improvement took place when a KERN-DSR11 Analytical plotter with computer system became available at the Technical University of Denmark. The first step was to establish quantitative geological analysis on oblique aerial photographs (Dueholm \& Pedersen 1988). Then followed the development of software which led to the concept of multi-model photogrammetry (Dueholm \& Coe 1989; Dueholm \& Pillmore 1989; Dueholm 1990), by means of which detailed geological analysis is carried 
out on suites of successive, partly overlapping stereomodels made from colour diapositives taken with smallframe cameras from a photographical platform that can be either a helicopter, a fixed-wing aeroplane, a boat or ground-based.

Since 1990 multi-model photogrammetry has been used extensively in the studies of the volcanic formations within the Nuussuaq Basin, both for planning and in subsequent compilation stages; and systematic photography with hand-held small-frame cameras from helicopter has been of high priority in the field. Summaries of the method and its application are given by Dueholm \& Pedersen (1990, 1992); Dueholm (1992); Garde (1992); G.K. Pedersen (1992); Pedersen \& Dueholm (1992); Dueholm \& Olsen (1993) and Dueholm et al. (1993). Whenever possible, compilations have been based on a combination of traditional photogrammetry based on vertical aerial photographs on different scales with multi-model photogrammetry based on colour diapositives, supplemented by other field photographs and field observations. The results have been published as geological maps (Pedersen et al. 2000, 2001, 2008), geological sections (see Pedersen et al. 2006b) and as combinations of maps and sections (Pedersen et al. 2007a, b).

Within the last ten years, the photogrammetrical laboratory at GEUS has developed a modern digital platform. The old photo templates on which the original photogrammetrical work in this bulletin was carried out have been digitised while the photogrammetrical parameters of the original stereo models have been preserved, so that the old photographs can be used in combination with new high-resolution stereo photographs, as exemplified by Sørensen et al. (2015a, b).

\section{Geochemistry}

Almost all major-element analyses in this work are by $\mathrm{X}$-ray fluorescence spectrometry (XRF) and were made by Jørgen Kystol and Ib Sørensen at the rock geochemical laboratory at GGU/GEUS. The analyses have been carried out over a wide time span during which some analytical and computational procedures have changed. The earlier analyses may therefore be somewhat variable, but the majority were done since 1984 and are generally of high and reproducible quality, as shown by analyses over the years of the in-house basalt standards Kap Stosch (GGU 95358) and Disko-1, and of international reference samples. Since 1993 the analytical procedures have been as described by Kystol \& Larsen (1999). Most elements were determined by XRF on fused glass discs with sodium tetraborate flux; $\mathrm{Na}_{2} \mathrm{O}$ was determined by atom- ic absorption spectrometry and $\mathrm{FeO}$ by potentiometric titration. The $\mathrm{FeO}$ determination is not iron-specific and is therefore too high if a sample contains significant amounts of other oxidisable components such as graphite, sulfide or metal. In samples rich in such phases, the apparent $\mathrm{Fe}_{2} \mathrm{O}_{3}$ may even become negative because it is calculated as the difference between the total iron determination by XRF and the 'FeO' determination. Such samples contain no or negligible $\mathrm{Fe}_{2} \mathrm{O}_{3}$, and for these $\mathrm{Fe}_{2} \mathrm{O}_{3}=0$ and $\mathrm{FeO}$ is the total iron determined by XRF, recalculated as $\mathrm{FeO}$. A few samples were analysed by classical wet chemical methods.

A large sample subset was analysed for trace elements by XRF on pressed powder pellets by John Bailey at the Geological Institute, Copenhagen, using standard analytical methods and with USGS reference materials for calibration. The large span of years, analytical set-ups and calibrations has introduced some minor analytical scatter in the results.

A smaller sample subset was analysed for trace elements by Jørgen Kystol at GEUS, using a PerkinElmer Elan 6100 DRC Quadrupole Inductively coupled Plasma Mass Spectrometer (ICP-MS). Sample dissolution followed a modified version of the procedure used by Turner et al. (1999) and Ottley et al. (2003). Calibration was done using two certified rare-earth element (REE) solutions and three international reference standards, with reference values from Govindaraju (1994) supplemented with newer values for the REE from the GEOROC database. Results for reference samples processed and run simultaneously with the unknowns are normally within $5 \%$ of the reference value for most elements with concentrations $>0.1 \mathrm{ppm}$.

Nearly all samples were ground in a tungsten carbide ball mill. This has introduced small amounts of Co and $\mathrm{Ta}$ into the powders. We estimate that 5-15 ppm Co has been added to the natural contents of 50-100 ppm Co which does not conceal the natural variations. The amount of Ta added is mostly very small but may be significant in the picrites where the natural contents of $\mathrm{Ta}$ are only about $0.2 \mathrm{ppm}$.

$\mathrm{Sr}, \mathrm{Nd}$ and $\mathrm{Pb}$ isotope ratios were presented and interpreted in Larsen \& Pedersen (2009). In this bulletin and its companion (Pedersen et al. 2018), isotope compositional data are included in the tabulated sample data but are not discussed in detail.

In total, about 1350 samples from the Vaigat Formation were analysed for major elements, 670 for traces by XRF and 190 for traces by ICP-MS. For the Maligât Formation, 1440 samples were analysed for major elements, 


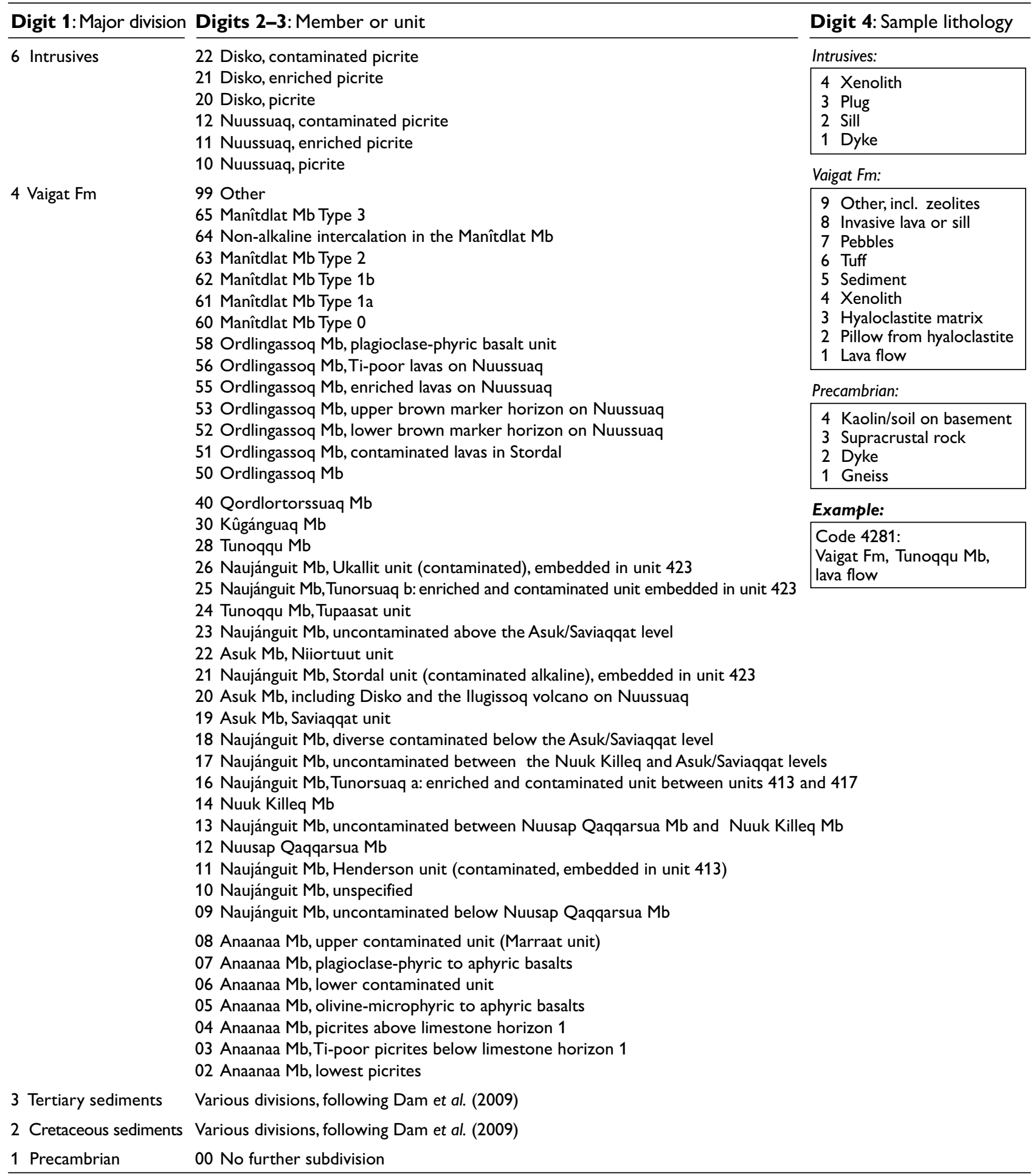

Even numbers are used for the contaminated units and uneven ones for the uncontaminated units, but e.g., unit 402 is uncontaminated and unit 419 is contaminated. In general, younger units have higher numbers. Some late-defined units, e.g. 421 and 424, are stratigraphically slightly out of place (too low).

400 for traces by XRF and 150 for traces by ICP-MS. For sills and dykes, 560 samples were analysed for major elements, 170 for traces by XRF and 140 for traces by
ICP-MS. In order to represent the range of possible contaminants for the magmas, 79 samples of mudstones and sandstones (partly as xenoliths in the igneous rocks) and 
Precambrian basement rocks were analysed for major elements, 33 for traces by XRF and 16 for traces by ICP-MS.

In the chemical variation diagrams shown in this work, the elements are recalculated to $100 \%$ on a volatilefree basis. Igneous rocks with more than $6 \mathrm{wt} \%$ volatiles and/or more than $14 \mathrm{wt} \% \mathrm{CaO}$, both due to alteration are not plotted.

\section{Stratigraphic subdivision and coding system}

The volcanic succession is subdivided into many lithological units both large and small. In order to handle both the units and the large number of samples of the various units, a four-digit sample coding system was established, shown in Table 1. The first digit signifies the formation (e.g. 4 for the Vaigat Formation) and the second and third digits signify the unit (e.g. unit 14 in the Vaigat Formation is the Nuuk Killeq Member); thus all units in the succession have unique three-digit codes. The fourth digit signifies the lithological character of a sample (e.g. 2 for a pillow from a hyaloclastite). Thus, a sample coded 4142 is a pillow from the Nuuk Killeq Member of the Vaigat Formation. In the descriptions and figures in this bulletin, individual units are frequently denoted by their identifying three-digit codes, e.g. unit 414 is the Nuuk Killeq Member.

The coding system shown in Table 1 also comprises intrusions, sediments and basement. The part covering the Maligât Formation starts with the digit 5 and is not included in the table but is presented in Pedersen et al. (2018). Other volcanic units in the region which are not covered by the present bulletins may still be added.

The numerical coding system was not used in the published geological maps and sections because it was completed after the publication of most of these. The unit codes have been added on many of the excerpts of maps and sections shown in this bulletin.

\section{Nomenclature}

The rules of the International Stratigraphic Guide (Murphy \& Salvador 1999) state that the spelling of a name of an established stratigraphic unit must not be changed even if the spelling of the place name has changed. Therefore, the old spelling of some units is maintained, e.g. of the Kûgánguaq Member although the name of the valley is now spelled Kuugannguaq.

For naming of the igneous rocks we use the conventional chemical classification of Le Maitre (2002), based on the total-alkali - silica (TAS) diagram. Picrites have $\mathrm{MgO} \geq 12 \mathrm{wt} \%$; for those with $12-15 \mathrm{wt} \% \mathrm{MgO}$ we may use the term 'olivine-poor picrites' because in the field their olivine phenocrysts are much less prominent. We use 'magnesian basalts' for basalts with $10-12 \mathrm{wt} \% \mathrm{MgO}$ which are usually visibly olivine-phyric. We use 'silicic basalts' for basalts which are crustally contaminated but have $\mathrm{SiO}_{2}<52 \mathrm{wt} \%$ (the boundary to basaltic andesites), because uncontaminated basalts in the Nuussuaq Basin rarely have more than $50 \mathrm{wt} \% \mathrm{SiO}_{2}$. It should be noted that the silicic rocks in West Greenland are quite distinct from orogenic rocks with the same TAS names. The basaltic andesites and andesites in West Greenland have much higher contents of $\mathrm{MgO}$ and $\mathrm{Cr}$ than their orogenic namesakes, and 'magnesian basaltic andesite' and 'magnesian andesite' are appropriate but cumbersome names.

The lithological terms 'hyaloclastite' and 'pillow breccia' are frequently used synonymously. Following White $\&$ Houghton (2006) we use hyaloclastite as a general term to denote primary clastic subaqueous volcanic deposits. However, we frequently use pillow breccia for coarse, clast-rich deposits even though these may include finer-grained, clast-poor parts. The term 'volcaniclastic' is used as a nongenetic term to denote any clastic deposit with a large component of volcanic material, including both primary volcanic and nonvolcanic deposits such as mass flows and other redeposited sediments.

\section{Geological sections and profiles}

In the descriptions in this bulletin, we frequently refer to the five published, photogrammetrically interpreted, long geological sections across the Nuussuaq Basin. To ease the reading, they will usually be referred to in short form as follows:

"North Nuussuaq section" (Pedersen et al. 2006a).

"Central Nuussuaq section" (Pedersen et al. 2002a).

"South Nuussuaq section" (Pedersen et al. 1993).

"Central Disko section" (Pedersen et al. 2005).

"South Disko section" (Pedersen et al. 2003).

Each of these $82-131 \mathrm{~km}$ long sections possesses a horizontal distance scale along its base with its origin at the westernmost, left end of the section. The excerpts shown here include the relevant parts of these distance scales; an expression such as "at $9-10 \mathrm{~km}$ " indicates a location 9-10 km from the left end of the original section.

'Profiles' are local, visited, measured and sampled sections, usually on mountain sides, and are presented in diagrams as vertical columns. The profiles constitute the basis for the definitions and correlations of the volcanic succession. The lithostratigraphic type and reference sections are illustrated by their corresponding profiles. 


\section{West Greenland Basalt Group}

The Tertiary volcanic rocks in West Greenland are all included in the West Greenland Basalt Group defined by Hald \& Pedersen (1975). The present work does not involve any revision of the original definition of the Group as such. Hald \& Pedersen (1975) defined three formations in the West Greenland Basalt Group, the Vaigat Formation, the Maligât Formation and the Hareøen Formation. The volcanic succession on Disko and Nuussuaq (and Hareøen) east of the Itilli Fault (Fig. 4) comprises the Vaigat Formation and the revised Maligât Formation and is all of Paleocene age.

\section{Summary of the petrology of the Vaigat and Maligât formations}

The petrology of the Vaigat and Maligât formations was presented by Larsen \& Pedersen (2009), and their conclusions are summarised below. Figures 7 and 8 show overview chemostratigraphic diagrams for the whole succession described here and in Pedersen et al. (2018).

The primary magmas for both formations were highly magnesian, picritic, with at least $16.6 \mathrm{wt} \% \mathrm{MgO}$. Melting in the asthenosphere took place in garnet facies because the melting column was curtailed by the $100 \mathrm{~km}$ thick lithosphere. The Vaigat Formation magmas fractionated olivine in the feeder channels before eruption but generally did not stop in magma chambers. Only minor magma batches stopped in high-level magma chambers where many of them became crustally contaminated. At the time of transition to the Maligât Formation, large, long-lived magma chambers developed, presumably in the lower crust. The Maligât Formation basalts have compositions buffered by magma chamber processes; large-scale cyclicity can be seen, with more and less fractionated steady-state compositions. The lower part of the Maligât Formation is not crustally contaminated whereas the upper part is contaminated throughout. Repeated pulses of new picritic magmas can be identified in both formations.

The $\mathrm{Sr}, \mathrm{Nd}$ and $\mathrm{Pb}$ isotope data show that the asthenospheric mantle source was heterogeneous and the dominant component was depleted, MORB-like mantle with $\mathrm{Nb} / \mathrm{La}<1$. An additional, less depleted mantle component akin to the Iceland source is evident in the upper Vaigat Formation (Ordlingassoq Member) but disappeared again at the transition to the Maligât Formation. An incompatible-element-rich lithospheric mantle component is seen in the Manitdlat Member of alkaline picrites and basalts. Single scattered tholeiitic lavas somewhat enriched in the same trace elements are considered to be slightly contaminated with this component. The volume of these rocks is diminutive.

In the Vaigat Formation, crustal contamination was episodic within the short-lived high-level magma chambers in the sedimentary succession. In the upper members of the Maligât Formation, weak contamination was continuous in the deep, long-lived magma chambers whereas additional episodes of strong contamination took place in local high-level, subvolcanic magma chambers. The dominant contaminants are the sediments in the Nuussuaq Basin. The contamination processes included bulk assimilation, inmixing of partial melts of the sediments, AFC processes and exchange reactions. When carbonrich mudstones were assimilated, severe reduction led to formation of graphite or metallic iron. All rocks more evolved than basalt arose by contamination processes. 

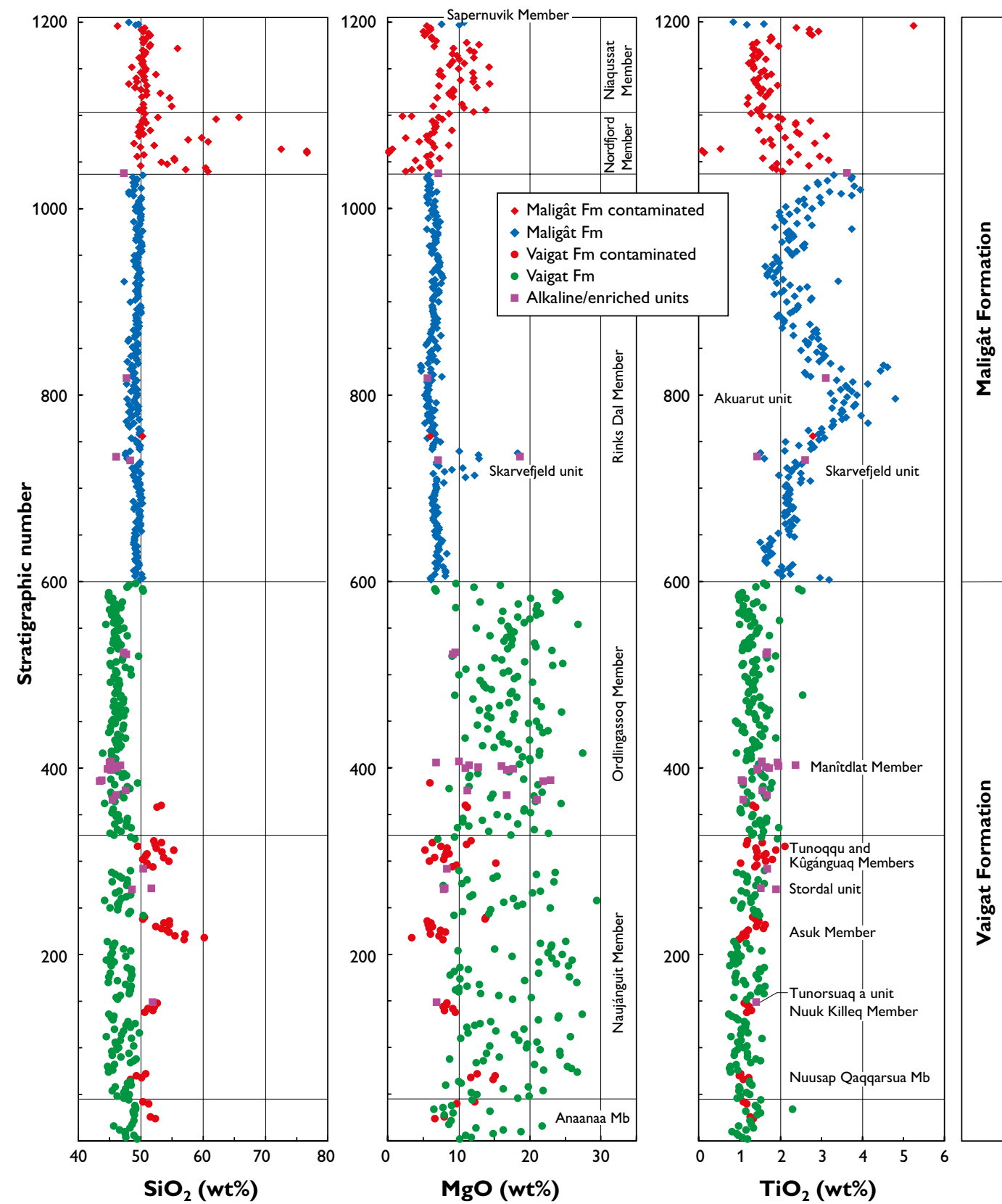

Fig. 7. Selected major-element chemostratigraphy of the Vaigat and Maligât Formations on Disko and Nuussuaq, based on a subset of 1200 samples (600 for each formation) arranged in stratigraphic order (the $y$ axis). The numbers of samples of each unit approximately reflect their volume proportions except for the Nordfjord Member which is overrepresented. Modified from Larsen \& Pedersen (2009). Compare the stratigraphy with Fig. 6. 

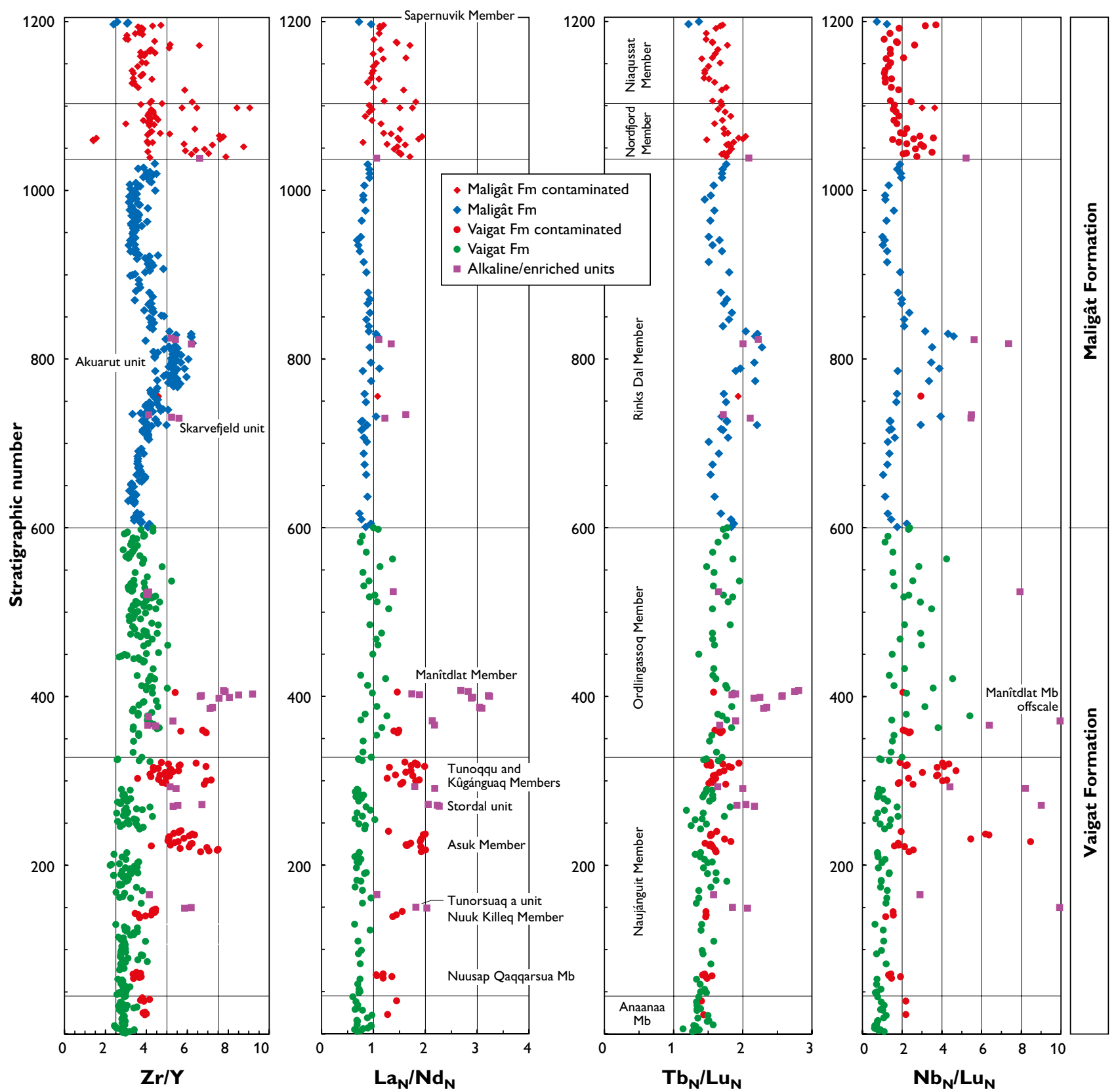

Fig. 8. Chemostratigraphy of some trace-element ratios in the Vaigat and Maligât Formations on Disko and Nuussuaq. See caption to Fig. 7. La/ $\mathrm{Nd}$ is shown instead of the more common $\mathrm{La} / \mathrm{Sm}$ because the REE patterns have maxima at $\mathrm{Nd}$. La/ $\mathrm{Nd}$ and $\mathrm{Tb} / \mathrm{Lu}$ are chondrite normalised and $\mathrm{Nb} / \mathrm{Lu}$ (a measure of the steepness of the multi-element patterns) is primitive mantle normalised. Normalisation factors from McDonough \& Sun (1995). Modified from Larsen \& Pedersen (2009). 


\section{Vaigat Formation}

The Vaigat Formation was formed during three major episodes of volcanic activity that gave rise to the three major members, the Anaanaa, Naujánguit and Ordlingassoq members, which are all dominated by picritic rocks. However, the succession also contains a number of lesser volcanic units that are discernible chemically and usually also lithologically. In the field, these units form brown marker horizons of lava flows and hyaloclastites interspersed with the normal grey picritic lavas and hyaloclastites. The brown colours vary from just discernible to distinctly rusty in units carrying native iron and sulfides. Chemically, most of the brown units consist of silicic basalts to magnesian andesites formed by reaction between picrite magmas and sediments. The first and second episodes of activity both ended with widespread crustal contamination, and contaminated units are most frequent in the products of the second episode (Figs 6-8; also Table 8). The Ordlingassoq Member is only sporadically crustally contaminated and consequently less subdivided; only in the Stordal area a small group of flows are strongly contaminated and even native-iron-bearing (unit 451 in Table 1). The brown lavas of the Manitdlat Member are not crustally contaminated but alkaline (Larsen et al. 2003).

The largest and most extensive and complex of the brown units have been assigned formal member status (Fig. 6). However, some of the brown units are small and local and in places less well delimited and are kept as informal units within the major members. The complete subdivision of the Vaigat Formation is shown in Table 1 together with the unit and sample codes for the formation.

The distribution of the three main members of the Vaigat Formation is shown in Fig. 9, and the distribution of the minor members and some local units is shown in Figs 10-12. The distribution maps also show the locations of a number of important profiles through the Vaigat Formation which are illustrated in Figs 13-17. Due to the lateral variability of the Vaigat Formation, the depicted profiles comprise only short of half the number of analysed samples; many short profiles and single samples cannot be shown.

All chemical analyses of rocks from the Vaigat Formation are available in a supplementary data file at: www. geus.dk/UK/publications/geol-survey-dk-gl-bull/39.

\section{Lithostratigraphy of the Vaigat Formation}

Revised formation

History. The Vaigat Formation was defined by Hald \& Pedersen (1975) and was subdivided into members on Disko by Pedersen (1985a). The revised lithostratigraphy presented here builds on this work and expands it to cover Nuussuaq, where some of the members defined on Disko are also present, together with new members, including the oldest known parts of the formation on western Nuussuaq.

Name. From the Vaigat strait (Sullorsuaq) between Disko and Nuussuaq (Fig. 4).

Distribution. The Vaigat Formation extends S-N over $c$. $260 \mathrm{~km}$ from central Disko and Hareøen east of the Itilli Fault through central Nuussuaq, Ubekendt Ejland and eastern Svartenhuk Halvø to southernmost Innerit (Fig. 2). Its delimitations to the south, east and north are depositional (exposure-determined on Ubekendt Ejland), whereas to the west the formation is concealed beneath the younger basalts. It is expected to continue westwards on the shelf (Larsen et al. 2016).

Type section. The type section is composite and consists of the two drill cores GANW\# 1 and Marraat-1 (Fig. 13, profiles 1,2) that cover the Anaanaa Member; Anaanaa south (Fig. 13, profile 4) that covers the lowest Naujánguit Member (all on western Nuussuaq); Kuugannguup Innartaa and Norddalen (Fig. 16, profiles 23, 24, 27) that cover the main part of the Naujánguit Member and all of the Ordlingassoq member including the upper boundary to the Maligât Formation (all on northern Disko). Locations in Fig. 5.

Profiles 23, 24, 27 are those originally designated type sections by Hald \& Pedersen (1975). The section in the Norddalen valley was then called Manîtdlat kugssinerssuat after the mouth of the river in Norddalen, but as the section is located in Norddalen, the name is changed here.

Reference sections. Qunnilik West (Fig. 13, profile 9); Tunorsuaq, Aaffarsuaq (Fig. 14, profiles 12, 15); Ametyst- 
skrænten, Orlingasoq (Fig. 16, profiles 25, 28); Niaqua (Fig. 17, profile 30). Locations in Fig. 5.

Thickness. The Vaigat Formation forms an elongate, shield-shaped deposit that tapers to the south, east and north and is thickest in its central parts. The thickness varies from 0 to $1.6 \mathrm{~km}$ on Disko and Nuussuaq, exceeds $5 \mathrm{~km}$ on Ubekendt Ejland and varies from more than 2.5 $\mathrm{km}$ to $0 \mathrm{~km}$ on Svartenhuk Halvø and Innerit.

Lithologies. The main lithologies of the Vaigat Formation comprise thin subaerial pahoehoe lava flows and associated hyaloclastites produced when the lavas flowed into water or were erupted under water. Many eruption sites are known, both subaerial and subaqueous. Uncontaminated rocks dominate and comprise grey picrites and olivine-phyric or aphyric basalts. The crustally contaminated rocks are mainly brown aphyric silicic basalts, magnesian basaltic andesites and magnesian andesites. Rocks with graphite and native iron occur in the Asuk and Ordlingassoq members.

Subdivisions. Based on lithologies and chemical compositions, the Vaigat Formation is subdivided into three major and seven minor members; a number of small informal units are included in the major members. The major Anaanaa, Naujánguit and Ordlingassoq members are dominated by grey picrites, whereas the minor Nuusap Qaqqarsua, Nuuk Killeq, Asuk, Tunoqqu, Kûgánguaq and Qordlortorssuaq members are dominated by brown basalts and basaltic andesites, and the Manîtdlat Member by alkali picrites and basalts (Fig. 6; Table 1).

Boundaries. The Vaigat Formation rests mainly on the Cretaceous and Tertiary sediments of the Nuussuaq Basin, but on Precambrian gneiss on central Disko and east of the eastern boundary fault on northern Nuussuaq and on Svartenhuk Halvø. The boundary between the sediments and the volcanic rocks is diachronous, younging towards the east. The boundary is frequently obscured by scree and landslides, e.g. along the Vaigat coasts. The lower boundary is below the level of exposure on Disko and Nuussuaq west of the Kuugannguaq-Qunnilik fault zone (Fig. 4), on Ubekendt Ejland and the south coast of Svartenhuk Halvø (Fig. 4).

At its upper boundary, the Vaigat Formation is overlain by the basalt lava flows of the Maligât Formation on Disko and Nuussuaq and those of the Svartenhuk Formation on Ubekendt Ejland and Svartenhuk Halvø. Over

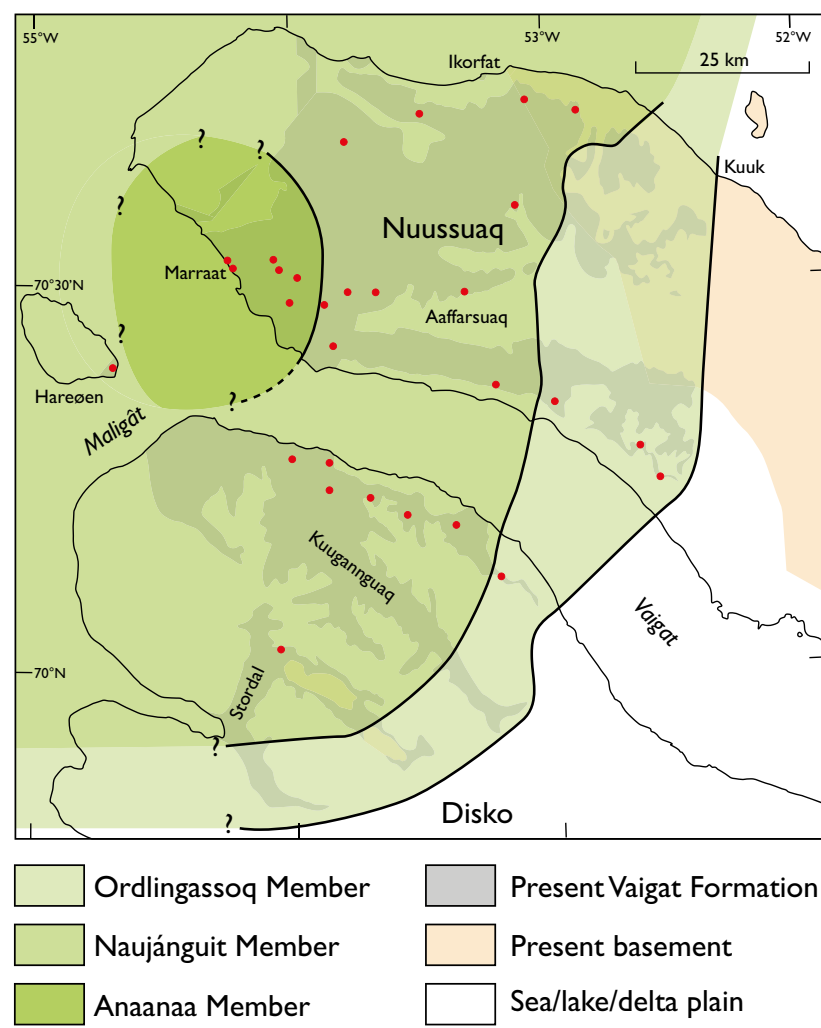

Fig. 9. Distribution of the three main members of the Vaigat Formation, showing the eastward and southward progression of the successive members. Note that in the area with the Anaanaa Member the Naujánguit and Ordlingassoq Members are also present, and in the area with the Naujánguit Member the Ordlingassoq Member is also present. Whereas the eastern and southern limits of the Vaigat Formation are well determined, the delimitations to the west and north are undetermined. The exposed succession on Hareøen comprises the Naujánguit and Ordlingassoq Members, indicating a significant extension to the west. Red dots show the locations of profiles illustrated in Figs 13-17 and subsequent figures.

large parts of Nuussuaq and eastern Svartenhuk Halvø the upper boundary is erosional.

Age. Paleocene, 62-61 Ma, magnetochrons C27n and C26r, based on radiometric dating (Storey et al. 1998; Larsen et al. 2016) and palaeomagnetic results (Riisager \& Abrahamsen 1999).

Correlation. Correlation to Hareøen is well established (Fig. 17). Correlation across the Itilli Fault to western Nuussuaq is not established. Correlation to Ubekendt Ejland and Svartenhuk Halvø is inferred (Larsen $e t$ al. 2016). 

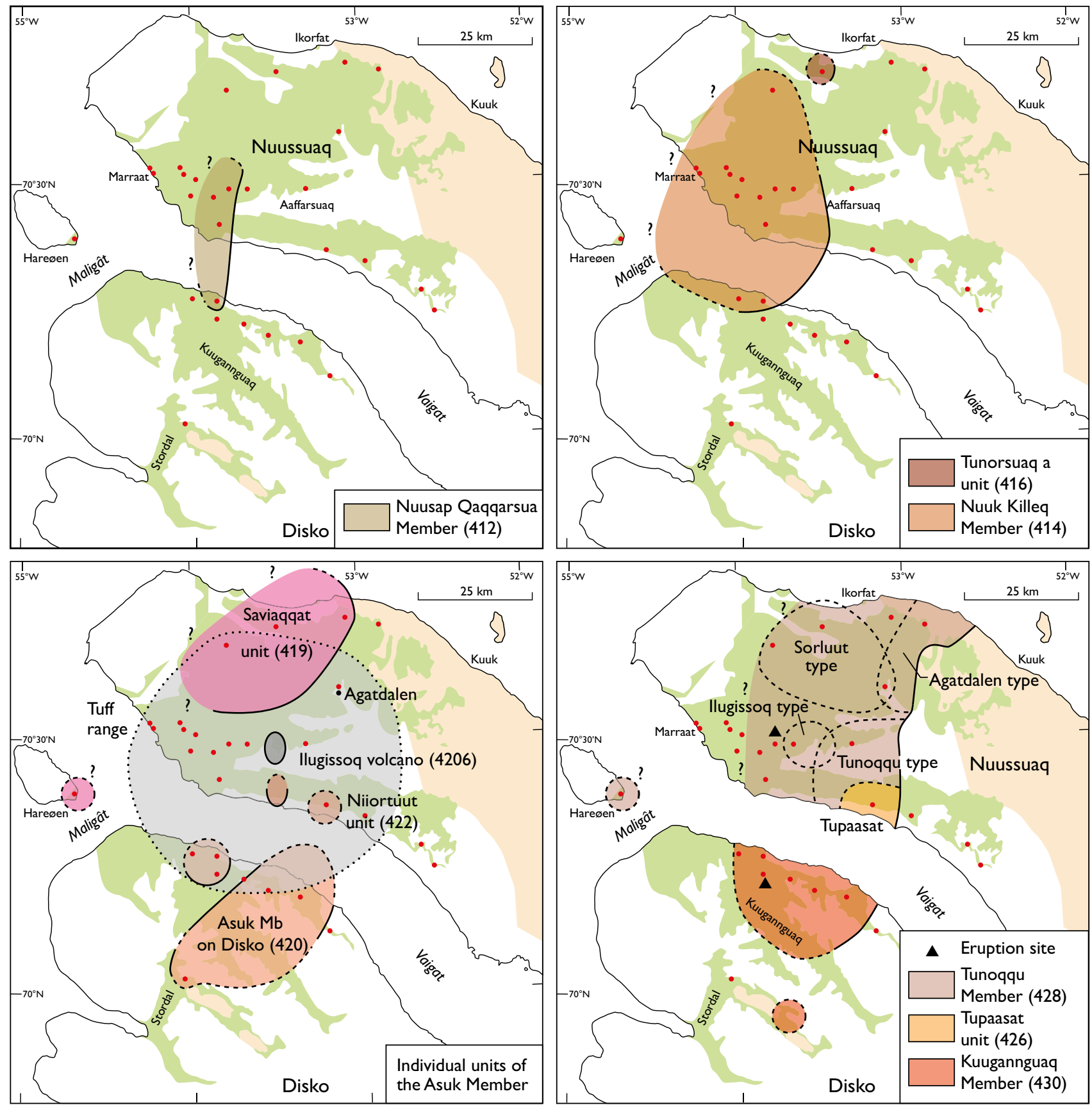

Fig. 10. Distribution of the crustally contaminated members and units of the Vaigat Formation. Numbers in parentheses are the numerical codes for the units (Table 1). Dashed outlines are inferred, whereas no outlines with question marks indicate lack of information. The range of airfall tuffs from the Ilugissoq volcano is shown with dotted outline. For the Tunoqqu Member the approximate extents of four different petrographic types, inferred to represent four individual eruption centres, are shown with dashed outlines. The red dots show the locations of profiles illustrated in Figs. 13-17. 

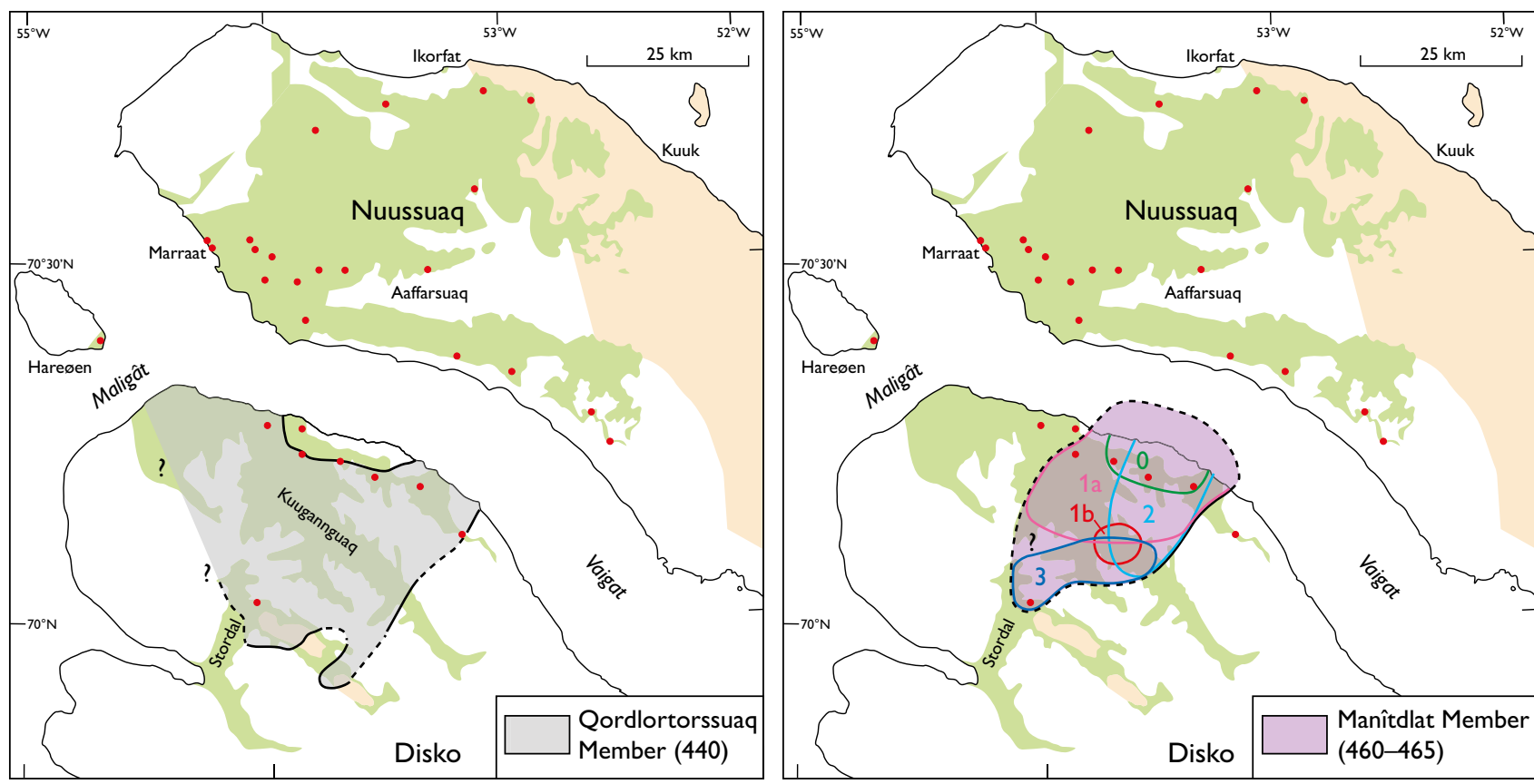

Fig. 11. Distribution of two minor uncontaminated members of the Vaigat Formation. In the Manitdlat Member diagram, the tentative distribution of the alkaline chemical types $0,1 \mathrm{a}, 1 \mathrm{~b}, 2$ and 3 described in the text is shown with coloured outlines. For other explanations, see Fig. 10.

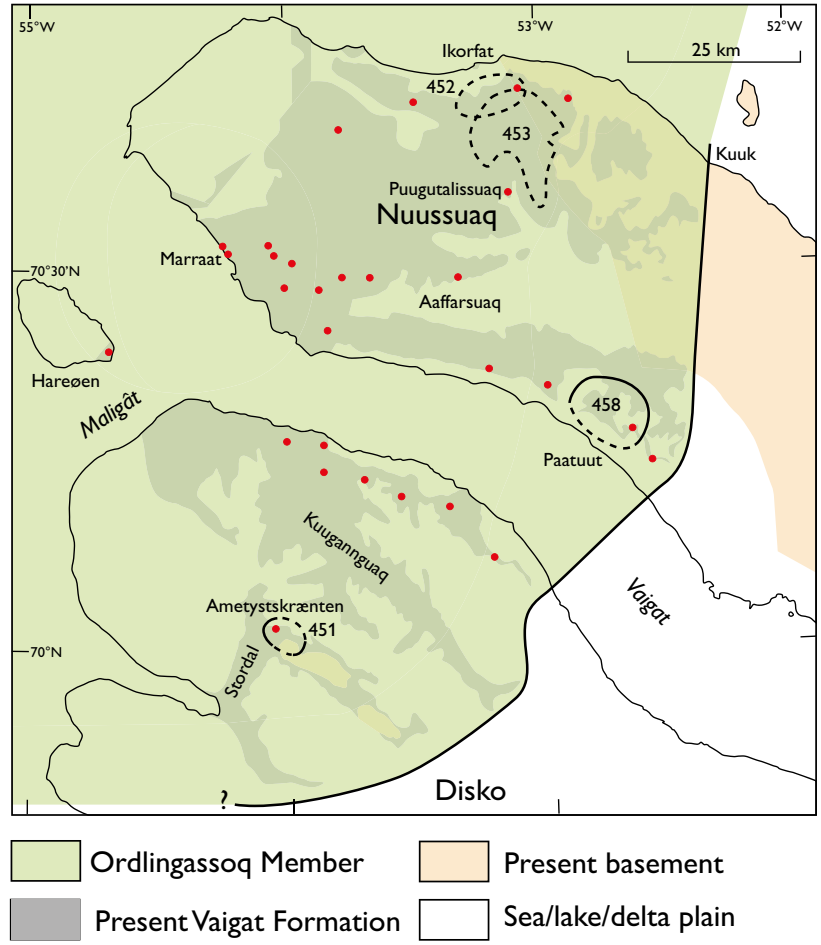

Fig. 12. Distribution of four small local units in the Ordlingassoq Member. Unit 451 comprises the contaminated lavas in the Stordal area. Units 452 and 453 are respectively the lower and upper brown markers on Nuussuaq, and unit 458 comprises plagioclase-phyric basalts near the top of the Vaigat Formation. For other explanations, see Fig. 10.
Pages 30-31:

Fig. 13. Profiles through the Vaigat Formation on south-western Nuussuaq. The vertical scales are altitude ( $m$ a.s.l.) for the surface profiles and depth below surface for the drill cores (profiles 1, 2, $6,7)$. As the succession in the GANW\#1 and Marraat-1 wells dips $20^{\circ} \mathrm{E}$, a conversion factor of 0.94 must be applied if thicknesses are required. Sample numbers are shown to the right of the columns; samples in the drill cores are sub-numbers of the GGU-numbers shown above the cores. Blue three-digit numbers are member/unit codes (see Table 1). Other explanations in the legend, which covers all figures with profiles through the Vaigat Formation. The profiles are located with numbered dots on the index map and in Fig. 5. 


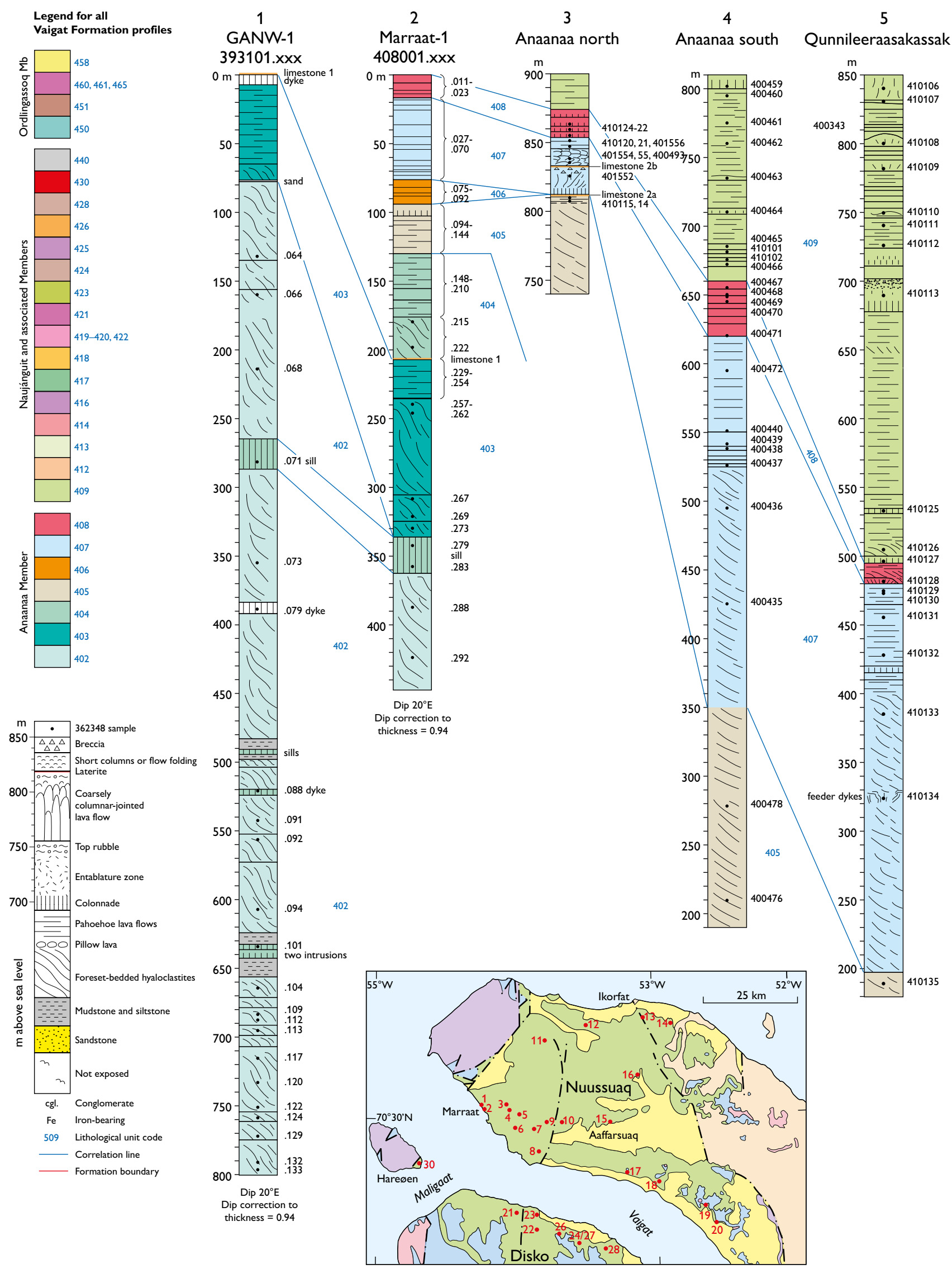




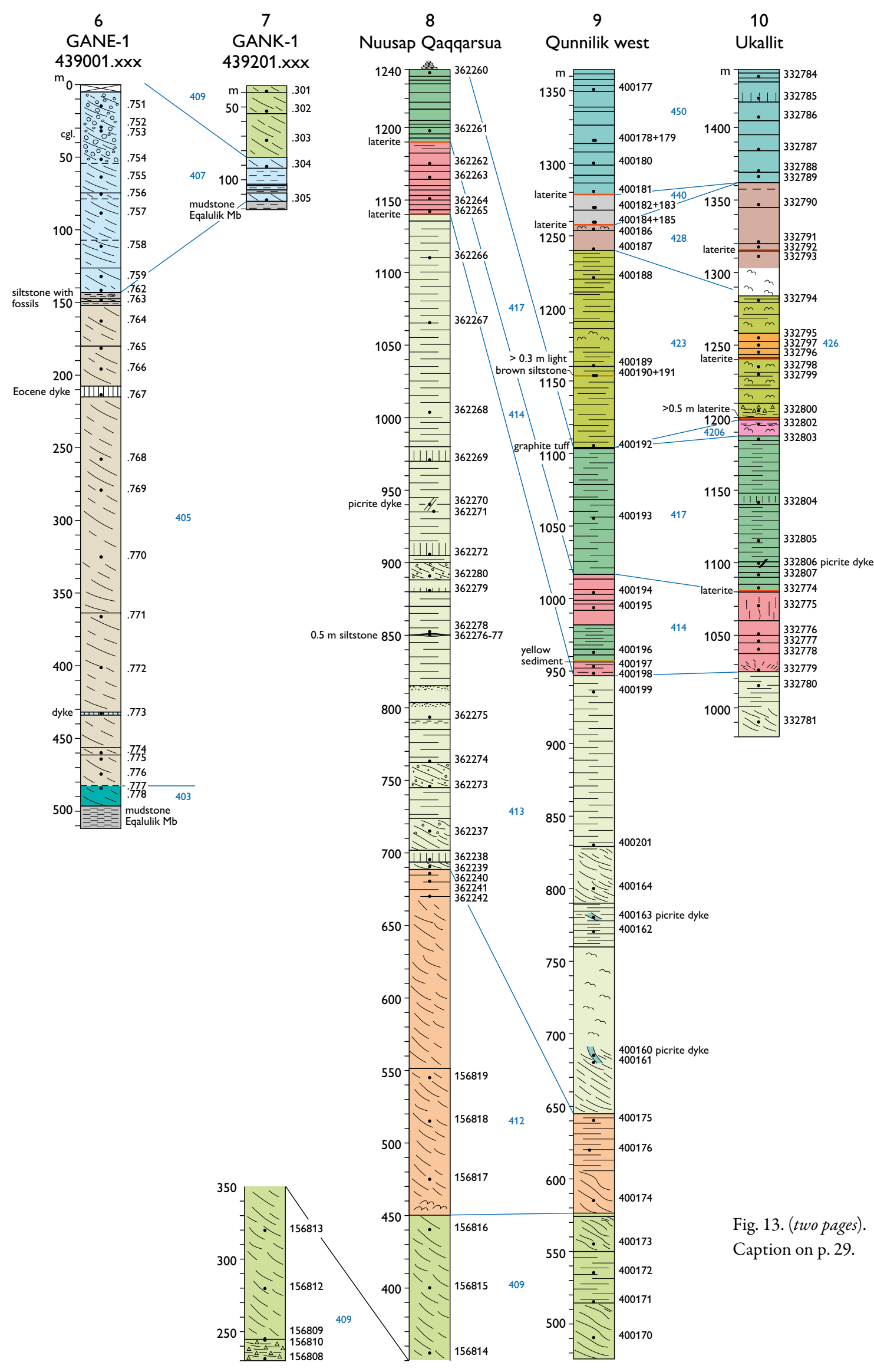



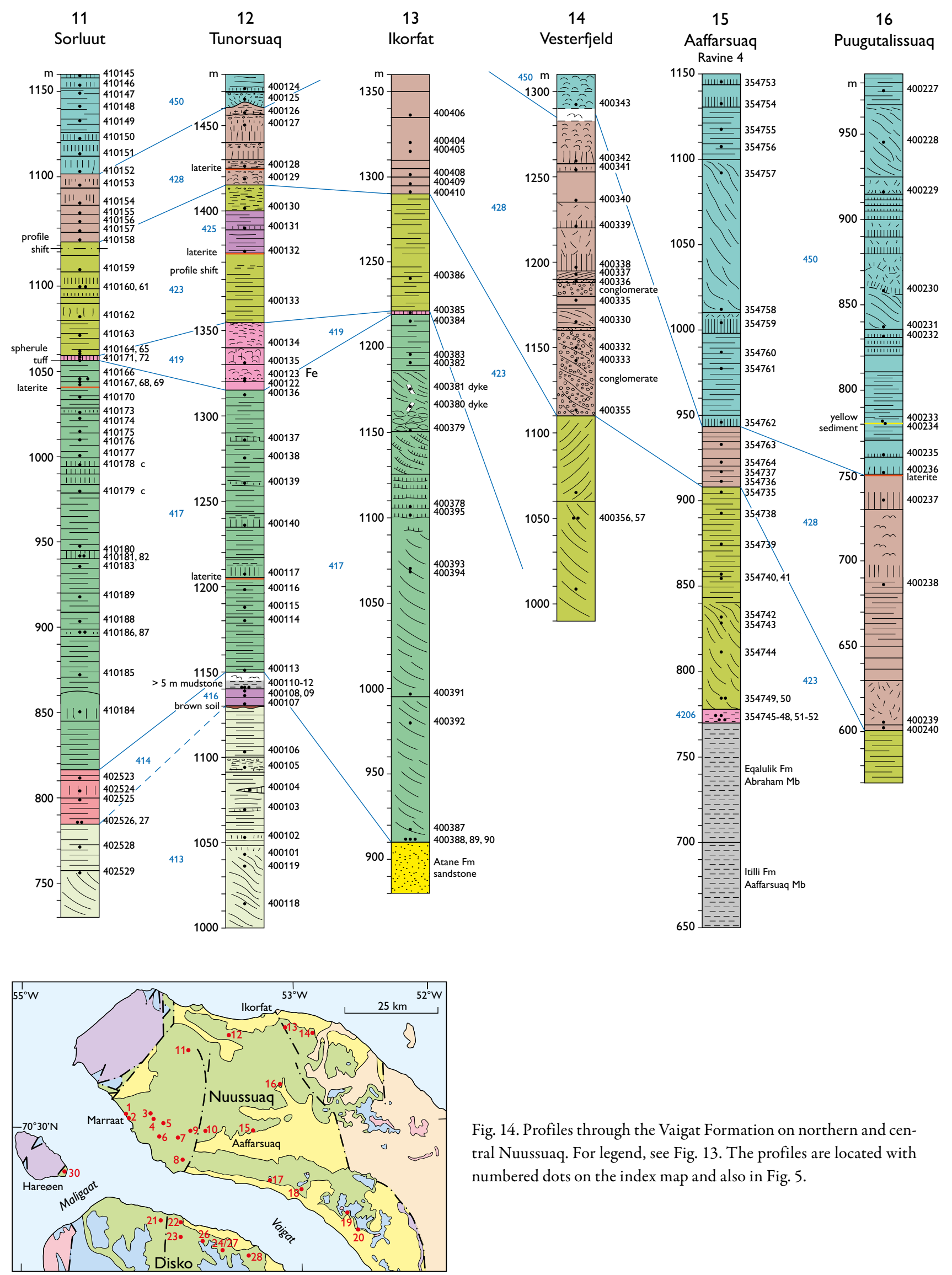

Fig. 14. Profiles through the Vaigat Formation on northern and central Nuussuaq. For legend, see Fig. 13. The profiles are located with numbered dots on the index map and also in Fig. 5. 


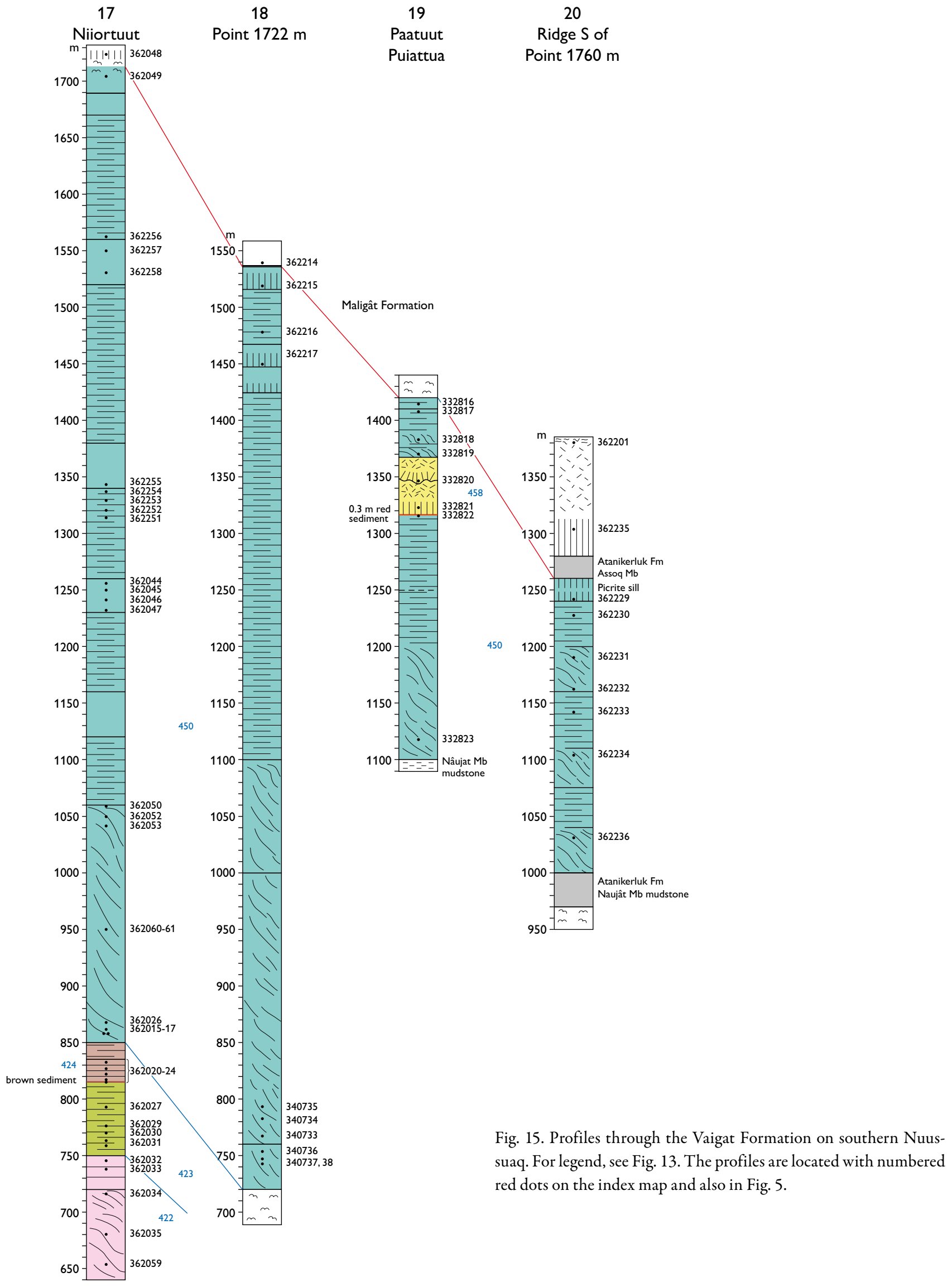




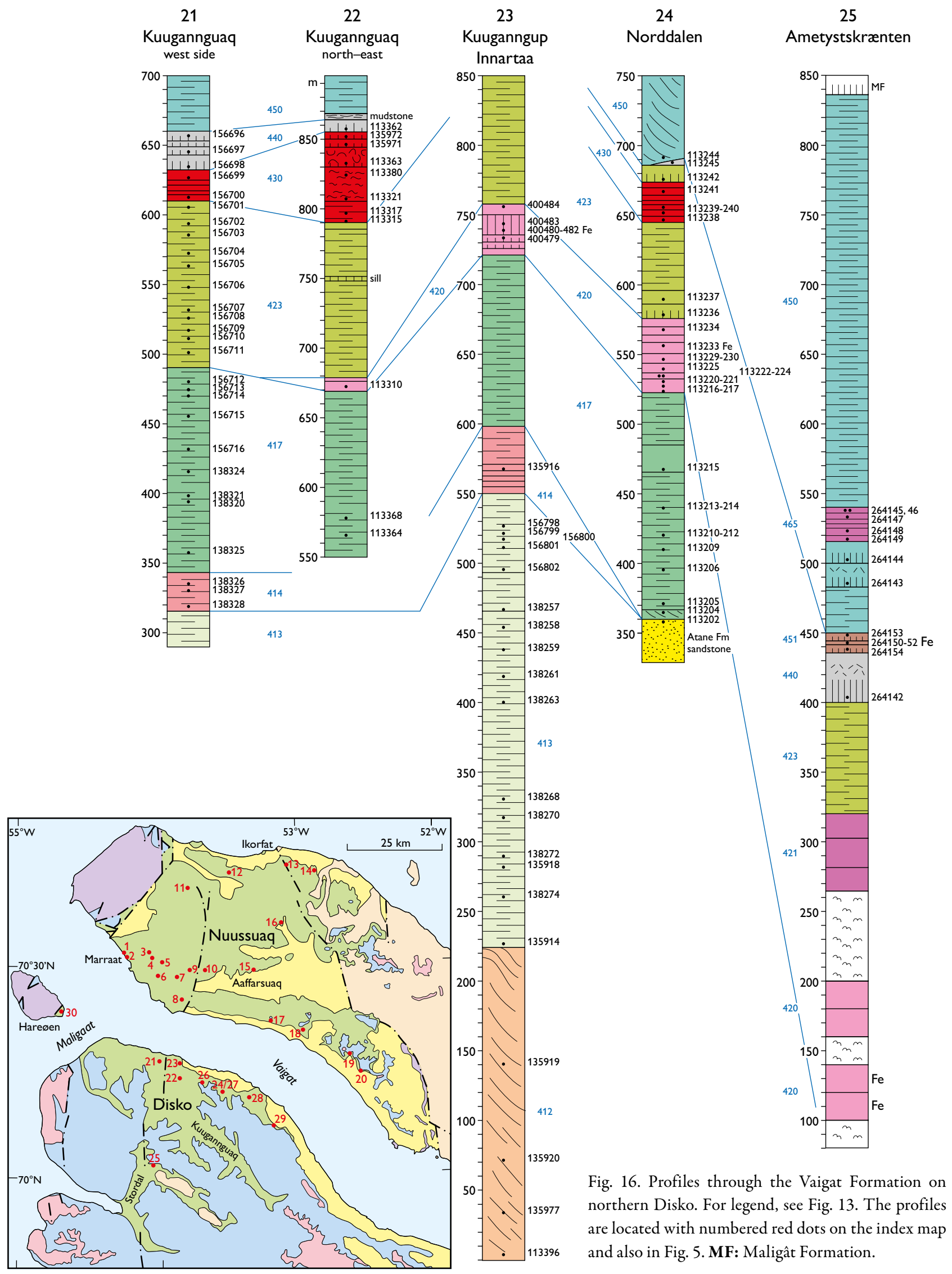


26

Kussinikassak

1500

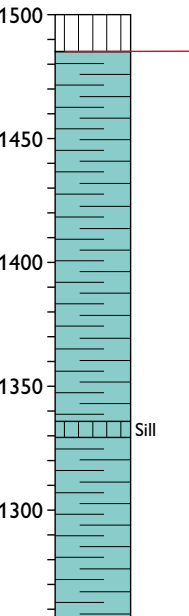

1250

12

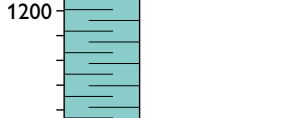

11

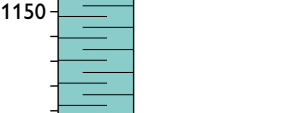

1100

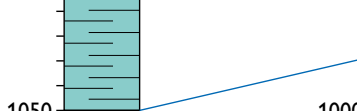

1050
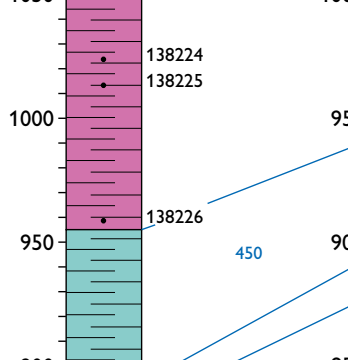

900

50
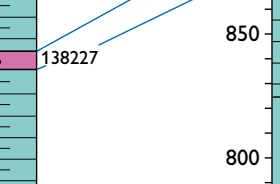

Norddalen

rlingasoq

$1200+136974$

${ }^{1450}$ ] III

$=$

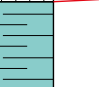

-

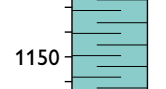

$1100=$
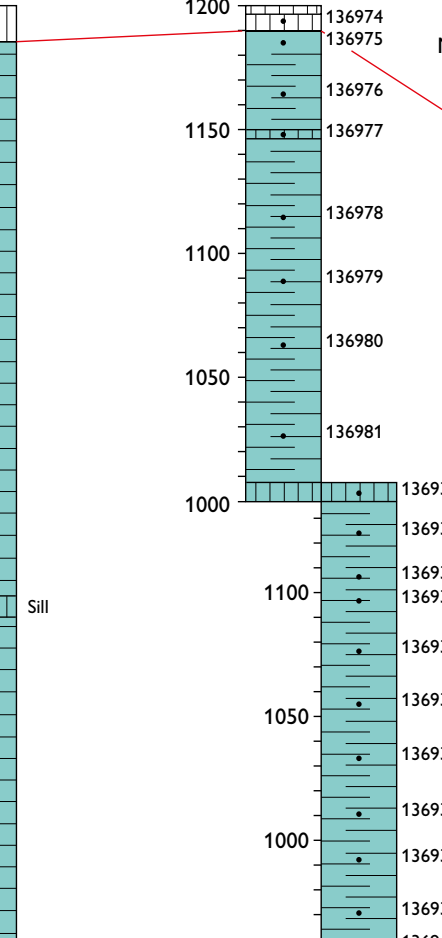

136979

0

136980

1000

136981

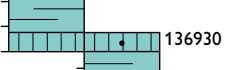

$1100-\frac{\cdot}{-} 136932$

1050
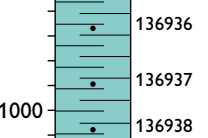

36939

36940
36941

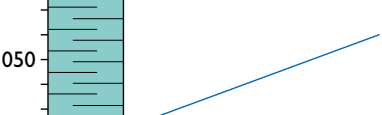

-
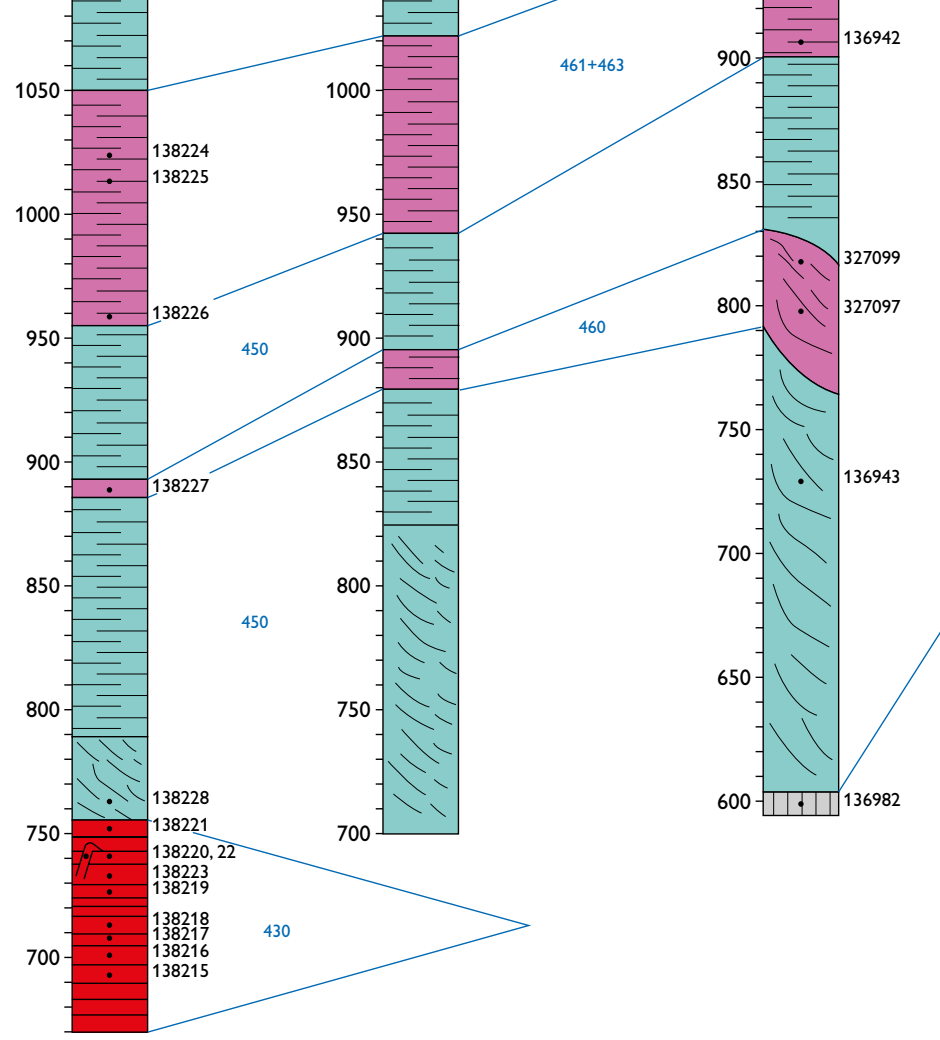

750

$800-$

450

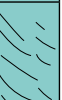

$\sqrt{1}$

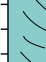

$50-$
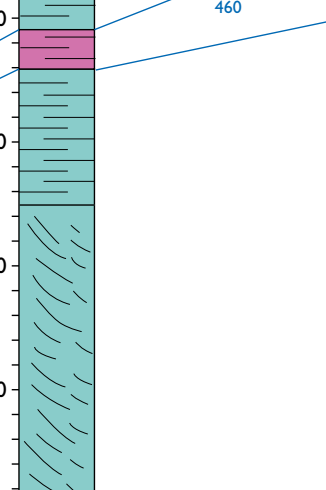

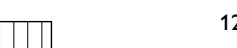

1200 \begin{tabular}{|l|l|l|l|l|l|l|l}
\hline & sil
\end{tabular}
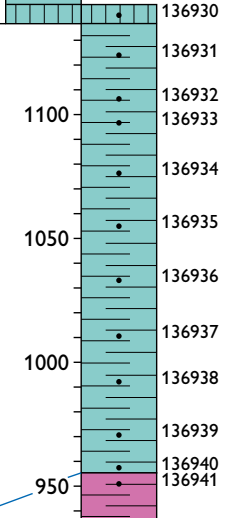

29

Peak 1100 m

$\mathrm{m} \underset{\approx 0}{\approx} \approx$

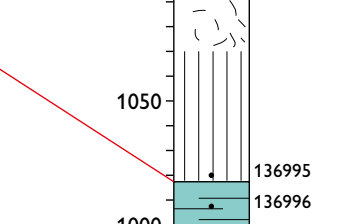

000

-

800

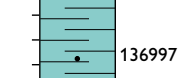

750

450

550 Nâujat Mb mud-
stone and tuffs
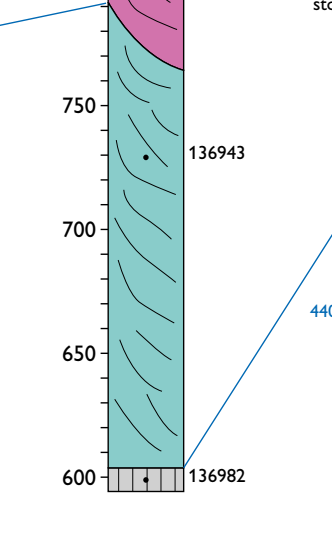

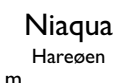

m

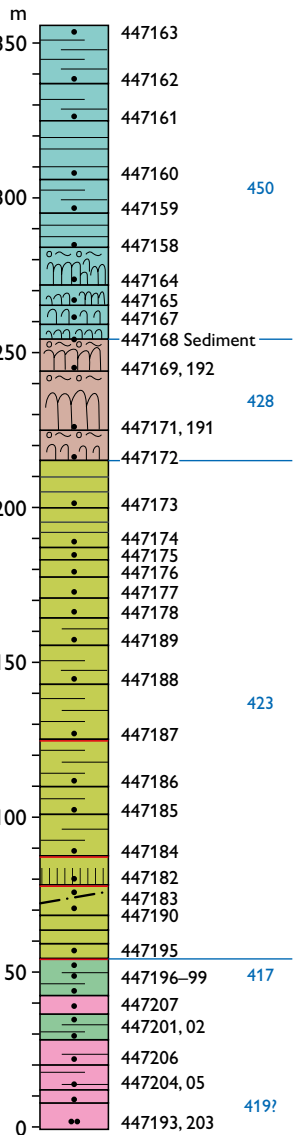

Fig. 17. Profile through the Vaigat Formation on Hareøen. The vertical scale gives photogrammetrically measured thicknesses in the strongly tilted succession (Fig. 131). For legend, see Fig. 13. The profile is located on the index maps in Figs 13-16 and also in Fig. 5. 


\section{First volcanic episode: Anaanaa Member}

\section{Summary of the main features of the Anaanaa Member}

- Oldest exposed volcanic rocks in the Nuussuaq Basin, only present on western Nuussuaq.

- Older part dominated by submarine picritic hyaloclastites; subaerial lava flows form subsided palaeoislands. Younger part dominated by basaltic lavas and foreset-bedded hyaloclastites with mass flows; large synvolcanic vertical movements.

- Normally magnetised, magnetochron C27n.

- Pattern of eastward progradation of thick foreset-bedded hyaloclastites established.

- Submarine eruption sites are widespread.

- Two basalt units, including the youngest, are crustally contaminated, but no crustal xenoliths are found.

- Economic geology: Migrated oil of the Marraat type is widespread in basalt lavas, mass flows and conglomerates. Oil of the Eqaluit type is rare.

\section{Lithostratigraphy of the Anaanaa Member}

New member

History. The name Anaanaa Member was introduced, with the same meaning as here, in 1996 after core drillings on western Nuussuaq were completed and the stratigraphy of the succession established. The name has since been used in several articles and reports as well as in the Central Nuussuaq section (Pedersen et al. 2002a) and the geological map of the area around Sikillingi, western Nuussuaq (Pedersen et al. 2008).

Name. After the mountain knoll Anaanaa (714 m), $4 \mathrm{~km}$ north of the central river in the Aaffarsuaq valley, western Nuussuaq (Fig. 18).

Distribution. The Anaanaa Member is only found within an area of $c .180 \mathrm{~km}^{2}$ on western Nuussuaq south-east of the Itilli Fault (Figs 9, 18). It is impossible to know if it is present, deeply buried, north-west of the fault. Its southwestern extent is determined by the present coastline, but it almost certainly continues on the shelf. Its eastern and south-eastern limits are depositional.
Type section. The drill cores GANW\# $\mathbf{1}$ and Marraat-1 from the coast of western Nuussuaq (Fig. 13, profiles 1,2; detailed profiles are also shown in Pedersen et al. 2008).

Reference sections. Anaanaa north, Anaanaa south, GANE\# 1 drill core and GANK\# 1 drill core (Fig. 13, profiles 3, 4, 6, 7; see also drill core logs in Pedersen et al. 2008). Locations in Figs 5, 18.

Thickness. Up to $1000 \mathrm{~m}$ in the combined drill cores GANW\# 1 and Marraat-1. Thins towards east and north. Thicknesses of individual units vary considerably with the volcanic facies (Fig. 19).

Lithology. Picrites and olivine-phyric basalts followed by aphyric and plagioclase-phyric basalts, some of which are crustally contaminated. The oldest unit is only known in subaqueous facies; most of the other units occur in both subaqueous and subaerial facies. Feeder dykes and submarine eruption sites are known. Subaqueous mass-flow deposits are widespread. Two thin horizons of marine fossiliferous limestone are present.

Subdivisions. The Anaanaa Member is subdivided into seven informal units based on lithology and chemostratigraphy (Table 1).

Boundaries. The lower boundary is mostly below the present level of exposure. Underlying sediments are exposed at the northern reaches of the Anaanaa Member, but the boundary is either faulted or covered by Quaternary deposits. The boundary is known from the drill cores GANE\# 1 and GANK\#1, where hyaloclastites of the Anaanaa Member rest on Paleocene sediments of the Eqalulik Formation. The mudstones in the upper part of the Eqalulik formation are interbedded with horizons of volcaniclastic material (Dam 1996; Dam et al. 2009).

The upper boundary is defined at the top of a series of brown, erosion-resistant lava flows and hyaloclastites of silicic basalt. These are conformably overlain by grey lava flows and hyaloclastites of the Naujánguit Member.

Age. Paleocene, Danian, nannoplankton zone NP4, 62.5-62.2 Ma, magnetochron C27n, based on the biostratigraphic age of the Eqalulik Formation (NøhrHansen et al. 2002), radiometric dating of the overlying 
parts of the Vaigat Formation (Storey et al. 1998; Larsen et al. 2016), and the normally magnetised character of the lava flows (Riisager \& Abrahamsen 1999).

Correlation. The Anaanaa Member is considered to be time-equivalent to the picrites on Cape Dyer, Baffin Island, Canada (Clarke 1970; Deutsch \& Kristjansson 1974; Starkey et al. 2009), based on the normally magnetised character of both successions and similarities in chemical compositions.

\section{Geology of the Anaanaa Member}

The Anaanaa Member comprises the oldest known volcanic rocks in the Nuussuaq Basin, produced during the first volcanic episode. It occurs in a limited area on western Nuussuaq which is strongly influenced by the proximity to the large Itilli fault zone, and the fact that the member is exposed at all is due to arching on this fault (Chalmers et al. 1999a). The area is intruded by dykes and sills (locally up to 5-10\% of the outcrop), fractured and faulted, and over large areas the rocks are hydrothermally altered and cut by veins. The area is also variably denuded and exposures are commonly poor. Moreover, a large part of the rocks are in hyaloclastite facies. In the Marraat Killiit area the succession is broken into a number of fault blocks by N-S- and NNW-SSE-trending, steeply dipping faults with downthrow to the west; the strata dip $14-26^{\circ} \mathrm{E}$, and there is considerable stratigraphic repetition between the fault blocks (Henderson 1975). It was only after the fully cored Marraat-1 well was drilled in 1993 that a repetition-free stratigraphy could be established. The likewise fully cored GANW\#1 well was drilled in 1994 in the same fault block as the Marraat-1 well; it extended the stratigraphy downwards and confirmed Henderson's (1975) observation that several hundred metres of volcaniclastic rocks (locally at least $700 \mathrm{~m}$ ) underlie the oldest lava flows. Because of the poorly exposed and fragmented character of the surface outcrops the two drill cores have been designated type sections for the Anaanaa Member. A new geological map on a scale of 1:100 000 of the area where the Anaanaa Member crops out is shown in Fig. 18.

Based on a combination of the drill cores, surface sample profiles and photogrammetry, the volcanic architecture of the Anaanaa Member has been reconstructed as shown in Fig. 19. This shows that the eastwards prograding, infilling pattern characteristic of the whole Vaigat Formation was established from the very beginning of the volcanism.
As the drilled strata in the Marraat-1 and GANW\#1 cores are inclined, the 'thicknesses' in the cores quoted in the following descriptions are measured intervals corrected by a factor $0.94\left(\cos 20^{\circ}\right.$, the average dip). Quotes of intervals such as "at 483-497 m depth" are directly measured intervals in the cores.

Migrated oil is widespread both in surface seeps and in drill cores (e.g. Pedersen et al. 2008). The oil types include the Marraat and Eqalulik types of which the Marraat type is dominant (Bojesen-Koefoed et al. 1999).

\section{Oldest picrites (unit 402)}

This unit forms hyaloclastites, pillow breccias and massflow deposits in most of the GANW\#1 core (at 76-800 $m$ depth) and in the lowest part of the Marraat- 1 core (at 362-448 m depth; Fig. 13). On the surface, the unit is only exposed along the west coast of Nuussuaq for a distance of about $3 \mathrm{~km}$ between Marraat Killiit and the Itilli valley (Fig. 18). The rocks are predominantly picrites and contain 10-20 wt $\%$ MgO.

In the GANW\# 1 core, about 17 hyaloclastite units can be recognised, interspersed with two intervals of volcaniclastic sediments interpreted to be turbidites (Christiansen et al. 1995b). Whereas very well-exposed, foresetbedded deposits can be used to infer the water depth of the marine embayment elsewhere within the Vaigat Formation (e.g. in the South Nuussuaq section), the lithologies in the GANW\# 1 core cannot be used to implicate an early basin depth in excess of $700 \mathrm{~m}$ because of the possibility of subsidence between eruptions. The largest minimum depth that can be inferred is $290 \mathrm{~m}$ for a thick depositional unit at $156-483 \mathrm{~m}$ depth (minus two intrusions) in the middle part of the core.

Several hyaloclastite units low in the succession, as well as several ones higher up, contain scattered indisputable fragments of vesiculated subaerial lava flows. This proves that even at this early stage of the volcanism, the submarine eruption products were able to build up to sea level and form emergent islands of subaerial lavas. As individual picrite eruptions were generally not very voluminous (e.g. Pedersen et al. 2002b), they were probably unable to build up to sea level from a water depth of more than $700 \mathrm{~m}$. This could indicate that the early volcanism took place in a relatively shallow marine basin and that the very thick hyaloclastite package representing unit 402 was accumulated through several phases of marked subsidence.

The two intervals of turbidites within the lower part of the GANW\# 1 core are of significance for the interpre- 


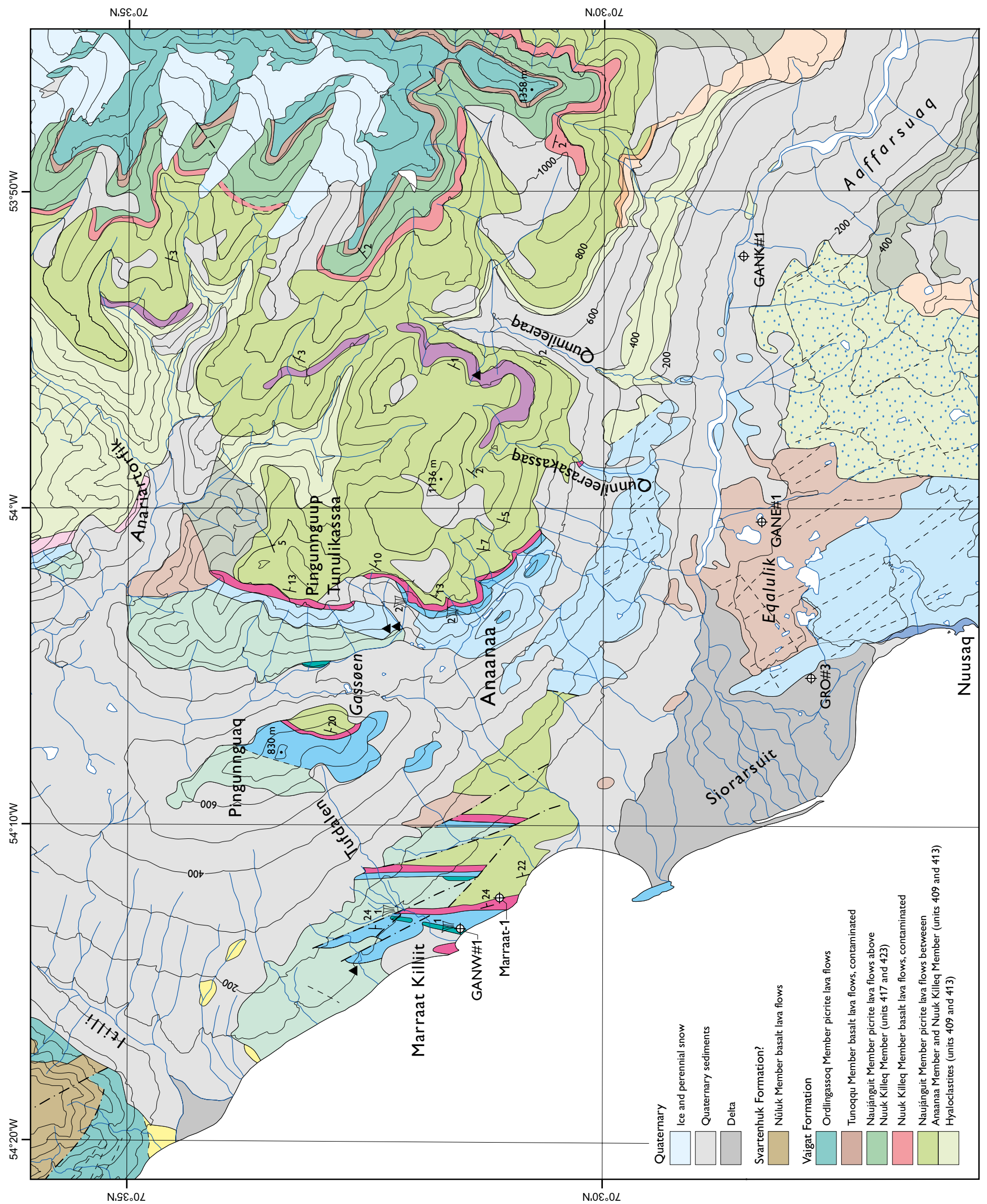




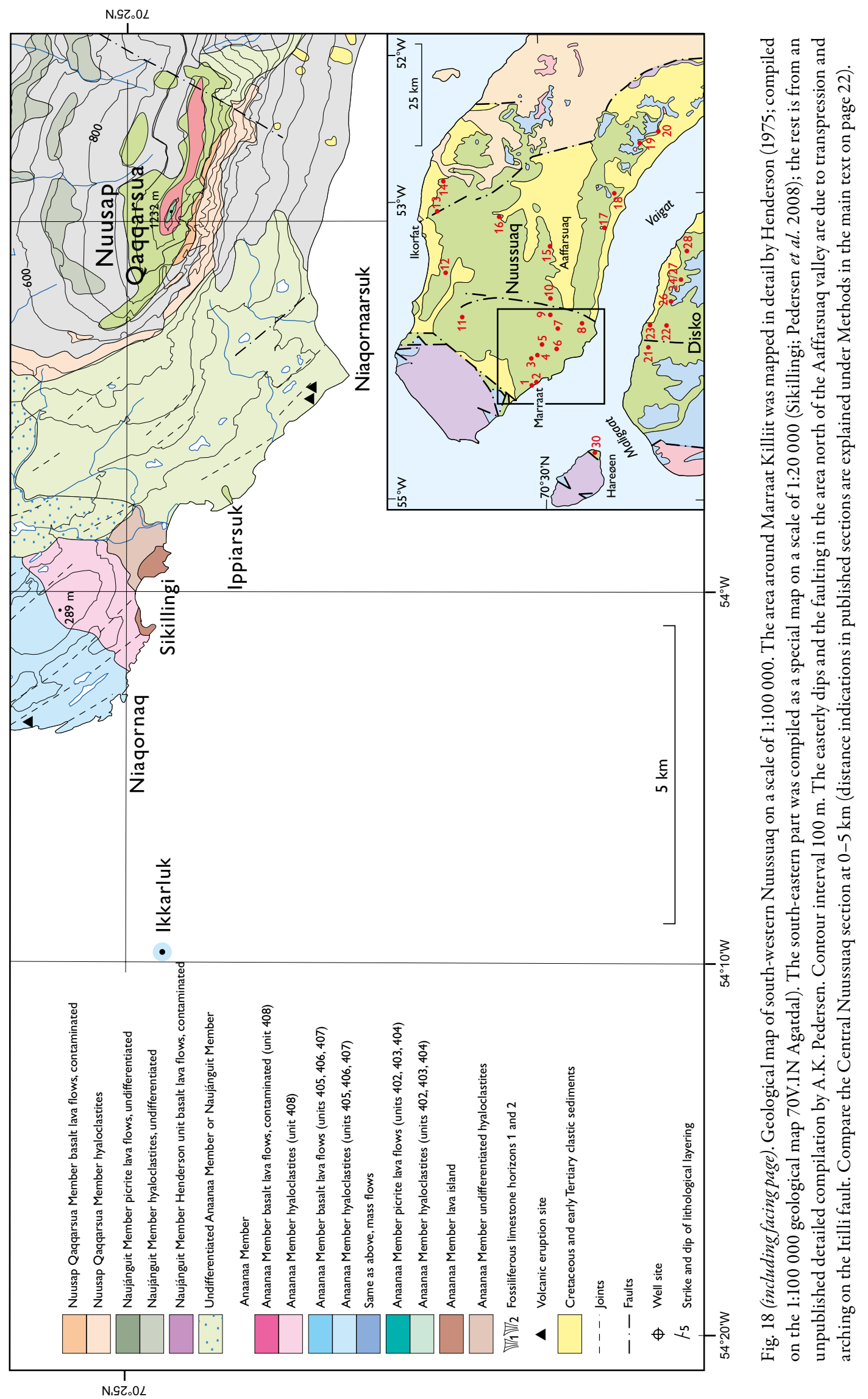




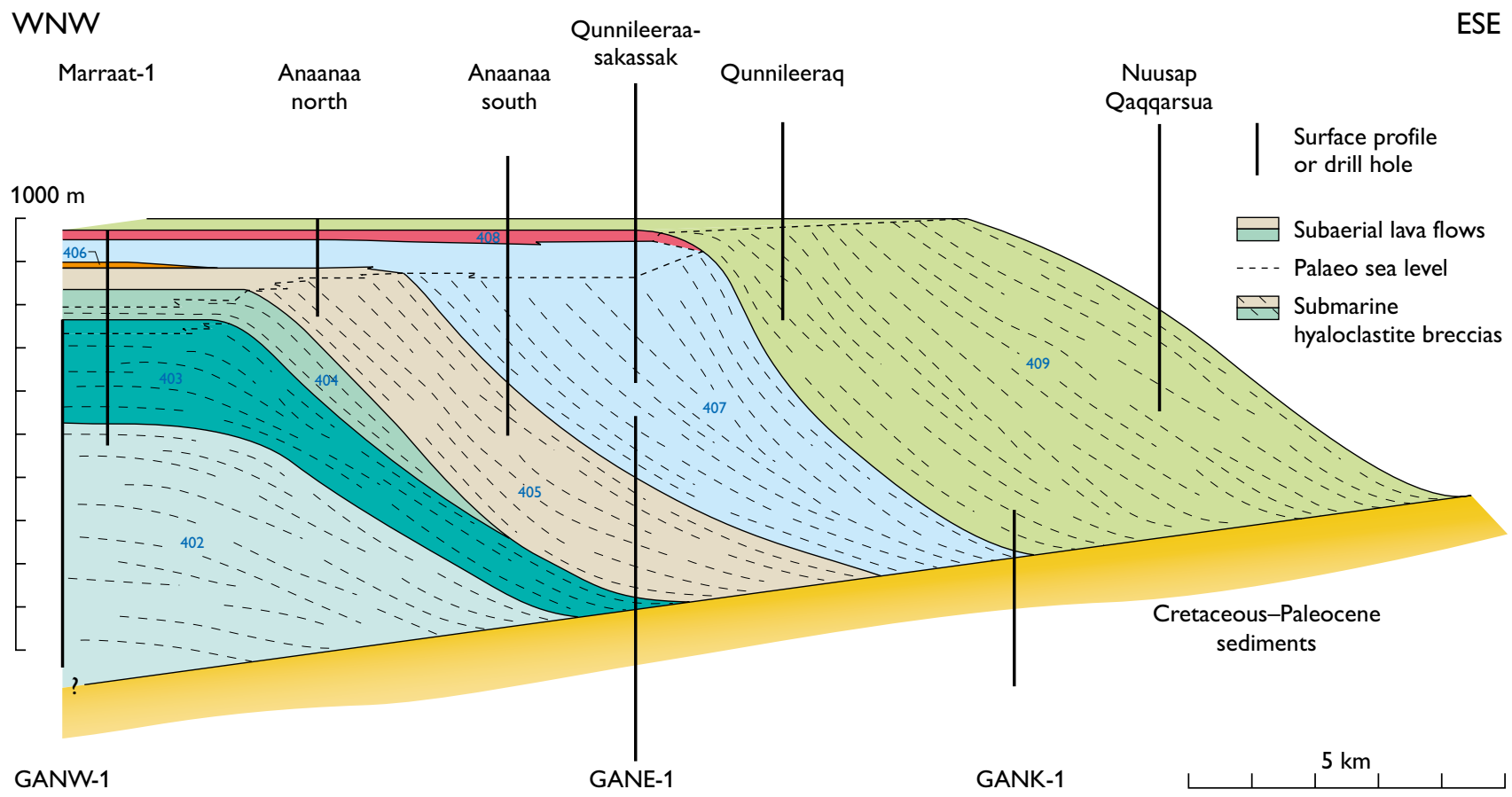

Fig. 19. The volcanic architecture of the Anaanaa Member (units 402-408) and the overlying lowest unit of the Naujánguit Member (409) showing the ESE-prograding infilling pattern of the successive units (unit codes in blue). Black vertical bars show the positions of the drill cores and surface profiles used in the reconstruction. Logs of these are shown in Fig. 13. Note $c .7$ times vertical exaggeration.

tation of the early volcanic environment of the Anaanaa Member. The lower one (at 624-656 m depth including $9 \mathrm{~m}$ of later intrusives) is mainly composed of volcaniclastic material, but it also includes several beds of quartzofeldspathic sediment of predominantly non-volcanic origin. The upper interval (at 483-497 m depth including $3 \mathrm{~m}$ of later intrusives) consists entirely of volcaniclastic sandstone and siltstone with an addition of scattered fragments of the coral Dendrophyllia candelabrum. This species is not highly light-dependent and could indicate a water depth of between $50 \mathrm{~m}$ and $300 \mathrm{~m}$ if it lived within the sediment (Floris 1972; S. Floris, personal communication 1995). Christiansen et al. (1995b) speculated that the turbidites were swept from a higher level down onto a deep marine shelf. The quartzo-feldspathic sediments could have been derived by denudation of small rotated fault blocks of the Cretaceous succession that were created by the very active tectonism and exposed at a relatively shallow marine level.

The surface exposures of unit 402 along the coast north of Marraat Killiit are poor, and going north towards Itilli, the rocks become successively more hydrothermally altered and extensively intruded by dykes. In the northern exposures, which probably represent the lowest exposures of the Vaigat Formation anywhere, the picritic hyaloclas- tites are extensively hydrothermally metamorphosed (Fig. 20) and contain scattered pyrite. There is a faulted contact to underlying mudstones which are also intruded by picrite sills (Henderson 1975).

The best exposures of unit 402 occur in a NE-SWtrending gully about $1.5 \mathrm{~km}$ north of Marraat Killiit (Fig. 18). About $500 \mathrm{~m}$ from the coast, erosion in the gully has exposed a submarine eruption site (Henderson 1975, fig. 4), the oldest one located within the province (Fig. 21).

The upper boundary of unit 402 has not been recognised in the field due to poor exposures. In the GANW\# 1 core it is marked by $30 \mathrm{~cm}$ of reworked hyaloclastite sand, and in the Marraat-1 core the level is occupied by a picrite intrusion. Unit 402 is covered by lithologically very similar hyaloclastites of the overlying unit 403, and from these a palaeo-water depth of $c .15 \mathrm{~m}$ at the time can be inferred for the GANW\# 1 core (Fig. 13; Christiansen et al. 1995b).

\section{Ti-poor picrites (unit 403)}

This unit consists of lava flows and associated hyaloclastites that are chemically (low $\mathrm{Ti}$, see later) but not lithologically distinguishable from the surrounding rocks. Unit 403 is present in the Marraat-1 core (at 208-337 
Fig. 20. Hydrothermal alteration in Anaanaa Member unit 402. Beds of foreset-bedded picritic hyaloclastite are cut by a number of basaltic dykes (d) which have given rise to metre-thick zones of greyish, hydrothermally altered hyaloclastite along the contacts. Exposures in a NE-SW-trending gully about $1.5 \mathrm{~km}$ north-north-west of Marraat Killiit.

Fig. 21. Submarine eruption site in Anaanaa Member unit 402, consisting of a c. $40 \mathrm{~m}$ high conical mound of close-lying picrite pillows. The mound is surrounded by picritic hyaloclastite (pi hy). The eruption occurred at a sufficient water depth to prevent primary explosive shattering of the magma, but the exposures do not allow an independent estimate of the water depth. About $1.5 \mathrm{~km}$ north-north-west of Marraat Killiit (indicated on Fig. 18).
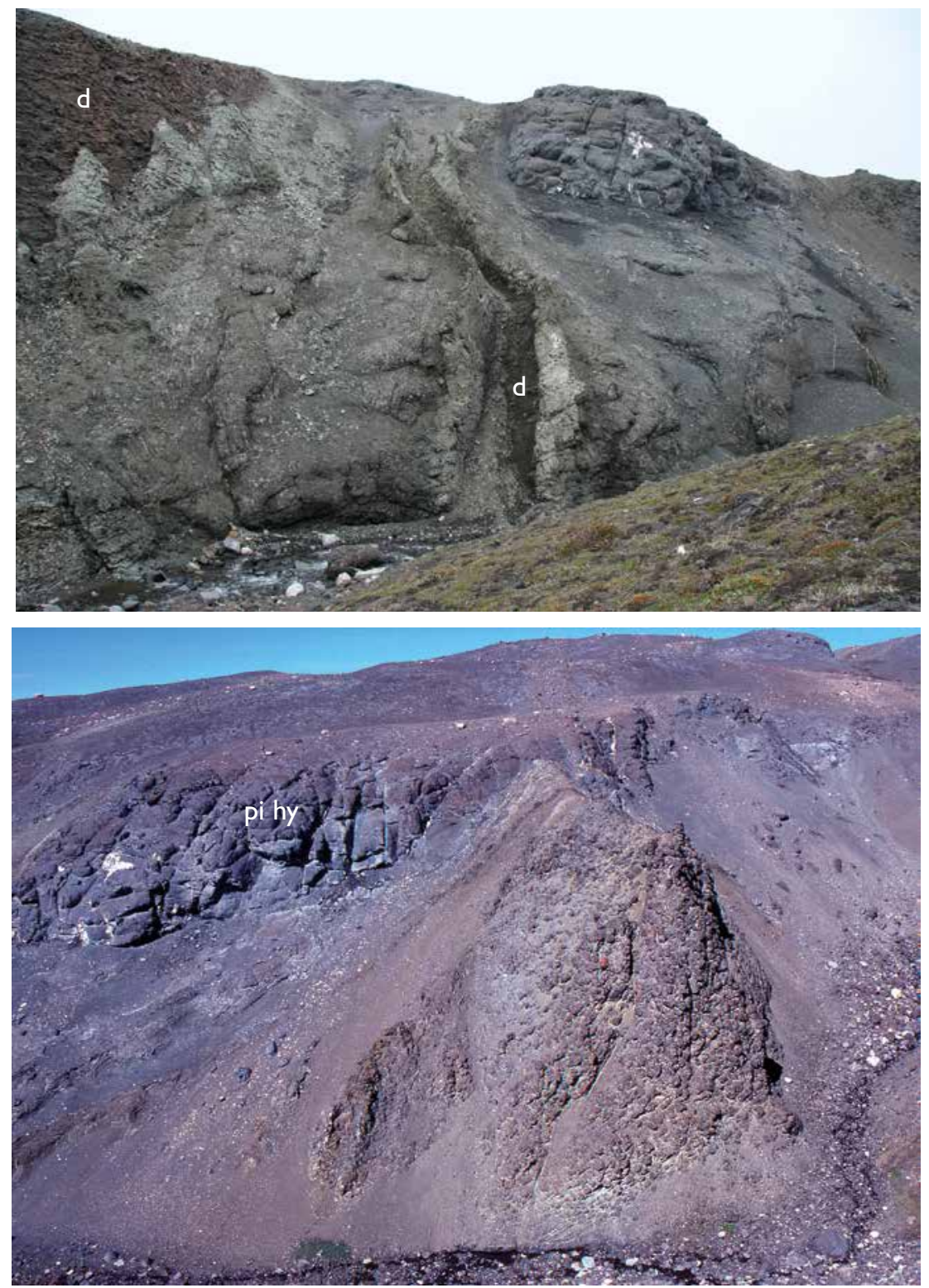

$m$ depth) and in the top of the GANW\# 1 core (at 7-76 $\mathrm{m}$ depth; Fig. 13) and is exposed at the coast in two fault blocks in the vicinity of Marraat Killiit and in the northern extension of these fault blocks in Tufdalen (Fig. 18). The rocks are predominantly picrites but have a range of $8-24$ wt $\%$ MgO.

The lower part of unit 403 consists of up to $90 \mathrm{~m}$ of foreset-bedded hyaloclastites. In the Marraat- 1 core a single hyaloclastite depositional unit (at 235-308 m) indicates a palaeo-water depth around $70 \mathrm{~m}$. About $15 \mathrm{~m}$ of hyaloclastites of unit 403 form the lowest volcanic unit in the GANE\# 1 core (at $c .482-497 \mathrm{~m}$ depth), resting on mudstones of the Eqalulik Formation. The upper part of unit 403 is subaerial, dominated by pahoehoe lava flows which vary in thickness from $8 \mathrm{~m}$ to less than $1 \mathrm{~m}$. The thickness of the subaerial succession varies from $53 \mathrm{~m}$ in GANW\# 1 to $24 \mathrm{~m}$ in Marraat-1. In Tufdalen the strongly faulted and weathered succession of small flows contains a distinct red tuffaceous layer (see Fig. 24) which suggests that the lavas of unit 403 were erupted as several flow fields separated in time (Kilburn 2000). The top of the lava series of unit 403 is strongly eroded, weathered, fractured and covered by a thin bed of marine limestone.

The subaerial lava flows of unit 403 demonstrate the earliest stage at which the submarine volcanism led to formation of one or more permanently emergent lava islands situated on a shallow sea floor. The early island was at least several kilometres large. 


\section{Limestone horizon 1}

A horizon of marine fossiliferous limestone caps the weathered lava surface of the Ti-poor picrite unit 403 (Fig. 13). In the Marraat-1 core, this limestone bed is 52 $\mathrm{cm}$ thick and contains an Ostrea sp. individual in life position' (Fig. 22). The GANW\#1 well, which was drilled in the same fault block as the Marraat-1 well, was placed on a rubbly exposure of this limestone. In both cores the lava flows underlying the limestone contain $0.1-1 \mathrm{~cm}$ wide irregular cracks filled with fossiliferous limestone, in GANW\# 1 down to $14.5 \mathrm{~m}$ beneath the limestone. At two localities north of the Marrat-1 drill site (Fig. 18), an up to $4 \mathrm{~m}$ thick conglomerate with rounded $10-40$ $\mathrm{cm}$ lava clasts in carbonate matrix (Fig. 23; Rosenkrantz 1970; Binzer \& Karup-Møller 1974; Jürgensen \& Mikkelsen 1974) represents a shallow-water, near-shore deposit (Henderson 1975) at the same stratigraphic level. The limestone is also found resting on hyaloclastites (Henderson 1975, Henderson et al. 1976, p. 356, fig. 319). The lava series underlying the conglomerate contains irregular, near-vertical fractures filled with limestone and reaching as deep as $15 \mathrm{~m}$ below the limestone horizon (Fig. 24). The fractures were probably filled due to liquefaction of the overlying carbonate sludge by a syndepositional earthquake. The eroded and weathered lava surface and the limestone indicate a lull in the volcanic activity; during this time the area subsided to make space for $32 \mathrm{~m}$ of seawater, as indicated by the thickness of the overlying hyaloclastites.

The total area once covered by the limestone is difficult to assess due to the poor exposures and the extensive faulting, but it must have exceeded several square kilometres.

\section{Picrites above Limestone horizon 1 (unit 404)}

This unit consists of hyaloclastites and overlying pahoehoe lava flows with chemical compositions similar to those of unit 402; the rocks are predominantly picrites and have a range of $10-26 \mathrm{wt} \% \mathrm{MgO}$. Unit 404 is present in the Marraat-1 core at 130-208 m depth and as poor surface exposures within four fault blocks in the Marraat Killiit area. The best exposures are in the second fault block 1.2-1.5 km due east of the GANW\#1 drill site; other exposures are fragmentary.

In the Marraat- 1 core, the lower part of unit 404 consists of $32 \mathrm{~m}$ of foreset-bedded hyaloclastites deposited on top of Limestone 1 (Fig. 13). The hyaloclastites are covered by $44 \mathrm{~m}$ of subaerial picrite lava flows; there are

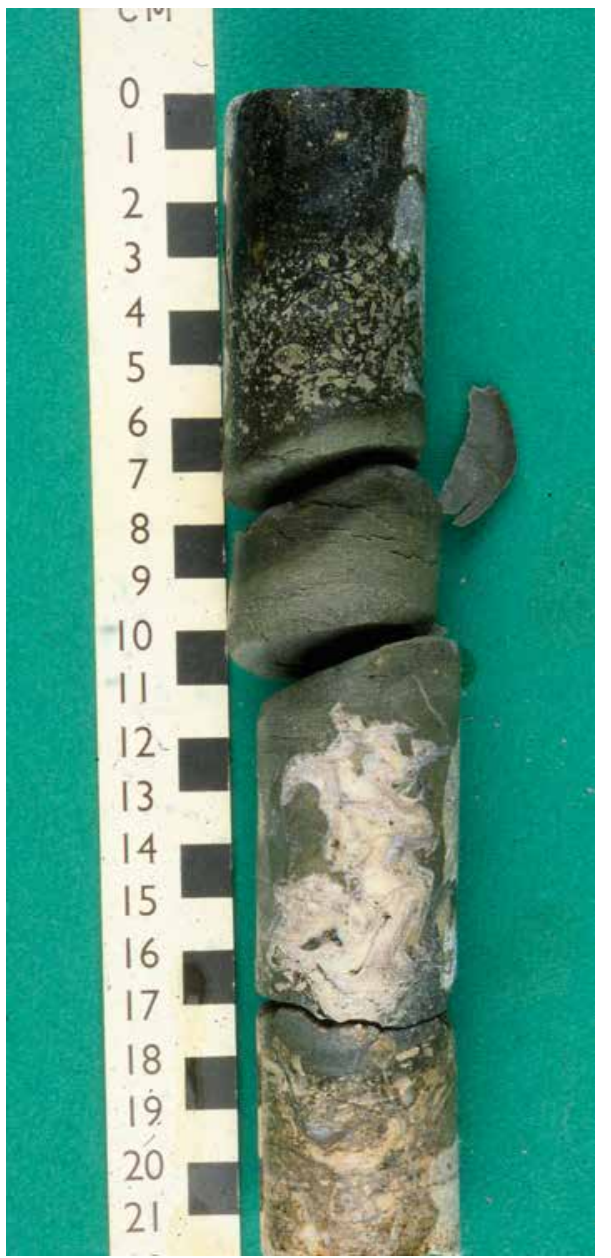

Fig. 22. A $4 \mathrm{~cm}$ large mussel individual, Ostrea sp., in life position. Limestone horizon 1, the Marraat-1 core at 208.12-208.38 m depth.

24 individual flows with thicknesses from 6.5 to less than $1 \mathrm{~m}$. These are covered by subaerial flows of unit 405 .

At the surface, unit 404 is present as a thick hyaloclastite succession over a distance of about $5 \mathrm{~km}$ between Pingunnguup Tunulikassaa and the Anariartorfik valley (Fig. 18). Figure 25 shows the succession on the western slope of the Pingunnguup Tunulikassaa mountain, just above Gassøen. Here, the lowermost exposure consists of $17 \mathrm{~m}$ of 1-2 $\mathrm{m}$ thick subaerial picrite lava flows of unit 402. Their upper contact is poorly exposed. These lava flows are covered by c. $300 \mathrm{~m}$ of foreset-bedded picritic hyaloclastites of unit 404 showing a westerly provenance, followed by basaltic hyaloclastites of unit 405 . Compared to the nearby Marraat- 1 core, the much thicker exposed hyaloclastites deposited on subaerial lavas record a much stronger local subsidence and indicate synvolcanic differential subsidence caused by both loading and rotation of fault blocks. Similar features have been documented in 
Fig. 23. Up to $4 \mathrm{~m}$ thick conglomerate with rounded $10-40 \mathrm{~cm}$ large lava clasts in carbonate matrix, representing Limestone horizon 1 in shallow-water, near-shore facies (Henderson 1975). Locality $2.5 \mathrm{~km}$ north of the Marrat-1 drill site (Fig. 18).

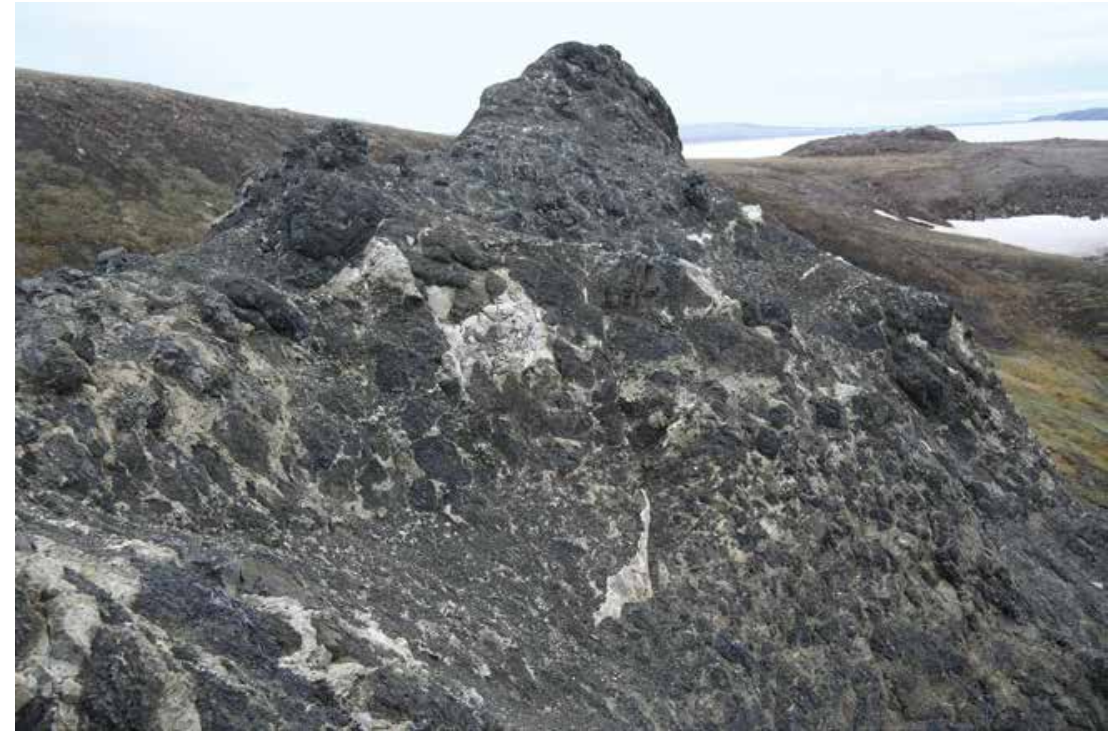

slightly younger rocks of the Vaigat Formation at Qunnilik (Pedersen et al. 2002b).

The northernmost exposures of unit 404 consist of $140 \mathrm{~m}$ of hydrothermally altered picritic hyaloclastites which form the lowest part of the volcanic succession in the north-western part of the Anariartorfik valley. They are covered by basaltic hyaloclastites of unit 407 (Fig. 18).

\section{Olivine microphyric to aphyric basalts (unit 405)}

This unit is the oldest non-picritic unit in the Vaigat Formation and comprises basalts with 6-10 wt\% $\mathrm{MgO}$ and a top flow of massive picrite with c. $20 \mathrm{wt} \% \mathrm{MgO}$. It is present in the Marraat- 1 and GANE\# 1 drill cores and is exposed from Marraat Killiit in the west to $c .3 \mathrm{~km}$ east of Anaanaa in the east and to Pingunnguup Tunulikassaa in the north (Figs 13, 18, 25).

After the deposition of unit 404 the western part of the area was a low-lying volcanic island. The overlying olivine microphyric to aphyric basalts of unit 405 are there-

Fig. 24. Irregular, centimetre- to millimetre- to hair-thin, near-vertical fractures filled with limestone, cutting lava flows underlying the conglomerate in Fig. 23 (the locality of Fig. 23 is seen in the uppermost right part of the picture). A thin red tuff (red arrows) was displaced by a syndepositional tectonic event which sent liquefied fossiliferous carbonate sludge down into new-formed cracks below the palaeosurface. The locality yields compelling evidence for early synvolcanic tectonic activity. Note that the fractures continue upwards to near the skyline. The exposure in the foreground is $c .5 .5 \mathrm{~m}$ high. fore in subaerial lava facies in the west around Marraat; going east the facies changes to lavas and hyaloclastites

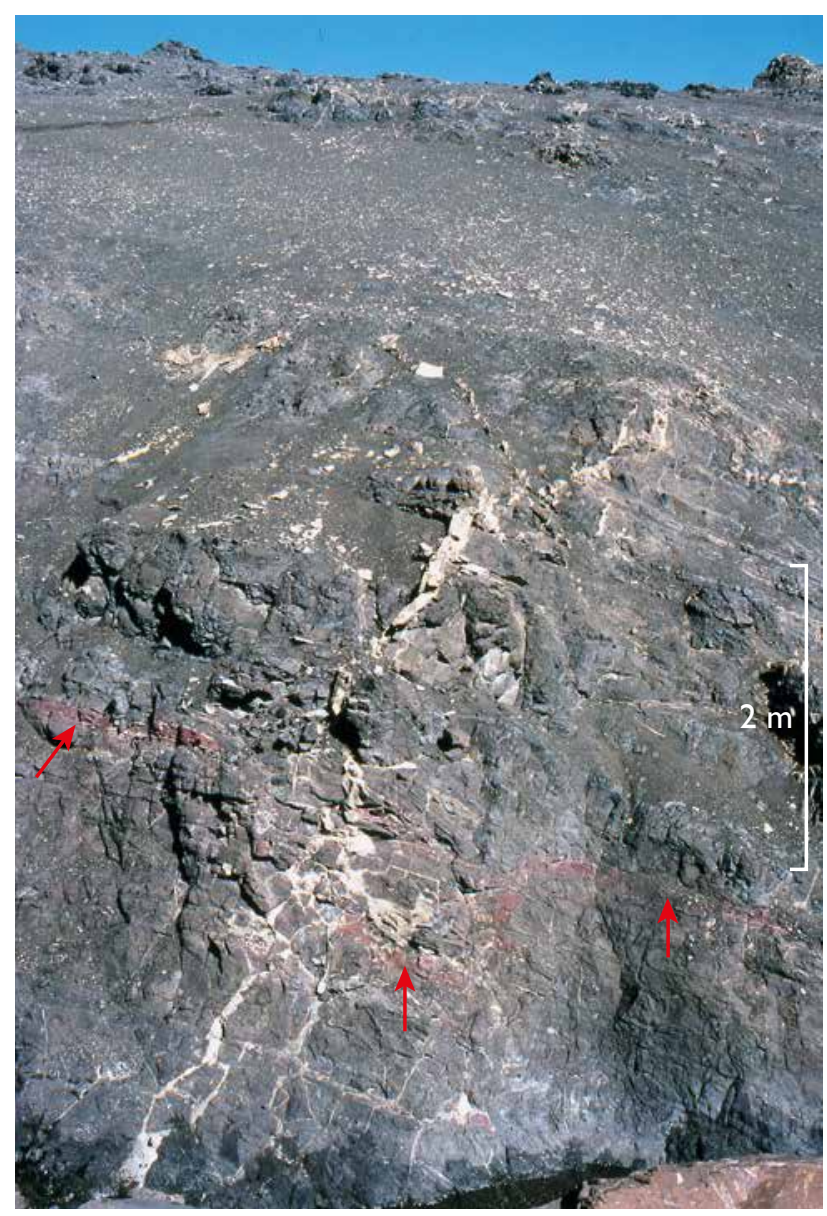




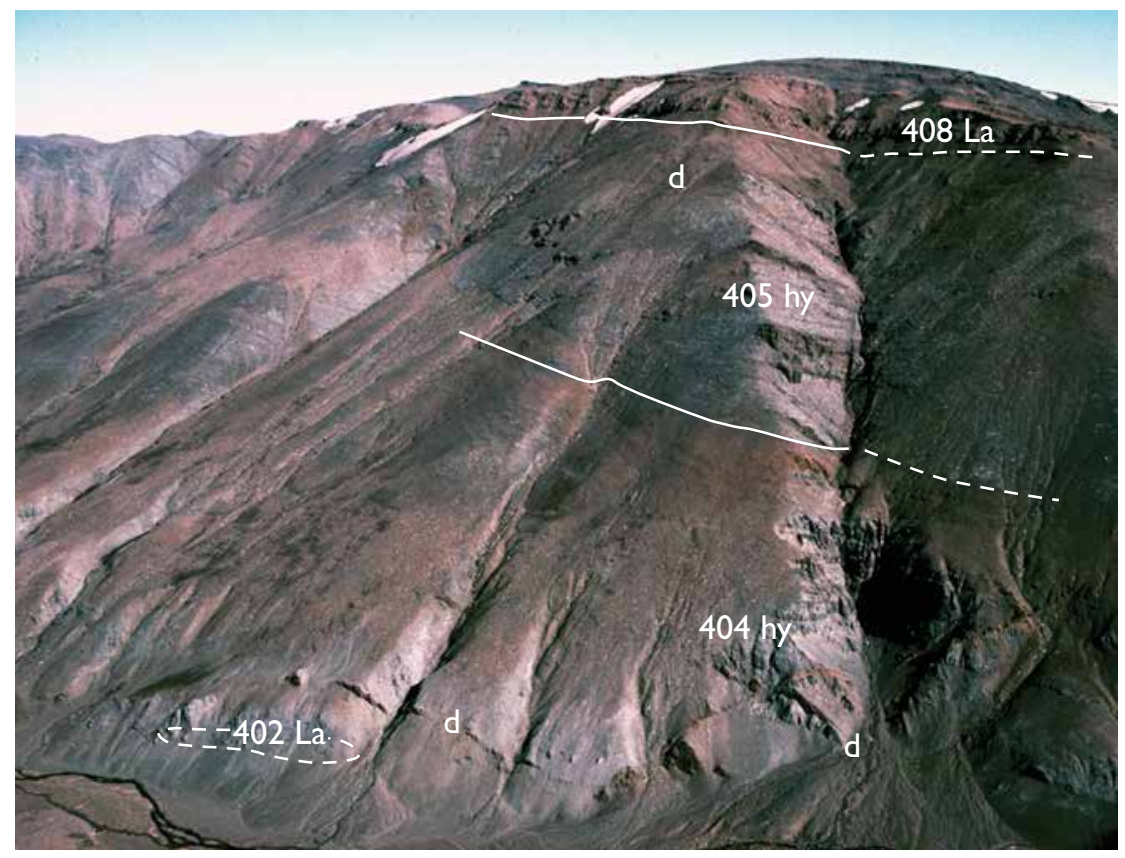

Fig. 25. A c. $600 \mathrm{~m}$ thick succession of Anaanaa Member hyaloclastites and lava flows of units 402-408. The lowermost exposure consists of subaerial picrite lava flows of unit $402(\mathbf{L a})$; these are overlain by c. $300 \mathrm{~m}$ of picritic hyaloclastites of unit 404 (hy) followed by thick basaltic hyaloclastites of unit 405 (hy), demonstrating a local subsidence of at least $400 \mathrm{~m}$ in the time interval spanned by units 404 and 405 . The hyaloclastites are overlain by subaerial basalt lava flows of unit 408 ( $\mathbf{L a})$. The succession is cut by several dykes (d). The western slope of the Pingunnguup Tunulikassaa mountain (Fig. 18).

at Anaanaa, and the unit continues to the east and north solely in hyaloclastite facies.

In the Marraat- 1 core, unit 405 is found at $93-130 \mathrm{~m}$ depth where it constitutes a $c .35 \mathrm{~m}$ thick succession of 20 lava flows varying in thickness between $9 \mathrm{~m}$ and less than $1 \mathrm{~m}$. In the Marraat Killiit area, the unit ends with one or two thick, well-exposed picrite lava flows that are not known in hyaloclastite facies (Fig. 26).

Between Marraat Killiit and Anaanaa, unit 405 forms a thick succession of foreset-bedded hyaloclastites covered by a few subaerial lava flows deposited as the marine space was filled out by the hyaloclastites. At Anaanaa, the hyaloclastite succession is covered by three to four thin subaerial lava flows that mark the easternmost extension of the emergent lava area at this stage.

At the western side of Pingunnguup Tunulikassaa, a more than $400 \mathrm{~m}$ thick succession of unit 405 is exposed (Fig. 25). Over a distance of $4 \mathrm{~km}$, foreset-bedded hyaloclastites of olivine microphyric and aphyric basalts cover a shelf slope defined by picritic hyaloclastites of unit 404 and demonstrate local subsidence of at least $400 \mathrm{~m}$ in the time interval spanned by units 404 and 405 . An eruption site is exposed close to the base of unit 405 . This comprises a number of 10-20 m high conical mounds consisting of close-lying pillows (Figs 27, 28). The mounds are covered by normal foreset-bedded hyaloclastites.

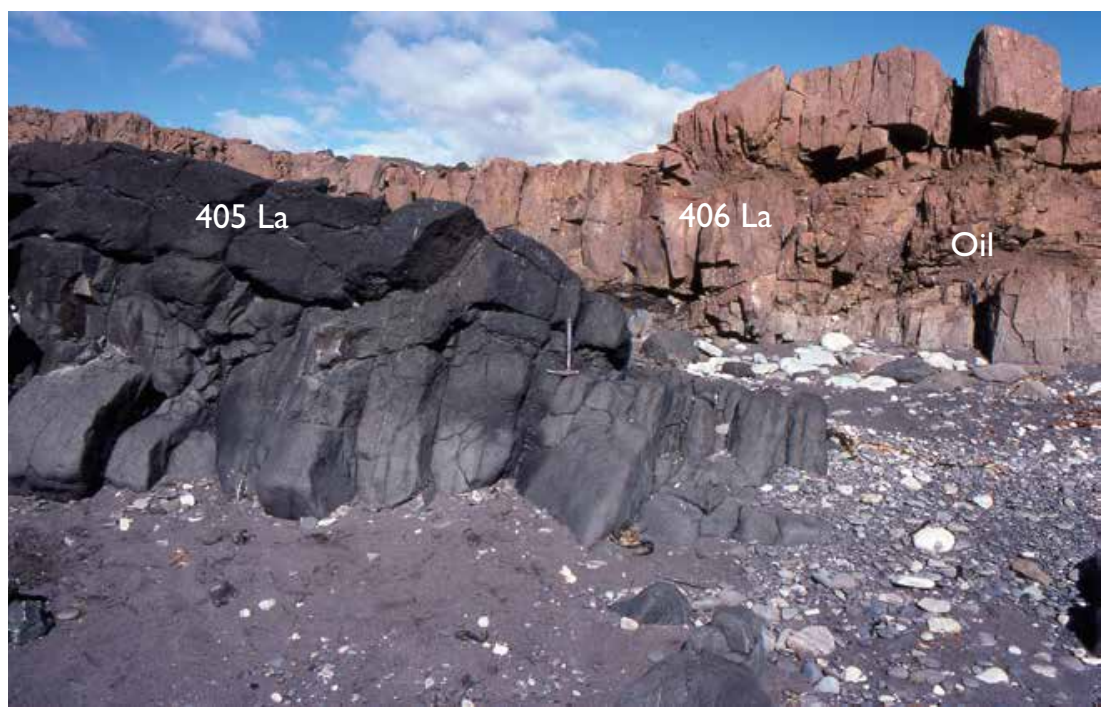

Fig. 26. Lava flows on the shore west of the Marraat-1 drill site. In the foreground is a very dark grey to black picrite lava flow that forms the top of unit 405 . It is overlain by a series of rusty-brown vesiculated pahoehoe flows and flow lobes of unit 406 with oilsaturated flow tops. Length of hammer 32 cm. See also Fig. 30. 
Fig. 27. Subaqueous eruption site in hyaloclastites of unit 405. The conical pillow mounds are 10-20 m high and are found over a distance of $c .200 \mathrm{~m}$. As exposed, the pillow mounds appear to be aligned along one or more linear features, and they are interpreted as a submarine eruption site with the mounds reflecting points of magma emission above one or more fissures. About $1.5 \mathrm{~km}$ south-east of Gassøen at $c .560 \mathrm{~m}$ a.s.l. (Fig. 18).

Fig. 28. Close-lying pillows in mound above eruption site in unit 405. Samples from such pillows are among the freshest available from the earliest part of the volcanic succession. The pillows consist of aphyric to slightly feldspar-phyric basalt; they contain up to decimetre-sized cavities with crystals of quartz and calcite. Length of knife 20 $\mathrm{cm}$. Same locality as Fig. 27.
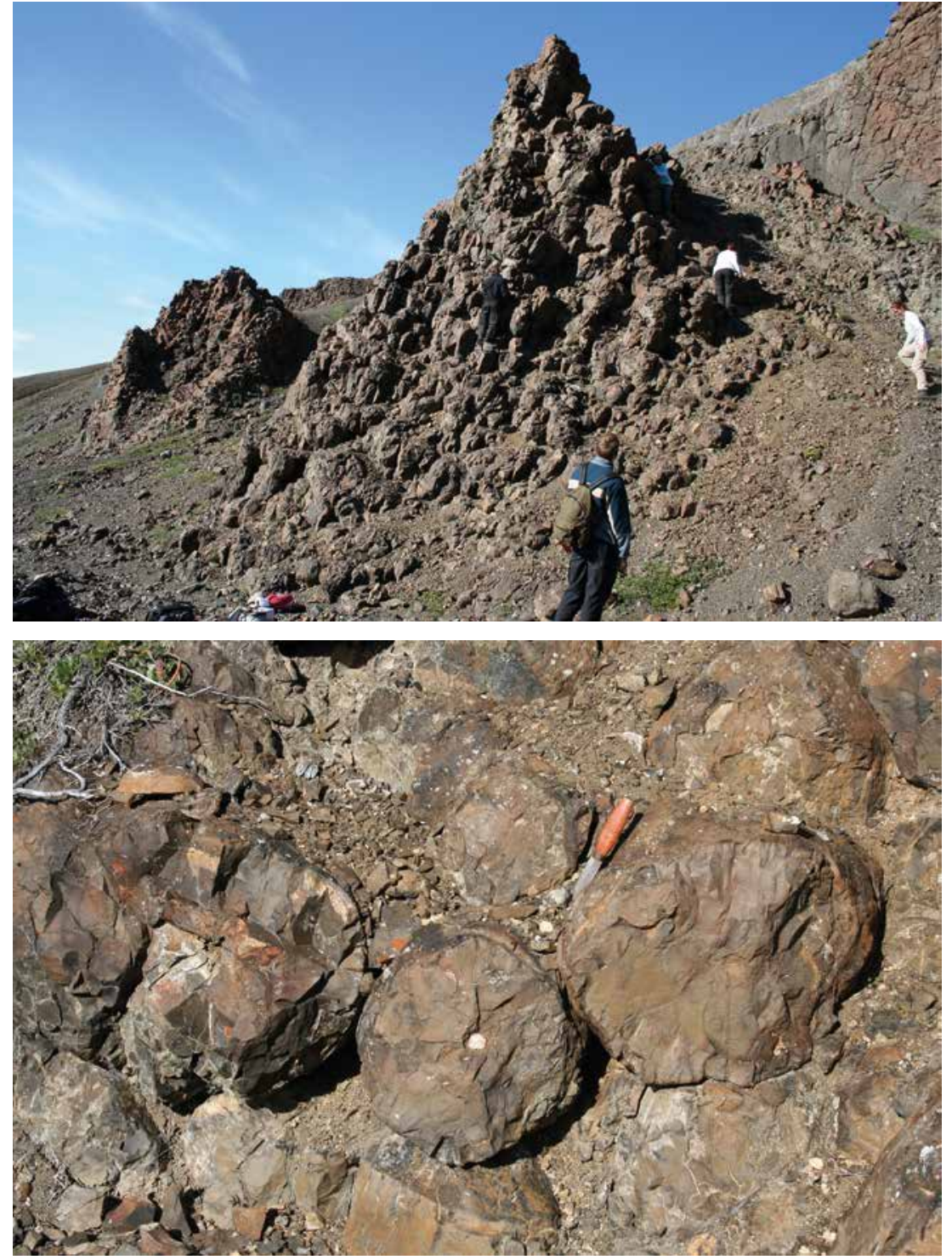

Unit 405 is also found below the present level of exposure in the GANE\#1 well in the Aaffarsuaq valley (Fig. 13; Larsen \& Pedersen 1997; Pedersen et al. 2008). At $152-482 \mathrm{~m}$ in the drill core, $330 \mathrm{~m}$ of hyaloclastites of aphyric and plagioclase microphyric basalt comprise six depositional units of which the thickest indicates emplacement at a minimum water depth of $184 \mathrm{~m}$. Unit 405 was here deposited directly on top of picritic hyaloclastites of unit 403 (Fig. 19).

The top of the unit is covered by $2.5 \mathrm{~m}$ of bedded hyaloclastite sand with scattered basalt clasts up to $10 \mathrm{~cm}$ in size. This volcaniclastic layer, which is part of the Eqalulik Formation, contains remains of carbonate-shelled invertebrates and corals. The layer has apparently acted as a seal because beneath it the uppermost $6.2 \mathrm{~m}$ of unit 405 in the GANE\# 1 core are saturated with live oil. The presence of fossiliferous volcaniclastic sand on top of unit 405 indicates an interruption in the volcanic activity.

\section{Brown aphyric basalts (lower contaminated unit, 406)}

This unit consists of a few thin, brown, aphyric to plagioclase- or olivine-plagioclase microphyric lava flows of silicic basalt; it is the oldest volcanic unit that is distinctly crustally contaminated. It is only found in a small area and is not known in hyaloclastite facies.

Unit 406 is present in the Marraat-1 core at $77-93 \mathrm{~m}$ where it forms a $15 \mathrm{~m}$ thick series of six subaerial lava flows which conformably overlies lava flows of unit 405 and is covered by lava flows of unit 407 (Fig. 13). Live oil was found in the core in this interval (Fig. 29). 


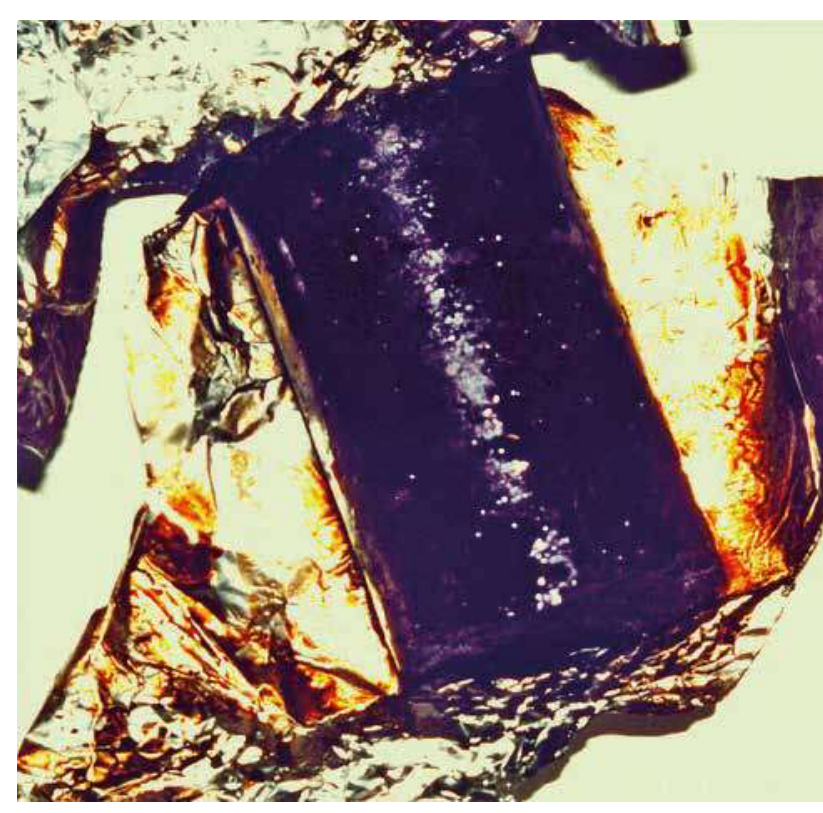

Fig. 29. Contaminated basalt core of unit 406 bleeding oil onto the alu foil wrapping. The Marraat-1 core at $c .90 \mathrm{~m}$ depth; core diameter $6.35 \mathrm{~cm}$. Photo: Flemming Getreuer Christiansen.
Lava flows of unit 406 have been recognised as scattered surface exposures in two of the fault blocks in the Marraat Killiit area. The best exposures are along the coast a few hundred metres west of the Marraat-1 well site (Fig. 30), where a series of pahoehoe flows and flow lobes with oil-saturated vesiculated flow tops overlie a picrite flow of unit 405 (Fig. 26). A massive basalt flow in the upper part of unit 406 forms a resistant exposure on the shore; within this flow a decimetre-sized gas cavity rimmed by calcite and filled with bitumen (Fig. 31) was discovered in 1992 as the first indication of widespread oil seeps in the basal part of the Vaigat Formation (Christiansen et al. 1994; Bojesen-Koefoed et al. 1999). The lava flows of unit 406 form part of the early emergent lava plateau established around Marraat Killiit. Lavas of this unit may also form one or more of the remnants of early drowned lava islands exposed at Sikillingi $14 \mathrm{~km}$ southeast of Marraat Killiit (see below).

\section{Limestone horizon 2}

Outside of the Marraat Killiit area, the basalts of unit 406 are not present, and the aphyric basalt lava flows and hya-

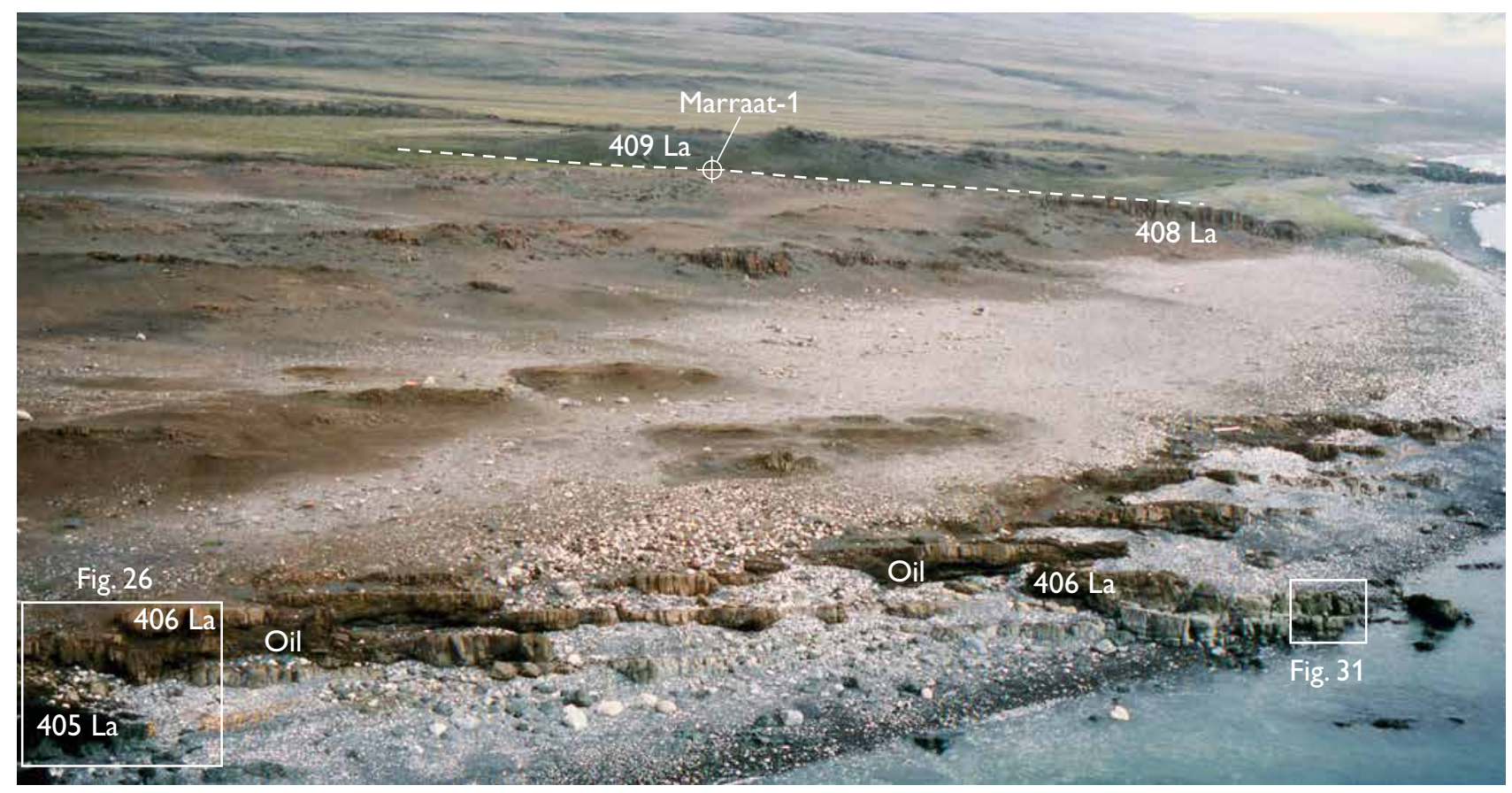

Fig. 30. Overview of the lava succession in the faulted coastal area west of the Marraat-1 well, looking east. The crags along the coast consist of pahoehoe flows and flow lobes of unit $406(406 \mathrm{La})$. The underlying massive picrite flow (La) of unit 405 (Fig. 26) is seen in the lower left of the picture. The 'point of discovery 1992' (Fig. 31) is situated near the water's edge in the crag in the lower right part of the picture. The low dark ridge in the far middle ground and the spit in the upper right part of the picture consist of lava flows of Naujánguit Member unit 409 . The Marraat-1 drill site is situated in the depression between this ridge and the brown ridge of unit 408 in the nearer middle ground. 
Fig. 31. 'Point of discovery 1992': a basalt lava flow of unit 406 with a decimetre-sized cavity rimmed by calcite and agate and filled with bitumen. Match is $4.8 \mathrm{~cm}$ long.

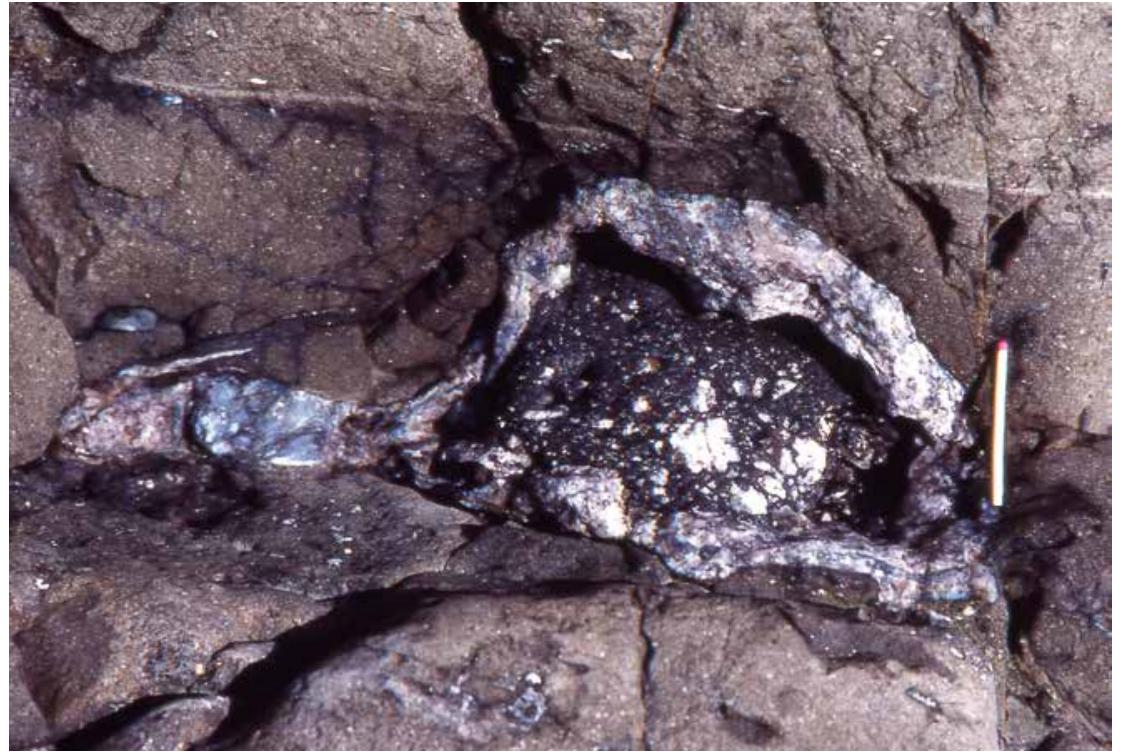

loclastites of unit 405 are overlain by plagioclase-phyric basalts of unit 407 (Fig. 19). At this level there is a thin marine horizon of volcaniclastic sediment commonly with a matrix of fossiliferous limestone. This Limestone 2 occurs between 1 and $4 \mathrm{~km}$ north of Anaanaa on the slopes of the eastern side of the valley between Anaanaa, Pingunnguaq and Pingunnguup Tunulikassaa (Fig. 18). Only two exposures have been visited, but loose pieces of limestone are seen coming down in the gullies over a distance of $3 \mathrm{~km}$. The horizon is also present as a fossiliferous siltstone in the GANE\# 1 core at 143-152 m (Fig. 13).

Approximately $2.1 \mathrm{~km}$ south-east of Gassøen, at an altitude of $c .785 \mathrm{~m}$, four or five thin aphyric basalt flows of unit 405 cover several hundred metres of hyaloclastites of the same unit. The flows are overlain by $8 \mathrm{~m}$ of matrixsupported conglomerate with basalt clasts and volcaniclastic matrix. In the lower $4 \mathrm{~m}$, the clasts are angular to slightly rounded lava clasts of feldspar microphyric unit 405 basalt. The upper 3-4 $\mathrm{m}$ have similar basalt clasts but the matrix contains an upward-increasing proportion of fossiliferous limestone gravel (Fig. 32). On the top of the conglomerate, oyster shells in life position are attached to the basalt clasts. There are also several decimetre-sized dendritic coral colonies in life position embedded in a well-cemented black glassy hyaloclastite (Fig. 33). The horizon is covered by pillow lavas of feldspar-phyric basalt of unit 407 with metre-sized basalt pillows. The locality is interpreted as a rocky coast of the early lava plateau where subaerial lava flows of unit 405 were eroded in a high-energy environment during a period of subsidence without local volcanic activity. The invertebrate fauna was annihilated by renewed volcanic activity of unit 407 which covered the fossils with a fine-clastic hyaloclastite deposit and subsequently coarse pillow lavas.

The upper part of the Anaanaa Member is exposed in a pass $c .1 \mathrm{~km}$ north of Anaanaa (Fig. 18; Fig. 13, profile 3). At an altitude of $c .800 \mathrm{~m}$, on top of several aphyric basalt flows of unit 405 , there is a poorly exposed, few decimetres thick, horizon of fossiliferous limestone. This is overlain by a $20-24 \mathrm{~m}$ thick strongly columnar-jointed lava flow of feldspar-phyric basalt of unit 407 (Fig. 34). The top of the flow is eroded and covered by $2 \mathrm{~m}$ of volcaniclastic sediment composed of basalt gravel and fossiliferous limestone, which in turn is covered by $12 \mathrm{~m}$ of basaltic pillow lavas of unit 407 followed by subaerial lavas. The environment at the locality is interpreted as a subsiding coast where a thick lava flow ponded in a shallow lagoon with fossil-rich lime sediment, was eroded, subsided, covered by more lagoonal sediment, and subsequently covered by pillow lavas as the subsidence continued.

The stratigraphic level represented by Limestone 2 in submarine facies between hyaloclastites of units 405 and 407 has not been observed in the field but is present in the GANE\# 1 core at $143.3-152.0 \mathrm{~m}$ (Fig. 13, profile 6; Larsen \& Pedersen 1997; Pedersen et al. 2008). Beneath more than $135 \mathrm{~m}$ thick hyaloclastites of unit 407 , the interval at $143.3-147.5 \mathrm{~m}$ consists of siltstone with mud, hyaloclastite glass and marine microfossils (Nøhr-Hansen et al. 2002). The sediment comprises beds of varying grain size including coarse beds of glass grains. Irregular bedding, slump structures and sparse, small shell fragments are found within this sediment (Larsen \& Pedersen 1997) which is assigned to the Eqalulik Formation by 

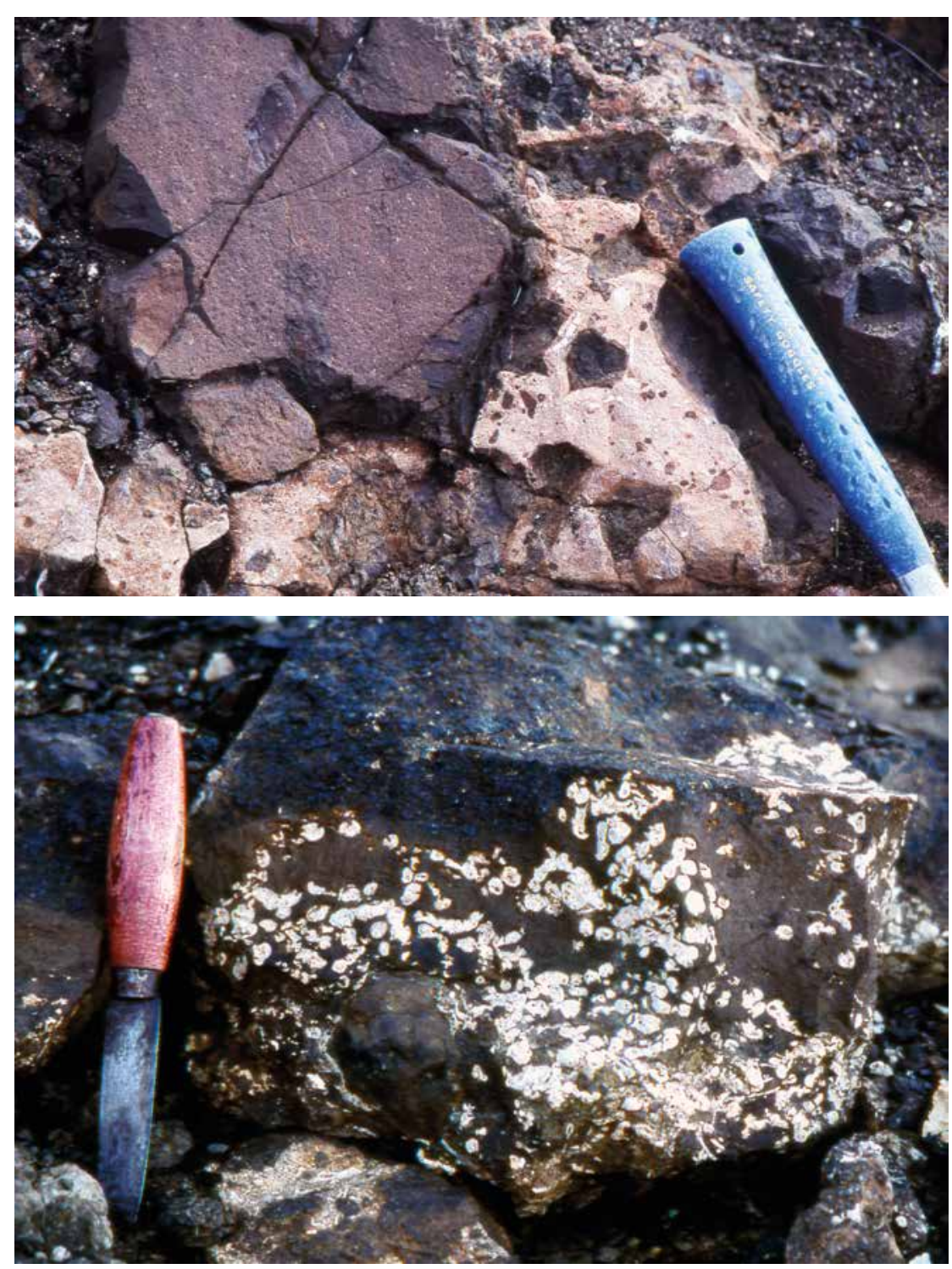

Fig. 32. Limestone horizon 2 between lava flows of unit 405 and pillow lavas of unit 407. A conglomerate with angular to slightly rounded lava clasts in which the matrix in the upper 3-4 m contains fossiliferous limestone gravel. Length of hammer handle $18 \mathrm{~cm}$.

Fig. 33. Limestone horizon 2, upper part: a dendritic coral colony in life position embedded in cemented black glassy hyaloclastite. Length of knife $20 \mathrm{~cm}$. For interpretation, see text.
Dam et al. (2009). The underlying bed (147.5-149.5 m) consists of hyaloclastite with up to $10 \mathrm{~cm}$ large clasts of feldspar microphyric basalt which is the lowermost volcanic rocks of unit 407 in the core. At 149.5-152.0 m the sediment is bedded hyaloclastite sand with remains of carbonate-shelled invertebrates including corals; this rests on top of hyaloclastite of unit 405 . The two separate fossiliferous sediment horizons in GANE\# 1 correlate remarkably well with the two horizons of fossiliferous limestone in the Anaanaa north profile and tie the subaerial lava stratigraphy to the marine litho- and biostratigraphy.

\section{Plagioclase-phyric and aphyric basalts (Niaqornaq unit, 407)}

This unit comprises a petrographic and chemical variety of evolved basalts: plagioclase microphyric, densely plagioclase-phyric, aphyric and plagioclase-clinopyroxene-phyric basalts. Two aphyric lava flows are silicic, and these and possibly other flows are crustally contaminated. Most flows contain 6-10 wt $\% \mathrm{MgO}$; rare picrites occur. The unit is probably the most voluminous and extensive of the Anaanaa Member units and is exposed from Marraat Killiit in the west to just east of Qunnileeraq in the east $(14 \mathrm{~km})$ and from Sikillingi in the south to Anariartorfik in the north (22 km; Fig. 18). It is present in the Marraat-1, GANE\# 1 and GANK\# 1 cores (Fig. 13). 


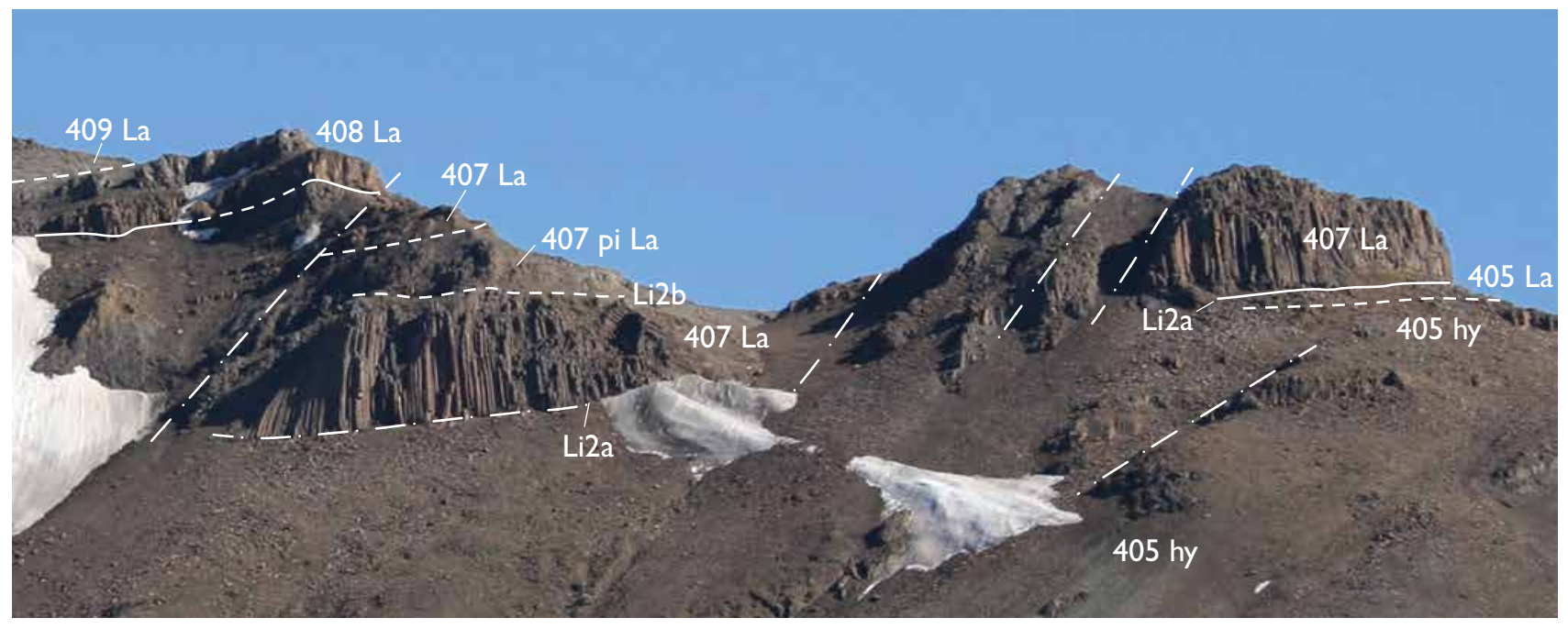

Fig. 34. Variable facies in the upper part of the Anaanaa Member. The gravelly slope in the foreground consists of hyaloclastites (hy) capped by a short succession of thin lava flows (La) of unit 405. The overlying volcanic unit is a massive, 20-24 m thick, strongly columnar-jointed lava flow from unit 407. This flow has thin horizons of fossiliferous limestone both at its base and on the top (Li2 horizons a and b). It is overlain by pillow lavas (pi La) and subsequent subaerial lavas of unit 407. For interpretation of the limestone environment, see text. West-facing mountain side $c .1 \mathrm{~km}$ north of Anaana (Fig. 18).

The deposition of unit 407 followed the pattern established by that time with formation of subaerial lava flows in the west and hyaloclastites prograding largely eastwards into the marine embayment.

Subaerial lava flows of unit 407. The unit comprises $c .14$ lava flows totalling c. $55 \mathrm{~m}$ in the Marraat Killiit area. It is found at $17-77 \mathrm{~m}$ depth in the Marraat- 1 core where the individual flows vary in thickness from less than 1 to $10 \mathrm{~m}$. The lava flows continue for $10 \mathrm{~km}$ to the east (Fig. 13, profiles 3, 4, 5) and must have continued for 13 $\mathrm{km}$ towards the south-east to just west of Sikillingi, but later erosion has removed the top of unit 407 south of the river in the Aaffarsuaq valley. At this stage the extent of the emergent lava plateau must have exceeded $100 \mathrm{~km}^{2}$. From Anaanaa north and eastwards the lavas give way to hyaloclastites.

The lavas occur both as single massive flows and as flow fields composed of small pahoehoe lobes. The largest individual flow is the ponded flow at Anaanaa north associated with limestone horizon 2 as described above (Fig. 34). Where the upper boundary is exposed, the lava flows of unit 407 are conformably overlain by lava flows of unit 408 .

Submarine hyaloclastites of unit 407. Submarine hyaloclastites of unit 407 , locally exceeding $200 \mathrm{~m}$ in thickness, occupy large areas both north and south of the Aaffar- suaq valley (Figs 13, 18; Central Nuussuaq section, unit a2; Pedersen et al. 2008, units Ap1 and Ap2); they are present in the GANE\# 1 and GANK\# 1 cores. The hyaloclastites, which are excellently exposed over a distance of $5 \mathrm{~km}$ along the coast from the Siorarsuit delta fan to $\mathrm{Ni}$ aqornaq, are separated into a lower and an upper part by a prominent mass-flow deposit centred around Nuusaq; these three parts will be characterised separately.

Lower hyaloclastites of unit 407 . These hyaloclastites are found along the coast just east of the southern part of the Siorarsuit delta fan and form a SE-dipping foresetbedded succession. The height of the beds indicates a water depth of more that $100 \mathrm{~m}$ at the time of deposition. Except for scattered fragments of vesiculated lavas the hyaloclastites are predominantly formed by waterquenched clasts. The subunit is considered to constitute the uppermost part of the GRO\#3 well (Christiansen $e t$ al. 1997). The oldest parts are composed of fragmented aphyric to slightly olivine microphyric basalts (Pedersen et al. 2008, unit A6p1). A slightly younger, morphologically similar succession of plagioclase microphyric basaltic hyaloclastites (Pedersen et al. 2008, unit A6p2) covers the aphyric basalts and was formed by continued southeastward progradation of the volcanic pile. The equivalent lava facies in the area has been removed by erosion but is preserved in the Marraat- 1 well. The subunit is covered by a number of beds of coarse mass-flow deposits. 

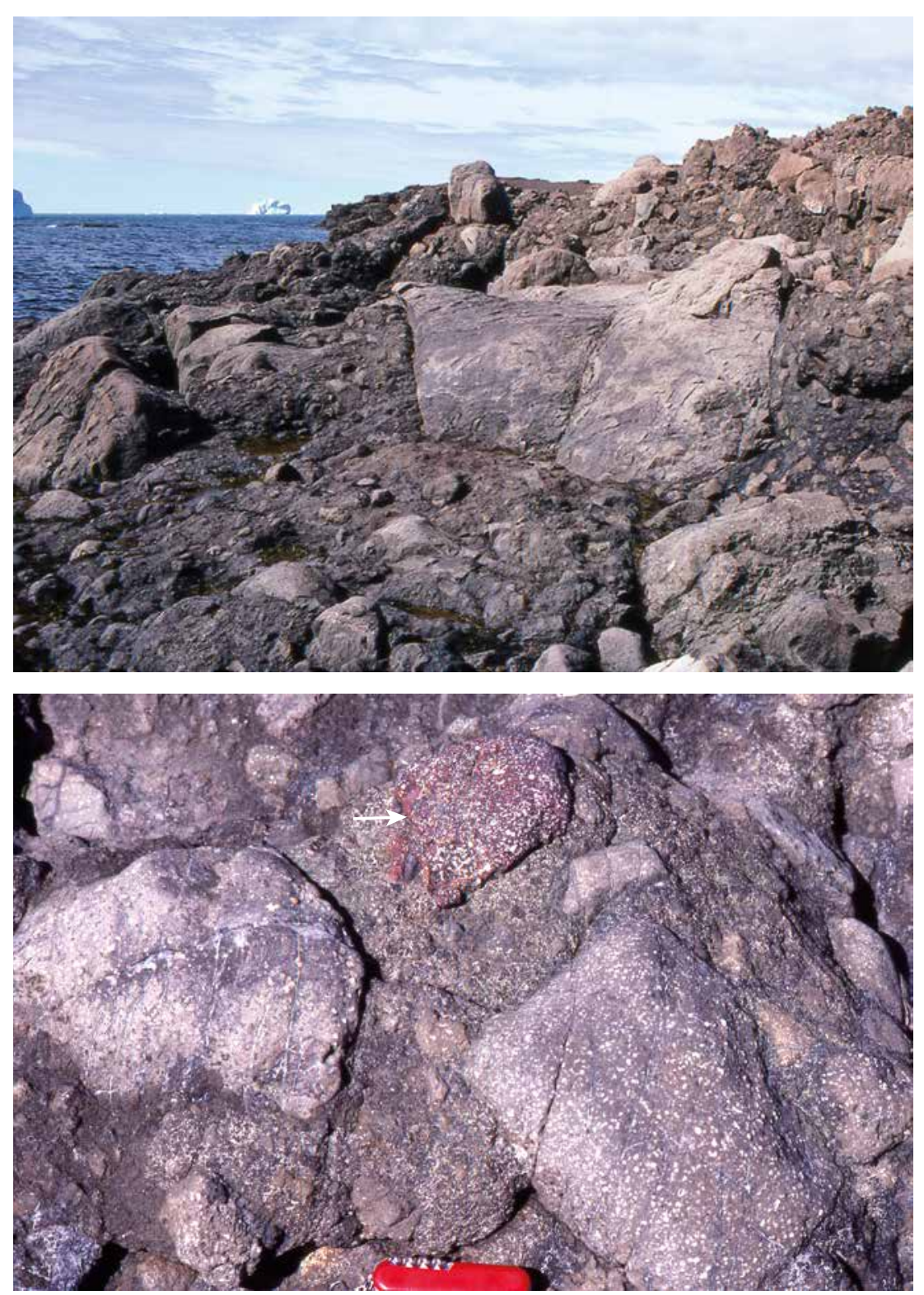

Fig. 35. Mass-flow deposit within the hyaloclastites of unit 407, with up to metre-sized lava fragments showing varying degrees of abrasion. The smaller clasts are dominated by fragmented pillows, and the matrix is mostly hyaloclastite sand and gravel. Small promontory just north of the house ruins at Nuusaq (Fig. 18).

Fig. 36. Close-up of vesicular fragments of high-temperature oxidised ropy pahoehoe lava in mass- flow deposit at Nuusaq. White arrow points to a distinctly red-oxidised clast. Length of Swiss army knife $8 \mathrm{~cm}$.
Mass flows of unit 407 around Nuusaq. A number of spectacular mass flows are exposed in the coastal cliffs around the old Inuit settlement Nuusaq, stretching from the small promontory just north of the house ruins and about $800 \mathrm{~m}$ to the south (Fig. 18). The individual massflow beds vary in thickness from a few metres to $10 \mathrm{~m}$ and also vary considerably in clast size and clast distribution, but they all contain an important clast component of subaerial lavas. The lowermost beds are exposed in the coastal cliff of the Nuusaq promontory. Here thin beds of mass flows dip $22^{\circ} \mathrm{SE}$ at sea level. They are truncated by massive mass flows with individual abraded lava clasts up to a few metres in size, separated from the lower beds by an erosional unconformity. One of these beds is well exposed in the south cliff of the promontory (Figs 35, 36). The rock type is aphyric to plagioclase microphyric basalt but additional fragments of plagioclase microphyric basalt pillows occur, some of which are rounded by abrasion. The distribution of the clasts appears to be chaotic. Other beds contain up to metre-sized, sharp-edged boulders floating in a matrix completely dominated by hyaloclastite-derived clasts (Fig. 37). What is probably the uppermost mass-flow bed is well exposed in the coastal cliff about $600 \mathrm{~m}$ south of Nuusaq. Here a bed overlying a clast-poor deposit is closely packed with lava clasts of which the largest one is a raft shown in Fig. 38. Farther south the same bed is packed with smaller fragments of probably the same lava flows. The basalts are extensively 


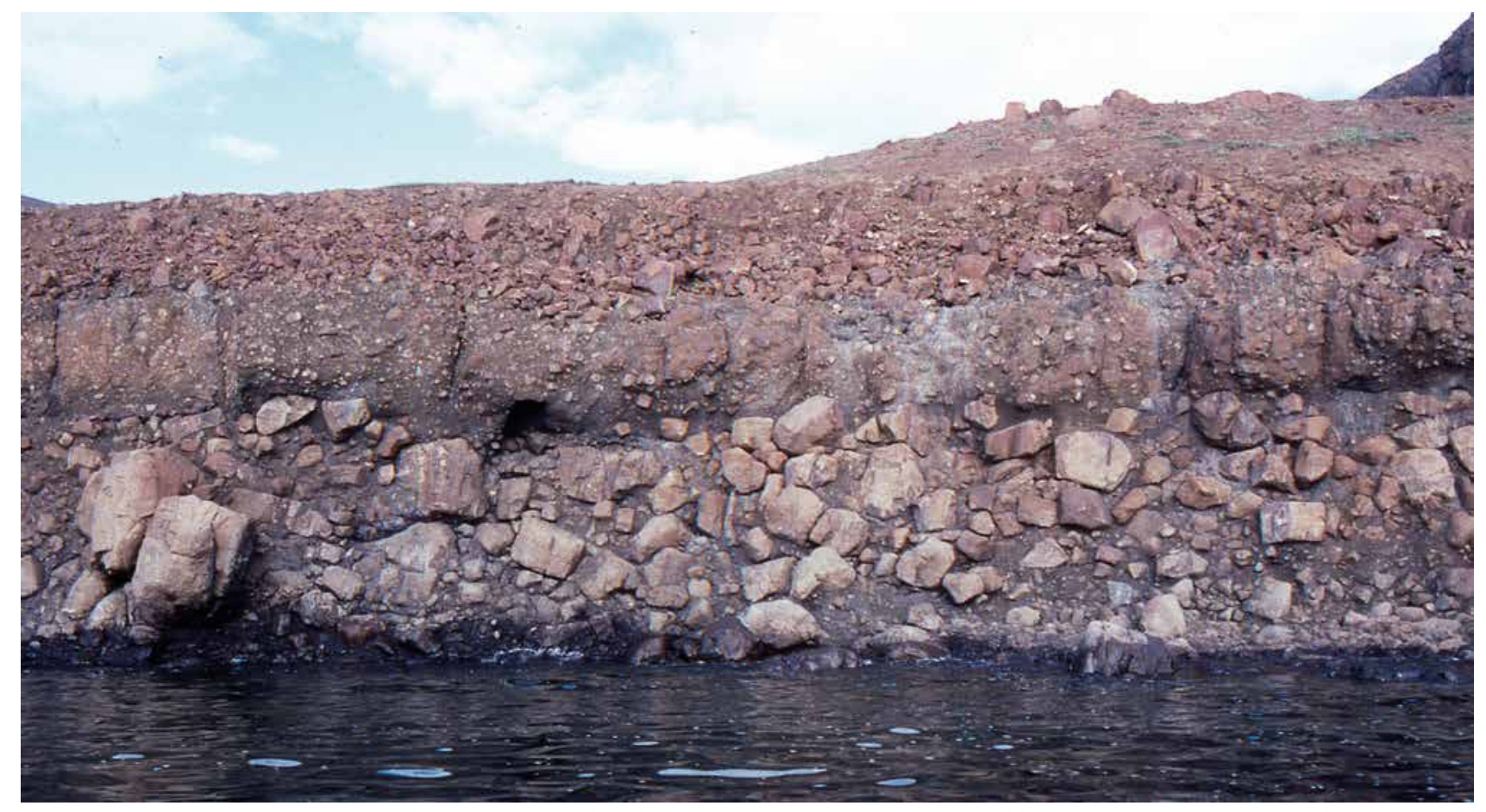

Fig. 37. A succession of three mass-flow deposits with sharp-edged lava boulders in a matrix dominated by hyaloclastite-derived material. The lava boulders in the lower deposit are up to metre-sized, and the height of the cliff is 7-8 m. Coastal cliff just south of the house ruins at Nuusaq (Fig. 18).

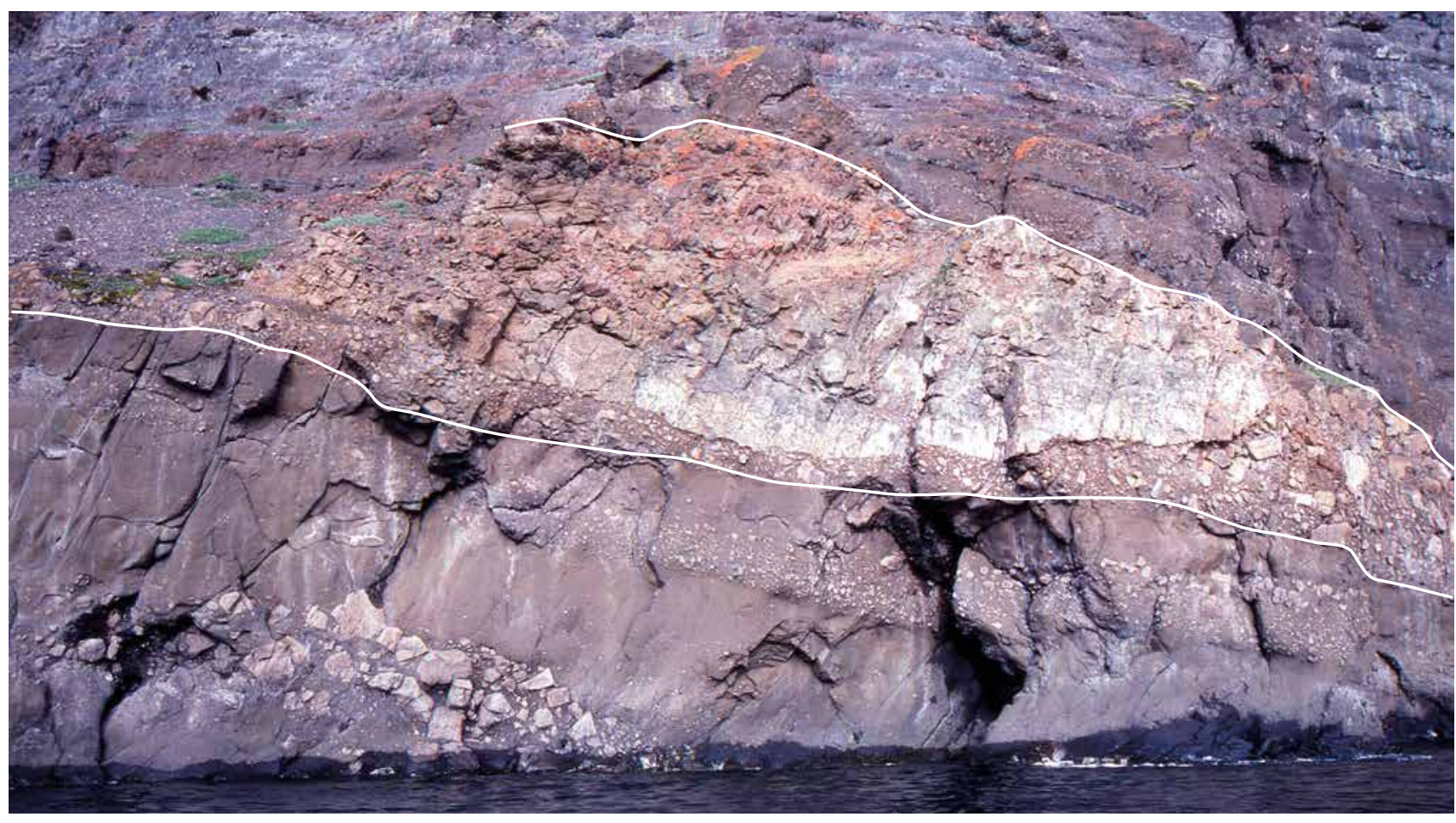

Fig. 38. Large lava raft in mass-flow deposit of unit 407. The raft is $28 \mathrm{~m}$ long and $10 \mathrm{~m}$ thick and is composed of two subaerial lava flows of aphyric basalt, a lower light grey and an upper brownish flow that shows high-temperature oxidation. The mass flow is traced by a white line; it is overlain by normal foreset-bedded hyaloclastites. Coastal cliff $c .600 \mathrm{~m}$ south of Nuusaq. 


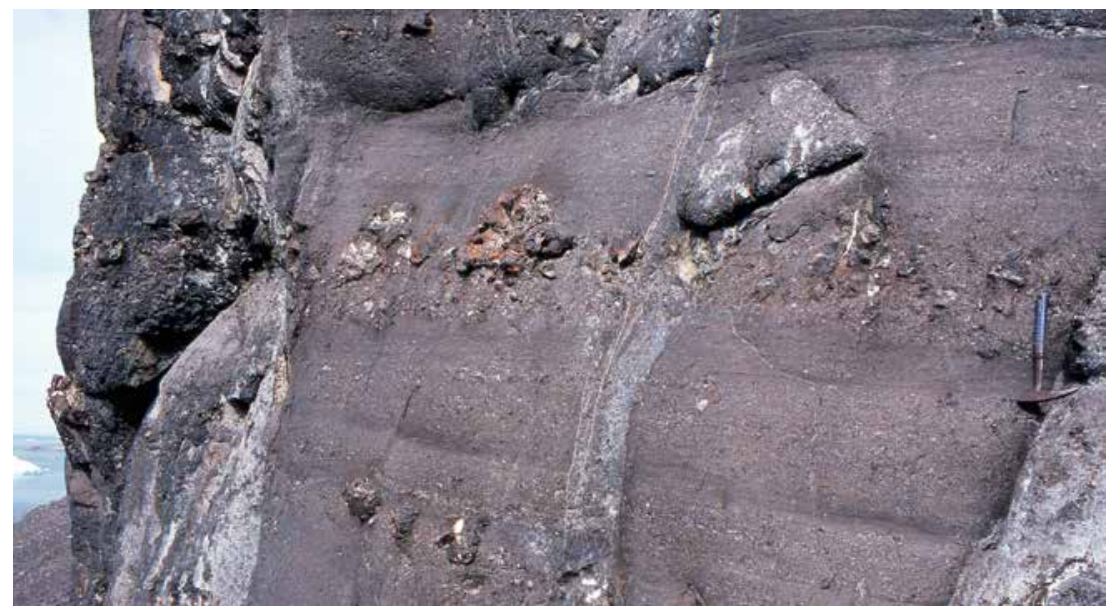

Fig. 39. Foreset-bedded hyaloclastite deposit of unit 407. Typical features of these deposits are the separation into thin individual beds made out by variations in grain size, and the irregular trains of larger clasts. Length of hammer $32 \mathrm{~cm}$. Gully $c .1 \mathrm{~km}$ south of Nuusaq.

hydrothermally altered, and the bed is oil saturated. The matrix is again composed of water-quenched glass gravel and pillow fragments.

The upper part of the GANE\# 1 core $(4-143 \mathrm{~m})$ consists of hyaloclastites of unit 407; the part at 4-74 m depth is a boulder conglomerate with up to $40 \mathrm{~cm}$ large, sub-rounded lava clasts in a hyaloclastite matrix. The boulders are strongly plagioclase-phyric and may derive from lavas similar to the flow at $25-26 \mathrm{~m}$ depth in the Marraat-1 core, which is petrographically similar. The boulder conglomerate may be part of the mass flows exposed at Nuusaq.

The mass flows around Nuusaq demonstrate that large masses of hyaloclastite and subaerial lava fragments were transported into the marine embayment from a shore of a growing lava plateau in a series of events within a narrow time interval. The size of the largest lava rafts and the abundance of hyaloclastite in all the beds suggest that the mass flows were not merely small passive landslides but were associated with active volcanism and tectonism and were probably triggered by earthquakes. A close recent

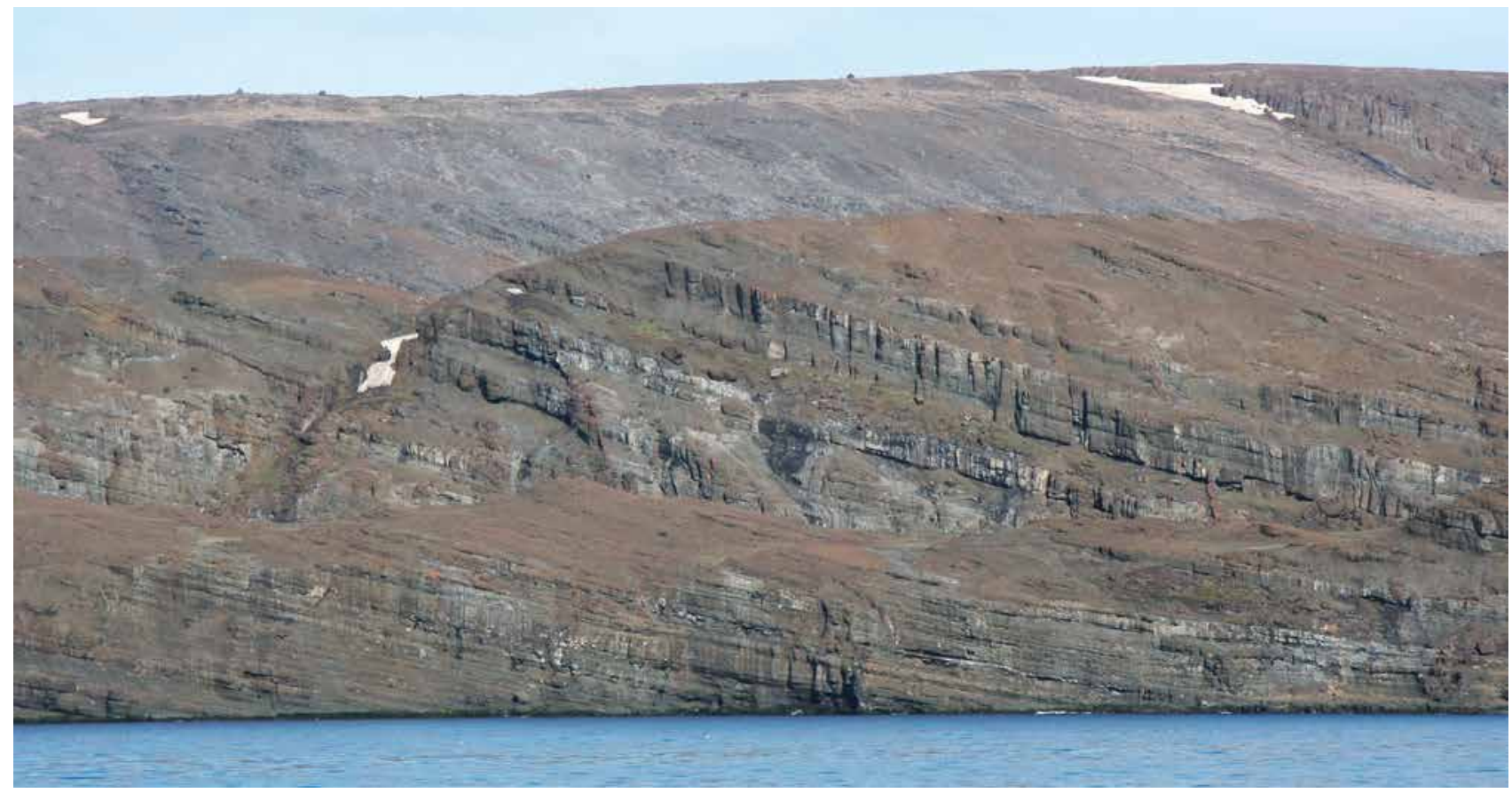

Fig. 40. Thick, monotonous foreset-bedded hyaloclastite deposits of unit 407 between Nuusaq and Niaqornaq (Fig. 18). The large lava delta prograded from north-west towards south-east, and the palaeo-waterdepth was more than $150 \mathrm{~m}$. The ridge in the middle ground is around $100 \mathrm{~m}$ high. 


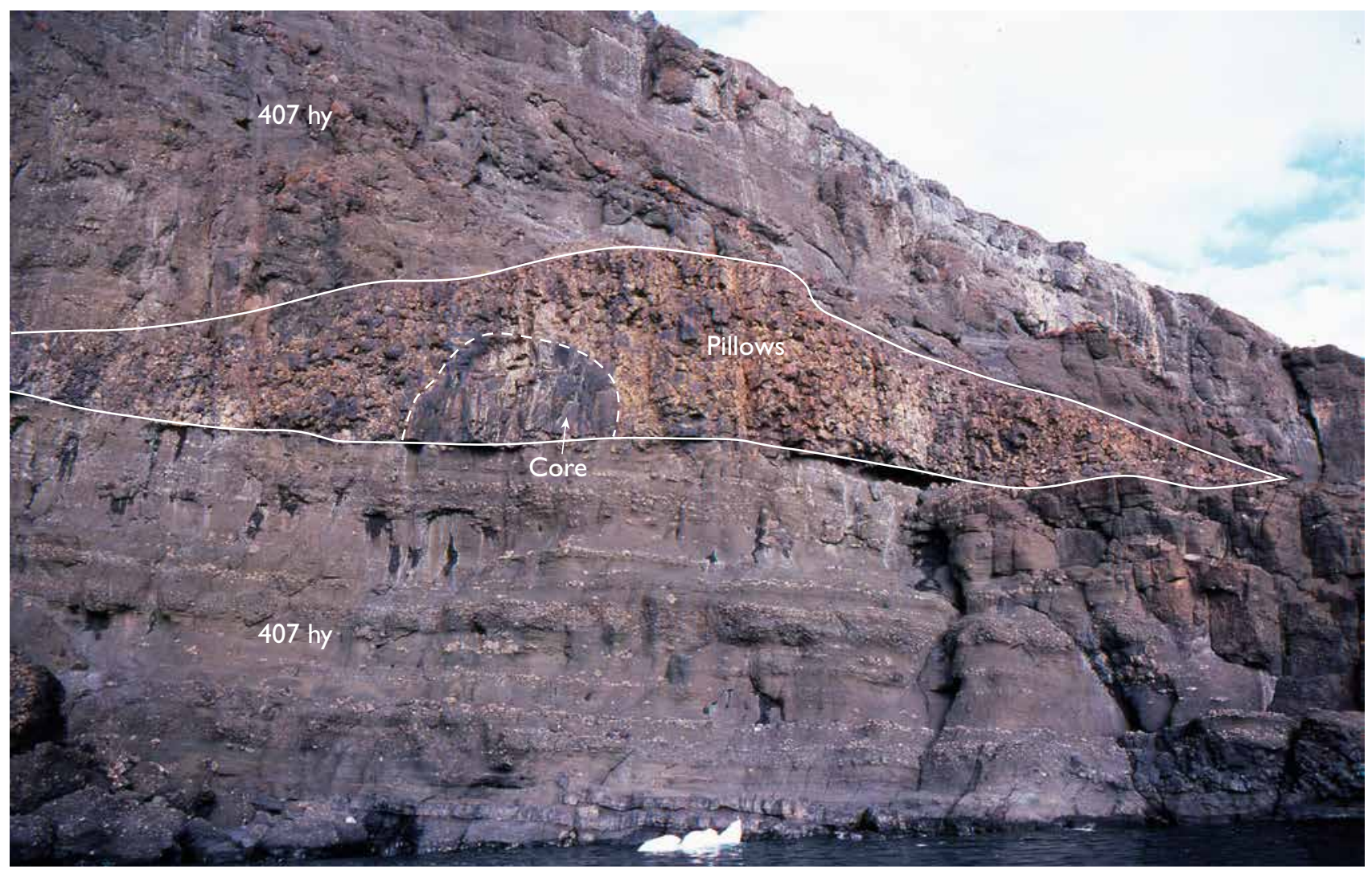

Fig. 41. Cross section through a minor eruption site within the hyaloclastites. A rounded mound of close-lying pillows is emplaced on the sloping hyaloclastite sea floor. The mound is $10-15 \mathrm{~m}$ high and extends downslope for more than $50 \mathrm{~m}$. At its base is a c. $5 \times 5 \mathrm{~m}$ hemispherical core of massive basalt. The mound is buried by advancing beds of hyaloclastite. Similar, less well-dissected pillow heaps are found in the vicinity of the main mound. One of these is exposed at sea level just $80 \mathrm{~m}$ south-east of the main mound and may have been formed during the same eruptive event. Coastal cliff $c .1 \mathrm{~km}$ south of Nuusaq (marked on Fig. 18).

analogue is the presently active lava delta on the south coast of Hawaii where small-scale coastal to low submarine landslides are an integral feature within and around the lava delta (Moore et al. 1989).

Upper hyaloclastites of unit 407. The distinctive clastrich mass flows are concordantly covered by a succession of hyaloclastite beds which dip 10-15 $\mathrm{SE}$. The beds have decimetre-sized clasts of pillow fragments of plagioclase microphyric basalt while lava fragments are very scarce or absent; however, the matrix is very similar to that in the mass flows (Fig. 39). The foresets demonstrate a palaeowater depth of more than $150 \mathrm{~m}$ and a fairly monotonous lava delta prograding from north-west towards south-east over a wide zone of more than two kilometres (Fig. 40). The zone of palaeoshore progradation can be followed northwards across the Aaffarsuaq valley to the northern Anariartorfik valley, but the northern exposures are much poorer than those at the southern coast. While all the hyaloclastites from Aaffarsuaq to the coast consist of evolved basalts, the hyaloclastites in the northern part of Anariartorfik consist of interlayered beds of picrite and evolved basalt of unit 407, demonstrating contemporaneous eruptions of widely differing magma compositions.

A number of widely spaced, less than $0.5 \mathrm{~m}$ thick irregular dykes of feldspar microphyric basalt intrude the hyloclastites along the coast between Nuusaq and $\mathrm{Ni}$ aqornaq and indicate relatively local sources for the hyaloclastites. This is substantiated by a well-exposed minor eruption site within the hyaloclastites (Fig. 41).

The easternmost occurrence of unit 407 is in the GANK\#1 well where the lowest volcanic units consist of hyaloclastite sand which represents the toesets of the prograding volcanic front entering the sea (at 84.3-114.9 $\mathrm{m}$ in the core). These volcaniclastic sands are interleaved with three thin beds of non-volcanic mudstone referred to the underlying Eqalulik Formation (Dam et al. 2009, p. 137, fig. 121). 


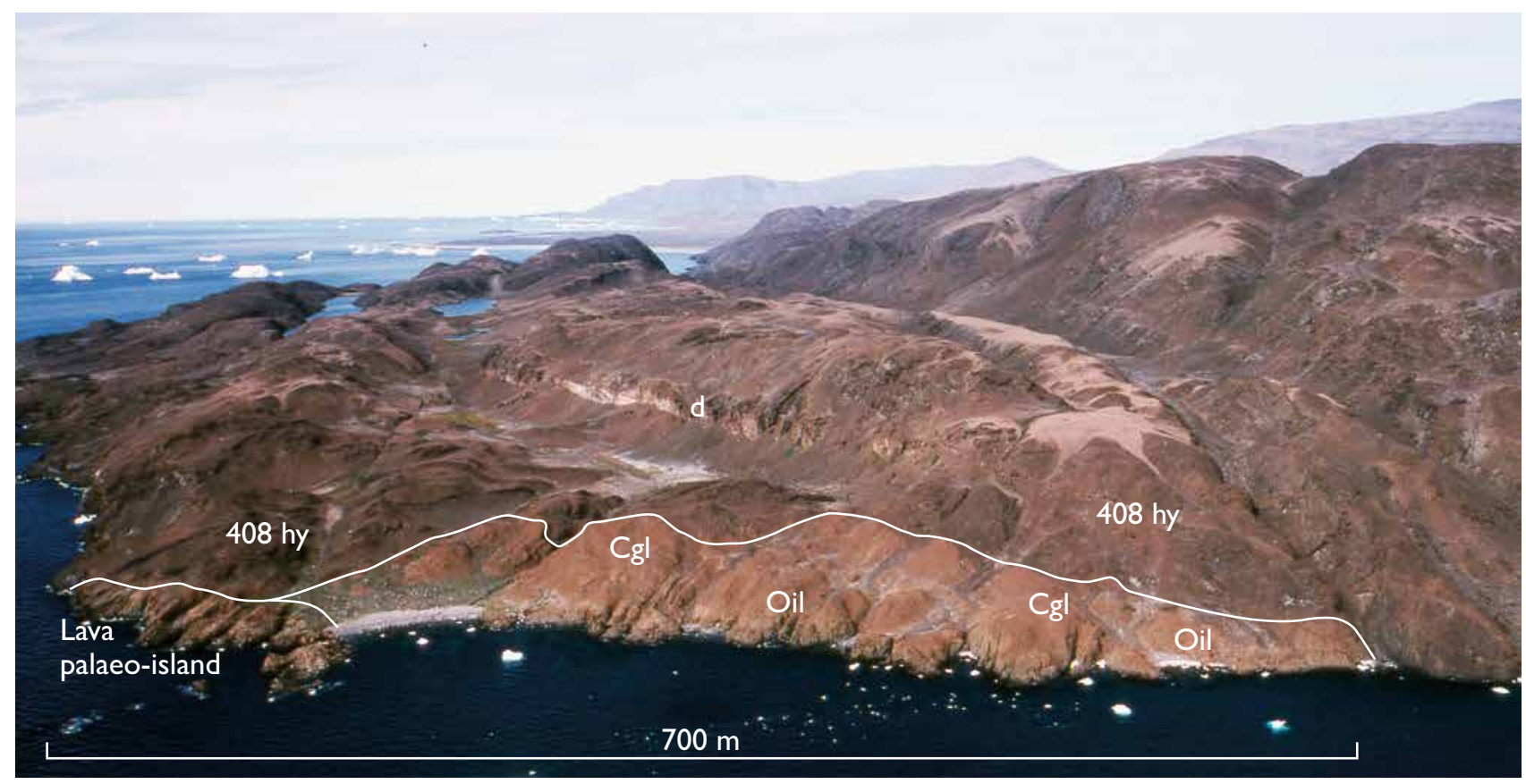

Fig. 42. The western lava palaeo-island and the oil-saturated basalt conglomerate (Cgl) at the old Inuit settlement Sikillingi (Fig. 18). The deposits are covered by hyaloclastites (hy) of unit 408. A large basalt dyke (d) cuts the hyaloclastites. For descriptions see text.

\section{Early lava islands of the Anaanaa Member}

Some unusual geological features are exposed over a stretch of $1.6 \mathrm{~km}$ along the south-western coast of Nuussuaq around Sikillingi and east of it. These are remnants of one or two small palaeo-islands of subaerial lava flows which already in Anaanaa Member time were eroded, submerged and covered by thick hyaloclastite deposits from younger volcanic units. Because these old lava islands are saturated with live oil, they will be described in some detail.

The western lava island is exposed around the old Inuit settlement Sikillingi (Fig. 42). Lava flows are only preserved over a distance of $130 \mathrm{~m}$, whereas associated conglomerates are found over $700 \mathrm{~m}$. The lava island is composed of the remnants of five to six vesiculated subaerial lava flows of aphyric basalt which are nearly horizontal and represent a vertical succession of only 10 to $15 \mathrm{~m}$. The lava flows are extensively eroded by palaeo-marine coastal abrasion and pass by in situ transformation into an overlying conglomerate (Fig. 43). The conglomerate is up to $35 \mathrm{~m}$ thick and clast supported with clast sizes ranging from a few centimetres to $2-3 \mathrm{~m}$. Most of the clasts and all those exceeding $20 \mathrm{~cm}$ in size are derived from vesiculated subaerial aphyric basalts. Some of the smaller clasts are abraded pillow fragments with partly preserved glassy margins (Fig. 44). The matrix is dominated by re- worked hyaloclastite although a minor fraction is derived from lavas. Both lavas and conglomerate are very extensively hydrothermally altered. They are carbonate-rich and have a reddish brown surface colour due to weathering of a siderite component in the carbonates. Both the western lava island and the conglomerate are relatively porous and filled with live oil. The oil impregnation is so pervasive that even vesicles in the interior of compact lava clasts are filled with liquid oil. Loose, oil-saturated lava clasts from the conglomerate are also washed up on the recent beach just east of the lava island.

The eastern lava island forms the rugged coast at the eastern end of the embayment about $1 \mathrm{~km}$ east of Sikillingi. Subaerial lava flows are exposed over an area of $300 \times$ $400 \mathrm{~m}$ but the island may have been larger and may once have been continuous with the western island. The eastern lava island is composed of an $18 \mathrm{~m}$ thick lower succession of lava flows overlain by $15 \mathrm{~m}$ of pillow lavas and lava flows transitional to pillow facies, followed by a 24 $\mathrm{m}$ thick upper succession of subaerial flows. The lavas are pahoehoe flows of olivine microphyric basalt which vary in thickness from a few metres to $5 \mathrm{~m}$ and dip $25-32^{\circ} \mathrm{W}$, in contrast to the flat-lying flows in the western lava island. The eastern lava island was probably previously covered by conglomerates similar to those of the western island, but due to erosion it is now only partially covered 


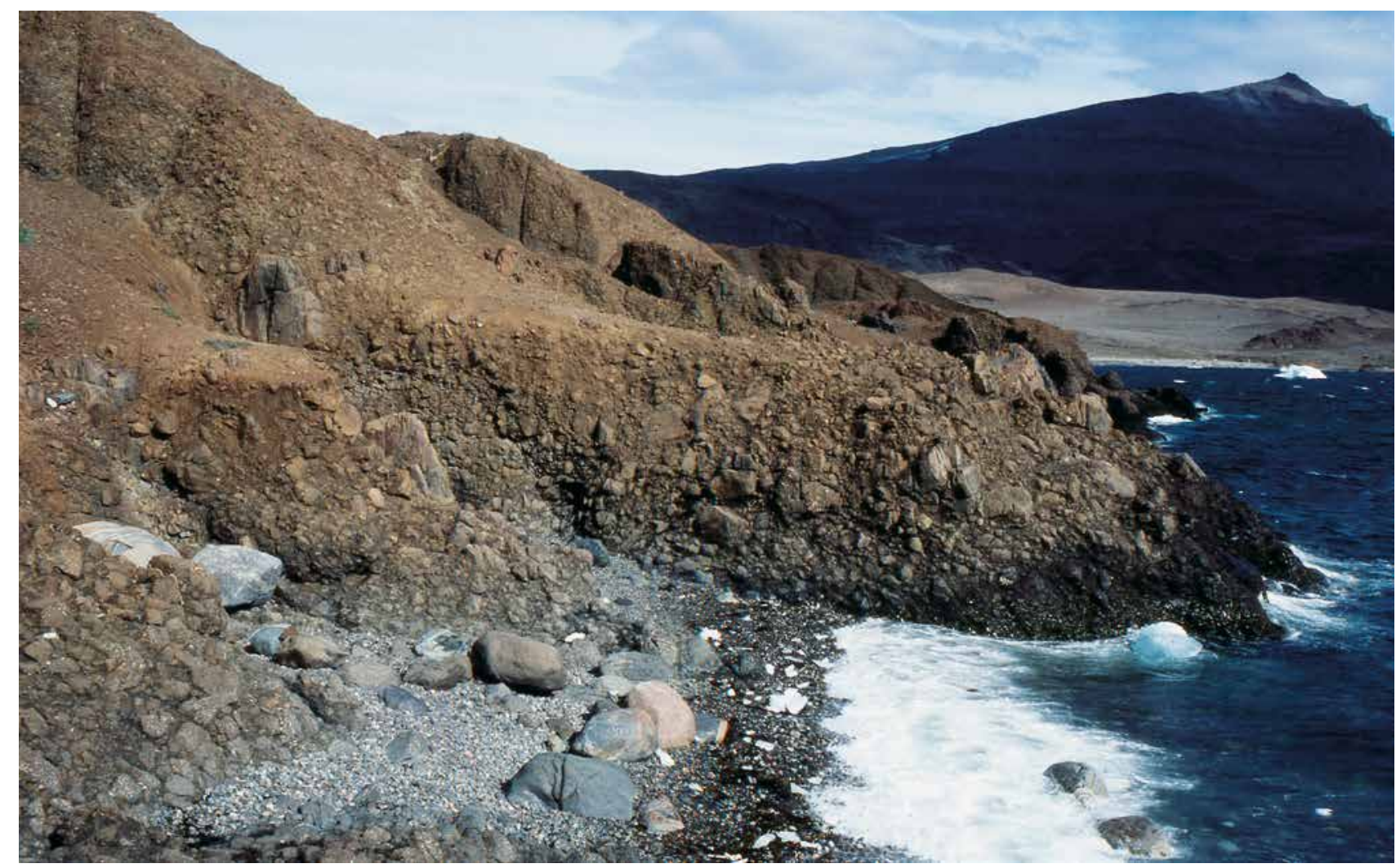

Fig. 43. Conglomerate overlying the western lava island at Sikillingi. The conglomerate was once an oil-saturated reservoir and the vugs in vesiculated lava fragment are now carbonate-rimmed and filled with bitumen or liquid oil. For description see text.

by poorly exposed volcaniclastic rocks. Just as the western island, the eastern island is extensively hydrothermally altered and saturated with live oil. The steep westerly dip is a synvolcanic feature and demonstrates significant rotation of this small block prior to the burial by the later hyaloclastites.
The conglomerates of the western lava island are covered by thick foreset-bedded hyaloclastites of aphyric to olivine microphyric contaminated basalts of unit 408 . The contact is exposed $c .600 \mathrm{~m}$ to the north-west where the foreset-bedded hyaloclastites of unit 407 are conformably overlain by those of unit 408 . The eastern lava island

Fig. 44. Clasts in conglomerate overlying the western lava island. The largest clasts consist of vesiculated subaerial basalt lava (La).

Several small clasts are pillow fragments and black glass (arrow marked hy). Arrows marked Oil point to vesicles with carbonate rims and oil- and bitumen-filled interiors. Lengt of knife $8 \mathrm{~cm}$.

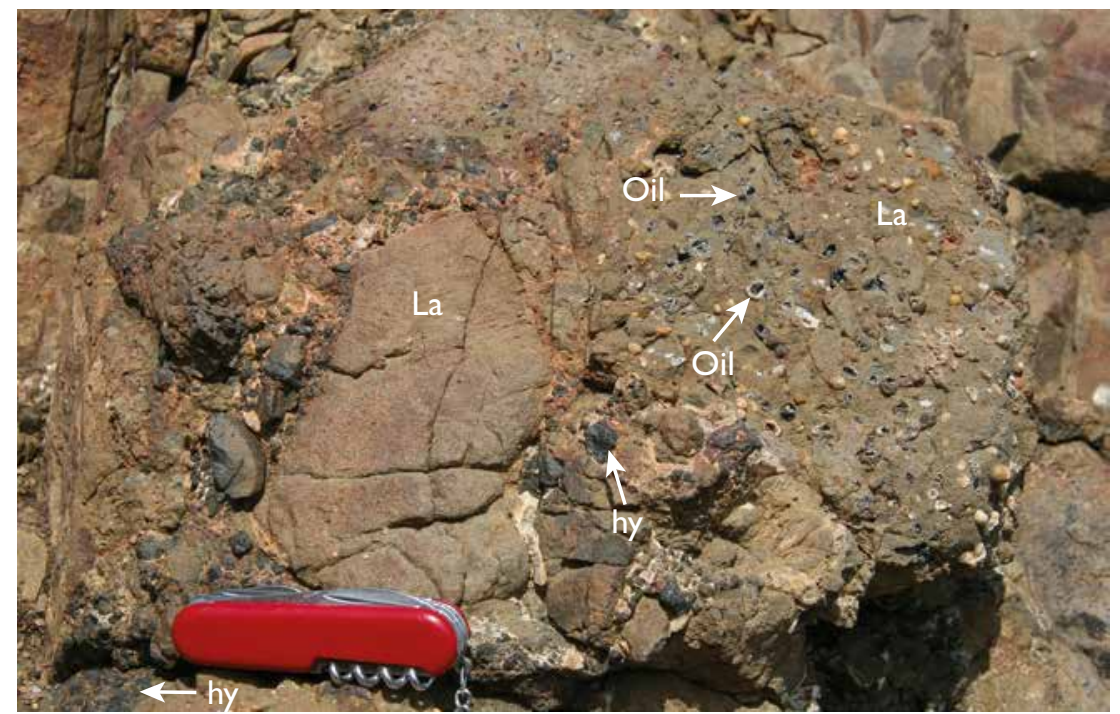


is also overlain by hyaloclastites, but it is unclear if these belong to the Anaanaa Member (unit 408) or to the widespread basal unit of the Naujánguit Member (unit 409).

The lava islands demonstrate an early formation of a subaerial lava plateau. During a pause in the volcanic activity the plateau was substantially eroded by the sea to form a rocky coast just like the present-day Sikillingi coast. A remnant of the flows was preserved because it subsided while the continued erosion of subaerial lava flows created the thick cover of conglomerate. Continued subsidence and faulting brought the lava island complex to a marine water depth of several hundred metres before it was buried by an advancing hyaloclastite front of unit 408 basalt.

The old lava islands are so chemically altered that their relation to a unit cannot be ascertained. They are presumably older than the younger part of the unit 407 basalts and are tentatively correlated with unit 405 basalts but could also correlate with the oldest unit 407 basalts.

\section{Brown aphyric basalts (Marraat unit or upper contaminated unit, 408)}

The uppermost unit of the Anaanaa Member consists of aphyric to sparsely olivine microphyric basalts and a few picrites with 7-13 wt $\% \mathrm{MgO}$, which are silicic and crustally contaminated. The unit is in lava facies in the Marraat Killiit area and eastwards to Qunnileeraasakassak; it is in hyaloclastite facies in the Sikillingi area in the south as well as in Anariartorfik in the north (Fig. 18).

In the Marraat Killiit area unit 408 consists of a 15-45 $m$ thick succession of massive, brown basalt lava flows (at $1-17 \mathrm{~m}$ in the Marraat- 1 core). The flows are from a few metres to $10 \mathrm{~m}$ thick and form erosion-resistant ridges and spits along the low-lying coast (Fig. 30). The basalts show irregular flow folding and small cracks indicating viscous break at near-solidus conditions. In the scoriaceous lava tops up to $5 \mathrm{~cm}$ irregular vesicles are partly filled by agate, quartz and carbonate. Freshly split samples tend to have liquid oil in vugs. Despite their crustally contaminated nature no xenoliths have been found. The lava flows of unit 408 cover subaerial lavas of unit 407 and are covered by olivine microphyric basalt flows of the Naujánguit Member (unit 409).

At Qunnileeraasakassak $c .10 \mathrm{~km}$ east of Marraat, unit 408 changes into hyaloclastite facies over a short distance and disappears rapidly in a short hyaloclastite fan (Central Nuussuaq section at $4 \mathrm{~km}$ ).

On the northern side of Anariartorfik, erosion has removed all subaerial lava flows of unit 408 but a c. 100 $m$ thick succession of brownish-weathering basalt pillow lavas and subaqueous lava tongues with breccia tops and strongly columnar-jointed, massive flow interiors overlies grey hyaloclastites of unit 407 .

At Sikillingi c. $20 \mathrm{~km}$ south of Marraat, a deposit of dark brown fairly massive hyaloclastites of unit 408 overlies hyaloclastites of unit 407 over a distance of $c .1 \mathrm{~km}$ along the coast and covers the early western lava island and its associated conglomerates. As a result of early zeolite facies crystallisation (Neuhoff et al. 2006), the unit 408 hyaloclastite has a very low remaining porosity and makes an efficient seal for migrating oil which has consequently accumulated in the underlying, highly porous lava island conglomerates, forming a model oil trap and reservoir.

\section{Chemical composition of the Anaanaa Member}

The rocks of the Anaanaa Member range from olivinerich picrites to evolved aphyric and plagioclase-phyric basalts. Many rocks in this member, particularly close to the Itilli fault, in the drill cores, and in the old lava islands in the Sikillingi area, are distinctly hydrothermally altered with hydration and frequent carbonate impregnation, leaving little or no fresh olivine. This alteration must have taken place while the area was still volcanically active; it is not a recent weathering phenomenon as is evident from the altered nature of the rocks in the drill cores that have never been exposed since deposition. Because of the alteration, the chemical screen for samples plotted in the variation diagrams for the Anaanaa Member was changed to $<10 \mathrm{wt} \%$ volatiles and $<15 \mathrm{wt} \% \mathrm{CaO}$; moreover, samples whose allocation to a unit is uncertain, such as some from Sikillingi, were not plotted. Representative chemical analyses are shown in Table 2.

\section{Major elements}

Variation diagrams of the major elements are shown in Fig. 45. The large range in $\mathrm{MgO}, 6-26 \mathrm{wt} \%$, is mainly due to olivine fractionation and accumulation, with the primary magmas having an estimated 17.0-18.5 wt\% $\mathrm{MgO}$ (Larsen \& Pedersen 2009). The variations seen for the other elements are strongly dominated by the olivine control, and decreasing $\mathrm{MgO}$ is accompanied by increases in all other elements except $\mathrm{FeO}^{*}$ which shows a slight decrease. Plagioclase saturation was reached at around 7 wt $\% \mathrm{MgO}$, but with few exceptions the plagioclase-phyric basalts do not have lowered $\mathrm{Al}_{2} \mathrm{O}_{3}$ and $\mathrm{CaO}$ below the olivine control line, indicating that significant removal 

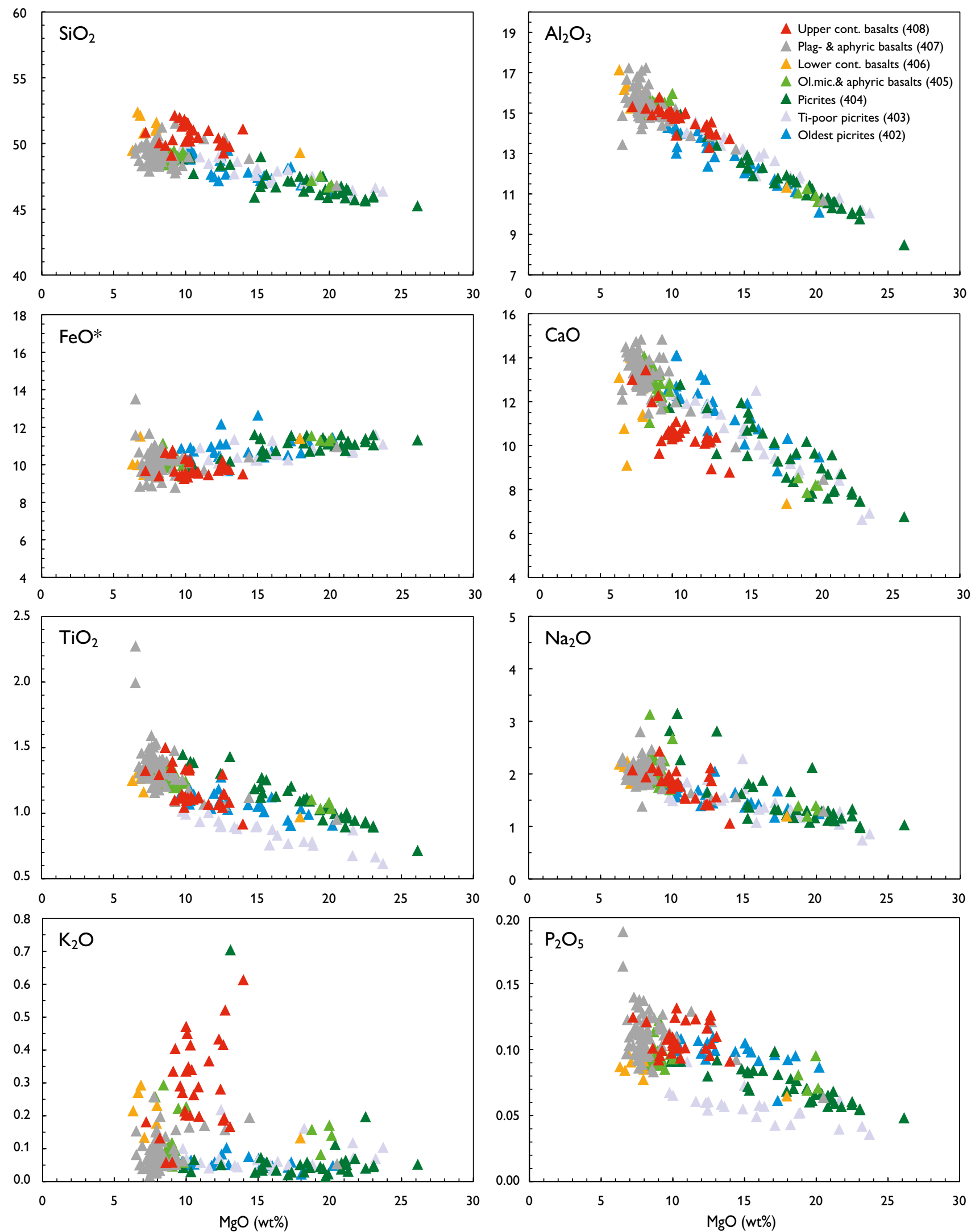

Fig. 45. Major-element variation diagrams for rocks of the Anaanaa Member. Data in wt\% oxides calculated volatile-free; FeO* is total iron as FeO. Three-digit unit codes (Table 1) in parentheses. Legend: Cont.: contaminated. Ol.mic.: olivine microphyric. Plag: plagioclase. 

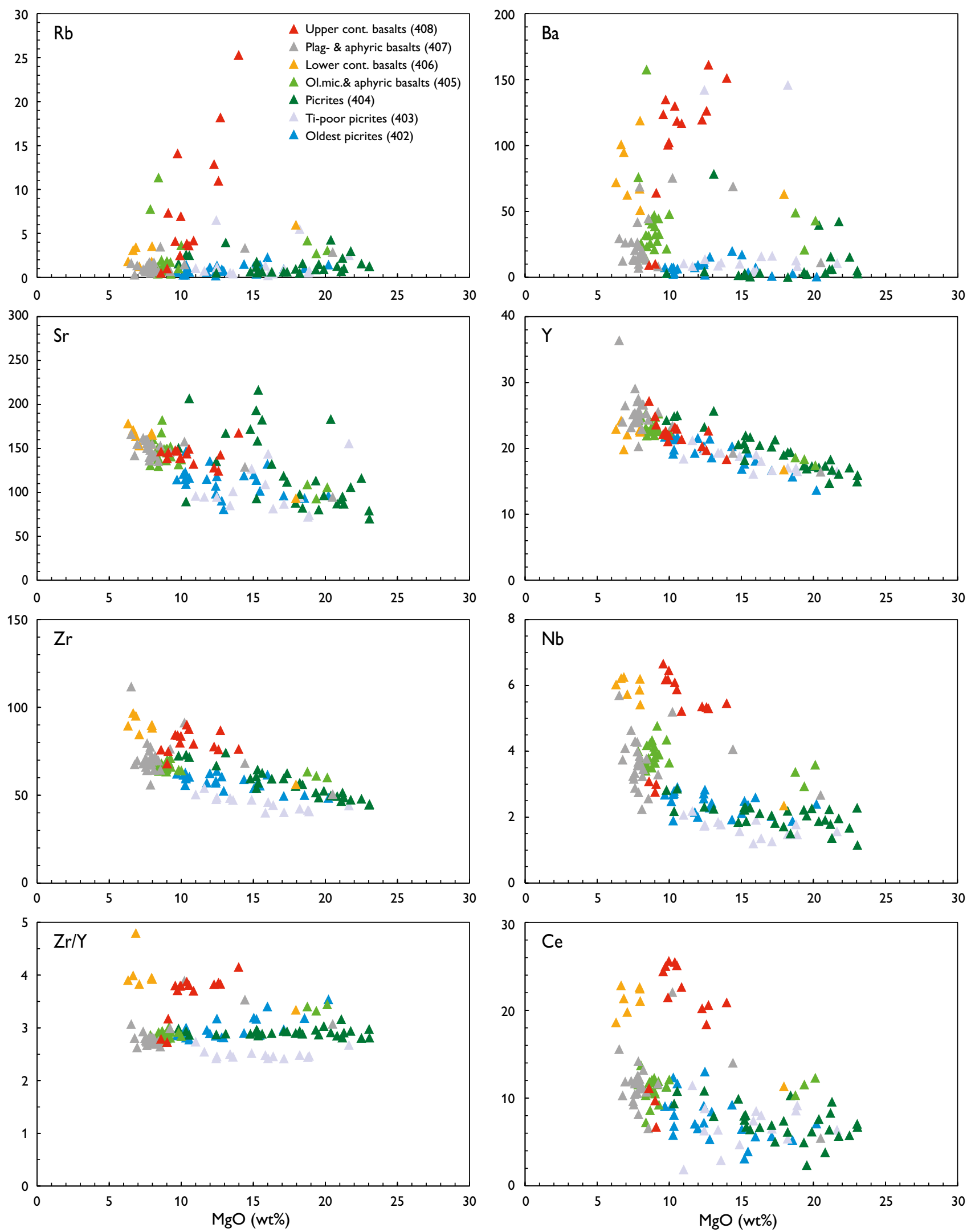

Fig. 46. Incompatible trace-element variation diagrams for rocks of the Anaanaa Member. Data in ppm. For abbreviations, see Fig. 45. 

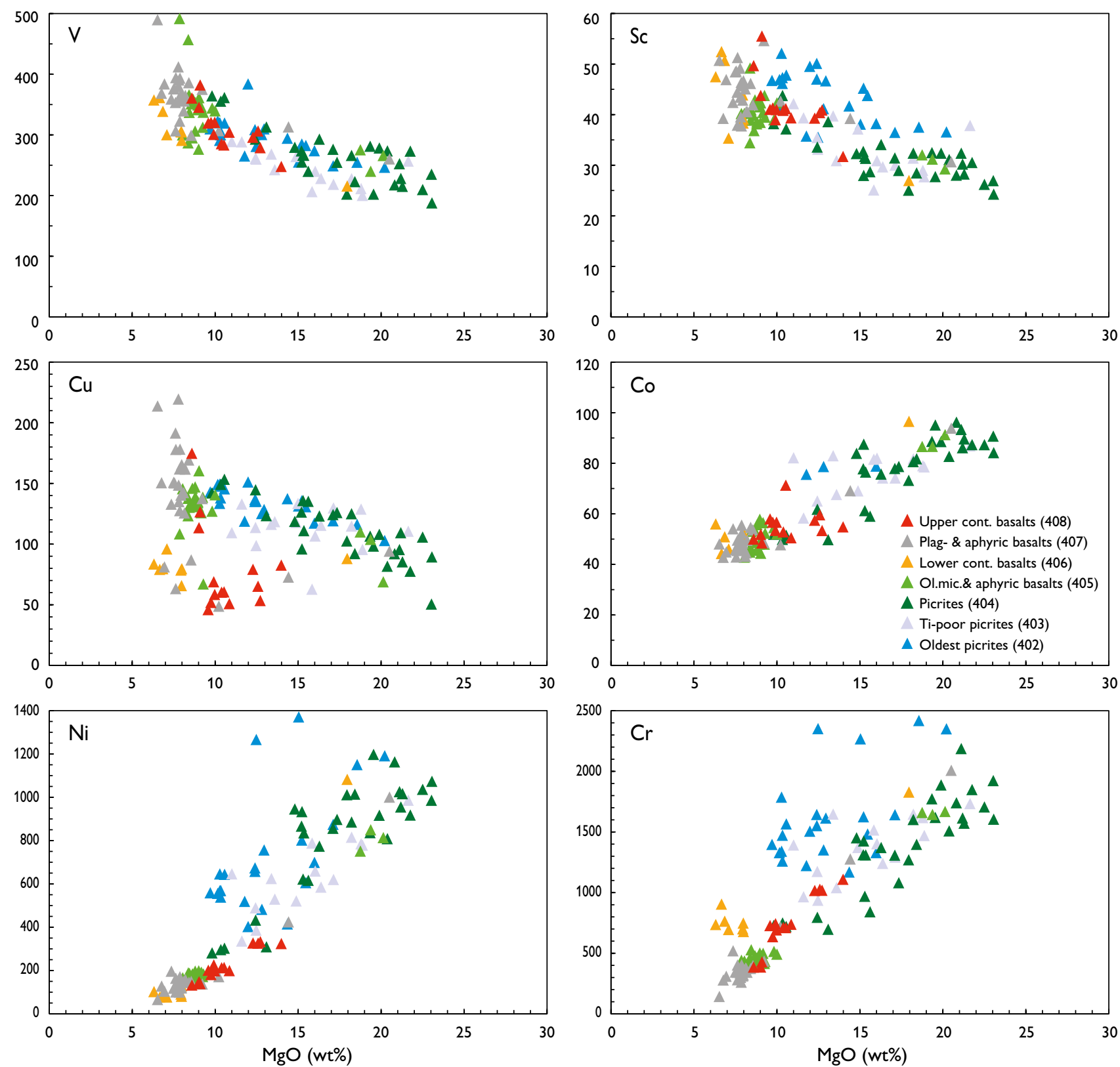

Fig. 47. Transition-element variation diagrams for rocks of the Anaanaa Member. Data in ppm. For abbreviations, see Fig. 45.

of plagioclase has generally not taken place. Two successive flows in unit 407 are exceptions which seem to owe their enrichment in $\mathrm{TiO}_{2}, \mathrm{FeO}$ and $\mathrm{P}_{2} \mathrm{O}_{5}$, and depletion in $\mathrm{Al}_{2} \mathrm{O}_{3}$ and $\mathrm{CaO}$, to plagioclase fractionation. The Tipoor picrite unit 403 has significantly lower $\mathrm{TiO}_{2}$ and $\mathrm{P}_{2} \mathrm{O}_{5}$ than the other picrite units. The brown basalts of units 406 and 408 have higher $\mathrm{SiO}_{2}$ (up to $52.4 \mathrm{wt} \%$ ) and $\mathrm{K}_{2} \mathrm{O}$ and lower $\mathrm{CaO}$ than the other basalts because they are crustally contaminated (Larsen \& Pedersen 2009).

\section{Trace elements}

Variation diagrams for trace elements are shown in Figs 46,47 . Olivine (and chromite) control is the dominant feature, making all elements except $\mathrm{Ni}$, Co and $\mathrm{Cr}$ incompatible and thus increasing with decreasing $\mathrm{MgO}$. $\mathrm{Rb}$ and $\mathrm{Ba}$, like $\mathrm{K}_{2} \mathrm{O}$, are scattered as a result of secondary alteration which is particularly apparent because the unaltered concentrations are very low. Some of the scatter in $\mathrm{Sr}$ is also due to alteration as $\mathrm{Sr}$ follows $\mathrm{Ca}$ in carbonate impregnations. The immobile elements $\mathrm{Zr}, \mathrm{Nb}$ and $\mathrm{Y}$ have the least scattered trends. 

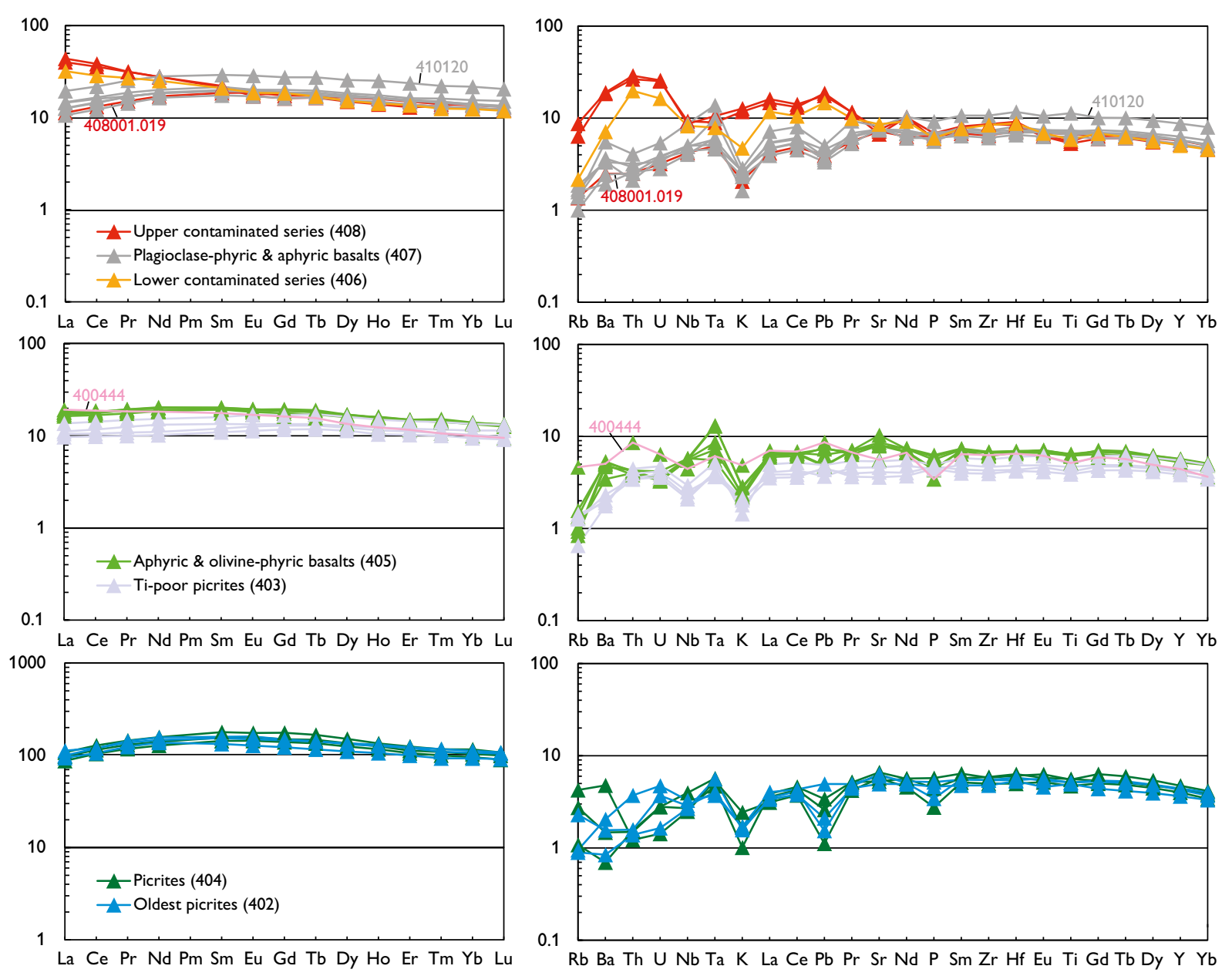

Fig. 48. REE and multi-element diagrams for representative rocks of the Anaanaa Member. Left diagram, chondrite normalised; right diagram, primitive mantle normalised; normalisation factors from McDonough \& Sun (1995). For abbreviations, see Fig. 45.

The Ti-poor picrite unit 403 is also $\mathrm{Zr}$-poor and has distinctly low $\mathrm{Zr} / \mathrm{Y}$.

The oldest picrite unit 402 has generally higher Sc than the other units, which may be a primary feature, although the scatter is fairly large. This unit, and some samples of the overlying units, also have much higher and more scattered $\mathrm{Ni}$ and $\mathrm{Cr}$ (at a given $\mathrm{MgO}$ ) than the other units. As $\mathrm{Ni}$ and $\mathrm{Cr}$ are known to be concentrated in hydrothermal alteration zones in some ultramafic rocks (e.g. Auclair et al. 1988), we tentatively ascribe these increased $\mathrm{Ni}$ and $\mathrm{Cr}$ levels to hydrothermal alteration.

The Si-enriched basalts of units 406 and 408 have distinctly increased $\mathrm{Rb}, \mathrm{Ba}, \mathrm{Zr}, \mathrm{Nb}$ and $\mathrm{Ce}$, and decreased $\mathrm{Cu}$, relative to the uncontaminated basalts. A few samples of unit 408 appear to be uncontaminated; however, in the field the boundary between units 407 and 408 is quite distinct.
REE and multi-element diagrams are shown in Fig. 48. The uncontaminated units show a relative depletion in the most incompatible elements, with normalised $\mathrm{La} / \mathrm{Nd}$ and $\mathrm{Rb} / \mathrm{Ta}<1$, leading to a curved, convex-up shape for both types of patterns. The two picrite units 402 and 404 have closely similar REE and multi-element patterns, the scatter for $\mathrm{Rb}-\mathrm{U}$ being ascribable to alteration. Troughs for $\mathrm{K}$ and $\mathrm{Pb}$ are of varying size, perhaps also due to alteration, and some but not all samples have a P trough. The evolved basalts of unit 407 have REE and multi-element patterns similar to those of the older picrites but displaced towards higher levels, particularly for the most evolved, Ti-rich sample (410120), implying that they evolved from similar parental magmas.

The Ti-poor picrite unit 403 and the olivine microphyric to aphyric basalt unit 405 both have REE patterns that are much flatter than those of the other units, primarily due to increased $\mathrm{La}-\mathrm{Sm}$. Their multi-element 
Table 2a. Chemical analyses of rocks, Anaanaa Member

\begin{tabular}{|c|c|c|c|c|c|c|c|c|c|c|c|c|}
\hline \multirow[b]{2}{*}{ Lith. code } & \multicolumn{3}{|c|}{ Oldest picrites } & \multicolumn{4}{|c|}{ Ti-poor picrites } & \multicolumn{3}{|c|}{ Picrites } & \multicolumn{2}{|c|}{$\begin{array}{l}\text { Enriched Ol-phyric } \\
\text { picrite basalt }\end{array}$} \\
\hline & 4022 & 4022 & 4022 & 4031 & 4031 & 4032 & 4032 & 4041 & 4042 & 4042 & 4051 & 4052 \\
\hline GGU No. & 393101 & 447107 & 408001 & 408001 & 408001 & 408001 & 439001 & 400457 & 400492 & 408001 & 400444 & 400490 \\
\hline \multicolumn{2}{|c|}{ Core subnumber .094} & & .292 & .233 & .242 & .273 & .778 & & & .222 & & \\
\hline Deg.W & 5413.09 & 5414.50 & 5412.29 & 5412.29 & 5412.29 & 5412.29 & 5400.40 & 5409.96 & 5404.36 & 5412.29 & 5412.66 & 5404.29 \\
\hline Deg. N & 7031.43 & 7032.57 & 7030.99 & 7030.99 & 7030.99 & 7030.99 & 7028.25 & 7031.16 & 7032.27 & 7030.99 & 7031.00 & 7032.19 \\
\hline Altitude, $\mathrm{m}$ & -595.2 & 57.3 & -421.4 & -203 & -210.5 & -318.6 & -372.1 & 100.4 & 552.1 & -187.6 & 3.53 & 565.2 \\
\hline $\mathrm{SiO}_{2}$ & 44.72 & 45.44 & 46.38 & 45.51 & 45.93 & 46.64 & 47.46 & 44.17 & 45.56 & 44.40 & 45.63 & 48.49 \\
\hline $\mathrm{TiO}_{2}^{2}$ & 0.95 & 1.08 & 1.01 & 0.75 & 0.80 & 0.97 & 0.91 & 0.91 & 1.02 & 1.06 & 1.01 & 1.21 \\
\hline $\mathrm{Al}_{2} \mathrm{O}_{3}$ & 10.60 & 11.80 & 13.75 & 11.29 & 12.49 & 14.03 & 13.61 & 9.95 & 10.83 & 11.24 & 10.35 & 15.31 \\
\hline $\mathrm{Fe}_{2} \mathrm{O}_{3}$ & 2.94 & 2.62 & 3.89 & 3.54 & 3.49 & 2.70 & 5.36 & 2.78 & 2.73 & 2.96 & 2.24 & 2.85 \\
\hline $\mathrm{FeO}$ & 8.10 & 7.97 & 7.18 & 7.16 & 6.96 & 7.44 & 5.74 & 8.21 & 8.20 & 8.02 & 9.12 & 7.38 \\
\hline $\mathrm{MnO}$ & 0.17 & 0.17 & 0.19 & 0.17 & 0.17 & 0.26 & 0.20 & 0.18 & 0.18 & 0.18 & 0.18 & 0.17 \\
\hline $\mathrm{MgO}$ & 17.69 & 15.33 & 11.45 & 17.99 & 15.69 & 11.15 & 10.65 & 21.01 & 19.10 & 17.43 & 19.59 & 8.87 \\
\hline $\mathrm{CaO}$ & 9.16 & 10.33 & 12.06 & 8.39 & 9.23 & 11.61 & 11.55 & 8.43 & 10.07 & 9.00 & 7.98 & 13.05 \\
\hline $\mathrm{Na}_{2} \mathrm{O}$ & 1.23 & 1.37 & 1.65 & 1.20 & 1.31 & 1.51 & 1.79 & 1.12 & 1.29 & 1.59 & 1.28 & 1.84 \\
\hline $\mathrm{K}_{2} \mathrm{O}$ & 0.046 & 0.047 & 0.048 & 0.050 & 0.059 & 0.040 & 0.057 & 0.068 & 0.045 & 0.028 & 0.137 & 0.068 \\
\hline $\mathrm{P}_{2} \mathrm{O}_{5}$ & 0.091 & 0.088 & 0.104 & 0.088 & 0.093 & 0.097 & 0.088 & 0.055 & 0.070 & 0.113 & 0.069 & 0.091 \\
\hline Volatiles & 3.85 & 3.39 & 2.18 & 4.04 & 3.78 & 3.31 & 2.37 & 2.82 & 1.12 & 3.70 & 2.11 & 0.87 \\
\hline Sum & 99.54 & 99.63 & 99.89 & 100.17 & 99.99 & 99.75 & 99.78 & 99.70 & 100.20 & 99.72 & 99.68 & 100.20 \\
\hline $\mathrm{Zn}$ & 80 & 89 & 79 & 70 & 71 & 77 & 75 & 78 & 86 & 77 & 89 & 93 \\
\hline $\mathrm{Cu}$ & 111 & 113 & 116 & 123 & 111 & 128 & 115 & 75 & 105 & 120 & 67 & 134 \\
\hline Co & 90 & 76 & 74 & 76 & 71 & 56 & 76 & 84 & 88 & 77 & 89 & 57 \\
\hline $\mathrm{Ni}$ & 1098 & 671 & 506 & 751 & 560 & 322 & 599 & 887 & 827 & 848 & 792 & 170 \\
\hline Sc & 36 & 37 & 35 & 28 & 28 & 38 & 36 & 30 & 32 & 31 & 29 & 42 \\
\hline V & 243 & 263 & 258 & 202 & 218 & 277 & 267 & 264 & 278 & 255 & 259 & 346 \\
\hline $\mathrm{Cr}$ & 2308 & 1277 & 1191 & 1549 & 1188 & 927 & 1353 & 1787 & 1753 & 1535 & 1625 & 497 \\
\hline $\mathrm{Ga}$ & 16 & 13 & 32 & 14 & 16 & 19 & 17 & 16 & 17 & 15 & 17 & 23 \\
\hline $\mathrm{Rb}$ & 1.31 & 1.58 & 0.56 & 0.75 & 0.73 & 0.38 & 0.83 & 2.47 & 0.53 & 0.62 & 2.71 & 0.60 \\
\hline $\mathrm{Sr}$ & 94.0 & 126 & 117 & 68.7 & 78.1 & 103 & 88.9 & 109 & 124 & 100 & 108 & 161 \\
\hline$Y$ & 14.9 & 18.1 & 18.5 & 15.8 & 17.1 & 22.7 & 18.3 & 16.6 & 18.1 & 19.5 & 18.5 & 24.0 \\
\hline $\mathrm{Zr}$ & 48.0 & 58.7 & 55.6 & 39.6 & 43.0 & 56.8 & 47.4 & 50.6 & 56.2 & 58.1 & 64.0 & 69.0 \\
\hline $\mathrm{Nb}$ & 2.23 & 2.11 & 2.03 & 1.32 & 1.40 & 1.86 & 1.60 & 1.58 & 1.74 & 1.70 & 2.84 & 3.60 \\
\hline Cs & 0.081 & 0.025 & 0.007 & 0.024 & 0.019 & 0.009 & 0.138 & 0.010 & 0.004 & 0.044 & 0.143 & 0.004 \\
\hline $\mathrm{Ba}$ & 9.83 & 9.35 & 13.1 & 12.8 & 14.7 & 11.2 & 12.2 & 30.4 & 5.51 & 4.41 & 32.4 & 22.4 \\
\hline $\mathrm{La}$ & 2.08 & 2.22 & 2.54 & 2.20 & 2.39 & 3.10 & 2.56 & 1.96 & 2.24 & 2.40 & 4.42 & 4.27 \\
\hline $\mathrm{Ce}$ & 6.06 & 6.87 & 7.04 & 5.77 & 6.20 & 8.36 & 6.94 & 6.04 & 6.81 & 7.37 & 11.2 & 10.89 \\
\hline $\mathrm{Pr}$ & 1.08 & 1.25 & 1.22 & 0.888 & 0.965 & 1.32 & 1.12 & 1.03 & 1.17 & 1.26 & 1.66 & 1.71 \\
\hline Nd & 5.88 & 6.74 & 6.42 & 4.46 & 4.83 & 6.70 & 5.84 & 5.54 & 6.22 & 6.78 & 8.12 & 8.50 \\
\hline Sm & 1.85 & 2.22 & 2.18 & 1.55 & 1.70 & 2.27 & 1.93 & 2.01 & 2.24 & 2.49 & 2.54 & 2.82 \\
\hline Eu & 0.673 & 0.850 & 0.804 & 0.610 & 0.681 & 0.913 & 0.726 & 0.769 & 0.860 & 0.927 & 0.924 & 1.07 \\
\hline Gd & 2.28 & 2.79 & 2.77 & 2.23 & 2.46 & 3.20 & 2.58 & 2.63 & 2.89 & 3.29 & 3.14 & 3.82 \\
\hline $\mathrm{Tb}$ & 0.392 & 0.485 & 0.488 & 0.408 & 0.446 & 0.595 & 0.468 & 0.463 & 0.517 & 0.567 & 0.548 & 0.679 \\
\hline Dy & 2.54 & 3.06 & 3.19 & 2.68 & 2.88 & 3.80 & 3.04 & 2.91 & 3.23 & 3.49 & 3.22 & 4.13 \\
\hline Ho & 0.541 & 0.650 & 0.680 & 0.543 & 0.600 & 0.785 & 0.651 & 0.603 & 0.664 & 0.692 & 0.654 & 0.846 \\
\hline $\mathrm{Er}$ & 1.49 & 1.81 & 1.87 & 1.57 & 1.71 & 2.21 & 1.85 & 1.60 & 1.75 & 1.87 & 1.81 & 2.32 \\
\hline $\mathrm{Tm}$ & 0.215 & 0.254 & 0.276 & 0.237 & 0.253 & 0.335 & 0.279 & 0.234 & 0.260 & 0.270 & 0.255 & 0.344 \\
\hline $\mathrm{Yb}$ & 1.40 & 1.62 & 1.72 & 1.45 & 1.59 & 2.08 & 1.78 & 1.46 & 1.62 & 1.75 & 1.56 & 2.19 \\
\hline Lu & 0.210 & 0.241 & 0.252 & 0.215 & 0.230 & 0.311 & 0.272 & 0.209 & 0.237 & 0.246 & 0.228 & 0.309 \\
\hline $\mathrm{Hf}$ & 1.43 & 1.71 & 1.60 & 1.14 & 1.18 & 1.63 & 1.32 & 1.36 & 1.52 & 1.65 & 1.79 & 1.89 \\
\hline $\mathrm{Ta}$ & 0.142 & 0.202 & 0.134 & 0.142 & 0.144 & 0.185 & 0.131 & 0.191 & 0.204 & 0.166 & 0.220 & 0.262 \\
\hline $\mathrm{Pb}$ & 0.301 & 0.374 & 0.721 & 0.654 & 0.627 & 0.705 & 0.536 & 0.162 & 0.228 & 0.488 & 1.26 & 1.08 \\
\hline Th & 0.120 & 0.114 & 0.287 & 0.261 & 0.267 & 0.340 & 0.303 & 0.094 & 0.109 & 0.118 & 0.664 & 0.316 \\
\hline U & 0.062 & 0.054 & 0.093 & 0.070 & 0.076 & 0.093 & 0.082 & 0.028 & 0.033 & 0.054 & 0.126 & 0.066 \\
\hline \multicolumn{13}{|c|}{ Isotope ratios calculated at $60 \mathrm{Ma}$} \\
\hline${ }^{87} \mathrm{Sr} /{ }^{86} \mathrm{Sr}_{60}$ & & & & 0.704482 & 0.704476 & 0.704301 & & 0.703024 & $\quad 0.703159$ & 0.703114 & 0.704716 & 0.703790 \\
\hline$\varepsilon S r$ & & & & -0.97 & -1.05 & -3.55 & & -21.66 & -19.75 & -20.38 & 2.35 & -10.79 \\
\hline${ }^{143} \mathrm{Nd} /{ }^{144} \mathrm{~N}$ & & & & 0.512735 & 0.512750 & 0.512774 & & 0.513071 & 0.513025 & $5 \quad 0.513021$ & 0.512709 & 0.512881 \\
\hline$\varepsilon N d$ & & & & 3.40 & 3.69 & 4.16 & & 9.96 & 9.05 & 8.97 & 2.89 & 6.26 \\
\hline${ }^{206} \mathrm{~Pb} /{ }^{204} \mathrm{~Pb}$ & & & & 17.316 & 17.181 & 17.146 & & 17.744 & 17.785 & 17.657 & 17.208 & 16.862 \\
\hline${ }^{207} \mathrm{~Pb} / 204 \mathrm{~Pb}$ & & & & 15.233 & 15.183 & 15.211 & & 15.390 & 15.408 & 15.383 & 15.193 & 15.188 \\
\hline${ }^{208} \mathrm{~Pb} /{ }^{204} \mathrm{~Pb}$ & & & & 37.182 & 37.049 & 37.106 & & 37.429 & 37.516 & 37.534 & 37.510 & 36.911 \\
\hline
\end{tabular}

For explanation of lithological codes, see Table 1. For petrographical notes on the samples, see Table 2c.

Drill core samples are identified by subnumbers. 393101: GANW\#1 core. 408001: Marraat-1 core. 439001: GANE\#1 core.

Geographical coordinates in WGS 84. First two digits are degrees, then follow minutes in decimal form.

Major elements in wt\% (XRF analyses). Trace elements in PPm ( $\mathrm{Zn}-\mathrm{Ga}$ : XRF analyses; Rb-U: ICP-MS analyses). 
Table 2b. Chemical analyses of rocks, Anaanaa Member

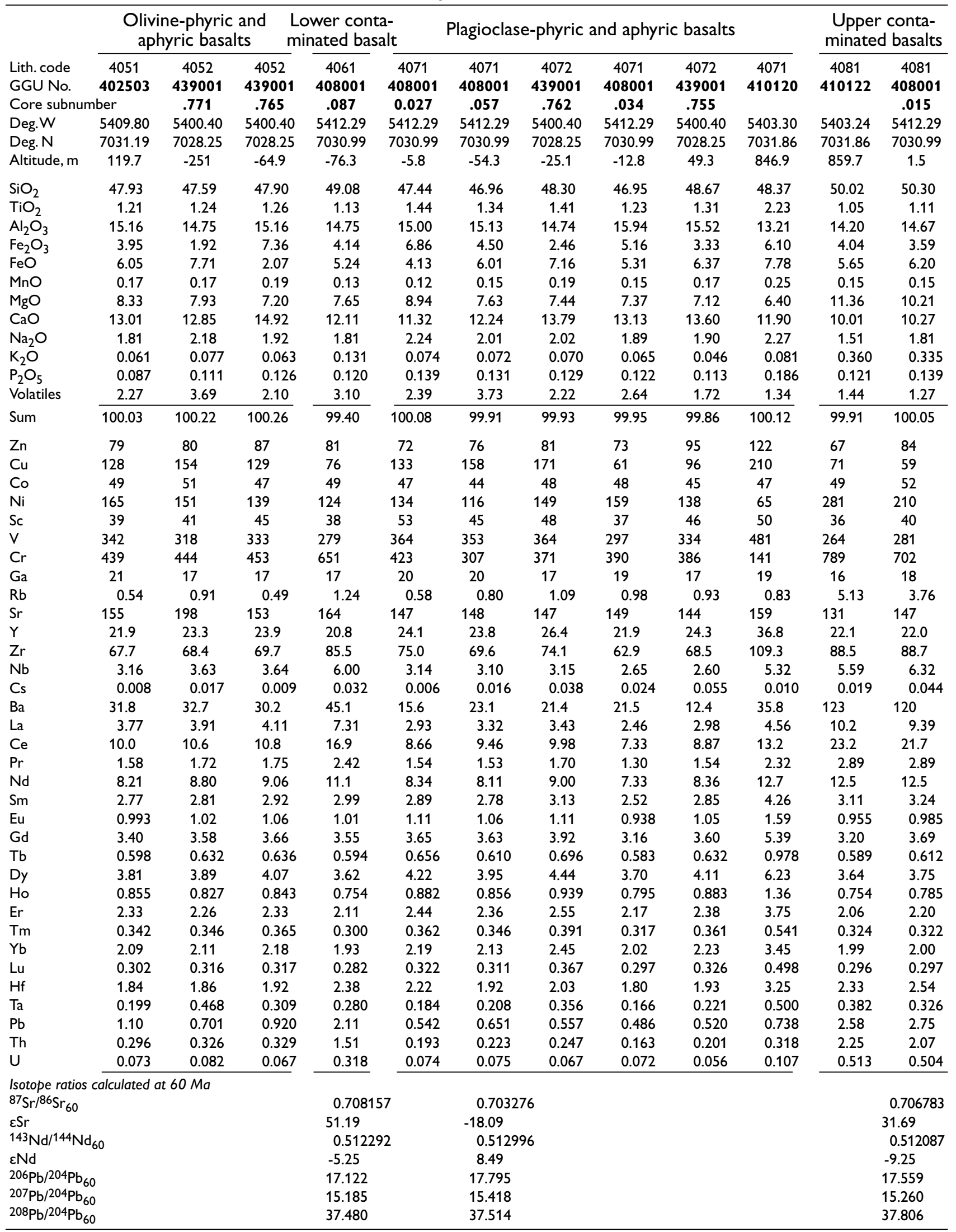


Table 2c. Notes on analysed samples from the Anaanaa Member

\begin{tabular}{|c|c|}
\hline 393101.094 & Picrite pillow from hyaloclastite, drill core GANW-1 at 609.8 m depth, Marraat Killiit. \\
\hline 447107 & Picrite pillow from $40 \mathrm{~m}$ high pillow cone at submarine eruption site $2 \mathrm{~km}$ north of Marraat Killiit (Fig. 21; Henderson 1975). \\
\hline 408001.292 & Olivine-phyric basalt pillow from hyaloclastite, drill core Marraat-1 at 433.4 m depth, Marraat Killiit. \\
\hline 408001.233 & Picrite lava flow, drill core Marraat-1 at 215 m depth, Marraat Killiit. \\
\hline 408001.242 & Picrite lava flow, drill core Marraat-1 at 222.5 m depth, Marraat Killiit. \\
\hline 408001.273 & Olivine-microphyric basalt pillow from hyaloclastite, drill core Marraat-1 at 330.6 m depth, Marraat Killiit. \\
\hline 439001.778 & Olivine-phyric basalt pillow from hyaloclastite, drill core GANE-1 at $488.1 \mathrm{~m}$ depth, Aaffarsuaq valley $10 \mathrm{~km}$ south-east of Marraat Killiit. \\
\hline 400457 & Picrite lava flow, profile Marraat-east, Marraat Killiit. \\
\hline 400492 & Picrite pillow from hyaloclastite, beneath profile Anaanaa-north, 6.5 km east of Marraat Killiit. \\
\hline 408001.222 & Picrite pillow from hyaloclastite above limestone horizon 1, drill core Marraat-1 at 199.6 m depth, Marraat Killiit. \\
\hline 400444 & Picrite lava flow with enriched geochemistry, Marraat Killiit near drill site GANW-1 (Fig. 26). \\
\hline 400490 & Olivine-plagioclase-phyric basalt pillow from hyaloclastite, beneath profile Anaanaa-north, 6.5 km east of Marraat Killiit. \\
\hline 402503 & Olivine-plagioclase-microphyric basalt lava flow, profile Marraat-east, Marraat Killiit. \\
\hline 439001.771 & $\begin{array}{l}\text { Plagioclase-microphyric basalt pillow from hyaloclastite, drill core GANE-1 at } 367.0 \mathrm{~m} \text { depth, Aaffarsuaq valley } 10 \mathrm{~km} \text { south-east of } \\
\text { Marraat Killiit. }\end{array}$ \\
\hline 439001.765 & $\begin{array}{l}\text { Plagioclase-olivine-microphyric basalt pillow from hyaloclastite, drill core GANE-1 at } 180.9 \text { m depth, Aaffarsuaq valley } 10 \mathrm{~km} \\
\text { south-east of Marraat Killiit. }\end{array}$ \\
\hline 408001.087 & Plagioclase-olivine-glomerophyric contaminated basalt lava flow, drill core Marraat-1 at 88.3 m depth, Marraat Killiit. \\
\hline 408001.027 & Aphyric basalt lava flow, drill core Marraat-1 at 17.8 m depth, Marraat Killiit. \\
\hline 408001.057 & Plagioclase-glomerophyric basalt lava flow, drill core Marraat-1 at 66.3 m depth, Marraat Killiit. \\
\hline 439001.762 & $\begin{array}{l}\text { Weakly plagioclase-phyric basalt pillow from hyaloclastite, drill core GANE-1 at } 141.1 \mathrm{~m} \text { depth, Aaffarsuaq valley } 10 \mathrm{~km} \text { south-east of } \\
\text { Marraat Killiit. }\end{array}$ \\
\hline 408001.034 & Strongly plagioclase-olivine-glomerophyric basalt lava flow, drill core Marraat-1 at 24.8 m depth, Marraat Killiit. \\
\hline 439001.755 & $\begin{array}{l}\text { Plagioclase-olivine-glomerophyric basalt pillow from hyaloclastite, drill core GANE-1 at } 66.7 \mathrm{~m} \text { depth, Aaffarsuaq valley } 10 \mathrm{~km} \\
\text { south-east of Marraat Killiit. }\end{array}$ \\
\hline 410120 & Weakly plagioclase-phyric basalt lava flow with small segregation patches, profile Anaanaa-north, 6.5 km east of Marraat Killiit. \\
\hline 410122 & Aphyric siliceous basalt lava flow, profile Anaanaa-north, 6.5 km east of Marraat Killiit. \\
\hline 408001.015 & Aphyric siliceous basalt lava flow, drill core Marraat-1 at 11.0 m depth, Marraat Killiit. \\
\hline
\end{tabular}

Phenocryst phases are mentioned in order of decreasing abundance. All picrites are strongly olivine-phyric.

patterns are similarly flat, with no or just a small $\mathrm{Pb}$ trough, relatively high $\mathrm{Th}-\mathrm{U}$, and, in unit 403 , a small $\mathrm{Nb}$ trough. The origin of these features is not certain but slight crustal contamination is a possibility.

The picritic top flow in unit 405 (sample 400444) is particularly enriched in the most incompatible trace elements $\mathrm{Rb}$ to $\mathrm{K}$ and has a relatively steep REE pattern that crosses the patterns of the other samples. This, and its high $\mathrm{Sr}$ - and low $\mathrm{Nd}$-isotope ratios, suggest that its man- tle source contained an enriched component (Larsen \& Pedersen 2009).

The Si-enriched basalts of units 406 and 408 show distinctly increased $\mathrm{La}-\mathrm{Sm}$ and $\mathrm{Rb}-\mathrm{K}$, with particularly high $\mathrm{Th}-\mathrm{U}$ and $\mathrm{Pb}$ and an ensuing $\mathrm{Nb}-\mathrm{Ta}$ trough. Flow 3 in the Marraat-1 drill core (sample 408001.019) is not $\mathrm{Si}$-enriched and its trace-element patterns are similar to those of the uncontaminated basalts of unit 407 . 


\section{Second volcanic episode: Naujánguit Member and associated members}

The rocks of the second volcanic episode have a complex stratigraphy with interfingering members (Fig. 49). The main member at all levels except at the top is the Naujánguit Member. Interfingering with this at different levels are the crustally contaminated Nuusap Qaqqarsua, Nuuk Killeq and Asuk members, while the contaminated Tunoqqu and Kûgánguaq members and the uncontaminated Qordlortorssuaq Member formed during the waning stage of the episode. In addition, the Naujánguit Member contains five minor informal contaminated units of which one is alkaline. In all, about $14 \mathrm{vol} \%$ of the magmas erupted during this episode were contaminated (see Table 8).

Due to this complexity, the constituent units of the second volcanic episode are not described in ascending stratigraphic order. Rather, the large Naujánguit Member and its informal units are described first, and then the other members in ascending stratigraphic order. However, as the parental magmas for all these rocks are closely related, their chemical compositions are treated together after the descriptions of all the members formed in the second volcanic episode.

An important change took place after the deposition of about one third of the rocks from this episode: The geomagnetic pole reversed, so that all lavas up to the base of the Nuuk Killeq Member are normally magnetised whereas the subsequent lavas are all reversely magnetised (Fig. 49). This difference provides a means of distinguishing between otherwise very similar deposits from before and after the reversal. For example, J. Riisager $e t$ al. (2003b, 2004) showed that the lowest Vaigat Formation exposed on Svartenhuk Halvø is reversely magnetised and thus younger than the reversal.

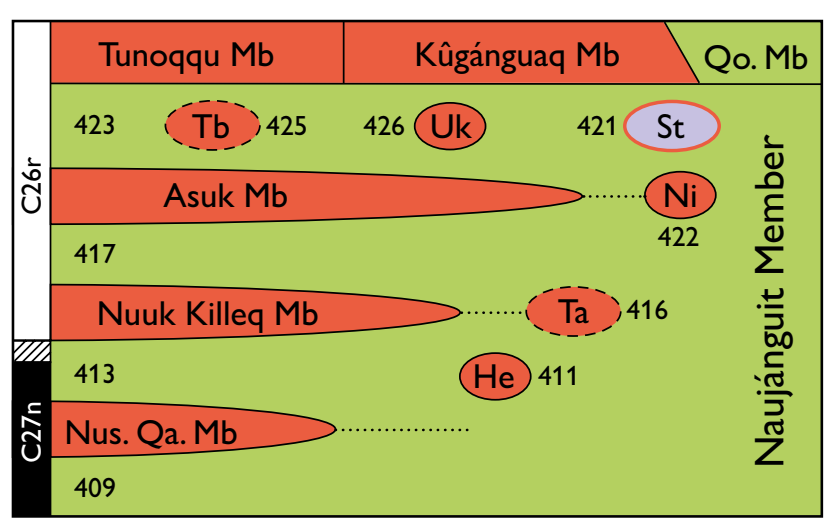

Fig. 49. Stratigraphic scheme for the second volcanic episode, showing the relations between the Naujánguit Member and the other members and informal units. Green units are uncontaminated, red are crustally contaminated, and purple with a red ring is an alkaline and contaminated unit. Geochemically enriched units have dashed outlines. The left column shows the geomagnetic polarity chrons; the small hachured area is the magnetic transition zone (Riisager \& Abrahamsen 1999). Three-digit numbers are lithological unit codes. He: Henderson unit. Ni: Niiortuut unit. Nus. Qa. Mb: Nuusap Qaqqarsua Member. Qo Mb: Qordlortorssuaq Member. St: Stordal unit. Ta: Tunorsuaq a unit. Tb: Tunorsuaq b unit. Uk: Ukallit unit 


\section{Naujánguit Member}

\section{Summary of the main features of the Naujánguit Member}

- The main member produced in the second volcanic episode.

- Dominated by grey picrite lava flows and associated hyaloclastites. Subordinate Mg-rich basalts.

- Divided into four successive extensive units, partially separated by three large contaminated members.

- The two lower units are normally magnetised (C27n + transition zone) and the two upper units are reversely magnetised (C26r).

- Five small informal units also comprise crustally contaminated basalts. Of these, the Stordal unit is the oldest alkaline unit known in the province.

- Continuation of the eastward progradation at high rates into the marine embayment. Conglomerate horizons and small unconformities indicate punctuated volcanism and active tectonism.

- Eruption sites are widespread, both submarine and subaerial.

- Economic geology: Migrated oil of the Niaqornaarsuk type occurs in the lowest unit (409).

\section{Lithostratigraphy of the Naujánguit Member}

Revised member

History. Originally defined by Pedersen (1985a) on Disko. Here revised and extended to also cover Nuussuaq and Hareøen.

Name. After the point Naajannguit (new spelling) on the north coast of Disko $4 \mathrm{~km}$ east-south-east of the entrance to the Kuugannguaq valley (Fig. 5).

Distribution. The Naujánguit Member extends over large areas on northern Disko and Nuussuaq and is also present on Hareøen east of the Itilli Fault (Fig. 9). Its western extension is below exposure level on Disko whereas on western Nuussuaq it is eroded away due to uplift. The member is assumed to be present at depth west of the Itilli Fault. To the south, on central Disko, the member thins and disappears below exposure level in the Stordal area, and its southern boundary must lie shortly south of Stordal. To the east, the member gradually thins and ter- minates, on Disko just east of Qorlortorsuaq, on southern Nuussuaq at Tupaasat and on northern Nuussuaq at Vesterfjeld. North of Nuussuaq the member is assumed to continue below exposure level.

Type section. The type section is composite. The lowest part of the member is covered by Anaanaa south on Nuussuaq (Fig. 13, profile 4); the main part is covered by Kuugannguaq north-east and Kuugannguup Innartaa on northern Disko (Fig. 16, profiles 22, 23; Pedersen 1985a, profiles 2, 3). Locations in Fig. 5.

Reference sections. Nuusap Qaqqarsua and Qunnilik west on south-western Nuussuaq (Fig. 13, profiles 8 and 9); Sorluut, Tunorsuaq and Vesterfjeld on north-western Nuussuaq (Fig. 14, profiles 11, 12, 14); Norddalen and Ametystskrænten on Disko (Fig. 16, profiles 24, 25); Niaqua on Hareøen (Fig. 17, profile 30). Locations in Fig. 5.

Thickness. The maximum thickness of the Naujánguit Member and associated members is $950 \mathrm{~m}$ at the type section on northern Disko and $1200 \mathrm{~m}$ around Qunnilik on Nuussuaq. To the south, the member gradually thins to $c .400 \mathrm{~m}$ before it disappears below exposure level in the Stordal area. To the east, the member gradually peters out. To the north on northern Nuussuaq thicknesses have decreased to 300-600 m. Thicknesses of individual units vary considerably with the volcanic facies.

Lithology. The Naujánguit Member comprises subaerial lava flows and associated hyaloclastites produced when the lavas flowed into water or were erupted subaqueously. Several eruption sites are known. Volcanic conglomerates occur locally, indicating significant erosion events. The dominant rocks are grey picrites; olivine-phyric and aphyric basalts are subordinate. Four small units of crustally contaminated rocks are brown aphyric or olivine microphyric basalts; a fifth unit, the Stordal unit, comprises the oldest alkali basalts known in the province.

Subdivisions. The Naujánguit Member is subdivided into a number of informal units (Fig. 49). The main body of uncontaminated picrites comprises four successive widespread units partially separated by three contaminated 
members; five small local units of contaminated basalt are embedded in the picrites.

Boundaries. On western Nuussuaq brown erosion-resistant silicic lava flows and hyaloclastites of the Anaanaa Member are conformably overlain by grey lava flows and hyaloclastites of the Naujánguit Member. Where the Anaanaa Member is not present, the Naujánguit Member rests unconformably on a very uneven, faulted, tilted and eroded surface of sediments of Cretaceous age (Atane and Itilli formations) and Paleocene age (Eqalulik Formation). The elevation of this surface varies from below sea level to $800 \mathrm{~m}$ a.s.l., and the prevolcanic relief was up to $300 \mathrm{~m}$ on Disko and $500 \mathrm{~m}$ on Nuussuaq. On central Disko, the Naujánguit Member rests on rounded hills of Precambrian gneiss which have locally developed kaolinised surfaces (regolith) many metres deep. The lower boundary of the Naujánguit Member is strongly diachronous, with successively younger units forming the base of the member from west to east, on both Disko and Nuussuaq.

The Naujánguit Member is overlain by three different members in different areas. On central and north-eastern Disko the overlying rocks are basaltic andesites and andesites of the Kûgánguaq Member; on north-western Disko they are the evolved basalts of the Qordlortorssuaq Member, and on the whole of Nuussuaq the Naujánguit Member is overlain by the widespread brown basalts and basaltic andesites of the Tunoqqu Member. All overlying members are in subaerial facies except for the easternmost parts of the Tunoqqu and Qordlortorssuaq members.

Age. Paleocene, nannoplankton zones NP4-NP5, c. 62.5-61 Ma, magnetochron C27n and C26r (Fig. 49), based on the biostratigraphic age of the Eqalulik Formation (Nøhr-Hansen et al. 2002), on radiometric dating (Storey et al. 1998), and on the two magnetochrons represented in the succession (Riisager \& Abrahamsen 1999).

Correlation. Any possible equivalents to the Naujánguit Member on Ubekendt Ejland and Svartenhuk Halvø are below the level of exposure.

\section{Geology of the Naujánguit Member}

The Naujánguit Member is the main member produced during the second volcanic episode and comprises a major, widespread body of uncontaminated picrites and a number of small crustally contaminated units embed- ded within the picrites at various levels (Fig. 49). These rocks are widely distributed on northern Disko and on Nuussuaq (Fig. 9) where they are well exposed in cliffs along the Vaigat strait and along the major valleys such as Kuugannguaq and Stordal on Disko and Aaffarsuaq on Nuussuaq. During this volcanic episode, subaerial lava flows and hyaloclastites continued the east-prograding filling of the rapidly subsiding Nuussuaq Basin, a filling pattern that was established during the first volcanic episode (Fig. 19).

The four widespread uncontaminated units will be described first.

\section{Uncontaminated Naujánguit Member below the Nuusap Qaqqarsua Member (unit 409)}

The oldest unit of the Naujánguit Member is only found on western Nuussuaq between Anaanaa, Sikillingi, Nuusap Qaqqarsua, Qunnilik and Anariartorfik (Fig. 18; Central Nuussuaq section at $1-12 \mathrm{~km}$, units $\mathrm{a}_{5}$ and $\mathrm{a}_{6}$ ). Its delimitations to the north and east are depositional, to the west erosional and to the south unknown; it may continue below exposure level across Vaigat to Disko in the area west of Kuugannguaq. It may also be present at depth west of the Itilli fault.

The rocks of unit 409 are grey, olivine-phyric basalts and picrites. The unit starts with a picrite flow; however, olivine microphyric basalts with $9-12 \mathrm{wt} \% \mathrm{MgO}$ are dominant in the lower part whereas picrites with 16-23 $\mathrm{wt} \% \mathrm{MgO}$ dominate in the upper part.

Migrated oil of the Niaqornaarsuk type is found in unit 409 in the area around Niaqornaarsuk (Fig. 18; Bojesen-Koefoed et al. 1999).

Boundaries. Lava flows of unit 409 conformably overlie Anaanaa Member flows of unit 408, and the presence of less than $10 \mathrm{~cm}$ of red soil and no trace of an angular unconformity indicate no large gap in time between the Anaanaa and Naujánguit members. Likewise, hyaloclastites of unit 409 overlie hyaloclastites of Anaanaa Member with apparent conformity. However, at Ippiarsuk $c$. $2 \mathrm{~km}$ south-east of Sikillingi, hyaloclastites of unit 409 cover two small areas of subaerial lava flows interpreted as islands in the palaeo-sea (Fig. 18; Pedersen et al. 2008).

Unit 409 is conformably overlain by brown lavas and hyaloclastites of the Nuusap Qaqqarsua Member.

Lithologies. The lowermost part of unit 409 around Anaanaa comprises about $160 \mathrm{~m}$ of lava flows, but only 3 $\mathrm{km}$ farther east at Qunnileeraasakassak there are $320 \mathrm{~m}$ 


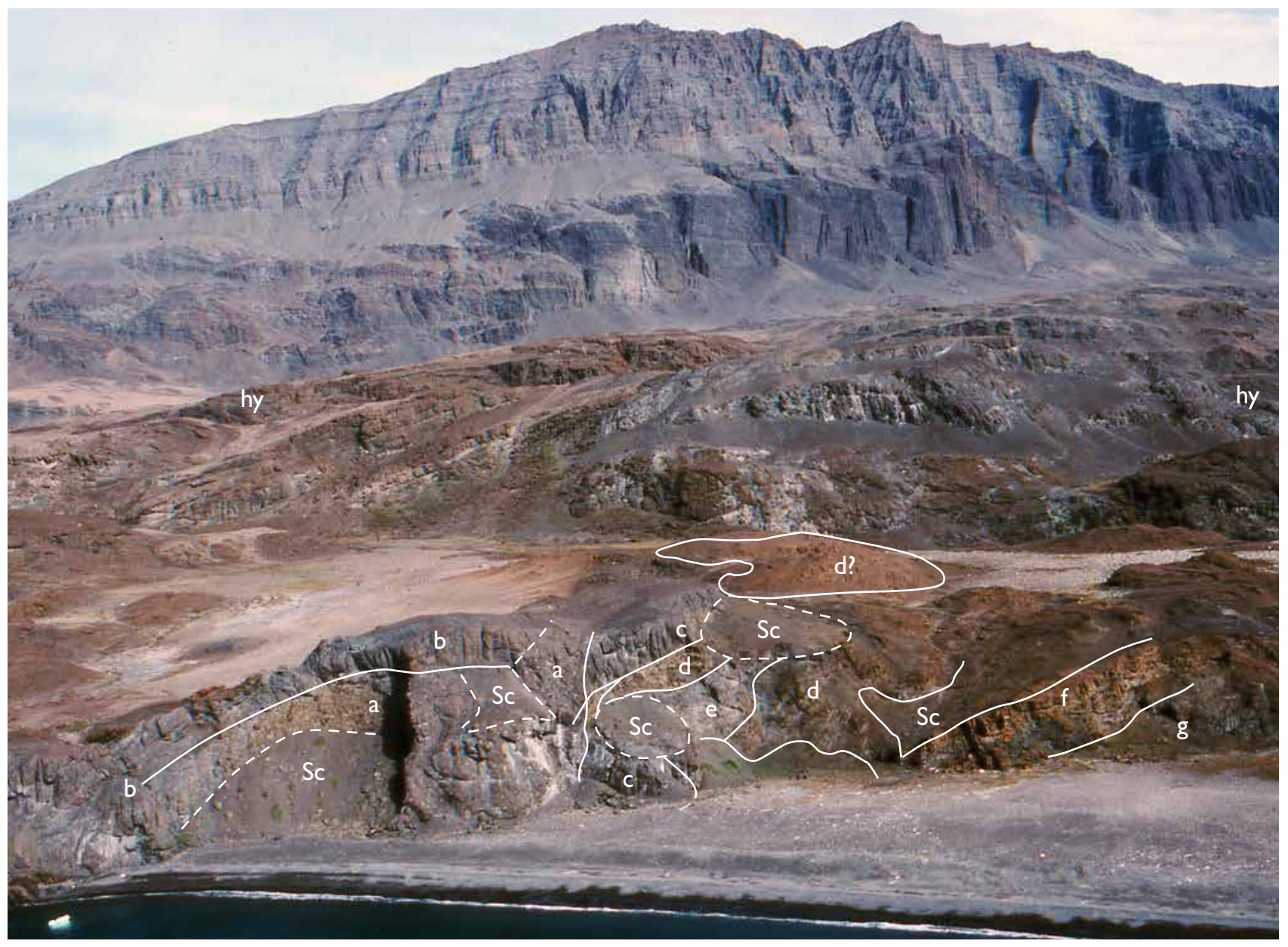

Fig. 50. Phreatomagmatic near-surface eruption site from unit 409 exposed on the Vaigat coast west of Niaqornaarsuk, western Nuussuaq (Fig. 18). A coarse breccia with up to $1.5 \mathrm{~m}$ large clasts (a) marks the main crater area; it is covered by hyaloclastites (b) and a fine-grained hyaloclastite resembling $\mathrm{b}(\mathbf{c})$. A succession of compact and vesiculated subaerial lava tongues (d) encloses hyaloclastite masses (e), and a succession of orange brown subaerial lavas, transitional flows and pillow lavas $(\mathbf{f})$ overlies hyaloclastites $(\mathbf{g})$. Sc: scree. The length of the structure is about $200 \mathrm{~m}$ and its height is $50 \mathrm{~m}$. The hyaloclastites $(\mathbf{h y})$ in the middle ground are from unit 409; the mountain in the background is Nuusap Qaqqarsua.

Fig. 51. Subaerial lava flows (La; unit $\mathbf{d}$ in Fig. 50) sandwiched between hyaloclastites (hy) forming part of the crater structure near Niaqornaarsuk. The facies variations indicate rapid dynamic fluctuations relative to the sea level.

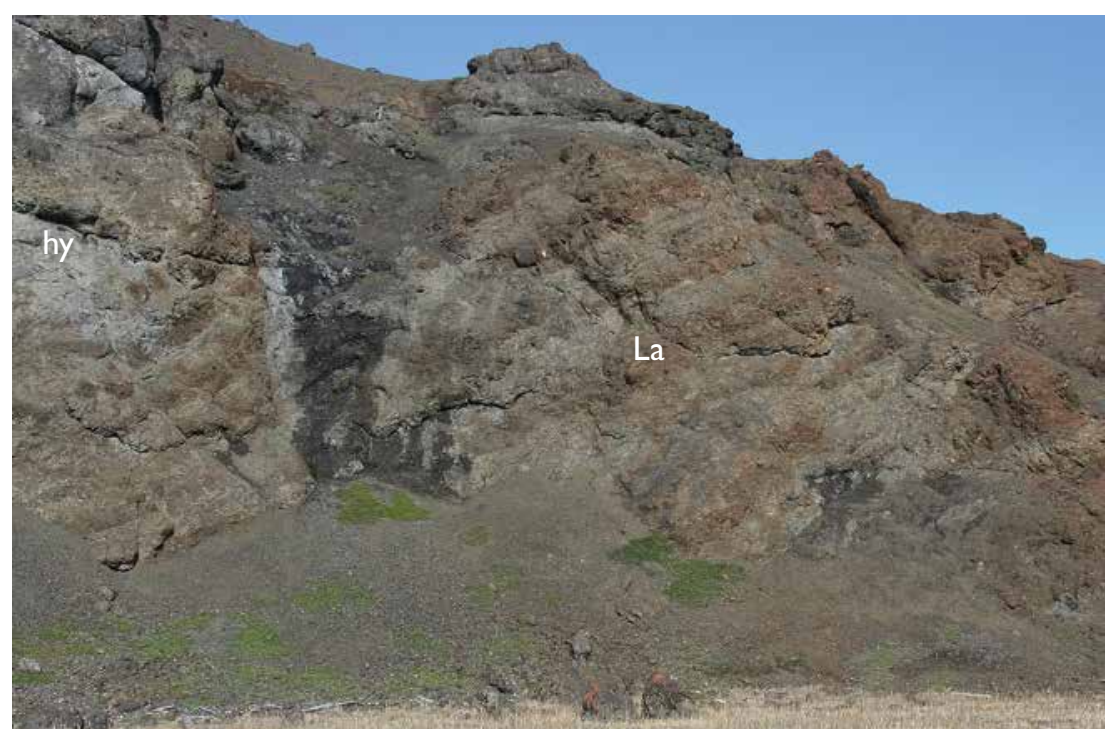




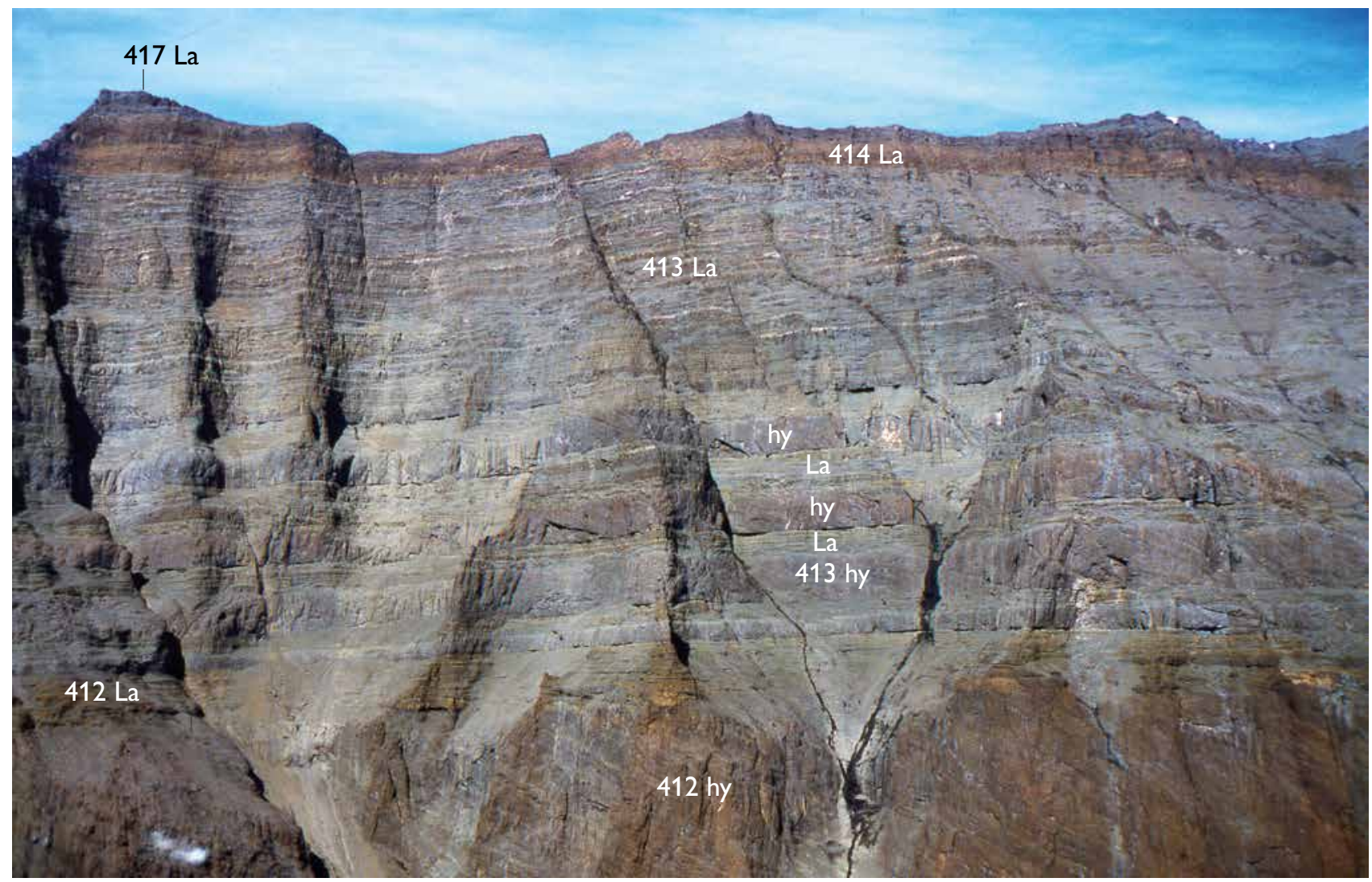

Fig. 52. Repeated vertical movements during basin infilling demonstrated by interbedded horizons of submarine hyaloclastites (hy) and subaerial pahoehoe lava flows (La) in the cliff facing the Vaigat strait below Nuusap Qaqqarsua, south-western Nuussuaq. The part of the cliff face shown here is $560 \mathrm{~m}$ high. The lower $c .200 \mathrm{~m}$ of Naujánguit Member unit 413 consist of interbedded thin horizons of submarine hyaloclastites (massive, cross-bedded) and subaerial pahoehoe lava flows; the upper c. $200 \mathrm{~m}$ of unit 413 consist solely of numerous thin subaerial pahoehoe flows. The lithologies indicate development very close to sea level, with aggradation finally outpacing subsidence of the basin. See also Figs 53-54. Units are indicated by their numerical codes (Table 1). The peak of Nuusap Qaqqarsua (1232 $\mathrm{m}$ a.s.l.) is seen to the left.

of lava flows (Fig. 13, profiles 4, 5). In both these profiles there is a $10-20 \mathrm{~m}$ thick columnar-jointed picrite flow that has been mapped as a marker horizon for $5 \mathrm{~km}$ along the north side of the Aaffarsuaq valley (Central Nuussuaq section at $1-6 \mathrm{~km}$ ). With an estimated volume of $0.2 \mathrm{~km}^{3}$ (thickness $0.02 \mathrm{~km}$, length $5 \mathrm{~km}$, width min. 2 $\mathrm{km}$ ) this is the earliest large lava flow for which a realistic minimum volume can be estimated. In general, the lava flows of unit 409 are uncharacteristic and crumbling and unsuited for yielding information about the size and extent of flow fields.

Eastwards from the Qunnileeraasakassak gully, hyaloclastite horizons appear within the succession of subaerial lava flows. These horizons mark basin subsidence during short periods with no local volcanic activity. The horizons are foreset-bedded and thicken towards the east and north-east until they merge into an up to $580 \mathrm{~m}$ thick hyaloclastite succession. When well exposed, such as in the Qunnileeraq gully, the geometry of lavas and hyaloclastites shows that, in addition to a general subsidence, active differential tilting of fault blocks towards the north-east occurred during the deposition of the volcanic rocks of unit 409 .

The area around the Anaanaa mountain knoll appears to be where the earliest permanent lava plateau was formed. Here, at least $500 \mathrm{~m}$ of Naujánguit Member, including $160 \mathrm{~m}$ of unit 409 , have been deposited as subaerial pahoehoe lavas (Central Nuussuaq section at 0-5 $\mathrm{km})$. On the other hand, large areas of hyaloclastites of unit 409 are exposed north of Anaanaa in the Anariartorfik valley and also south of the Aaffarsuaq valley in a $3 \mathrm{~km}$ wide belt extending southwards to east of Sikillingi and the foot of Nuusap Qaqqarsua (Fig. 13, profile 8; Fig. 18; Pedersen et al. 2008). 


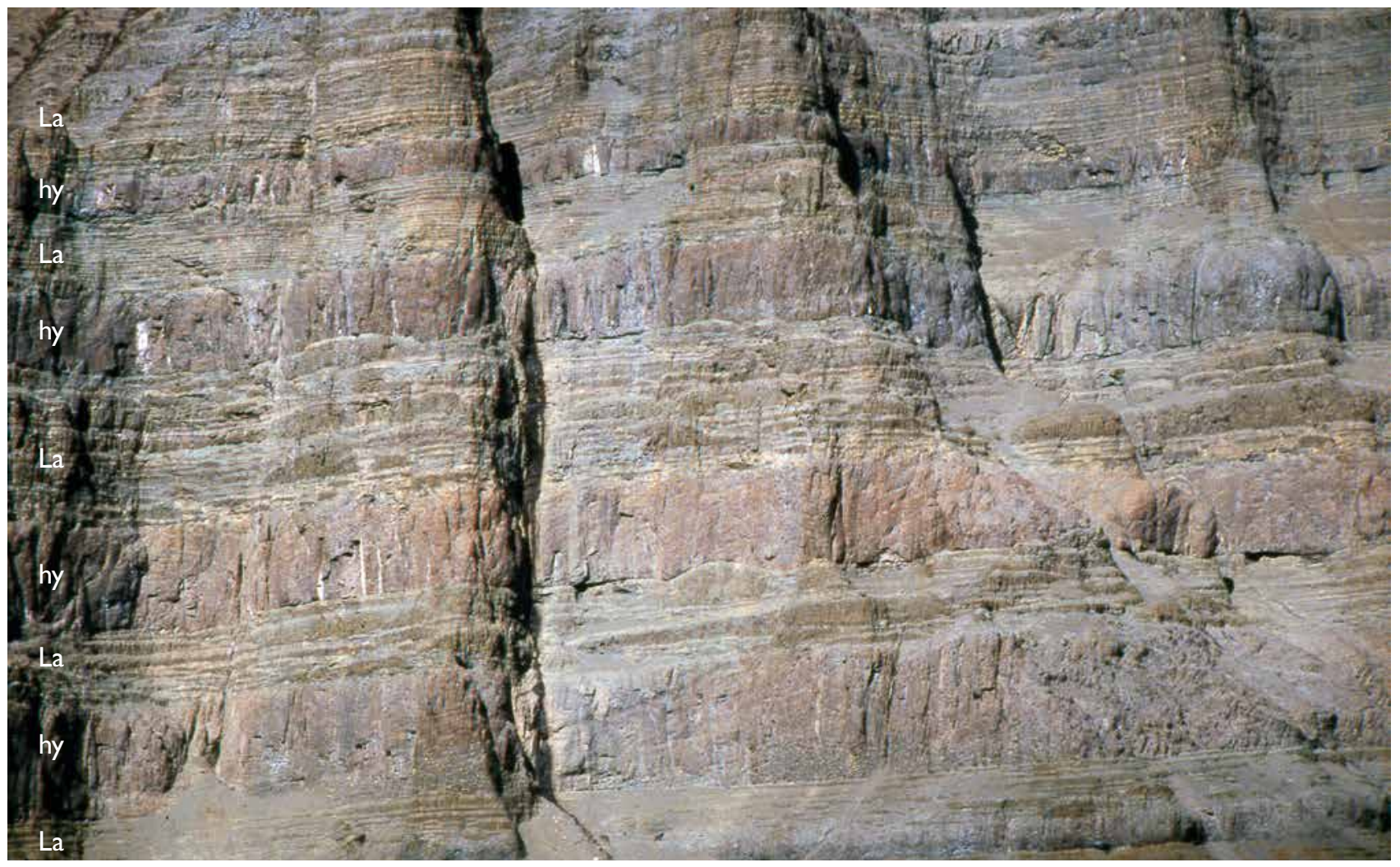

Fig. 53. Closer view of interbedded 10-20 m thick horizons of submarine hyaloclastites (hy) and subaerial pahoehoe lava flows (La) of the lower part of unit 413 in the cliff face below Nuusap Qaqqarsua. The hyaloclastite horizons are massive and show inclined, mainly W-dipping, bedding planes. The pahoehoe lava flows consist of numerous metre-thin flow lobes with light grey vesicular tops. Height of cliff face $180 \mathrm{~m}$. See also Figs 52 and 54.

Eruption sites. Several phreatomagmatic eruption sites are exposed on the Vaigat coast just west of Niaqornaarsuk (Fig. 18; Pedersen et al. 2008). These consist of masses of pillow lavas, short successions of subaerial pahoehoe lava flows and coarse breccias rich in metre-sized lava boulders, both sharp-edged and rounded. In an area close to the point at Niaqornaarsuk the hyaloclastites show an unusual feature: over a length of $200 \mathrm{~m}$ an up to $50 \mathrm{~m}$ high igneous body occurs with an updomed core of pyroclastic material (Fig. 50). Within the body there are some $10-15 \mathrm{~m}$ thick, somewhat irregular subaerial lava flows (Fig. 51). This feature was not studied in detail but may be a surface-near submarine eruption site with a core of hydrothermally altered pyroclastic rocks and slightly younger subaerial lava flows that formed when the volcano reached above the sea.

\section{Uncontaminated Naujánguit Member between Nuusap Qaqqarsua Member and Nuuk Killeq Member (unit 413)}

This unit of grey, uncontaminated rocks consists of picrites and olivine-phyric basalts with 8-27 wt $\% \mathrm{MgO}$. It comprises a 300-400 $\mathrm{m}$ thick lava package and associated prograding hyaloclastite fans up to $850 \mathrm{~m}$ thick. It is the oldest unit of the Naujánguit Member on Disko where it is exposed along the north coast for $c .30 \mathrm{~km}$ from Serfarsuit to east of Naajannguit. On Nuussuaq, it is found in an up to $20 \mathrm{~km}$ wide zone that extends N-S across the peninsula between Nuusap Qaqqarsua and Nuuk Killeq on the south coast, between Anaanaa and Ilugissoq in the Aaffarsuaq valley and between the east side of the Itilli valley and Saviaqqat on northern Nuussuaq. The southern, western and northern limits are erosional. The eastern limits are everywhere depositional.

Boundaries. Unit 413 conformably overlies the Nuusap Qaqqarsua Member and, due to the eastward prograda- 


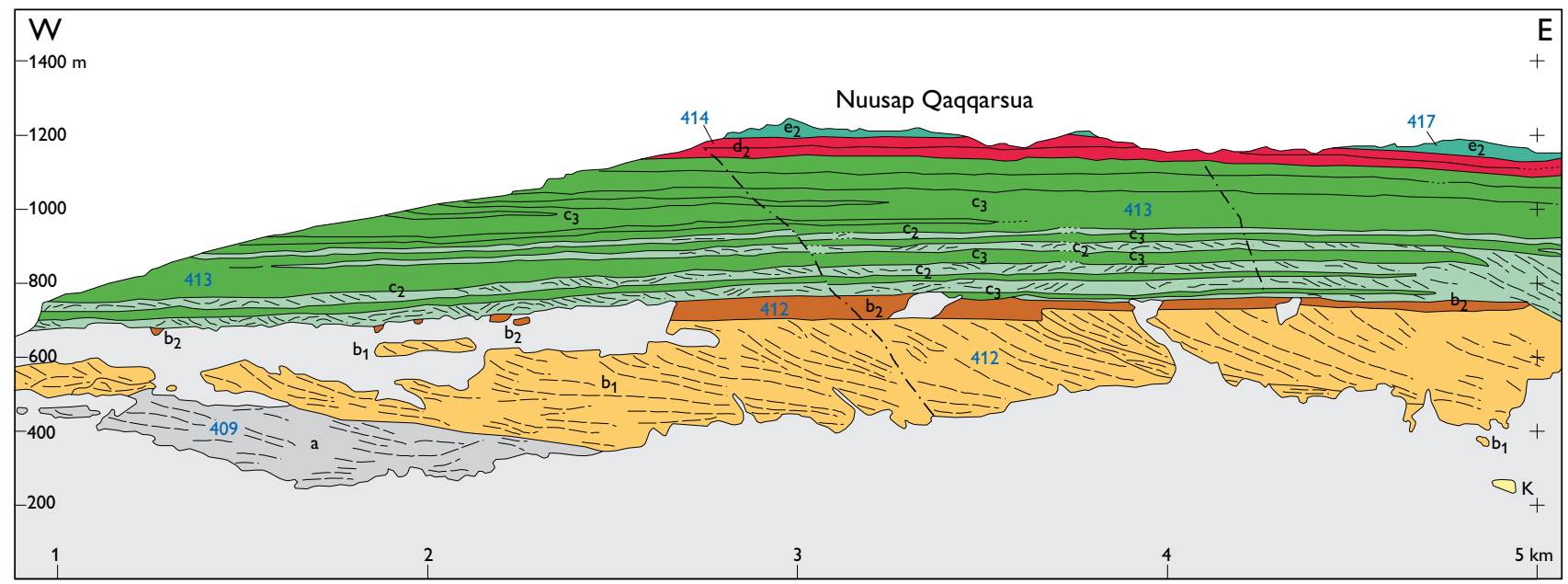

Fig. 54. Photogrammetrically measured cliff face below Nuusap Qaqqarsua, slightly modified from the South Nuussuaq section (Pedersen $e t$ al. 1993). Compare Fig. 52. Blue numbers are unit codes; other unit annotations are from the original.

tion, hyaloclastites of unit 413 also overlie sediments of the Nuussuaq Basin. Contacts to the sediments are rarely exposed; however, at $c .100 \mathrm{~m}$ altitude west of Nuuk Killeq there is a well-exposed boundary between grey fissile mudstones of the Eqalulik Formation and finegrained, glass-rich toesets of unit 413 (see below). An- other locality of particular interest is the lower boundary at Naajaanguit where lava flows have filled a steep-walled canyon carved into Cretaceous clastic sediments of the Atane Formation (Pedersen et al. 2002b, fig. 10).

Unit 413 is conformably overlain by the Nuuk Killeq Member and, on northern Nuussuaq, the lateral equiva-

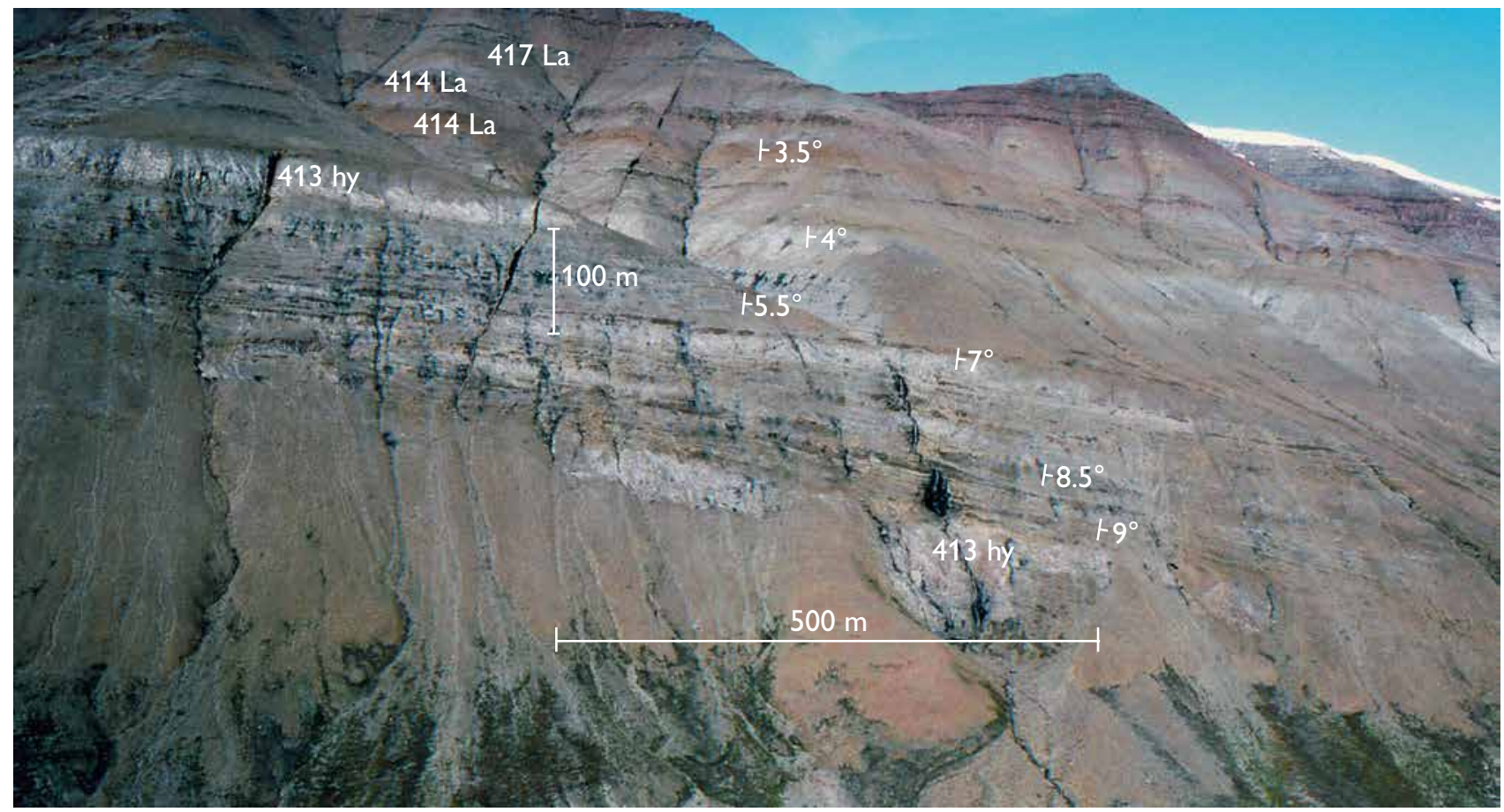

Fig. 55. Naujánguit Member unit 413. A fanning succession of alternating subaerial lava flows and submarine hyaloclastites with dips gradually decreasing upwards from $9^{\circ}$ to $3.5^{\circ}$ demonstrate differential synvolcanic subsidence of a large fault block. The overlying lavas belong to the Nuuk Killeq Member (414 La) and Naujánguit Member unit 417. West side of the Qunnilik valley, western Nuussuaq. 
Fig. 56. The lower boundary of Naujánguit Member unit 413. The person is standing on dark brownish-grey mudstones of the Eqalulik Formation. These are overlain by light-coloured, jointed, fine-clastic hyaloclastites which are toesets of hyaloclastites of Naujánguit Member unit 413. See also Fig. 57. This locality is an important stratigraphic tie-point between the Vaigat and Eqalulik formations (Piasecki et al. 1992; Dam et al. 2009). Just west of Nuuk Killeq, south coast of Nuussuaq (Fig. 85 at $16.2 \mathrm{~km}, 90 \mathrm{~m}$ a.s.l.).

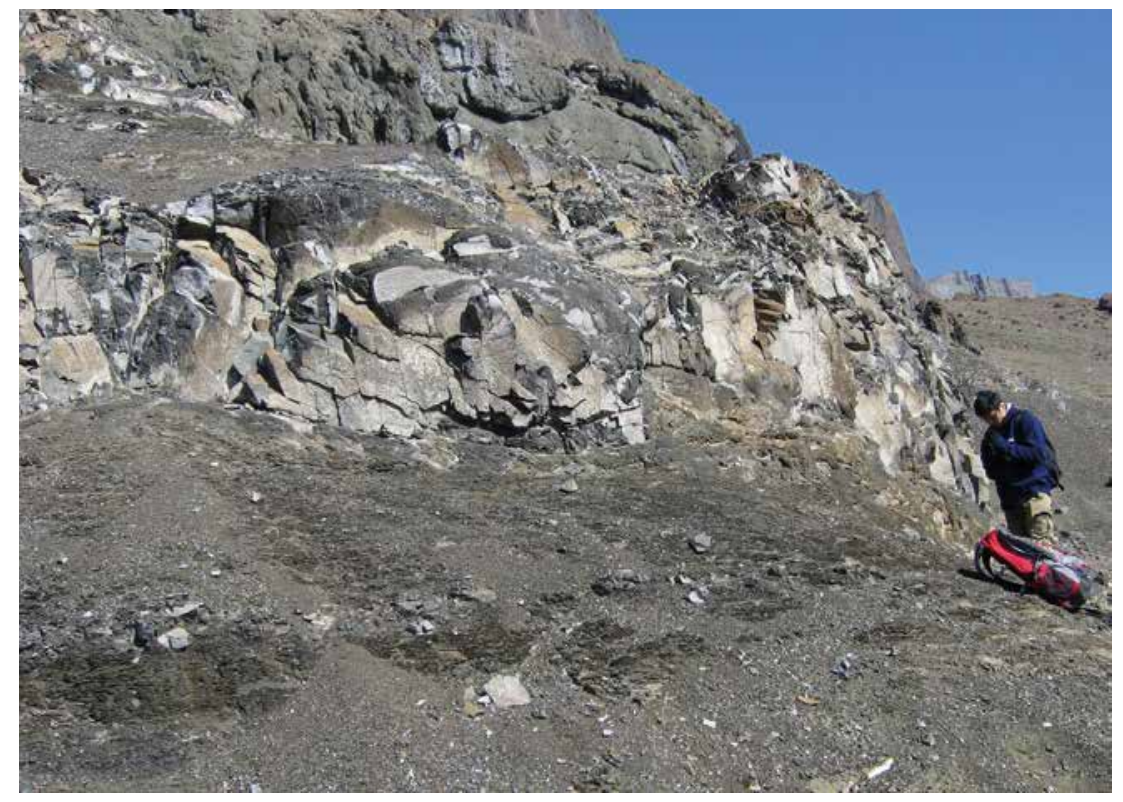

lent of this, the Tunorsuaq a unit. Where none of these units are present, exposures are poor and the boundary to unit 417 is usually covered.

Lithologies and volcanic history. This part of the Naujánguit Member continued the eastward progradation into the marine embayment, but in its lower part thin horizons of lava flows and hyaloclastites are interbedded, as spectacularly exposed in the cliff face below Nuusap Qaqqarsua (Figs 52-54; Pedersen et al. 2002b, fig. 8), indicating repeated vertical movements and a development very close to sea level, while the main marine embayment to the east at the same time had a water depth of several hundred metres (South Nuussuaq section at 5-12 km). At the western side of the Qunnilik valley, rapidly alternating and fanning lava and hyaloclastite successions demonstrate differential synvolcanic subsidence of a large fault block (Fig. 55; Pedersen et al. 2002b, fig. 11). During deposition of the upper part of the unit, the subaerial lava plateau stayed above sea level whereas the corresponding hyaloclastites were deposited on a steep, well-defined shelf slope more than $500 \mathrm{~m}$ high at Alianaatsunnguaq (see also Fig. 85 at $11-12 \mathrm{~km}$ ). Eastwards of the slope, finer fractions of the hyaloclastites were transported horizontally as suspension flows for at least $4 \mathrm{~km}$ along the sea floor and deposited as toesets that overlie mudstones of the Eqalulik Formation just west of Nuuk Killeq (Figs 56, 57; see also Fig. 85 at 13-17 km).

On northern Nuussuaq the upper part of unit 413 is the oldest volcanic unit present (North Nuussuaq section at $0-7 \mathrm{~km})$. Hyaloclastites are widespread and rest on

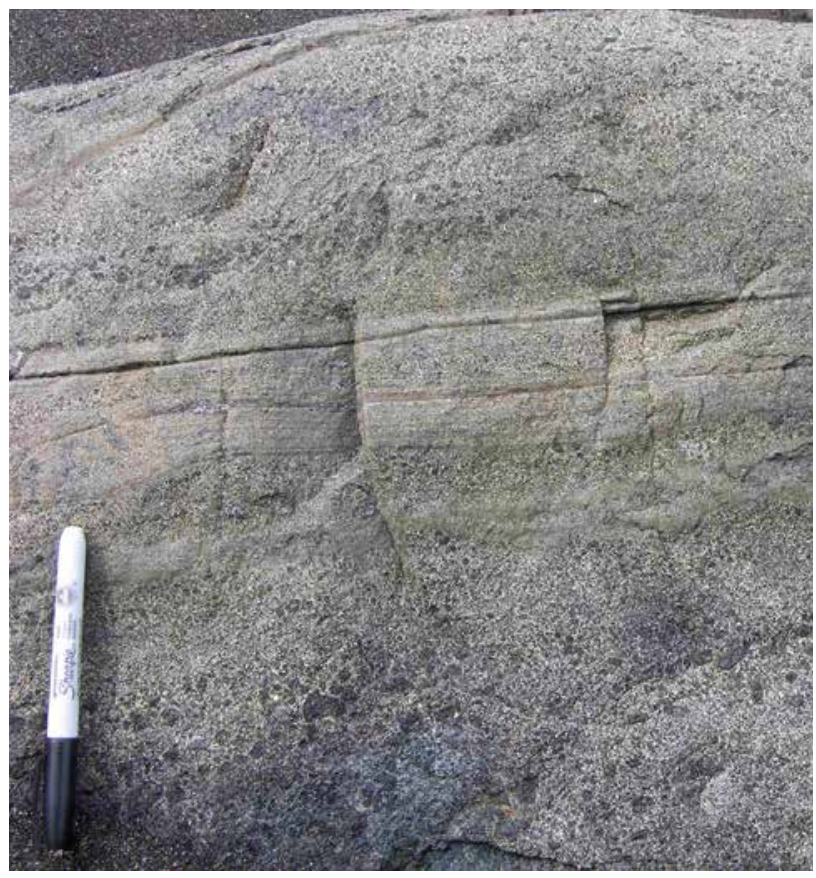

Fig. 57. Lithology of toesets of Naujánguit Member unit 413, same locality as Fig. 56. The hyaloclastic material was transported horizontally as suspension flows for at least $4 \mathrm{~km}$ eastwards along the sea floor before deposition. Note the faint bedding in the coarser layers and the well-defined bedding in the finer, mud-rich layers. The deposit was probably formed from several individual suspension flows with lulls between them. Length of marker pen with black cap 13 cm. Photo: Chris Schenck. 


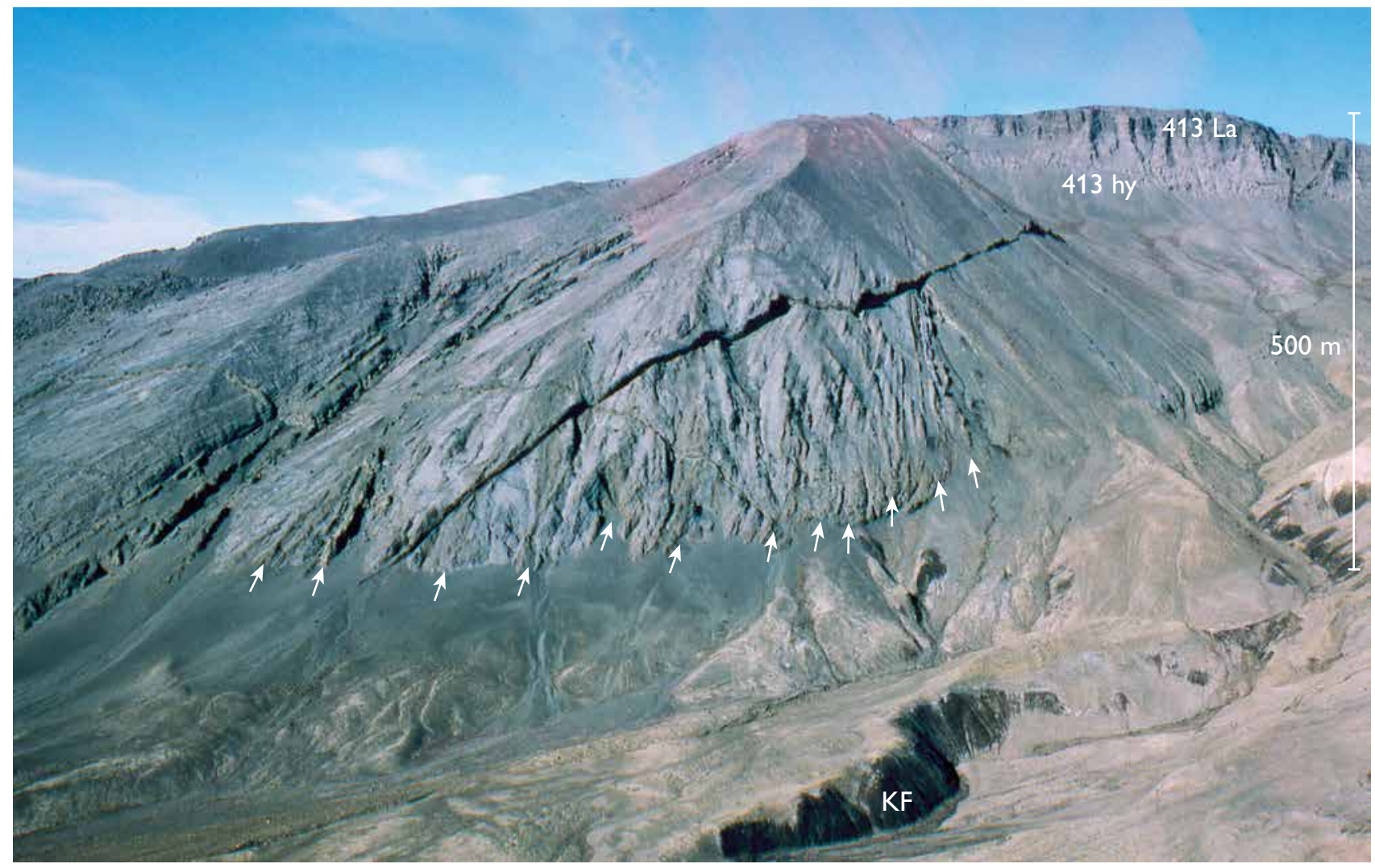

Fig. 58. Submarine eruption site in Naujánguit Member unit 413. Numerous dyke-like and partly pillowed feeder bodies (white arrows) extend vertically into a mound of pillow breccias. At higher levels the feeders are pillowed throughout and become part of the mound. The mound is c. $500 \mathrm{~m}$ high and stands on black mudstones of the Kangilia Formation (KF) seen in the foreground (centre and right). It is cut from left to right by a younger dyke (black). Unit 413 lava flows (La) and hyaloclastites (hy) are seen in the background. North side of Tunorsuaq valley, northern Nuussuaq. Photo: Finn Ulff-Møller.

mudstones of the Eqalulik Formation (Dam et al. 2009, fig. 87), but exposures of the boundary are poor and disturbed by landslides.

During the deposition of unit 413 the N-S-oriented volcanic front prograded 5-6 km eastwards into the sea.

Magnetic transition zone. The upper part of unit 413 records the transition from normal to reversed magnetisation (C27n-C26r, Fig. 49). The magnetic transition zone has been found in profiles on both Nuussuaq (Nuusap Qaqqarsua, Riisager \& Abrahamsen 1999) and Disko (Kuugannguup Innartaa, J. Riisager et al. 2003b). In these profiles the lava package of the transition zone is respectively $170 \mathrm{~m}$ and $190 \mathrm{~m}$ thick, and as the transition is estimated to have lasted only around 5000 years this indicates very high rates of both eruption and subsidence (Pedersen et al. 2002b).

Because magnetic pole positions change very rapidly during a magnetic transition event, analysis of closely spaced lava profiles provides a test of the physical extent of individual picritic flow groups. J. Riisager et al. (2003b) compared the transition zone flows in the two lava profiles on Nuussuaq and Disko, situated $15 \mathrm{~km}$ apart across the Vaigat strait, and found no evidence that any one flow group was present in both profiles. Thus, individual flow groups extend for less than $15 \mathrm{~km}$, at least in this part of the succession.

Eruption sites. Submarine eruption sites are found at Ukallit in the Aaffarsuaq valley and in the north side of the Tunorsuaq valley (Fig. 58). Local mounds of pillow breccia contain swarms of irregular dyke-like feeder bodies which extend vertically into the breccia mounds; the bodies have massive interiors and pillowed margins. They are widest at low levels and taper upwards; the massive parts disappear gradually upwards and the pillowed margins blend with the surroundings and become indistinguishable. 


\section{Uncontaminated Naujánguit Member between Nuuk Killeq Member and Asuk Member (unit 417)}

This unit of grey uncontaminated rocks consists of picrites and olivine-phyric basalts with 8-28 wt $\% \mathrm{MgO}$ and also includes some slightly contaminated basalts. It comprises an up to $240 \mathrm{~m}$ thick lava packet and associated prograding fans of hyaloclastites, pillow lavas and subaqueous flows up to $400 \mathrm{~m}$ thick. On Disko it is exposed along the north coast and in the Kuugannguaq valley. Its western and southern extensions on Disko are below exposure level; however, it reappears on the southeastern corner of Hareøen east of the Itilli fault (Fig. 17). On Nuussuaq it is found in an up to $21 \mathrm{~km}$ wide zone that extends $\mathrm{N}-\mathrm{S}$ across the peninsula between Nuusap Qaqqarsua and Nuuk Qiterleq on the south coast, between Qunnileeraq and Point 1756 m north of the Aaffarsuaq valley and between Kiggannguaq and just east of Ikorfat on the north coast. The limits to the west and north on Nuussuaq are erosional. The eastern limits are everywhere depositional.
Boundaries. Within the range of extent of subaerial lava flows of the Nuuk Killeq Member (unit 414) on Disko and Nuussuaq lavas of unit 417 rest on a red soil horizon less than a few decimetres in thickness. On northern Nuussuaq, lavas of unit 417 rest on the sediments of the Eqalulik Formation that overlie the lava flows of the Tunorsuaq a unit (416, see below and the North Nuussuaq section at $12.5-20 \mathrm{~km}$ ). Outside the range of the subaerial lavas, the hyaloclastites of unit 417 rest on the top fans of Nuuk Killeq Member hyaloclastites and thin veneers of Eqalulik Formation sediments, or on the Atane Formation.

On Disko east of the range of the lavas of the Nuuk Killeq Member, the lower boundary of unit 417 is poorly defined in the field, but the unit can be distinguished from older picrite units by its reversed magnetic signature (Chron 26r) as opposed to the normal magnetic signature (Chron 27n) of the older picrites of unit 413 (Fig. 49). For example, the picrite succession at 360-523 m in the upper type section of the Vaigat Formation in the

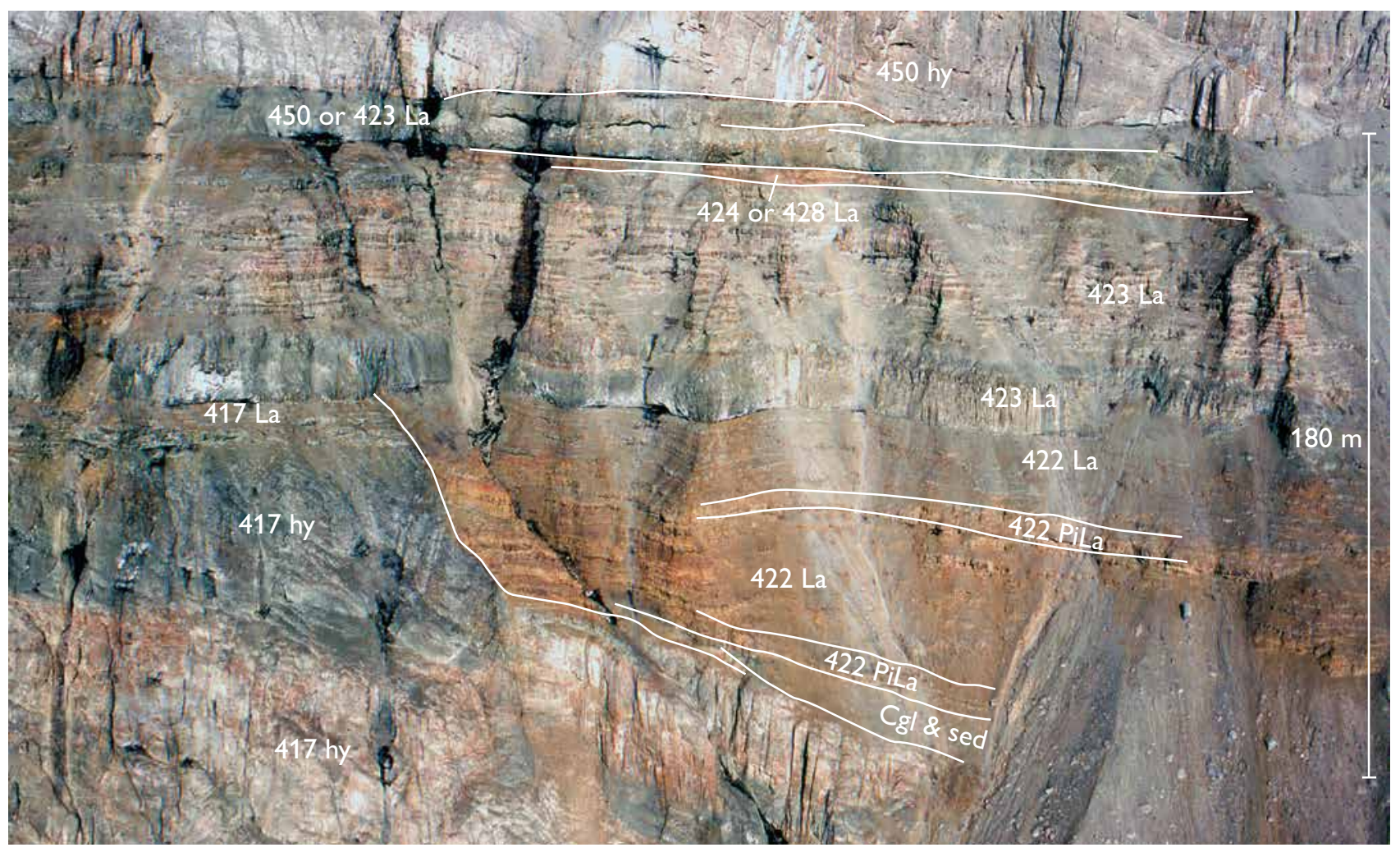

Fig. 59. Angular unconformity between eroded hyaloclastites (hy) and lava flows (La) of Naujánguit Member unit 417 and lava flows (La) and pillow lavas (PiLa) of Asuk Member unit 422 (Niiortuut unit) with up to $8 \mathrm{~m}$ of conglomerate and finer-grained sediment (Cgl \& sed) at the boundary. Lava flows of Naujánguit Member unit 423 overlie the earlier units conformably. See text for detailed description. South coast of Nuussuaq near Niiortuut (South Nuussuaq section at 23.7-23.9 km, Fig. 129). 
Norddalen valley (Fig. 16, profile 24) is reversely magnetised (Athavale \& Sharma 1975) and can be assigned to unit 417. In this profile a $6 \mathrm{~m}$ thick picritic hyaloclastite and overlying picrite lava flows have been deposited directly on Cretaceous sediments of the Atane Formation.

Unit 417 is overlain by lava flows and tuffs of the Asuk Member and its subunits, or by thin layers of Eqalulik Formation sediments. The boundary is poorly defined on north-western Disko and western Nuussuaq outside the depositional range of the Asuk Member.

Unconformity at the upper boundary of unit 417 west of Niiortuut. From Nuuk Killeq to just east of Point 1589 $\mathrm{m}$ on the Vaigat coast of Nuussuaq (South Nuussuaq section at $16-24 \mathrm{~km}$ ), picritic subaerial lava flows and their equivalent foreset-bedded hyaloclastites form a fairly monotonous, eastwards-prograding succession. However, east of Point $1589 \mathrm{~m}$ at $23.7-23.9 \mathrm{~km}$ in the South Nuussuaq section, unit 417 is separated from the overlying Niiortuut unit (422) of the Asuk Member by an angular unconformity (Fig. 59). Over a distance of about $200 \mathrm{~m}$ the upper boundary of unit 417 forms a sloping surface of hyaloclastite which is eroded, oxidised and hardened. It is covered by an up to $8 \mathrm{~m}$ thick deposit of interleaved lenticular bodies of conglomerate and hyaloclastite. The lower $c .2 \mathrm{~m}$ thick conglomerates contain up to metre-sized rounded and polished boulders, mainly of picrite and subordinate red-oxidised basalt. Higher conglomerates are finer and contain only centimetre-sized clasts which are rounded and polished. The upper part of the deposit consists of fine-grained hyaloclastite, and at the top there are two up to $10 \mathrm{~cm}$ thick beds of red and brown claystone of which the lower contains a ma- rine Paleocene dinocyst assemblage (Piasecki et al. 1992, p. 21, 22, sample 362154). The deposit is covered by a brownish-weathering pillow lava and subsequent thin brownish subaerial lava flows of unit 422 of the Asuk Member, which onlap the eroded surface of unit 417 over a vertical distance of $c .50 \mathrm{~m}$ (Fig. 59) and thereby demonstrates a relative, synvolcanic uplift between the deposition of the two units. Detailed photogrammetric analysis of subaerial flows of the Naujánguit and the overlying Ordlingassoq members has revealed local synvolcanic tectonic activity at this locality during the Naujánguit Member volcanic phase, but not during the later Ordlingassoq Member volcanism (Pedersen \& Dueholm 1992, fig. 10).

Lithologies. There is a considerable regional variation in the compositional range of erupted magmas and hence in the lithological appearance within unit 417. On Disko and Nuussuaq south of the Aaffarsuaq valley, most of the erupted rocks are picrites with only a few basalts, whereas on central and northern Nuussuaq basalts with 8-12 $\mathrm{wt} \% \mathrm{MgO}$ are common and a number of crustally contaminated basalts occur.

Subaerial facies. The typical picritic lava succession is composed of thin pahoehoe flows with vesiculated tops and massive interiors which locally display a pronounced concentration of olivine towards their base. Subhorizontal, vesiculated segregation veins are characteristic in the upper half of the massive flows (Fig. 60). These flows are parts of larger flow fields (Kilburn 2000), but due to lack of soil horizons or tuffs it is difficult to estimate sizes or volumes of these fields. North of the Aaffarsuaq valley

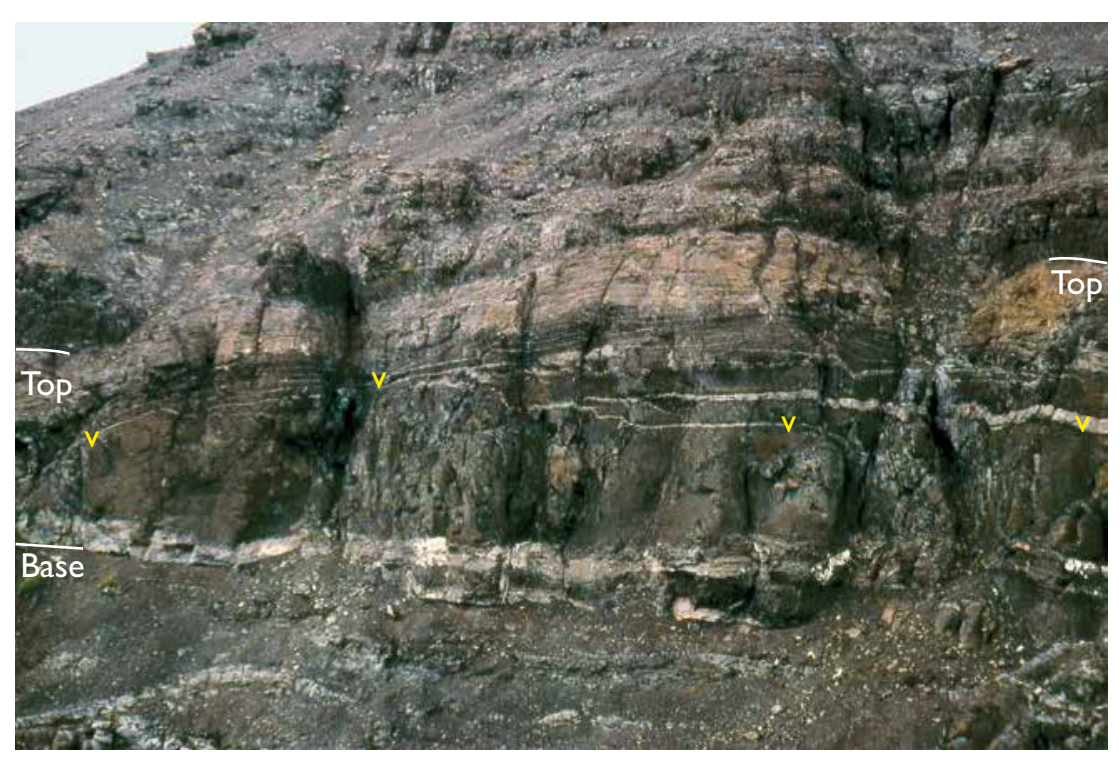

Fig. 60. Picrite pahoehoe lava flows of unit 417 with up to $15 \mathrm{~cm}$ thick subhorizontal segregation veins $(\mathbf{v})$ consisting of pegmatitic dolerite and white Ca-hydrosilicates and zeolites. The finely vesiculated top and basal zones of the slightly domed, central flow are also light-coloured by these minerals. The central flow is $c .4 \mathrm{~m}$ thick. 


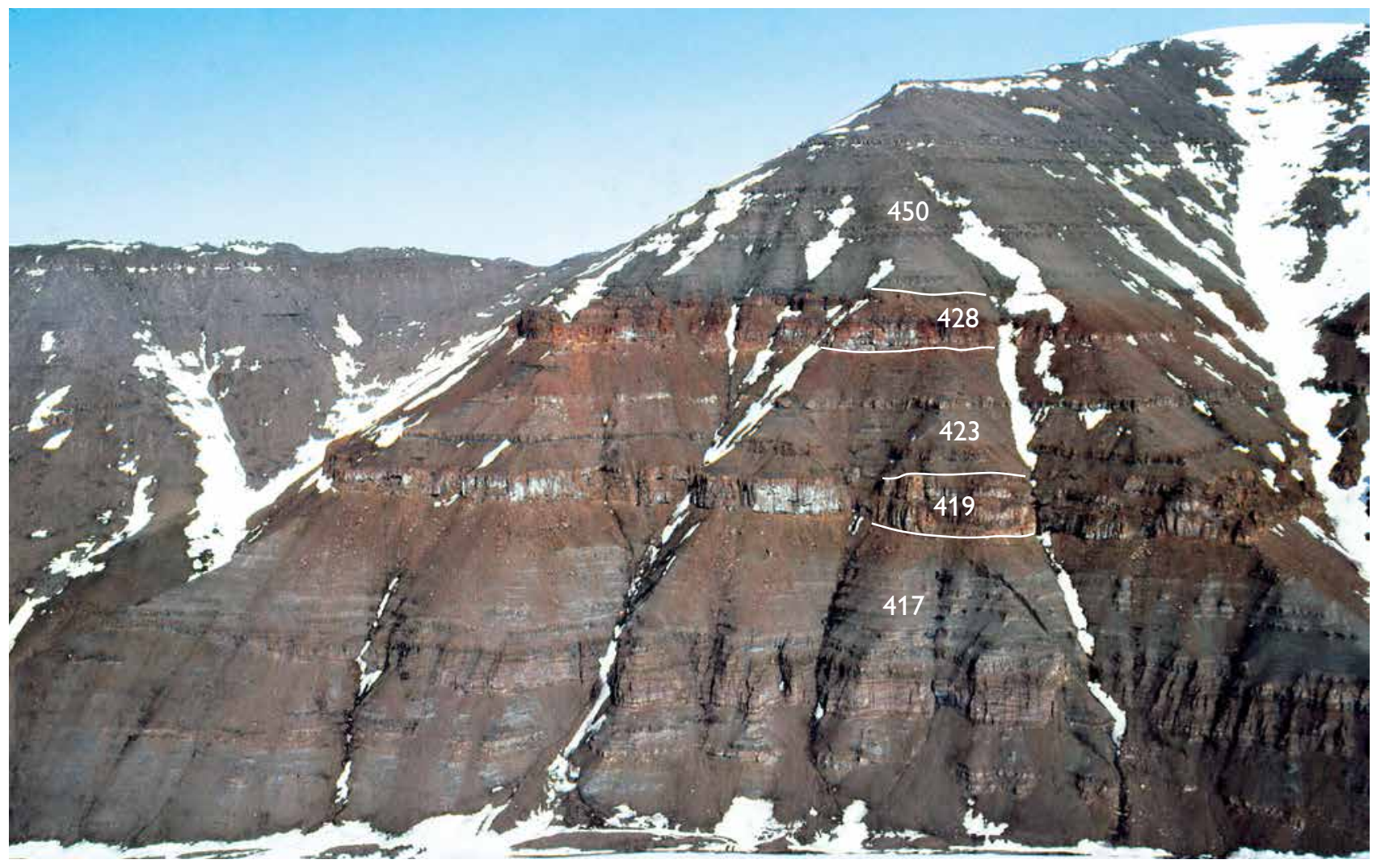

Fig. 61. Lava succession just south of Snekuplen. The lower part of the $600 \mathrm{~m}$ high succession consists of subaerial lava flows of Naujánguit Member unit 417 that form distinct flow fields. The overlying succession comprises brown contaminated lavas of the Saviaqqat unit (419) of the Asuk Member, picrites of Naujánguit Member unit 423, and red-brown contaminated lavas of the Tunoqqu Member (428), capped by picrite flows of the Ordlingassoq Member (450). See also the Snekuplen profile, Fig. 121. Northern wall of arcuate, north-to-east-trending side valley to the Qunnilik valley, central western Nuussuaq.

the subaerial lavas of unit 417 become less monotonous with the appearance of flow fields composed of a few to scores of individual brownish-weathering, relatively erosion-resistant pahoehoe flows of olivine-poor picrites and basalts (Fig. 61, see also Fig. 123).

Subaqueous facies. The lithological diversity within unit 417 is greatly increased in the $c .8 \mathrm{~km}$ wide zone where the unit entered the marine embayment towards the east and transformed into hyaloclastites, in particular where the volcanic front prograded across large older fault zones of the Nuussuaq Basin. Along the Vaigat coast of Nuussuaq the pattern of east-prograding hyaloclastites is well exposed between Nuuk Killeq and Nuuk Qiterleq (South Nuussuaq section at 18-24 km; Fig. 62). Hyaloclastite fans from individual flow fields may be separated by surfaces with slight erosion and in places sedimentation.

Where successive flow fields have different magma compositions, flow rates and volumes, more varied subaqueous lithologies result. Such a succession is well ex- posed on the north coast of Nuussuaq around Ikorfat (North Nuussuaq section at $27-30 \mathrm{~km}$; Fig. 14, profile 13). Here, a number of successions of olivine-poor picrites and basalts (with variable $\mathrm{MgO}$ contents in the range 9-23 wt\%) flowed into water from west to east across the Ikorfat fault (Fig. 63). Of particular interest is a thick marker succession (unit $\mathrm{e}_{3.1}$ ) which in subaerial facies forms an up to $60 \mathrm{~m}$ thick flow field of pahoehoe lavas, some of which are more than $30 \mathrm{~m}$ thick (Fig. 64). In subaqueous facies this voluminous unit forms a succession of subaqueous lava flows with brecciated tops, pillow lavas and pillow breccias (Figs 63, 65). In contrast, the underlying thin pahoehoe flows (unit $\mathrm{e}_{2}$ ) form foresetbedded hyaloclastites and the overlying thin pahoehoe flows (unit $\mathrm{e}_{3}$ ) likewise form foreset-bedded hyaloclastites.

The Ikorfat fault is an important pre-volcanic fault zone which also displays both synvolcanic and postvolcanic movements (Fig. 63). 


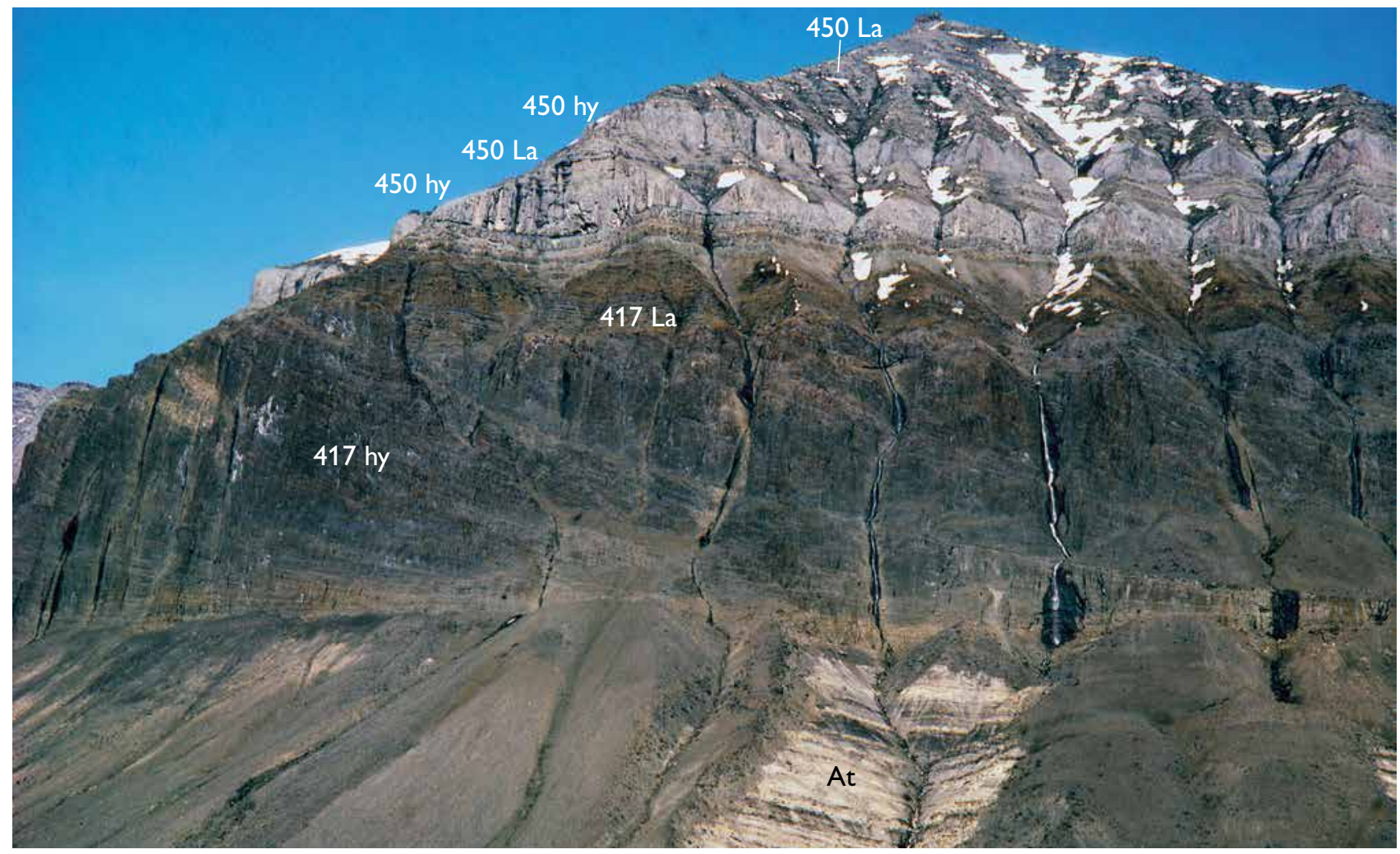

Fig. 62. East-prograding hyaloclastite fans of Naujánguit Member unit 417. Hyaloclastite fans from individual flow fields are separated by surfaces with slight erosion and in places sedimentation on the slope. The height of the foresets is $c .300 \mathrm{~m}$. The hyaloclastites overlie Cretaceous sediments of the Atane Formation (At) and a thin layer of mudstone of the Paleocene Eqalulik Formation (not distinguishable on photo). South coast of Nuussuaq between Nuuk Killeq and Nuuk Qiterleq.

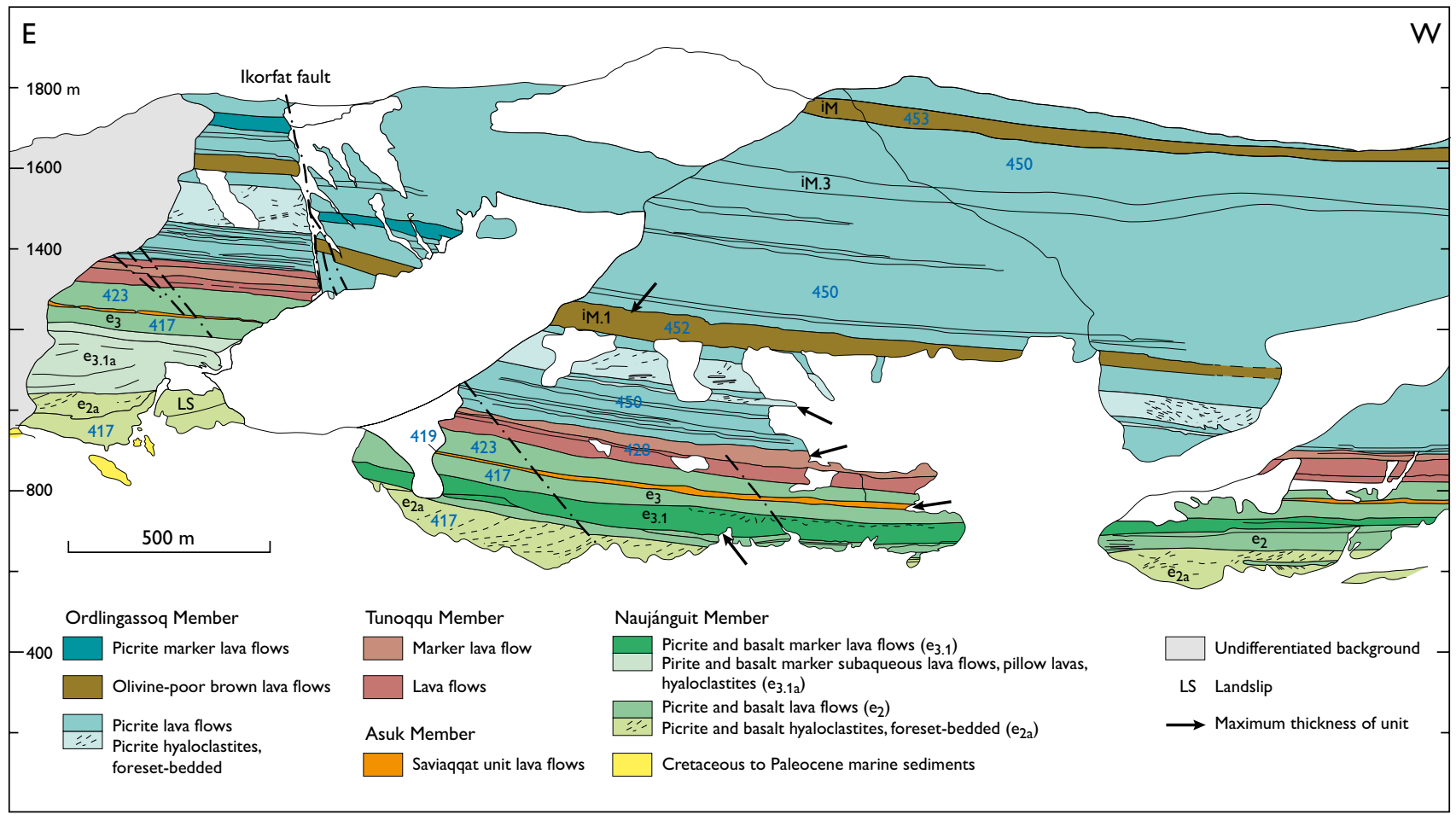




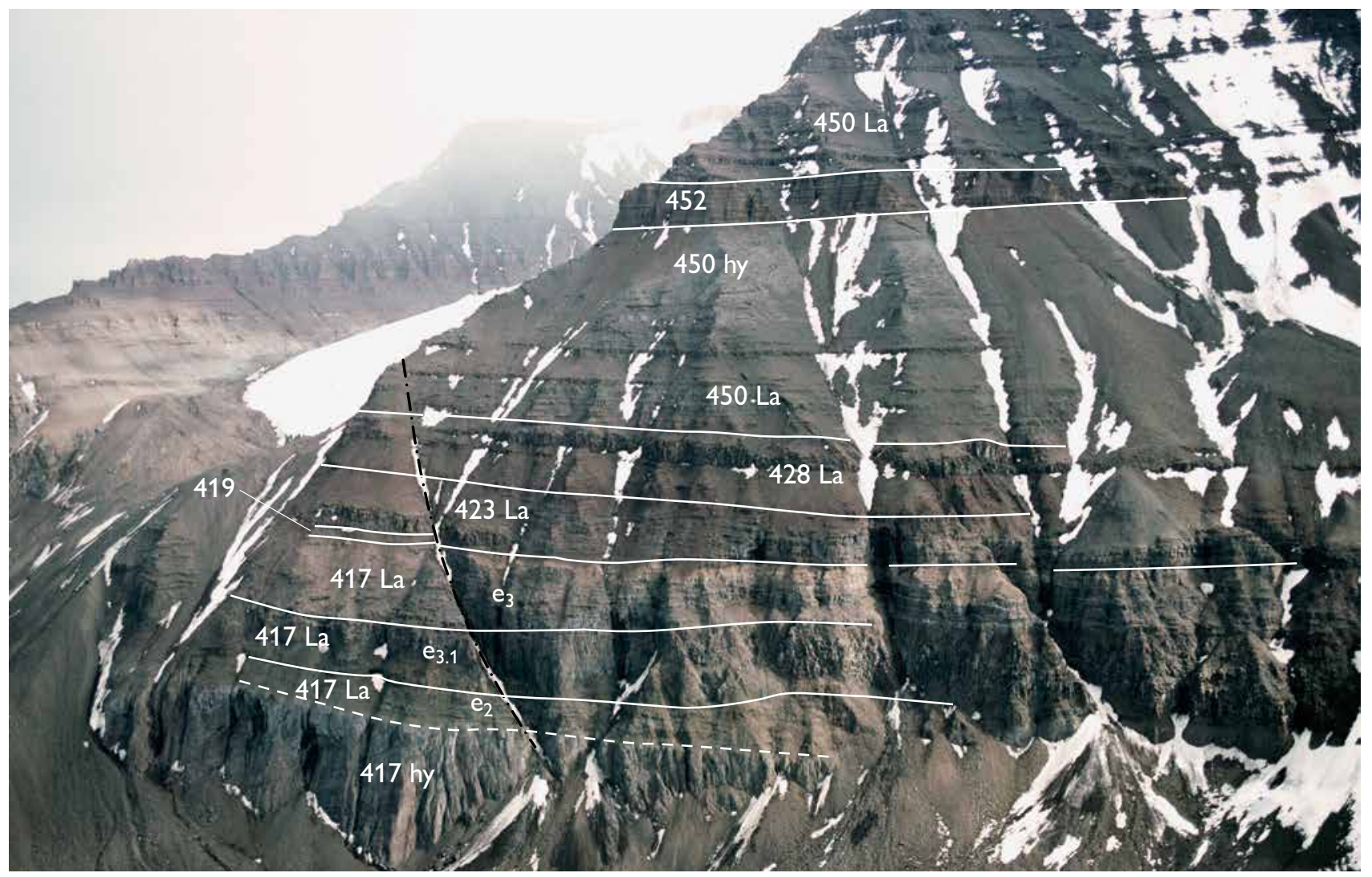

Fig. 64. North-facing mountain side at the north coast of Nuussuaq immediately west of the Ikorfat fault. The succession is shown in the central part of Fig. 63 at 600-1400 m altitude, west of the tongue-shaped glacier lobe. The single thin lava flow of the Saviaqqat unit (419) is seen as a light bed; except for its leftmost part only its top is outlined. See text and Figs 63 and 65 for interpretation and discussion. In the background the succession east of the Ikorfat fault is seen.

\section{Facing page:}

Fig. 63. Photogrammetrically measured section along the north coast of Nuussuaq around Ikorfat, looking south (compare the North Nuussuaq section at $27-30 \mathrm{~km}$, looking north at a different angle). The annotation of various units follows that in the North Nuussuaq section, e.g. $\mathbf{i}_{\mathbf{M}}$ to $\mathbf{i}_{\mathbf{M} 3}$ are marker horizons; numerical codes are added for consistence. The section illustrates a number of flow fields in Naujánguit Member unit 417 in different facies; the small flow field of thin pahoehoe lavas $\left(\mathbf{e}_{2}\right)$ produced foreset-bedded hyaloclastites $\left(\mathbf{e}_{2 \mathrm{a}}\right)$, whereas the thicker flow field of thick pahoehoe lavas $\left(\mathbf{e}_{3.1}\right)$ produced coherent subaqueous lava flows with brecciated tops, pillow lavas and pillow breccias ( $\mathbf{e}_{3.1 \mathrm{a}}$ in the left part of the figure). See also Figs 64-65. The section also shows the synvolcanic differential subsidence of the area just west of the Ikorfat fault where all units attain maximum thicknesses (black arrows).
Eruption sites. Several eruption sites are known for unit 417.

Subaerial eruption sites. The many local flow fields make it evident that there must be local eruption sites for unit 417, but in particular the crumbling erosion of the picrites makes these sites difficult to recognise in subaerial facies. An example is found at Sorluut where a $250 \mathrm{~m}$ wide lava dome indicates a local eruption site (Fig. 66).

Two other lava features within unit 417 are also probable eruption sites. One of these is a $15-20 \mathrm{~m}$ thick body with highly oxidised scoriaceous patches found at Saviaqqat (Fig. 67). The second feature comprises some nearsurface erosive lava tunnels that indicate proximity to an eruption site. It has been observed by Finn Ulff-Møller (unpublished field diary 1987) in the northern side of the Qunnilik valley, Nuussuaq (Fig. 68).

Subaqueous eruption sites. Two subaqueous eruption sites in unit 417 are excellently exposed in the steep northern side of the Aaffarsuaq valley between Ilugissoq and Qilakitsoq (Central Nuussuaq section at 21-25 km; Figs 69, 70; see also Fig. 103), and several more are 


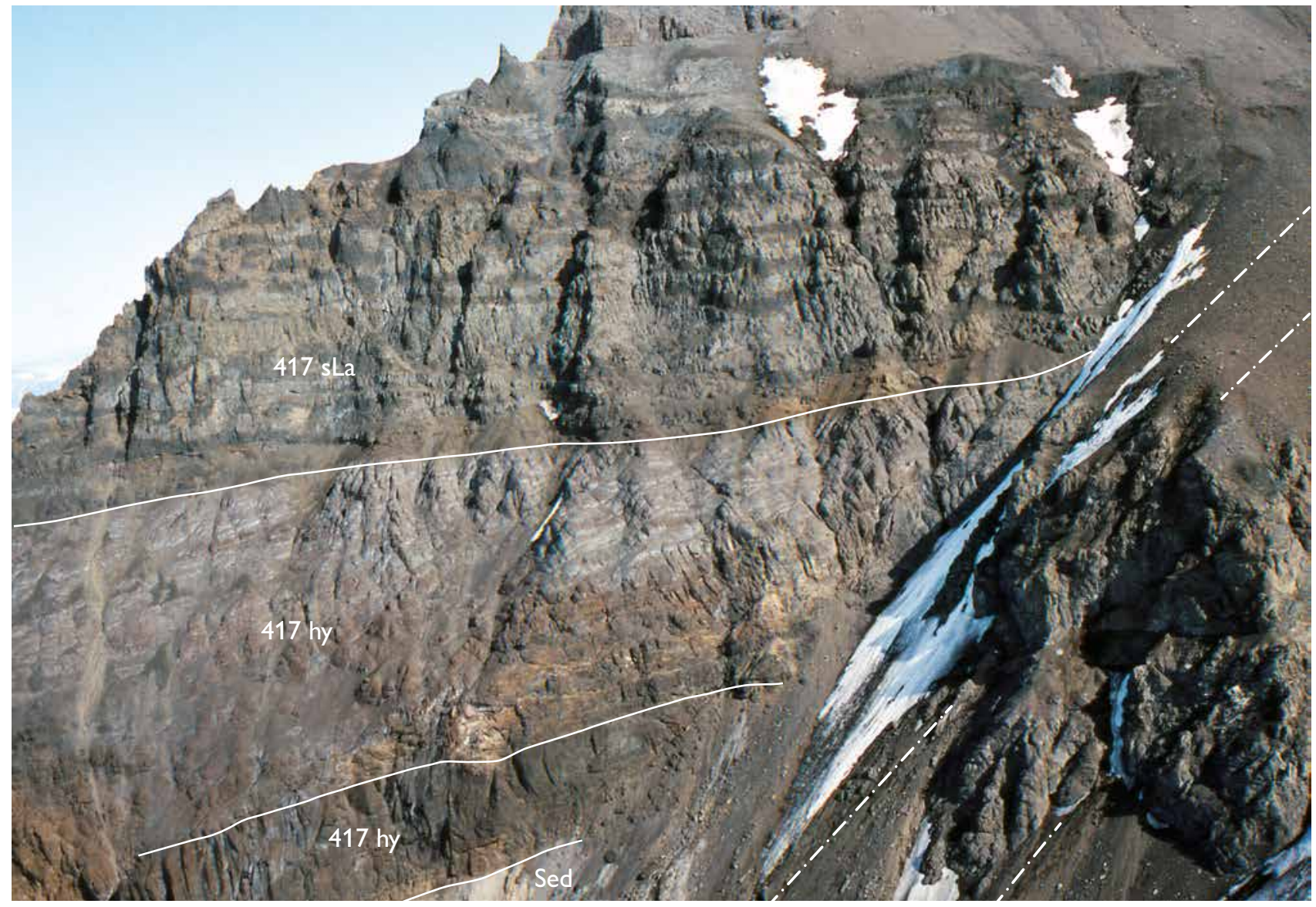

Fig. 65. Detail of Fig. 63. Different subaqueous facies in subunits of Naujánguit Member unit 417. The two lowermost units consist of foresetbedded hyaloclastites ( 417 hy; $\mathbf{e}_{2 \mathrm{a}}$ in Fig. 63), and the upper unit consists of subaqueous lava flows with brecciated tops and pillow lavas (417 sLa; $\mathbf{e}_{3.1}$ in Fig. 63). Sed: sediments. Mountain side just east of the Ikorfat fault; the succession is seen in the left part of Fig. 63 at $900-1200$ m altitude.

partially exposed in the western side of Qilakitsoq. Additional unexposed sites may exist within the zone extending northwards from these sites.

\section{Uncontaminated Naujánguit Member above the Asuk Member (unit 423)}

This is the uppermost unit of grey uncontaminated picrites and olivine-phyric basalts in the Naujánguit Member (Fig. 49). They contain 7-24 wt \% MgO, and the large majority are picrites. The unit is in subaerial facies over most of its extent and comprises a lava package of variable thickness that apparently filled existing depressions in a flat-lying landscape. On Disko the unit is exposed along the north coast between Serfarsuit and Qorlortorsuaq, in the Kuugannguaq valley and in Stordal where it onlaps the Disko Gneiss Ridge. Its western and southern limits on Disko are below exposure level; however, it re-appears on Hareøen east of the Itilli fault where it is $180 \mathrm{~m}$ thick (Fig. 17). On Nuussuaq it is found in a $22-30 \mathrm{~km}$ wide zone that extends $\mathrm{N}-\mathrm{S}$ across the peninsula between Alianaatsunnguaq and Tupaasat on the south coast, between Qunnileeraq and Tunoqqu in the Aaffarsuaq valley and between Kiggannguaq and Vesterfjeld on the north coast. The western and northern limits on Nuussuaq are erosional. The eastern limits are everywhere depositional.

The thickness of the lava package is not great; on Disko it is commonly around $50 \mathrm{~m}$ and varies from $0 \mathrm{~m}$ to $180 \mathrm{~m}$. On the south coast of Nuussuaq, the unit is only $0-20 \mathrm{~m}$ thick and the lavas peter out in subaerial facies because the Niiortuut unit filled out the sea there (see also Fig. 128). In the Aaffarsuaq valley, the unit reached the sea and produced a 40-140 m thick succession of hyaloclastites that prograded c. $7 \mathrm{~km}$ eastwards. On the north coast of Nuussuaq the unit is $50-100 \mathrm{~m}$ thick where it is in lava facies. It rapidly increases in thick- 
Fig. 66. Subaerial eruption site for Naujánguit Member unit 417. The $250 \mathrm{~m}$ wide and $c$. $40 \mathrm{~m}$ high lava dome is composed of several short, inflated picrite flows, all of which are much thicker than the surrounding lava flows. The eruption site overlies a $35 \mathrm{~m}$ thick succession of crustally contaminated pahoehoe flows of the Nuuk Killeq Member (unit 414). Sorluut, northern Nuussuaq.

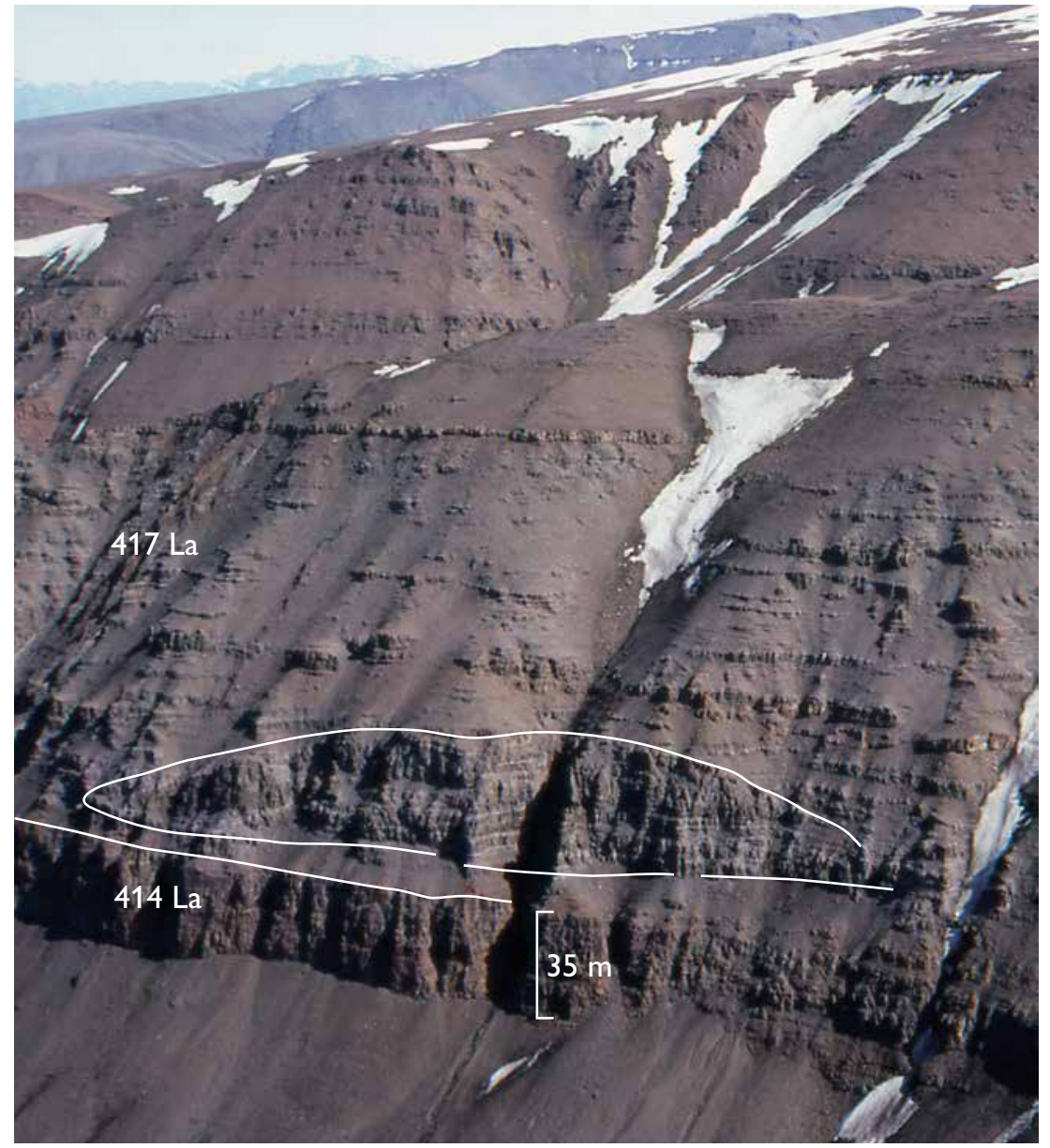

ness where it has entered the marine embayment east of Ikorfat and reaches a maximum thickness of about 380 $\mathrm{m}$ south of Ravn Kløft (North Nuussuaq section at $c .36$ $\mathrm{km})$. Unit 423 is missing entirely in a small area around crater D of the Ilugissoq volcano (see also Fig. 102; Pedersen \& Larsen 2006).

The minor contaminated and enriched units embedded in unit 423 (units 421, 425 and 426, Fig. 49) are described separately below.

Boundaries. Unit 423 rests on the top of the Asuk Member on Disko (Fig. 71) and on various subunits of the Asuk Member on Nuussuaq. At the boundary there is usually a few decimetres of lateritic soil which may contain graphite where the underlying rocks are graphite andesite tuffs. At Ikorfat there is a small angular unconformity at the lower boundary (Fig. 72). In the Aaffarsuaq valley, picritic hyaloclastites of unit 423 are deposited on top of marine sediments of the Itilli or the Atane formations (Central Nuussuaq section at 25-39 km; Dam et al. 2009, fig. 82). However, at many places where the boundary is not well exposed, mudstones with thin beds of graphite andesite tuff derived from the Ilugissoq volcano, assigned to the Abraham Member of the Eqalulik Formation, may separate unit 423 from the Cretaceous sediments. On the north coast of Nuussuaq unit 423 covers the Saviaqqat unit of the Asuk Member (Fig. 72), and east of the place where a single thin Saviaqqat unit flow enters the marine embayment and stops, unit 423, even if rarely exposed, overlies either the Eqalulik Formation or the Kingittoq Member of the Atane Formation (Dam et al. 2009, fig. 29).

Unit 423 is overlain by the Kûgánguaq Member (unit 430) on north-east Disko, the Qordlortorssuaq Member (unit 440) on north-west Disko and the Tunoqqu Member (unit 428) on Nuussuaq. Over large areas on both Disko and Nuussuaq, the boundary is marked by up to $0.5 \mathrm{~m}$ lateritic soil. At the western margin of the marine embayment, unit 423 forms a shelf slope of hyaloclastites which are covered by thin mudstones or conglomerates, and at one locality in the Aaffarsuaq valley a rocky palaeoshore is preserved, which shows marine erosion of subaerial lava flows and production of conglomerates 


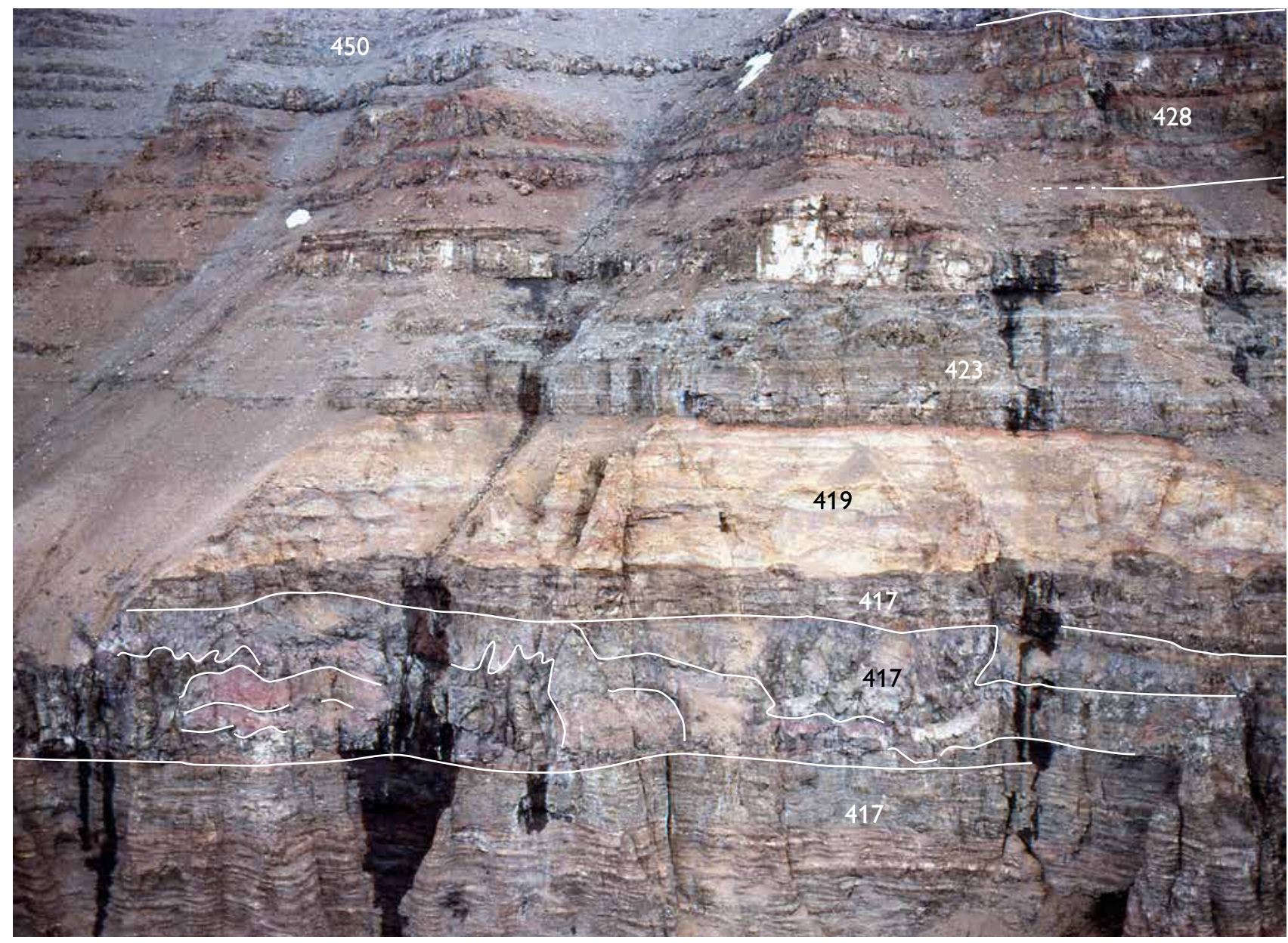

Fig. 67. A probable eruption site for Naujánguit Member unit 417. Within a succession of thin-bedded pahoehoe flows in the lower part of the picture occurs a 15-20 m thick body comprising one to three irregular flow tongues (outlined) with highly oxidised scoriaceous patches; no feeder channels are exposed. The $c .20 \mathrm{~m}$ thick, light-coloured yellowish brown lava succession in the centre is the crustally contaminated basalt of the Saviaqqat unit (419) of the Asuk Member. Other higher volcanic units are labelled by numerical codes. Saviaqqat, northern Nuussuaq.

from these (see also Fig. 137). The boundary is in subaerial facies over most of its extent.

Lithologies. Over most of its area of extent unit 423 is composed of subaerial lava flows, dominantly picrites. The lavas form a large number of flow fields in which the individual lava lobes vary in thickness from less than $1 \mathrm{~m}$ to about $12 \mathrm{~m}$. Many flows are inflated pahoehoe flows which have characteristic, highly vesicular, light greyweathering top zones and lower, vesicle-poor parts commonly with olivine accumulation near the base. Subhorizontal, up to $25 \mathrm{~cm}$ thick vesiculated segregation veins are common in the central parts of the flow lobes.

A detailed survey of unit 423 on northern Disko beneath the Kuugannguaq volcanic centre shows a $130 \mathrm{~m}$ thick succession of 45 flow tongues with a mean thick- ness of c. $3 \mathrm{~m}$ (shown schematically in Fig. 16, profile 22; see also Fig. 143). Lateritic soil is present at the base and top of unit 423, but within the succession only one thin $(10-15 \mathrm{~cm})$ soil layer was found, indicating a high eruption rate, as also shown for unit 413 by Pedersen et al. (2002b).

The individual lava flows of unit 423 reach a maximum thickness of about 20-25 m. The thick flows are more erosion-resistant than typical picrites and tend to form distinct benches. Most prominent is a $25 \mathrm{~m}$ thick flow of magnesian basalt (Table 3, sample 113325) which overlies native-iron-bearing flows of the Asuk Member on the north-east side of the Kuugannguaq valley (Pedersen 1985a, fig. 9 loc. 5).

In a kilometre-wide belt on Nuussuaq, picritic pahoehoe flow lobes of unit 423 enter the marine embayment 

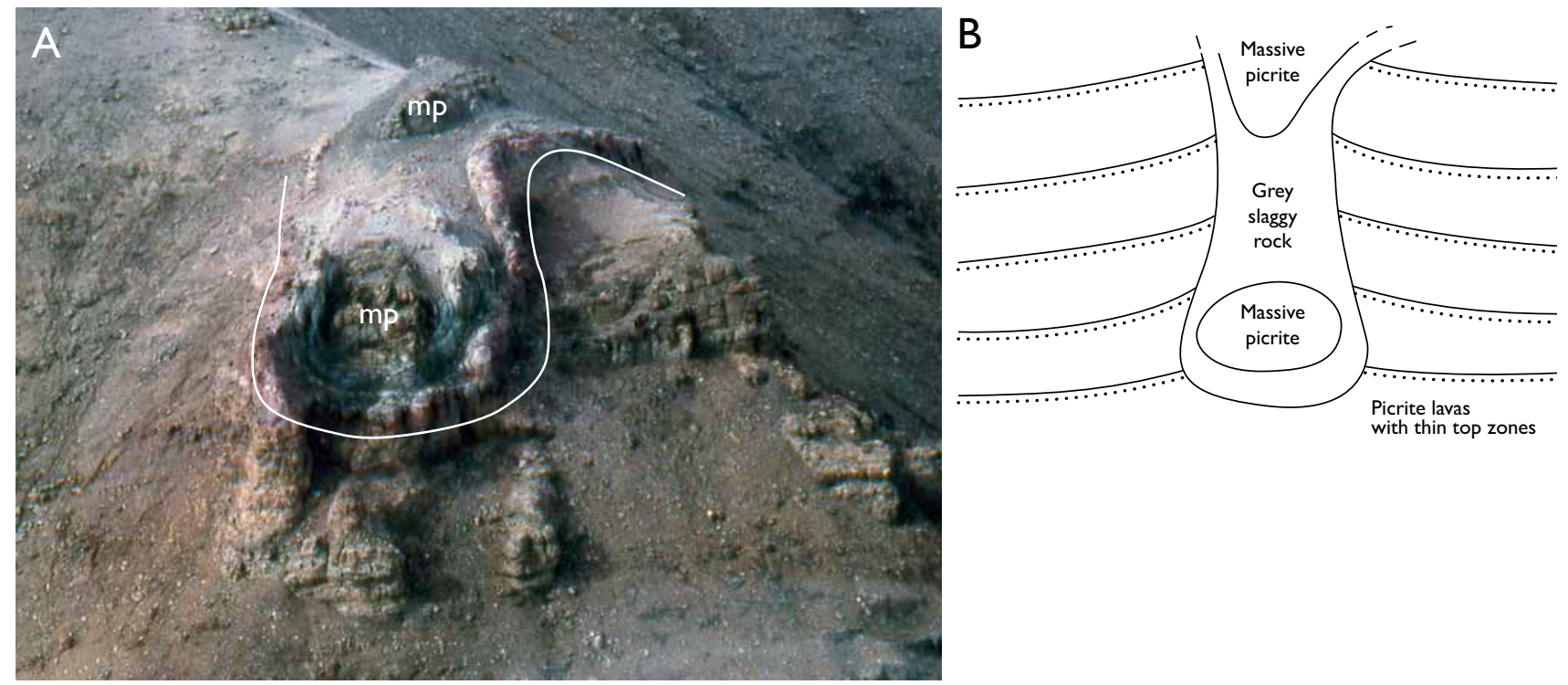

Fig. 68. Eruption site for Naujánguit Member unit 417. A: A feeder channel cutting a succession of subaerial lava flows. The channel is closed downwards and open but narrow upwards; it is exposed in a number of ridges on the valley side and must have a horizontal orientation. The channel has a lower core of massive picrite $(\mathbf{m p})$ which is surrounded by grey scoria. Its margin is red from high-temperature oxidation and is more erosion-resistant than the surrounding flows. On top of the channel is a massive picrite (mp) with an envelope of oxidised scoria. B: Interpretative field sketch. A few kilometres south of Point $1640 \mathrm{~m}$ in the northern wall of the Qunnilik valley, at $c .1150 \mathrm{~m}$ altitude. Photo and field sketch: Finn Ulff-Møller.

to form foreset-bedded hyaloclastites (Fig. 73) which are very similar to those formed by other units of the Vaigat Formation. An exception is described below.

Eruption sites. On both sides of the valley Norddalen on northern Disko, two thick erosion-resistant flows are ex- posed at the base of unit 423 . On the western side of the valley, the second lava flow is about $25 \mathrm{~m}$ thick and short, with fairly steep flanks which are onlapped by many small flow lobes (Fig. 71). The eruption site of this thick flow must be situated close to the exposure, and just $50 \mathrm{~m}$ north of the northern flank of the flow an acentral sec-

Fig. 69. The older of two submarine eruption sites for Naujánguit Member unit 417 exposed in the northern side of the Aaffarsuaq valley, central Nuussuaq (unit $\mathbf{e}_{3}$ in Fig. 103). A body of solid dark brown basalt is surrounded by brown pillow breccias (417 er) deposited directly on the Atane Formation (At). The structure rises to $c .100 \mathrm{~m}$ above the palaeo-seafloor and is covered by foresetbedded picritic hyaloclastites ( 417 hy). Several dark, dyke-like bodies are visible within the brown body, but none of these occur within the Atane Formation sandstones.

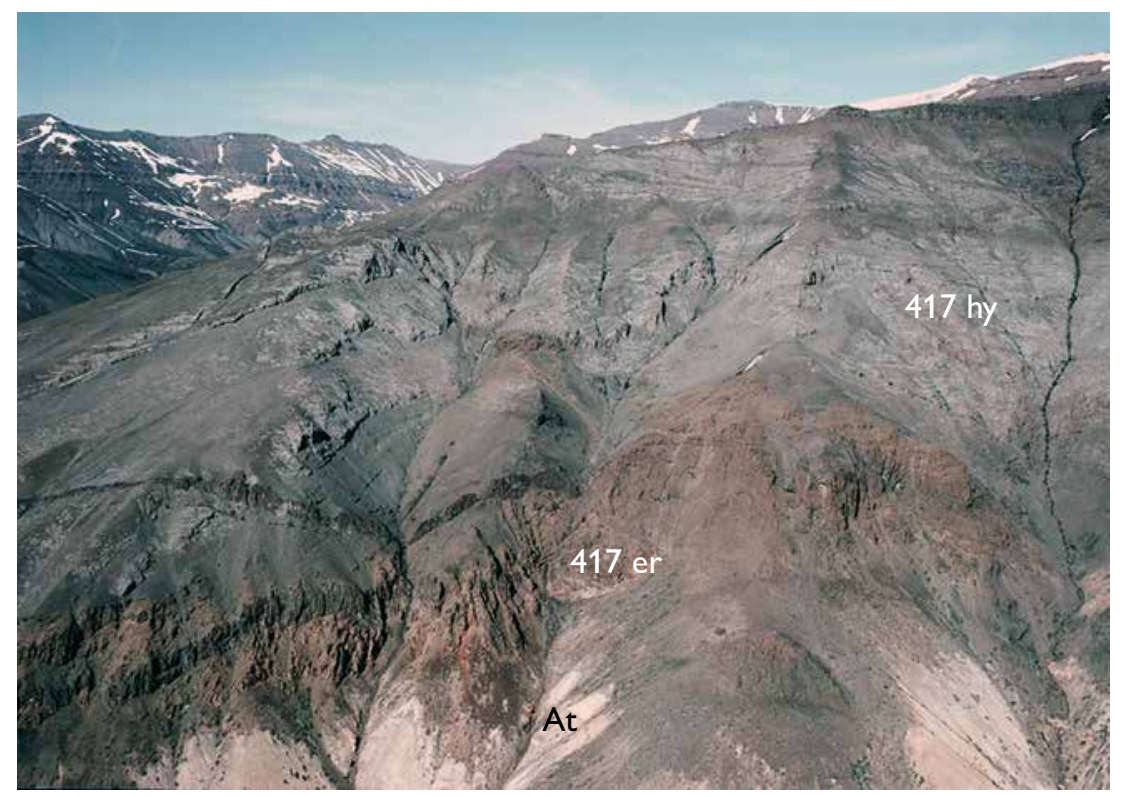




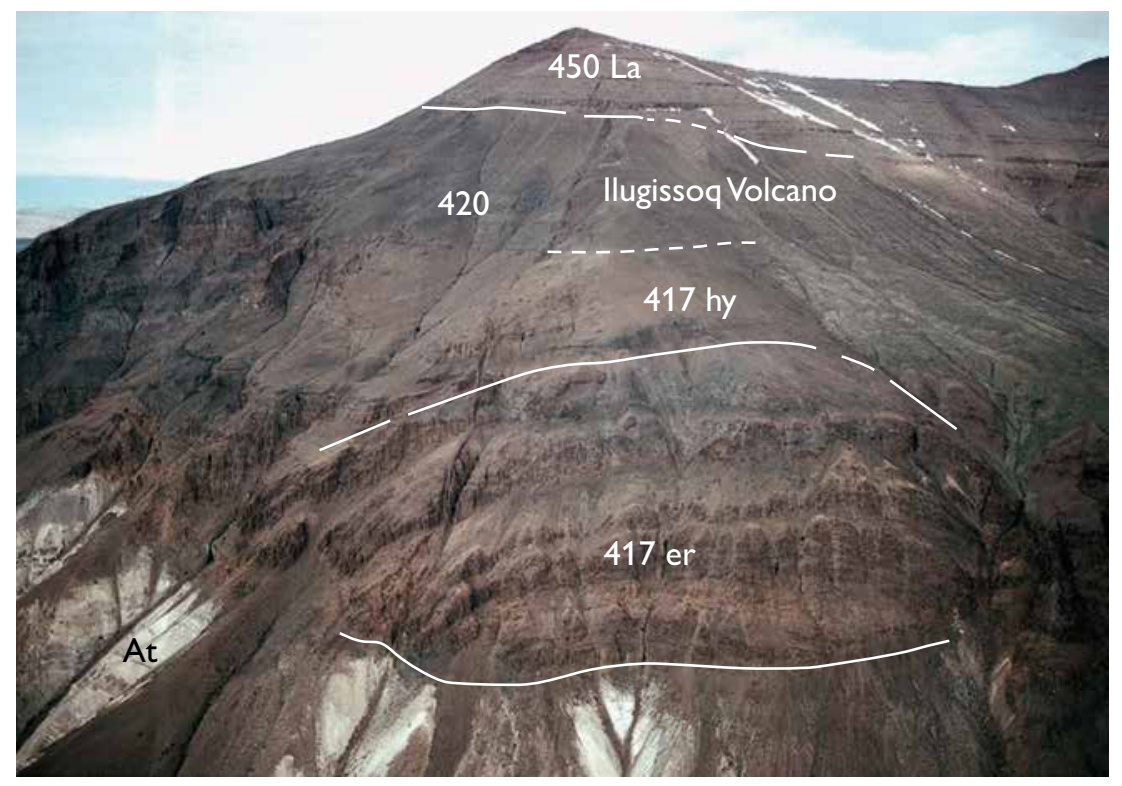

Fig. 70. The younger of two submarine eruption sites for Naujánguit Member unit 417 exposed on the northern side of the Aaffarsuaq valley, central Nuussuaq (unit $\mathbf{e}_{\mathbf{1}}$ in Fig. 103). A $200 \mathrm{~m}$ thick picritic pillow breccia body is composed of a number of convex-upward breccia beds ( 417 er) which have probably almost reached the top of the water column without causing notable explosions. The body is covered by picritic hyaloclastites ( 417 hy; unit $\mathbf{e}_{\mathbf{1 b}}$ ) probably deposited from nearby lavas, which are in turn covered by a thick layer of graphite andesite tuff erupted from the Ilugissoq volcano (420). Subaerial picrite lavas of the Ordlingassoq Member $(450 \mathrm{La})$ occur at the top of the exposure.

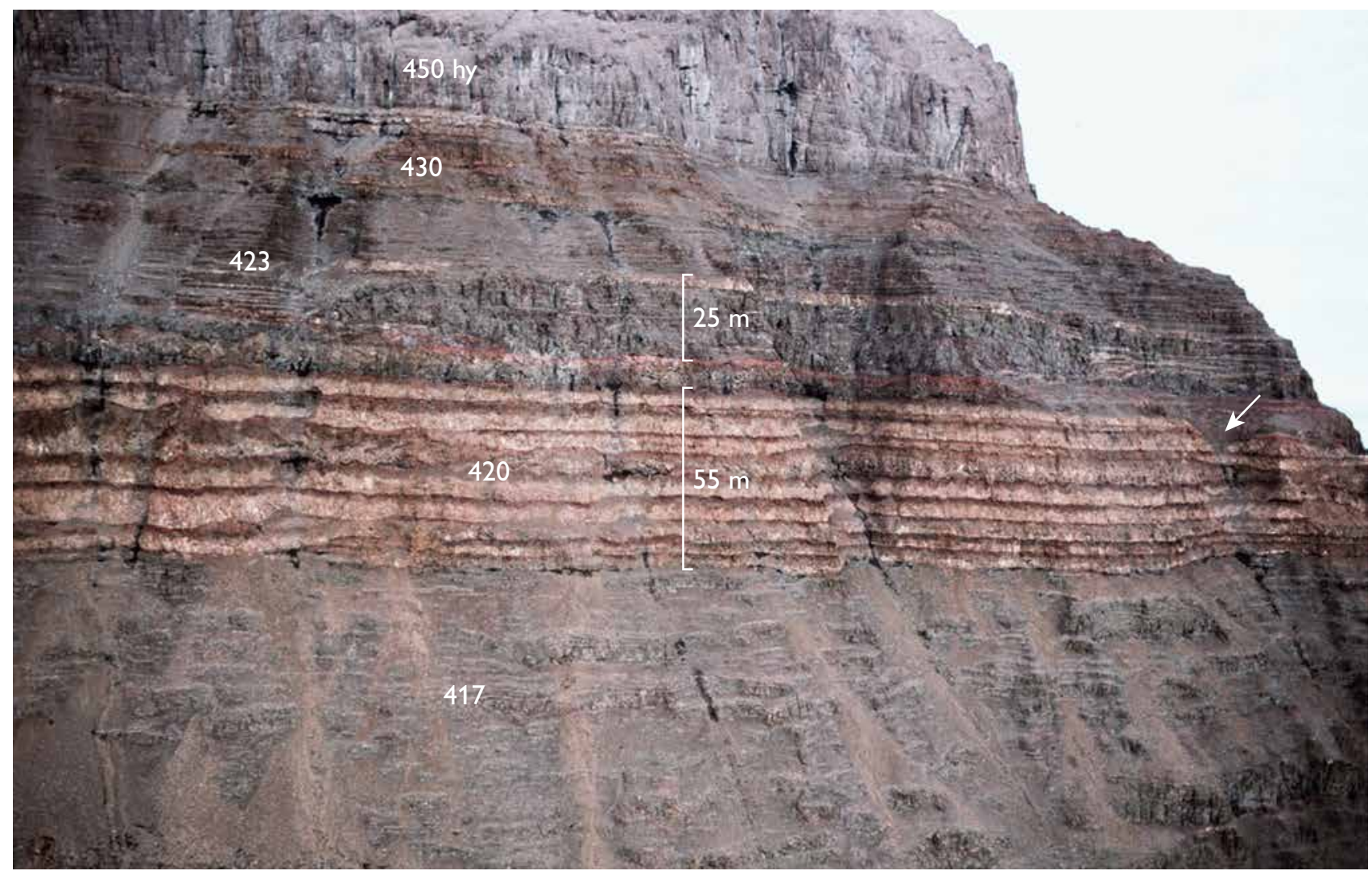

Fig. 71. The western wall of Norddalen on northern Disko. Grey picritic lava flows of Naujánguit Member unit 423 overlie light-coloured, yellowish brown, contaminated lava flows of the Asuk Member (unit 420). The $25 \mathrm{~m}$ thick second flow of unit 423, onlapped by many small flow lobes both to the right and left, must be close to its eruption site; a possible candidate for this is marked by a white arrow to the right in the photo, where the upper flows of the Asuk Member are missing, presumably removed by the eruption. Unit 423 is overlain by $c .25 \mathrm{~m}$ of brown subaerial lava flows of the Kûgánguaq Member (430) and subsequently grey hyaloclastites of the Ordlingassoq Member (450 hy). 


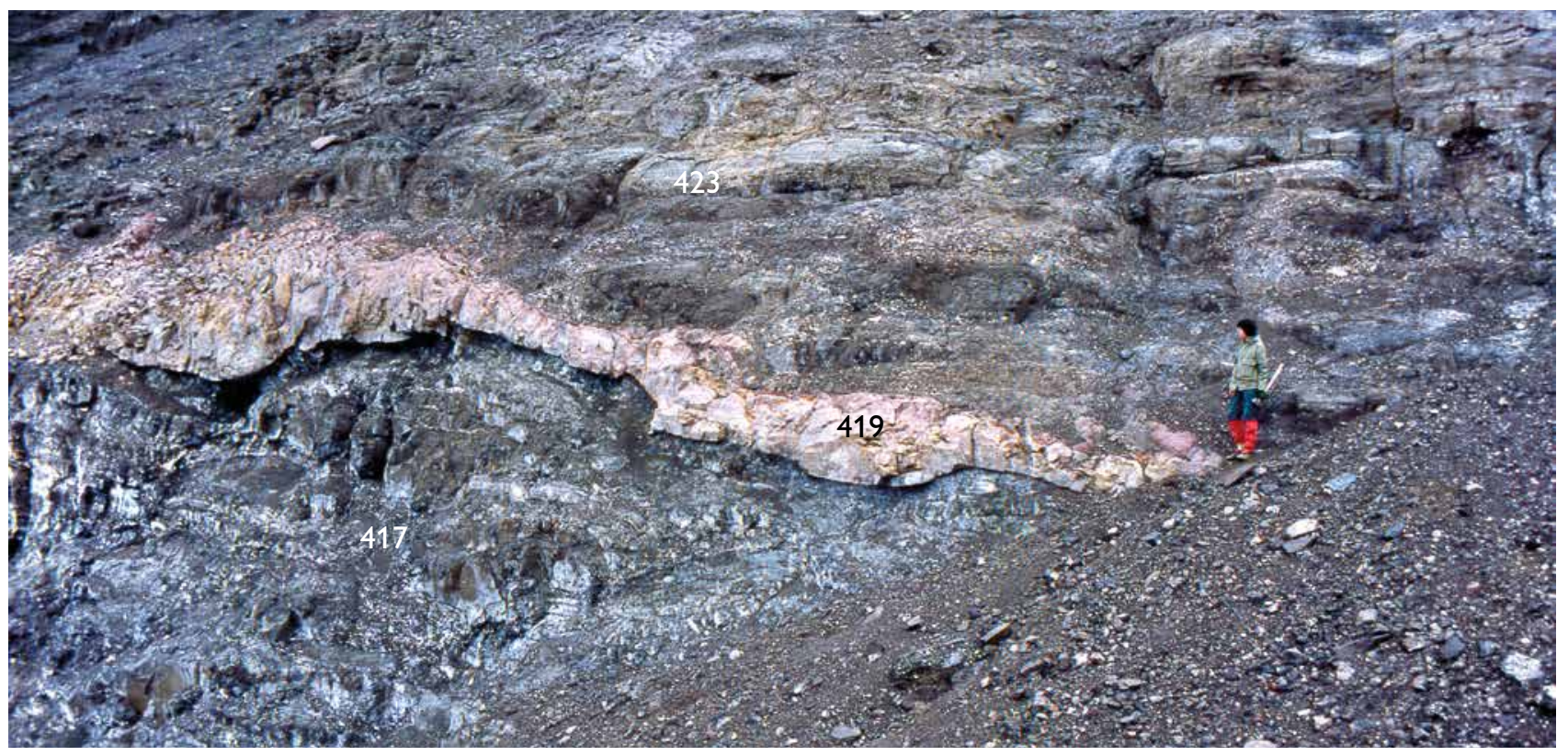

Fig. 72. Angular unconformity at the lower boundary of unit 423. Thin picrite lava flows of Naujánguit Member unit 423 that onlap a light yellowish-brown, strongly contaminated lava flow of the Savaiqqat unit (419) of the Asuk Member. To the right, person for scale. North coast of Nuussuaq just east of the Ikorfat Fault (North Nuussuaq section at $29.5 \mathrm{~km}$ ).

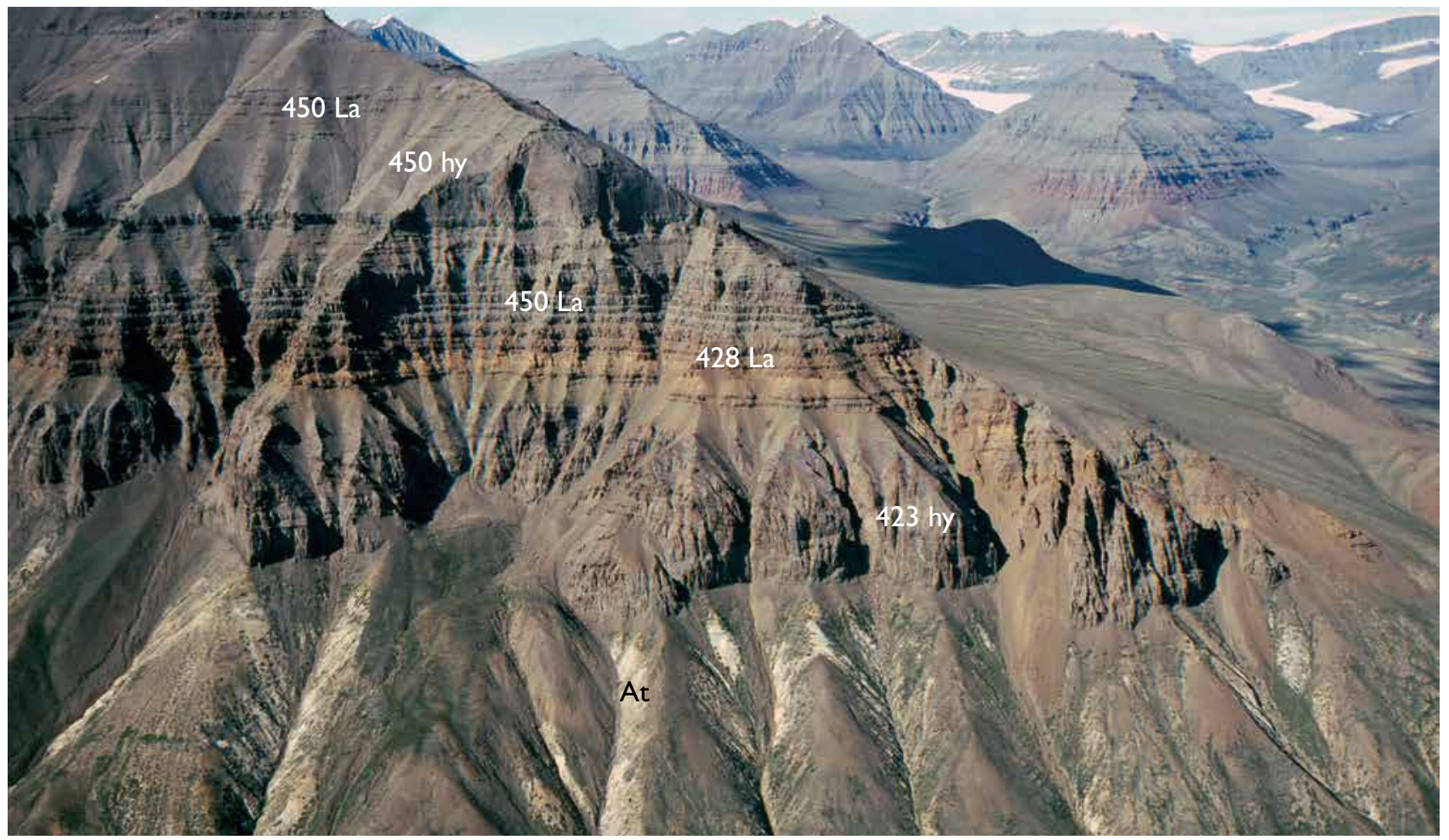

Fig. 73. Volcanic succession in the northern wall of the Kangersooq valley, central Nuussuaq. At the base of the succession, sandstones of the Qilakitsoq Member of the Atane Formation (At; see Dam et al. 2009, fig. 82) are covered by foreset-bedded hyaloclastites of Naujanguit Member unit 423. In the centre, brownish lava flows of the Tunoqqu Member ( $428 \mathrm{La}$ ) are covered by lava flows ( $450 \mathrm{La}$ ) and hyaloclastites ( 450 hy) of the Ordlingassoq Member. In the background the valley Agatdalen with the mountain ridge Puugutalissuaq between the two arms of the valley. Puugutalissuaq is also shown in Fig. 171. 

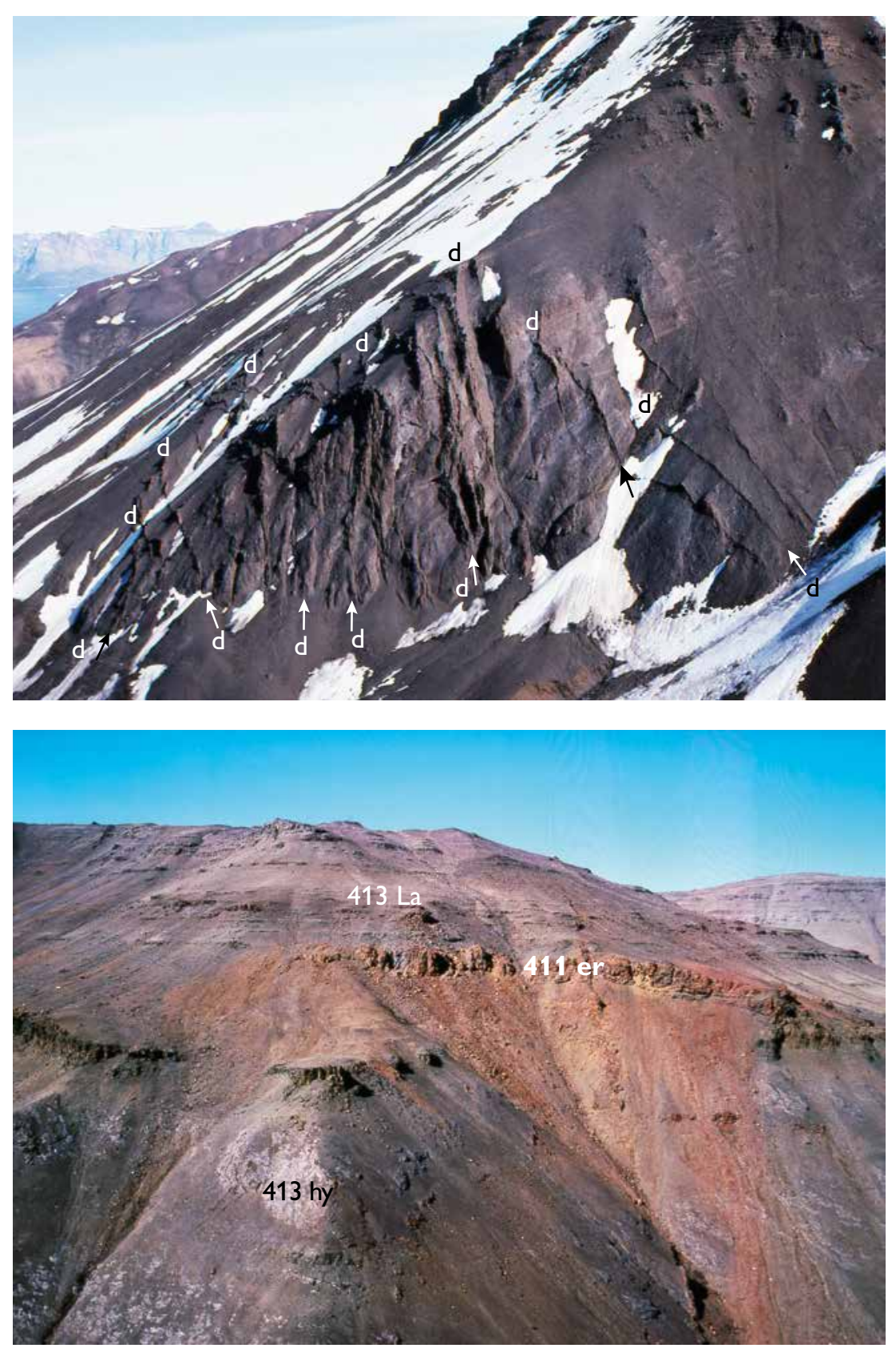

Fig. 74. A probable eruption site for Naujánguit Member unit 423. Hyaloclastites of unit 423 are intruded by a local swarm of thin, dark, irregular dyke bodies (d), many of which terminate upwards. Steep mountain side c. $1 \mathrm{~km}$ south of Ravn Kløft, north coast of Nuussuaq.
Fig. 75. Eruption site (er) for unit 411 (the Henderson unit) of the Naujánguit Member embedded within picrite lava flows of Naujánguit Member unit 413 (413 La), exposed in the western wall of the Qunnileeraq gully. The rusty brown crater rock is about $25 \mathrm{~m}$ thick. In the foreground hyaloclastites of unit 413. tion through a crater site is exposed on top of the Asuk Member. The eruption has blown away or eroded the uppermost Asuk Member lava flow (Fig. 71), and this crater, or a similar one nearby, may be the source of a flow field of which the large flow is the biggest.

Despite the fact that subaerial eruption sites for unit 423 must be frequent and widespread on Disko and Nuussuaq, no other subaerial sites have been located.

In the steep mountain side $c .1 \mathrm{~km}$ south of Ravn Kløft on the north coast of Nuussuaq (North Nuussuaq sec- tion at $36 \mathrm{~km}$ ), unit 423 reaches a maximum thickness of c. $380 \mathrm{~m}$ of which the lower $300 \mathrm{~m}$ are hyaloclastites. These are intruded by a local swarm of thin irregular dyke bodies, many of which disappear upwards (Fig. 74). By analogy with similar occurrences in the Ordlingassoq Member which are documented in detail by photogrammetry (see also Fig. 178), the swarm south of Ravn Kløft is interpreted as a submarine eruption site for unit 423 . 


\section{Minor units in the Naujánguit Member}

\section{Henderson unit (unit 411)}

This small unit is embedded in the grey uncontaminated rocks of unit 413 and is normally magnetised (Fig. 49). It is up to $c .60 \mathrm{~m}$ thick and consists of distinctly brown olivine-poor picrites and olivine-phyric basalts that only occur within an $8 \times 2 \mathrm{~km}$ area on western Nuussuaq between Qunnileeraq and Anariartorfik. It was partly mapped by G. Henderson as aphyric basalts and is shown on the 1:100 000 geological map Agatdal, though it is there in part included with the aphyric basalts of unit 408; the correct distribution of the unit is shown on the recently compiled map in Fig. 18. The unit consists mainly of lava flows; a few hyaloclastites are found in the Anariartorfik area. The flows were erupted subaerially from a well-exposed crater in the Qunnileeraq area (Fig. 75). The rocks contain 10-16 wt $\% \mathrm{MgO}$ and are weakly crustally contaminated. Most of the rocks from this unit are markedly affected by hydrothermal alteration and owe their characteristic brown weathering colour to the presence of carbonate.

\section{Tunorsuaq a: Enriched contaminated basalts below the Saviaqqat level (unit 416)}

This is a small local unit in the Tunorsuaq area on northern Nuussuaq (Fig. 10), stratigraphically situated around

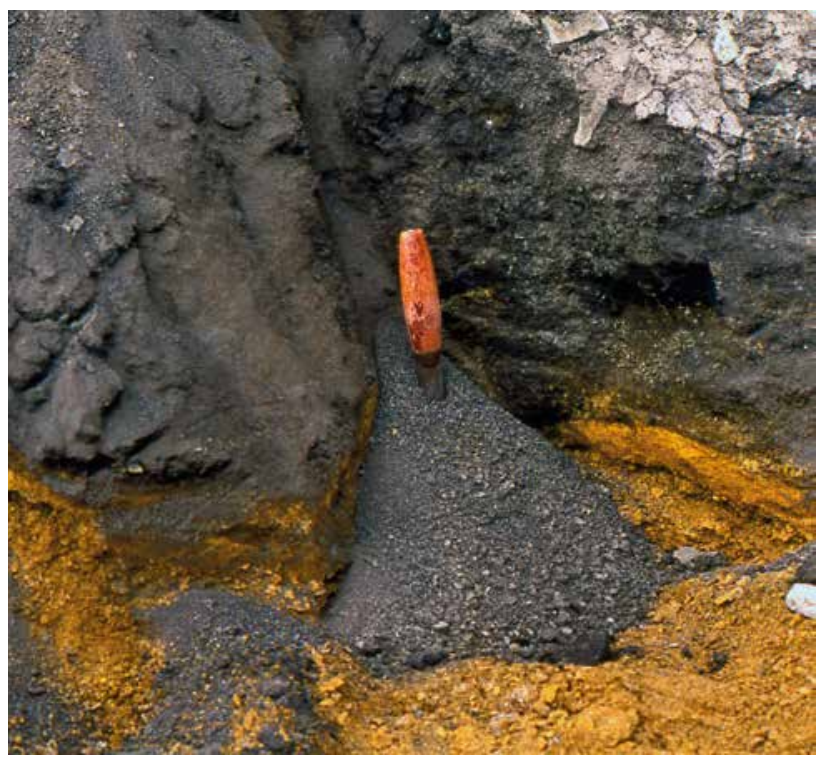

Fig. 76. The top of the Tunorsuaq a unit. The flow top is strongly altered to orange, clayey rubble and is covered by at least $5 \mathrm{~m}$ of black, poorly sorted mudstone. Length of knife handle $10 \mathrm{~cm}$. North wall of the Tunorsuaq valley (North Nuussuaq section at $13.7 \mathrm{~km}$ ). the level of the Nuuk Killeq Member which is not present in the Tunorsuaq area (Fig. 49). It consists of crustally contaminated basalts with some resemblance to the basalts of the Nuuk Killeq Member but in addition it is geochemically enriched (see later). In the Tunorsuaq profile (Fig. 14, profile 12), the unit consists of two brown, vesicular lava flows each $c .5 \mathrm{~m}$ thick. At the base of the unit there is a $2-10 \mathrm{~cm}$ thick layer of dark brown soil deposited on a slightly irregular lava surface. The top of the unit is strongly altered and covered by at least $5 \mathrm{~m}$ of black, poorly sorted mudstone with millimetre-sized, only slightly abraded chert and quartz clasts (Fig. 76).

The Tunorsuaq a unit can be followed for $7 \mathrm{~km}$ along the north coast of Nuussuaq from Kiggannguaq to Point $1908 \mathrm{~m}$ (North Nuussuaq section at $c .13$ to $20 \mathrm{~km}$ ) and thickens towards the east. The overlying sediments are assigned to the Eqalulik Formation (Dam et al. 2009). Palynological investigation of the sediments has revealed a wide range of re-deposited Cretaceous dinocysts but no well-preserved Paleocene species (H. Nøhr-Hansen, unpublished GEUS data 1995). Lava flows from this unit were sampled by Lightfoot et al. (1997) in their section N91-08 (their sample 7834) c. $5 \mathrm{~km}$ east of our Tunorsuaq profile, and probably also in their section N91-10 (their sample 7865).

\section{Stordal unit (unit 421)}

This unit consists of lava flows produced from a small volcanic centre in the Stordal area on Disko. It is exposed on the north side of the Stordal valley and is partly embedded within the picrites of unit 423 (Fig. 49). The rocks are dark brown- to black-weathering, aphyric to olivine-clinopyroxene microphyric alkali basalts (ankaramites) that are also crustally contaminated (Larsen et al. 2003). The unit is of particular interest because it represents the earliest alkaline magmatism in the Vaigat Formation. The volcanic centre is situated just west of the old fault block represented by the Disko Gneiss Ridge, quite close to the major Kuugannguaq-Qunnilik fault zone which is likely to have affected the channelling of magma to the surface. The unit is exposed over a total distance of $c .8 \mathrm{~km}$ (Central Disko section at $25.5-33.5 \mathrm{~km}$, unit $e_{5}$, see also Fig. 183) and consists of lava flows centred around a small volcanic neck (Fig. 77). The volcano is well exposed on the side of Stordal (Fig. 16, profile 25) and rises to $140 \mathrm{~m}$ above the base of the lowest flows. The volume is estimated to be $c .4 \mathrm{~km}^{3}$ but the extension of the unit towards the north and south is very poorly constrained. The lava flows were banked up against the 


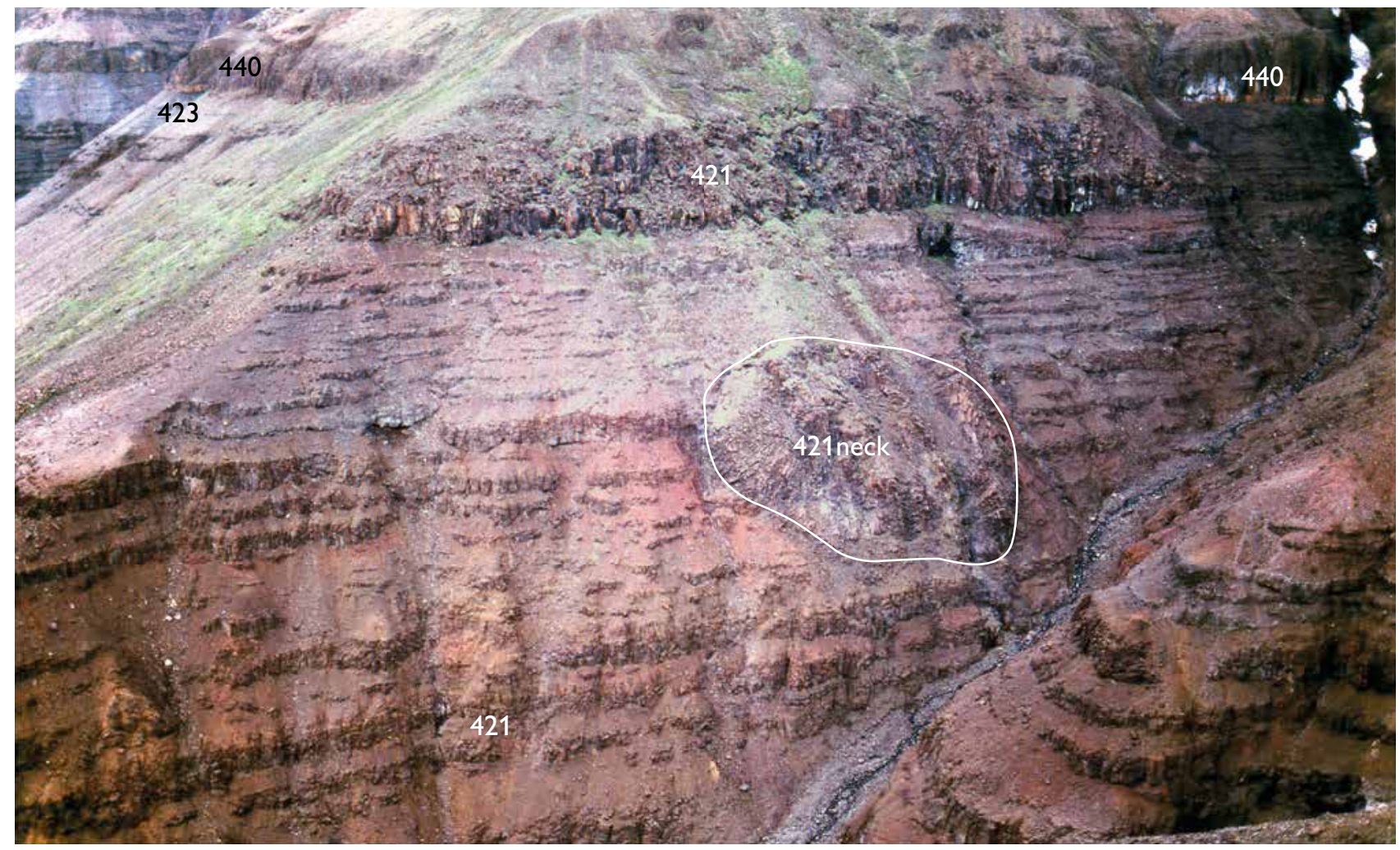

Fig. 77. Erosional section through the near-cylindrical volcanic neck through which the lava flows of the Stordal unit (421) were erupted. The diameter of the neck is $85 \mathrm{~m}$ at its widest. The surrounding lava flows are also from the Stordal unit. Small gully entering Stordal at $28.2 \mathrm{~km}$ in the Central Disko section; see also Fig. 183.

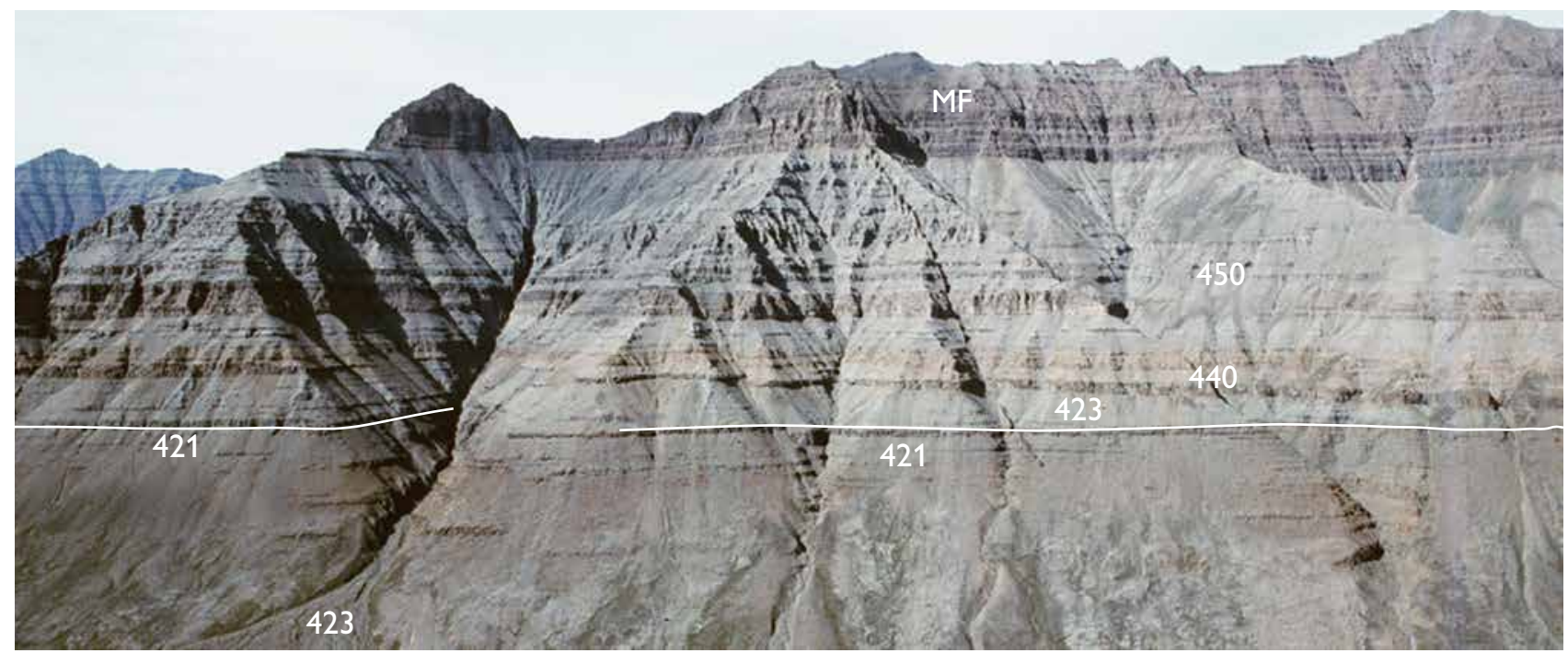

Fig. 78. The north side of the Stordal valley on central Disko. Dark lava flows of the alkaline Stordal unit (421) are onlapped by thin greyweathering picrite flows from Naujánguit Member unit 423. Other units are indicated by their numerical codes. Dark brownish lava flows of the Maligât Formation (MF) cap the succession. Location in Fig. 183 at 25.3-28.2 km; slightly different orientation. 
Fig. 79. Conglomerate on top of the Stordal unit, composed of well-rounded pebbles and boulders of basalt lava and gneiss in a matrix of hyaloclastite, lava fragments, decomposed gneiss and coal. Stordal; location in Fig. 183 at $33.6 \mathrm{~km}(\mathrm{Cgl})$. Length of pencil $15 \mathrm{~cm}$.

Fig. 80. Subaerial lava flows of the Stordal unit (421 La) covered by two large subaqueous lava flows of the Qordlortorssuaq Member (440 sl). There is no sediment between the two units at this locality. The unit 440 lava flows are covered by about $50 \mathrm{~m}$ of foreset-bedded hyaloclastite of the Ordlingassoq Member (450 hy). In the higher lava succession an orange brown unit of crustally contaminated lavas (unit $451 \mathrm{La}$ ) is seen. North wall of Stordal, Central Disko section at $33.2 \mathrm{~km}$ (Fig. 183). Photo: Finn Ulff-Møller.
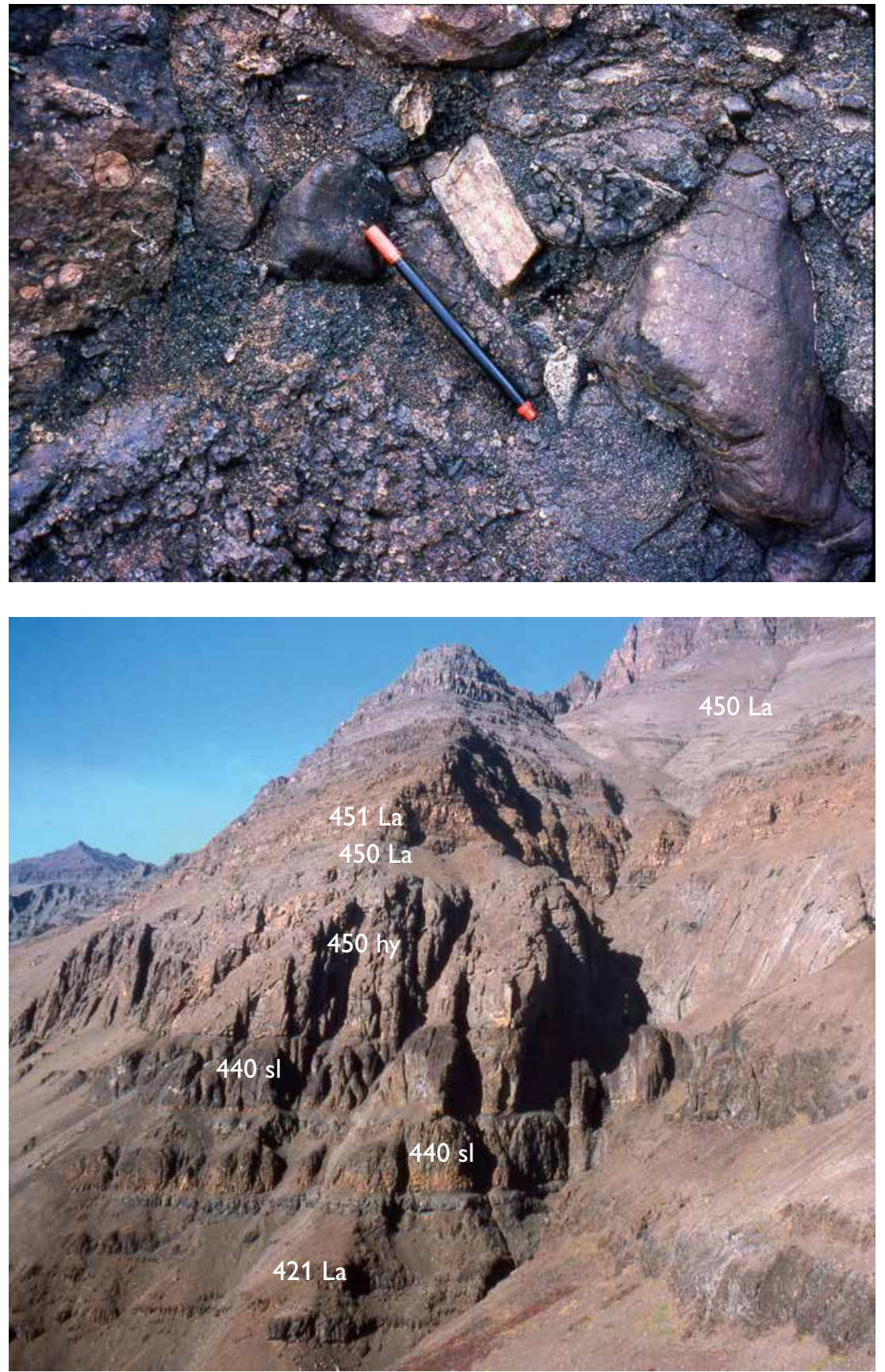

western hill of the Disko Gneiss Ridge, but some flows travelled $3 \mathrm{~km}$ farther eastwards and entered a palaeovalley in the hilly landscape, where they reached a combined maximum thickness of $60 \mathrm{~m}$ before they were stopped by the next hill.

This unit was also sampled by Lightfoot et al. (1997) in their profile D-91-02 (their samples 7759, 7760).

Boundaries. West of the central neck, unit 421 overlies lava flows of unit 423 but there are only few exposures of the lower boundary. The upper boundary is well ex- posed for $2.5 \mathrm{~km}$ on the upper slope of Ametystskrænten where the dark lava flows that form the upper surface of the shield volcano are onlapped by thin grey-weathering picrite flows of unit 423 (Fig. 78) with a distinct, lowangular unconformity of $c .2^{\circ}$. The picrite flows of unit 423 did not cover the highest parts of the volcano, and an erosion-resistant flow of feldspar-phyric basalt of the following Qordlortorssuaq Member (unit 440) overlies the picrites of unit 423 and also directly covers the top of the volcanic edifice. 
East of the central neck where the flows of unit 421 onlap the Disko Gneiss Ridge, the easternmost exposure of the contact has been studied (at $33.5 \mathrm{~km}$ in the Central Disko section, see also Fig. 183). Here more than $6 \mathrm{~m}$ of locally derived sandstones with rounded gneiss clasts and thin beds of mudstone and lignite lie on top of the Precambrian gneiss. Two dark grey- to black-weathering lava flows of unit 421 , in total about $10-15 \mathrm{~m}$ thick, overlie the sediments and are themselves covered by $10 \mathrm{~cm}$ of claystone and about $4 \mathrm{~m}$ of locally derived sediment, perhaps a debris flow, with metre-sized rounded gneiss clasts and up to $0.5 \mathrm{~m}$ large, rounded lava clasts in a matrix of decomposed gneiss and lava clasts (Fig. 79). The upper sediment must have formed contemporaneously with the volcanism that formed the unit 423 picrite flows on the western flank of the volcano. The sediment is covered by strongly columnar-jointed flows of the Qordlortorssuaq Member which have ponded in a small wet basin (Fig. 80).

\section{Tunorsuaq $b$ : Enriched contaminated basalts above the Saviaqqat level (unit 425)}

This is a small local unit in the Tunorsuaq area on northern Nuussuaq, embedded in unit 423 (Fig. 49). In the Tunorsuaq profile (Fig. 14, profile 12) it consists of $c .25$ $\mathrm{m}$ of thin, brownish pahoehoe lava flows of basalt with $c$. $8 \mathrm{wt} \% \mathrm{MgO}$. The underlying picrite lava flow is heavily red-oxidised at the top and overlain by $c .10 \mathrm{~cm}$ of brickred laterite. The Tunorsuaq $b$ unit is overlain by a thick picrite flow with no sediment in between.

This unit was sampled by Lightfoot et al. (1997) in their section N91-10 (their sample 7860) c. $8 \mathrm{~km}$ east of our Tunorsuaq profile.

\section{Ukallit unit (unit 426)}

This is a small unit, embedded in unit 423, of distinctly contaminated basalt with c. $10 \mathrm{wt} \% \mathrm{MgO}$ and $51 \mathrm{wt} \%$ $\mathrm{SiO}_{2}$ that is only known from two localities on western Nuussuaq. On the eastern corner of the mouth of the Qunnilik valley (Fig. 13, profile 10), the unit consists of four flows of brown vesicular olivine-phyric basalt, separated from the surrounding grey picrites of unit 423 by distinct red laterite horizons. It can be followed eastwards for less than $1 \mathrm{~km}$. However, a laterally extensive flow with identical lithology and chemical composition, and red soil at the base, is well exposed at the same stratigraphic level in the Qilakitsoq valley $9 \mathrm{~km}$ east of the Ukallit occurrence. It is probable that the unit has a wider occurrence in the Qunnilik-Qilakitsoq area and flowed around the edifice of the Ilugissoq volcano. 


\section{Nuusap Qaqqarsua Member}

\section{Summary of the main features of the Nuusap Qaqqarsua Member}

- A succession of yellowish brown lava flows and hyaloclastites prograding eastwards.

- Excellent marker horizon due to the brown colour.

- Oldest exposed unit of the Vaigat Formation on Disko.

- Normally magnetised (C27n).

- Crustally contaminated picrite and olivine-phyric basalt lava flows and hyaloclastites. No crustal xenoliths are found. No eruption sites are known.

- Contains an excellent exposure of a palaeo-sea cliff and associated submarine talus fan.

- Economic geology: Migrated oil of the Kuugannguaq type was found in this member on Disko.

\section{Lithostratigraphy of the Nuusap Qaqqarsua Member}

New member

History. The name Nuusap Qaqqarsua Member was introduced, with the same meaning as here, in the South Nuussuaq section (Pedersen et al. 1993, unit b). It has subsequently been used in the Central Nuussuaq section (Pedersen et al. 2002a) and in research articles by Pedersen et al. (2002b) and Larsen \& Pedersen (2009).

Name. After the mountain Nuusap Qaqqarsua (1232 m) on south-western Nuussuaq, overlooking the Vaigat strait (Fig. 18).

Distribution. The Nuusap Qaqqarsua Member is exposed within a 5-7 km wide belt that extends south-north for $30 \mathrm{~km}$ from the eastern mouth of the Kuugannguaq valley on Disko northwards through Nuusap Qaqqarsua to west of the Qunnilik valley on Nuussuaq (Fig. 10). Its total present areal coverage is $c .180 \mathrm{~km}^{2}$ but the original coverage was minimum $300 \mathrm{~km}^{2}$. Its western limit on Nuussuaq is in lava facies and is erosional, whereas the eastern and southern limits are in hyaloclastite facies and are depositional. The northern extension is poorly delimited.

Type section. Nuusap Qaqqarsua (Fig. 13, profile 8; South Nuussuaq section at 2-4 km; Fig. 54). Location in Fig. 5.
Reference sections. Qunnilik west on central western Nuussuaq (Fig. 13, profile 9; Central Nuussuaq section at 9-10 km); Kuugannguup Innartaa on northern Disko (Fig. 16, profile 23). Locations in Fig. 5.

(5) Thickness. Lava facies 20-60 m thick; hyaloclastite facies up to $400 \mathrm{~m}$ at Nuusap Qaqqarsua.

Lithology. Crustally contaminated picrites and olivinephyric basalts of brown to yellowish-brown colour. Hyaloclastites are capped by the associated subaerial lava flows. A very coarse submarine talus fan was deposited on a sloping foreset front below a sea cliff during a period when the lava front was being eroded by the sea.

Boundaries. The member conformably overlies the grey picrites of Naujánguit Member unit 409. Due to the eastward progradation, hyaloclastites of the member also overlie the sediments in the Nuussuaq Basin, but no contacts are exposed. The member is conformably overlain by the picrites of Naujánguit Member unit 413 .

Age. Paleocene, nannoplankton zone NP4, 62.5-62.2 $\mathrm{Ma}$, magnetochron $\mathrm{C} 27 \mathrm{n}$, based on the biostratigraphic age of the Eqalulik Formation (Nøhr-Hansen et al. 2002), on radiometric dating of the overlying parts of the Vaigat Formation (Storey et al. 1998), and the normally magnetised character of the lava flows (Riisager \& Abrahamsen 1999).

\section{Geology of the Nuusap Qaqqarsua Member (unit 412)}

The Nuusap Qaqqarsua Member is the oldest volcanic unit exposed on Disko and is seen there only in a 3 $\mathrm{km}$ long coastal section from the entrance of the Kuugannguaq valley and eastwards to Naajannguit (Pedersen et al. 2002b, fig. 5A). On Nuussuaq, it is excellently exposed on the steep mountain sides bordering the Vaigat strait and the Aaffarsuaq valley, as shown on the South Nuussuaq and Central Nuussuaq geological sections.

Migrated oil of the Kuugannguaq type was found in hyaloclastites in this member at the entrance of the Kuugannguaq valley (Bojesen-Koefoed et al. 1999). 
Lithologies. The Nuusap Qaqqarsua Member is composed of brown lava flows and hyaloclastites of olivine microphyric picrites with $12-15 \mathrm{wt} \% \mathrm{MgO}$ and a few basalts with $8-10 \mathrm{wt} \% \mathrm{MgO}$. The rocks have increased silica contents (49-53 wt\% $\mathrm{SiO} 2$ ) and are distinctly contaminated by reaction with the continental crust (Larsen \& Pedersen 2009), but no xenoliths or xenocrysts of crustal origin have been found.

Lithologies on Disko are solely hyaloclastites (Pedersen 1985a, fig. 4, profile 3).

The best exposures of the relations between lava flows and hyaloclastites are found near the type section, the steep, south-exposed wall of the mountain Nuusap Qaqqarsua on western Nuussuaq. The lava flows form a succession of many thin pahoehoe flows with a mean flow thickness of less than $2 \mathrm{~m}$. The flow succession is very monotonous and it has not been possible to recognise the number or size of individual flow fields. The flows must have been erupted within a few kilometres of Nuusap Qaqqarsua, but eruption sites are not known.

Volcanic history. During the deposition of the member the volcanic front prograded $2-4 \mathrm{~km}$ eastwards, but with oscillations caused by synvolcanic vertical movements (Pedersen et al. 2002b). Two main stages in the deposition can be recognised, which were sufficiently separated in time to allow for the development of a steep sea cliff in the pause.

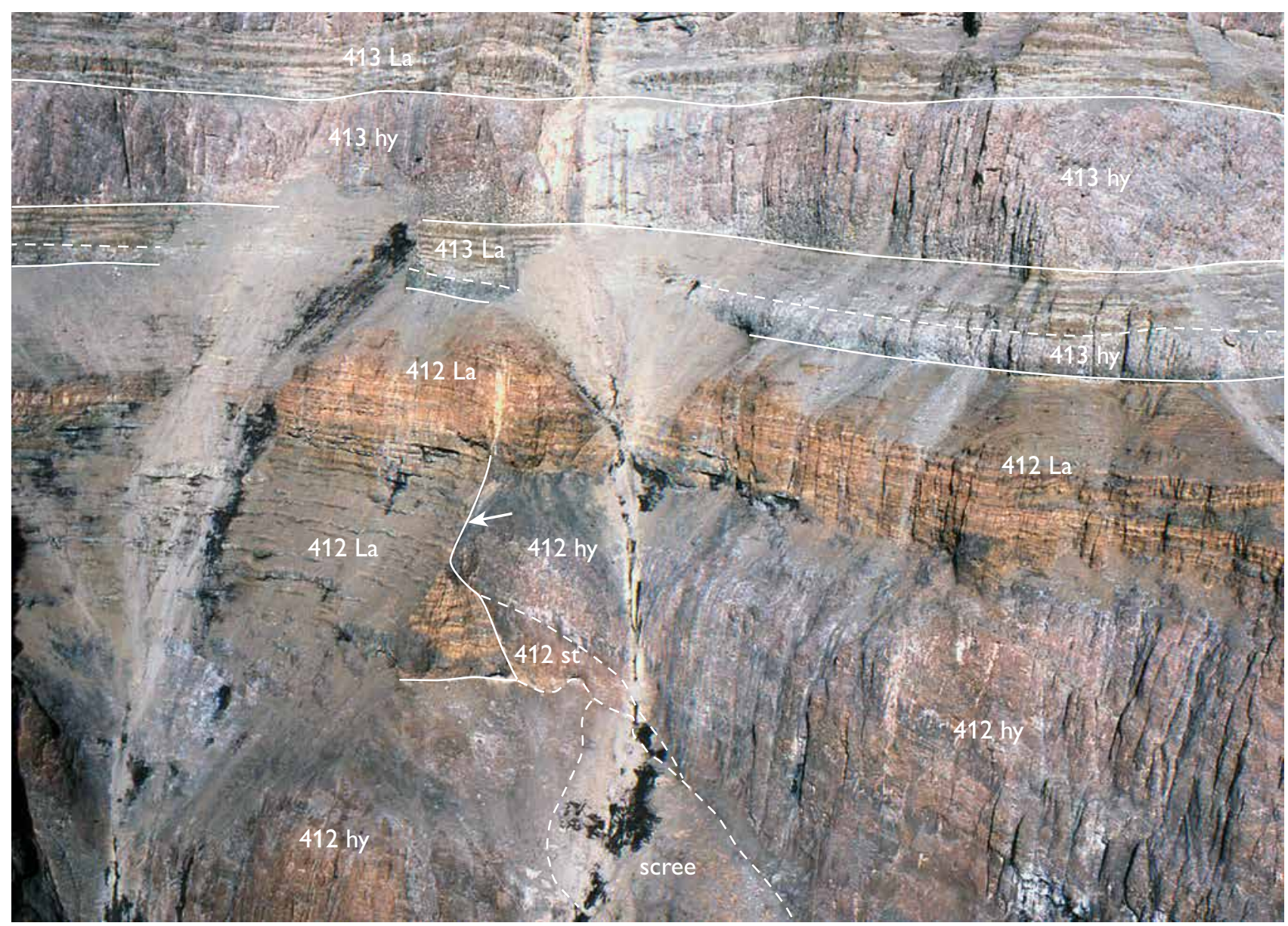

Fig. 81. Palaeo-cliff in the Nuusap Qaqqarsua Member. Subaerial lava flows of the Nuusap Qaqqarsua Member (412 La) were eroded by the contemporaneous sea to form a $40 \mathrm{~m}$ high palaeo-coastal cliff (at arrow). At the foot of the cliff a prominent light brown submarine talus fan (412 st) leads downslope. Subsequent foreset-bedded hyaloclastites (412 hy) are banked up against the cliff, and still younger subaerial lava flows ( $412 \mathrm{La}$ ) pass undisturbed over it. The Nuusap Qaqqarsua Member flows are overlain by the Naujánguit Member unit 413 consisting of a succession of alternating subaerial lavas $(413 \mathrm{La})$ and hyaloclastites ( $413 \mathrm{hy}$ ) which indicates a balance between volcanic aggradation and basin subsidence. South coast of Nuussuaq (South Nuussuaq section at $3.7 \mathrm{~km}$ ). The locality was described by Pedersen $e$ t al. 2002b, figs 7, 8; see also Figs 54, 82, 83 . 
Fig. 82. The submarine talus deposit leading downslope from the palaeo-cliff (arrow at left) shown in Fig. 81. The deposit is enclosed within dark brown, foreset-bedded hyaloclastites of the Nuusap Qaqqarsua Member (412 hy) and is $33 \mathrm{~m}$ thick in its lowermost part. Note that the talus deposit has eroded the underlying hyaloclastites (arrow at its base). The light yellowish brown colour of the talus deposit is due to penecontemporaneous hydrothermal alteration and weathering.

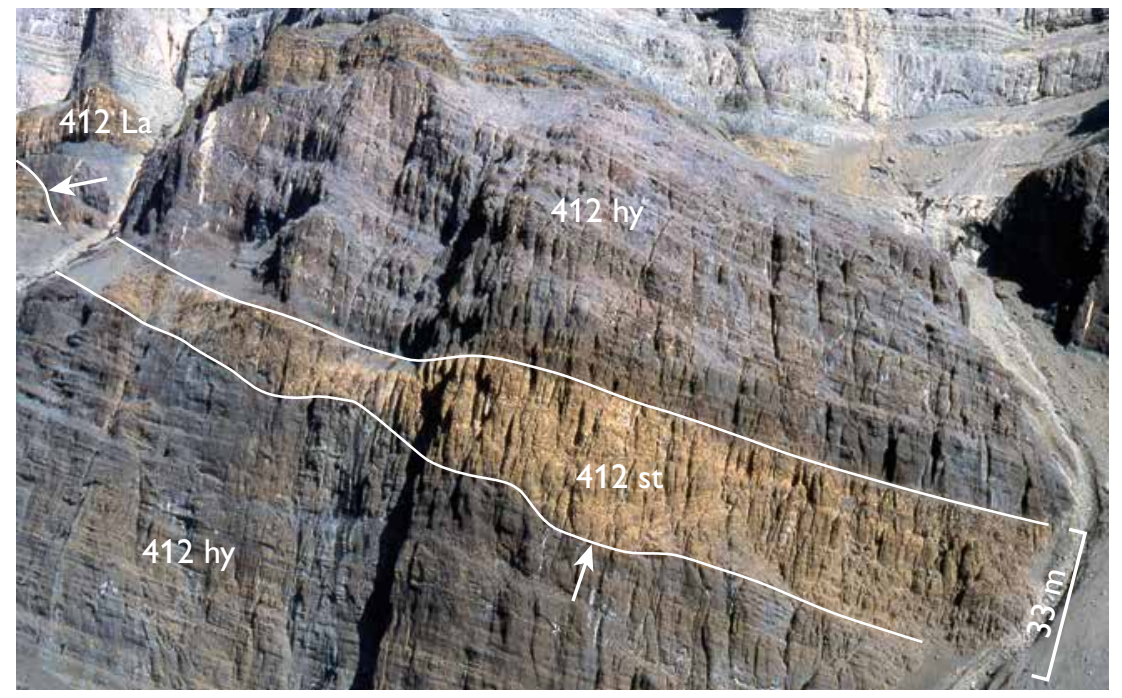

Fig. 83. Talus foot. Detail of the lower part of the submarine talus deposit shown in Fig. 82, at about $160 \mathrm{~m}$ below the palaeo-sea surface.

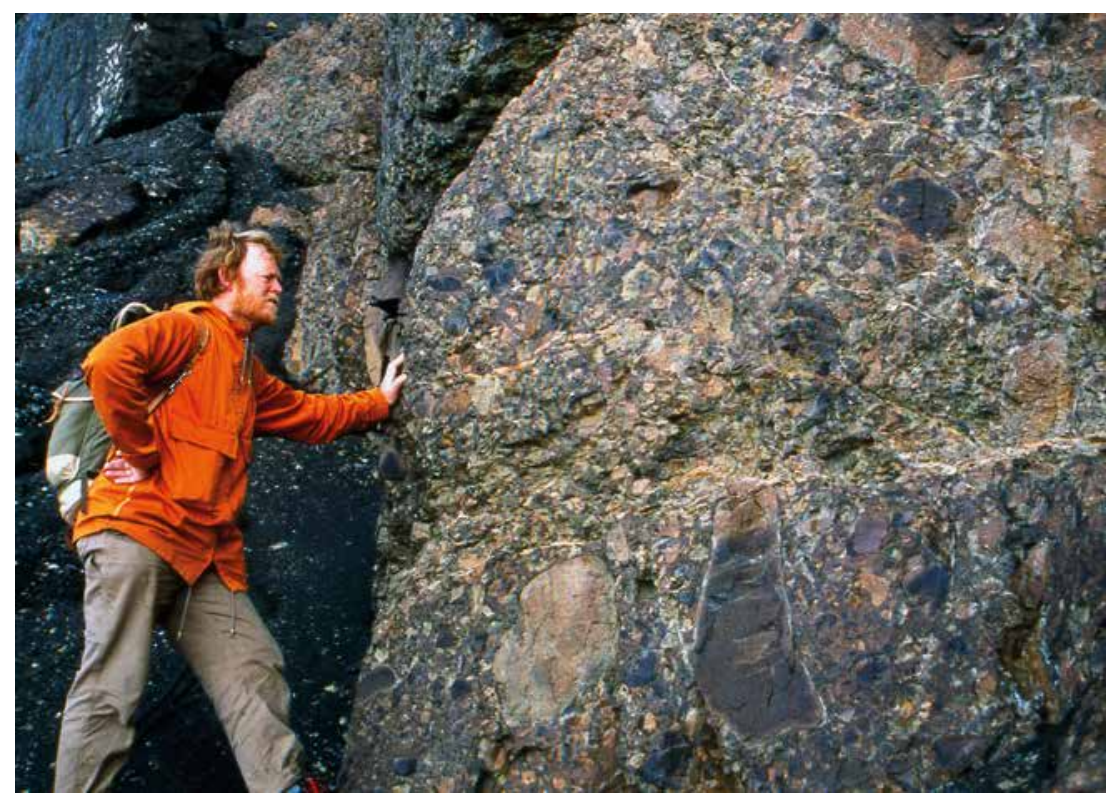

Pre-cliff lava flows and hyaloclastites. At least $40 \mathrm{~m}$ of pahoehoe lava flows ( $>24$ lava sheets) were emplaced at this stage. Eastwards, the flows transform into foresetbedded hyaloclastites indicating flow from the west into a marine embayment about $150 \mathrm{~m}$ deep in the western part and at least $320 \mathrm{~m}$ deep farther east. The succession records a progradation of the lava plateau by $>3 \mathrm{~km}$ towards the east. Within the lower part of the dark brown hyaloclastites, at $500 \mathrm{~m}$ altitude on the western shoulder of Nuusap Qaqqarsua, is exposed a lenticular body of bright orange hyaloclastite which is hydrothermally altered and shows marked Ni-enrichment (Pedersen $e t$ al. 2008). This could mark the site of a hot submarine spring.
Cliff formation. A section through a $40 \mathrm{~m}$ high, steep coastal cliff is seen in the south wall of Nuusap Qaqqarsua (Figs 54, 81; Pedersen et al. 2002b, fig. 7). Extending from the cliff foot, a prominent up to $40 \mathrm{~m}$ thick, light brown layer can be followed for $800 \mathrm{~m}$ down the palaeo-slope, recording a sea depth of more than 200 $\mathrm{m}$. The layer is easily distinguishable against the dark brown foreset-bedded hyaloclastites below and above it (Fig. 82). This layer is a submarine talus deposit from the cliff, a matrix-supported conglomerate composed of up to $50 \mathrm{~cm}$ large, rounded to sharp-edged clasts of subaerial lava, which are commonly strongly vesiculated, and smaller clasts of pillow fragments (Fig. 83). The matrix is a mixture of hyaloclastite sand and gravel derived from the cliff. The layer, which had a relatively high porosity, is 


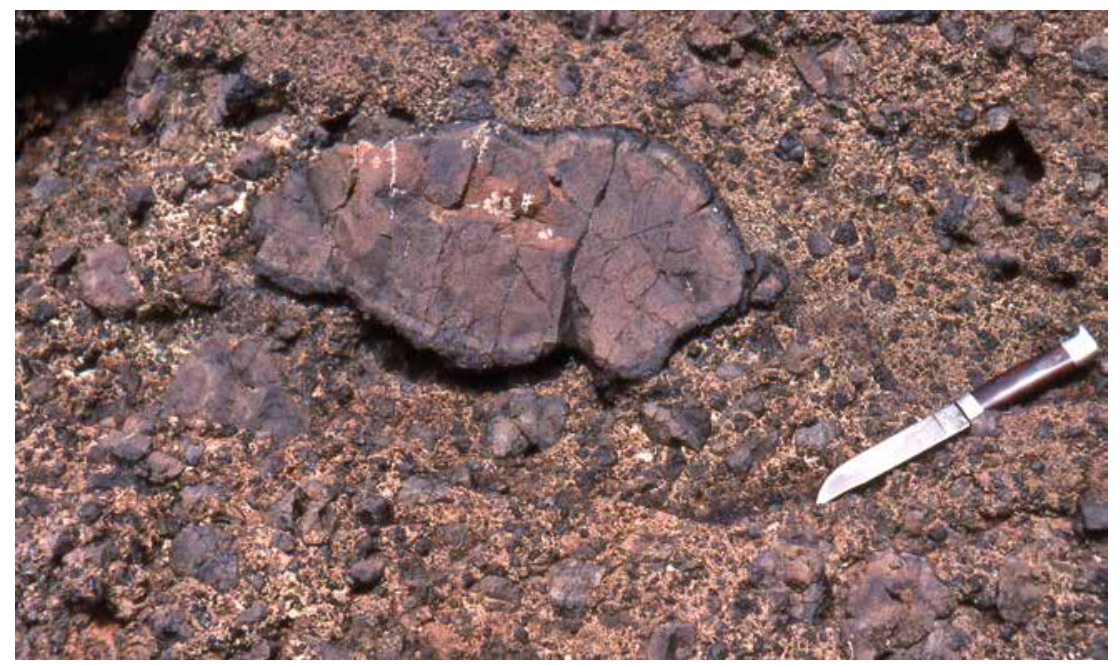

Fig. 84. Typical hyaloclastite the Nuusap Qaqqarsua Member with a single pillow and many small clasts of pillow fragments and glass. Length of knife $23 \mathrm{~cm}$. North wall of Aaffarsuaq valley, Central Nuussuaq section at $c .12 \mathrm{~km}$.

extensively metasomatised by iron-bearing carbonate and silica. Within the layer at least four individual zones rich in coarse clasts are separated by zones of finer-grained hyaloclastite, recording individual down-slope mass-flow events. These mass flows were highly erosive and excavated channels into the underlying hyaloclastite (Fig. 82). The surface of the talus layer has a slope parallel to the slope of the overlying ordinary, dark brown hyaloclastites from the post-cliff stage.
Post-cliff lava flows and hyaloclastites. The uppermost $20 \mathrm{~m}$ of the lava succession of the Nuusap Qaqqarsua Member are of post-cliff age but are not physically different from the thin sheet flows of pre-cliff age (Fig. 81). The sea level had risen $c .40 \mathrm{~m}$, and the new lavas met the sea at the submerged cliff and continued seawards to form a regular foreset-bedded hyaloclastite until the last flow entered the sea $c .1 .3 \mathrm{~km}$ east of the cliff. A typical hyaloclastite (Fig. 84) contains scattered pillows up to several decimetres large, smaller pillow fragments and centimetre- to millimetre-sized glass clasts in a finer matrix. 


\section{Nuuk Killeq Member}

\section{Summary of the main features of the Nuuk Killeq Member}

- A succession of distinct brown lava flows and hyaloclastites prograding eastwards. Spectacular exposure of high foresets at the type locality.

- Excellent and widespread marker horizon due to the brown colour.

- Oldest reversely magnetised succession in the Vaigat Formation (C26r).

- Crustally contaminated olivine-plagioclase-phyric basalt lava flows and hyaloclastites. Xenoliths of sandstone and mudstone. First occurrences of orthopyroxene.

- Individual flow groups indicate intermittent eruptions.

- Magmas evolved in separate magma chambers within sediments of the Nuussuaq Basin.

- Large submarine eruption sites are known.

\section{Lithostratigraphy of the Nuuk Killeq Member}

New member

History. The name Nuuk Killeq Member was introduced, with the same meaning as here, in the South Nuussuaq section (Pedersen et al. 1993, unit d). It has subsequently been used in the Central Nuussuaq section (Pedersen $e t$ al. 2002a, unit d) and in a number of research articles (Riisager \& Abrahamsen 1999; Pedersen et al. 2002b; Larsen \& Pedersen 2009).

Name. After the point Nuuk Killeq on the Vaigat coast of Nuussuaq.

Distribution. On Disko the Nuuk Killeq Member is present in lava facies for more than $22 \mathrm{~km}$ along the north coast from Serfarsuit in the west to Naajannguit where it dies out. On Nuussuaq it is present in a $c .14 \mathrm{~km}$ wide stretch between Nuusap Qaqqarsua and Nuuk Killeq on the Vaigat coast and between Qunnileeraq and Ilugissoq on the north side of the Aaffarsuaq valley; it extends northwards for at least $35 \mathrm{~km}$ from the south coast to Sorluut and Arnold Heim Dal (Fig. 10). It is not present at the north coast of Nuussuaq where the lavas of unit 416 occur at about the same stratigraphic level. Its western limit is in lava facies and is erosional, whereas its eastern limit is depositional and is the end of a tapering hyaloclastite fan. Its northern and southern extensions are poorly delimited.

Type locality. The steep mountain wall facing the Vaigat strait just west of Nuuk Killeq (South Nuussuaq section at $12-17 \mathrm{~km}$; Fig. 85$)$.

Reference sections. Nuusap Qaqqarsua, Qunnilik west, Ukallit and Sorluut on Nuussuaq (Fig. 13, profiles 8-10; Fig. 14, profile 11); Kuugannuaq west side and Kuugannguup Innartaa on northern Disko (Fig. 16, profiles 21, 22). Locations in Fig. 5.

Thickness. In subaerial lava facies the member is $30-50$ $\mathrm{m}$ thick, whereas in hyaloclastite facies thicknesses are up to $600 \mathrm{~m}$.

Lithology. Brown, crustally contaminated olivine-plagioclase-phyric basalt lava flows and hyaloclastites. Lava flows dominate in the west and south, whereas foresetbedded hyaloclastite fans dominate in the east. In some areas the member is intercalated with a few grey picrite lava flows. Subaqueous eruption sites are known from near Ukallit on western Nuussuaq. The oldest known xenoliths of sandstone and mudstone are found in this member.

Boundaries. The Nuuk Killeq Member lies conformably on the grey picrite lavas and hyaloclastites of Naujánguit Member unit 413. A 5-20 cm thick red soil horizon at the boundary indicates a lull in the volcanic activity, estimated from facies analysis to a duration of $c .0 .5 \mathrm{ka}$ (Pedersen et al. 2002b).

The member is conformably overlain by the grey picrite lavas and hyaloclastites of Naujánguit Member unit 417. The top of the uppermost lava flow is highly oxidised and is covered by up to $15 \mathrm{~cm}$ of brick-red lateritic sediment.

Age. Paleocene, nannoplankton zone NP4, c. $62 \mathrm{Ma}$, lowest magnetochron $\mathrm{C} 26 \mathrm{r}$, based on the biostratigraphic age of the Eqalulik Formation (Nøhr-Hansen et al. 2002), on radiometric dating of the member itself (Storey et al. 1998, sample 402525), and on the reversely 


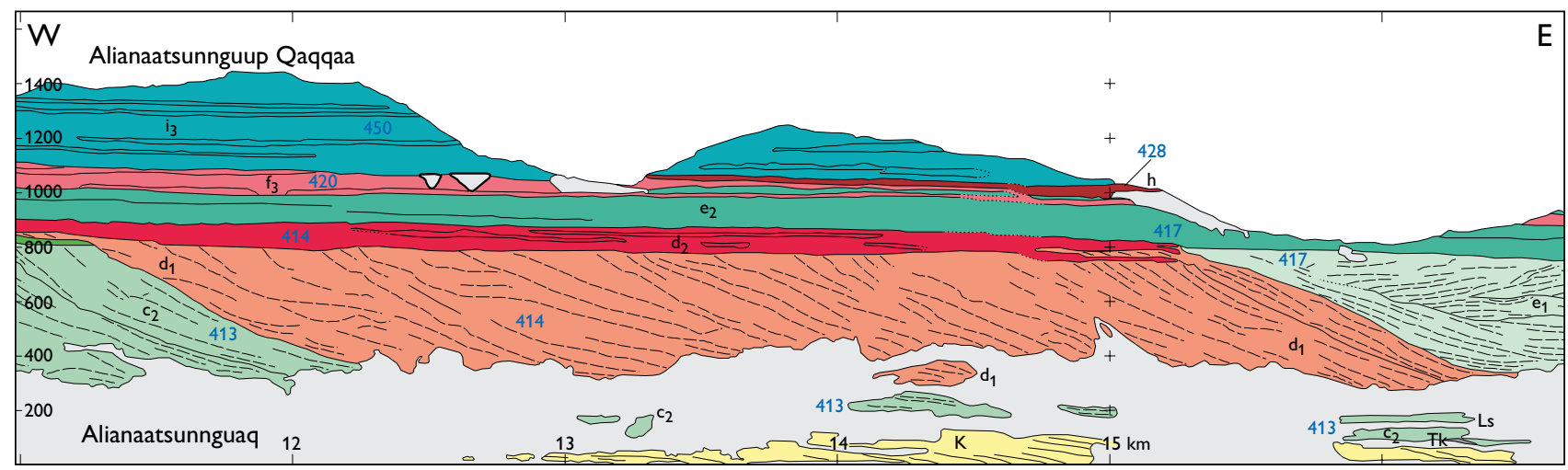

Fig. 85. Photogrammetrically measured cliff face at the south coast of Nuussuaq between Alianaatsunnguaq and Nuuk Killeq, the type area for the Nuuk Killeq Member (unit 414) which is present in both subaerial facies (dark orange) and submarine facies (light orange). Blue numbers are unit codes; other unit annotations are from the original. Excerpt from the South Nuussuaq section at 11-16.7 km (Pedersen et al. 1993).

magnetised character of the lava flows which lie immediately above transitionally magnetised flows that mark the end of C27n (Riisager \& Abrahamsen 1999; Fig. 49). According to the Geological Time Scale 2012 the age of the $\mathrm{C} 27 \mathrm{n}$ to $\mathrm{C} 26 \mathrm{r}$ transition is $62.2 \mathrm{Ma}$.

\section{Geology of the Nuuk Killeq Member (unit 414)}

The Nuuk Killeq Member is one of the large contaminated units in the Vaigat Formation and originally covered a minimum area of $1500 \mathrm{~km}^{2}$ on Disko and Nuussuaq (Fig. 10) with a volume around $180 \mathrm{~km}^{3}$ (see also Table 8). Due to its distinct brown weathering colours the Nuuk Killeq Member forms a prominent marker horizon throughout its extent. The rocks contain 7.5-11 wt $\% \mathrm{MgO}$ and 50-53 wt $\% \mathrm{SiO}_{2}$ and are distinctly crustally contaminated.

Petrography. The rocks of the Nuuk Killeq Member are generally brown, olivine and olivine-plagioclase microphyric basalts with traces of chromite; there are, however, significant regional variations in petrography (Fig. 86). On Disko several lava flows carry microphenocrysts of orthopyroxene in addition to olivine and plagioclase, and several of these flows also contain up to $5 \mathrm{~cm}$ xenoliths of sandstone and magma-modified graphitic mudstone. On Nuussuaq lava flows at Nuusap Qaqqarsua and a feeder dyke and lavas and hyaloclastite in the Aaffarsuaq valley carry glomerocrysts of augite in addition to olivine and plagioclase. At the easternmost extent of the member along Vaigat and in Aaffarsuaq, the hyaloclastites have only olivine and plagioclase or olivine alone as phenocryst phases. The lava flows from the western part

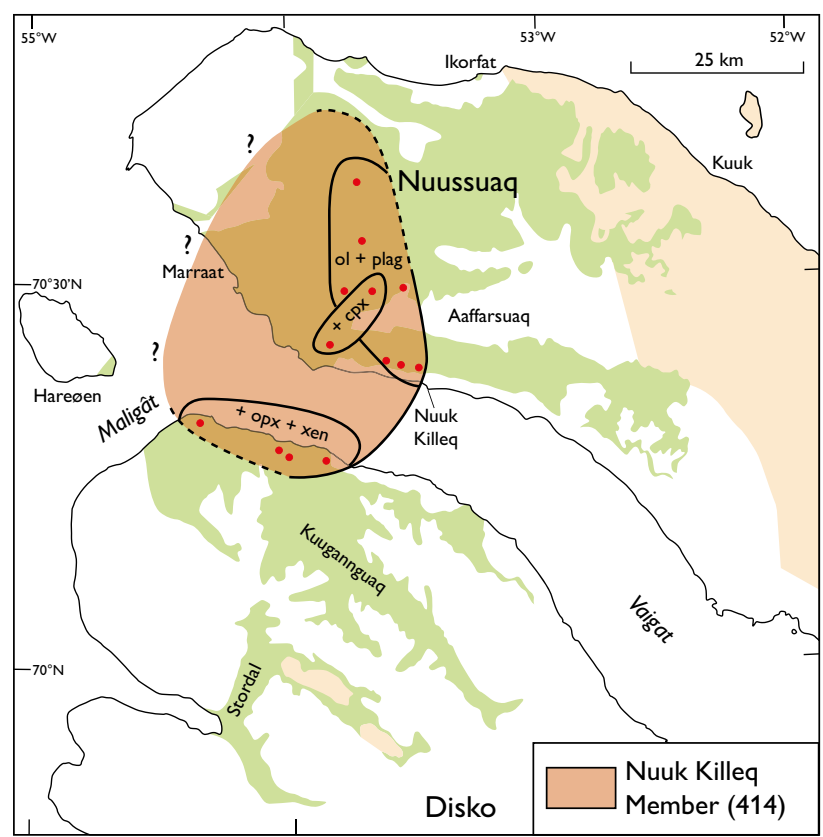

Fig. 86. Known distribution of three different petrographic types of the Nuuk Killeq Member basalts. The basic type has microphenocrysts of olivine (ol) and plagioclase (plag); in addition to these phases, the basalts in a small area on Nuussuaq also have augite (cpx) glomerocrysts, and on Disko, the basalts have orthopyroxene (opx) and sediment xenoliths (xen) besides olivine and plagioclase.

of Qunnilik to Sorluut are either aphyric or carry olivine and plagioclase phenocrysts. These regional variations indicate that the Nuuk Killeq Member magmas evolved in individual, high-level magma chambers of which at least the one erupting on Disko resided within clastic sediments. 


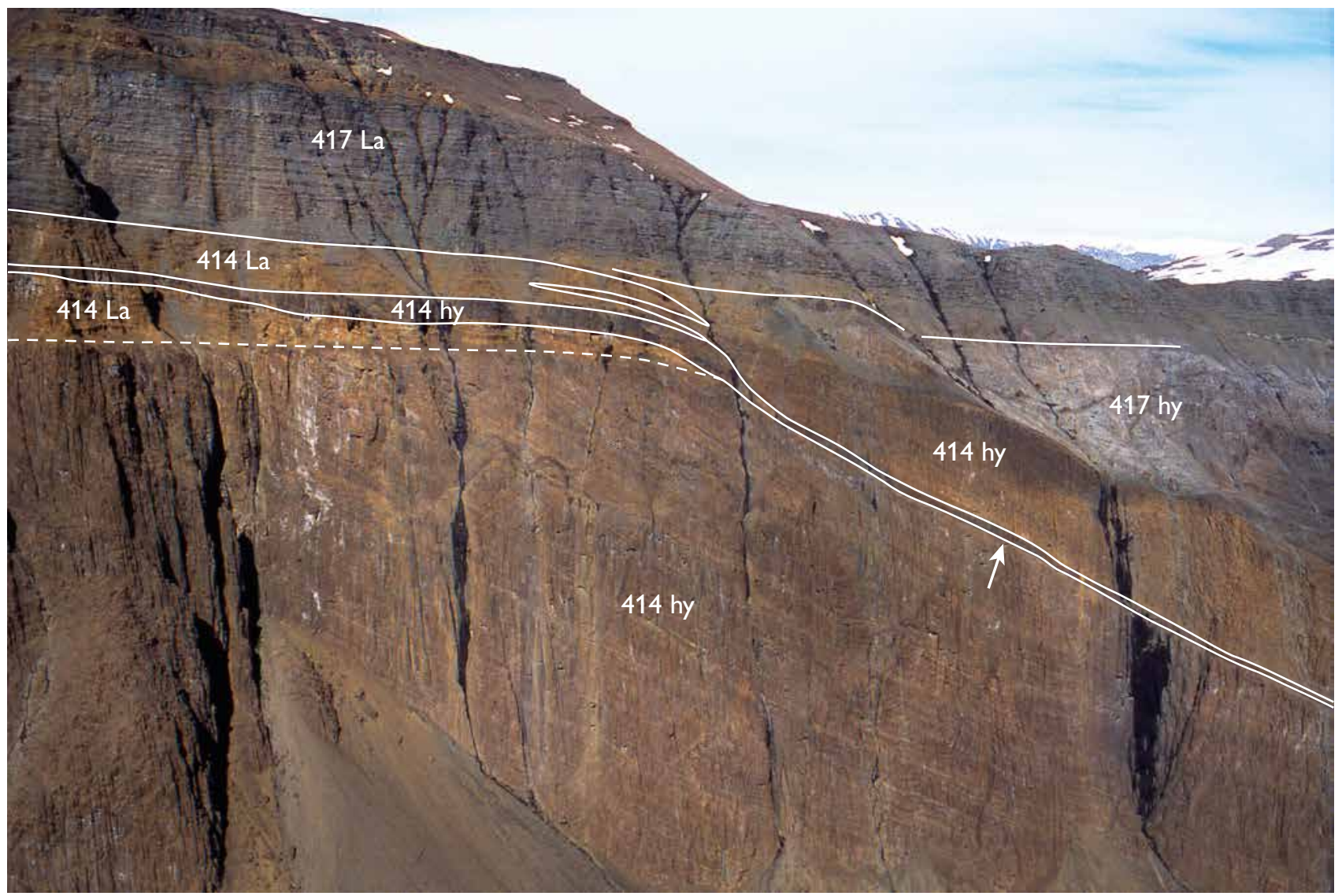

Fig. 87. Brown lava flows of the Nuuk Killeq Member ( $414 \mathrm{La})$ entering the marine embayment to form brown foreset-bedded hyaloclastites (414 hy). Three minor upper hyaloclastite horizons merge with the main horizon, indicating that several flow groups separated in time entered the sea while the basin was continuously subsiding. The arrow points to a very dark brown hyaloclastite horizon (outlined) that can be followed from the palaeo-shore to the basin floor (Figs 88, 89). The lava flows and hyaloclastites of the Nuuk Killeq Member are covered by grey picrite flows and hyaloclastites of Naujánguit Member unit 417. South coast of Nuussuaq at around $15 \mathrm{~km}$ on the South Nuussuaq section (Fig. 85), c. 400-1150 m a.s.l.

Carbonate is widespread as a hydrothermal phase, and weathering of the siderite component of the carbonate probably accounts for the rusty brown weathering colour of the rocks. Other secondary minerals such as quartz and agate form frequent vesicle fillings.

Lithologies and volcanic history. The Nuuk Killeq Member comprises a succession of pahoehoe lava flows up to $50 \mathrm{~m}$ thick and composed of up to 25 flow tongues, foreset-bedded hyaloclastites up to $600 \mathrm{~m}$ thick, and some more complex deposits of pyroclastics and lava mounds at submarine eruption sites.

The deposition of the member continued the previously established eastward progradation into the marine embayment and pushed the volcanic front $4-5 \mathrm{~km}$ eastwards. The steep mountain wall facing the Vaigat coast on Nuussuaq near Nuuk Killeq provides excellent exposures of lava flows of the Nuuk Killeq Member entering the sea to form a lava delta (Fig. 85). This locality is designated type locality for the member and has been illustrated by Henderson (1973, fig. 4), Clarke \& Pedersen (1976, fig. 326) and Henderson et al. (1981, fig. 6). Details of the type locality are shown in Figs 87-89.

Eruption of the member occurred intermittently. At sites with excellent exposures at least four to five lava flow groups can be recognised, separated by oxidised flow tops and in places reddish soil or tuff, e.g. at Sorluut (Fig. 90). In the vertical wall at Nuuk Killeq where the youngest of the Nuuk Killeq Member lava flows entered the marine embayment, at least four flow groups can be recognised which were sufficiently spaced in time to allow basin subsidence to influence the shore position between eruptions, resulting in a succession of alternating lava flows and hyaloclastites (Fig. 87). Several stages of infilling of 


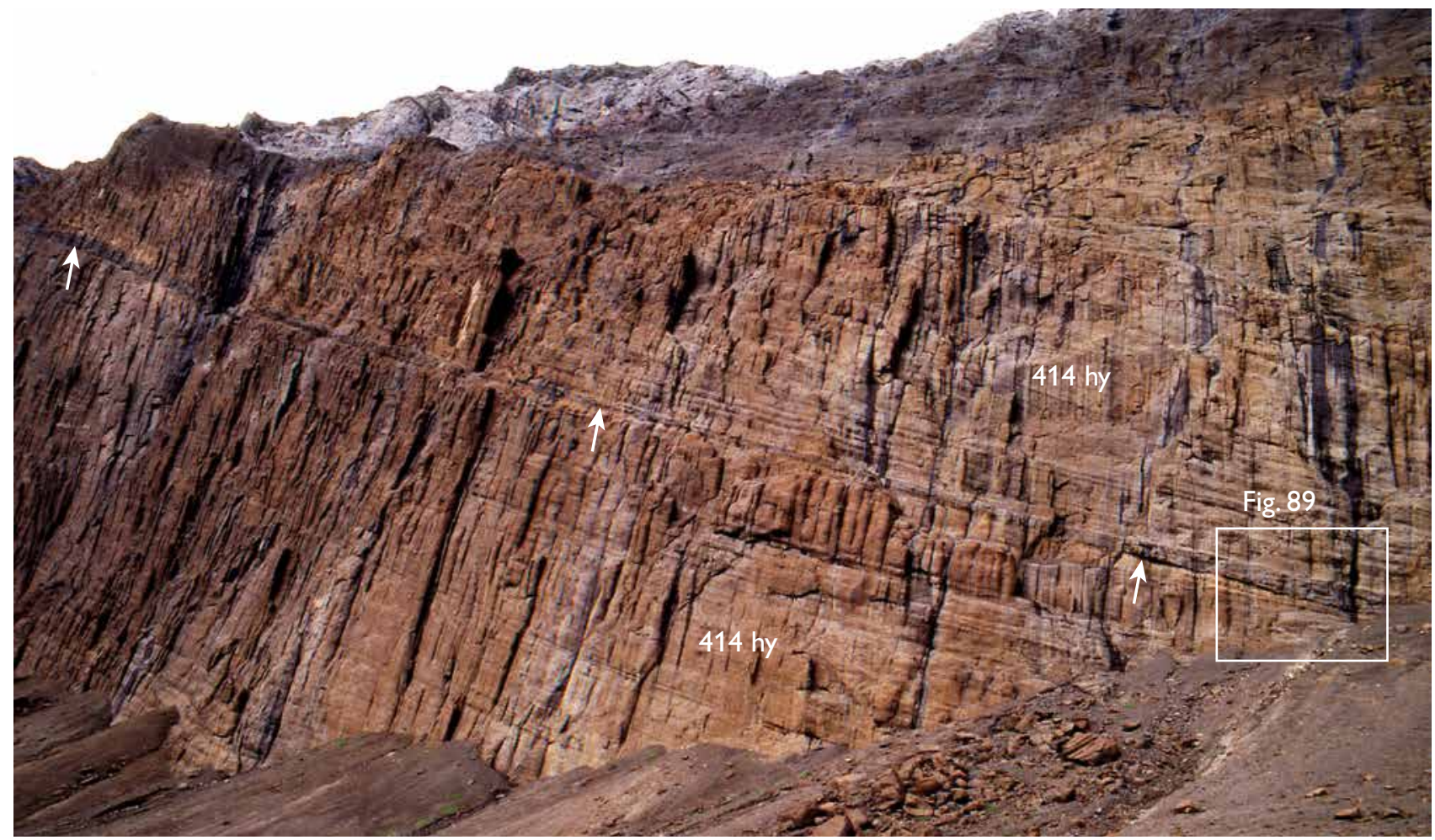

Fig. 88. The $c .500 \mathrm{~m}$ high vertical cliff of brown foreset-bedded hyaloclastites of the Nuuk Killeq Member seen from below. Arrows point to an individual thin, dark brown hyaloclastite horizon that is also outlined in Figs 87 and 89. The position of Fig. 89 is indicated with a white frame. South coast of Nuussuaq at $15-16.2 \mathrm{~km}$ on the South Nuussuaq section (Fig. 85).

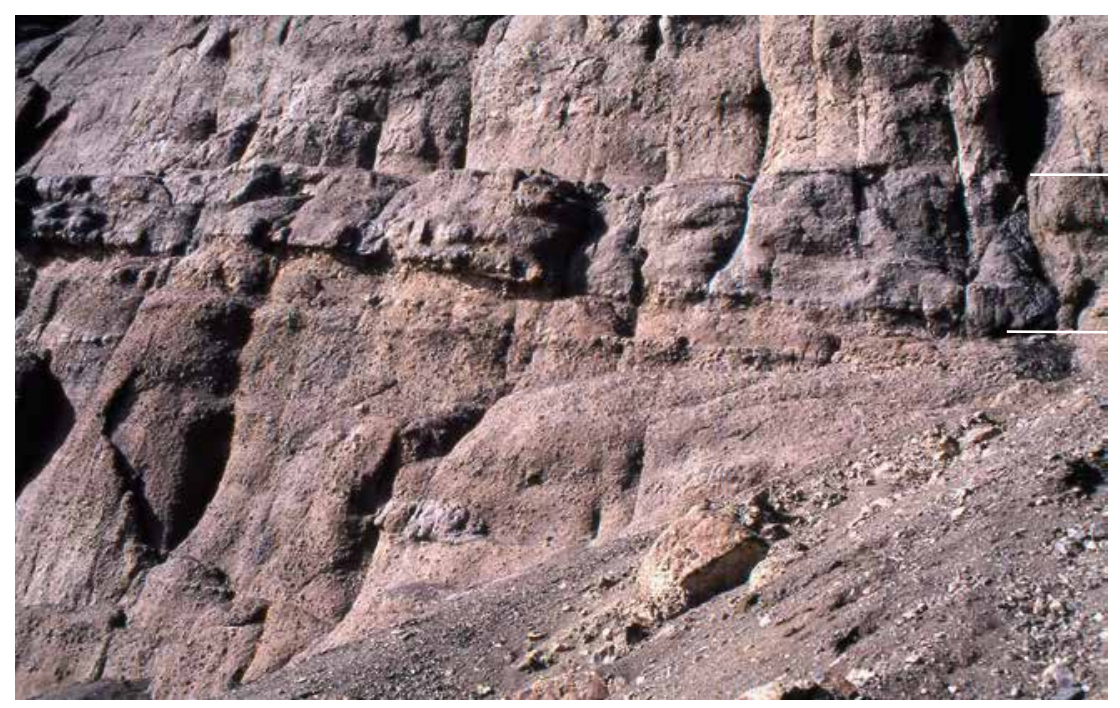

Fig. 89. Brown hyaloclastites of the Nuuk Killeq Member about $480 \mathrm{~m}$ below the palaeoshore. The dark brown hyaloclastite horizon is up to $4 \mathrm{~m}$ thick (boundaries indicated at right margin); the dark colour is presumably caused by an unusually high proportion of glass. The position of the photo is outlined in Fig. 88. South coast of Nuussuaq at $16.2 \mathrm{~km}$ on the South Nuussuaq section.

the basin are also recorded in the Qunnilik valley (Fig. 91). On both Disko and Nuussuaq the light brown lavas of the member in places contain an intercalation of grey picrite flows, indicating contemporaneous eruption of uncontaminated and contaminated magmas (Fig. 13, profile 9; Fig. 91).
A temporary interruption of the volcanic activity at the final stage of deposition of the Nuuk Killeq Member is also indicated by the latest and easternmost occurrence in the Aaffarsuaq valley area. A $4.8 \mathrm{~m}$ thick tuffaceous layer with embedded corals occurring within mudstones in 'Koralravine' on the eastern side of the Ilugissoq valley 


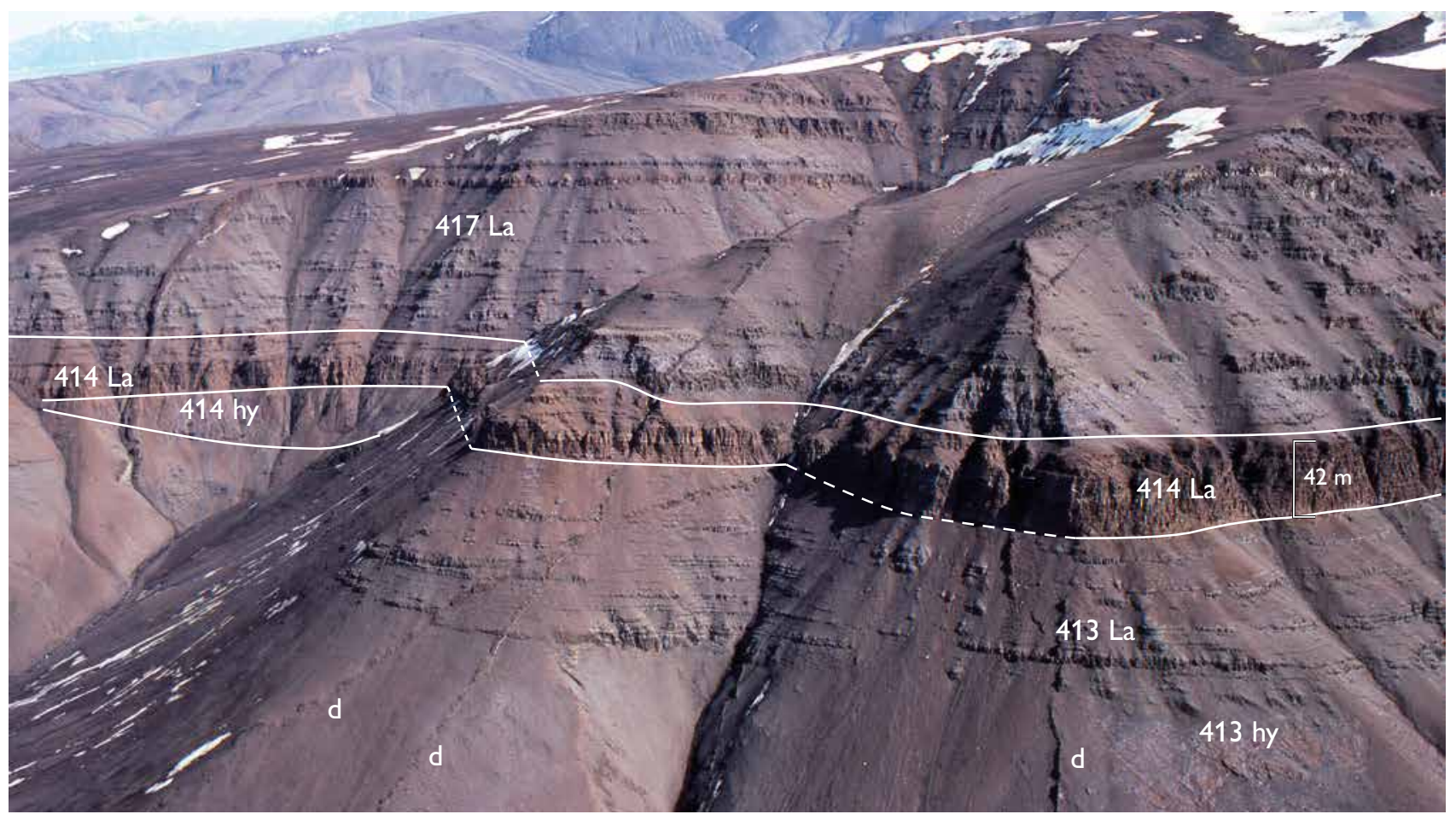

Fig. 90. Lava flows of the Nuuk Killeq Member ( $414 \mathrm{La}$ ) forming a prominent brown marker horizon up to $42 \mathrm{~m}$ thick, in which several flow groups can be distinguished. To the left, a small local basin is filled with hyaloclastites ( 414 hy). Unit 414 is underlain by hyaloclastites and subaerial lavas of Naujánguit Member unit 413 and is covered by picrite flows of Naujánguit Member unit 417 . The succession is cut by many dykes (d). Side valley to the Sorluut valley, north-western Nuussuaq, looking north. In the background the Tunorsuaq valley.



Fig. 91. The Nuuk Killeq Member in the Qunnilik valley. The member here consists of a lower (414a) and an upper (414c) group of orangebrown contaminated basalt lavas enclosing grey uncontaminated basalts (414b). Where these units entered the marine embayment, two orange-brown hyaloclastite successions ( $414 \mathrm{a}$ hy and $414 \mathrm{chy}$ ) were created, and in between them three successions of lava flows and light grey hyaloclastites (414b La + hy) were formed. The Nuuk Killeq Member (unit 414) rocks rest on light grey hyaloclastites of Naujánguit Member unit 413 and are covered by picrite lavas of Naujánguit Member unit 417. Rusty brown lava flows of contaminated basalt of the Tunoqqu Member ( $428 \mathrm{La}$ ) can be seen high on the ridge. Dykes (d) cut the hyaloclastites. North side of the Qunnilik valley, west-central Nuussuaq. 


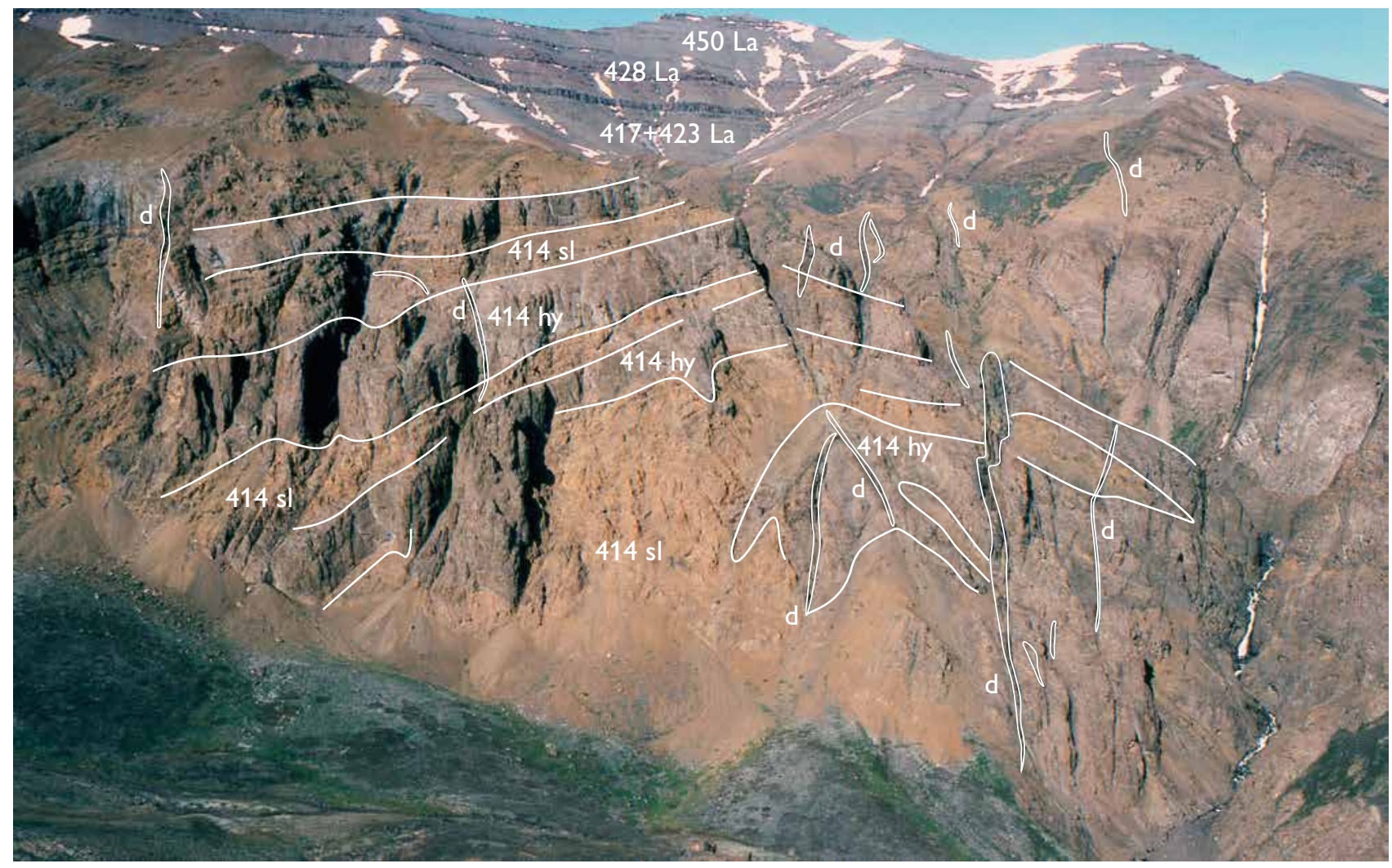

Fig. 92. A large submarine eruption site for the Nuuk Killeq Member. The structure is composed of at least two successive mounds and is more than $1.5 \mathrm{~km}$ wide and at least $500 \mathrm{~m}$ high. Several small swarms of columnar-jointed feeder dykes and an onion-shaped structure composed of alternating hyaloclastite ( $414 \mathrm{hy}$ ) and subaqueous flow tongues $(414 \mathrm{sl})$ indicate that the intermittent eruptions occurred on the slope break. An irregular swarm of feeder dykes (d) can be seen. The succession in the background comprises picrite flows of Naujánguit Member units 417 and 423 (below unit 428), brown contaminated flows of the Tunoqqu Member (428 La) and grey picrites of the Ordlingassoq Member ( $450 \mathrm{La}$ ). Interpretation from photogrammetry; the site has not been visited in the field. North side of the Aaffarsuaq valley, Central Nuussuaq section at $18-20 \mathrm{~km}$.

was discovered by Floris (1972, p. 15-18, figs 10-13). This layer is a hyaloclastite composed of up to $4 \mathrm{~cm}$ large basalt fragments and up to $5 \mathrm{~mm}$ large, sharp-edged clasts of fresh basaltic glass, all of which carry olivine (pseudomorphosed) and plagioclase microphenocrysts. The corals are scattered throughout the hyaloclastite layer but are absent in the surrounding mudstones. The corals must have grown on a shelf slope composed of hyaloclastites of the Nuuk Killeq Member, been picked up by a new hyaloclastite pulse, transported into the deep part of the marine embayment and deposited as part of a toeset which represents one of the last eruptions of the Nuuk Killeq Member. The surrounding mudstones belong to the Eqalulik Formation (Dam et al. 2009), and the volcanic bed represents an important tie-point in the detailed correlation of the Eqalulik and Vaigat formations (Piasecki et al. 1992).
The lava flows of the Nuuk Killeq Member are the oldest reversely magnetised volcanic rocks recorded in the volcanic province of West Greenland. The polarity shift may be applied to time-correlate the Nuuk Killeq Member laterally with parts of the Vaigat Formation outside the range of the Nuuk Killeq Member itself. The shift must also be present within the Eqalulik Formation.

Eruption sites. Submarine eruption sites are found in the Aaffarsuaq valley only a short distance from the similar eruption sites for unit 413 described above. The local mound structure is even more pronounced in the Nuuk Killeq Member than in unit 413. The structure composed of alternating hyaloclastite and subaqueous flow tongues indicates that the intermittent eruptions occurred on the slope break (Fig. 92). 


\section{Asuk Member}

\section{Summary of the main features of the Asuk Member}

- Four contemporaneous subunits in different areas evolved in separate magma chambers within marine mudstones. All rocks are strongly contaminated and reduced and range from silicic basalt to andesite. Magma-modified mudstone xenoliths are frequent.

- The Asuk Member on Disko comprises subaerial lava flows of which some are composite, a few subaqueous flows and tuffs. Several flows contain native iron, graphite and sulfides. The subaqueous flow at Asuk is the most reduced igneous rock on Earth.

- The Ilugissoq graphite andesite volcano on Nuussuaq was formed by phreatic eruptions in the coastal zone. It forms the largest eruption centre in the Vaigat Formation. Pyroclastic deposits from the volcano are a widespread marker found for example on Disko and in Agatdalen. A native-iron-bearing lava flow at Nuuk Killeq was probably sourced from the volcano's magma chamber.

- The Saviaqqat unit on northern Nuussuaq comprises subaerial plagioclase-phyric basalt flows. Some flows contain native iron. A spectacular accumulation of native iron in a flow at Saviaqqat is probably the source of the iron utilised for tools by the Inuits in the region.

- The Niiortuut unit on southern Nuussuaq comprises strongly contaminated lava flows and hyaloclastites which do not contain graphite or native iron.

- Some strongly contaminated sills along the Vaigat coast probably belong to the Asuk Member. Those on the Disko side are native-iron-bearing.

- Economic geology: Some rocks on Disko and the Saviaqqat unit show large losses of $\mathrm{Cu}$ and $\mathrm{Ni}$ due to sulfide fractionation. All rock groups except the $\mathrm{Ni}$ iortuut unit have been subjected to exploration for $\mathrm{Ni}$ and platinum-group elements.

\section{Lithostratigraphy of the Asuk Member}

Revised member

History. In 1872 K.J.V. Steenstrup discovered a volcanic rock with native iron in the Asuk area on Disko (Steenstrup 1875, 1882). The Asuk Member was formally defined by Pedersen (1985a). It is here extended to also comprise, besides the original Asuk Member on Disko (unit 420), the contemporaneous Ilugissoq volcano (also unit code 420) on central western Nuussuaq, the Saviaqqat unit (unit 419) on northern Nuussuaq and on Hareøen, and the small Niiortuut unit (unit 422) on the south coast of Nuussuaq (Fig. 49).

Further notes on the history of the Asuk Member are found in the descriptions of the individual units.

Name. After the small point Asuk on the north-east coast of Disko (Fig. 4).

Distribution. The four subunits occupy different areas with little overlap (Fig. 10).

The Asuk Member on Disko occurs on the north coast between Norddalen and Asuk and extends south-west to the inner Kuugannguaq valley and the Stordal area (Pedersen 1985a).

The Ilugissoq volcano has covered $c .19 \mathrm{~km}^{2}$ between the Ilugissoq and Qilakitsoq valleys, but its airfall tuff layer is spread over large parts of Nuussuaq. In Sorluut, this tuff layer is found immediately below the Saviaqqat unit, testifying to the near-contemporaneity of the two units.

The Saviaqqat unit is known from northern Nuussuaq between Snekuplen, Tunorsuaq and Ikorfat; its northern and western limits are undefined; its southern and eastern limits are depositional. A similar succession is present on Hareøen east of the Itilli fault; the connection between the two areas is not clear.

The Niiortuut unit is only known from the south coast of Nuussuaq between Nuuk Qiterleq and Tupaasat where its lavas and hyaloclastites filled in the marine embayment over a distance of $7 \mathrm{~km}$.

Type locality. North-east Disko around Asuk where the member forms part of a large landslipped block (Pedersen 1985a).

Reference sections and localities. Kuugannguup Innartaa, Norddalen, Ametystskrænten (Fig. 16, profiles 23, 24, 25 ) and original profiles $4-7$ of Pedersen (1985a), all on Disko. The Ilugissoq valley (Figs 102, 104), Saviaqqat (Fig. 125), Sorluut, Tunorsuaq (Fig. 14, profiles 11, 12) and Niiortuut (Fig. 15, profile 17), all on Nuussuaq. Niaqua (Fig. 17) on Hareøen. 
Thickness. Up to at least $140 \mathrm{~m}$ on Disko; on Nuussuaq the Ilugissoq volcano is up to $350 \mathrm{~m}$ thick, the Saviaqqat unit up to $50 \mathrm{~m}$ thick and the Niiortuut unit up to 200 m thick.

Lithology. The Asuk Member on Disko comprises silicic basalts, magnesian basaltic andesites and subordinate andesites and forms subaqueous breccias, pillow lavas, tuffs and subaerial lava flows including thick composite flows. Several rocks contain native iron. Eruption sites are not known.

The Ilugissoq volcano on central western Nuussuaq is a small volcano that erupted through $c .300 \mathrm{~m}$ of water; its products consist of pyroclastic rocks, mostly lapilli tuffs. The rocks are orthopyroxene-phyric magnesian andesites rich in disseminated graphite. The rocks of the volcano are identical to layers of graphite andesite airfall and redeposited tuffs in a horizon that has a wide distribution (Fig. 10) and is particularly known from Agatdalen. These tuffs must have been sourced from the volcano and provide a good time marker in the succession.

At Nuuk Killeq on the south coast of Nuussuaq a short, thick lava flow of native-iron-bearing magnesian andesite was probably sourced from the magma chamber of the Ilugissoq volcano $15 \mathrm{~km}$ to the north.

The Saviaqqat unit on northern Nuussuaq and on Hareøen consists of one to four rusty brown lava flows that are very strongly plagioclase-phyric and form an excellent marker horizon. The lavas flowed into the sea east of Ikorfat on the north coast; eruption sites are not known. Between Tunorsuaq and Saviaqqat one of the four lava flows contains native iron.

The Niiortuut unit on southern Nuussuaq consists of brown lava flows and associated hyaloclastites of olivine microphyric to aphyric basalts and picrites. The rocks are not as strongly contaminated as the other units in the Asuk Member.

Boundaries. The various units of the member overlie the grey uncontaminated picrites of Naujánguit Member unit 417 and are overlain by the picrites of Naujánguit Member unit 423.

In the Stordal area, Asuk Member flows rest on the Disko Gneiss Ridge and in the Asuk area on CretaceousTertiary sediments, but no contacts are exposed.

The Ilugissoq volcano edifice was gradually covered by onlapping lava flows of the overlying units.

Age. Paleocene, nannoplankton zone NP5-6, c. $61 \mathrm{Ma}$, magnetochron C26r, based on dinoflagellate cysts (Pi- asecki et al. 1992), reversed magnetic polarity (Athavale \& Sharma 1975) and radiometric dating of older and younger rocks in the succession (Storey et al. 1998; Riisager \& Abrahamsen 1999).

Correlation. The Asuk Member is correlated with the Abraham Member of the Eqalulik Formation based on the presence in both of graphite andesite tuffs, and on intercalated mudstones with dinoflagellate cysts (Piasecki et al. 1992; Dam et al. 2009).

\section{Geology of the Asuk Member (units 419, 420 and 422)}

The Asuk Member as defined here comprises four separate units of strongly reduced, frequently native-ironbearing rocks at the same stratigraphic level. They were formed in at least four separate, minor volcanic systems that were active at around the same time. Some nativeiron-bearing tuffs in the Eqalulik Formation in Agatdalen belong to this group of rocks because they were sourced from a volcano of the Asuk Member.

The strongly contaminated volcanic rocks vary from silicic basalt to magnesian andesite. Because of the widespread occurrence of xenoliths and xenocrysts derived from mudstones and sandstones, there is no doubt that the contamination occurred in high-level magma reservoirs within sediments of the Nuussuaq Basin. The abundance of carbon compounds, sulfides and native iron in the volcanic rocks indicates that the dominant contaminant was a marine mudstone; however, contributions from sandstone can also be discerned.

\section{Asuk Member on Disko (part of unit 420)}

The 'classical' area of the Asuk Member is the type locality around Asuk on the north-east coast of Disko. In 1872 K.J.V. Steenstrup here discovered a volcanic rock which on detailed examination proved to contain disseminated native iron (Steenstrup 1875, 1882). The subsequent literature on the lavas and breccias and the native iron at Asuk is extensive and includes Steenstrup (1883, 1900); Törnebohm (1878); Lorenzen (1882); Nicolau (1900); Bøggild (1953, review); Pauly (1958, 1969); Vaasjoki (1965); Melson \& Switzer (1966); Goodrich \& Patchett (1991); Pedersen (1969, 1973, 1978a, b, 1979a, 1985a); Pedersen \& Pedersen (1987); Pedersen \& Rønsbo (1987); Pedersen \& Larsen (2006); and Larsen \& Pedersen (2009). 
The Asuk Member on Disko comprises basaltic andesites and andesites with 52-57 wt $\% \mathrm{SiO}_{2}$, with phenocrysts or microphenocrysts of orthopyroxene and in some cases olivine or tiny plagioclases. The rocks contain a range of sediment-derived xenoliths and xenocrysts, such as plagioclase with graphite inclusions, magnesian spinel, corundum and quartz. Some rocks carry native iron, cohenite $\left((\mathrm{Fe}, \mathrm{Ni})_{3} \mathrm{C}\right)$, schreibersite $\left((\mathrm{Fe}, \mathrm{Ni})_{3} \mathrm{P}\right)$ and troilite $(\mathrm{FeS})$ and show a notable scarcity in $\mathrm{Fe}$-Ti-oxides. Altogether, the volcanic rocks and xenoliths of the Asuk Member represent the most reduced volcanic environment on Earth; see Table 4 and the chapter on crustal contamination in the companion bulletin on the Maligât Formation (Pedersen et al. 2018).

Distribution. The Asuk Member on Disko covers a minimum of $565 \mathrm{~km}^{2}$ on northern Disko and comprises a main field of $c .525 \mathrm{~km}^{2}$ and a satellite field of $c .40 \mathrm{~km}^{2}$ (Fig. 10). The main field is an elongate, NE-SW-trending, c. $20 \mathrm{~km}$ wide area that extends from the north-east coast of Disko to Stordal where lava flows of the Asuk Member onlap the Disko Gneiss Ridge. The extensions towards the west and east in the southern part of the area are below the level of exposure and are unconstrained. The extensions to the west and east nearer the Vaigat coast are depositional. The rocks must originally have extended well beyond the north coast of Disko, though not to Nuussuaq.
Eruption sites. The feeder systems for the Asuk Member on Disko have not been discovered, despite extensive search by the Geological Survey and several mining companies, but they must be present within the eastern part of the area between Asuk and the inner Kuugannguaq valley. This is deduced from thickness variations and from the presence of large composite basalt to andesite lava flows around Asuk and in the inner part of Kuugannguaq (Pedersen 1985a, fig. 9, profiles 5, 6; see also Fig. 94); the andesite magma must have been highly viscous and unable to spread far from its eruption sites. The Asuk Member was erupted on the gently SE-dipping lava plain of unit 417 picrites and shows a general onlap onto this surface from the south-east, where the thickness is more than $140 \mathrm{~m}$, towards the north-west where the number of flows and the thickness decrease to zero.

The satellite field is centred around Kuuganngup Innartaa and must have been erupted there.

Boundaries. Over most of its extent on northern Disko, the Asuk Member covers picritic lava flows of unit 417, but the contact is only exposed in steep mountain sides. In general, the onlap pattern of Asuk Member lava flows on unit 417 suggests a very subtle angular unconformity. In Stordal lava flows of the Asuk Member onlap the Disko Gneiss Ridge (Central Disko section, see also Fig. 183) but the contact itself is not exposed. At the eastern margin, where the Asuk Member gradually enters marine facies, the detailed contact is obscured by landslides (e.g. Pedersen 1985a, fig. 8). In this area a thin veneer of Pale-

Fig. 93. The lower boundary of the Asuk Member in the west side of Norddalen, Disko. Two tuff layers (a black and a red, weathered) on the top of picrite lava flows of Naujánguit Member unit 417 mark the initiation of the Asuk Member volcanism at this site. The combined thickness of the two tuffs is $0.8 \mathrm{~m}$. The tuffs are overlain by crustally contaminated lava flows of the Asuk Member (420). In the background, on the opposite valley side, a number of successive units are seen, comprising lavas of Naujánguit Member unit 417 to hyaloclastites of the Ordlingassoq Member (450 hy). See Table 1 for the unit codes.

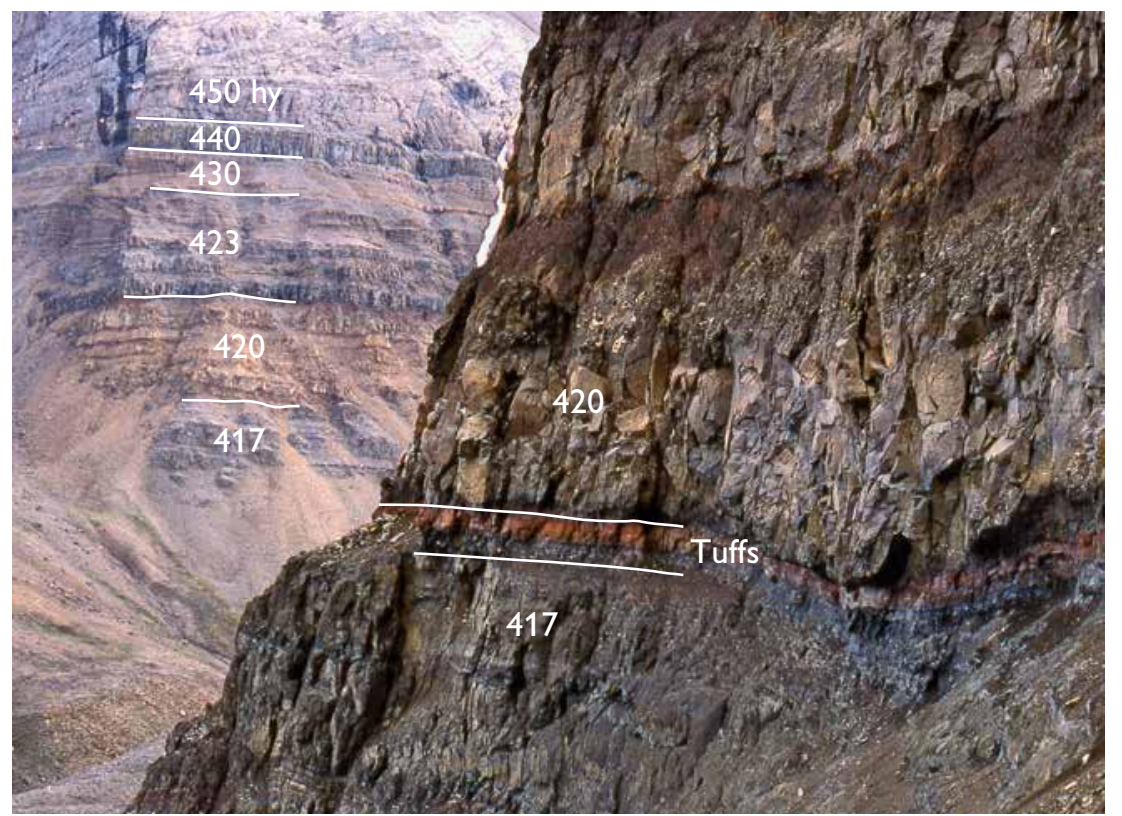


ocene marine mudstone may be present at the base, but the Asuk Member may also be in direct contact with Cretaceous clastic sediments of the Itilli or Atane formations. In the Norddalen valley, $c .80 \mathrm{~cm}$ thick Asuk Member tuffs are preserved at the base of the lava flows (Fig. 93). In the inner part of Kuugannguaq, the lower boundary of the Asuk Member is below the level of exposure (see also Fig. 200).

The upper boundary of the Asuk Member on Disko is only well exposed in steep mountain sides. In Norddalen there are traces of lateritic sediment on top of the Asuk Member, covered by basaltic and picritic lava flows of unit 423 (Fig. 71). The upper boundary is obscured by landslides in the zone of marine facies transition between Asuk and Asup Innartaa.

\section{Lithologies}

The dominant lithology of the Asuk Member on Disko is subaerial lava flows. The flows are either entirely basic or composite with an early eruptive pulse of basic magma followed by a later pulse of magnesian andesite, or in a single case entirely andesitic. Some of the flows are composite close to their feeder system but entirely basic in their distal parts. Along the eastern margin of the main field, the Asuk Member changes into shallow-water subaqueous facies over a $1-2 \mathrm{~km}$ wide transition zone with very variable lithologies of columnar-jointed, pillowed and brecciated lavas. This takes place between Asuk and Qorlortorsuaq on the Vaigat coast and southwards from there (Pedersen 1985a, fig. 11), but because of large landslides along the coast (Pedersen 1985a, fig. 8) the exposures are discontinuous. Farther inland, the transition zone is below the level of exposure. Tuffs are quite subordinate on Disko but are important for lateral correlation. A native-iron-bearing intrusion (sill) considered to belong to the Asuk Member occurs at Qullissat close to but outside the occurrences of lavas and breccias of the Vaigat Formation (see also Fig. 161).

Simple lava flows. The most basic lavas of the Asuk Member on Disko are magnesian basaltic andesites very close to basalt, with $6-10 \mathrm{wt} \% \mathrm{MgO}$ and just above $52 \mathrm{wt} \%$ $\mathrm{SiO}_{2}$. The flows are 5-12 m thick (except where ponded) and appear as a visually striking succession of light yellowish brown flows with reddish brown vesicular top zones (Figs 71, 93). The flows may contain vesicles up to several decimetres in size which may be filled, completely or partially, by agate, quartz, carbonate and zeolites. In very fresh exposures the rocks are light grey due to a

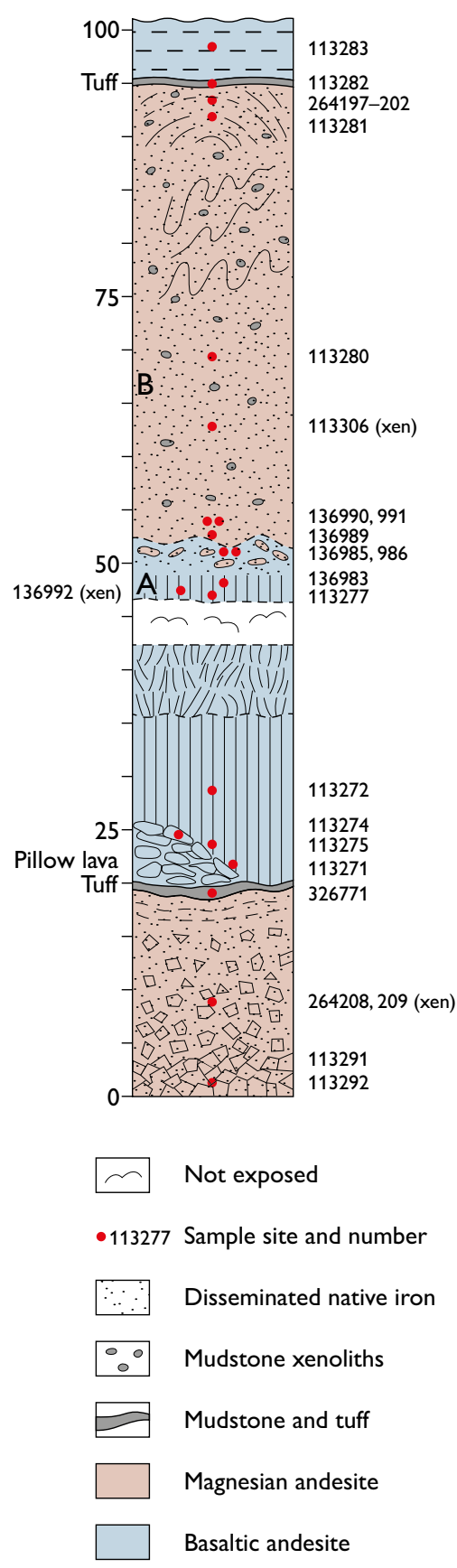

Fig. 94. Drawing reconstructed to vertical of the lava and tuff succession in the coastal cliff at Asuk, northern Disko. The basaltic andesites have 52-55.5 wt $\% \mathrm{SiO}_{2}$ and 6-10 wt $\% \mathrm{MgO}$, and the magnesian andesites have $56.5-58 \mathrm{wt} \% \mathrm{SiO}_{2}$ and 6-7 wt $\% \mathrm{MgO}$; chemical analyses in Table 5. Internal structures of the flows such as columns, pillows, entablature, fractures and flow lines are shown schematically. Note that the flow at $47-95 \mathrm{~m}$ is composite with a more than $6 \mathrm{~m}$ thick basal zone of basaltic andesite (A) followed, with some mixing, by $42 \mathrm{~m}$ of andesite (B). xen: xenolith. See detailed descriptions in the text. Photos of the succession are shown in Figs 95, 97. 
smaller content of Fe-Ti oxides than in normal basalts of the Vaigat Formation.

Most of the simple lava flows do not contain native iron. In the Kuugannguaq valley there are six or seven native-iron-free lava flows with a total thickness of $60 \mathrm{~m}$ beneath a large composite native-iron-bearing flow (Pedersen 1985a, fig. 9, profile 6), and in Norddalen (Fig. 16, profile 24) there are eight lava flows with a total thickness of $50 \mathrm{~m}$, of which only one is native-iron-bearing. Flow no. 5 is $12 \mathrm{~m}$ thick and contains native iron as millimetre- to centimetre-sized irregular bodies in its lower two thirds, and about $1.3-1.5 \mathrm{~m}$ above the base a distinctive, but not compact, igneous cumulate of native iron with sulfide is developed. This flow (sample 113233) is more strongly contaminated than the other flows and is lighter grey with rusty patches and internal flow structures.
The classical profile at Asuk illustrates many characteristic features of the Asuk Member on Disko and will be described in some detail, not least because its location at the coast makes it easily accessible for visitors. A sketch is shown in Fig. 94. Asuk lies in the marine transition zone and the lava flows change up-section from submarine to subaerial.

The lowermost exposed unit is a submarine, nativeiron-bearing, magnesian andesite flow breccia, first identified as native-iron-bearing by Steenstrup (1882, p. 124, unit a). It is at least $20 \mathrm{~m}$ thick, and its lowermost exposed part at sea level is a non-vesicular, dense, almost glassy rock jointed into masses of decimetre-sized irregular polyhedra (Fig. 95). Parts of the flow form irregular, pillow-like bodies with no matrix between them. Upwards it transforms into a breccia with increasing proportions of matrix, while an increasing number of vesicu-

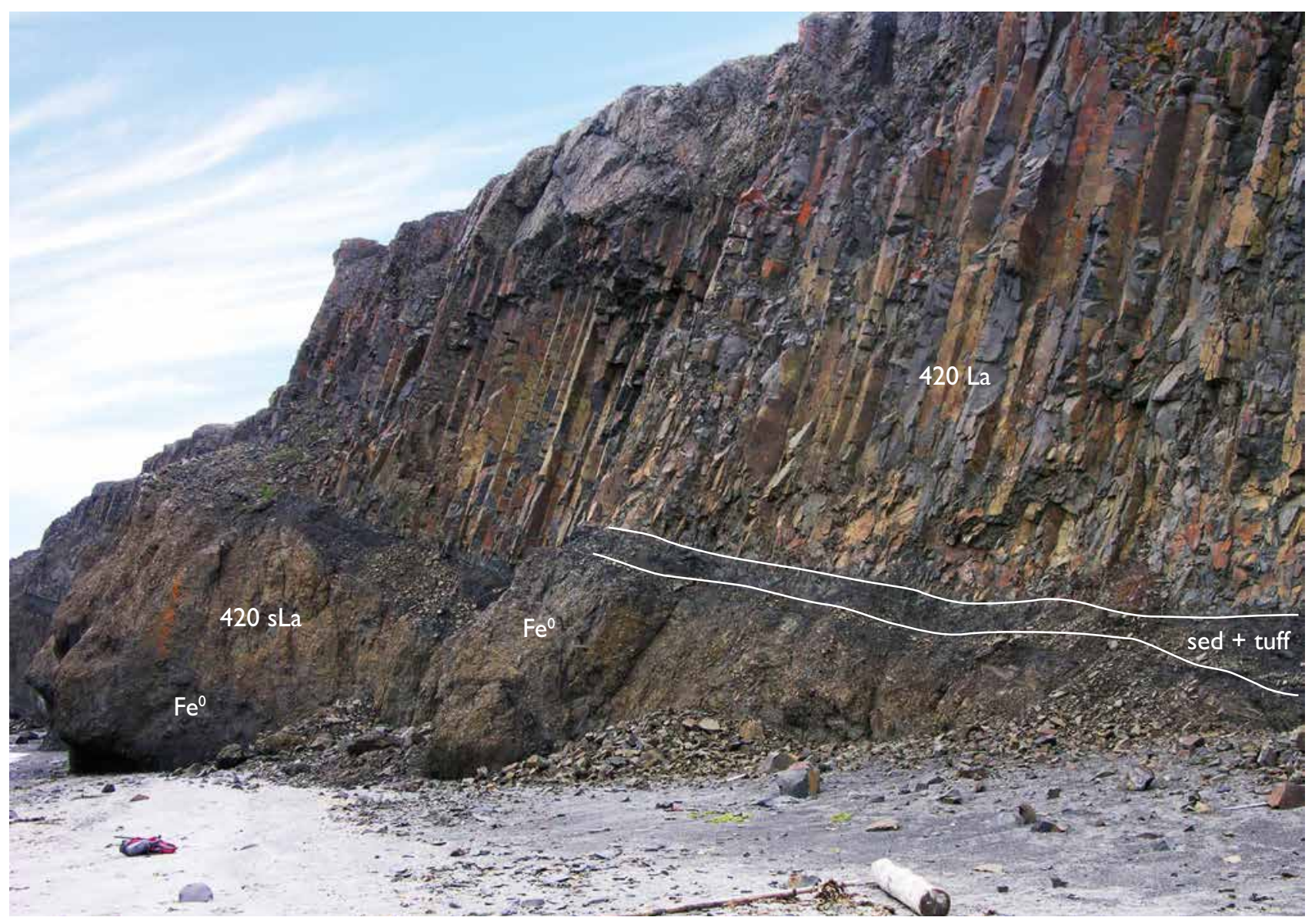

Fig. 95. The lower part of the lava and tuff succession at Asuk, northern Disko. Below, a subaqueous lava flow of magnesian andesite ( $420 \mathrm{sLa})$ with disseminated native iron $\left(\mathbf{F e}^{\mathbf{0}}\right)$ throughout the flow (Fig. 94). On its irregular top there are small basins with silicified marine mudstone with tuff layers (sed + tuff). The basins are covered by a strongly columnar-jointed basaltic andesite lava flow. The same flow is seen in the left part of Fig. 97. Height of cliff section c. 30 m. Photo: Chris Schenck. 

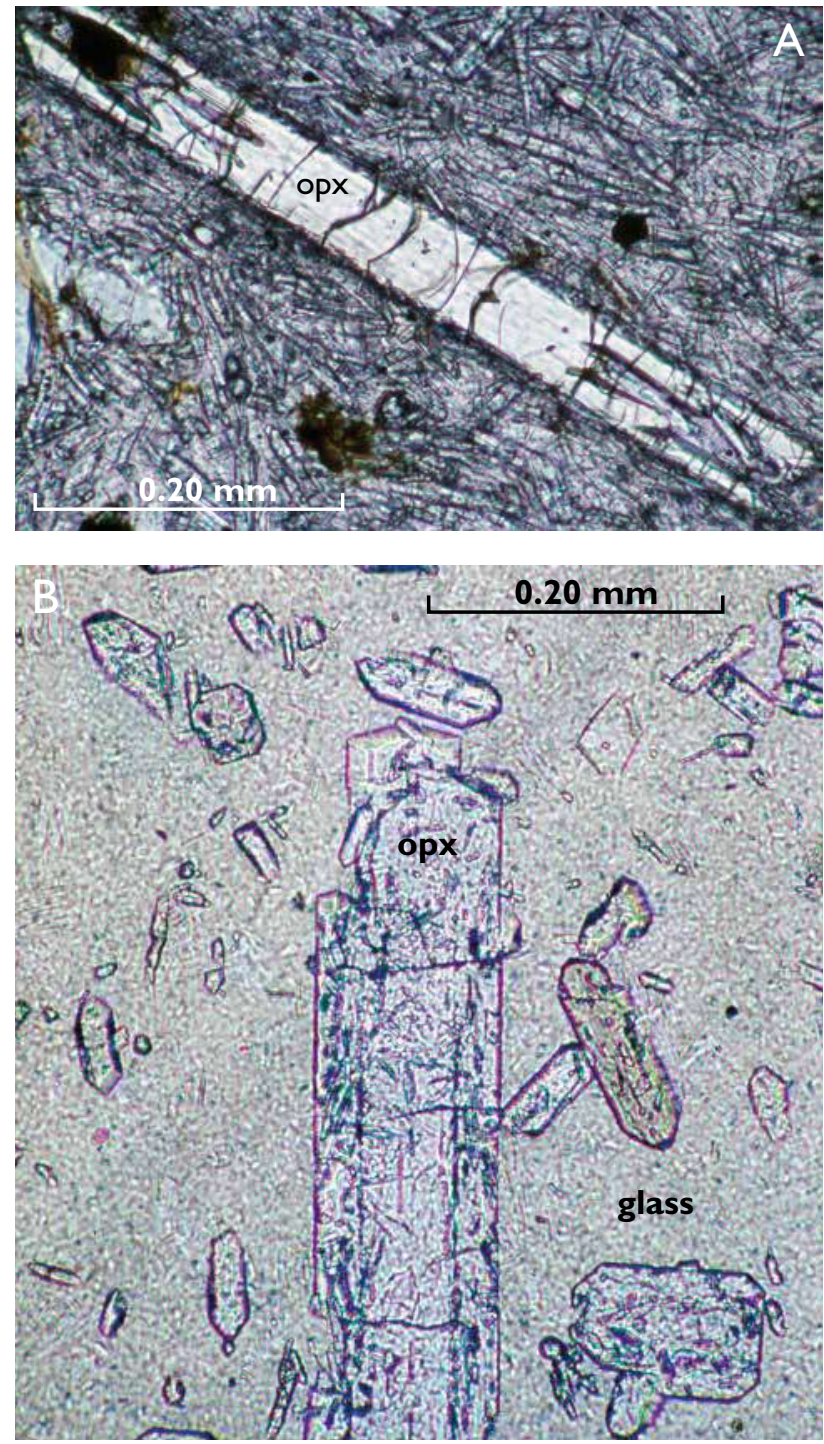

Fig. 96. Microphotographs (plane polarised light) of quenched orthopyroxene crystals in Asuk Member lavas. A: Orthopyroxene phenocryst (opx) with quench texture in andesite with native iron (dark round bodies) and glass-rich groundmass. Subaqueous lava flow at Asuk, sample 113291 (Fig. 94). B: Orthopyroxene (opx) crystals in clear glass in a basaltic andesite pillow rim at Asuup Innartaa, sample 326768 .

lated clasts appear. In the uppermost part of the flow, a weakly layered breccia grades into a $c .40 \mathrm{~cm}$ thick, coarse, tuffaceous volcaniclastic sediment. The upper surface of the flow is undulating, with small basins in the lows where up to $1.5 \mathrm{~m}$ thick deposits of mudstone with tuffs have accumulated (see section on tuffs below), while local small crests are slightly eroded. The main rock is an almost glassy magnesian andesite with phenocrysts of orthopyroxene and very minor olivine, and with dissemi- nated, less than $0.5 \mathrm{~mm}$ bodies of native iron and troilite. Xenocrysts as well as magma-modified sediment xenoliths are widespread (see section on xenoliths below). This flow is particularly interesting because it provides rapidly quenched, very strongly reduced rocks (Fig. 96A; analysis in Table 5, sample 113291). It probably represents the most highly reduced volcanic rock on Earth.

A thin flow of olivine microphyric lava of near-basaltic composition overlies the andesite breccia and tuffs. Westwards, this flow runs into the marine mudstone basin and develops into pillow fingers and pillows until it tapers out. The flow is extensively altered but its chilled parts contain fresh glass and fresh olivine. The flow is covered by a thin mudstone layer, and mudstone also partly fills the space between pillows.

Next follows an up to $20 \mathrm{~m}$ thick ponded lava flow of orthopyroxene microphyric basaltic andesite, first illustrated by Steenstrup (1900, plate 11). Its has an up to $15 \mathrm{~m}$ high, very regularly jointed colonnade which grades upwards into an entablature zone (Fig. 95). Its top is vesiculated and was cooled above the shallow marine embayment that was filled in by the lower part of the flow. This flow appears in landslipped blocks several kilometres to the south-east where it is composed of lobes with entablature structure and pillowed lobes with up to $3 \mathrm{~m}$ large pillows with fresh glass and skeletal orthopyroxene crystals (Fig. 96B).

On top of this flow follows a thick composite lava flow that is described in the next section.

Composite lava flows. A very distinctive feature of the Asuk Member on Disko comprises composite lava flows with native iron, known from Asuk and the inner Kuugannguaq valley.

The composite flow at Asuk is exposed above the remains of the old hunters' hut which was ruined by a tsunami in 2000 (Dahl-Jensen et al. 2004). It can be followed in discontinuous exposures for $c .4 \mathrm{~km}$ along the coast in the large landslides from Asuk to Asuup Innartaa and farther to the south-east. The sketch (Fig. 94) and Fig. 97 show a c. $50 \mathrm{~m}$ thick subaerial lava flow consisting of an early pulse of basaltic andesite magma (A), followed by a much thicker later pulse of andesite magma that carries native iron (B). Three chemical analyses are presented in Table 5.

The basal zone A is about 6.3 m thick; its lower contact is obscured by scree. The lower $4 \mathrm{~m}$ are a fine-grained aphyric, near-basaltic rock with $52-54 \mathrm{wt} \% \mathrm{SiO}_{2}$ which is jointed into regular columns with chisel marks. The volcanic rock does not contain visible native iron, but scattered flat xenoliths of mudstone buchite containing 


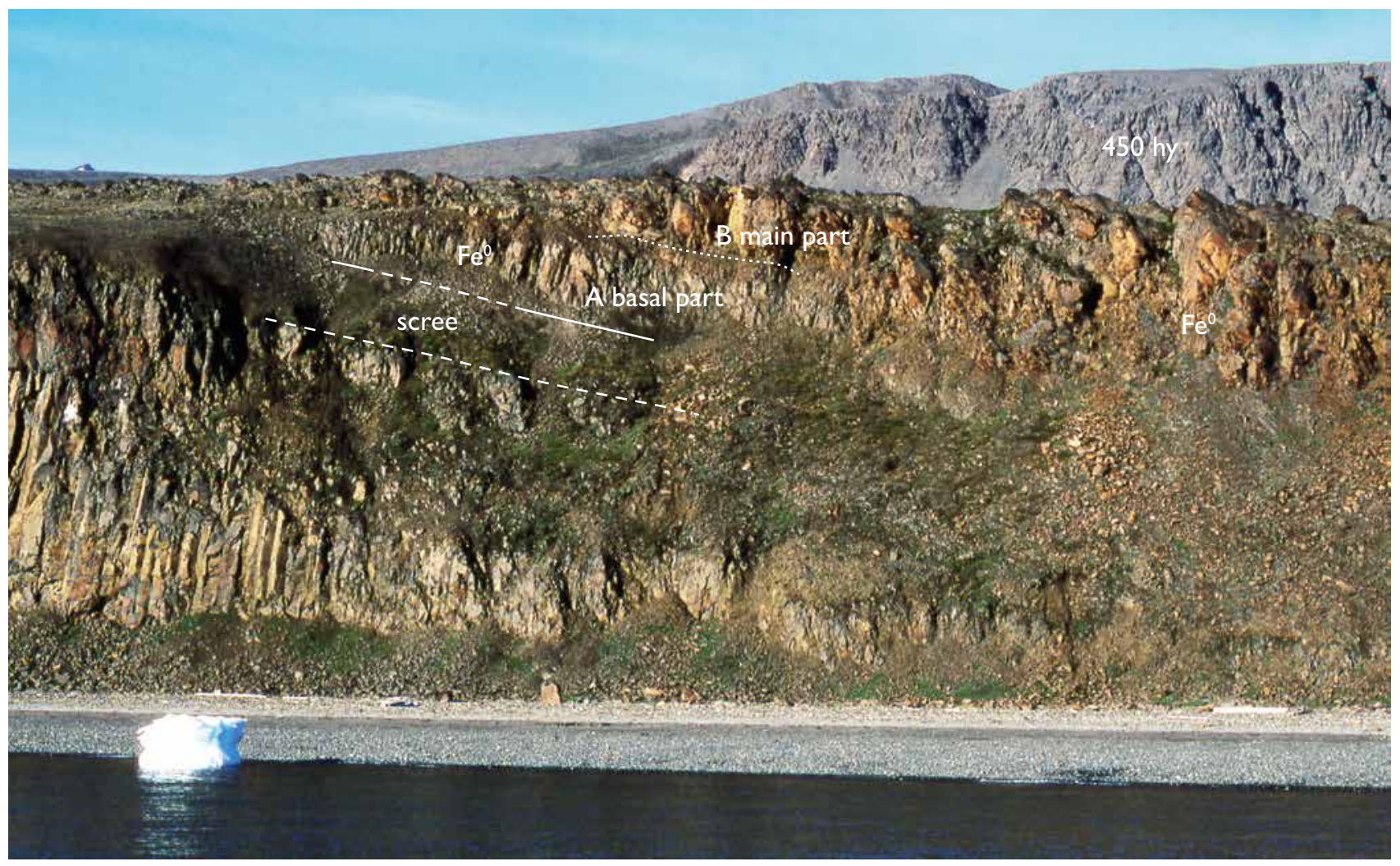

Fig. 97. Lava flows in the cliff at Asuk. The lowest flow is a columnar-jointed basaltic andesite flow with entablature top (Fig. 95). The next flow, above a scree zone, is a thick composite lava flow with a basal part (A) of basaltic andesite and a main part (B) of rusty brown andesite; both parts carry disseminated native iron $\left(\mathbf{F e}^{\mathbf{0}}\right)$. This slipped exposure corresponds to the reconstructed column in Fig. 94 at 30-70 m. The top of the cliff in the foreground is $35 \mathrm{~m}$ a.s.l. The mountain in the background consists of picritic hyaloclastites of the Ordlingassoq Member (450 hy).

native iron occur in this part (Pedersen 1979a, sample 136992). From $4 \mathrm{~m}$ and upwards the rock becomes spotted and inhomogeneous and starts to carry millimetresized blebs of native iron and sulfide together with amoeboid bodies of native-iron-bearing andesite identical to the rock in zone $\mathrm{B}$. The shapes of these bodies, which may be up to $70 \times 20 \mathrm{~cm}$ in size, show that they were carried as highly viscous melts in the much more fluid basic melt, and their shape allows for an assessment of local flow directions within zone A. At the top of zone A, the rock has become a hybrid basaltic andesite with 55.5 $\mathrm{wt} \% \mathrm{SiO}_{2}$. The contact with the overlying magnesian andesite is mostly sharp but without any chill zone, and at some places the contact is vesicular but without any trace of high-temperature oxidation. At Asuup Innartaa, apophyses from zone A intrude zone B.

Zone $\mathrm{B}$ consists throughout of native-iron-bearing magnesian andesite with $56.5-58.5 \mathrm{wt} \% \mathrm{SiO}_{2}$. It is a very fine-grained, almost flinty rock with millimetre-sized phenocrysts of orthopyroxene and disseminated, drop- like $<1 \mathrm{~mm}$ large bodies of native iron and troilite in a groundmass with a distinctive globular texture characterised by darker blebs in a lighter matrix. In the upper part of the flow, this globular texture enhances a flow folding structure. The andesite is jointed into large columns up to several metres thick which tend to develop conchoidal jointing. The rock is characterised by a light rusty brown weathering colour (Fig. 97) due to weathering of native iron and sulfide.

In the upper few metres of the flow, the groundmass becomes very fine-grained and the globular texture disappears or becomes much less prominent. The flow remains very vesicle-poor up to $c .0 .5 \mathrm{~m}$ from the slightly irregular, blocky top surface, and there is native iron up to within $30 \mathrm{~cm}$ of the surface. The flow is covered by $c$. $20 \mathrm{~cm}$ of sandy andesite tuff, probably originating from the same eruption as the flow itself.

Composite flows in Kungannguaq. Two native-ironbearing composite flows on top of each other are exposed in the north-eastern side of the inner Kuugannguaq val- 


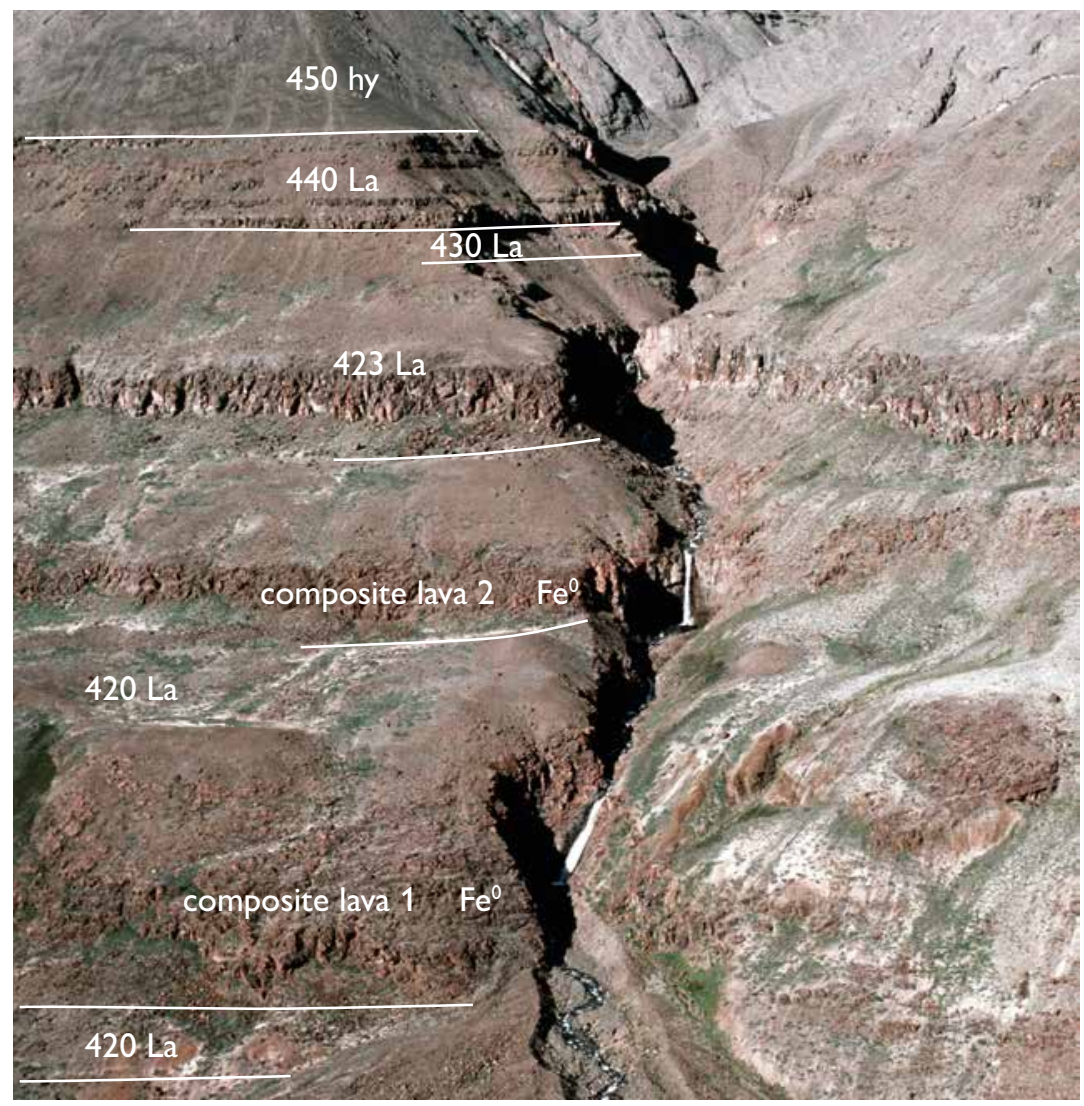

Fig. 98. Two thick composite, native-iron-bearing $\left(\mathbf{F e}^{\mathbf{0}}\right)$ lava flows of the Asuk Member in the Kuugannguaq valley. The flows are covered by lava flows of units 423,430 and 440 and by hyaloclastite ( $450 \mathrm{hy}$ ) of the Ordlingassoq Member. The profile is shown by Pedersen (1985a, figs 9 , 14, loc. 5). The combined thickness of the two composite flows is $120 \mathrm{~m}$. Gully in the northeastern side of the Kuugannguaq valley $23 \mathrm{~km}$ from its entrance.

ley (Pedersen 1985a, fig. 9, profile 5; Fig. 98). The upper flow is about $55 \mathrm{~m}$ thick and very similar, but not identical, to the composite flow at Asuk, both in composition and in structure. A distinguishing feature is that basic dyke-like bodies without native iron intrude from the basal zone A far up into the andesitic zone B. The lower composite flow, which is exposed for at least $5 \mathrm{~km}$ along Kuugannguaq, is 60-65 m thick and is more magnesian than the upper composite flow, but its structure is very similar to that of the Asuk flow. Like this, it contains amoeboid andesite melt bodies in the upper part of the basic zone A. Zone B differs from the Asuk flow by having upwards decreasing amounts of native iron and increasing disseminated graphite in its lower part, and constant and low iron and very high graphite contents in its upper part (up to $2 \mathrm{wt} \% \mathrm{C}$, see Table 4).

Interpretation. The composite flows show that the magmas of the Asuk Member on Disko originated in zoned, high-level magma chambers (Pedersen 1975). During eruption, a less viscous basic magma pulse was emplaced first and formed the basal part (zone A) of the lava flow. This magma pulse picked up packets of the overlying, more viscous andesite melt to form the amoeboid andesite inclusions in the upper part of zone
A. Then followed the volumetrically larger and less dense andesite pulse to form zone B.

The volumes of the individual composite flows are difficult to assess, but with exposure lengths of at least 5 $\mathrm{km}$ and thicknesses of 50-65 $\mathrm{m}$, the erupted volumes of individual flows must be in the order of $1 \mathrm{~km}^{3}$.

Similar composite flows are found in the likewise crustally contaminated Nordfjord Member of the Maligât Formation (Pedersen 1977b); their intrusions have similar build-ups (Ulff-Møller 1977, 1991). These features are described in the companion bulletin on the Maligât Formation (Pedersen et al. 2018).

Asuk Member flows in Stordal. A succession of lava flows of the Asuk Member is partly exposed at low levels in Stordal on central Disko (Central Disko section at 24.8$33 \mathrm{~km}$, see also Fig. 183) where the flows extend for $c .9$ $\mathrm{km}$ eastwards from the canyon at the mouth of Steenstrup Dal. To the east, the flows onlap the Disko Gneiss Ridge where they have partly filled an E-W-trending palaeovalley in the old gneiss hills. The boundaries are not well exposed, but a minimum thickness of about $100 \mathrm{~m}$ can be estimated. 
Steenstrup Dal canyon. A near-vertical excellent exposure in this canyon displays five basaltic andesite flows of which no. 2 and 5 with certainty carry native iron as millimetre-sized irregular bodies. Below the five flows are three poorly exposed flows that also belong to the Asuk Member, and above them are three greyish-weathering, thin flows of uncertain status, capped by a $10-15 \mathrm{~m}$ thick columnar-jointed basalt younger than the Asuk Member. No composite flows are exposed.

Satellite lava field around Kungannguup Innartaa on northern Disko. This small lava field is centred around the ridge Kuugannguup Innartaa, east of the entrance to the Kuugannguaq valley (Fig. 10 and Fig. 16, profile 23). The Asuk Member lavas are in total $c .40 \mathrm{~m}$ thick and comprise three brown flows, two near-basaltic flows with c. $52.5 \mathrm{wt} \% \mathrm{SiO}_{2}$ and an overlying $20 \mathrm{~m}$ thick native-ironbearing, near-andesitic flow with $56-57 \mathrm{wt} \% \mathrm{SiO}_{2}$ (Fig. 99). The native-iron-bearing flow is very fine-grained and carries orthopyroxene phenocrysts, disseminated native iron and small scattered xenoliths of plagioclase-graphite-spinel rock and sandstone. The flow is quite similar in appearance to the andesites with native iron from the upper part of the composite flows in Kuugannguaq and at Asuk. The feeder to the andesite has not been found but it must be close to the single exposure.

Tuffs in the Asuk Member on Disko. Well-preserved tuffs of the Asuk Member on Disko are found in Norddalen and at two localities at Asuk. Other localities may be found, but the tuffs are likely to be covered by scree at the base or top of the succession except in the most excellent exposures.

Tuffs in Norddalen. In Norddalen about $80 \mathrm{~cm}$ of tuff and volcaniclastic sediments are deposited directly on the top of picritic lava flows of unit 417 without any trace of soil formation at the boundary surface (Figs 93, 100). The lowermost $15-20 \mathrm{~cm}$ of sediment is a black tuff $\left(\mathrm{T}_{1}\right)$ composed of fresh glass clasts which in thin section are yellow and carry skeletal olivine. The glass composition is that of a basaltic andesite very similar to the composition of the Asuk Member lavas, whereas the bulk composition of the glass plus olivine is more primitive than most Asuk Member flows. A minor component of the tuff is picritic clasts with glass, olivine and chromite. On top of the basal tuff follows a $c .35 \mathrm{~cm}$ thick volcaniclastic sediment $\left(\mathrm{T}_{2}\right)$ with rounded, $0.5-1 \mathrm{~cm}$ large lava clasts and smaller, non-volcanic quartz clasts. This is overlain

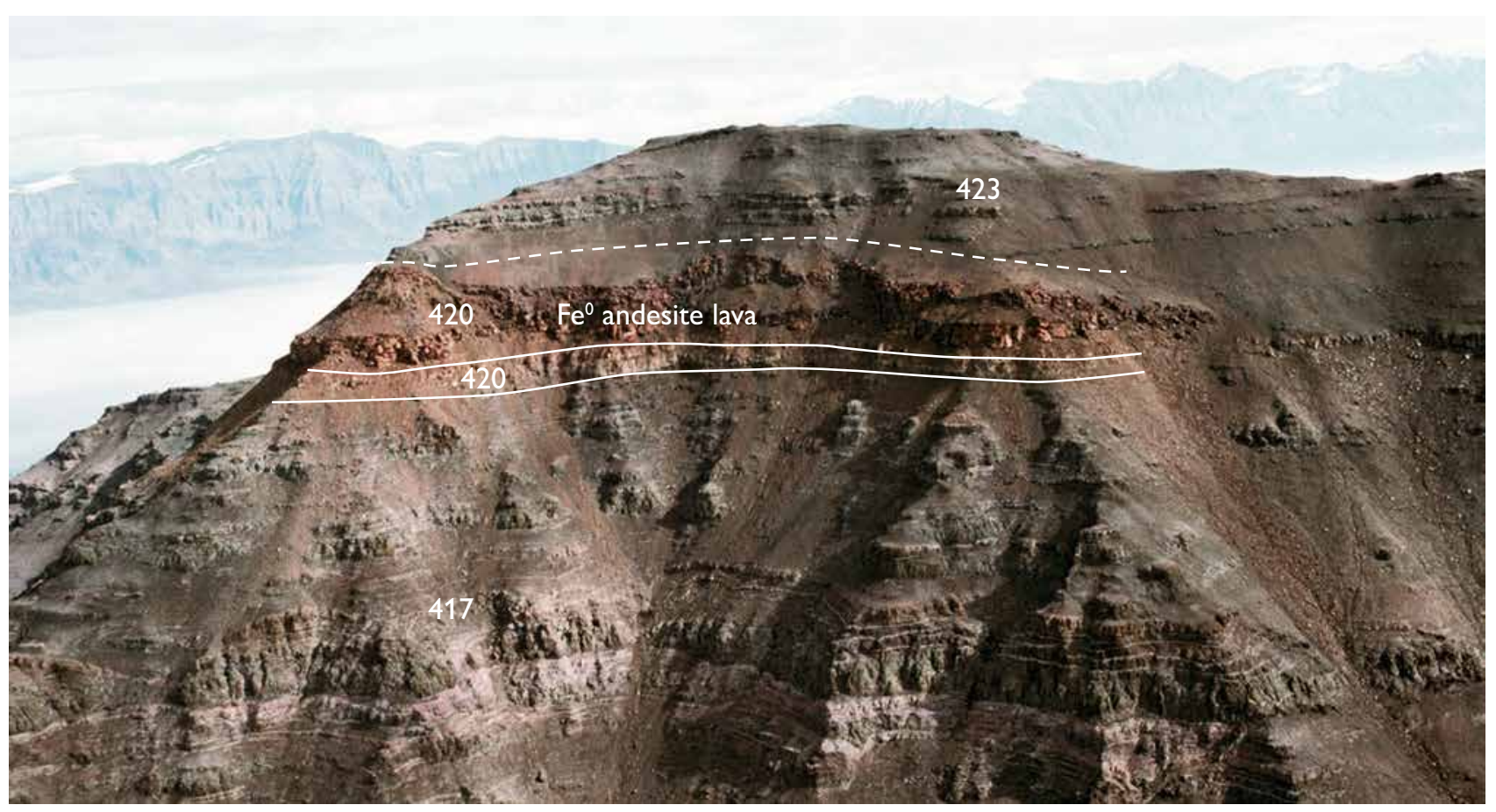

Fig. 99. Satellite lava field of the Asuk Member in the Kuugannguaq area. Two thin, light grey contaminated basalt lava flows (420) and an overlying thick, rusty brown andesite lava with native iron $\left(\mathrm{Fe}^{\mathbf{0}}\right)$ marks the proximity to an eruption site in the northern end of the Kuugannguaq valley. The Asuk Member succession is around $40 \mathrm{~m}$ thick. Kuugannguup Innartaa, northern Disko. 


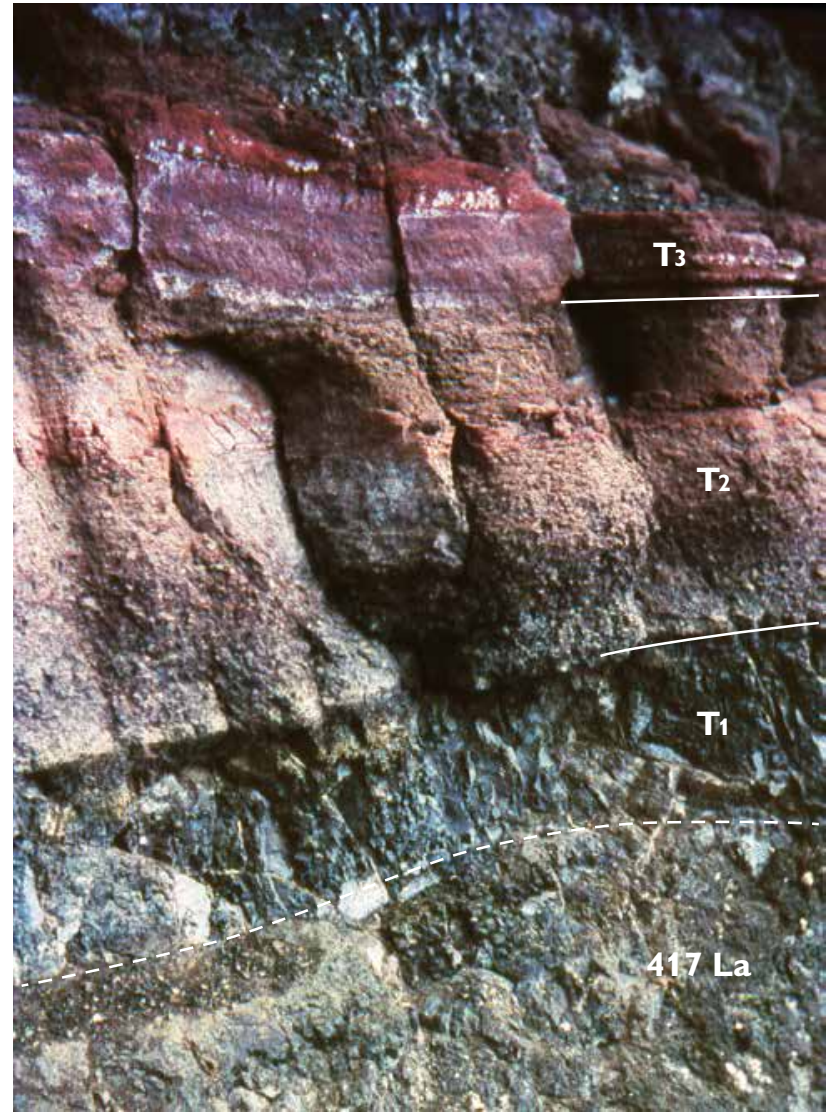

Fig. 100. Three tuff horizons (T1-T3) with a combined thickness of $80 \mathrm{~cm}$ at the base of the Asuk Member at Maniillat, northern Disko. See text for descriptions of the tuffs.

by a $25 \mathrm{~cm}$ thick sandy tuff $\left(\mathrm{T}_{3}\right)$ which is weathered and contains a mixed assemblage of graphite andesite clasts, orthopyroxene crystals, picrite clasts, plant debris and sharp-edged grains of non-volcanic quartz and feldspar (plagioclase and microcline) and clay (Fig. 101A). The tuff is highly oxidised on the top, and a cast of a tree trunk $15-20 \mathrm{~cm}$ in diameter was found at the contact to the overlying Asuk Member lava flow. A partly burnt and partly silicified wood fragment is preserved $60 \mathrm{~cm}$ above the base of the lava flow. The main component of the tuff is interpreted as an airfall tuff from the Ilugissoq volcano on Nuussuaq described below. During the time of deposition of the small tuff succession, local soil beds allowed the growth of trees.

Small tuff basin at Asuk. An up to $1.5 \mathrm{~m}$ thick deposit of silicified mudstone with tuffs has accumulated in a depression in the top surface of the subaqueous andesite flow at Asuk. The small basin is covered by a columnarjointed lava flow of basaltic andesite (Fig. 94). There are at least seven tuff layers of which six are basic, aphyric or with scattered microphenocrysts of orthopyroxene, and likely to be of very local origin. However, tuff no. 3, 30$34 \mathrm{~cm}$ from the base, (Fig. 101B) is a graphite andesite tuff with orthopyroxene phenocrysts and subordinate picrite glass clasts (Pedersen \& Larsen 2006, table 1 nos $13,14)$. This tuff is identical in appearance to the tuffs from the Ilugissoq graphite andesite volcano on Nuussuaq (Pedersen et al. 1989; Pedersen \& Larsen 2006). The occurrence of this characteristic tuff allows a firm correlation between the Asuk Member on Disko, the Ilugissoq volcano and the tuffs in Agatdalen on Nuussuaq (see below).

Intrusions. Over a distance of about $5 \mathrm{~km}$ from Qullissat and southwards, a number of isolated exposures of nativeiron-bearing basaltic andesite occur below $300 \mathrm{~m}$ altitude (see also Fig. 161). The exposures form columnar-jointed masses surrounded by Quaternary landslides and solifluction. No contact relations to Cretaceous or Tertiary sediments are preserved. At Nuungarut (see also Fig. 161), a small landslide has carried the rocks down to the shore and here Steenstrup (1900, p. 268) briefly described an intrusive rock with native iron and graphite and pointed out its similarity to the native-iron-bearing andesite at Asuk. The exposures are interpreted as a high-level sill belonging to the Asuk Member but spatially separated from any equivalent volcanic rocks by at least $10 \mathrm{~km}$.

On the south coast of Nuussuaq, a 30-40 m thick sill of basaltic andesite has intruded the upper part of the Quikavsak Formation over a horizontal distance of about $15 \mathrm{~km}$ from Niiortuut to just east of Ataata Kuua (South Nuussuaq section at c. $26 \mathrm{~km}$ to $41 \mathrm{~km}$; see also Fig. 128). The sill is frequently landslipped. Because of its occurrence just beneath the Niiortuut unit the sill was thought to be related to this, but it is petrographically and geochemically completely different from the Niiortuut unit and, on the other hand, very similar to the Asuk Member on Disko to which it must be closely related.

Xenoliths in the Asuk Member on Disko. Xenoliths of magma-modified sediments are widespread in the Asuk Member on Disko although they are scarce or absent in many of the more basic lava flows. The most common type, known from Asuk for more than 130 years (e.g. Törnebohm 1878; Lorenzen 1882; Steenstrup 1882; Nicolau 1900; Melson \& Switzer 1966), is a plagioclaserich rock with graphite, red spinel and in some cases corundum, formed by extensive reaction between magma and mudstone. A particular variety, which is confined to the subaqueous andesite flow with native iron at Asuk, 


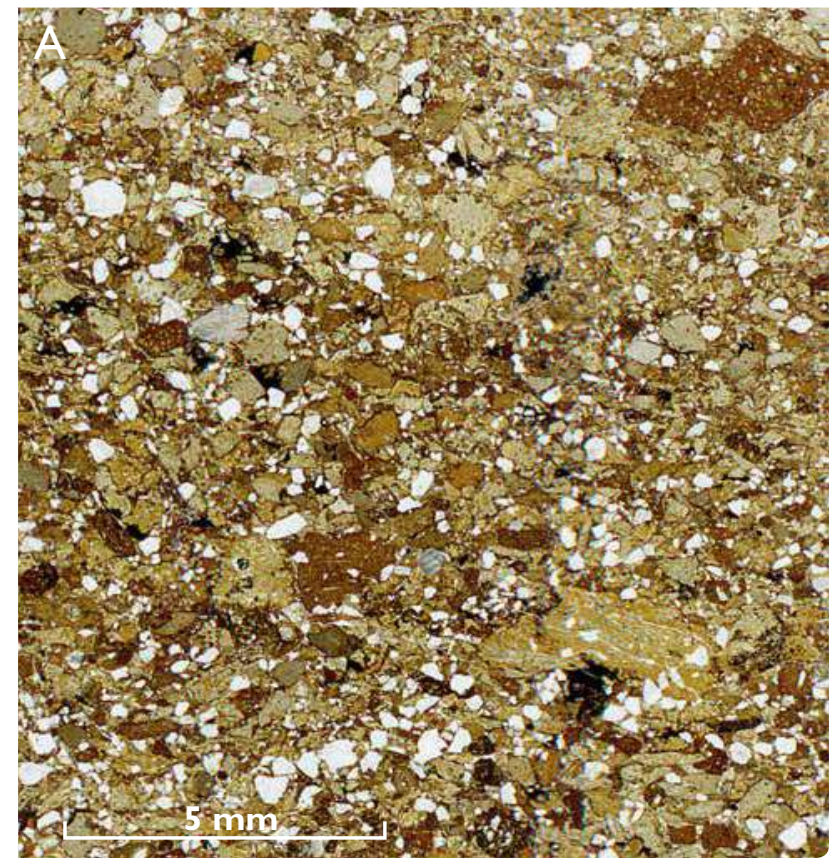

Fig. 101. Thin sections (scanned images) of Asuk Member tuffs. A: The upper, oxidised pyroclastic layer T3 shown in Fig. 100. A reworked and oxidised volcaniclastic rock with clasts of orthopyroxene-bearing graphite andesite, picrite, quartz, microcline, plagioclase, clay minerals and plant fragments. Sample 113217. B: Tuff layer $c .34 \mathrm{~cm}$ above the base of the mudstone basin on top of a subaqueous lava flow at Asuk, see Fig. 95. The tuff is normally graded and composed of clasts of orthopyroxene-bearing graphite andesite and picrite glass and is identical to tuffs from the Ilugissoq volcano. Sample 326771 .

contains non-stoichiometric spinel the formation of which requires very high temperatures and rapid quenching (Pedersen 1978a).

Much less magma-modified mudstone xenoliths from Asuk have preserved sedimentary structures and now carry reduced oxides, native iron and troilite. The high sulfur contents indicate that the mudstones are marine, in accordance with the widespread iron sulfides in the native-iron-bearing volcanic rocks (Pedersen 1979a; Pedersen \& Rønsbo 1987). See the section on 'Carbon, sulfur and native iron in the Asuk Member' in the chapter on geochemistry; see also the chapter on crustal contamination, with analytical data, in Pedersen et al. (2018).

Sandstone xenoliths and xenocrystic quartz are much less common than the plagioclase-graphite-spinel rocks but they are not rare. One $8 \mathrm{~m}$ thick lava flow in Norddalen carries numerous partially melted and vesiculated sandstone xenoliths up to $20 \mathrm{~cm}$ in size. Despite careful search, no limestone xenoliths have been found.

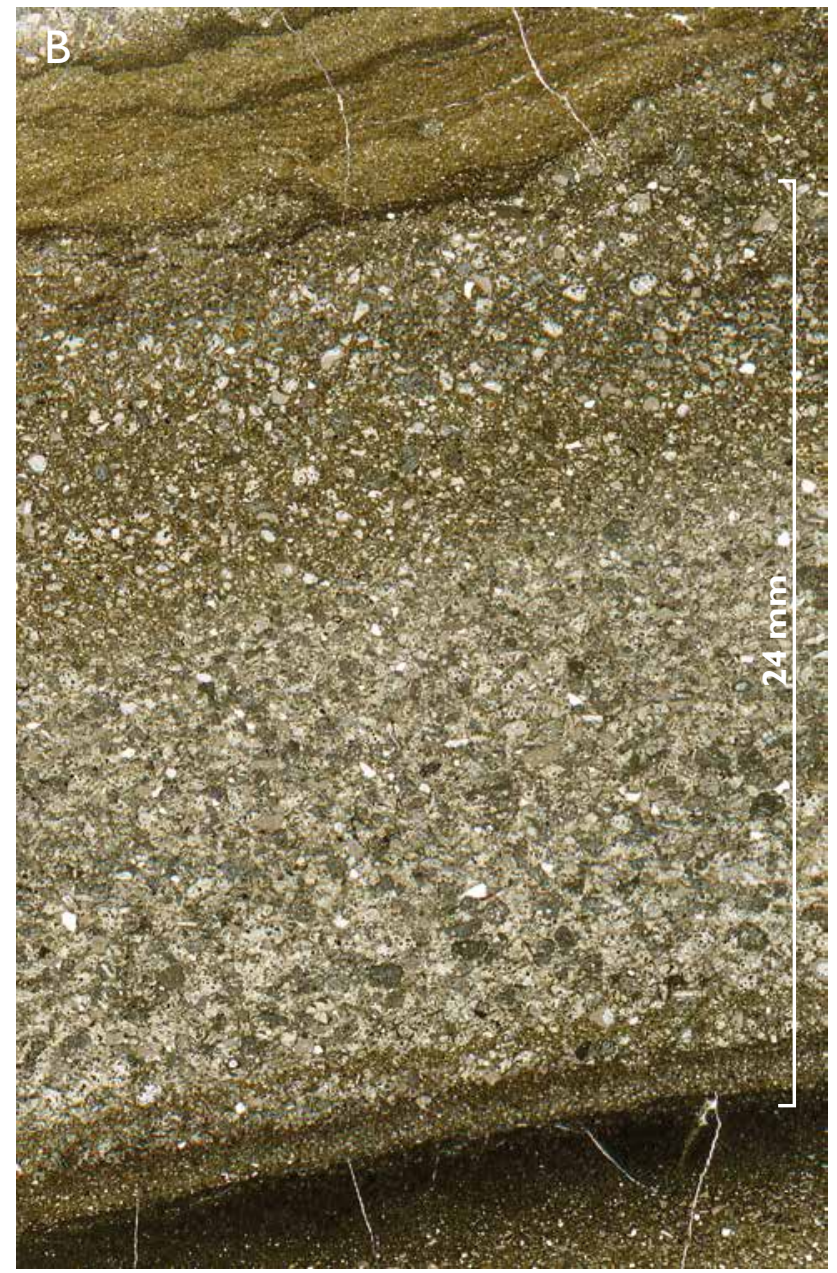

From an overall assessment of the sediment lithologies picked up from the sidewalls of the high-level magma reservoirs, it can be concluded that marine mudstone was dominant while sandstone was subordinate but also widespread.

\section{The llugissoq graphite andesite volcano (part of unit 420)}

The Ilugissoq volcano is the largest known individual volcanic eruption site of the Vaigat Formation and was described in some detail by Pedersen \& Larsen (2006). It is situated on Nuussuaq in the eastern side of the Ilugissoq valley and extends into the northern side of the Aaffarsuaq valley. It consists of a row of four, partly overlapping cones (cones A-D) of pyroclastic graphite andesite extending roughly NNW-SSE for at least $4.2 \mathrm{~km}$ (Fig. 102). The northern end of the row is beneath exposure level whereas the southern end is partly eroded away and 


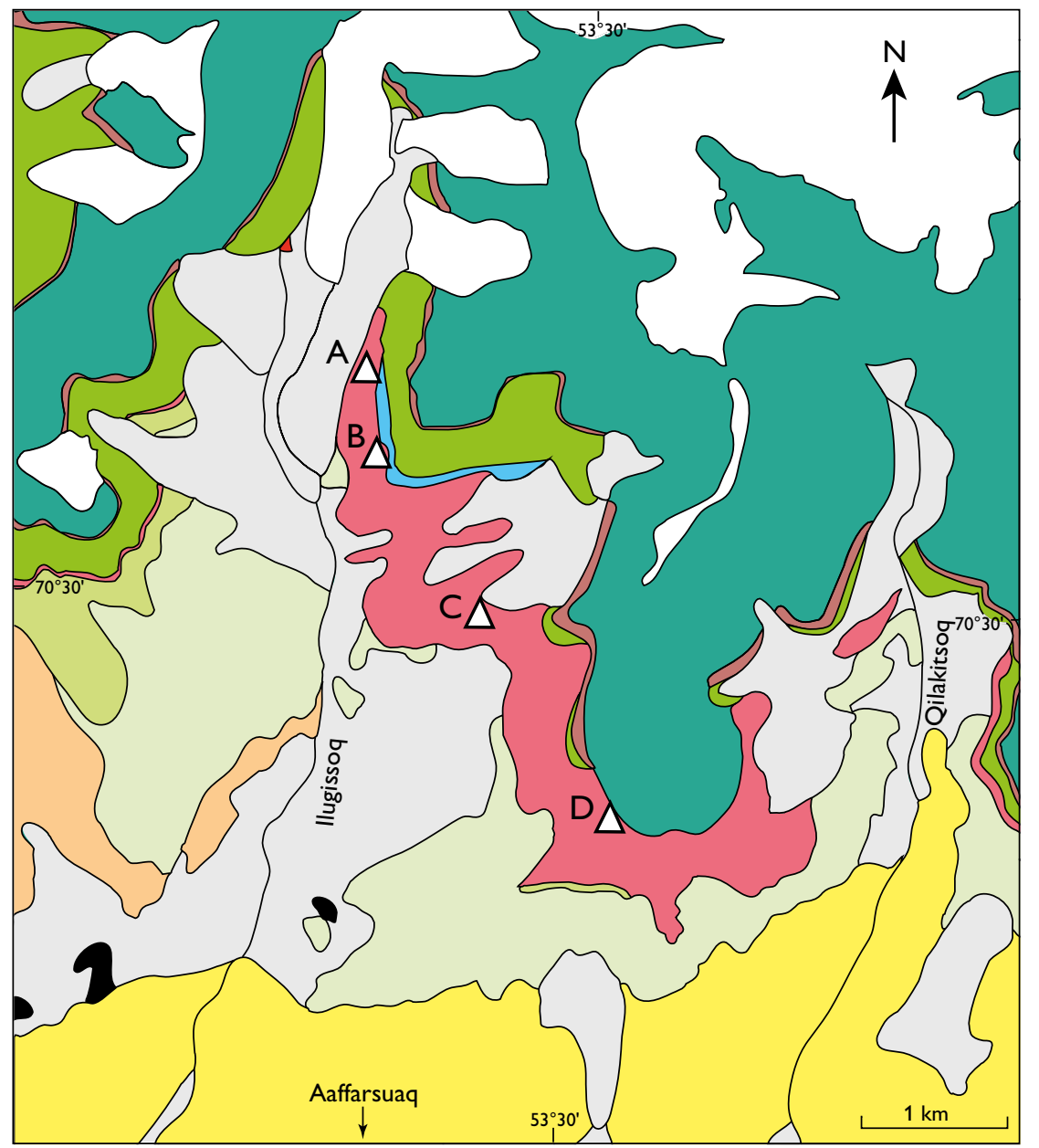

$\square$ Ice

Quaternary cover

Ordlingassoq Member

Picritic lavas

Tunoqqu Member

Contaminated lavas (marker horizon)

Naujánguit Member (unit 423)

Picritic lavas

Naujánguit Member (unit 423)

Picritic hyaloclastites and pillow breccias

$\triangle$ Volcanic cone

Ilugissoq volcano

Graphite andesite tuffs

Naujánguit Member (unit 417)

Picritic lavas

Naujánguit Member (unit 417)

Picritic hyaloclastites and pillow breccias

Nuuk Killeq Member

Contaminated basalt hyaloclastites

Late Cretaceous to

Paleocene mudstones

Cretaceous clastic sediments,

mostly sandstones

Fig. 102. Map of the Ilugissoq graphite andesite volcano, central western Nuussuaq. Modified from Pedersen \& Larsen (2006).

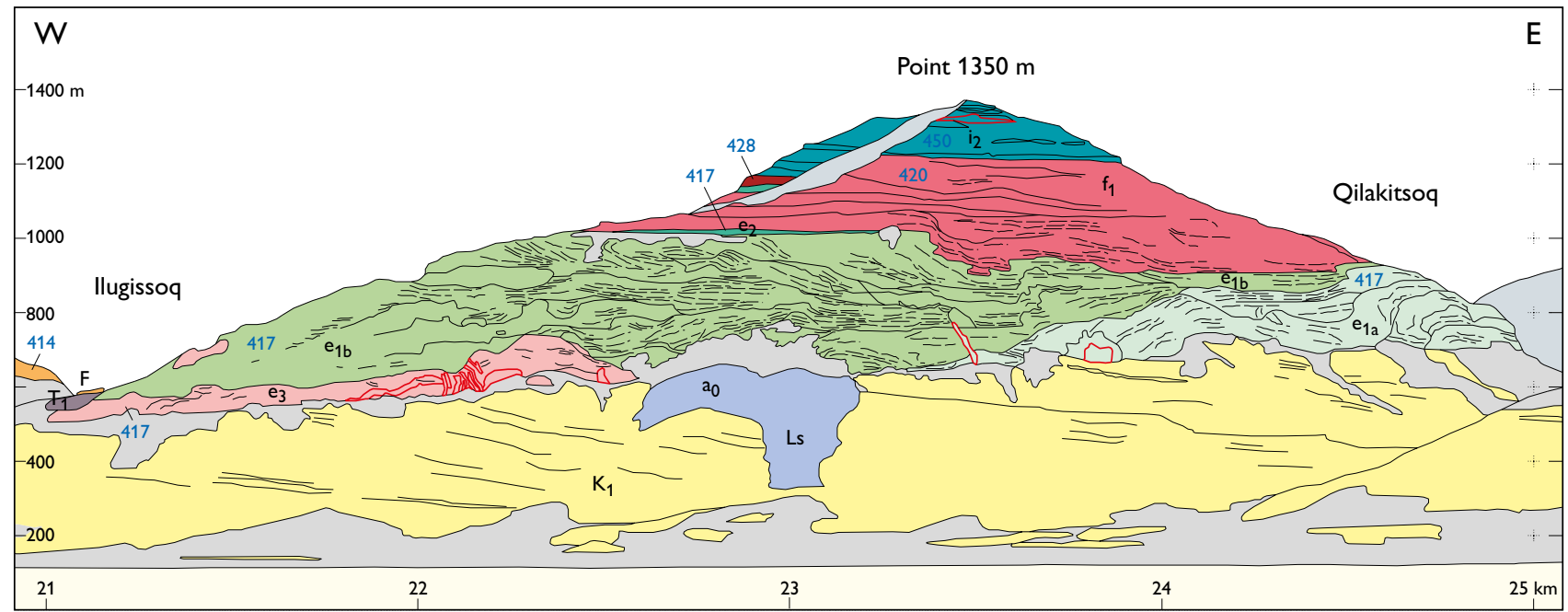

Fig. 103. Photogrammetrically measured section along the north side of the Aaffarsuaq valley, showing the southern part of the Ilugissoq graphite andesite volcano (pink unit 420). Blue numbers are unit codes; other unit annotations are from the original. Excerpt from the Central Nuussuaq section at $21-25 \mathrm{~km}$ (Pedersen et al. 2002a). 
may have extended farther into the Aaffarsuaq valley. The volcano and its satellite at Nuuk Killeq (see below) were emplaced just west of a major fault zone (fault $\mathrm{P}$ of Chalmers et al. 1999a) that was active several times during the evolution of the Nuussuaq Basin and which has down-thrown the Atane Formation more than $300 \mathrm{~m}$ (Dam et al. 2009).

The volcano erupted onto a marine shelf composed of foreset-bedded picritic hyaloclastites of Naujánguit Member unit 417. The southern flank of the volcano is shown in Figs 103, 104A. The two northern cones A and B (Fig. 104B) are exposed in the north-eastern side of Ilugissoq where they cover the picritic hyaloclastites and rise from a palaeo-water depth of several hundred metres to just above the palaeo-sea level. Their flanks are covered by picritic hyaloclastites of the overlying unit 423 , and their eroded tops are covered by a few subaerial picritic lavas. The two southern cones $\mathrm{C}$ and D (Fig. 105) reached well above sea level, and the highest cone, $\mathrm{D}$, may have reached $200 \mathrm{~m}$ out of the sea. Before being buried by younger lava flows, cone $\mathrm{D}$ was levelled by erosion and is now $160 \mathrm{~m}$ above the palaeo-sea level (Fig. 103). The western flank of cone D (Fig. 104A) rests on a few subaerial picrite flows of unit 417 which overlie $c$. $400 \mathrm{~m}$ of hyaloclastites, showing that the infilling of the marine embayment had just been completed at this site before the eruption of the volcano began.

The Ilugissoq volcano is estimated to have covered an area of at least $19 \mathrm{~km}^{2}$, based on extrapolation of existing exposures where the thickness exceeds $100 \mathrm{~m}$. If areas with more than $10 \mathrm{~m}$ of pyroclastic rocks are included, the volume of pyroclastic products from the volcano is estimated to exceed $5 \mathrm{~km}^{3}$.

Despite the presence of the well-defined volcanic cones, no well-defined feeder bodies have been found. A compact, black and very well-preserved pyroclastic rock occurs in a small gully between cones B and C (Fig. 106) which resembles a non-fragmented dyke rock, and this is interpreted to be part of the feeder system. Furthermore, beneath cone $\mathrm{C}$ there are bodies of pyroclastic rocks from the volcano which form irregular intrusions into older hyaloclastite.

Lithologies. The Ilugissoq volcano is composed of pyroclastic rocks which can be classified as coarse tuffs and lapilli tuffs (Schmid 1981) of both subaerial and phreatic character. Despite a careful search, no subaerial lavas or pillow lavas have been found. The dominant rock type is orthopyroxene-phyric magnesian andesite and basaltic andesite (54.3-58.3 wt $\% \mathrm{SiO}_{2}, 7.3-9.8 \mathrm{wt} \% \mathrm{MgO}$ ) rich in disseminated flakes of graphite. The graphite (typically $2-3 \mathrm{wt} \% \mathrm{C}$ ) imposes a dark grey colour on the fresh rock. The weathered rocks have rusty colours due to disseminated sulfides. The rocks contain an assemblage of magma-modified mudstone and scarce sandstone xenoliths. Cognate inclusions of graphite-poor andesite and contaminated basalt also occur, together with an assemblage of picritic clasts derived from hyaloclastite, pillows and crystalline rock.

The airfallen lapilli tuffs from the subaerial cones are crudely bedded (Fig. 107). Along the eastern flank of the volcano, a thick apron of pyroclastic material fell in a shallow, partly marine environment and on a shelf slope below up to more than $100 \mathrm{~m}$ water depth (Pedersen $\&$ Larsen 2006, fig. 5; Fig. 103) to form thick, fine-bedded tuff layers (Fig. 108), in places disturbed by small mudflows.

Graphite andesite tuffs outside the central crater area of the Ilugissoq volcano. The central crater area is delimited by the eastern side of the Ilugissoq valley, the western side of the Qilakitsoq valley and the northern side of the Aaffarsuaq valley (Fig. 102). Outside this area, graphite andesite tuffs have been found at a number of localities within $10 \mathrm{~km}$ of the central area (e.g. unit $\mathrm{f} 1$ in the Central Nuussuaq section at 11.5 and $29.3 \mathrm{~km}$ ). The pencilgrey, smudging graphite is very distinctive even in highly weathered tuff dug out from below scree.

Most notable is a $35 \mathrm{~m}$ thick horizon of graphitic, tuffaceous, clastic sediments on the western side of Ilugissoq c. $2 \mathrm{~km}$ west of cones A and B (Pedersen et al. 1989; Fig. 109). Some of the tuff horizons are cemented and fairly erosion-resistant. The tuffs may be well sorted (Fig. 110). The most coarse-grained beds reach clast sizes in excess of $1 \mathrm{~cm}$, and in addition to clasts of graphite andesite and picrite they contain magma-modified mudstone xenoliths (Fig. 110). The tuffaceous sediments have yielded Paleocene dinoflagellate cysts (Piasecki et al. 1992, loc. 7), and with a present altitude of $c .1150 \mathrm{~m}$ a.s.l. they are the highest uplifted marine sediments recorded in the Nuussuaq Basin.

Graphite andesite tuffs in sediments in the Agatdalen area are described in a separate section below.

Xenoliths in the Ilugissoq graphite andesite. Xenoliths are very common in the pyroclastic rocks of the Ilugissoq volcano. The most frequent type consists of magma-modified mudstone, whereas more scattered types include quartz-rich sandstone and very rare limestone (some with enclosed fossiliferous wood) derived from carbona- 


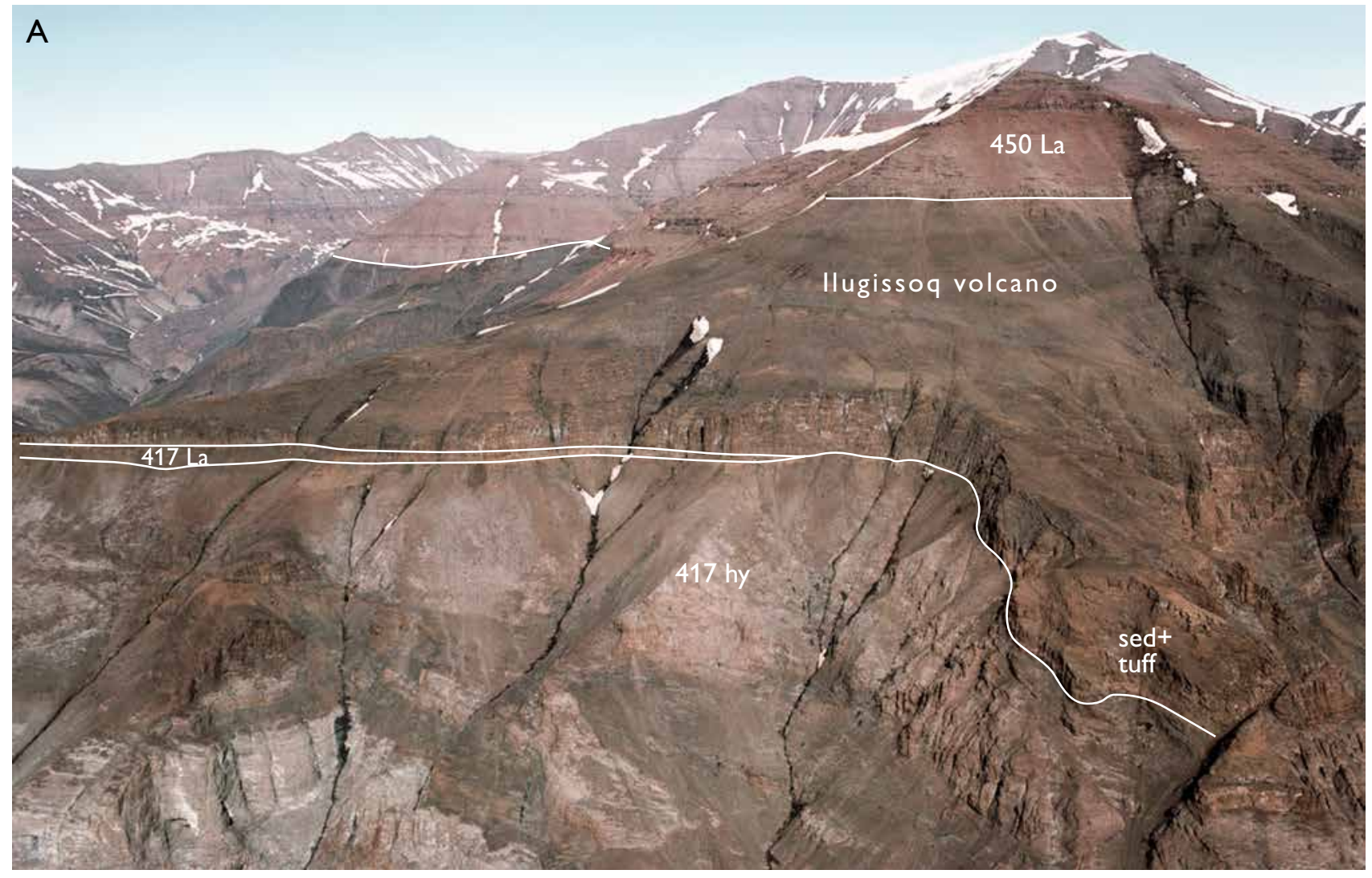

B

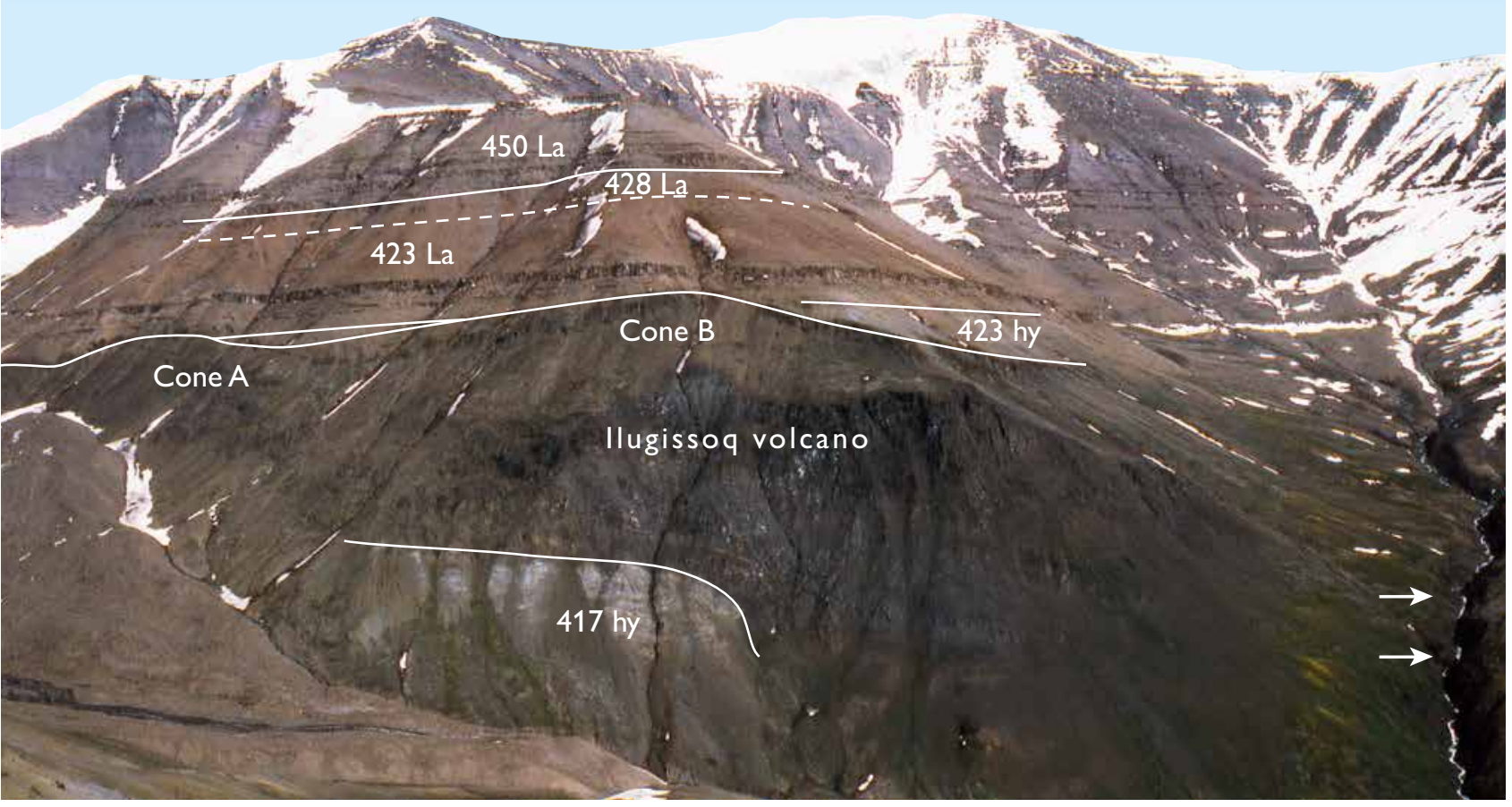




\section{Facing page:}

Fig. 104. Two views of the Ilugissoq graphite andesite volcano. A: The southern part of the volcano viewed from the south; see also Fig. 103. Dark subaerial pyroclastic deposits erupted from cone D (Fig. 102) cover a few subaerial picrite flows of the Naujánguit Member ( $417 \mathrm{La})$. To the right, the marine embayment is filled out downslope with subaqueous tuffs and sediments (sed + tuff). The top of the volcano is eroded away and covered by subaerial picrite lavas of the Ordlingassoq Member ( $450 \mathrm{La}$ ). Beneath the volcano are older picritic hyaloclastites (417 hy). Height of section c. $500 \mathrm{~m}$. B: The northern part of the volcano with cones $\mathbf{A}$ and $\mathbf{B}$, viewed from the west. Part of the original marine shelf slope with picritic hyaloclastites ( $417 \mathrm{hy}$ ) is preserved and cut and covered by black graphite andesite tuffs from the volcano. The flanks of the cones are partly covered by younger picritic hyaloclastites ( $423 \mathrm{hy}$ ), indicating that the northern cones reached just above sea level. Subaerial lava flows of the Naujánguit (423 La) and Tunoqqu (428 La) members cover this northern part of the volcano but not its southern part seen in A. On the top, lava flows of the Ordlingassoq Member (450 La) occur. The most compact and best preserved pyroclastic rocks from the volcano were found in the small gully to the right marked by white arrows. Height of section $c .700 \mathrm{~m}$.

ceous concretions in Cretaceous sediments (Pedersen \& Larsen 2006). The minerals in the mudstone xenoliths indicate several stages of sediment-magma reaction, and one assemblage consists of a plagioclase-graphite rock with stellate mullite that is partly pseudomorphosed by magnesian spinel (Fig. 111). This characteristic texture has also been observed in native-iron-bearing rocks from Disko, but there the mullite has completely reacted out to spinel + plagioclase, leaving only the stellate texture behind. The dominance of mudstone xenoliths and the abundance of disseminated graphite in the sulfide-bearing graphite andesites leaves no doubt that the high-level magma reservoir of the Ilugissoq volcano resided within Cretaceous (or pre-Cretaceous) marine mudstones of the Nuussuaq Basin.

A satellite to the Ilugissoq volcano at Nuuk Killeq. About $10 \mathrm{~km}$ south of cone D of the Ilugissoq volcano a possible satellite of this is exposed in the steep mountain wall facing the Vaigat sound above Nuuk Killeq (Larsen \& Pedersen 1988; South Nuussuaq section at $c .18 \mathrm{~km}$ ). Here, a very prominent $45 \mathrm{~m}$ thick and $1 \mathrm{~km}$ wide lava flow at $860-900 \mathrm{~m}$ altitude is a native-iron-bearing graphite andesite with $60-61 \mathrm{wt} \% \mathrm{SiO}_{2}$ and 3-7 wt\% $\mathrm{MgO}$ (calculated volatile-free). It has a distinctive rusty colour discernible from a distance of more than $10 \mathrm{~km}$ (Fig. 112). Small dykes of graphite-rich basalt or andesite have been observed in the steep mountain-wall beneath the lava flow and represent the local feeders to the flow (Ulff-Møller 1991). In a partly scree-covered exposure east of the lava flow there is a $c .10 \mathrm{~m}$ thick scoriaceous pyroclastic rock rich in black xenoliths of magma-modified mudstone that is interpreted as a local crater breccia facies of graphite andesite. In thin section the graphite imposes a very unusual reticulate texture to this igneous rock (Fig. 113).
Fig. 105. The southern part of the Ilugissoq volcano with the eroded top of cone $\mathbf{D}$, viewed from the west. The cone rose to well above sea level and is onlapped by younger lava flows of the Naujánguit Member (423 La) and a flow of the Tunoqqu Member ( $428 \mathrm{La}$ ). Traces of soil are found on the flank and top of the cone (white arrows). Cone $\mathbf{D}$ was subsequently overflowed by lavas of the Ordlingassoq Member $(450 \mathrm{La})$. Height of section $c .550 \mathrm{~m}$.

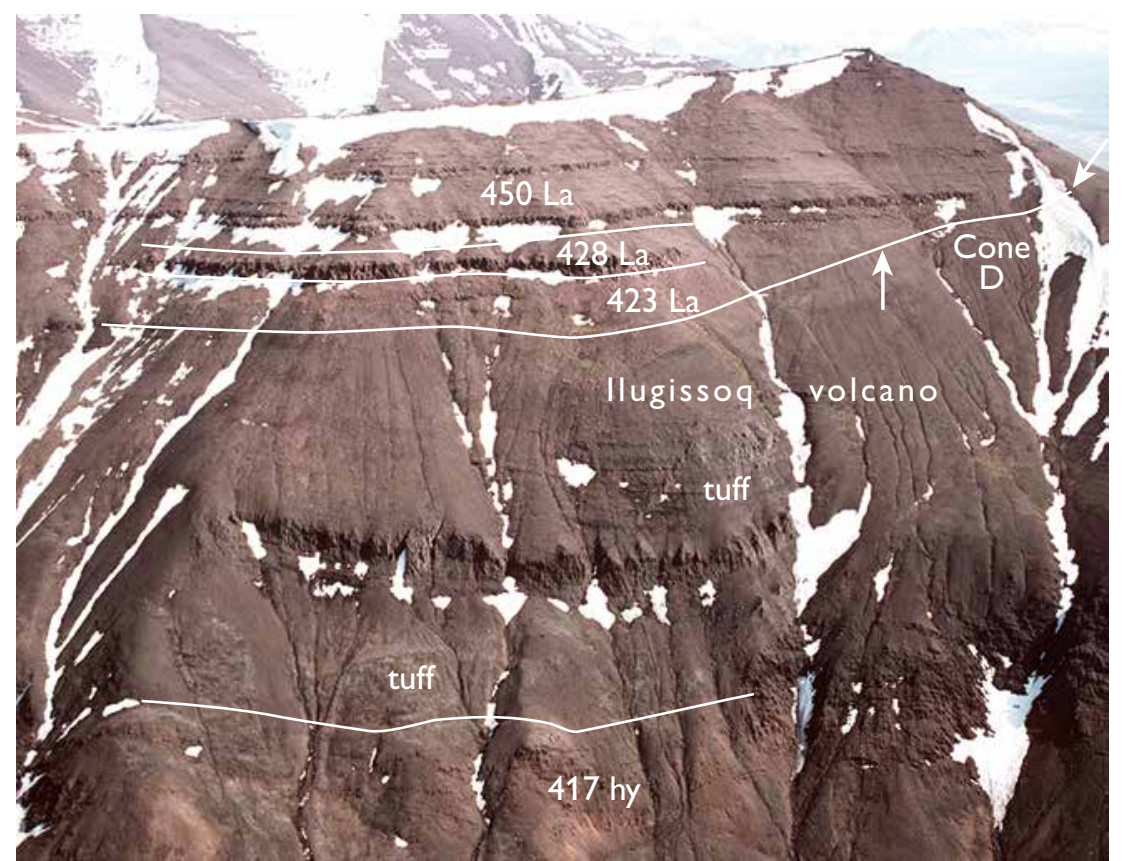




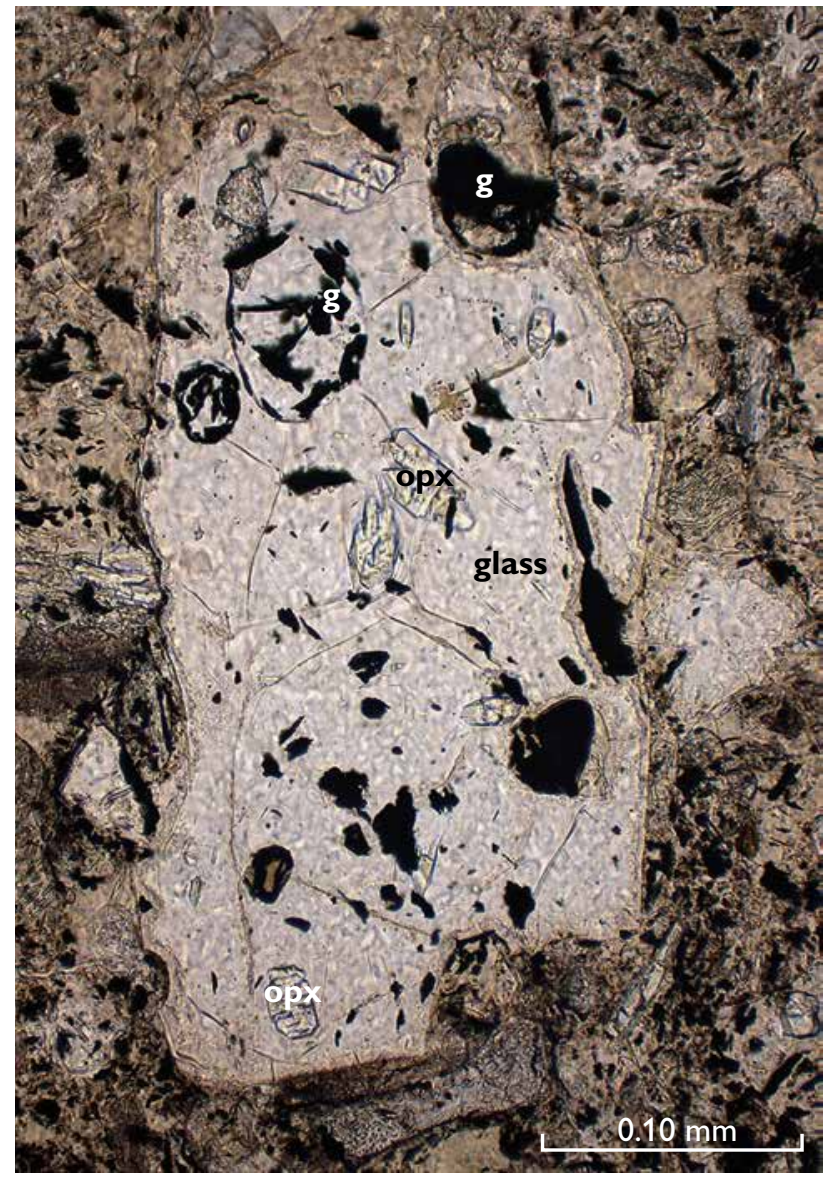

Fig. 106. Microphotograph (plane polarised light) of the most compact graphite andesite tuff from the root zone of the Ilugissoq volcano. The dominant lithology comprises clasts of clear andesite glass with orthopyroxene microphenocrysts (opx) and graphite (opaque, g). Gas bubbles commonly formed around the graphite during the eruption. The matrix is rich in altered glass and clay minerals. Sample 400286.

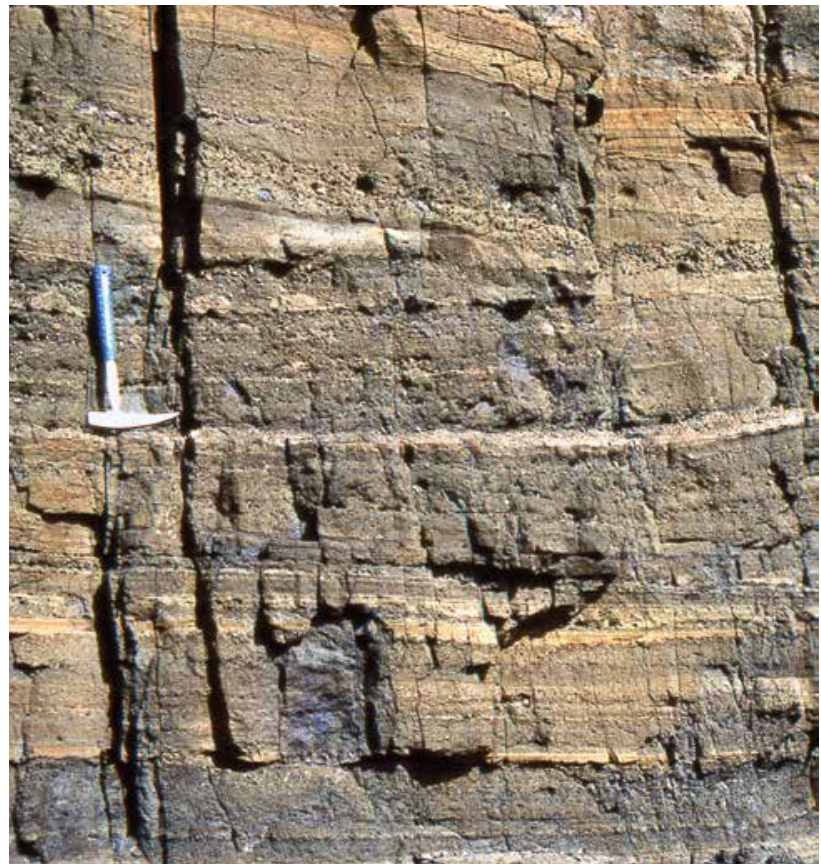

Fig. 108. Finely bedded, volcaniclastic layers of tuffs from the Ilugissoq volcano deposited in a near-shore marine environment beneath cone $\mathrm{D}$. Individual tuff beds are up to $10 \mathrm{~cm}$ thick and vary in grain size and sorting. Many beds are uniform in thickness. Above the hammer a moderately sorted bed pinches out over a distance of $c$. $1 \mathrm{~m}$. The overlying, coarse-grained bed appears to truncate beds at its base in the right part of the photo. The structures most probably formed during eruption and rapid deposition of repeated showers of material through the shallow water column.

Length of hammer $32 \mathrm{~cm}$.

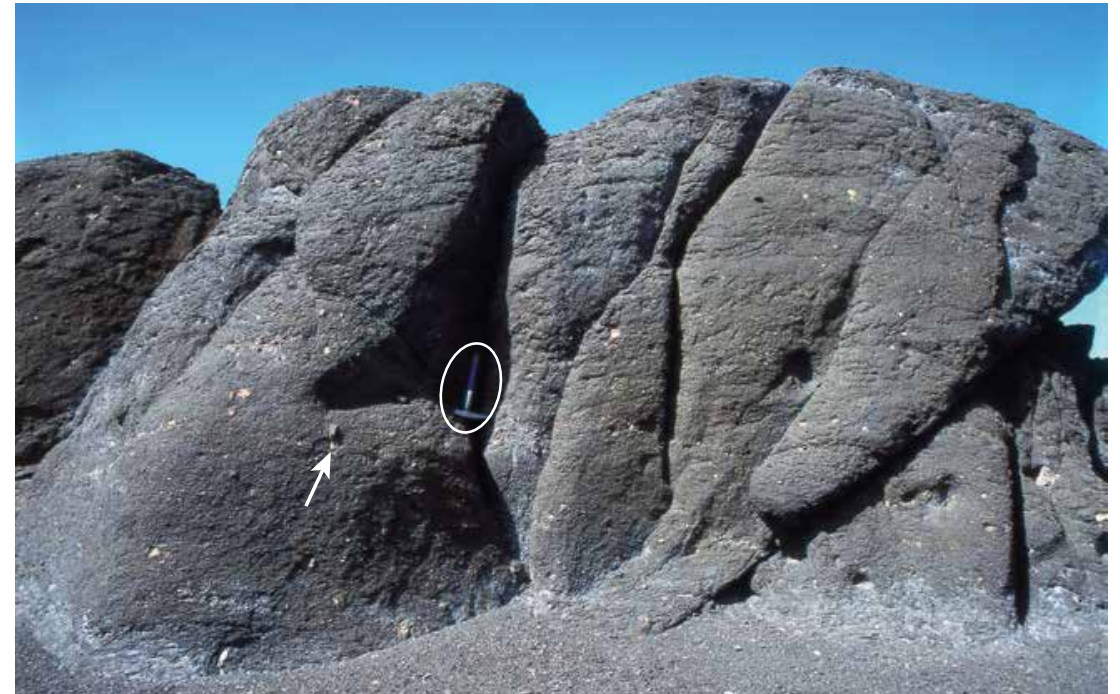

Fig. 107. Crudely bedded, dark grey lapilli tuffs of graphite andesite from the subaerial cone C (Fig. 102) of the Ilugissoq volcano. Note the whitish grey clasts of hydrothermally altered, contaminated basalt (at arrow) which indicate that the volcano had an early basaltic component. Length of hammer (encircled) $32 \mathrm{~cm}$. 


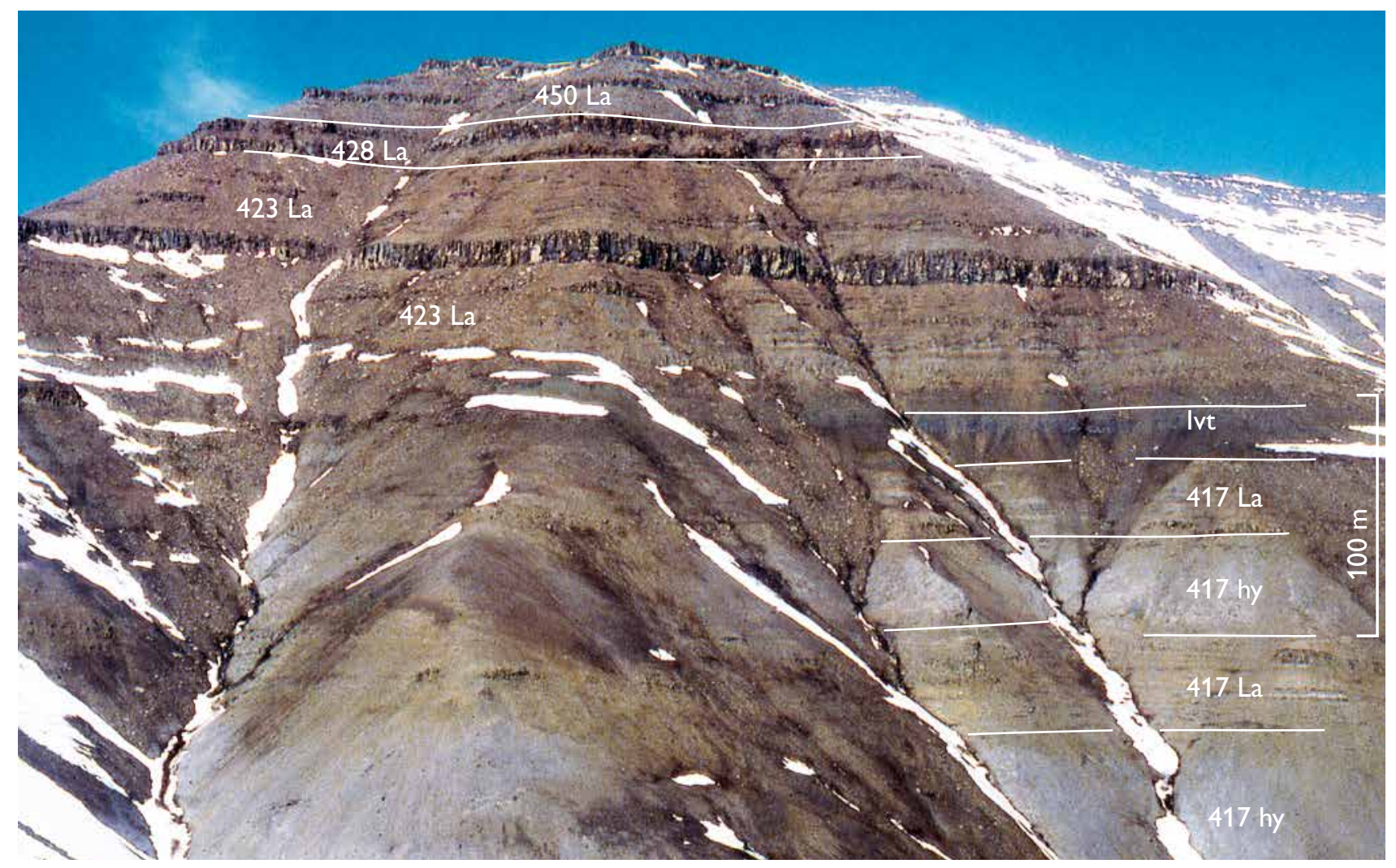

Fig. 109. The western side of the Ilugissoq valley with a 30-35 m thick succession of dark grey reworked graphite andesite tuffs (Ivt) from the Ilugissoq volcano (see Pedersen et al. 1989 and the Central Nuussuaq section at $19.8 \mathrm{~km}$ ). Dinoflagellates in the tuffs (Piasecki et al. 1992) now at $c .1150 \mathrm{~m}$ a.s.l. make the tuffs the highest uplifted marine strata yet recorded in the Nuussuaq Basin. A number of stratigraphic units of the Vaigat Formation are indicated by their numerical codes (Table 1).

\section{Graphite andesite tuffs in the Abraham Mem- ber in the Agatdalen area, central Nuussuaq}

A very unusual assemblage of tuffs and volcaniclastic sediments occurs within a $10-20 \mathrm{~m}$ thick mudstone succession in the Agatdalen area of central Nuussuaq. The succession was defined as the Abraham Member of the
Agatdal Formation by Rosenkrantz in Koch (1959, p. 75-78) and redefined as the Abraham Member of the Eqalulik Formation by Dam et al. (2009, p. 138-139 and plate 3). Several detailed logs of the Abraham Member were published by Robin et al. (1996, fig. 2).

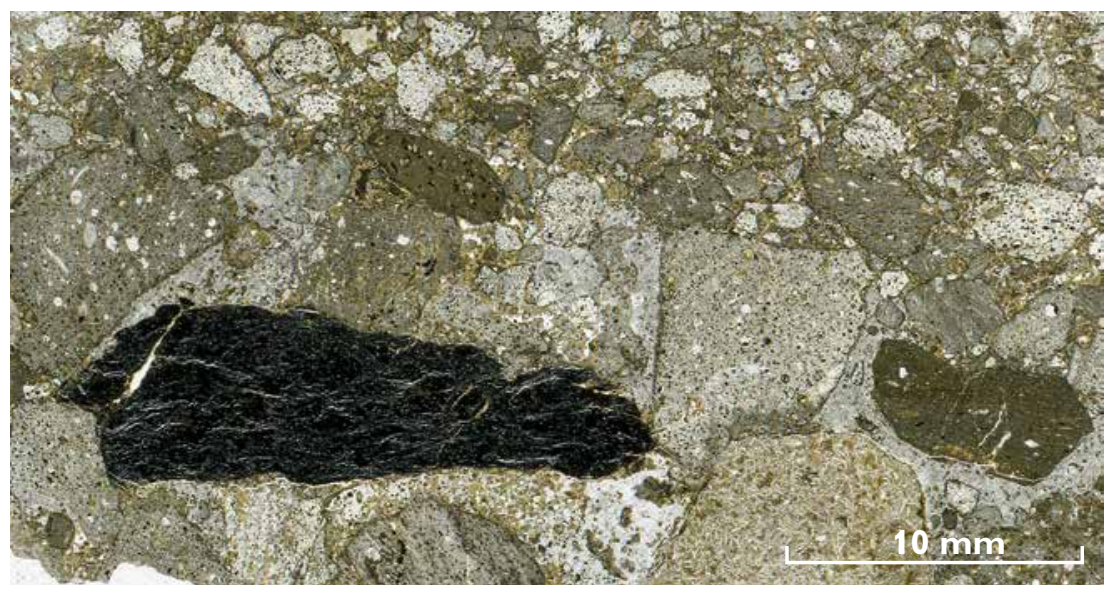

Fig. 110. Thin section (scanned image) of a coarse-grained volcaniclastic sediment with clasts of greenish graphite andesite and subordinate colourless picrite from the Ilugissoq volcano. A $20 \mathrm{~mm}$ long, black magma-modified mudstone clast is also observed. Sample F316, western side of the Ilugissoq valley (locality in Fig. 109). 


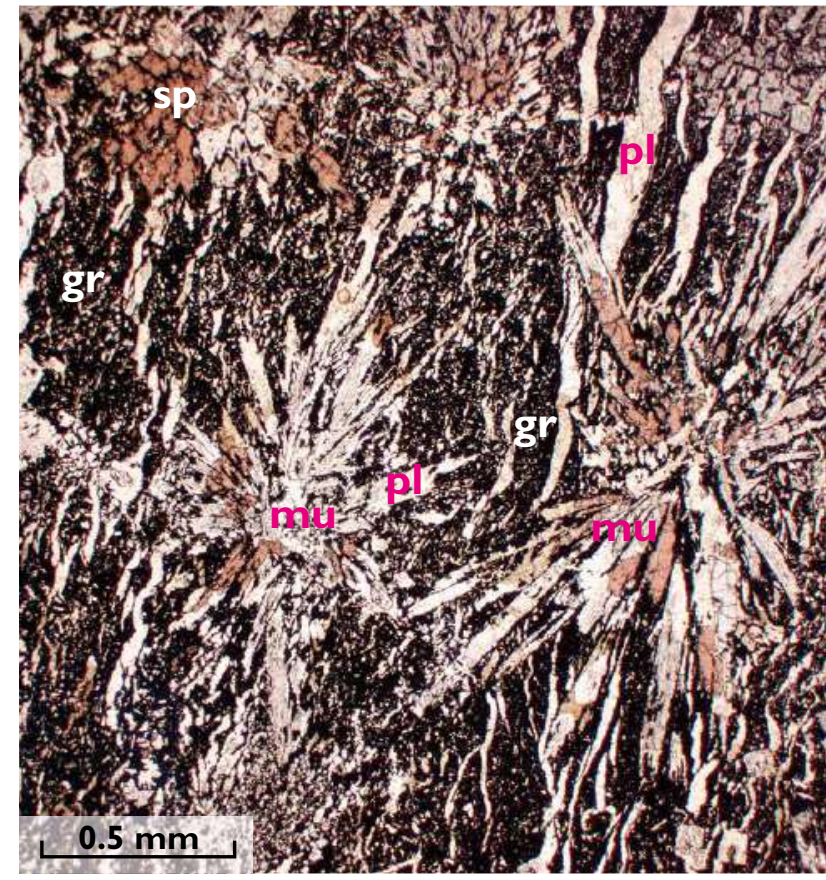

Fig. 111. Microphotograph (plane polarised light) of a magmamodified mudstone xenolith from the Ilugissoq volcano. The rock was originally a mullite-cordierite-graphite-melt rock but has been modified to a spinel-plagioclase-graphite rock. The original stellate mullite clusters are transformed into aggregates of plagioclase ( $\mathbf{p l})$ and spinel (sp) with relict mullite (mu), and their stellate forms are preserved by the abundant graphite (gr). Sample 400293.

Based on a collection of samples taken by A. Rosenkrantz, the tuffs were first described by Pedersen (1978b) who found that the majority of them were graphite-rich magnesian andesites which must have been erupted from a major explosive centre on Nuussuaq. At that time the centre was unknown; it was only later identified as the Ilugissoq volcano (Pedersen \& Larsen 2006; this work) which is now firmly correlated with the Asuk Member on Disko.

Among the Rosenkrantz samples, a loose piece (no. 5646, Pedersen 1978b, fig. 3) from Agatkløft has proved to be of particular importance. It is cemented with carbonate and silica and contains several very well-preserved tuff layers. One of these layers has a main component of native-iron-bearing glass grains of silicic basalt to magnesian andesite which are very inhomogeneous and commonly flow folded. Orthopyroxene is a common phenocryst phase in the andesite grains. The tuff also contains a rich assemblage of pyrometamorphic minerals derived from reaction between basic magma and mudstone; in addition it contains unusual diagenetic sulfides rich in $\mathrm{Cu}, \mathrm{Ni}$ and $\mathrm{Co}$. Many of the glass grains form perfect spherules, a feature which was originally misinterpreted as being due to abrasion (Pedersen 1978b).

The cemented horizon was discovered in situ in 1985 by one of the authors (AKP) in the gully Pyramidedal that leads down to Agatdalen from the north-west, and it has since then received international attention because of the similarity between the spherules of the Agatdal tuff and spherule beds formed by meteorite impact (Margolis et al. 1991, Robin et al. 1996, Jones et al. 2005).

According to our interpretation, the tuff originated by an explosive eruption from a high-level magma chamber within carbon-rich Cretaceous sediments at a stage when sediment-magma reactions had been in progress for some time to produce plagioclase-graphite-spinel assemblages (Pedersen 1978b). The spherules were formed in lava fountains (Robin et al. 1996). Additional evidence for the volcanic origin of the tuff is that the magma was strongly reduced prior to quenching, as indicated by the vanadium-rich composition of its chromites: in reduced state vanadium $\left(\mathrm{V}^{3+}\right.$ and $\left.\mathrm{V}^{2+}\right)$ fits into the chromite lattice (Pedersen 1978b, 1985a). Moreover, orthopyroxene as a phenocryst phase is confined to the strongly sediment-contaminated volcanic rocks of the Nuussuaq Basin.

Lithology of the volcanic components of the Abraham Member. According to Dam et al. (2009, p. 138) "the Abraham Member consists of black and grey sandy mudstones intercalated with fossiliferous reworked volcaniclastic sandstones and basement pebble conglomerates." The depositional environment was marine, and "sedimentary structures in the volcaniclastic sandstones indicate deposition from turbidity currents" (Dam et al. 2009, p. 139).

Some features of the volcaniclastic rocks are further described here based on observations from Pyramidedal. Here, the Abraham Member is $15-20 \mathrm{~m}$ thick and somewhat disturbed by synsedimentary slumping and by later deformation caused by the heavy advancing front of picritic pillow breccias of unit 423 which covered the unconsolidated mudstones. A schematic reconstructed section is shown in Fig. 114. The succession is composed of three parts, a lower $c .5 \mathrm{~m}$ thick section which includes a cemented horizon with a spherule tuff bed, a middle c. $10 \mathrm{~m}$ thick section which contains numerous beds of fossiliferous volcaniclastic sandstones and a $c .4 \mathrm{~m}$ thick upper section of foreset-bedded, volcaniclastic cemented sand.

The lower section $(0-c .5 \mathrm{~m})$. The succession rests on quartzo-feldspathic sandstones which mark the top of 


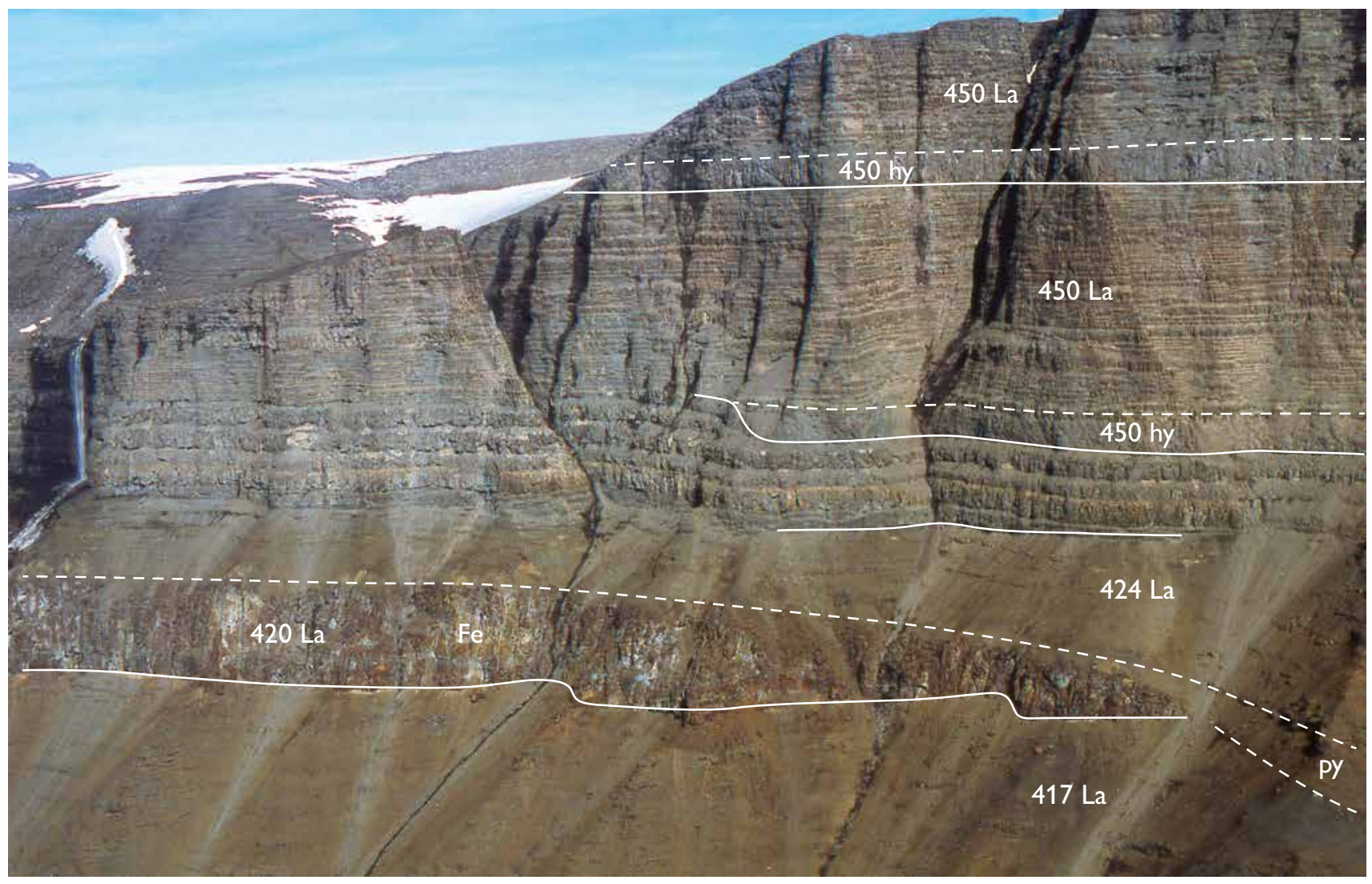

Fig. 112. A $45 \mathrm{~m}$ thick native-iron-bearing graphite andesite lava (420 La) and graphite-rich scoria (py) of the Asuk Member in the steep mountain wall above Nuuk Killeq on the south coast of Nuussuaq (South Nuussuaq section at $c .18 \mathrm{~km}$ ). The flow covers lava flows of the Naujánguit Member ( $417 \mathrm{La}$ ) and is covered by contaminated lava flows of the Tupaasat unit ( $424 \mathrm{La}$ ) of the Tunoqqu Member, followed by picrite lava flows $(450 \mathrm{La})$ and two thin horizons of hyaloclastite ( 450 hy) of the Ordlingassoq Member.

the Andreas Member of the Agatdal Formation (Dam et al. 2009). It consists of mudstones with a few beds of sand and volcaniclastic sand. Above $c .4 \mathrm{~m}$ there is an up to $30 \mathrm{~cm}$ thick, cemented horizon comprising mudstones, tuffs and volcaniclastic beds which are extremely well preserved. The internal beds show pre-diagenetic deformation which ranges from small-scale faulting (Figs $115,117)$ to major slump folding (Fig. 116); hence thicknesses may be very variable. The lowermost part of the

Fig. 113. Thin section (scanned image) of clast of graphite-rich scoria associated with the native-iron-bearing andesite lava flow from Nuuk Killeq (Fig. 112). The graphite ( $4.2 \mathrm{wt} \% \mathrm{C}$ in bulk rock) defines a reticulate texture in the groundmass. A magma-modified mudstone xenolith (Mxen) is seen in the upper right. Sample 113518.

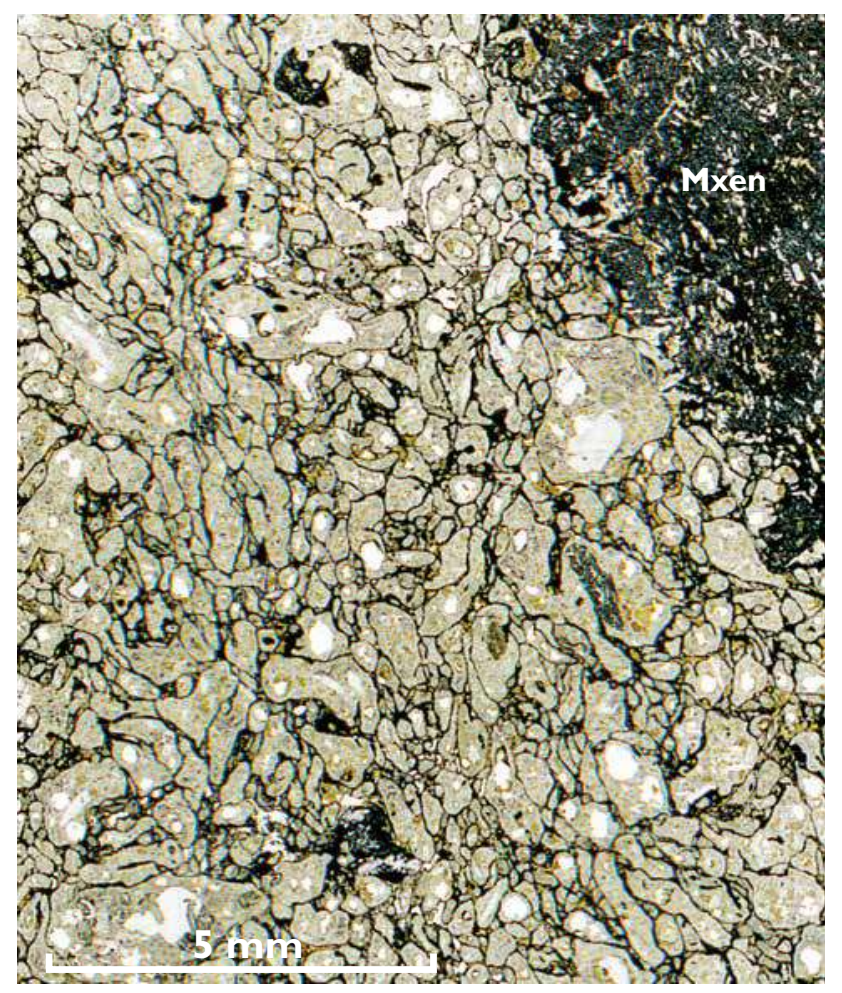




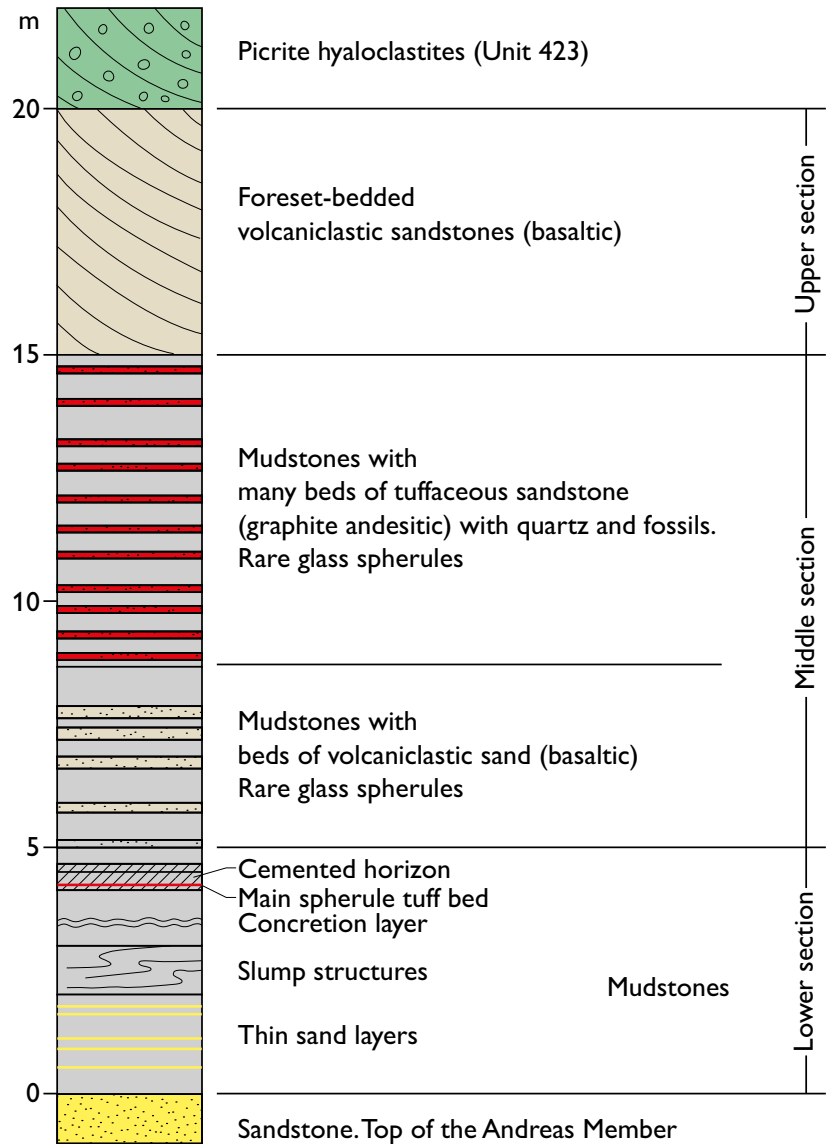

Fig. 114. Schematic reconstructed section of the Abraham Member in the gully of Pyramidedal, northern Agatdalen area, central Nuussuaq. Graphite andesite tuffs are shown in red.

cemented horizon contains the main spherule-rich tuff bed which may be up to $12 \mathrm{~cm}$ thick (Fig. 115). This bed is essentially an air-fall tuff which has only been slightly reworked. A few centimetres above the spherule tuff, and still within the cemented horizon, a number of volcaniclastic beds occur which consist almost entirely of uncon- taminated basaltic glass shards (Pedersen 1978b, table 3 no. 2) and plagioclase phenocrysts. On microscale these beds display pre-diagenetic fault structures (Fig. 117).

The middle section (c. 5-15 m). In the lowermost few metres above the cemented horizon there are several 10$20 \mathrm{~cm}$ thick beds of volcaniclastic sand with schlieren of mudstone. The sand is dominantly composed of basaltic glass grains and plagioclase crystals, and in addition there are rare glass spherules and microxenoliths of plagioclase intergrown with graphite and red magnesian spinel, presumably derived from the underlying spherule tuff. The upper part of the middle section contains many tuffaceous sandstone beds, which in addition to the volcanic components may contain up to $8 \mathrm{~mm}$ large quartz clasts

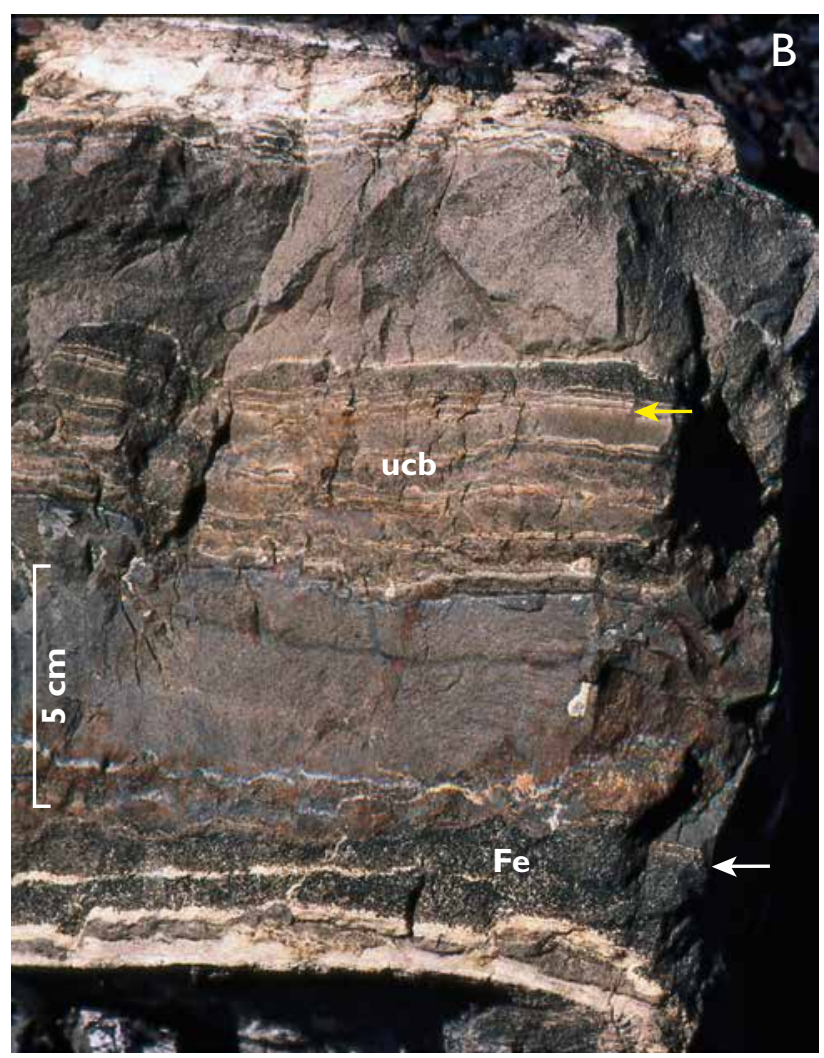

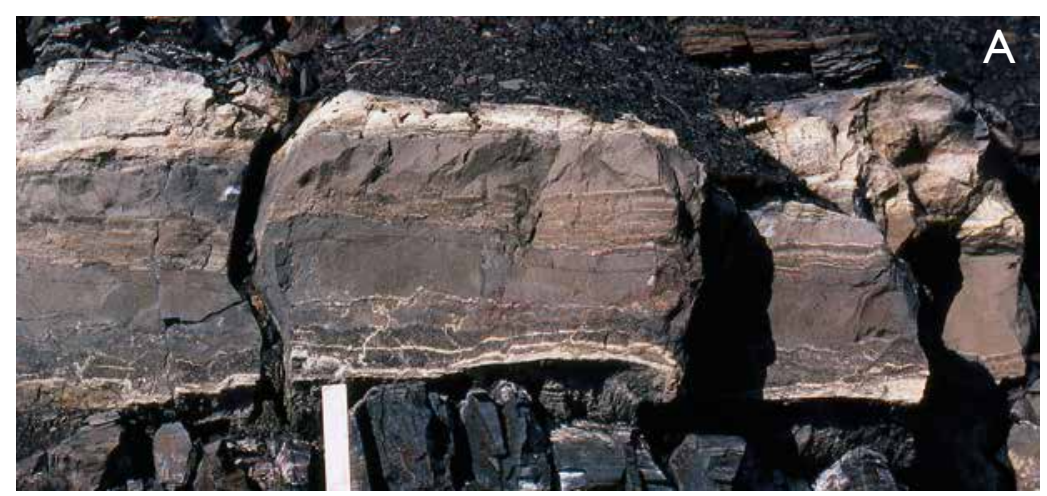

Fig. 115. Tuffs in the Abraham Member. A: A 20-30 cm thick, cemented horizon (profile in Fig. 114 at $4.1-4.4 \mathrm{~m}$ ) with excellently preserved tuff beds within silicified mudstones. B: Close-up of the right part of the central block in $\mathbf{A}$. A nativeiron-bearing spherule tuff bed is seen at the base (Fe and white arrow). The middle part comprises a number of volcaniclastic tuff beds of uncontaminated basalt (ucb) with plagioclase; the yellow arrow points to the location of the thin section in Fig. 117. Note several microfaults. Pyramidedal, central Nuussuaq. 
Fig. 116. A c. $1 \mathrm{~m}$ long concretion block with Abraham Member lithologies which demonstrates intense prediagenetic slumping of mudstone and tuffs. Pyramidedal, central Nuussuaq.

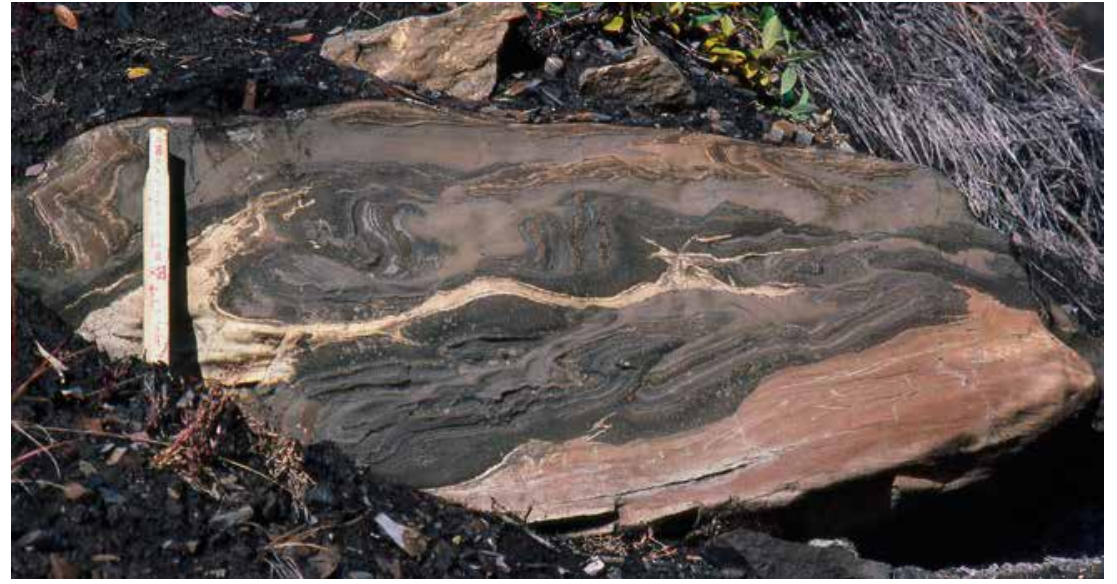

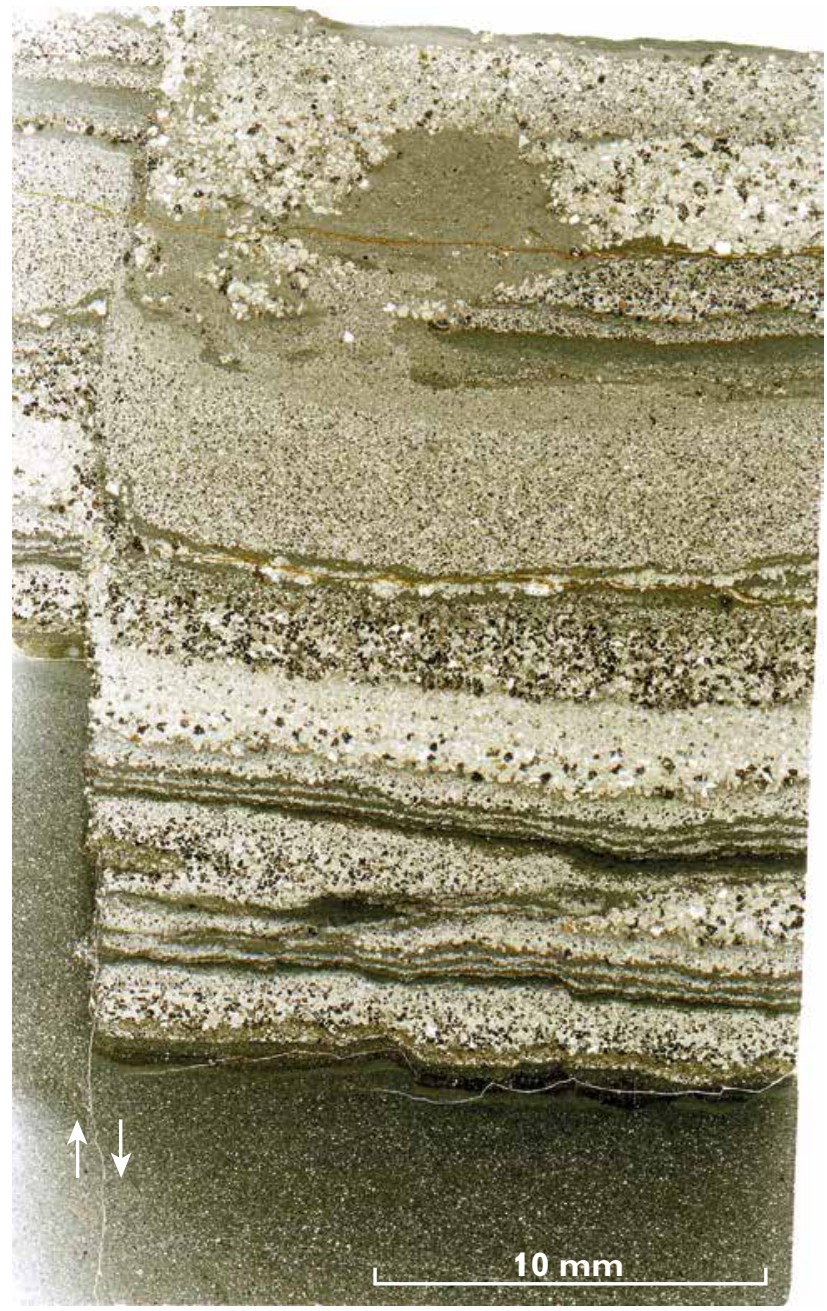

Fig. 117. Thin section (scanned image) of volcaniclastic beds dominated by uncontaminated basalt glass with plagioclase phenocrysts from the middle part of the cemented block shown in Fig. 115B. Note the distinct prediagenetic microfault in the left side of the image (arrows). Sample 274478, Pyramidedal, central Nuussuaq.
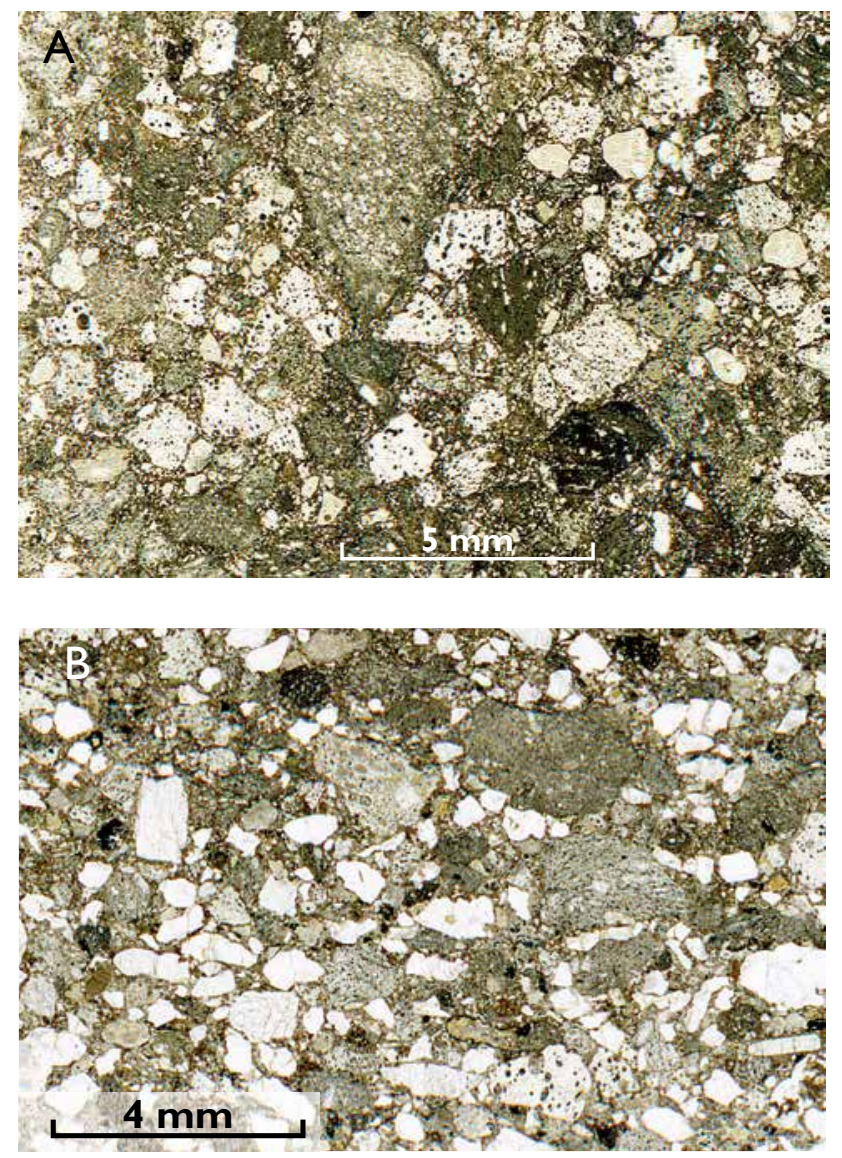

Fig. 118. Thin sections (scanned images) of two beds of volcaniclastic sandstone from the upper part of the middle section of the Abraham Member in Pyramidedal, central Nuussuaq, see Fig. 114. A: Volcaniclastic bed with many up to $5 \mathrm{~mm}$ large clasts of dark graphite andesite with orthopyroxene phenocrysts, subordinate clasts of light picrite glass (with small black vesicles), and scarce clastic quartz grains. Sample GGU 8542. B: Volcaniclastic bed with the same volcanic components as in A and abundant unabraded, colourless clasts of quartz and potassic feldspar derived from Precambrian gneiss. Sample 274463. 


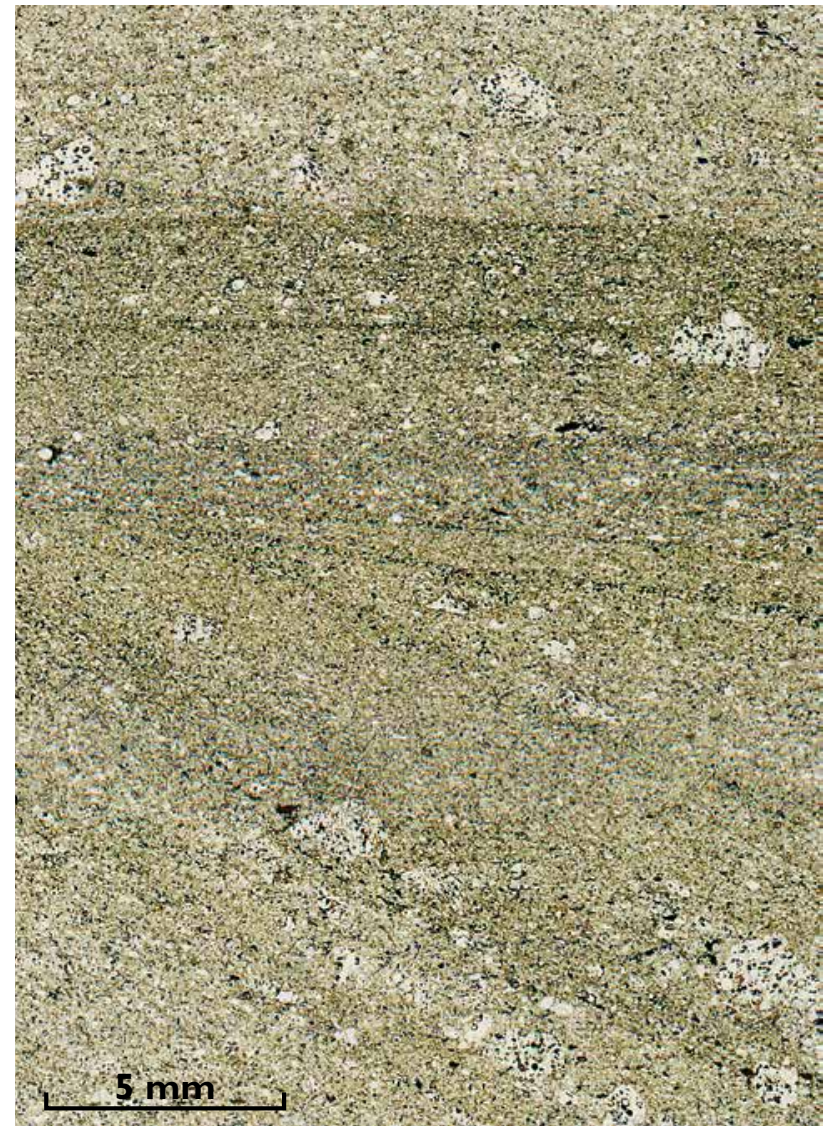

Fig. 119. Thin section (scanned image) of very fine-grained, volcaniclastic sandstone bed of contaminated basalt with microphenocrystic olivine from the upper section of the Abraham Member. The larger glass clasts may contain vesicles developed around small flakes of graphite. The bed shows distinctive cross-bedding and is virtually devoid of nonvolcanic clastic components. Sample 274477 , Pyramidedal, central Nuussuaq.

and fragments of invertebrate fossils. The volcaniclastic beds are dominated by vesiculated clasts of graphite andesite with orthopyroxene and in some cases olivine microphenocrysts; they also contain subordinate clasts of picritic hyaloclastite (Fig. 118A). Some beds contain abundant clasts of quite immature quartz and potassic feldspar derived from Precambrian gneiss (Fig. 118B). Very subordinate and scattered glass spherules identical to those of the spherule tuff below also occur.

The upper section $(c .15-20 \mathrm{~m})$. The uppermost 4-5 $\mathrm{m}$ comprise cross-bedded volcaniclastic sandstones composed of fine-grained and very sharp-edged clasts of contaminated basalt with microphenocrystic olivine (Fig. 119). The larger clasts, which may reach a size of $2.5 \mathrm{~mm}$, contain vesicles with small flakes of graphite inside them. The sand is virtually devoid of nonvolcanic components

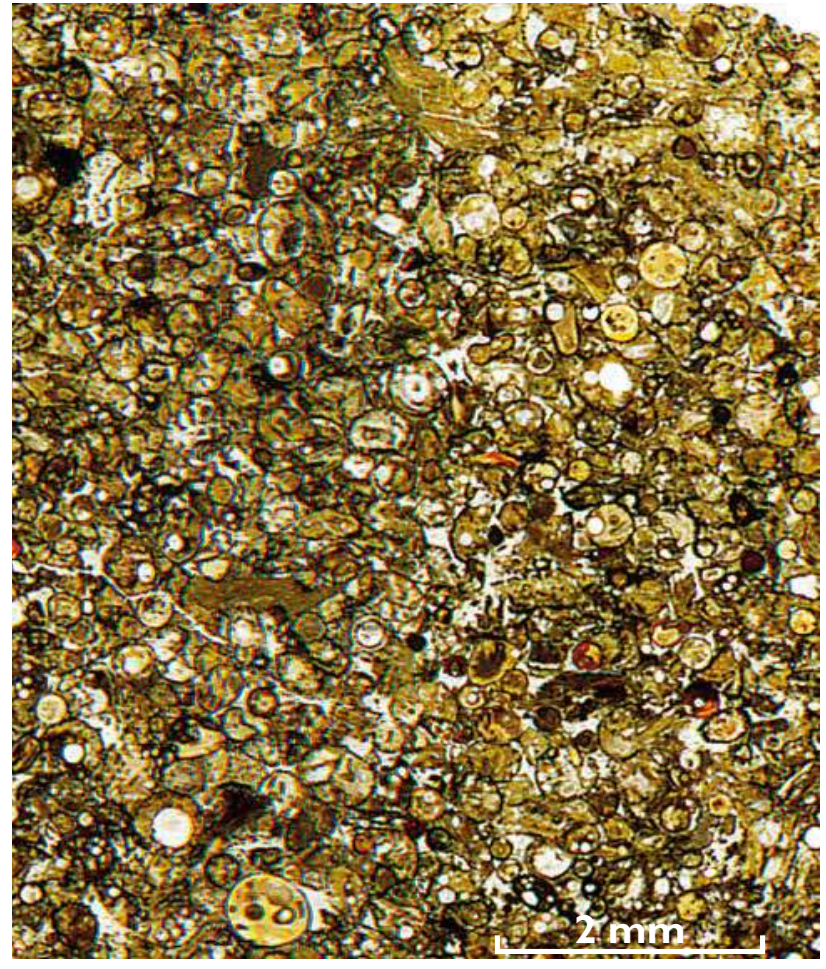

Fig. 120. Thin section (scanned image) of spherule tuff at the base of the Saviaqqat unit at Sorluut, northern Nuussuaq. The tuff is composed of basaltic glass and scarce clasts of plagioclase and clinopyroxene. The spherule size ranges from 0.1 to $0.6 \mathrm{~mm}$. The tuff is weathered and lithologically different from the complex native-ironbearing spherule tuff from the Abraham Member. Sample 410172.

and is cemented to a varying degree. The succession is overlain by picritic hyaloclastites of unit 423 .

Sources of the tuffs in the Abraham Member. The dominant volcanic component of the Abraham Member is graphite andesite. It is indistinguishable from the pyroclastic rocks of the Ilugissoq volcano, which is undoubtedly the source (Pedersen \& Larsen 2006).

An eruption site with lithologies similar to those of the native-iron-bearing spherule tuffs is not known. The only other presently known spherule glass bed is found at the base of a lava flow of the Saviaqqat unit of the Asuk Member at Soorluut (see below and Fig. 120), north-east of the Ilugissoq volcano. We consider that an early spherule-producing eruption site at Ilugissoq may have been destroyed by the main explosive phase. The grain morphology of the spherule tuff suggests an eruption on dry land.

The uncontaminated, plagioclase-phyric tuff beds above the spherule tuff are characterised by sharp-edged glass grains and must have originated by phreatomagmatic activity from an eruption site rising out of the shallow 
sea near the western shore of the marine embayment that existed at the time of emplacement of the Asuk Member.

The thick volcaniclastic sandstone beds at the top of the Abraham Member contain contaminated graphitebearing basalt that was erupted by phreatomagmatic activity. The complete absence of a lithic component of the very characteristic andesites of the Ilugissoq volcano excludes the source from being this volcano, but it may have been a satellite to the Ilugissoq volcano now removed by erosion.

\section{Saviaqqat unit (unit 419)}

The lava flows of this unit are easily recognisable in the field because of their abundant plagioclase phenocrysts, and they are sufficiently different from the other parts of the Asuk Member that they have been assigned a separate unit and coding status. The unit is found in an area measuring c. $28 \mathrm{~km}$ by $10 \mathrm{~km}$ on northern Nuussuaq, extending from Sorluut to just east of Ikorfat. It covers a minimum area of about $300 \mathrm{~km}^{2}$ (Fig. 10) and its minimum volume is estimated at $c .13 .5 \mathrm{~km}^{3}$, but the unit may have extended considerably beyond the present north coast of Nuussuaq. Its western limits are either erosional or depositional, the eastern limit is depositional, the southern limit is below exposure level, and the northern limit is erosional. It also occurs on Hareøen.

The Saviaqqat unit is named after a locality on the north coast of Nuussuaq 7-8 km west of Ikorfat. Saviaqqat means 'small pieces of iron' in old Greenlandic (Hans Kristian Olsen, personal communication 2011; savik means iron or knife in modern Greenlandic). Lava pieces containing native iron can be found on the alluvial fan close to the coast at Saviaqqat, and the name probably indicates that this iron was the source of the native iron that the Inuits on Nuussuaq used for making knives (Buchwald \& Mosdal 1985). This was first implicated by the discovery by Steenstrup (1882, p. 121) of nine fragments of well-crystallised lava with native iron in a burial site at Eqaluit on the eastern north coast of Nuussuaq (at $51^{\circ} 14^{\prime}$ W longitude).

The in situ exposure near Saviaqqat from where the native-iron-bearing lava pieces originate, is located in the steep eastern wall of a corrie $c .3 \mathrm{~km}$ south of the coast. It was found in 1985 by F. Ulff-Møller. A succession of three subaerial lava flows exposed at an altitude of about 865-885 m comprises a flow with one of the most spectacular occurrences of native iron in West Greenland (see also Figs 123-125). This locality is designated type locality for the Saviaqqat unit.

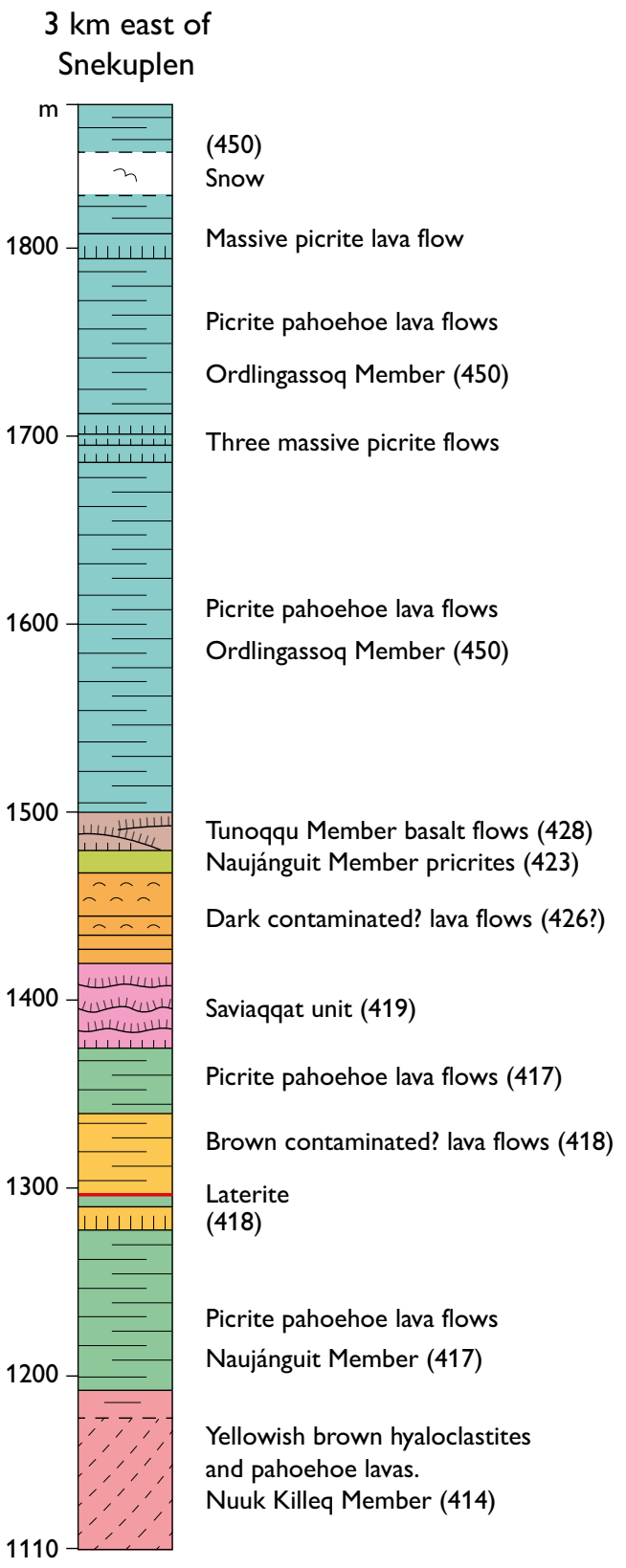

Fig. 121. Photogrammetrically measured profile $3 \mathrm{~km}$ east of Snekuplen, central Nuussuaq. The Saviaqqat unit is here $45 \mathrm{~m}$ thick and consists of four lava flows. There seem to be contaminated lavas both below and above the Saviaqqat unit level, but these have not been visited.

Boundaries. The lava flows of the Saviaqqat unit rest conformably on the weathered surfaces of picritic or basaltic subaerial lava flows of Naujánguit Member unit 417. However, at Sorluut, where the Saviaqqat unit consists of a single irregular flow lobe, this was found to overlie a $2-10 \mathrm{~cm}$ thick sediment described in the field as a grey, baked, poorly exposed siltstone. The sediment is in fact 


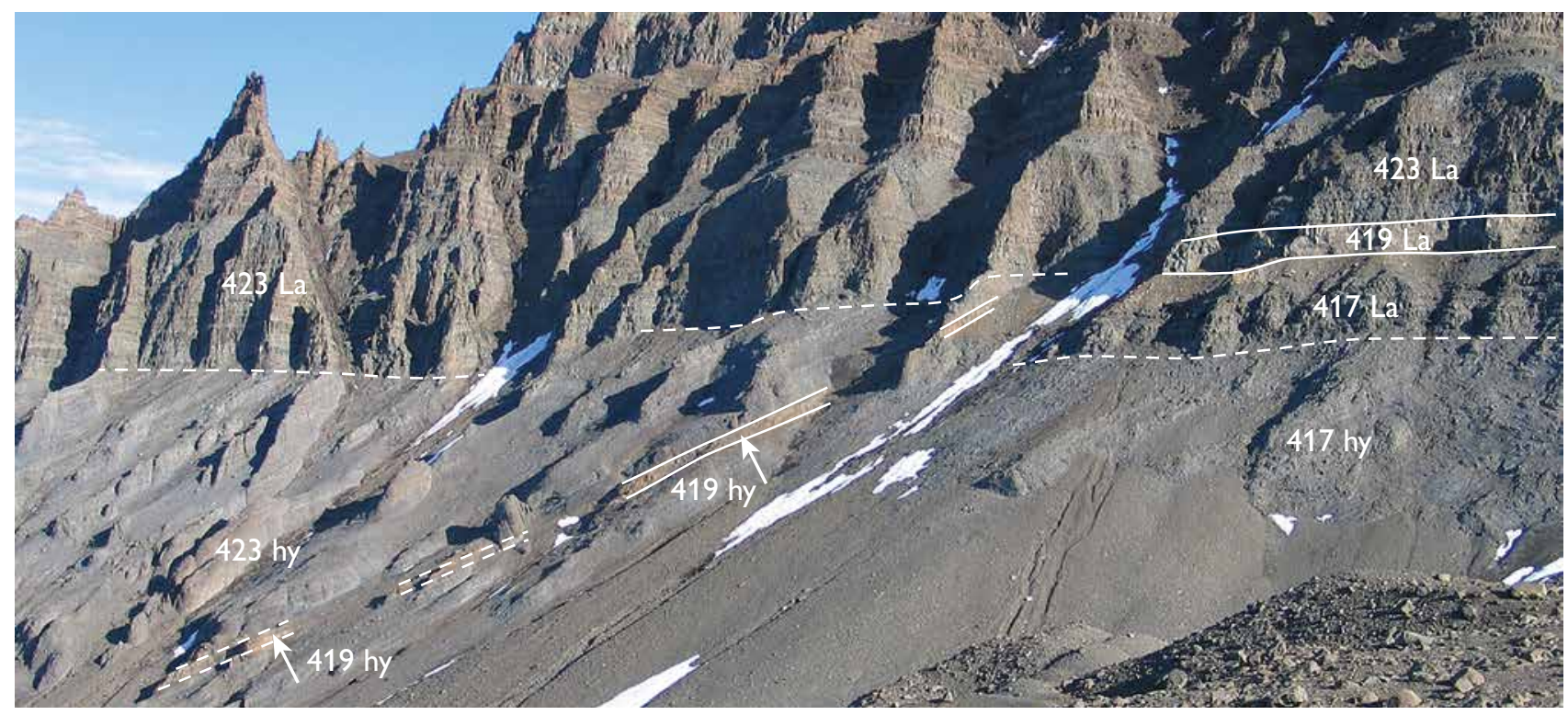

Fig. 122. The eastern termination of the Saviaqqat unit. Two subaerial lava lobes of basaltic andesite (419 La) entered the marine embayment and continued downslope for $130 \mathrm{~m}$ as a thin, light grey hyaloclastite marker horizon (white arrows and 419 hy). Other units are indicated by their unit codes. Mountain side above Ikorfat, north coast of Nuussuaq (North Nuussuaq section at $c .31 \mathrm{~km}$ ). Photo: Finn Dalhoff.

a spherule-textured glass tuff (Fig. 120) of contaminated basalt interpreted to have formed by magma fountaining. While presumably related to the Ilugissoq and Agatdal tuffs (see the preceding sections), it differs from these by a much less complex lithology without native iron, graphite, orthopyroxene or pyrometamorphic sedimentary minerals. Nevertheless, the spherule tuff indicates that the Saviaqqat unit is contemporaneous with the other parts of the Asuk Member.

At the upper boundary, the pahoehoe lava surfaces of the Saviaqqat unit are slightly eroded and in places overlain by a centimetre- to decimetre-thick layer of lateritic claystone which has impregnated the upper part of the flow to depths of up to $0.5 \mathrm{~m}$. The surface is mostly conformably overlain by picritic or basaltic lava flows of Naujánguit Member unit 423. However, at Ikorfat there is a slight but distinctive angular unconformity at the upper surface (Fig. 72). Here a single, $0.5-2 \mathrm{~m}$ thick vesicular flow lobe of unit 419 is onlapped by several picritic flows. This indicates differential basin subsidence, probably combined with synvolcanic tectonic movement on the Ikorfat fault system, in the short time interval between the eruption of the Saviaqqat unit and the overlying picrites of unit 423 (Fig. 63).

Lithologies and volcanic history. The rocks of the Saviaqqat unit constitute a thin but widespread succession of subaerial pahoehoe lava flows. The flows have vesiculat- ed zones filled with silica, carbonate and zeolites, which gives the succession a distinctive, light greyish brown weathering colour (Fig. 67). The rocks are crustally contaminated basalts and basaltic andesites with $49-55 \mathrm{wt} \%$ $\mathrm{SiO}_{2}$ and 5-8 wt $\% \mathrm{MgO}$. They are strongly plagioclaseand pyroxene-phyric, mostly with both ortho- and clinopyroxene. Rusty zones in some flows indicate an uneven distribution of native iron and sulfide.

The Saviaqqat unit has been mapped photogrammetrically along the north coast of Nuussuaq as the units $f_{3}$ and $f_{3 \mathrm{a}}$ over a distance of $17 \mathrm{~km}$ from Kiggannguaq in the west to $c .3 \mathrm{~km}$ east of Ikorfat (North Nuussuaq section at $14-31 \mathrm{~km})$. The unit is between 20 and $40 \mathrm{~m}$ thick in the inner part of Tunorsuaq and at Saviaqqat (Fig. 14, Tunorsuaq profile) where it is composed of three to seven subaerial lava flows. It thins to $10 \mathrm{~m}$ or less, comprising just one or two flows, at its eastern limit around Ikorfat (Fig. 14, Ikorfat profile) and its western limit at Sorluut. Prominent southern exposures are found $2 \mathrm{~km}$ south of Snekuplen (Fig. 61) and $3 \mathrm{~km}$ east of Snekuplen (Fig. 121).

The eastern termination of the unit is only exposed at one locality. About $3 \mathrm{~km}$ east of Ikorfat two lava lobes of unit 419 have entered the marine embayment to form a $c$. $20 \mathrm{~m}$ thick layer of pillow-rich hyaloclastite deposited on a shelf slope showing at least $120 \mathrm{~m}$ deep water (Fig. 122; North Nuussuaq section at $c .31 \mathrm{~km}$ ). 


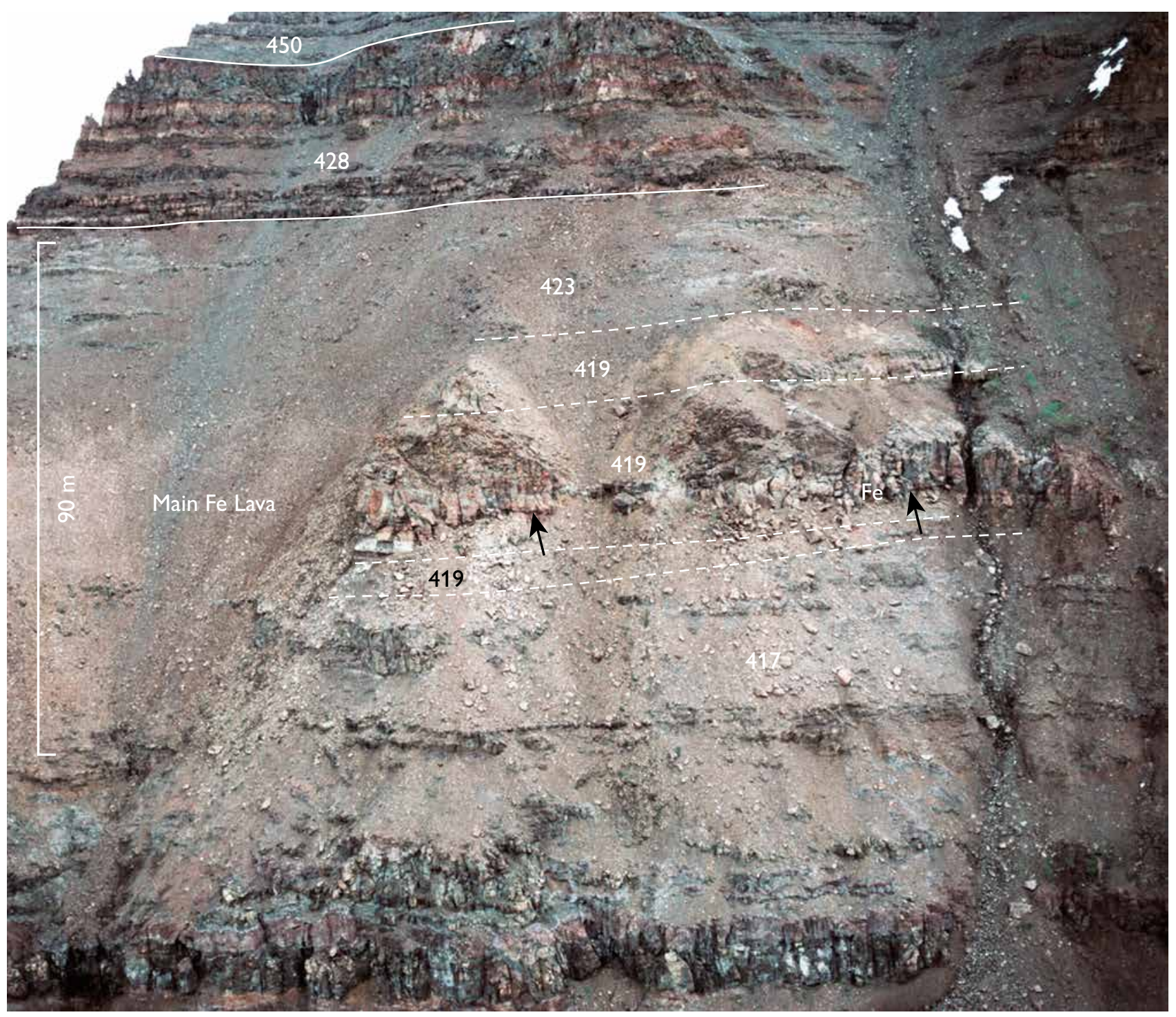

Fig. 123. Three lava flows of the Saviaqqat unit (419) at the type locality. The thickest flow $(22 \mathrm{~m})$ contains a native-iron cumulate zone seen as a rusty band (black arrows). The site of sample 402560 is at the black arrow to the right. See also Figs 124, 125. The Saviaqqat unit lava flows are embedded in Naujánguit Member picrite lavas (units 417 and 423). The distinct brown lava flows above unit 423 are the Tunoqqu Member (428). West-facing mountain wall c. $3 \mathrm{~km}$ south of Saviaqqat on the north coast of Nuussuaq (North Nuussuaq section at $c .23 \mathrm{~km}$ ).

Despite extensive search no feeder bodies to the Saviaqqat unit have been located, but at least one feeder system is believed to have been located close to the Saviaqqat locality itself.

The Saviaqqat unit was also sampled by Lightfoot $e t$ al. (1997) in their profiles N-91-05 and N-91-10 (their samples $7862,7911,7912)$.

The native-iron-bearing lava flows. The most notable feature of the Saviaqqat unit is the occurrence of plagioclase-, ortho- and clinopyroxene-phyric basaltic andesite lava flows with native iron. The native-iron-bearing flows cov- er at least $120 \mathrm{~km}^{2}$ and probably substantially more. Only one native-iron-bearing flow is found at each locality, but it is not known whether these represent a single or several individual flows. The flow thickness ranges from less than $10 \mathrm{~m}$ to $22 \mathrm{~m}$ (Fig. 123) and at all localities the native iron occurs as millimetre- to centimetre-sized bodies assembled in a cumulate zone which is $0.5-1 \mathrm{~m}$ thick and loosely packed with native iron. The base of the cumulate zone is situated c. $0.5 \mathrm{~m}$ above the base of the flow. At Saviaqqat, over a limited horizontal distance, the cumulate zone becomes very massive while it thins to just 10-20 cm (Figs 124, 125), as first observed by Finn Ulff-Møller 


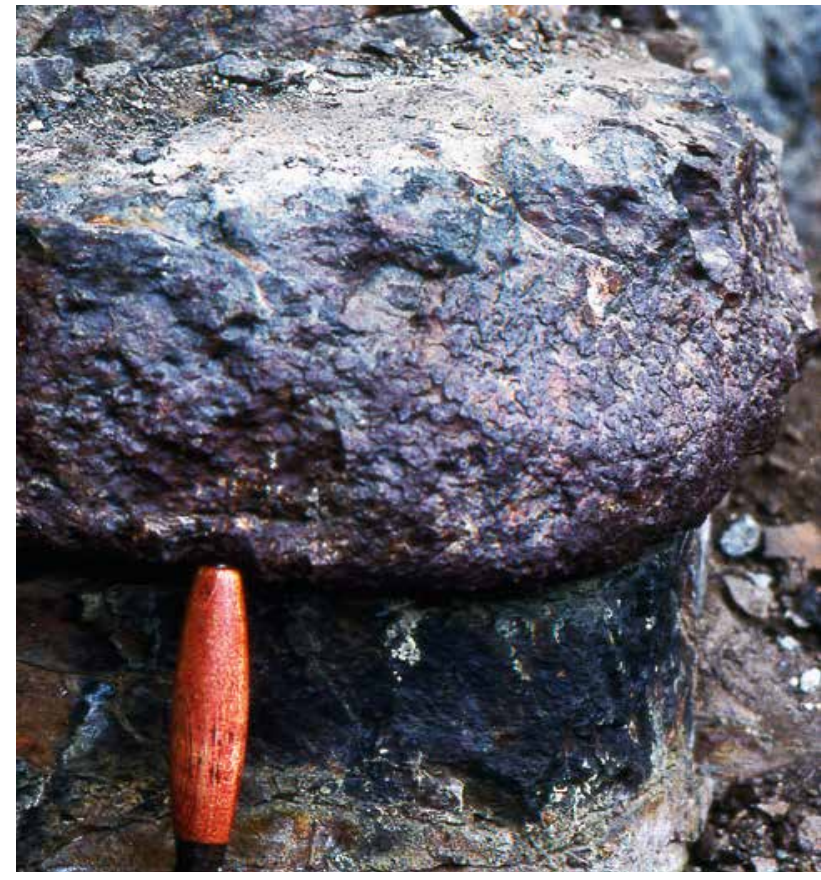

Fig. 124. The main native-iron cumulate zone in the lava flow at $\mathrm{Sa}$ viaqqat (Figs 123, 125). The knife handle is $10 \mathrm{~cm}$ long. (unpublished field diary 1987). He observed (Fig. 126) that while most of the native-iron-bearing lava flow with loosely packed native-iron cumulate has a crude columnar jointing, the very compact and thin native-iron cumulate is overlain by a lava zone with cylindrical jointing. He suggested that a feeder channel within the flow had caused localised relative heating (or slower cooling) and hence allowed more efficient settling of native iron within this part of the flow. He also estimated that the total volume of native iron per area unit is approximately the same in areas with densely and loosely packed cumulates.

Xenoliths in the native-iron-bearing flows. At Saviaqqat scattered xenoliths of magma-modified sediments occur in the upper part of the flow (Fig. 127). The xenoliths are typically $1-5 \mathrm{~cm}$ in size, and the dominant type comprises graphite-red spinel-plagioclase rocks derived from mudstones. Cognate dolerite inclusions also occur. Outside Saviaqqat graphite-rich xenoliths are uncommon but have been observed $2 \mathrm{~km}$ south of Snekuplen where the lava also contains millimetre-sized patches of extensively digested sediment with tiny red spinel grains and plagioclase.

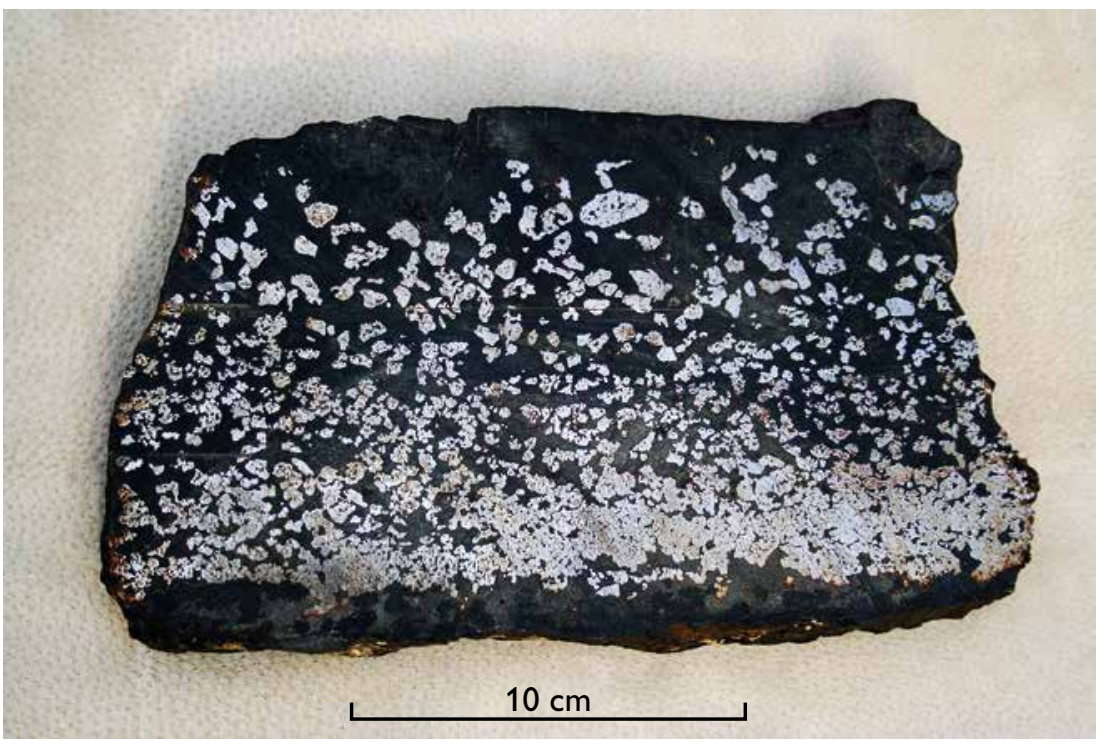

Fig. 125. Cut slab of the native-iron cumulate zone in the lava flow at Saviaqqat. The iron metal is light grey in the black lava matrix. Note the upward change in grain size and degree of packing of the metal grains. See also Figs 123, 124, 126. Sample 402560.

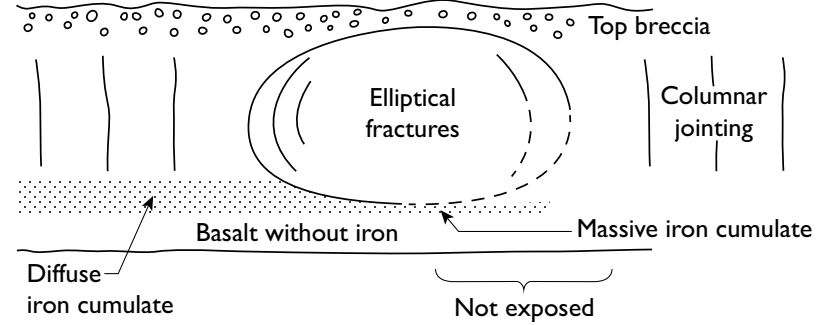

Fig. 126. Structures in the native-iron-bearing lava flow at Saviaqqat. The parts of the flow overlying a loosely packed, diffuse iron cumulate have a crudely columnar jointing, whereas the part of the flow overlying a massive and thin iron cumulate has cylindrical jointing. Field sketch by F. Ulff-Møller. See text for interpretation. 


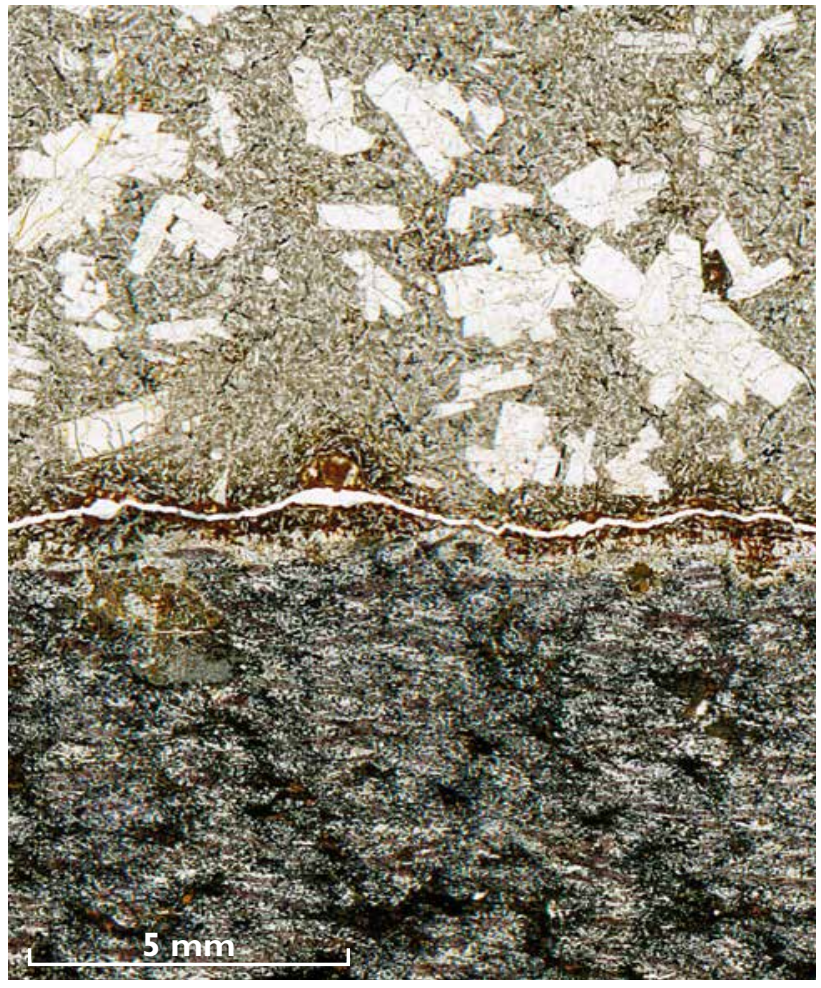

Fig. 127. Thin section (scanned image); upper part: basaltic andesite with phenocrysts of plagioclase, orthopyroxene and pigeonite; lower part: enclosed magma-modified mudstone xenolith with plagioclase, red spinel and graphite. Such xenoliths are rare in the Saviaqqat unit except at the locality at Saviaqqat (Fig. 123). Sample 402568 from above the native-iron cumulate zone in the lava flow at Saviaqqat.

Isolated exposures. Two isolated occurrences have been assigned to the Saviaqqat unit.

West of Sorluut. A 1.3 to $2 \mathrm{~m}$ thick vesiculated lava flow of aphyric, distinctly crustally contaminated basaltic andesite (402534) occurs $2 \mathrm{~km}$ south-west of the innermost part of the Sorluut valley. There are traces of black to dark grey mudstone at the base of the flow. A c. $3.5 \mathrm{~m}$ thick lava flow of plagioclase-phyric basalt (402533) with pseudomorphs of a mafic phase partly onlaps the aphyric flow. It is a weakly contaminated basalt which differs from the other basalts of the Saviaqqat unit by a lack of pyroxene phenocrysts. This flow could represent the scarcely contaminated but evolved basaltic magma parental to the Saviaqqat lavas which erupted just outside the flow fields covered by the normal Saviaqqat unit lavas.

Hareøen. The south-eastern part of Hareøen at Niaqua consists of a succession of Vaigat Formation lava flows which dip $30-45^{\circ} \mathrm{W}$ to NW (see also Fig. 131) and are separated from the Eocene lavas of Talerua Member (Hald 1977b) by the Itilli Fault. Within the Vai- gat Formation lavas, a c. $20 \mathrm{~m}$ thick succession of light grey-brownish weathering aphyric or plagioclase-phyric basaltic andesites occurs which has been assigned to the Saviaqqat unit. There are about 15-20 flows, all of which are extensively hydrothermally altered. They are approximately contemporaneous with the Asuk Member, and their top is situated $c .120-160 \mathrm{~m}$ beneath the base of the Tunoqqu Member. The lavas are chemically similar to the basaltic andesites of the Saviaqqat unit, but they do not contain native iron or sediment xenoliths and there is no indication that they shared high-level magma reservoirs or feeder systems with the Saviaqqat unit lavas on central and northern Nuussuaq.

\section{Niiortuut unit (unit 422)}

This small unit is considered to be a part of the Asuk Member produced in a separate volcanic system. It forms a succession of lava flows and hyaloclastites of crustally contaminated picrites and basaltic andesites with 7.5$14.5 \mathrm{wt} \% \mathrm{MgO}$ and $50-53.3 \mathrm{wt} \% \mathrm{SiO}_{2}$. The unit has a distinctive brownish weathering colour and is seen over a distance of $c .7 \mathrm{~km}$ in the steep wall facing the Vaigat strait on the south coast of Nuussuaq between Nuuk Qiterleq and Tupaasat (Fig. 15, profile 17; Fig. 128). The extent of the unit is poorly constrained both towards north and south; it is missing entirely on Disko and in the northern side of the Aaffarsuaq valley. Its extent is estimated at $c$. $50 \mathrm{~km}^{2}$ and its volume at $c .6 \mathrm{~km}^{3}$, but both estimates are very uncertain.

Boundaries. The lower boundary of the Niiortuut unit is exposed $2 \mathrm{~km}$ west of Niiortuut. Here there is a distinct unconformity as pillow lavas of unit 422 in transition facies to hyaloclastite rest on an up to $8 \mathrm{~m}$ thick volcanic conglomerate, and pillow lavas and subaerial flows of unit 422 onlap the eroded surface of picrite unit 417 , as described for the upper boundary of unit 417. Farther to the east the lower boundary is not exposed, but close to Tupaasat (South Nuussuaq section at $c .30 .7 \mathrm{~km}$ ) the hyaloclastites are only separated from sandstones of the Paatuut Member of the Quikavsak Formation (Dam et al. 2009, figs 97,98 ) by less than $10 \mathrm{~m}$ of scree.

At the upper boundary, subaerial lava flows of the Niiortuut unit are covered by a thin succession of subaerial picrite flows of Naujánguit Member unit 423. There are traces of brown or reddish claystone at the boundary, but no long period of volcanic inactivity is indicated. The eastern termination is obscured by a large landslide (South Nuussuaq section east of $c .30 .7 \mathrm{~km}$ ); at the east- 


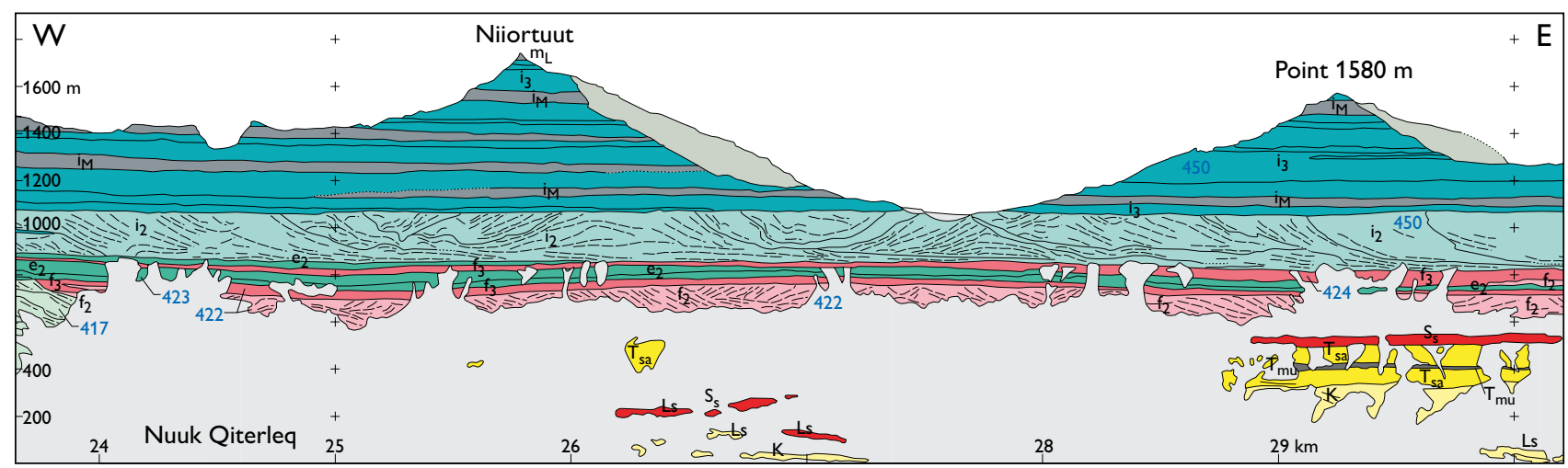

Fig. 128. Photogrammetrically measured cliff face at the south coast of Nuussuaq around Niiortuut, showing the Niiortuut unit (422) entering the marine embayment from the left and filling it in eastwards over a distance of more than $6 \mathrm{~km}$. The overlying Naujánguit Member unit 423 thins eastward to only about $20 \mathrm{~m}$ so that the overlying Tupaasat unit (424) of the Tunoqqu Member is almost in contact with the Niiortuut unit. Blue numbers are unit codes; other unit annotations are from the original. Excerpt from the South Nuussuaq section at $24-30 \mathrm{~km}$ (Pedersen et al. 1993), slightly modified. Photographs in Fig. 129 and the frontispiece of this bulletin (at $25-26 \mathrm{~km}$ ).

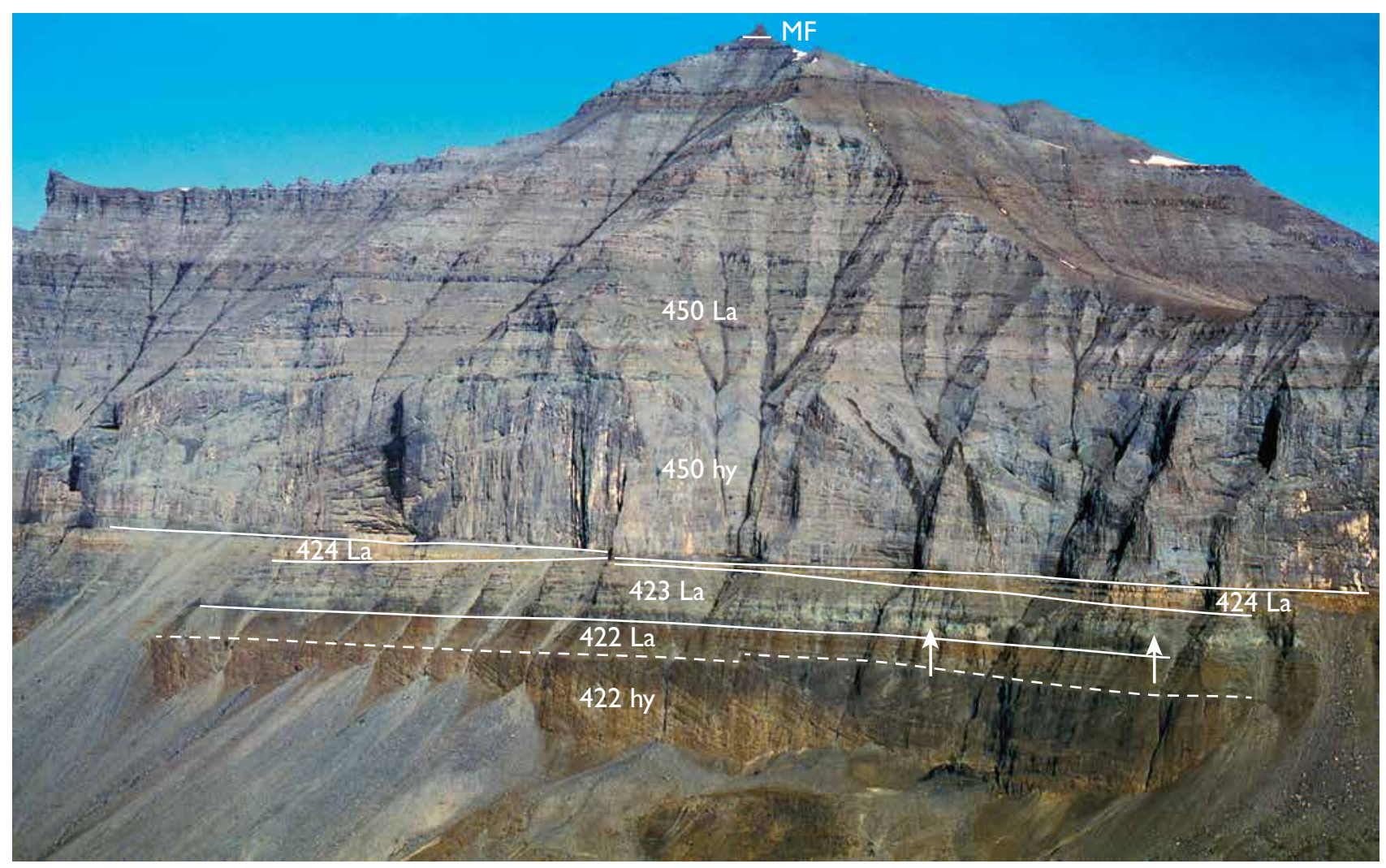

Fig. 129. The $c .1100 \mathrm{~m}$ high cliff face below the Niiortuut peak, showing brown subaerial lava flows (422 La) and foreset-bedded hyaloclastites ( 422 hy) of the Niiortuut unit. To the right several thick picrite bodies (at arrows) indicate an eruption site of Naujánguit Member unit 423. Just beneath the thick, foreset-bedded hyaloclastite of the Ordlingassoq Member ( 450 hy) several yellowish grey, contaminated lava flows of the Tupaasat unit ( $424 \mathrm{La}$ ) of the Tunoqqu Member are seen. The top flow on the Niiortuut peak (1735 $\mathrm{m}$ a.s.l.) is a single remnant flow of the Maligât Formation (MF). South coast of Nuussuaq at Niiortuut (see also Fig. 128 and Fig. 15, profile 17). 
ernmost exposures the picrite flows of unit 423 peter out so that farther east the Niiortuut unit may be overlain directly by hyaloclastites of the Tupaasat unit (424).

Lithologies. The Niiortuut unit is composed of 20-50 $\mathrm{m}$ of pahoehoe lava flows underlain by foreset-bedded hyaloclastites filling the marine embayment (Fig. 129). The floor of the basin is not exposed but the water depth must have reached about $200 \mathrm{~m}$ at the eastern end of the exposures. The foresets indicate a general infilling from the west, but local changes in the directions of infill are seen (Figs 128, 129).

The picrites and basaltic andesites contain phenocrysts or microphenocrysts of olivine with minor chromite, and the basaltic andesites in addition carry plagioclase microphenocrysts. Significantly, orthopyroxene, which is a common phase in most of the other subunits of the Asuk Member, is not found in the Niiortuut unit. 


\section{Tunoqqu Member}

\section{Summary of the main features of the Tunoqqu Member}

- Brown contaminated basalts and basaltic andesites evolved in a number of simultaneously established magma chambers in the crust. The Tupaasat unit contains contaminated picrites.

- Only present on Nuussuaq; time-equivalent to the Kûgánguaq Member on Disko.

- An important marker horizon, widespread and characteristic.

- Weakly contaminated basalts are widespread. More strongly contaminated basalts are related to some local centres.

- East-prograding volcanics; exceptional exposure of ponded lava flows at Tunoqqu. The member reached the eastern gneiss highland and closed the strait between the open sea to the north and the marine embayment to the south, transforming this to a lake. Huge boulder conglomerates were deposited at the outlet from the new lake.

- Economic geology: The unit has been explored for $\mathrm{Ni}$ and platinum-group elements.

\section{Lithostratigraphy of the Tunoqqu Member}

Revised member

History. Originally defined by Pedersen et al. (1996). Here extended to include lava flows on Hareøen.

Name. After the mountain top Tunoqqu on the north side of the Aaffarsuaq valley, central Nuussuaq.

Distribution. The Tunoqqu Member covers more than $2000 \mathrm{~km}^{2}$ on Nuussuaq (Fig. 10). Its western limit on Nuussuaq is erosional, and the presence of the member on Hareøen signals an originally large western extent. To the north and south the member is delimited by the coastline of Nuussuaq, whereas the eastern limit is depositional.

Type locality. The south side of the Tunoqqu mountain (Figs 137, 138; Pedersen et al. 1996, fig. 7; Central Nuussuaq section at $38-40 \mathrm{~km}$ ).
Reference sections. Qunnilik west, Ukallit (Fig. 13, profiles 9, 10), Sorluut, Tunorsuaq, Ikorfat, Vesterfjeld, Aaffarsuaq and Puugutalissuaq (Fig. 14, profiles 1116) on Nuussuaq; eastern Hareøen (Fig. 17, profile 30).

Thickness. From less than $50 \mathrm{~m}$ to about $300 \mathrm{~m}$ on Nuussuaq and $40 \mathrm{~m}$ on Hareøen.

Lithology. Brown, mostly aphyric or plagioclase-phyric basalts, basaltic andesites and silicic picrites forming subaerial lavas, subaqueous lavas, hyaloclastites and boulder conglomerates dominated by volcanic clasts.

Subdivisions. Three local volcanic centres are identified: the Tupaasat centre, the Agatdalen centre (eruption sites inferred in both cases), and the Qunnilik centre with a well-exposed eruption site. Of these, the products from the Tupaasat centre are coded separately as unit 424, the rest as unit 428. The Kûgánguaq Member erupted on northern Disko may be considered to be a fourth centre but is maintained as a separate member. In addition, the Tunoqqu Member includes some widespread lava flows that have no apparent relation to the volcanic centres and are much less contaminated than these.

Boundaries. The Tunoqqu Member rests on grey picritic lava flows and hyaloclastites of the Naujánguit Member, on marine and non-marine Cretaceous sediments, or on Precambrian gneiss. In parts of southern Nuussuaq the lower boundary is not exposed. The Tunoqqu Member is overlain by grey picrite lava flows and hyaloclastites of the Ordlingassoq Member.

Age. Paleocene, nannoplankton zone NP5-6, c. 61 Ma, magnetochron C26r, based on dinoflagellate cysts (Piasecki et al. 1992) and radiometric dating of older and younger rocks in the succession (Storey et al. 1998).

Correlation. The Kûgánguaq Member on Disko is contemporaneous with the Tunoqqu Member.

On Svartenhuk Halvø, the lowest exposed unit of the Vaigat Formation, the Kakilisaat Member (Larsen \& Pulvertaft 2000), consists of brown silica-enriched basalt lavas and hyaloclastites (Larsen \& Grocott 1991) which are reversely magnetised (J. Riisager et al. 2003b). They 
may possibly be equivalent to the Tunoqqu Member (Larsen et al. 2016).

\section{Geology of the Tunoqqu Member}

The Tunoqqu Member on Nuussuaq and the contemporaneous Kûgánguaq Member (unit 430) on Disko represent a relatively short-lived event at the end of the second volcanic episode when crustally contaminated basalts to magnesian andesites were erupted from a number of sites over an area of more than $5000 \mathrm{~km}^{2}$. The distinctive brownish weathering colours of the rocks of both members contrast markedly to the greyish to black weathering colours of the surrounding volcanic units of the Vaigat Formation, both in subaerial and subaqueous facies, which makes these members an important marker horizon that helps to define both the synvolcanic and the postvolcanic structure of the Nuussuaq Basin over large areas (e.g. Fig. 63; the South and Central Nuussuaq sections; Sørensen et al. 2017).

\section{Tupaasat unit (unit 424)}

The Tupaasat unit was produced in a volcanic centre near Tupaasat on the south coast of Nuussuaq. It consists of contaminated picrites and magnesian basaltic andesites with 9.5-16 wt $\% \mathrm{MgO}$ and 51-53.4 wt $\% \mathrm{SiO}_{2}$. It is one of the most magnesian contaminated units and is compositionally akin to the Kûgánguaq Member on Disko.

The Tupaasat unit is only known from the steep wall at the south coast of Nuussuaq (Fig. 10). The south side of the Aaffarsuaq valley has not been investigated, and the unit is not present on the north side of this valley, or on Disko. It is loosely estimated to cover around $260 \mathrm{~km}^{2}$ with a volume of around $20 \mathrm{~km}^{3}$. Its western limit is uncertain and it probably interfingers with the widespread lavas of unit 428 towards the west. Its eastern limit is a transition to marine facies at Tupaasat.

Boundaries. Like the underlying units, the Tupaasat unit has been affected by synvolcanic subsidence around Nuuk Qiterleq (Pedersen \& Dueholm 1992, fig. 10; Fig. 128). The unit semi-conformably overlies picritic lava flows of unit 423 and is separated from these by at most a few decimetres of brown to reddish claystone. At its easternmost extension at Tupaasat, the lower boundary is not exposed but the thick succession of pillow breccias is believed to cover a thin horizon of clastic sediments of the Eqalulik Formation deposited on the floor of the marine embayment.

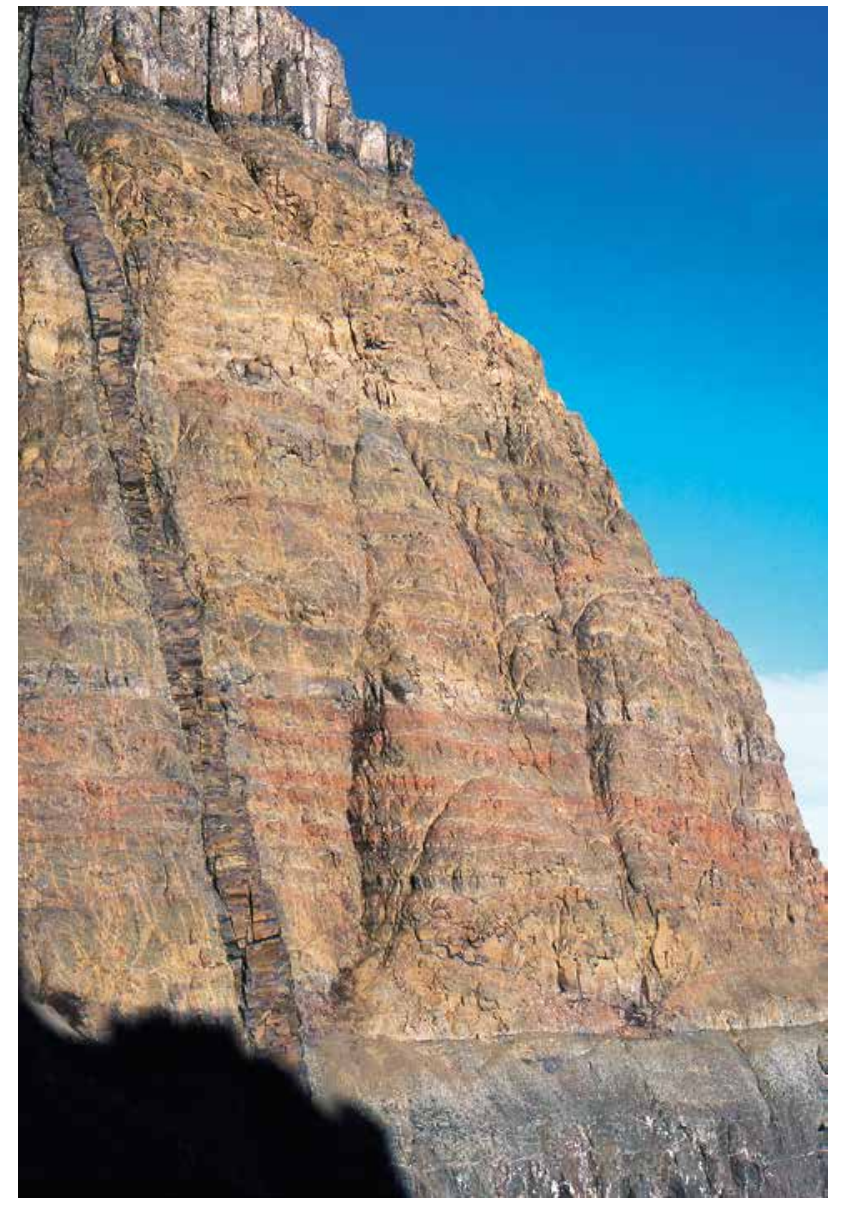

Fig. 130. A c. $40 \mathrm{~m}$ thick succession of pahoehoe lava flows of the Tupaasat unit of the Tunoqqu Member. The lavas form several flow fields, and there are no internal soil horizons within the succession. Note the well-exposed but inaccessible contacts to the picrite lava flows of the underlying Naujánguit Member unit 423 and the overlying Ordlingassoq Member hyaloclastites. South coast of Nuussuaq south-east of Niiortuut (South Nuussuaq Section at $28.2 \mathrm{~km}$; Figs 128-129).

At the subsidence centre at Nuuk Qiterleq (South Nuussuaq section at $25 \mathrm{~km}$, Fig. 128), the Tupaasat unit $\left(f_{3}\right.$ in Fig. 128$)$ is covered by about $20-30 \mathrm{~m}$ of subaerial picrite flows of unit 423 ( $e_{2}$ in Fig. 128). East of Nuuk Qiterleq it is separated from the overlying thick hyaloclastites of the Ordlingassoq Member by $5-10 \mathrm{~cm}$ of claystone. Farther east, close to the final entry point into the sea of the lavas at Tupaasat, the lavas are capped by about $1 \mathrm{~m}$ of marine mudstone with dinoflagellate cysts (Piasecki et al. 1992, loc. 9).

Lithologies and volcanic history. The Tupaasat unit forms a continuous succession of subaerial lava flows over a 


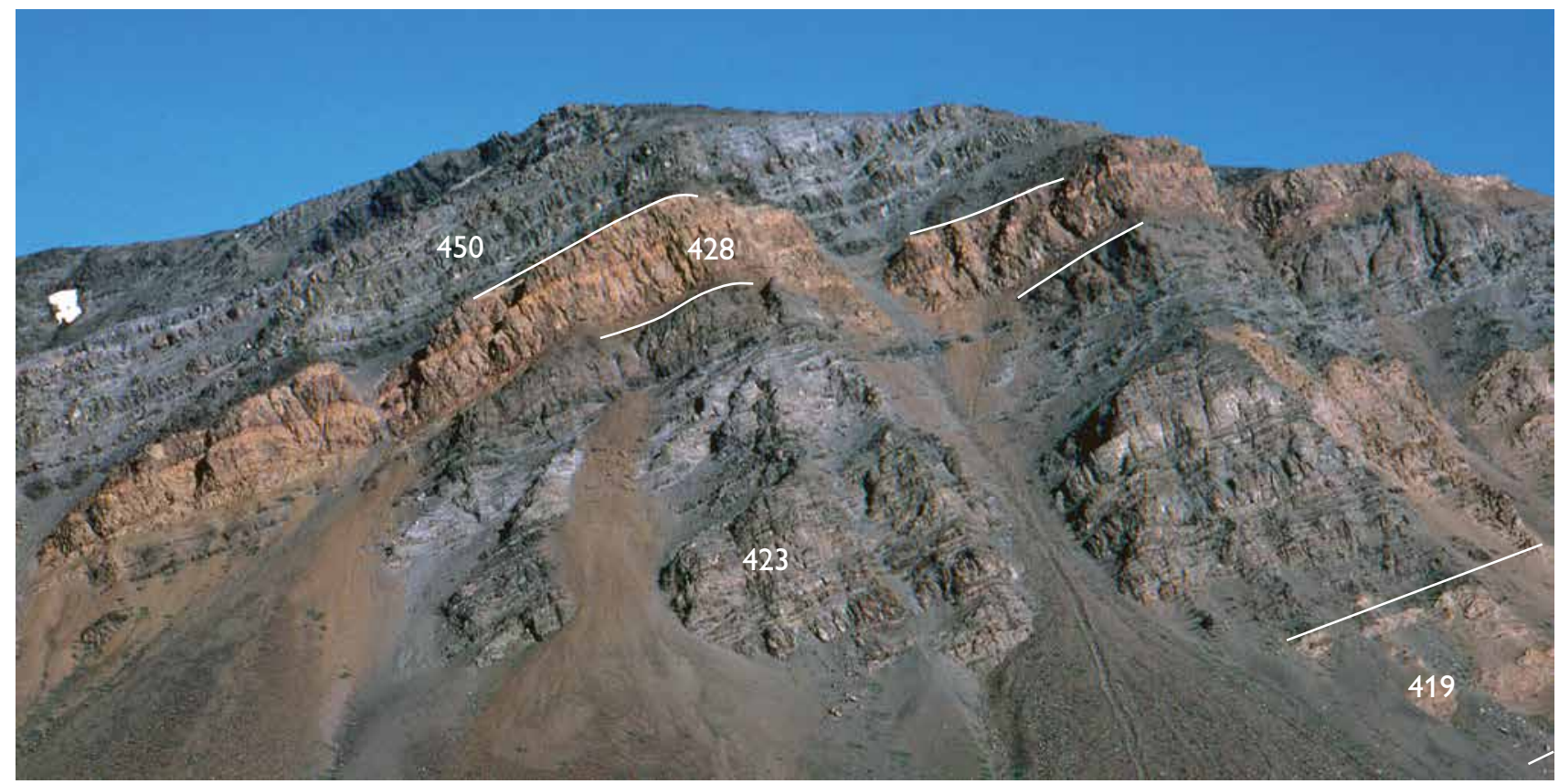

Fig. 131. Subaerial lava flows of the Vaigat Formation at the south-eastern corner of Hareøen, viewed from the south-south-east. The $c .40 \mathrm{~m}$ thick light brown lava flows of the Tunoqqu Member (unit 428) form a prominent marker horizon. In the lower right corner, light yellowish brown, extensively hydrothermally altered felspar-phyric basalt lavas are tentatively identified as the Saviaqqat unit (419) of the Asuk Member. Picrite flows of the Ordlingassoq Member (unit 450) occur at the top. The lava succession dips $35^{\circ} \mathrm{NW}$ due to the proximity to the Itilli Fault. Total thickness of section $350 \mathrm{~m}$ (Fig. 17).

distance of $c .10 \mathrm{~km}$ from just west of Nuuk Qiterleq to Tupaasat (at 23.9-33 km in the South Nuussuaq section, Figs 128, 129). A few flows may extend towards the west for another $6 \mathrm{~km}$, and a flow with the chemical character of the Tupaassat unit was sampled at Point $930 \mathrm{~m}$ above Nuuk Killeq (340766). The succession is $10-60 \mathrm{~m}$ thick, thickest in the synvolcanic subsidence area around Nuuk Qiterleq. The lavas are pahoehoe flows forming several flow fields (Fig. 130), and there are no internal soil horizons within the succession. The lavas entered the marine embayment just west of Tupaasat to form a less than $10 \mathrm{~m}$ thick pillow breccia horizon on top of one or two subaerial picrite flows of unit 423 (at 29.9-30.7 km in the South Nuussuaq section, Fig. 128); the continuation to the east is obscured by talus, and when the unit reappears $\left(f_{2}\right.$ and $f_{3}$ at $31.7-32.8 \mathrm{~km}$ in the South Nuussuaq section), the subaqueous part consists of more than 160 $\mathrm{m}$ of hyaloclastites and the last lava flows can be seen to enter the basin.

The rocks are olivine-phyric or microphyric with minor chromite. Orthopyroxene microphenocrysts have been observed in some samples. Neither xenoliths nor xenocrysts of sedimentary origin have been observed but may occur.
Eruption sites or feeder bodies are not known for this unit.

\section{Main Tunoqqu Member (unit 428)}

The Tunoqqu Member unit 428 comprises contaminated basaltic andesites and silicic basalts with 5-8.3 wt\% $\mathrm{MgO}$ and $51-55 \mathrm{wt} \% \mathrm{SiO}_{2}$ erupted from centres in $\mathrm{Ag}$ atdalen and Qunnilik, and much less contaminated, dispersed flows of basalt with 6-11 wt $\% \mathrm{MgO}$ and 49-51 wt $\% \mathrm{SiO}_{2}$. The Tunoqqu Member unit 428 is present on Nuussuaq in a $25-40 \mathrm{~km}$ wide zone extending between Alianaatsunnguaq and Nuuk Qiterleq on the south coast, between Qunnileeraq and Agatdalen on central Nuussuaq, and between Tunorsuaq and Østerfjeld on the north coast. The western limit of the Tunoqqu Member on Nuussuaq is erosional, and its presence on Hareøen indicates that the estimated area and volume on Nuussuaq $\left(c .2500 \mathrm{~km}^{2}\right.$ and $\left.160 \mathrm{~km}^{3}\right)$ are distinctly minimum values. Its eastern limit is depositional. Thicknesses vary from less than $50 \mathrm{~m}$ to about $300 \mathrm{~m}$ on Nuussuaq and the largest thicknesses are encountered where the unit enters the marine embayment to form ponded flows, hyaloclas- 


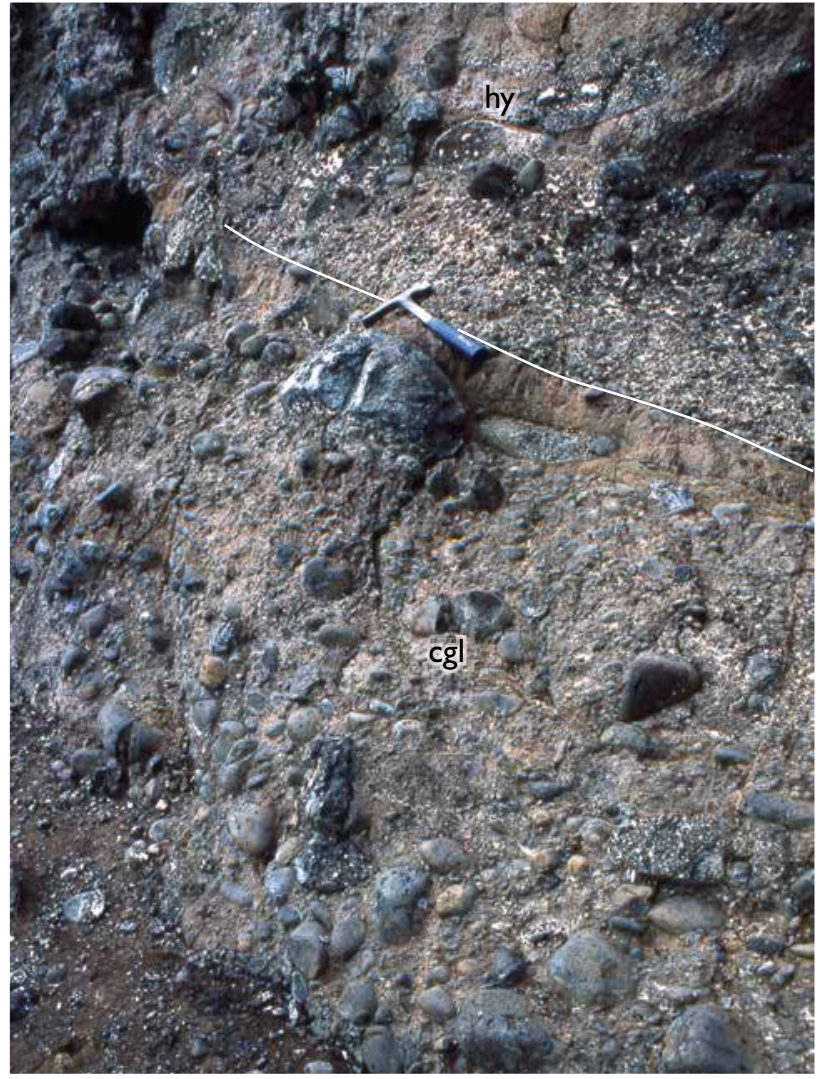

Fig. 132. Local conglomerate at the base of the Tunoqqu Member. The conglomerate (cgl) extends downslope from the palaeoshore and is covered by hyaloclastite (hy). Most of the conglomerate clasts are derived from subaerial lava flows, while the reworked matrix is mostly hyaloclastite. Length of hammer $32 \mathrm{~cm}$. Tunoqqu, central Nuussuaq.

tites and conglomerates. On Hareøen, the isolated occurrence of lava flows is about $40 \mathrm{~m}$ thick (Figs 17, 131).

During the deposition of the Tunoqqu Member, the east-prograding volcanic front reached the gneiss highland on north-eastern Nuussuaq whereby the marine embayment on eastern Nuussuaq and eastern Disko became sealed off from the sea in the north. The embayment was subsequently transformed into a lake filled with fresh water from the north-west-flowing river. The outlet to the sea was situated around Vesterfjeld and Mellemfjeld on northern Nuussuaq, where spectacular foreset-bedded boulder conglomerates up to $200 \mathrm{~m}$ thick were formed (Pedersen et al. 1996).

Boundaries. Over most of their extent, lava flows of unit 428 rest on a layer of lateritic soil a few decimetres thick, deposited on eroded surfaces of picritic lava flows of unit 423. At crater cone D of the Ilugissoq volcano (unit 420), a lava flow of the Tunoqqu Member laps onto the flank of the cone of graphite andesite (Figs 102, 103; Pedersen \& Larsen 2006, figs 2, 4). To the east, at Tunoqqu, the lower boundary is marked by eroded picritic lava flows of unit 423 forming a rocky palaeoshore and an associated conglomerate (Fig. 132; see also Fig. 137). About 1 $\mathrm{km}$ farther to the east, Tunoqqu Member hyaloclastites and subaqueous lava tongues may directly overlie marine sediments of the Itilli Formation or a thin veneer of sediments of the Eqalulik Formation (Dam et al. 2009, fig. 82).

Along the north coast of Nuussuaq, on the western side of Vesterfjeld, Tunoqqu Member conglomerates overlie foreset-bedded picritic hyaloclastites of unit 423 (Fig. 133). On the eastern side of Vesterfjeld, Tunoqqu Member conglomerates and foreset-bedded hyaloclastites overlie clastic sediments of the Ravn Kløft Member of the Atane Formation (Dam et al. 2009, fig. 30; the North Nuussuaq section, panel P-Q at $72 \mathrm{~km}$ ). Farther east, on Mellemfjeld and Østerfjeld, Tunoqqu Member conglomerates and hyaloclastites overlie sediments of the Kome Formation (Dam et al. 2009, fig. 22). On Mellemfjeld and Østerfjeld, and to the south at Timiusartorfik, the Tunoqqu Member units onlap Precambrian gneiss (Figs 134, 135).

Over most of their extent, lava flows of the Tunoqqu Member are covered by lateritic soil overlain by either subaerial flows (e.g. Fig. 73) or hyaloclastites of Ordlingassoq Member picrites (unit 450). In the area from Vesterfjeld to Østerfjeld, the Tunoqqu Member is covered by hyaloclastites or subaqueous flows of the Ordlingassoq Member with traces of mudstone at the base of unit 450 .

Lithologies and volcanic history. The Tunoqqu Member is composed of more or less crustally contaminated, evolved rocks. No xenoliths derived from crustal rocks have been found, but numerous plagioclase xenocrysts with 'spotted' cores indicate that crustal contamination is responsible for the general enrichment in silica (see chapter on crustal contamination in Pedersen et al. 2018). Orthopyroxene is present in a number of the most silica-rich rocks, but the majority of the basalts and basaltic andesites of the Tunoqqu Member are olivine-phyric or microphyric or show variable combinations of olivine, plagioclase and clinopyroxene phenocrysts and microphenocrysts. Some rocks are almost aphyric. In general, many of the basalts are petrographically indistinguishable from uncontaminated basalts of the Vaigat Formation.

Over the main part of its extent, the Tunoqqu Member is composed of subaerial lava flows which include 


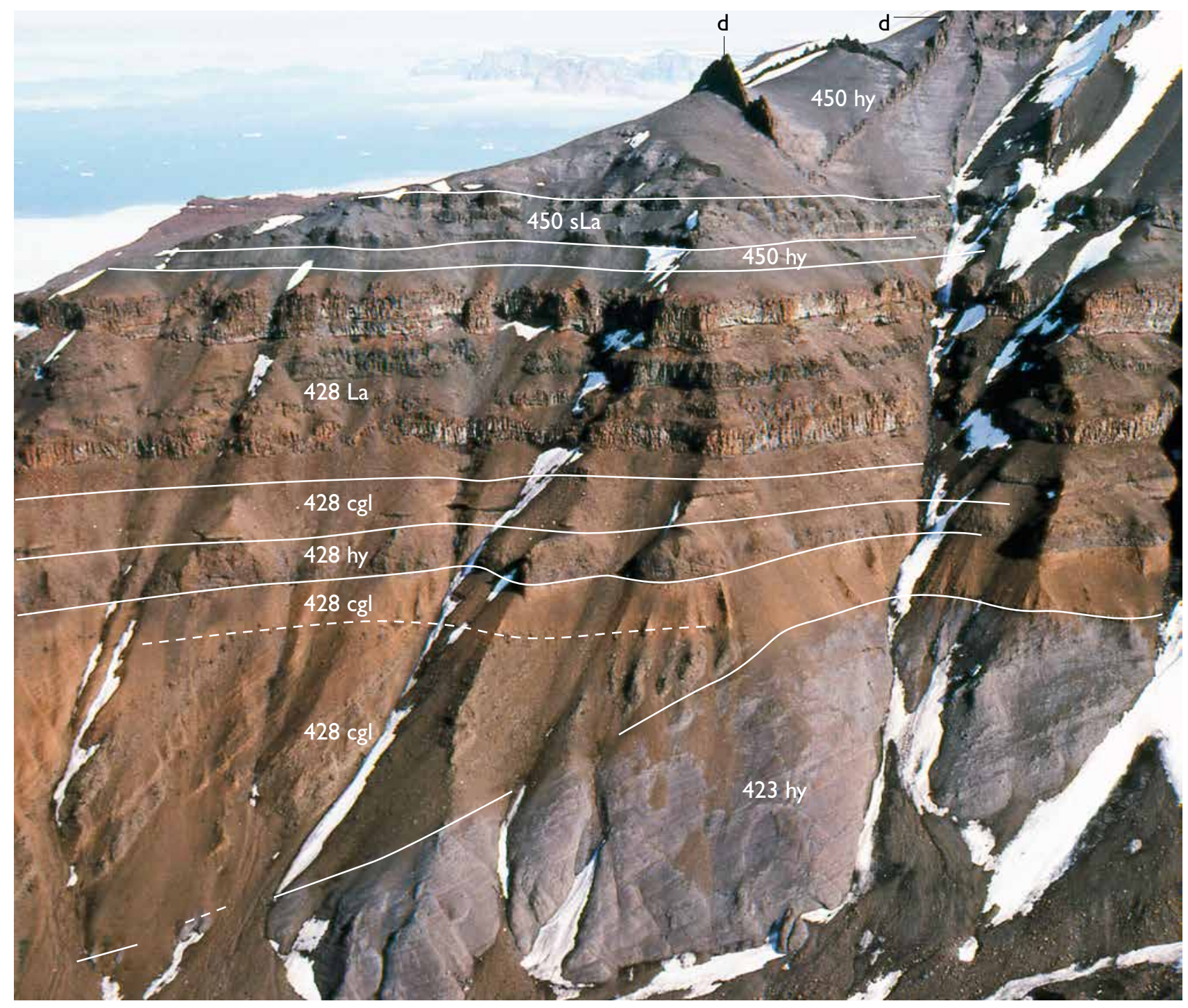

Fig. 133. Brown-weathering subaerial lava flows ( $428 \mathrm{La}$ ), hyaloclastites ( $428 \mathrm{hy}$ ) and conglomerate beds ( $428 \mathrm{cgl}$ ) of the Tunoqqu Member. The partly foreset-bedded conglomerate beds contain older blocks of gneiss and picrite in addition to lava clasts of the Tunoqqu Member and overlie foreset-bedded marine picritic hyaloclastites of the Naujánguit Member ( 423 hy). On top of the Tunoqqu Member are picritic hyaloclastites and subaqueous lava flows of the Ordlingassoq Member ( $450 \mathrm{hy}, 450 \mathrm{sLa}$ ). Several dykes (d) cut the succession. Western side of Vesterfjeld, north coast of Nuussuaq. The Tunoqqu Member lava succession $(428 \mathrm{La})$ is $100 \mathrm{~m}$ thick.

both compound flows with many flow lobes and thick individual flows. The compound flows are well exemplified by a large compound flow erupted from a small neck in the western part of the Qunnilik valley. The large individual flows reach a maximum thickness of $c .25 \mathrm{~m}$ except at the eastern margin where they may exceed $60 \mathrm{~m}$ due to ponding. Soil horizons and in some areas several conglomerate horizons are found within the member. This, together with diverse eruption sites and a considerable variation in composition, points to a duration of the member well in excess of some thousands of years.
The development of the Tunoqqu Member and its interaction with the sea is illustrated in the cartoons in Fig. 136. The entry of the volcanic rocks of the Tunoqqu Member into the marine embayment to the east is marked by a $c$. 5-6 km wide zone with variable lithologies which were described in some detail by Pedersen $e t$ al. (1996). At the type locality at Tunoqqu a c. $225 \mathrm{~m}$ thick succession of hyaloclastites and subaqueous and subaerial lava flows is exposed (Fig. 137). The lower part is composed of foreset-bedded hyaloclastites and interbedded small lobes of subaqueous lava which record the 


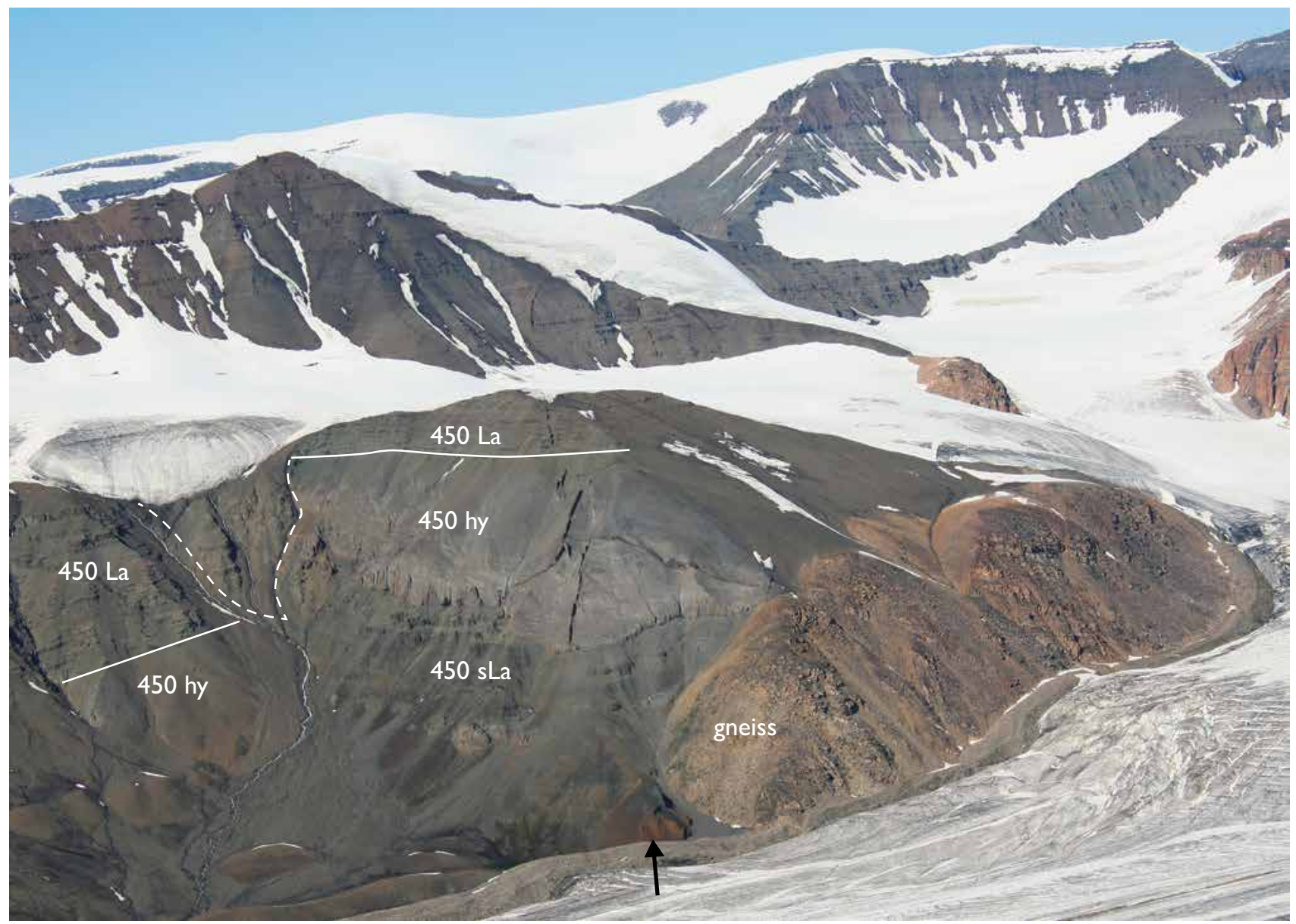

Fig. 134. Contact between the volcanic succession and Precambrian gneiss hills across the eastern boundary (Ikorfat) fault system. The first volcanics to make the contact are seen in a small triangular exposure of orange-brown lava flows and subaqueous lava tongues of the Tunoqqu Member (at black arrow, mid-lower photo) banked up against gneiss at the site where the marine embayment was first plugged (Fig. 136-1; see also detailed view in Fig. 135 and photogrammetric section in Pedersen et al. 1996, fig. 9). The Tunoqqu Member deposits are overlain by hyaloclastites, subaqueous and subaerial lava flows of the Ordlingassoq Member ( 450 hy, $450 \mathrm{sLa}$, $450 \mathrm{La}$ ). Movement along the Ikorfat fault system has crushed the triangular area outlined by the dashed curve. Timiusartorfik east of Agatdalen, central Nuussuaq, viewed from the south.

entry of a compound lava flow into water (Pedersen $e t$ al. 1996, fig. 8). The upper part of the section is composed of several strongly columnar-jointed lava flows which form one of the most spectacular exposures of the entire Vaigat Formation on Nuussuaq (Fig. 138). Three or four flows with regular colonnades and large entablature zones may all have been emplaced during the same eruption. The lower two flows have 'bulldozed' into the

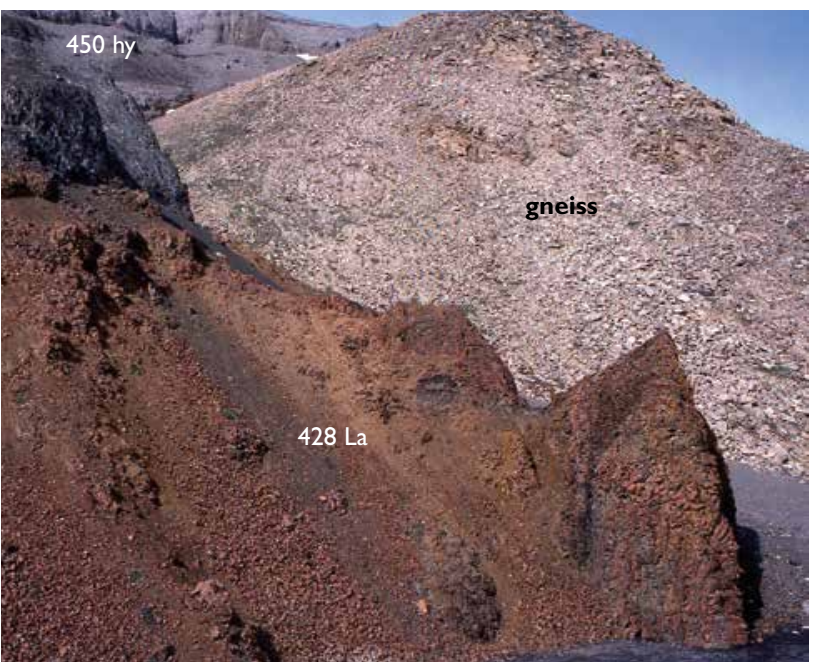

Fig. 135. Orange-brown, contaminated basalt flows of the Tunoqqu Member (428 La) almost in contact with Precambrian gneiss. The flows have strongly developed entablature zones due to a wet environment during emplacement. Unit 428 is overlain by picritic hyaloclastites of the Ordlingassoq Member ( 450 hy) which must also have been in direct contact with the gneiss. Compare with Fig. 134 The thickness of the exposed Tunoqqu Member lavas is about 50 m. Timiusartorfik east of Agatdalen, central Nuussuaq, close view. 


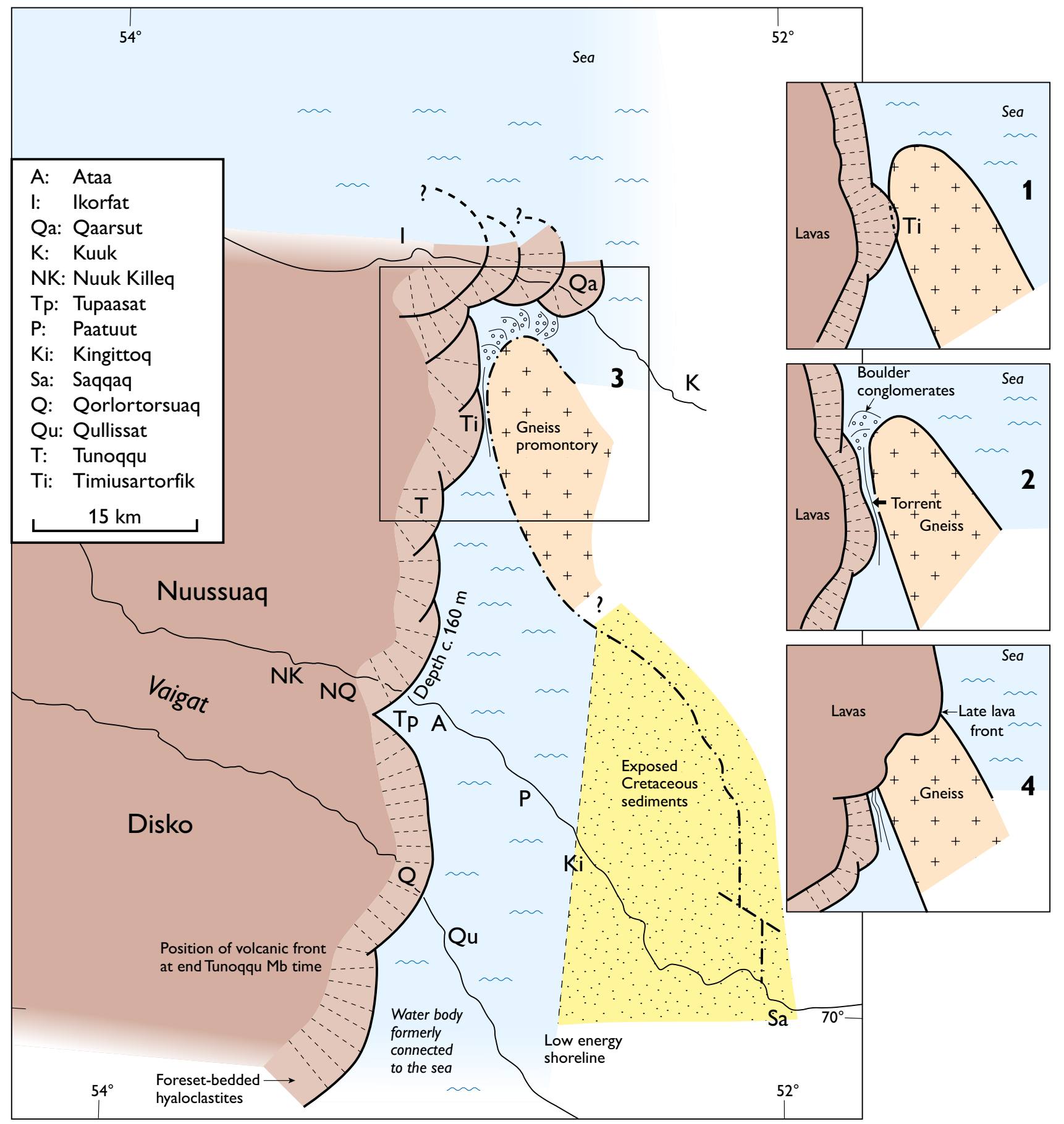

Fig. 136. Reconstruction of the palaeogeography of central Nuussuaq and north-eastern Disko during deposition of the Tunoqqu Member. A water body with a depth of $c .160 \mathrm{~m}$ was confined between a high gneiss promontory in the north-east, a low-energy clastic shoreline in the east, and the advancing volcanic front in the west, leaving only a narrow connection to the sea in the north. Three stages in the development are illustrated on separate maps. 1: Progradation of Tunoqqu Member hyaloclastites towards the east. The hyaloclastite onlaps the gneiss surface at Timiusartorfik. 2: Fluvial erosion occurs between the easily erodable Tunoqqu Member volcanic rocks and the gneiss promontory. A boulder conglomerate is deposited in front of the torrent. 3: Continued volcanic activity produces additional hyaloclastites and lavas in the north, which force the conglomerates eastwards. 4: Finally, both volcanics and conglomerates are covered by subaerial lava flows onlapping the gneiss. Redrawn from Pedersen et al. (1996). 
Fig. 137. The type locality for the Tunoqqu Member. The member here comprises a $c$. $225 \mathrm{~m}$ thick succession of hyaloclastites and subaqueous lavas (label $\mathbf{g}_{1}$ ) and subaerial lava flows (label $\mathbf{g}_{2}$ ). See text for descriptions. Excerpt from the Central Nuussuaq section at $38-40 \mathrm{~km}$ (Pedersen et al. 2002a). Blue numbers are unit codes; other unit annotations are from the original. See photo in Fig. 138. Tunoqqu, central Nuussuaq.

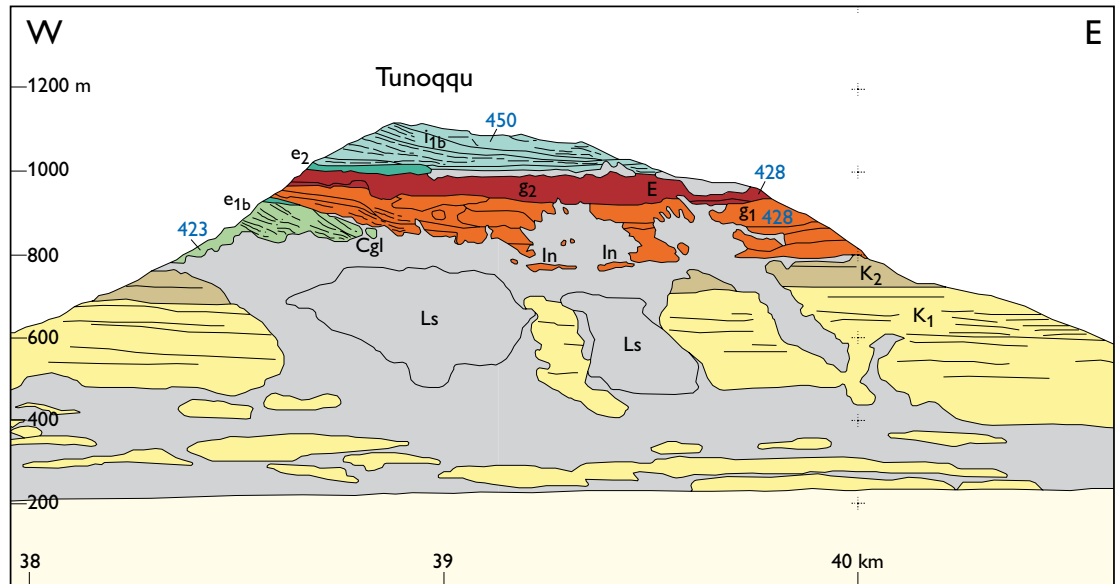

underlying hyaloclastites, and the upper flow thickens rapidly eastwards as the basin became filled. The top of the upper flow stayed above the water level and its top of oxidised scoria was later eroded and re-deposited as an upwards-fining conglomerate rich in oxidised basalt pebbles. The eroded flow is covered by, in succession, a single picrite flow of the Ordlingassoq Member, a thin layer of mudstone, and at least $100 \mathrm{~m}$ of foreset-bedded picritic Ordlingassoq Member hyaloclastites.

Similar features are exposed in the eastern side of Agatdalen. The easternmost exposure in this general area is at Quleruannguaq where about $140 \mathrm{~m}$ of Tunoqqu Member volcanic rocks overlie mudstones of the Eqalulik Formation (Central Nuussuaq section at $45-46 \mathrm{~km}$ ). Here, several brownish-weathering sills are interpreted to

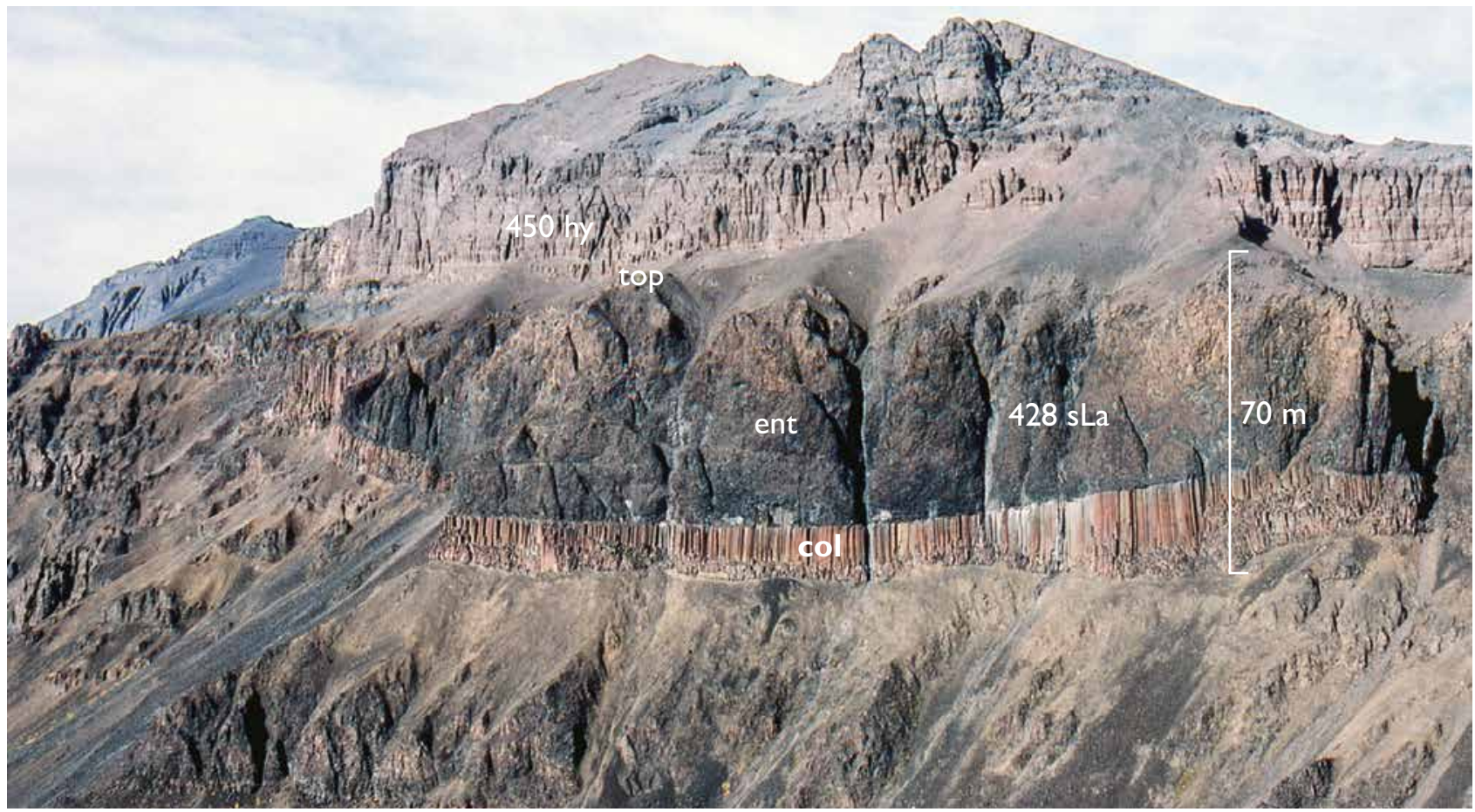

Fig. 138. Subaqueous to transitional facies lava flows of the Tunoqqu Member (428) covered by a succession of foreset-bedded hyaloclastites of the Ordlingassoq Member ( 450 hy). The most prominent feature is a $c .70 \mathrm{~m}$ thick lava flow which has ponded to form a local lava lake. The flow has a very regular lower colonnade (col), a thick dark entablature zone (ent) and a crumbling lava top (top) with oxidised scoria. See also Fig. 137. Tunoqqu, central Nuussuaq. Photo: Finn Ulff-Møller. 


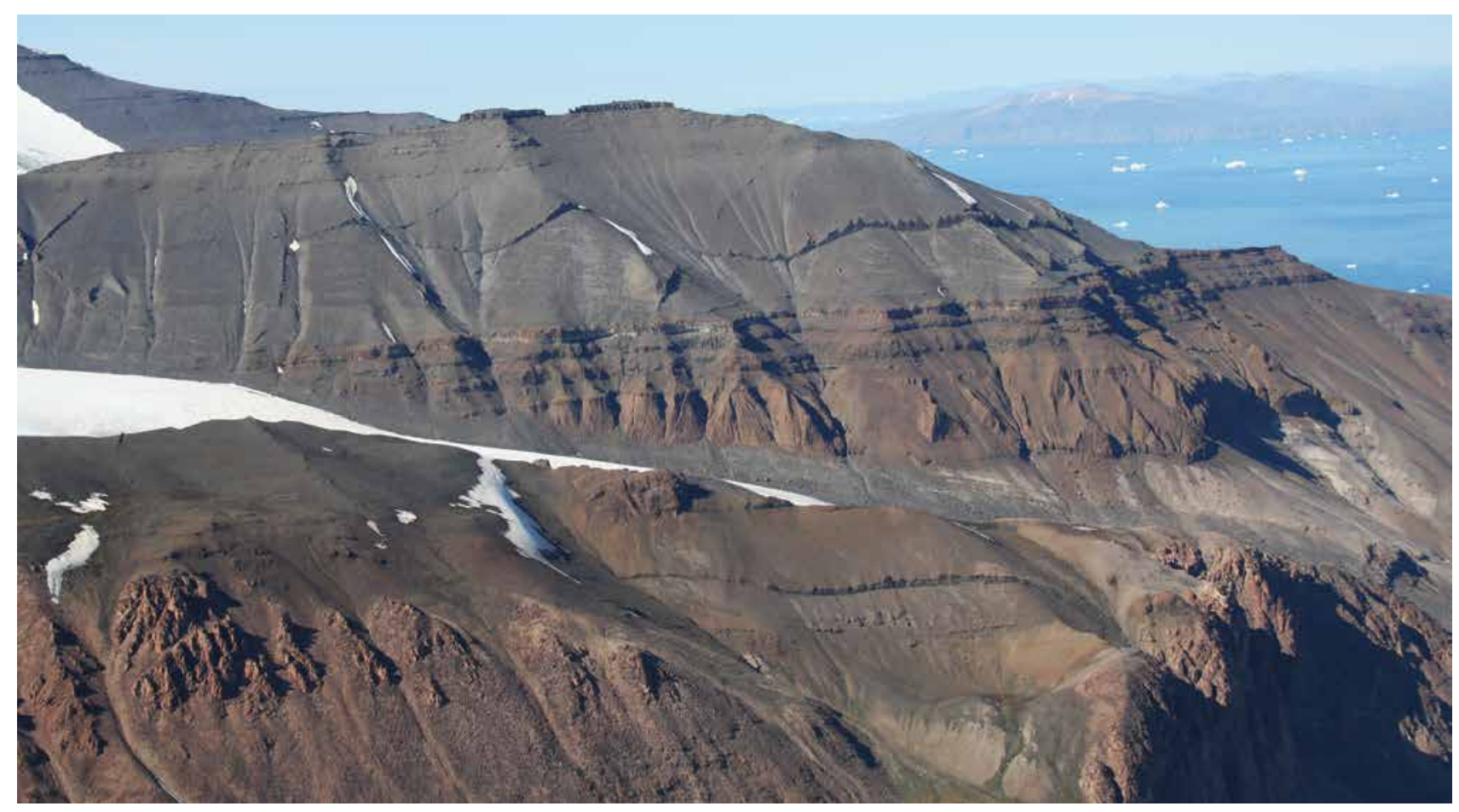

Fig. 139. The Tunoqqu Member on northern Nuussuaq. In the foreground the northerly sloping and eroded surface of Precambrian gneiss (brown) and Cretaceous sediments (whitish) is onlapped by brownish weathering conglomerates, hyaloclastites and dark brown lava flows of the Tunoqqu Member. A subhorizontal succession of grey hyaloclastites and lavas of the Ordlingassoq Member overlie the Tunoqqu Member lava flows. Scattered dark dykes cut the succession. See also the North Nuussuaq section, panel P-Q. Vesterfjeld viewed from the south-east.

be invasive Tunoqqu Member lavas. Unit 428 is here covered by more than $300 \mathrm{~m}$ of foreset-bedded hyaloclastites of Ordlingassoq Member unit 450.

The lithological variation and development of the $\mathrm{Tu}$ noqqu Member on the north coast of Nuussuaq are complex because the sealing point and later the outlet from the new-formed lake behind the volcanic seal were situated here, and episodes of catastrophic tapping seem to have taken place. The geology is illustrated by Pedersen et al. (1996, fig. 10a to d) and in the North Nuussuaq section, panel $\mathrm{P}-\mathrm{Q}$. The volcanic front advanced from the west towards a gneiss promontory near Vesterfjeld with a palaeotopography of more than $750 \mathrm{~m}$. On this gneiss hill some eroded remnants of $\mathrm{N}$-dipping, tilted Cretaceous sediments of the Kome and Atane formations were resting (Dam et al. 2009, figs 22, 29, 30; Fig. 139). On the west side of Vesterfjeld (Fig. 133), the lowermost unit of the Tunoqqu Member is a more than 100 $\mathrm{m}$ thick, foreset-bedded conglomerate which contains clasts of picrite, Precambrian gneiss and contaminated basalt in a hyaloclastite-rich matrix. It covers a thin veneer of mudstone with marine dinoflagellate cysts (S. Piasecki, personal communication 1994) resting on picritic hyaloclastite of unit 423. On the east side of Vesterfjeld, the lowermost unit of the Tunoqqu Member is an up to $140 \mathrm{~m}$ thick, foreset-bedded hyaloclastite entirely composed of contaminated basalt (Figs 140, 141). The top of the hyaloclastite is eroded and covered by a $10-15 \mathrm{~m}$ thick horizontal bed of conglomerate which continues downslope to the north, increasing in thickness to up to $200 \mathrm{~m}$. The conglomerate is composed of rounded lava clasts and rounded pillow fragments in a matrix largely composed of hyaloclastite gravel, all dominated by volcanic material from the Tunoqqu Member. The conglomerate is covered by additional horizontal conglomerate beds and lava flows of the Tunoqqu Member, several of which are strongly columnar-jointed and show evidence of emplacement in a humid environment.

Mellemfjeld farther to the east is composed of a number of conglomerate beds with different clast sizes and orientations of bedding, invasive lava flows and a cover of subaerial lavas, all of unit 428 (Pedersen et al. 1996, fig. 12), resting on Cretaceous sediments and Precambrian basement. This locality has been important for the geological reconstruction of the plugging and filling of the marine embayment by the Tunoqqu Member (Fig. 136). 


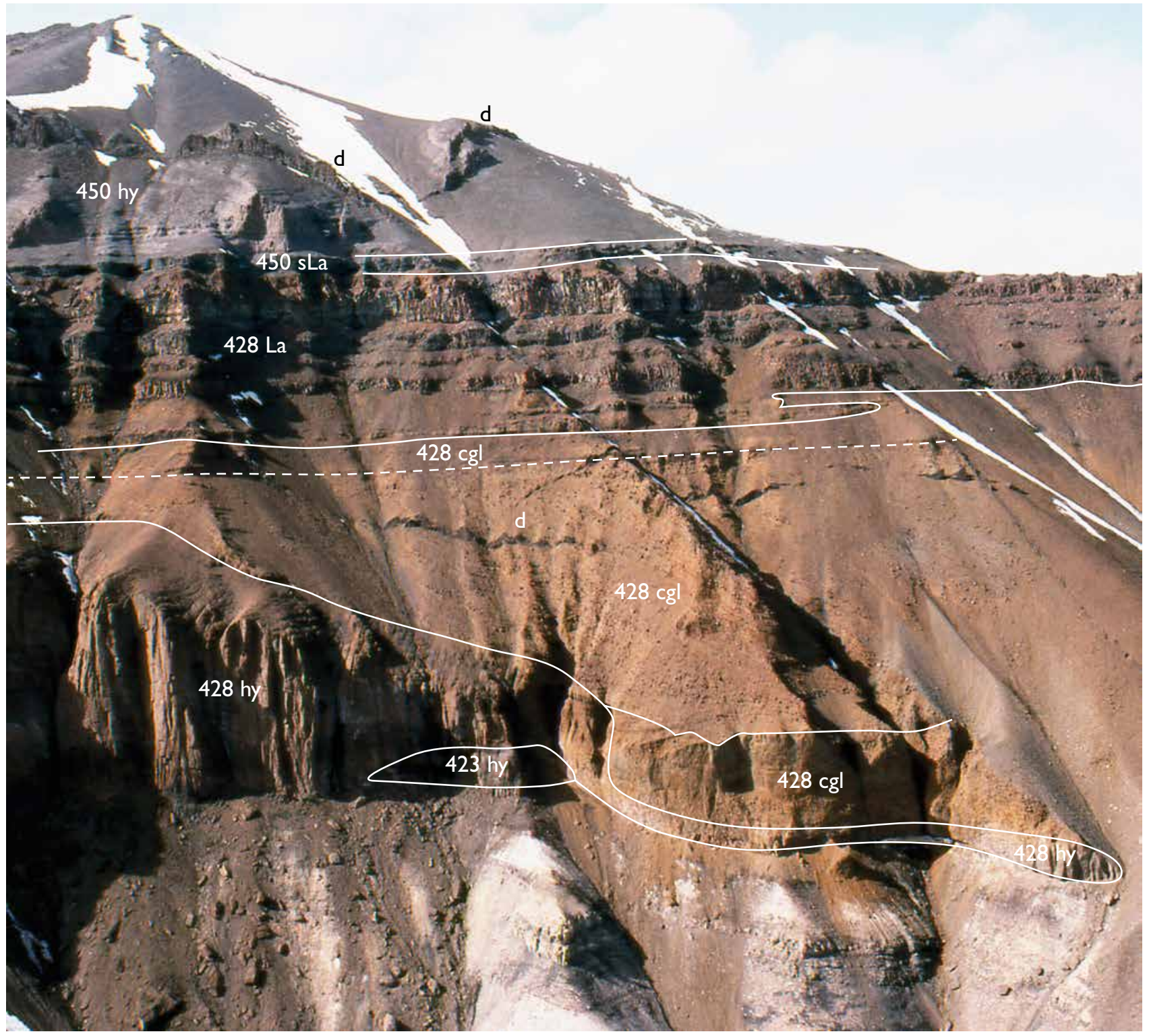

Fig. 140. The Tunoqqu Member on northern Nuussuaq. At the base, whitish clastic sediments of the Slibestensfjeldet Formation are onlapped by hyaloclastites of first the Naujanguit Member ( $423 \mathrm{hy}$ ) and then the Tunoqqu Member ( $428 \mathrm{hy}$ ), and then by up to $200 \mathrm{~m}$ thick fans of conglomerates dominated by Tunoqqu Member material $(428 \mathrm{cgl})$. These are overlain by subaerial lava flows ( $428 \mathrm{La}$ ) of the Tunoqqu Member, in turn covered by hyaloclastites and a subaqueous lava flow of the Ordlingassoq Member ( 450 hy, $450 \mathrm{sLa})$. The succession is cut by dykes (d). Eastern side of Vesterfjeld; total height of section is $c .700 \mathrm{~m}$. See also Fig. 141 at $71-72 \mathrm{~km}$, Pedersen et al. 1996, fig. 10b and Dam et al. 2009, fig. 22).

The southernmost locality where volcanic rocks of the Tunoqqu Member reached the Precambrian gneiss promontory was interpreted from photogrammetry to be at Timiusartorfik east of Agatdalen (Pedersen $e t$ al. 1996; Figs 134-136). Later field work has shown that the locality comprises a unit 428 lava flow with a welldeveloped entablature zone and an eroded top covered by a thick conglomerate dominated by rocks derived from the Tunoqqu Member. The succession is covered by picritic lava and hyaloclastite of the Ordlingassoq Member. The contact to the nearby steep gneiss hill is not exposed.

From a sedimentological point of view, the volcanic conglomerates of the Tunoqqu Member may be considered part of the sedimentary Eqalulik Formation (Dam et al. 2009), but they form an integral part of the Tunoqqu Member deposits and are treated here as part of unit 428 . 


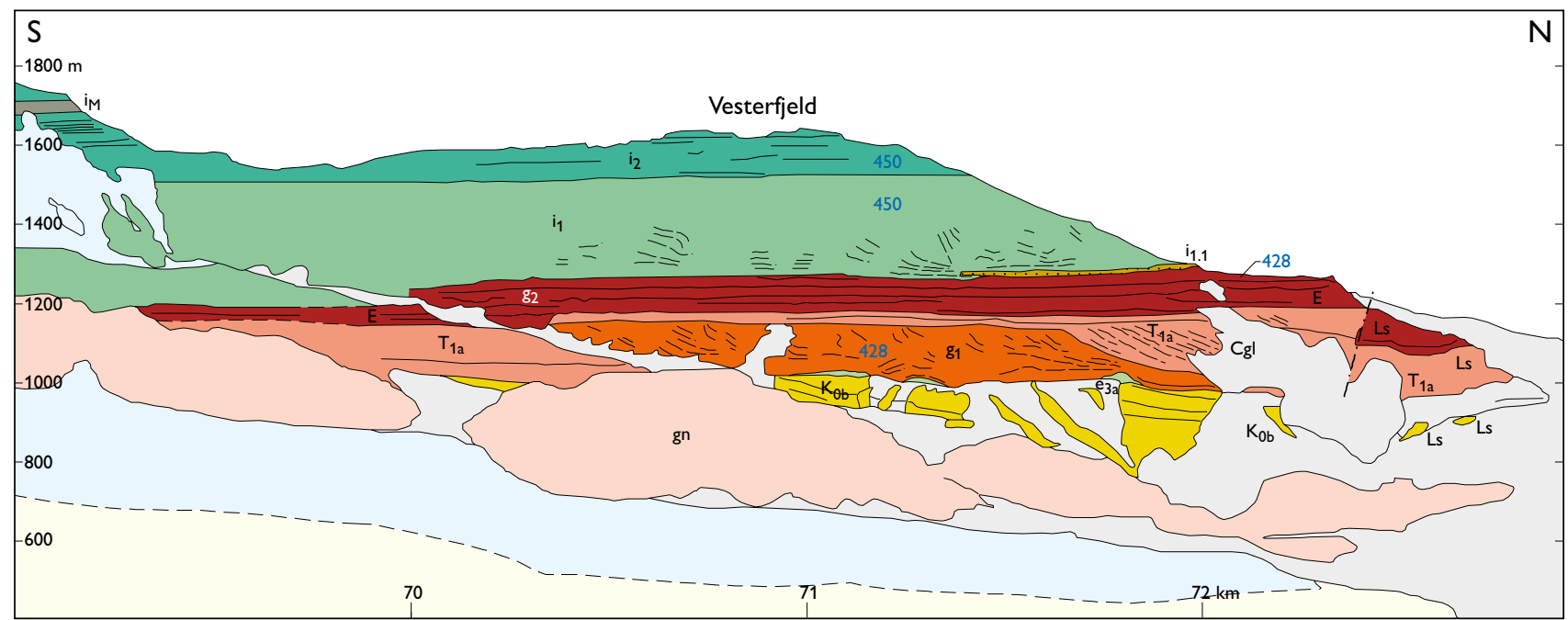

Fig. 141. Photogrammetrically measured section along the eastern side of Vesterfjeld, north coast of Nuussuaq. Successive hyaloclastites of the Tunoqqu Member $\left(\mathbf{g}_{\mathbf{1}}\right)$ and conglomerates dominated by Tunoqqu Member material $\left(\mathbf{T}_{\mathbf{1 a}}\right)$ fill in northwards and are overlain by subaerial lava flows of the Tunoqqu Member $\left(\mathbf{g}_{\mathbf{2}}\right) \cdot \mathbf{K}_{\mathbf{0 b}}$ is sediments of the Slibestensfjeldet Formation. Compare Fig. 140. Blue numbers are unit codes; other unit annotations are from the original. Excerpt from the North Nuussuaq section, panel P-Q at 69-73 km (Pedersen $e$ al. 2006).

The Tunoqqu Member was also sampled by Lightfoot et al. (1997) in their sections N-91-05 and N-91-10 (their samples 7856, 7859, 7904, 7907).

Eruption sites and centres of the Tunoqqu Member. Only one small volcanic neck is known from the Tunoqqu Member, and the evidence that unit 428 was derived from eruption sites scattered across Nuussuaq is based on analysis of the chemistry and petrography of rocks from widely spaced localities. Pedersen et al. (1996) recognised that the most silica-enriched and most crustally contaminated rocks occur in two areas, around the Qunnilik valley where a volcanic neck is located, and in an area extending between the inner Agatdalen and the Vesterfjeld area on the north coast. This distribution is taken to indicate two individual eruption centres, the Qunnilik and the Agatdalen centres (Fig. 10).

Three distinctive petrographic types of basalt, each with a limited geographical distribution, can be identified; they can therefore be used to indicate eruption sites. These types are among the least crustally contaminated rocks of the member and they are all basalts with small phenocrysts of olivine (commonly pseudomorphosed), plagioclase and scarce clinopyroxene microphenocrysts.

One type (the 'Tunoqqu type') is characterised by microphenocrystic plagioclase and olivine and may in addition contain xenocrystic clusters of plagioclase with 'spotted' cores. It includes all basalts of the type locality at Tunoqqu and is also present at Qilakitsoq and Alianaatsunnguaq. It thus delineates a production centre around the Aaffarsuaq valley in the easternmost part of the Tunoqqu Member area (Fig. 10).

A second type (the 'Ilugissoq type') is characterised by small phenocrysts of olivine, plagioclase and clinopyroxene. It is known from Ukallit, Ilugissoq and Qilakitsoq, and, although fairly similar to the Tunoqqu type, it is sufficiently distinctive to delineate several eruptions around the Ilugissoq-Ukallit area (Fig. 10; Central Nuussuaq section at $16-23 \mathrm{~km}$ ).

A third and very distinctive type (the 'Sorluut type') contains very abundant small clusters of plagioclase and larger, commonly prismatic, pseudomorphosed olivine grains. It also contains scattered plagioclase xenocrysts with 'spotted' cores. One population is known from Sorluut, Tunorsuaq and Puugutalissuaq and delineates a distribution field on northern Nuussuaq (Fig. 10), while two rather similar but chemically more enriched samples from Ikorfat and Tunorsuaq may delineate another northern flow field.

Large areas exist where the Tunoqqu Member has been mapped but not sampled, and more detailed work is likely to reveal additional eruption centres. 


\section{Kûgánguaq Member}

\section{Summary of the main features of the Kûgánguaq Member}

- Brown contaminated basalts, basaltic andesites and andesites erupted from a centre in Kuugannguaq. Basaltic welded tuffs occur in the central eruption area.

- Only present on Disko; time-equivalent to the Tunoqqu Member on Nuussuaq.

- High degrees of contamination; the contaminant was sandstone.

- Economic geology: Basaltic andesites show large losses of $\mathrm{Cu}$ and $\mathrm{Ni}$ due to sulfide fractionation, and the subvolcanic parts have been subjected to exploration for $\mathrm{Ni}$ and platinum-group elements.

\section{Lithostratigraphy of the Kûgánguaq Member}

History. Originally defined by Pedersen (1985a). No revision is applied here. The member was described in considerable detail by Pedersen (1985b).

Name. After the large Kuugannguaq (new spelling) valley on northern Disko (Fig. 4).

Distribution. North and north-east Disko (Fig. 10). Delimitations are depositional within Disko and erosional towards the Vaigat strait.

Type section. The mountain side at the northern corner of the opening from Kuugannguaq into Harald Moltke Dal (Pedersen 1985b, profiles 2, 3); here Kuugannguaq north-east (Fig. 16, profile 22).

Reference sections. Kuugannguaq west side, Norddalen, Kussinikassak (Fig. 16, profiles 21, 24, 26); see also detailed profiles in Pedersen 1985b.

Thickness. From $0 \mathrm{~m}$ to $90 \mathrm{~m}$ in the central eruption area.

Lithology. Yellowish brown weathering olivine microphyric basalt and magnesian andesite lava flows. Basaltic airfall tuffs form a conspicuous red-coloured volcanic cone in the central eruption area.

Boundaries. The lower boundary is a thin red soil horizon on top of picrite lavas of the Naujánguit Member. The upper boundary in a small area is an eroded surface that is overlain by picrite lavas and hyaloclastites of the Ordlingassoq Member. Elsewhere, the member is covered by basalt lavas of the Qordlortorssuaq Member.

Age. Paleocene, nannoplankton zone NP5-6, c. 61 Ma, magnetochron C26r, based on dinoflagellate cysts (Piasecki et al. 1992) and radiometric dating of older and younger rocks in the succession (Storey et al. 1998).

Correlation. The Tunoqqu Member on Nuussuaq is situated at the same stratigraphic level as the Kûgánguaq Member on Disko, and the two members are considered to be contemporaneous.

\section{Geology of the Kûgánguaq Member (unit 430)}

The main part of the Kûgánguaq Member was produced from a central eruption site in the northern Kuugannguaq valley. The member is composed of crustally contaminated rocks, and olivine microphyric silicic basalts and magnesian basaltic andesites (grading into picrites) with $10-12.7 \mathrm{wt} \% \mathrm{MgO}$ and $51-53 \mathrm{wt} \% \mathrm{SiO}_{2}$ constitute $c$. $92 \%$, olivine- and orthopyroxene microphyric magnesian andesites with 8-10 wt $\% \mathrm{MgO}$ and 57-60 wt $\% \mathrm{SiO}_{2}$ constitute $c .7 \%$, and feldspar-phyric basaltic andesites with c. $6.5 \mathrm{wt} \% \mathrm{MgO}$ and 52.4-53.3 wt $\% \mathrm{SiO}_{2}$ constitute less than $1 \%$ of the member (Pedersen 1985b).

The volcanic rocks of the Kûgánguaq Member cover an area of around $500 \mathrm{~km}^{2}$ on northern Disko (Fig. 10; Pedersen 1985a, fig. 12) and probably extended for several hundred square kilometres into the present area of the Vaigat strait. The original volume on Disko is in excess of $10 \mathrm{~km}^{3}$, and if the former extent in the Vaigat strait is included a volume of $15-20 \mathrm{~km}^{3}$ is estimated. The Kûgánguaq Member reaches a thickness of $c .90 \mathrm{~m}$ in the central eruption area in Kuugannguaq and thins to less than 15 $\mathrm{m}$ thickness in the distal areas (Fig. 16; Pedersen 1985b, fig. 5). Furthermore, there is an isolated occurrence in the inner part of Stordal (Fig. 10; Central Disko section at $41.1-44.4 \mathrm{~km}$, unit $\mathrm{g}_{2}$, see also Fig. 183. Here a lava succession which is at least $80 \mathrm{~m}$ thick has flowed into a palaeovalley in the eastern flank of the Disko Gneiss Ridge, probably from the north. These lavas are aphyric to weakly olivine microphyric basaltic andesites with 


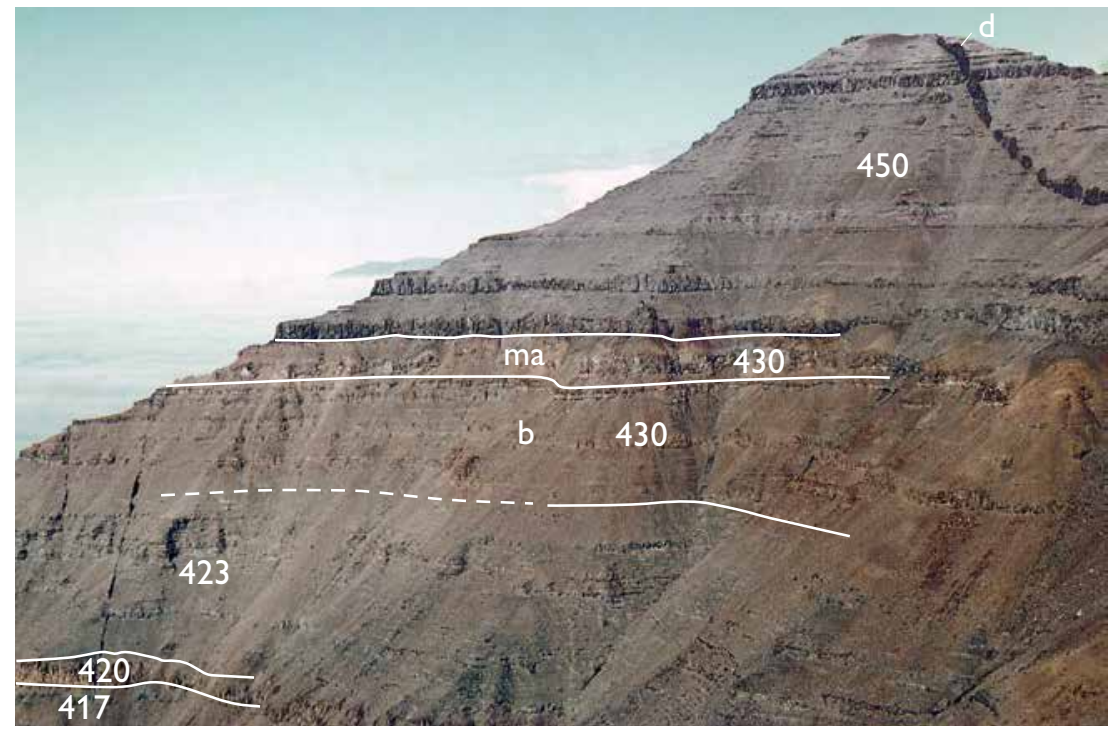

Fig. 142. Kûgánguaq Member lava flows (unit 430) comprising silicic basalt and basaltic andesite flows (b) and a magnesian andesite flow (ma) in the eastern side of the outer Kuugannguaq valley on northern Disko. The Kûgánguaq Member is $c .90 \mathrm{~m}$ thick at this locality, see also Pedersen 1985b, fig. 5, profile 3. Below, to the left, a single silicic basalt flow of the Asuk Member (420) is covered by Naujánguit Member picrite flows (unit 423). On the top are picrite lavas of the Ordlingassoq Member (unit 450) cut by a dyke (d).

7.5-8.5 wt $\% \mathrm{MgO}$ and 52.6-54.4 wt $\% \mathrm{SiO}_{2}$ and were presumably derived from a minor high-level magma reservoir that was active contemporaneously with the main centre at Kuugannguaq.
Overall, the Kûgánguaq Member, like other successions of crustally contaminated lavas, constitutes a distinctive stratigraphical marker horizon, occurring within a succession of greyish weathering picrite and basalt lava flows (Figs 142, 143).

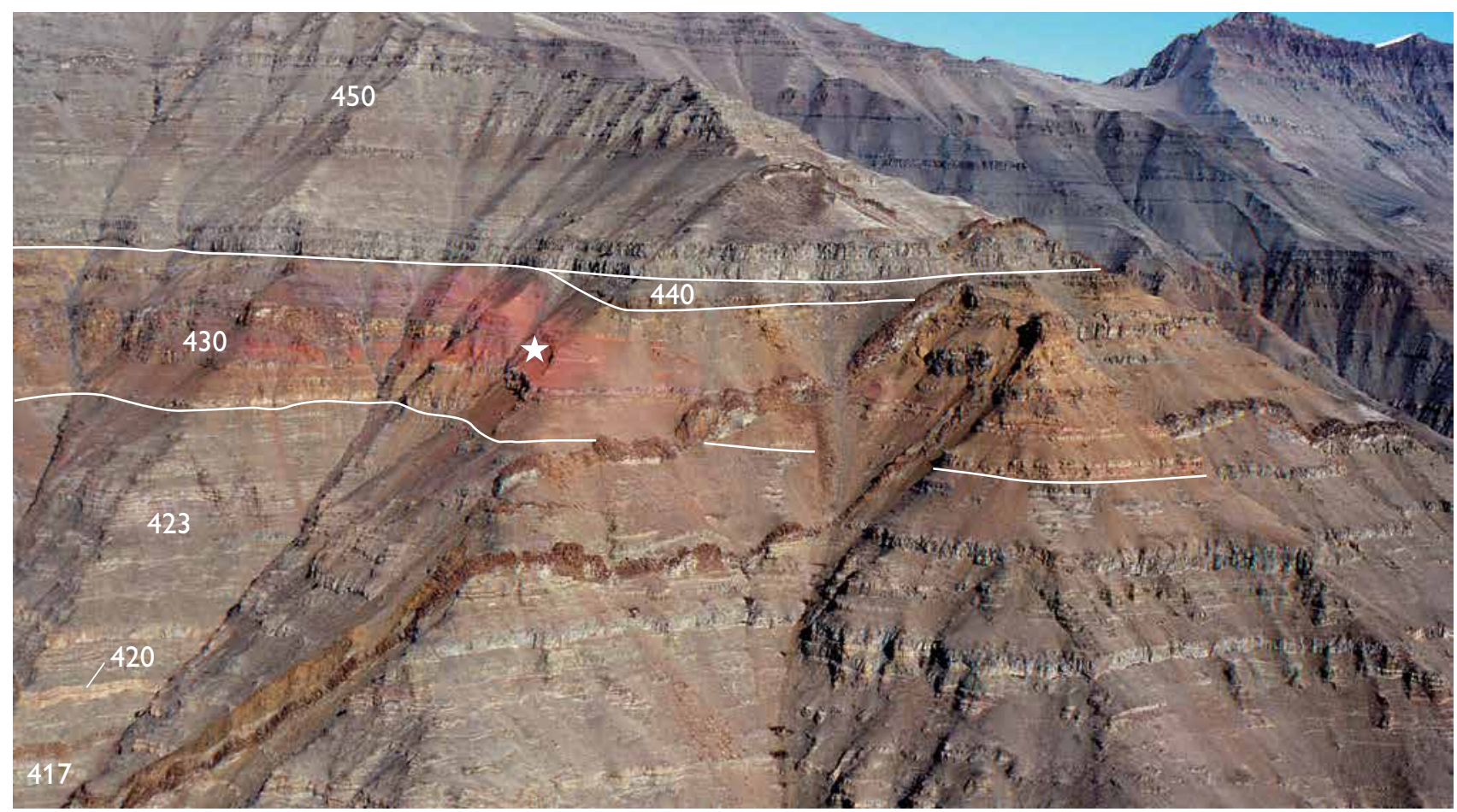

Fig. 143. Kûgánguaq Member lava flows and tuffs (430) in the eastern side of the Kuugannguaq valley on northern Disko. The crater area stands out with red-oxidised, basaltic welded tuffs; the centre is marked by a white star. The crater deposits are eroded on the top and the southern part is capped by a basalt flow of the Qordlortorssuaq Member (440). Other units are indicated by their numerical codes. Dark brown dykes cut the lava succession. The Kûgánguaq Member is 55-60 m thick. 
Boundaries. The lower boundary is marked by a few centimetres to a few decimetres of lateritic claystones deposited on the surfaces of subaerial picrite lavas of unit 423.

In Stordal and over most of the Kuugannguaq area, unit 430 is covered by a few decimetres of lateritic claystone followed by subaerial basalt lava flows of the Qordlortorssuaq Member (unit 440). In a limited area north of $70^{\circ} 13$ ' N, where the Kûgánguaq Member forms a small tuff shield, the top of this shield is eroded and levelled. Here, unit 440 is missing and the tuffs and the overlying thin lateritic claystone is covered by subaerial picrite lavas or hyaloclastites of the Ordlingassoq Member (unit 450; Fig. 16; Pedersen 1985b, figs 5, 6).

Lithologies. The Kûgánguaq Member comprises four different lithologies.

Olivine microphyric basaltic lavas. The dominant lithology of the Kûgánguaq Member is olivine microphyric pahoehoe lava flows that in the field are described as basalts but chemically range from silicic basalts to magnesian basaltic andesites. These lavas have a characteristic yellowish brown weathering colour (Figs 142, 143). The flows are from less than $1 \mathrm{~m}$ to $8 \mathrm{~m}$ thick and commonly form thin-bedded flow fields up to $70 \mathrm{~m}$ in thickness (Pedersen 1985b, figs 5, 6).

Olivine microphyric basaltic welded tuffs. The most conspicuous feature of the Kûgánguaq Member is a central eruption area of intensely red-coloured, oxidised pyroclastic beds of welded basaltic tuffs with compositions similar to the lavas. The tuffs are exposed in the eastern side of the Kuugannguaq valley about $6 \mathrm{~km}$ south of the Vaigat coast and are visible from a distance of more than $35 \mathrm{~km}$ (Fig. 143). The welded tuffs form a shield-like body centred within an area of $c .500 \mathrm{~m}$ by $300 \mathrm{~m}$; outside this area the tuffs decrease in thickness from many metres to less than $10 \mathrm{~cm}$ and cover an area of more than $10 \mathrm{~km}^{2}$ around the central tuff shield. The welded tuffs, which are described in considerable detail by Pedersen (1985b, p. 13-20), constitute a volume of only $0.005-0.01 \mathrm{~km}^{3}$ and thus comprise only a small part of unit 430 . No feeder bodies to the tuffs are exposed.

The welded tuffs form two partly overlapping bodies together 30-40 m thick. The lower tuff shield (Figs $144,145)$ was deposited on olivine microphyric basaltic pahoehoe lavas and is $30-40 \mathrm{~m}$ thick. It is composed of three parts, a basal zone, a massive zone and a more crumbling zone. The basal, $0.3-0.4 \mathrm{~m}$ thick zone is unwelded and composed of finely vesiculated clasts generally of subspheroidal form, ranging in size from less than $1 \mathrm{~mm}$ to a few centimetres. This zone grades rapidly into a $c$.
3 m thick, massive, columnar-jointed zone of intensely welded olivine microphyric basaltic glass rock (Pedersen 1985b, fig. 15). Within this zone occur scattered, crumbling, vesiculated xenoliths of quartzo-feldspathic sandstone. The glass zone grades upwards into an up to 30-35 $m$ thick upper zone of basaltic tuff with fiamme structure (Pedersen 1985b, fig. 9).

The upper welded tuff shield is $10-30 \mathrm{~m}$ thick and onlaps the lower shield without any erosion at the contact. It is partly inaccessible due to steep topography. It is generally similar to the lower shield, except that its lower part is a non-vesiculated olivine microphyric basalt up to $10 \mathrm{~m}$ thick, which is petrographically a basaltic hornfels (Pedersen 1985b, fig. 16). Without any intrusive contact features this hornfels grades up into a red to purple basaltic welded tuff with fiamme structure as an ignimbrite.

The welded basaltic tuff shields are partly onlapped by lava flows of magnesian andesite and feldspar-phyric basaltic andesite likewise of the Kûgánguaq Member; however, the highest part of the upper welded tuff formed a local hill during the final stage of formation of the Kûgánguaq Member (Fig. 143).

Magnesian andesite lavas. Outside the central part of the welded basaltic tuff shields, but still within $2-3 \mathrm{~km}$ of these, occurs an up to $45 \mathrm{~m}$ thick succession of magnesian andesite lava flows which carry microphenocrysts of olivine and orthopyroxene. There are up to six flows with individual thicknesses of up to $30 \mathrm{~m}$ (Pedersen 1985b, fig. 5). These flows have massive, vesicle-poor lower parts which tend to be jointed along spheroidal fractures (Pedersen 1985b, fig. 11), quite unlike the basaltic lavas but similar to the native-iron-bearing magnesian andesites of the composite flows of the Asuk Member. The upper parts of the flows consist of blocky heaps of scoria with piles of very oxidised, massive and scoriaceous inclusions; the flow surfaces are very irregular and may from a distance resemble craters (Figs 142, 145, flows 'D').

A few layers of magnesian andesite tuff are associated with the lavas. The largest is a $2 \mathrm{~m}$ thick airfall tuff deposited on the uppermost andesite lava found in the northern part of the central crater area (Pedersen 1985b, figs 5 , 6, p. 32).

No macroscopic sediment xenoliths have been found, but resorbed quartz xenocrysts with molten reaction zones are widespread in the andesites (Pedersen 1985b, fig. 19).

Feldspar-phyric basaltic andesites. These rocks form blocky pahoehoe flows and weather with a light yellowish brown colour. Besides plagioclase phenocrysts they 


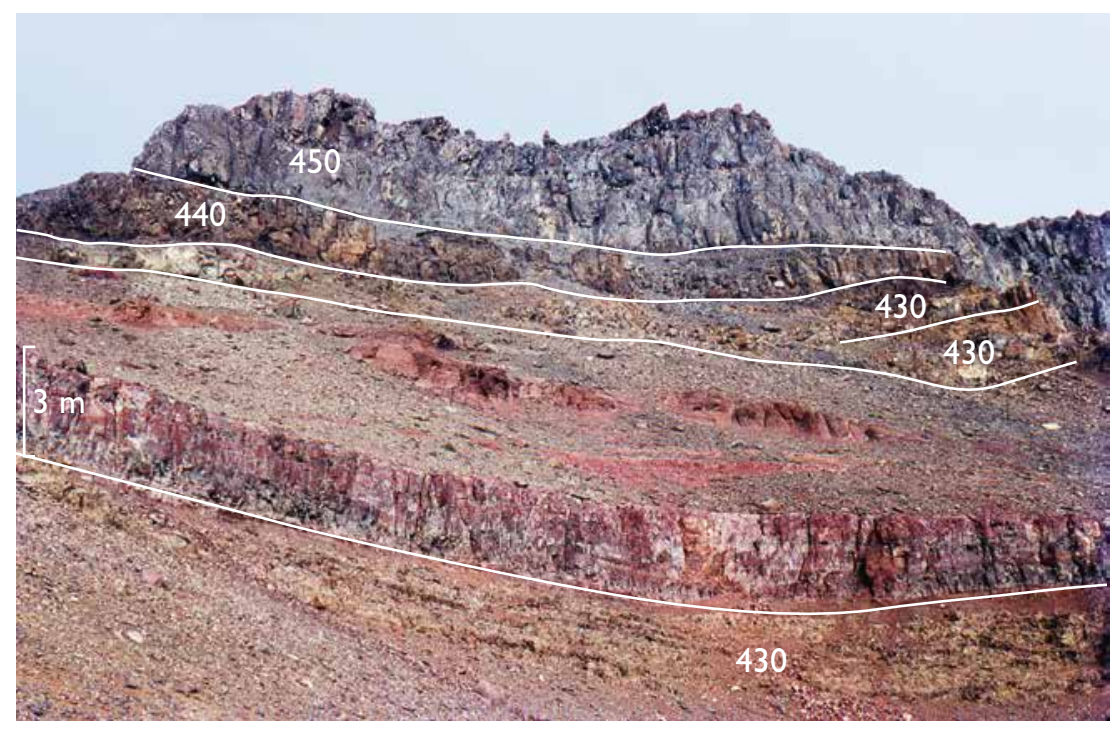

Fig. 144. Welded basaltic tuffs in the Kûgánguaq Member. The massive, columnar-jointed bed in the foreground comprises both a thin unwelded basal layer and an intensely welded layer of olivine microphyric basaltic glass. The overlying zone consists of less welded tuff with fiamme structure. The tuff crater is partly covered by Kûgánguaq Member lava flows of silicic basalt (430) and by a single basalt lava flow of the Qordlortorssuaq Member (440). On the top follow compact picrite flows of the Ordlingassoq Member (450). The area shown is seen in Fig. 143 immediately to the right of the white star. See also Pedersen 1985b, fig. 5, profile 2a and fig. 8a.

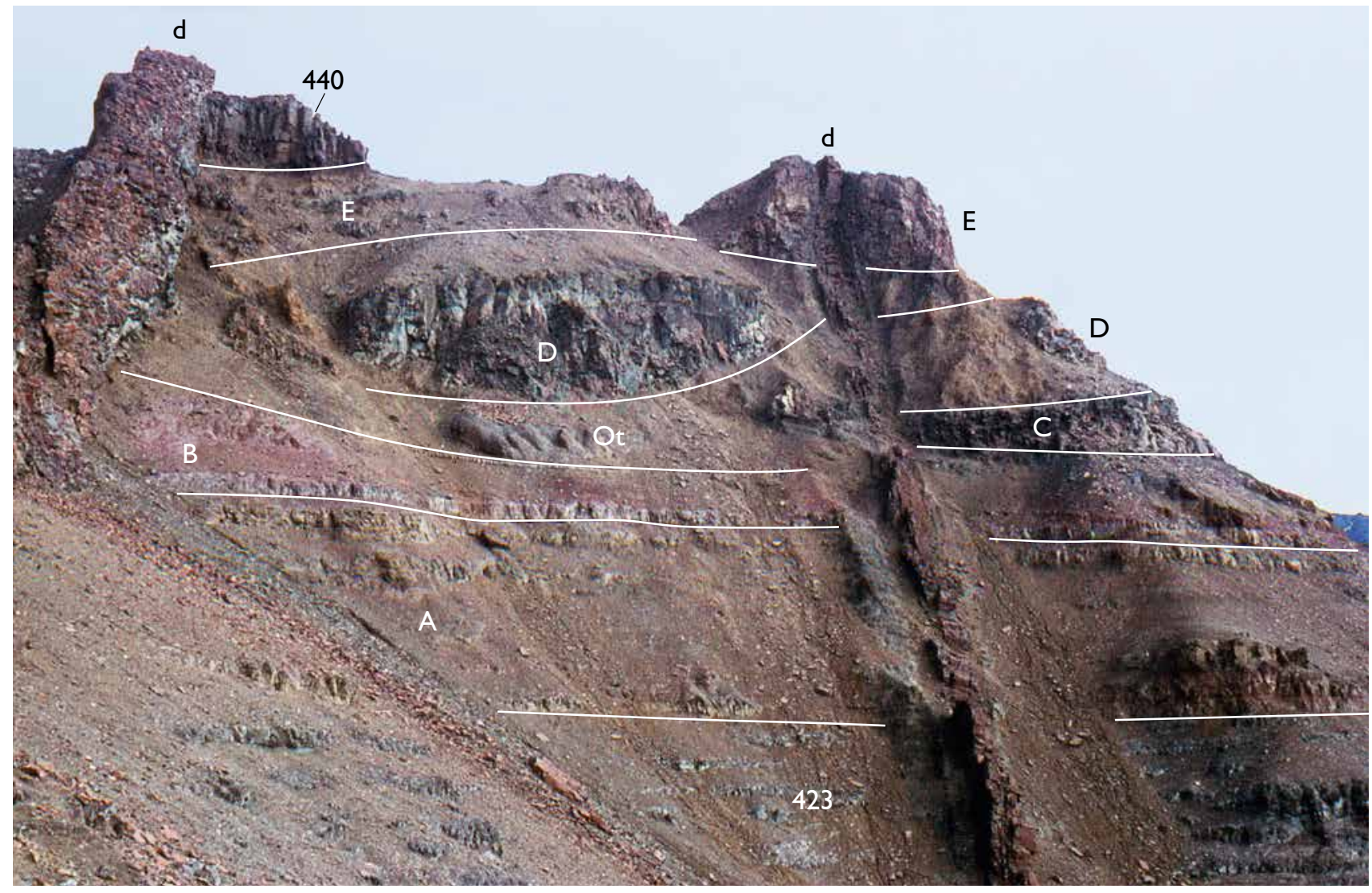

Fig. 145. A range of Kûgánguaq Member lithologies including contaminated olivine microphyric basalt lava flows (A and C), the welded basaltic tuff shield (B), an olivine microphyric basaltic unwelded tuff $(\mathbf{O t})$, magnesian andesite lava flows $(\mathbf{D})$ and feldspar-phyric contaminated basalt lava flows $(\mathbf{E})$. The thickness of the succession from the base of A to the top of $\mathrm{E}$ is $57 \mathrm{~m}$. The area shown is seen in Fig. 143 $4-7 \mathrm{~cm}$ to the right of the white star (see also Pedersen 1985b, fig. 5, profile 2b and fig. 7). At the base, picrite flows of the Naujánguit Member (unit 423) and at the top a single basalt flow of the Qordlortorssuaq Member (440). The south-western part of the crater area in the eastern wall of the Kuugannguaq valley, northern Disko. Total height of section $c .80 \mathrm{~m}$. 
contain subordinate microphenocrysts of orthopyroxene and clinopyroxene.

Interpretation of the formation of the basaltic tuffs. The central crater area developed above a palaeo-escarpment on northern Disko (Pedersen et al. 2002b, figs 5, 10); this escarpment was later reactivated and forms part of the postvolcanic Kuugannguaq-Qunnilik fault system (Chalmers et al. 1999a). A high-level magma reservoir fed along a fault located beneath Kuugannguaq must have resided within lithologies dominated by sandstones (Pedersen 1985b). The crustally contaminated volcanic rocks of unit 430 are distinctly reduced compared to uncontaminated rocks of the Vaigat Formation (Pedersen 1985b), although less so than the graphite-rich rocks with native iron of the Asuk Member. The basaltic welded tuff units, which are also distinctly reduced and are morphologically highly unusual for basalts in the region, were formed by subaerial eruptions and not by phreatic eruptions like the slightly older Ilugissoq volcano (unit 420; Pedersen \& Larsen 2006), and they did not become gas-enriched through reaction with local aquifers. We speculate that the high-level magma reservoir of unit 430 may have interacted with, or even created, a hydrocarbon gas reservoir, and that high-temperature dissociated gas components participated to create the two small basaltic ignimbrite eruptions.

Eruption sites. The main part of the Kûgánguaq Member was erupted from the centre in Kuugannguaq. No direct feeder bodies to the centre have been located. However, at Kussinikassak c. $6 \mathrm{~km}$ east of the centre there is a NWSE-trending feeder dyke from which olivine microphyric contaminated basalts were erupted (Pedersen 1985b); there may be other independent feeder systems farther east. 


\section{Qordlortorssuaq Member}

\section{Summary of the main features of the Qordlortorssuaq Member}

- Thin, widespread succession of evolved, erosion-resistant uncontaminated basalt lava flows. A few picrites.

- Only present on Disko.

- Centred in the marginal areas of the extent of the Naujánguit Member.

- Marks the final stage of the second volcanic episode.

\section{Lithostratigraphy of the Qordlortorssuaq Member}

History. Originally defined by Pedersen (1985a). No revision is applied here.

Name. After the waterfall Qorlortorsuaq (new spelling) about $5 \mathrm{~km}$ east-north-east of the mountain Pyramiden, northern Disko.

Distribution. Northern Disko (Fig. 11). The western limit of extent is unconstrained because it is below exposure level. The southern, south-eastern and eastern limits are depositional, and the northern limit is partly depositional, partly erosional.

Type section. The mountain side in the corrie of the Qorlortorsuaq waterfall on north-eastern Disko (Pedersen 1985a, fig. 14).

Reference sections. Kuugannguaq west side, Kuugannguaq north-east, Ametystskrænten and Point 1100 m (Fig. 16, profiles 21, 22, 25, 29) on Disko.

Thickness. From $0 \mathrm{~m}$ to at least $75 \mathrm{~m}$.

Lithology. Olivine-poor, slightly plagioclase-phyric basalts. A few picrite flows; in the type section there is a basalt-picrite composite lava flow. To the east and southeast, the flows have developed prominent entablature zones and ultimately transform into hyaloclastites.

Boundaries. The member rests on the Kûgánguaq Member on northern and north-western Disko and in other parts of Disko on picrites of the Naujánguit Member. It is overlain by picritic hyaloclastites and lava flows of the Ordlingassoq Member, on north-east Disko separated by a sediment horizon consisting of mudstone with tuff layers.

Age. Paleocene, nannoplankton zone NP5-6, c. $61 \mathrm{Ma}$, magnetochron C26r, based on dinoflagellate cysts (Piasecki et al. 1992) and radiometric dating of older and younger rocks in the succession (Storey et al. 1998).

\section{Geology of the Qordlortorssuaq Member (unit 440)}

The Qordlortorssuaq Member comprises relatively few lava flows emplaced during the waning stage of the second volcanic episode (Fig. 49). It consists of uncontaminated, olivine-poor to aphyric basalts with $6.5-10.7 \mathrm{wt} \%$ $\mathrm{MgO}$ and a few picrites with up to $23.7 \mathrm{wt} \% \mathrm{MgO}$. The massive basaltic lava flows are erosion-resistant and constitute a useful marker horizon where they are interbedded between the thin picritic pahoehoe flows of the Naujánguit and Ordlingassoq members (Fig. 146).

The Qordlortorssuaq Member has a wide horizontal distribution on northern to central Disko and is well exposed in coastal and valley sections (Figs 146, 147). It is lacking along the north coast of Disko between eastern Kuugannguaq and Norddalen (Pedersen 1985a, fig. 17) due to elevated older rocks in this area. A few evolved subaerial lava flows occur at a similar stratigraphic level on Nuussuaq, but these are isolated occurrences and their place is mostly taken up by the horizontally extensive Tunoqqu Member.

The Qordlortorssuaq Member occupies an area of at least $1000 \mathrm{~km}^{2}$ on Disko, and with a mean thickness of more than $30 \mathrm{~m}$ the erupted volume must be in excess of $30 \mathrm{~km}^{3}$. Thicknesses increase towards the east due to ponding in the eastern basin. At the type locality at Qorlortorsuaq (Pedersen 1985a, fig. 14, profiles 8, 9), the member reaches a maximum thickness of about $90 \mathrm{~m}$ where lava flows entered the eastern basin which eventually became the Naajaat Lake (Dam et al. 2009; see also the Ordlingassoq Member chapter below).

Boundaries. The Qordlortorssuaq Member rests on lavas and pyroclastic rocks of the Kûgánguaq Member and, outside the range of this smaller member, on picritic lava flows of Naujánguit Member unit 423 on western Disko. It is separated from these older units by up to $40 \mathrm{~cm}$ of a 
Fig. 146. Erosion-resistant basalt lava flows of the Qordlortorssuaq Member (440) form a marker horizon in the northern side of Jens Vahl Dal on northern Disko. The member overlies picrite lavas of the Naujánguit Member unit 423 and underlies picrite lavas of the Ordlingassoq Member (450). The succession is cut by many dykes (d). Total height of section $c .600$ m. Photo: Finn Ulff-Møller.
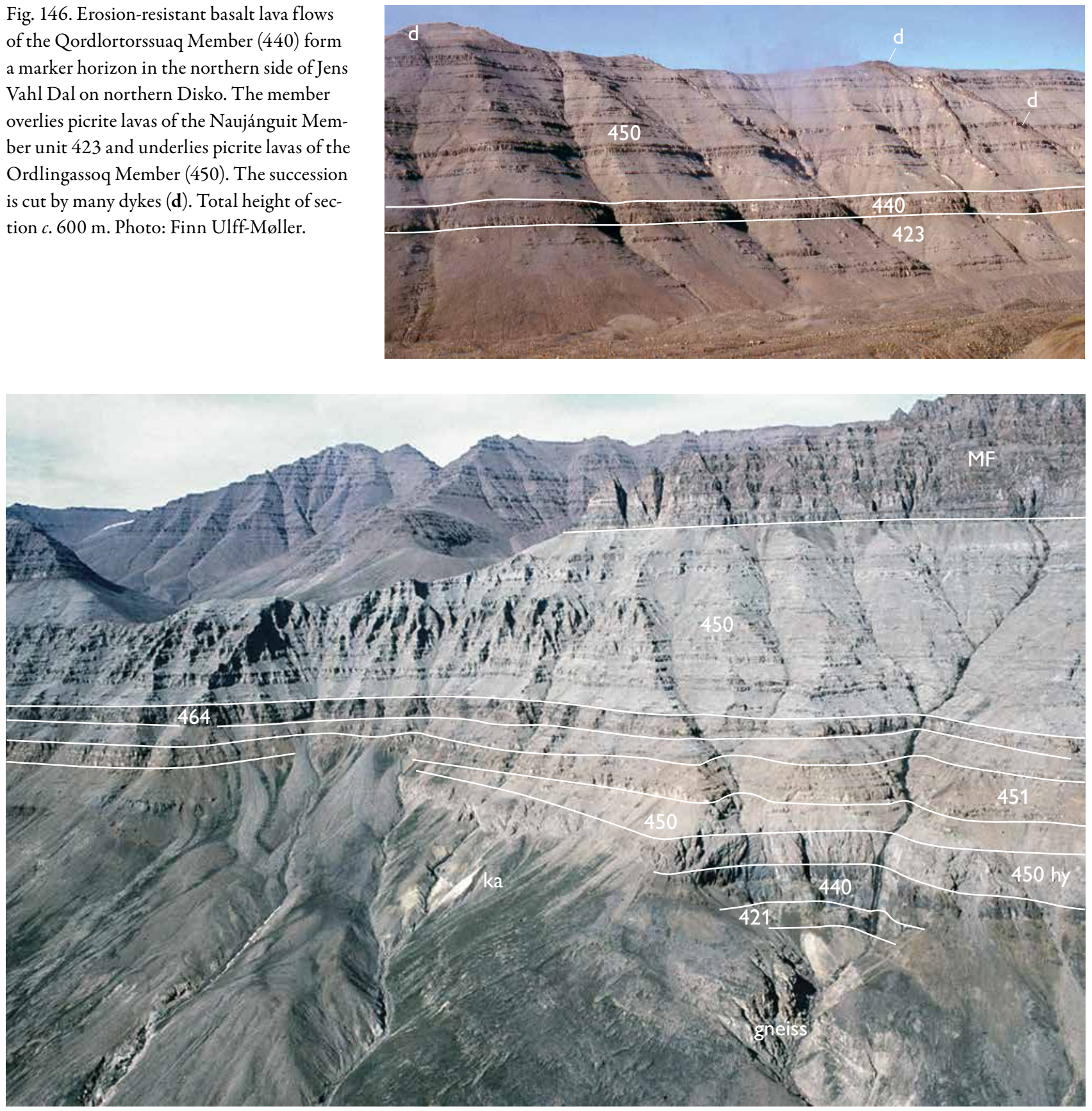

Fig. 147. The northern wall of Stordal on Disko (see also Fig. 183, the Central Disko section at 30-32km). Wet-facies lava flows of the Qordlortorssuaq Member (440) overlap a few flows of the Stordal unit (421) and the Disko gneiss ridge (gneiss) with kaolinite weathering on its top (ka). The Qordlortorssuaq Member flows are covered by picritic hyaloclastites of the Ordlingassoq Member ( 450 hy). Low in unit 450 there is a unit of strongly contaminated basalts (unit 451) and a horizon of slightly contaminated feldspar-phyric basalts (unit 464, in other places associated with the Manîtdlat Member). The Ordlingassoq Member is covered by basalt lava flows of the Maligât Formation (MF). Total height of section in the foreground $1000 \mathrm{~m}$.

residual lateritic claystone which may be dark-coloured by disseminated organic material. Around the Disko Gneiss Ridge in Stordal, the Qordlortorssuaq Member onlaps the strongly weathered gneiss surface (Fig. 147) and is partly absent due to the palaeotopography of the gneiss. At other localities in Stordal it rests on the Stordal volcanic unit (unit 421), either directly or separated from this unit by a $4 \mathrm{~m}$ thick conglomerate of mixed gneissic 


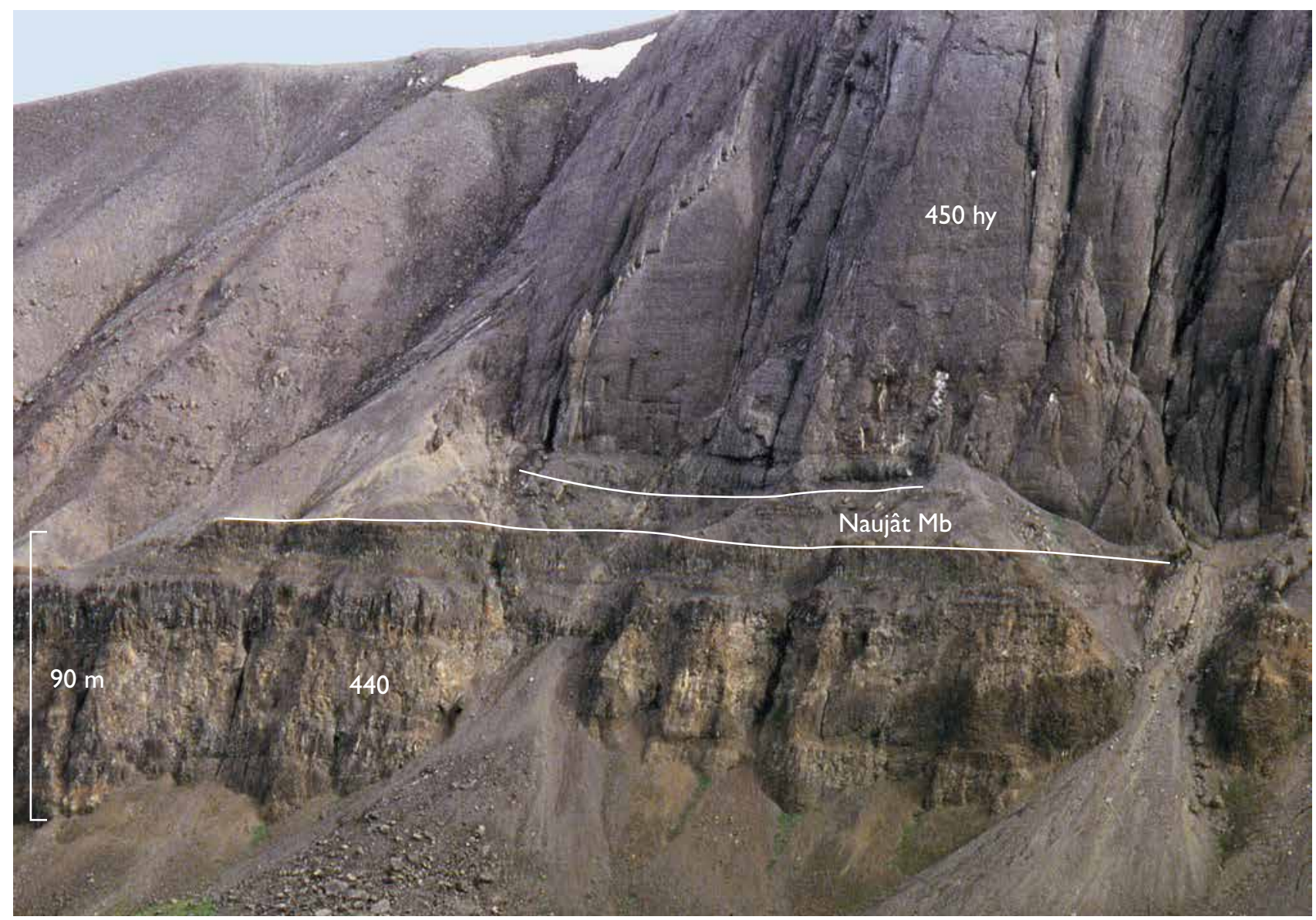

Fig. 148. The Qordlortorssuaq Member close to the type section. A $90 \mathrm{~m}$ thick succession of water-influenced Qordlortorssuaq Member lava flows (440) covered by $c .15 \mathrm{~m}$ of Naujât Member mudstones deposited at the bottom of the Naajaat Lake, in turn covered by hyaloclastites belonging to the Ordlingassoq Member (450 hy). See also Fig. 16, profile 29 and Pedersen 1985a, fig. 14, profile 9. Eastern wall of the Qorlortorsuaq corrie, north Disko.

and volcanic material (Fig. 79), see text for unit 421 . Farther east in Stordal it overlies lavas assigned to the Kûgánguaq Member. In the western part of Qorlortorsuaq, a thick Qordlortorssuaq Member lava flow overlies a Kûgánguaq Member volcaniclastic tuffaceous layer with minor clastic quartz which has been re-melted to an obsidian layer by the flow. At the easternmost localities with unit 440 at Qorlortorsuaq and Kuugannguaq, the lower boundary is not exposed (Fig. 148).

Throughout its extent the Qordlortorssuaq Member is overlain by picrites of the Ordlingassoq Member. The boundary on Disko is marked by an up to metre-thick sediment layer (either lateritic soil, conglomerate, siltstone or mudstone) or by an erosion surface. An instructive locality is preserved in a large landslipped block $c$. $1 \mathrm{~km}$ south-south-west of Asuk; here the eroded surface of a large subaerial lava flow of the Qordlortorssuaq Member is covered by a several metres thick conglom- erate with centimetre- to decimetre-sized, rounded lava clasts embedded in a lateritic matrix. This sediment layer is disturbed by the advancing front of picritic hyaloclastites of the Ordlingassoq Member. In the Stordal area the uppermost lava flows of the Qordlortorssuaq Member are slightly eroded and directly covered by Ordlingassoq Member hyaloclastites, see Central Disko section at 33 km (Fig. 80; also Fig. 183). Farther to the east (Central Disko section at $43.3 \mathrm{~km}$, see also Fig. 183) the uppermost lava flow is covered by $1 \mathrm{~m}$ of clastic sediment consisting of grey sandy siltstones with mica-rich layers and lignite, topped by black mudstone. At the type locality in Qorlortorsuaq the uppermost lava flow is covered by black mudstones with plant fossils of the Naujât Member (Fig. 148).

Lithologies. The Qordlortorssuaq Member forms subaerial lava flows over most of its extent, but it transforms 


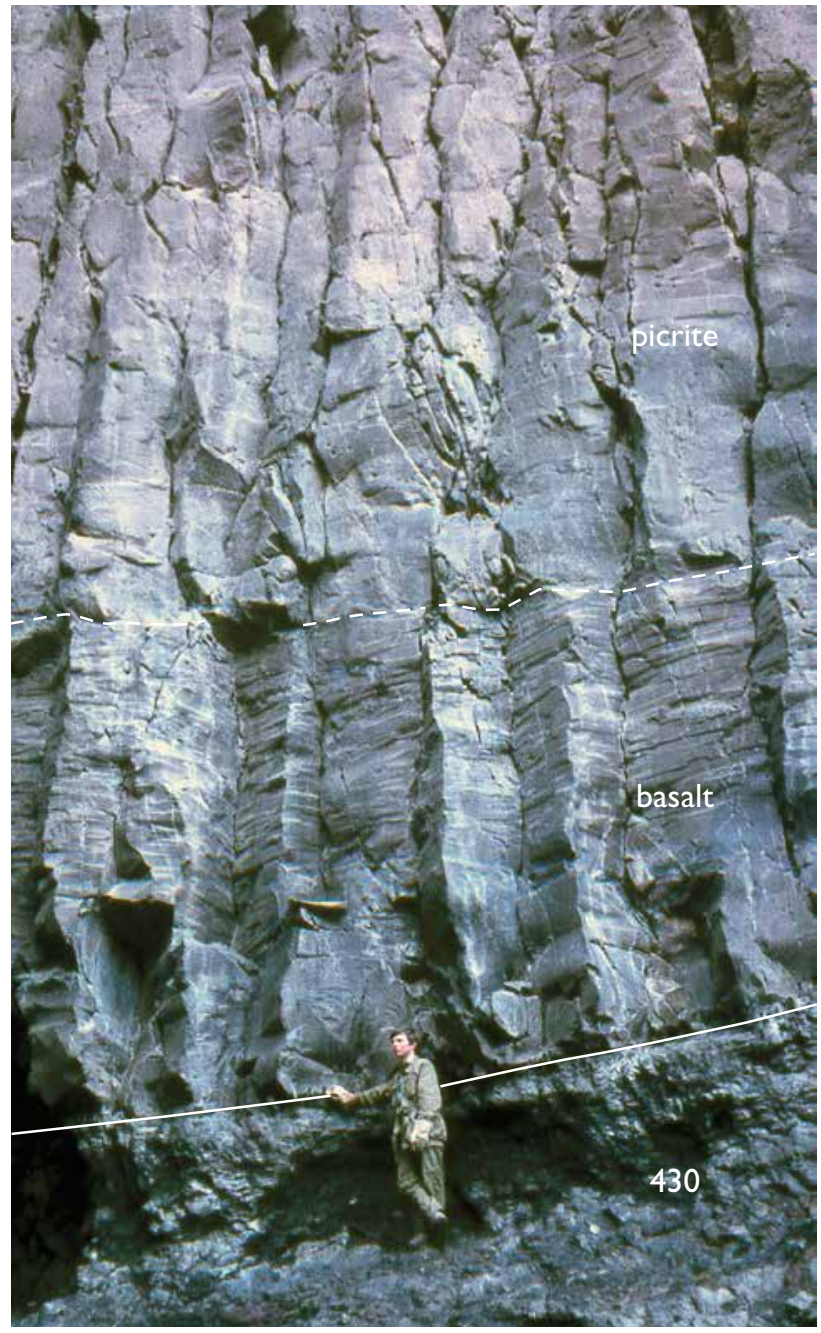

Fig. 149. Composite lava flow of the Qordlortorssuaq Member The flow is $c .40 \mathrm{~m}$ thick and strongly columnar-jointed. The lower part of the flow consists of olivine-poor basalt (Fig. 150A); around $5 \mathrm{~m}$ from the flow base there is an abrupt compositional change to a strongly olivine-phyric picrite (Fig. 150B) which is about $30 \mathrm{~m}$ thick. See also Pedersen 1985a, fig. 14, profile 8. The flow is emplaced on the top of contaminated basalts of the Kûgánguaq Member (430). Western part of the Qorlortorsuaq corrie, north Disko.

into short hyaloclastite fans as it enters the eastern basin along a SW-NE-running line between Stordal on central Disko and Qorlortorsuaq on northern Disko.

Over most of the area the individual subaerial lava flows are between $5 \mathrm{~m}$ and $15 \mathrm{~m}$ thick but may exceed $40 \mathrm{~m}$ when accumulated in depressions. Where erupted on dry land surfaces the flows display a crude columnar jointing in their lower parts and have moderately oxidised blocky flow tops; these flows can be characterised as blocky pahoehoe flows. Where erupted over wet surfaces
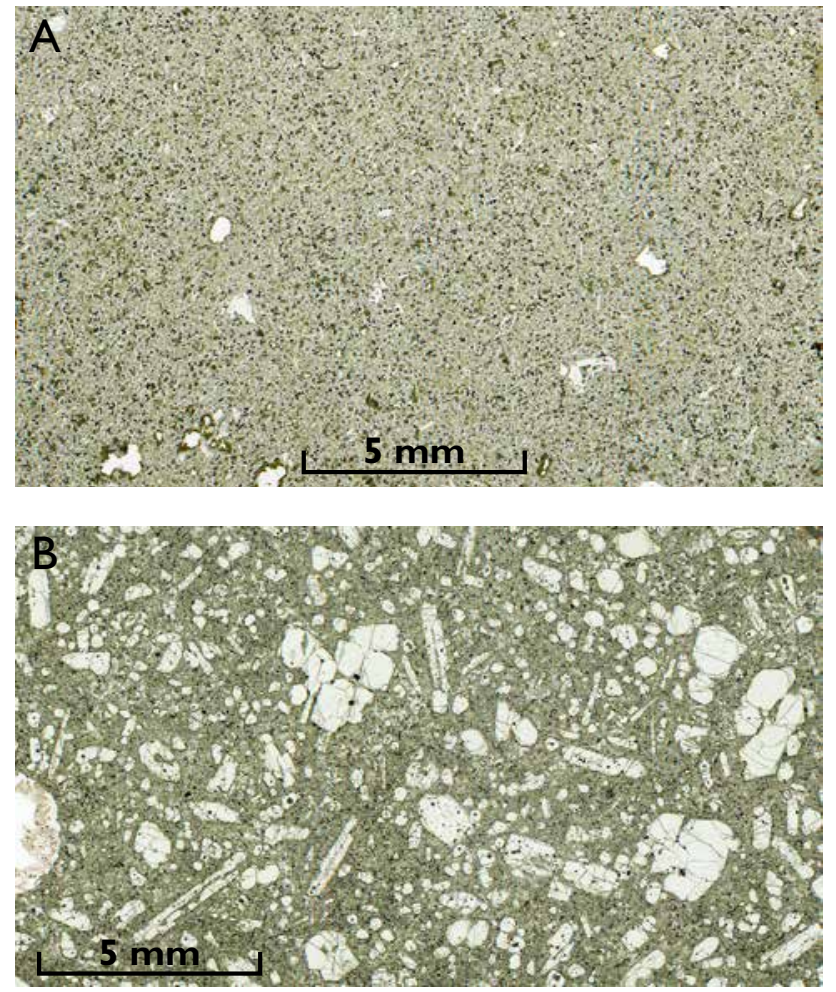

Fig. 150. Thin sections (scanned) of a $40 \mathrm{~m}$ thick composite lava flow of the Qordlortorssuaq Member. A: Basal part (early pulse) of weakly olivine-phyric basalt sampled $1.2 \mathrm{~m}$ above the base. Sample 138343. B: Later pulse of strongly olivine-phyric picrite with up to centimetre-sized olivine phenocrysts. Sample $138345,30 \mathrm{~cm}$ above the base of the picrite pulse.

or into the water-filled eastern basin, the flows change morphology and become strongly columnar-jointed, commonly with very well-developed entablatures (Fig. $80)$.

A c. $40 \mathrm{~m}$ thick composite lava flow is exposed in the western part of the Qorlortorsuaq corrie (Fig. 149). An early pulse of sparsely olivine-phyric basalt was inflated by a later pulse of strongly olivine-phyric picrite with up to centimetre-sized olivine phenocrysts (Fig. 150). The basaltic base of the flow is jointed into metre-thick columns which range from curve-jointed to very regular columns with pronounced chisel marks (Fig. 149). The chisel marks disappear upwards at the base of the picrite pulse. At the boundary between basalt and picrite, diapirs of almost aphyric basalt are seen protruding upwards into the highly olivine-charged picrite without any chill zone. The picrite pulse is around $30 \mathrm{~m}$ thick. The top zone of the flow is up to $5 \mathrm{~m}$ thick and composed of almost aphyric basalt from the first pulse, and at the boundary, picrite bodies protrude upwards into the ba- 
salt without chill, demonstrating that the two pulses were closely associated. The structure of the composite flow strongly suggests that the basalts of the Qordlortorssuaq Member were derived by olivine fractionation from a picritic magma.

The member reaches its maximum thickness of about $90 \mathrm{~m}$ in the eastern part of the Qorlortorsuaq corrie. It is here composed of at least six lava flows which are extensively columnar-jointed. Several of the flows have waterbrecciated tops or have developed into crude elongated pillow lobes, showing that they are transitional to subaqueous lava flows. The uppermost flow here is $c .20 \mathrm{~m}$ thick and composite with a picrite core. The flow is covered by mudstone into which a basaltic sill is intruded; this is probably the latest flow in the Qordlortorssuaq Member in invasive facies.

Eruption sites. No eruption sites for the Qordlortorssuaq Member have been located. However, the thickness and number of flows strongly suggest that the member was erupted along the eastern margin of its area of extent, between Stordal and Qorlortorsuaq, almost certainly from stagnating magma reservoirs situated marginally to the general area of magma outflow at the end of the second volcanic episode. The exclusive occurrence of a large composite lava flow at Qorlortorsuaq in particular shows that this flow must have been erupted locally. 


\section{Chemical compositions of the members of the second volcanic episode: Naujánguit Member and associated members}

The rocks of the second volcanic episode with their complex stratigraphy (Fig. 49) are here treated in one chapter because they are closely related. The contaminated rocks are described and plotted in groups in stratigraphically ascending order.

Summary of the main features of the geochemistry of the members of the second volcanic episode

- The Naujánguit Member is geochemically depleted in the most incompatible elements. $\mathrm{TiO}_{2}$ increases slightly with height in the succession.

- The Nuusap Qaqqarsua Member comprises one unit which is moderately crustally contaminated.

- The Nuuk Killeq Member comprises a number of flow groups which are moderately to strongly contaminated and geochemically similar.

- The Asuk Member comprises at least four separate eruption centres which are strongly contaminated and geochemically distinguishable. Several rocks are notable for contents of carbon, sulfur and native iron. The main contaminant was marine mudstone.

- The Tunoqqu Member comprises a regional lava succession and a number of different eruption centres on Nuussuaq. The rocks are weakly to strongly contaminated and partly geochemically distinguishable.

- The Kûgánguaq Member is a Tunoqqu-time-equivalent eruption centre on Disko. It is strongly contaminated and shows evidence of sulfide fractionation. The dominating contaminant was sandstone.

- The Qordlortorssuaq Member is uncontaminated and the evolved magmas were produced during the waning stage of the second volcanic episode.

\section{Uncontaminated rocks}

The uncontaminated rocks of the Naujánguit and Qordlortorssuaq members range from olivine-rich picrites to evolved olivine-plagioclase microphyric and aphyric basalts. The rocks are generally fairly fresh, although some scatter of mobile elements such as $\mathrm{K}, \mathrm{Rb}$ and $\mathrm{Ba}$ indicates some secondary alteration. Representative chemical analyses are shown in Table 3.

\section{Major elements}

Variation diagrams for the major elements are shown in Fig. 151. The rocks cover a large range in $\mathrm{MgO}, 6.5-28$ wt\%, which is the same as seen in the Anaanaa and Ordlingassoq members, and as in these members there is a strong olivine control leading to linear fractionation trends. Plagioclase fractionation (decreased $\mathrm{CaO}$ and $\mathrm{Al}_{2} \mathrm{O}_{3}$ ) is not seen except perhaps in a few basalts of the Qordlortorssuaq Member. The four main stratigraphic units of uncontaminated rocks in the Naujánguit Member (units 409, 413, 417, 423) cover the same $\mathrm{MgO}$ ranges, however, there is a preponderance of basalts with 8-12 wt\% $\mathrm{MgO}$ in unit 409. The Qordlortorssuaq Member comprises mainly basalts with $7-10 \mathrm{wt} \% \mathrm{MgO}$ and only a few picrites. An evolution with time towards higher contents of the incompatible elements $\mathrm{TiO}_{2}$ and $\mathrm{P}_{2} \mathrm{O}_{5}$ (for similar $\mathrm{MgO}$ ) is seen, with particularly clear increases in unit 423 and the overlying Qordlortorssuaq Member (Fig. 152).

\section{Trace elements}

Variation diagrams for trace elements are shown in Figs 153, 154. Olivine (and chromite) control is the dominant feature, making all elements except $\mathrm{Ni}, \mathrm{Co}$ and $\mathrm{Cr}$ incompatible and thus increasing with decreasing $\mathrm{MgO}$. $\mathrm{Rb}$ and $\mathrm{Ba}$, like $\mathrm{K}_{2} \mathrm{O}$, are low and scattered as a result of secondary alteration. An evolution with time towards higher contents of incompatible elements at similar $\mathrm{MgO}$ is only seen for Sr; the Qordlortorssuaq Member, however, has higher $\mathrm{Sr}, \mathrm{Zr}, \mathrm{Nb}$ and REE than the preceding units.

REE and multi-element diagrams are shown in Fig. 155. The general geochemical character of the rocks is a relative depletion in the most incompatible elements, with normalised $\mathrm{La} / \mathrm{Nd}$ and $\mathrm{Rb} / \mathrm{Ta}<1$, leading to a curved, convex-up shape for both types of pattern. The REE patterns for the five major uncontaminated units are near-parallel; differences in concentration levels are mainly due to variable $\mathrm{MgO}$ contents (7-27 wt\%), with $\mathrm{MgO}$-rich samples having the lowest concentrations and $\mathrm{MgO}$-poor samples the highest. In detail some REE patterns cross-cut. There is a systematic shift of the culminations on the REE patterns up-section from around $\mathrm{Eu}$ in the lowest to around $\mathrm{Nd}-\mathrm{Sm}$ in the highest unit. Like the 

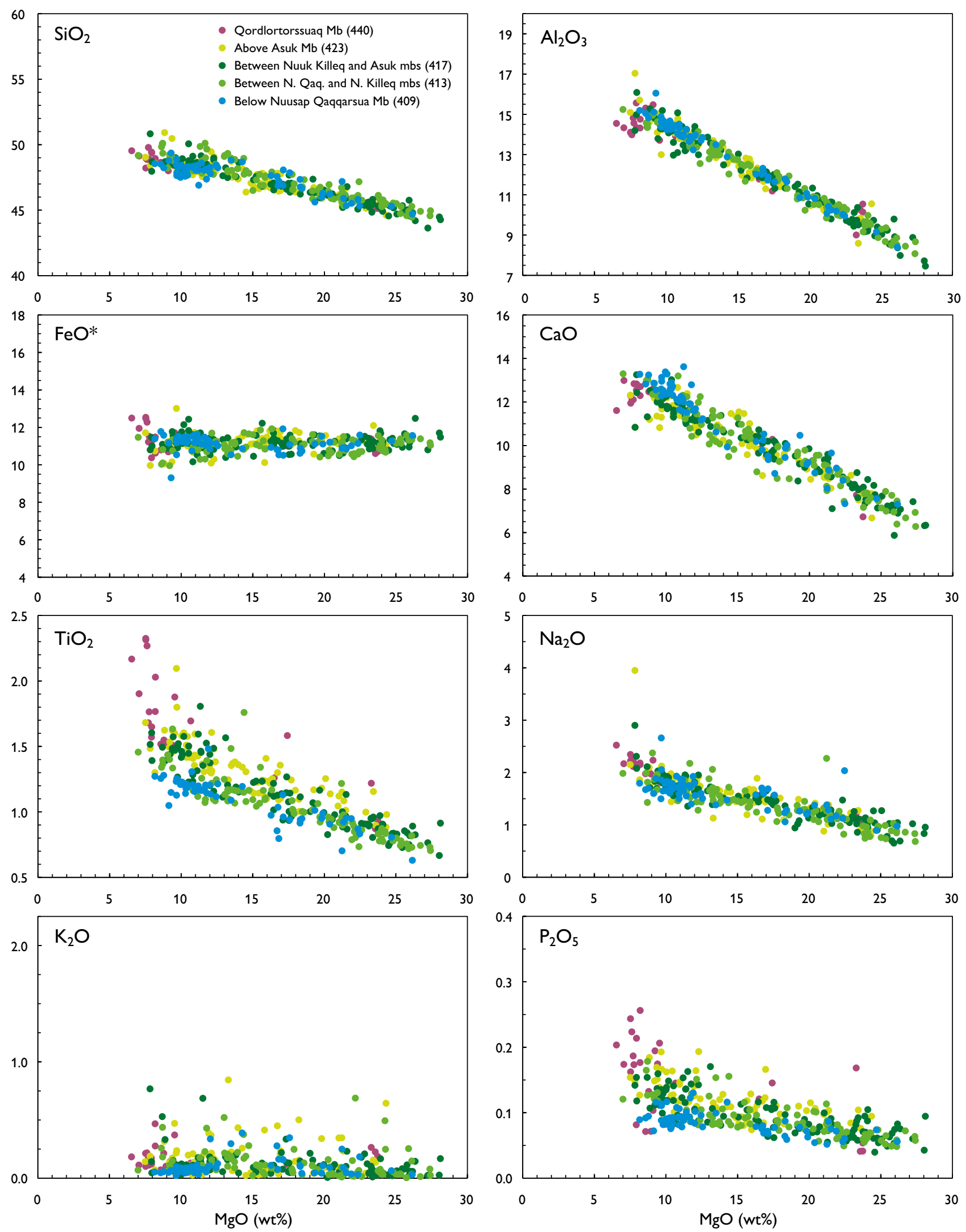

Fig. 151. Major-element variation diagrams for the uncontaminated rocks of the Naujánguit and Qordlortorssuaq Members. Data in wt\% oxides calculated volatile-free. $\mathbf{F e O}^{*}$ is total iron as $\mathrm{FeO}$. 
Table 3a. Chemical analyses of uncontaminated rocks, Naujánguit and Qordlortorssuaq Members

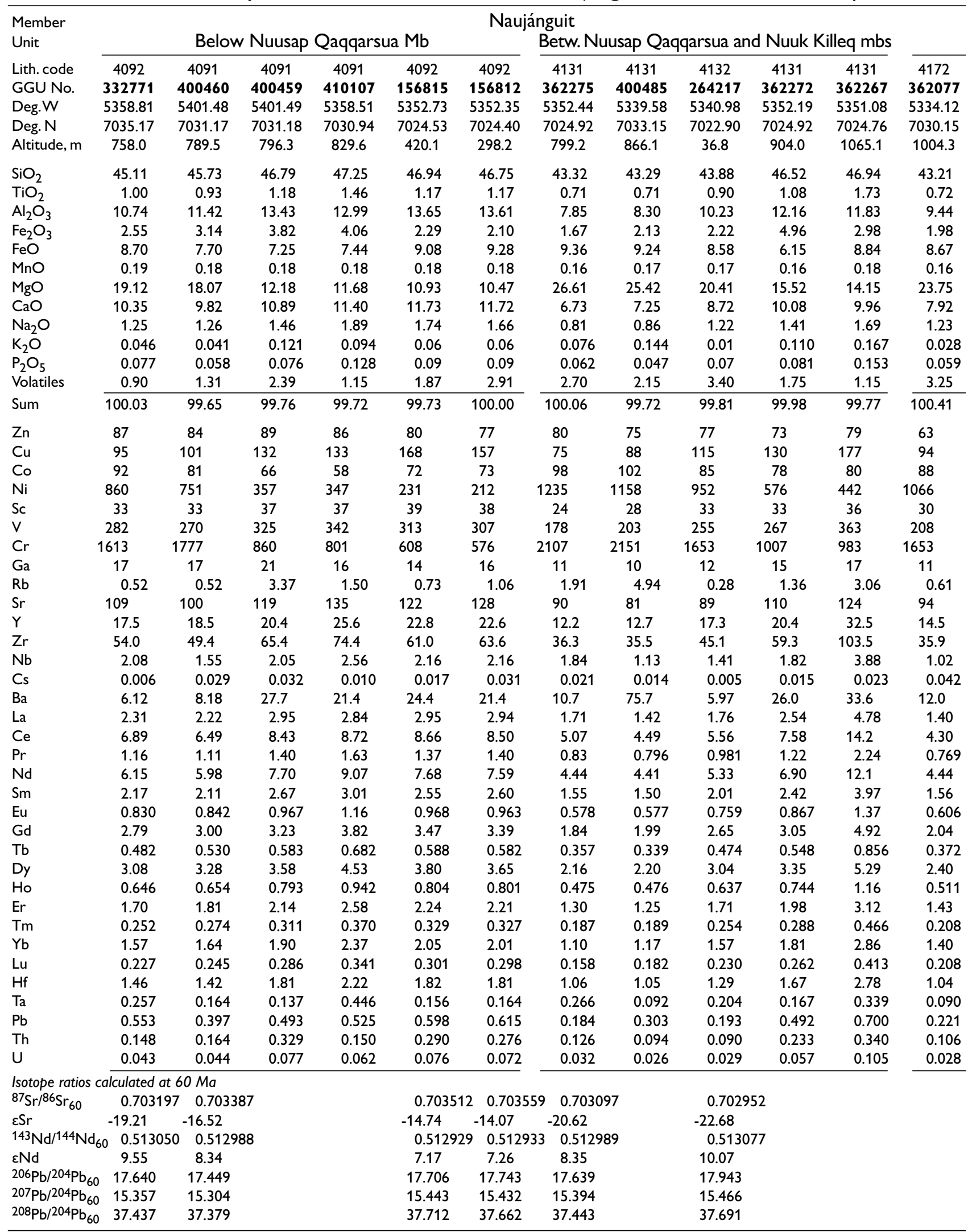

For explanation of lithological codes, see Table 1. For petrographical notes on the samples, see Table 3d.

Geographical coordinates in WGS 84. First two digits are degrees, then follow minutes in decimal form

Major elements in wt\% (XRF analyses). Trace elements in PPm (Zn-Ga: XRF analyses; Rb-U: ICP-MS analyses). 
Table 3b. Chemical analyses of uncontaminated rocks, Naujánguit and Qordlortorssuaq Members

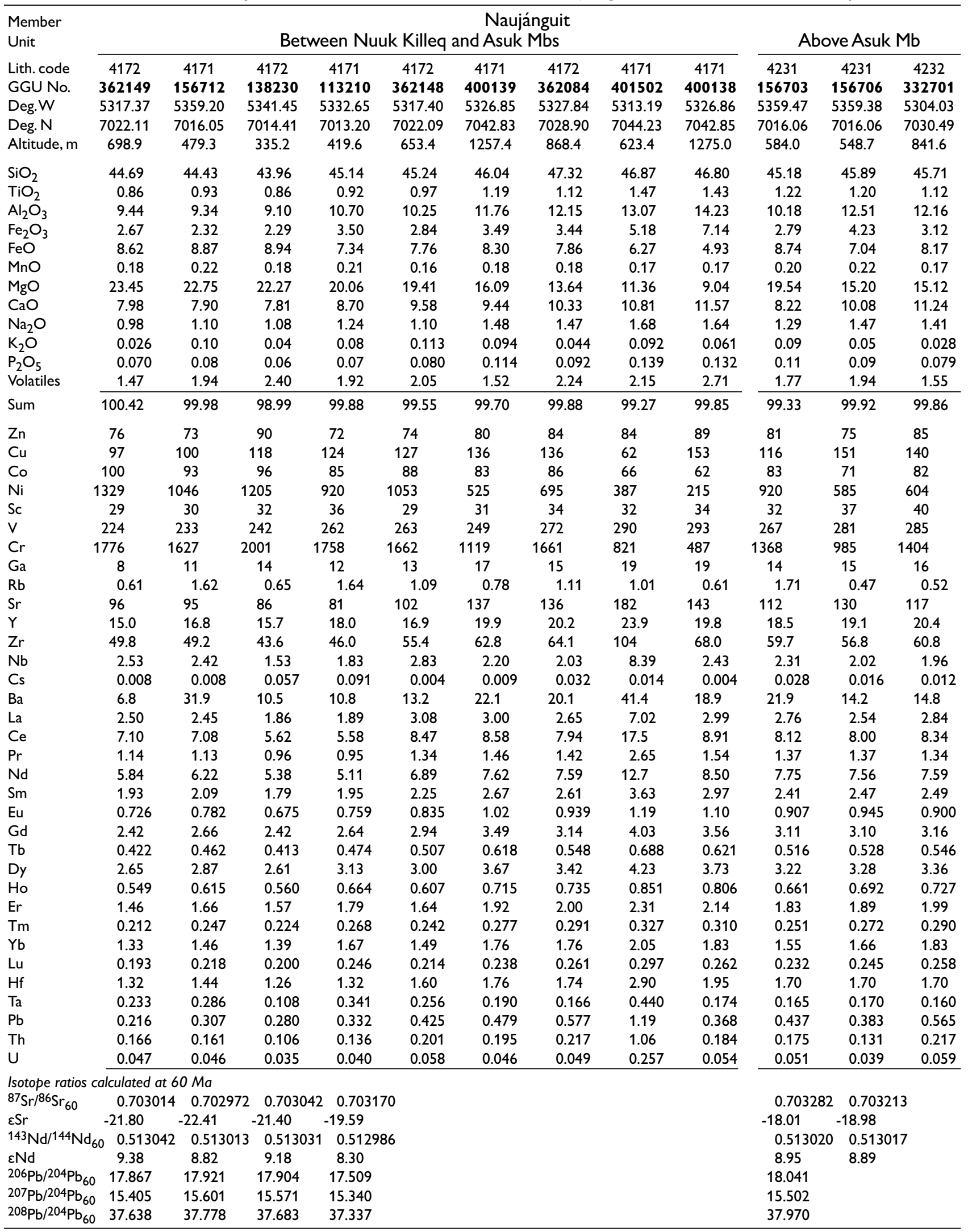


Table 3c. Chemical analyses of uncontaminated rocks, Naujánguit and Qordlortorssuaq Members

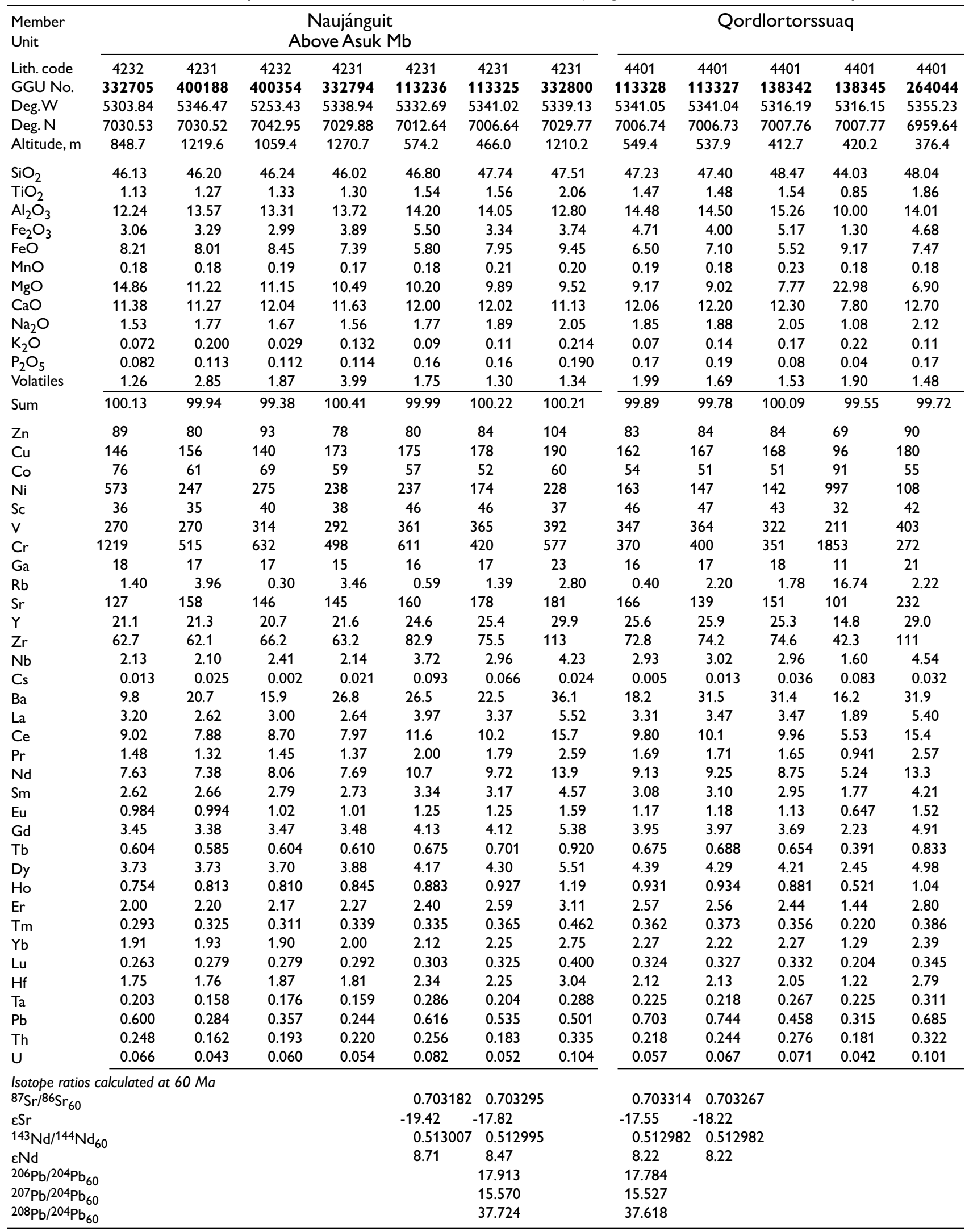




\section{Table 3d. Notes on analysed uncontaminated samples from the Naujánguit and Qordlortorssuaq Members}

332771 Picrite pillow from hyaloclastite, profile Anariartorfik, western Nuussuaq.

400460 Picrite lava flow, profile Anaanaa-south, Anaanaa, western Nuussuaq.

400459 Thick olivine-poor picrite lava flow, profile Anaanaa-south, Anaanaa, western Nuussuaq.

410107 Olivine-phyric basalt lava flow with segregation patches, profile Qunnileeraasakassaq, western Nuussuaq.

156815 Olivine-microphyric basalt pillow from hyaloclastite, foot of breccia wall below Nuusap Qaqqarsua, south coast of Nuussuaq.

156812 Nearly aphyric basalt pillow from hyaloclastite, foot of breccia wall below Nuusap Qaqqarsua, south coast of Nuussuaq.

362275 Olivine-rich picrite lava flow, profile Nuusap Qaqqarsua, south coast of Nuussuaq.

400485 Olivine-rich picrite lava flow, northern end of Qunnilik valley, central-western Nuussuaq.

264217 Picrite pillow from hyaloclastite, Nuuk Killeq, south coast of Nuussuaq.

362272 Thick picrite lava flow, profile Nuusap Qaqqarsua, south coast of Nuussuaq.

362267 Picrite lava flow with slightly enriched geochemistry, profile Nuusap Qaqqarsua, south coast of Nuussuaq.

362077 Olivine-rich picrite pillow from hyaloclastite, west side of llugissoq valley, Nuussuaq.

362149 Olivine-rich picrite pillow from hyaloclastite, Nuuk Qiterleq, south coast of Nuussuaq.

156712 Picrite lava flow, west side of Kuugannguaq valley $2.5 \mathrm{~km}$ from the coast, northern Disko.

138230 Picrite pillow from hyaloclastite, Kussinikassak gully, northern Disko.

113210 Picrite lava flow, Norddalen, northern Disko.

362148 Picrite pillow from hyaloclastite, Nuuk Qiterleq, south coast of Nuussuaq.

400139 Picrite lava flow, profile Tunorsuaq, Tunorsuaq valley, northern Nuussuaq.

362084 Picrite pillow from hyaloclastite, llugissoq valley, Nuussuaq.

401502 Olivine-phyric basalt pillow lava with slightly enriched geochemistry, $3.5 \mathrm{~km}$ south of Serfat, north coast of Nuussuaq.

400138 Aphyric basalt lava flow, profile Tunorsuaq, Tunorsuaq valley, northern Nuussuaq

156703 Picrite lava flow, west side of Kuugannguaq valley $2.5 \mathrm{~km}$ from the coast, northern Disko.

156706 Picrite lava flow, west side of Kuugannguaq valley $2.5 \mathrm{~km}$ from the coast, northern Disko.

332701 Picrite pillow from hyaloclastite, profile Tunoqqu, Tunoqqu mountain, central Nuussuaq.

332705 Picrite pillow from hyaloclastite, profile Tunoqqu, Tunoqqu mountain, central Nuussuaq.

400188 Olivine-phyric basalt lava flow, profile Qunnilik-west, west mouth of Qunnilik valley, western Nuussuaq.

400354 Olivine-phyric basalt pillow from hyaloclastite, profile Vesterfjeld,Vesterfjeld, northern Nuussuaq.

332794 Olivine-plagioclase-phyric basalt lava flow, profile Ukallit, east mouth of Qunnilik valley, western Nuussuaq.

113236 Weakly olivine-phyric basalt lava flow, Norddalen, northern Disko.

113325 Weakly olivine-plagioclase-phyric basalt lava flow, east side of Kuugannguaq valley $16 \mathrm{~km}$ from the coast, northern Disko.

332800 Olivine-phyric basalt lava flow with segregation patches, profile Ukallit, east mouth of Qunnilik valley, western Nuussuaq.

113328 Very weakly olivine-plagioclase-phyric basalt lava flow, east side of Kuugannguaq valley $16 \mathrm{~km}$ from the coast, northern Disko.

113327 Nearly aphyric basalt lava flow, east side of Kuugannguaq valley $16 \mathrm{~km}$ from the coast, northern Disko.

138342 Weakly plagioclase-microphyric basalt, lower part (5 m) of $40 \mathrm{~m}$ thick composite lava flow, Qorlortorsuaq corrie $6 \mathrm{~km}$ from the coast, northern Disko (Fig. 149).

138345 Olivine-rich picrite, upper part of 40 m thick composite lava flow, Qorlortorsuaq corrie, north coast of Nuussuaq (Fig. 149).

264044 Very weakly olivine-plagioclase-phyric basalt lava flow, Stordal, central Disko.

Phenocryst phases are mentioned in order of decreasing abundance. All picrites are strongly olivine-phyric.

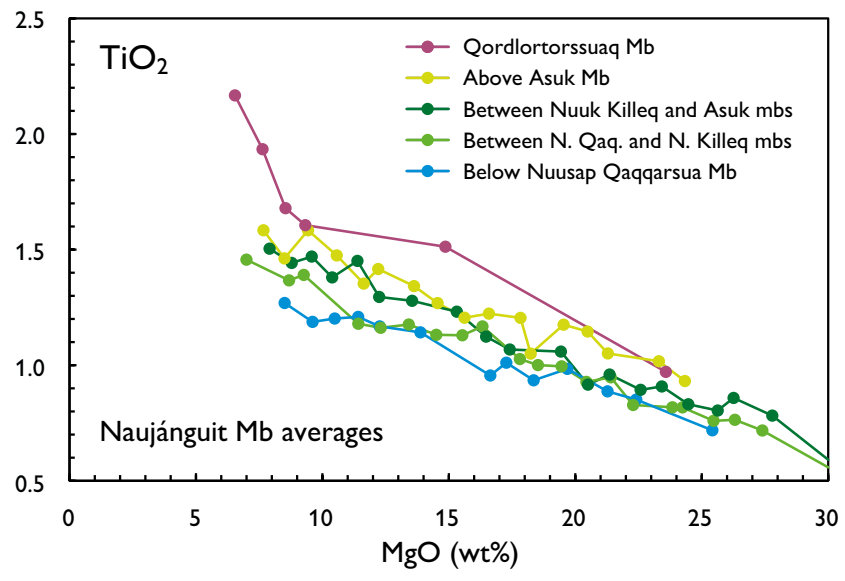

Fig.152. $\mathrm{TiO}_{2}$ variation diagram for the four uncontaminated units of the Naujánguit Member and the Qordlortorssuaq Member, showing an evolution with time towards higher $\mathrm{TiO}_{2}$ contents at similar $\mathrm{MgO}$. The data for each unit were averaged in intervals of $\mathrm{MgO}$, usually $1 \%$-intervals but larger where there are only few data points. 

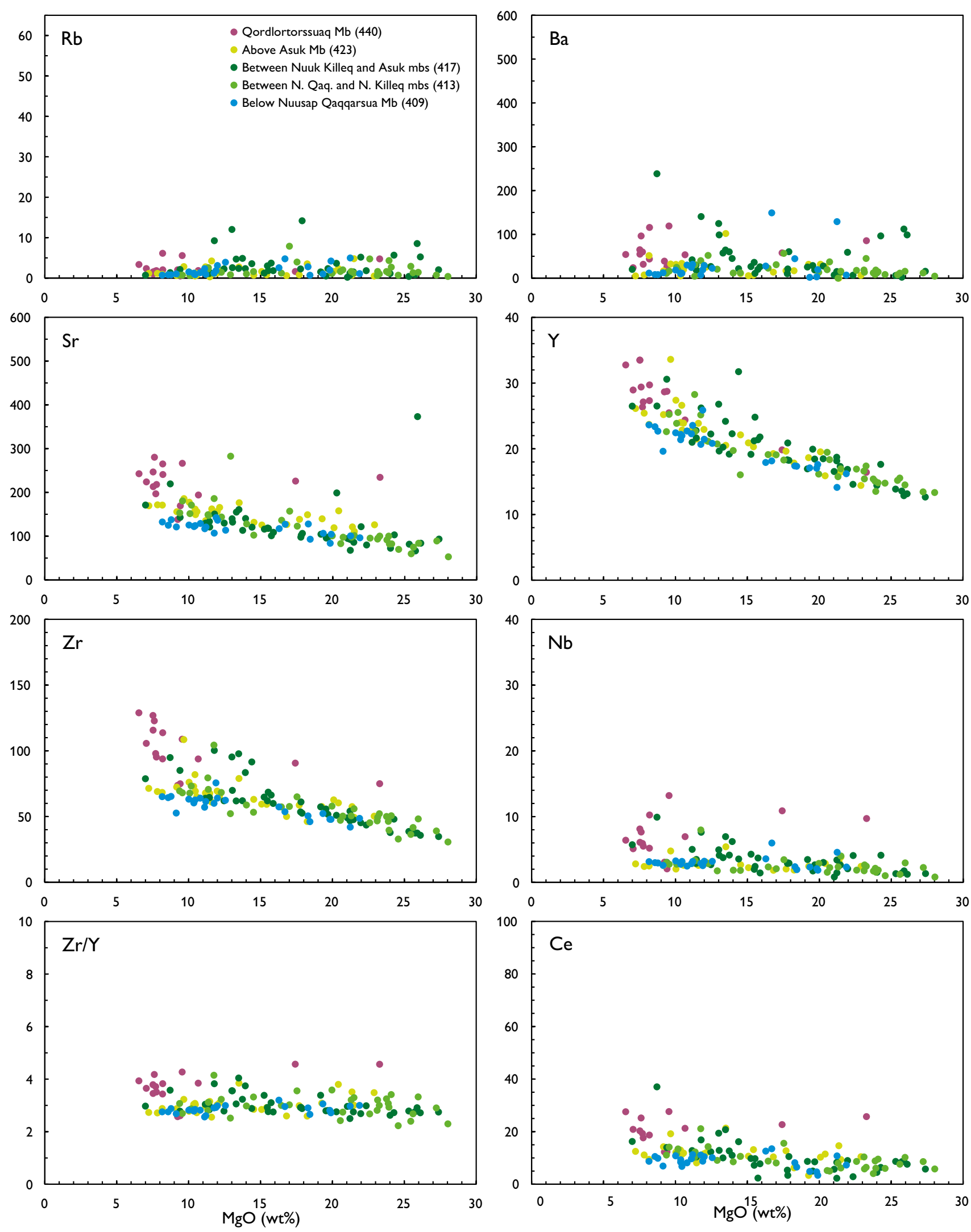

Fig. 153. Incompatible trace-element variation diagrams for the uncontaminated rocks of the Naujánguit and Qordlortorssuaq Members. Data in ppm. 

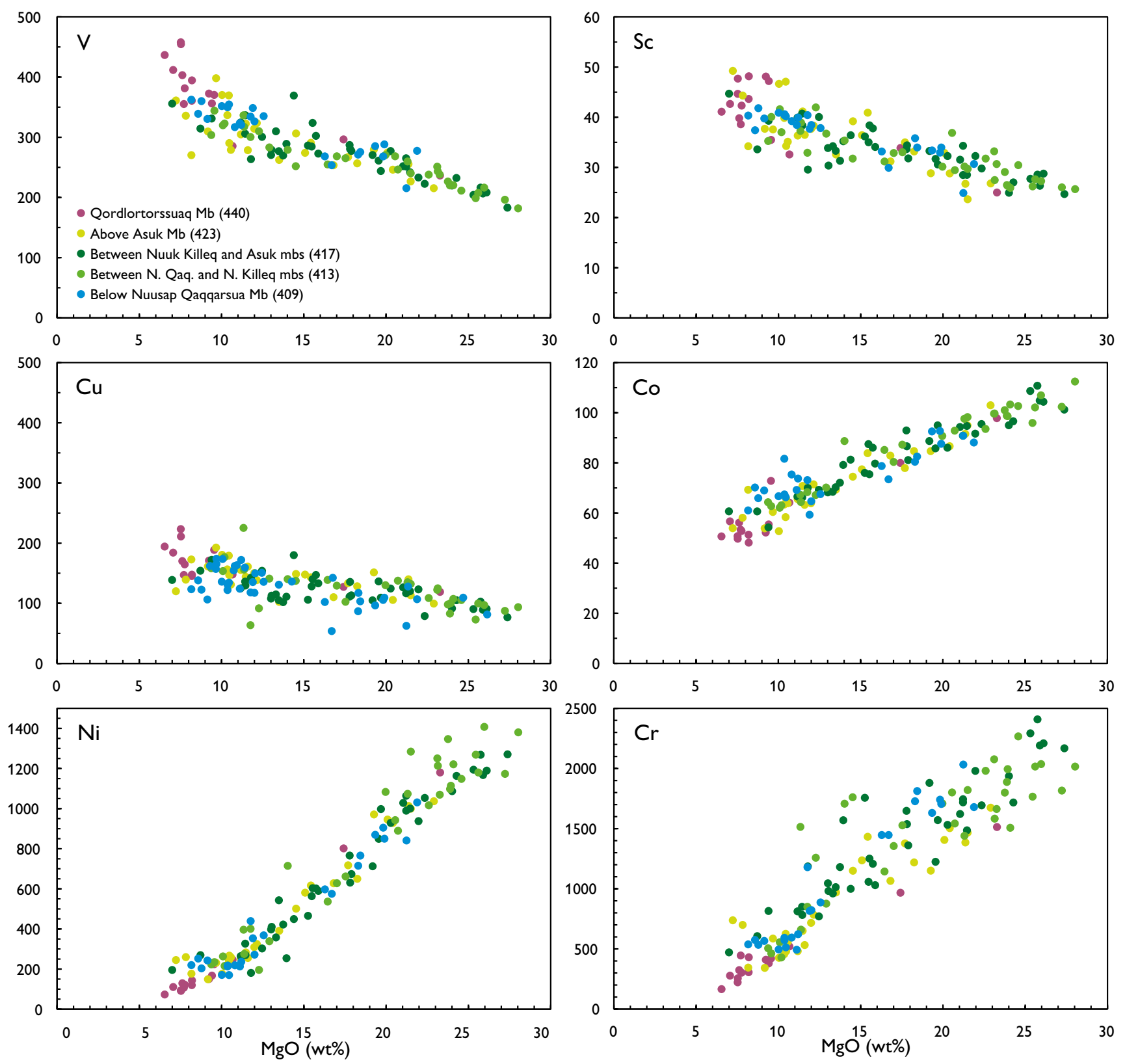

Fig. 154. Transition-element variation diagrams for the uncontaminated rocks of the Naujánguit and Qordlortorssuaq Members. Data in ppm.

REE patterns, the multi-element patterns are also generally parallel, with some fanning of the $\mathrm{Rb}-\mathrm{Nb}$ limbs; the data scatter of the $\mathrm{Rb}-\mathrm{U}$ part is at least partly due to alteration. There are deep troughs at $\mathrm{K}$ and $\mathrm{Pb}$ and a smaller trough at P. Some individual samples deviate significantly from the common patterns. One sample (401502, in unit $417)$ is systematically enriched in a whole suite of incompatible trace elements. Two other samples (402573 in unit 417 and 332732 in unit 413) have slightly increased $\mathrm{Ba}$, Th, U, light REE (LREE) and $\mathrm{Pb}$ and may be very slightly crustally contaminated, although the major elements do not show any signs of this.

Isotope compositional data are presented in Larsen \& Pedersen (2009) and are not treated in detail here. 

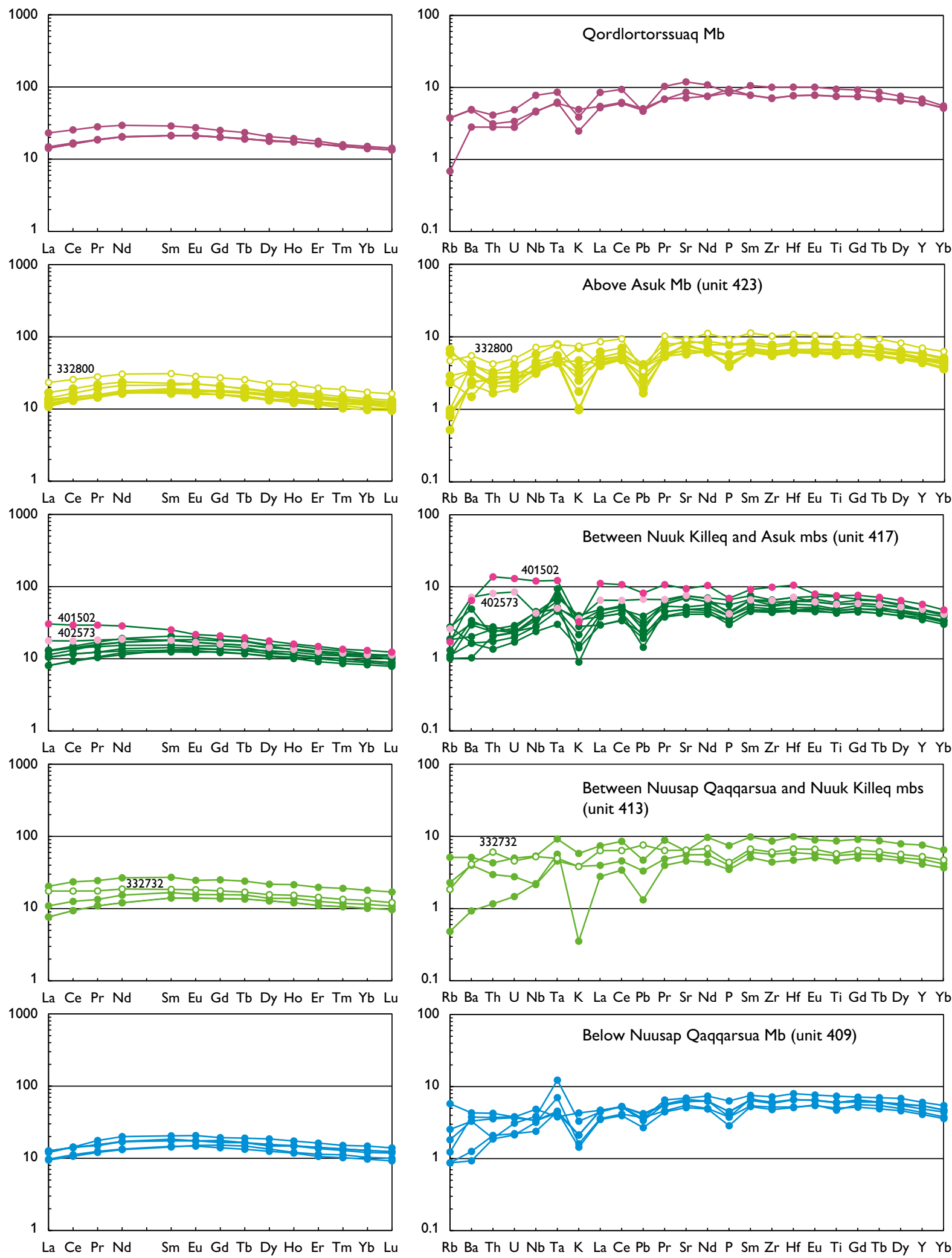

$\mathrm{Rb}$ Ba Th U Nb Ta K La Ce Pb Pr Sr Nd P Sm Zr Hf Eu Ti Gd Tb Dy Y Yb

Fig. 155. REE and multi-element diagrams for representative rocks of the Naujánguit and Qordlortorssuaq members. Left diagrams, chondrite normalised; right diagrams, primitive mantle normalised; normalisation factors from McDonough \& Sun (1995). 


\section{Crustally contaminated rocks}

The crustally contaminated rocks are very diverse and range from picrites through silicic basalts to magnesian andesites with up to $62 \mathrm{wt} \% \mathrm{SiO}_{2}$ (volatile-free). In the chemical variation diagrams shown here, all samples are recalculated to $100 \%$ on a volatile-free basis and all samples are plotted, also the graphite andesites of the Ilugissoq volcano which have pre-eruption volatile contents of 6-12 wt\%. Excepting these, and three hydrothermally altered samples from Hareøen, all samples have less than 7 $\mathrm{wt} \%$ volatiles and most have less than $5 \mathrm{wt} \%$. Representative chemical analyses are shown in Table 5 (p. 174-178). Variation diagrams for major elements are shown in Fig. 156, for incompatible trace elements in Fig. 157 and for transition elements in Fig. 158. REE and multi-element diagrams are shown in Fig. 159. In the descriptions of the characteristics of the individual contaminated units given below, reference to these figures is implied but not generally given because it would clog the text.

The effects of crustal contamination on the chemical composition of the magmas in West Greenland have been described in detail by Pedersen (1978a, 1979a, b, 1981, 1985b), Goodrich (1984), Ulff-Møller (1985, 1989, 1990), Pedersen \& Pedersen (1987), Pedersen \& Rønsbo (1987), Goodrich \& Patchett (1991), Pedersen et al. (1996), Lightfoot et al. (1997) and Larsen \& Pedersen (2009). The contaminated rocks have relatively low $\mathrm{MgO}, 3-16 \mathrm{wt} \%$. Relative to uncontaminated magmas with similar $\mathrm{MgO}$, contaminated magmas have increased $\mathrm{SiO}_{2}$ and $\mathrm{K}_{2} \mathrm{O}$ and decreased $\mathrm{FeO}$ and $\mathrm{CaO}$. $\mathrm{TiO}_{2}$ mainly decreases by contamination, but concomitant fractionation may lead to an overall increase. $\mathrm{Al}_{2} \mathrm{O}_{3}, \mathrm{Na}_{2} \mathrm{O}$ and $\mathrm{P}_{2} \mathrm{O}_{5}$ are little affected. Of the trace elements, $\mathrm{Rb}, \mathrm{Ba}$, LREE, $\mathrm{Zr}, \mathrm{Nb}$ and $\mathrm{Cr}$ increase whereas $\mathrm{V}, \mathrm{Sc}, \mathrm{Cu}$ and $\mathrm{Ni}$ decrease. The changes are brought about by a number of processes, as discussed by Larsen \& Pedersen (2009) and in more detail in Pedersen et al. (2018). The processes comprise simple digestion of and mixing with crustal material, mixing with partial melts of crustal material, reactions involving loss of elements (mainly $\mathrm{Ca}$ ) from the melt to the sidewall, and redox reactions with organic components in the sediments. The redox reactions ultimately led to the formation of sulfide and metal phases. Fractionation of orthopyroxene led to decreased $\mathrm{MgO}$, and in the most reduced rocks fractionation of sulfides and metals removed a significant proportion of the Fe, $\mathrm{Cu}, \mathrm{Ni}$ and PGE inventory of the magmas. All these processes are reflected in the variation diagrams.

$\mathrm{Cr}$ is useful because it is increased in the contaminated rocks relative to uncontaminated rocks with similar
$\mathrm{MgO}$. No high-Cr contaminant is known, and in the contaminated magma chromite either ceased to form or failed to fractionate because of increased viscosity. Therefore, $\mathrm{Cr}$ can be used to estimate the $\mathrm{MgO}$ content of the original magma before contamination.

Isotope ratios of $\mathrm{Nd}$ and $\mathrm{Sr}$ are sensitive indicators of the degree of contamination of a magma, and isotope ratios are given in the analytical tables. Figure 160 shows a $\mathrm{Nd}$ vs. Sr isotope plot of the Vaigat Formation rocks with a bulk mixing curve between uncontaminated picrite and an average sediment of the Nuussuaq Basin; despite the simplification of bulk mixing the model works well for the isotope data, and the approximate degrees of contamination can be estimated.

\section{Henderson unit, Nuusap Qaqqarsua Member and Nuuk Killeq Member}

These three units are weakly to moderately contaminated. The Henderson unit and the Nuusap Qaqqarsua Member are still picritic, with up to $15-16$ wt $\% \mathrm{MgO}$. Locally increased $\mathrm{Cr}$ contents in some of the picrites seem to be due to hydrothermal alteration (Auclair et al. 1988), and the original magmas probably had no more than about $17 \mathrm{wt} \% \mathrm{MgO}$. Each unit shows only limited compositional variation, and the three units are clearly chemically distinguishable.

The Henderson unit is the least contaminated. Silica contents have barely increased and the other major elements are unchanged. However, increased $\mathrm{K}, \mathrm{Rb}, \mathrm{Ba}$, $\mathrm{LREE}$ and $\mathrm{Pb}$ are tell-tale signs of contamination which are supported by the slightly increased $\mathrm{Sr}$ isotope ratio $\left({ }^{87} \mathrm{Sr} /{ }^{86} \mathrm{Sr}=0.7058\right)$ and decreased $\mathrm{Nd}$ isotope ratio $\left({ }^{143} \mathrm{Nd} /{ }^{144} \mathrm{Nd}=0.5125\right)$, indicating around $5-6 \%$ contamination.

The Nuusap Qaqqarsua Member is more contaminated. Silica contents are evidently increased (48.5-52.8 $w t \% \mathrm{SiO}_{2}$ ), and $\mathrm{TiO}_{2}, \mathrm{FeO}^{*}$ and $\mathrm{CaO}$ are decreased. Potassium, $\mathrm{Rb}, \mathrm{Ba}$, Th, LREE and $\mathrm{Pb}$ are increased, and Fig. 160 indicates around $10 \%$ contamination.

The Nuuk Killeq Member is distinctly contaminated (around 15\%) and fractionated. The rocks are silicic basalts and magnesian basaltic andesites with 7-11 wt\% $\mathrm{MgO}$ and up to $53.0 \mathrm{wt} \% \mathrm{SiO}_{2} ; \mathrm{TiO}_{2}$ and $\mathrm{FeO}^{*}$ are low, and there is a distinct loss of $\mathrm{CaO}$. Potassium, $\mathrm{Rb} \mathrm{Ba}, \mathrm{Th}$, $\mathrm{U}, \mathrm{LREE}$ and $\mathrm{Pb}$ are increased, and, relative to the surrounding uncontaminated rocks, so are $\mathrm{Zr}$ and $\mathrm{Nb}$. The increase in $\mathrm{Nb}$ is only slight, and as the increases in $\mathrm{Th}$, $\mathrm{U}$ and LREE are considerably greater, the multi-element patterns have developed $\mathrm{Nb}-\mathrm{Ta}$ troughs. Of the transi- 

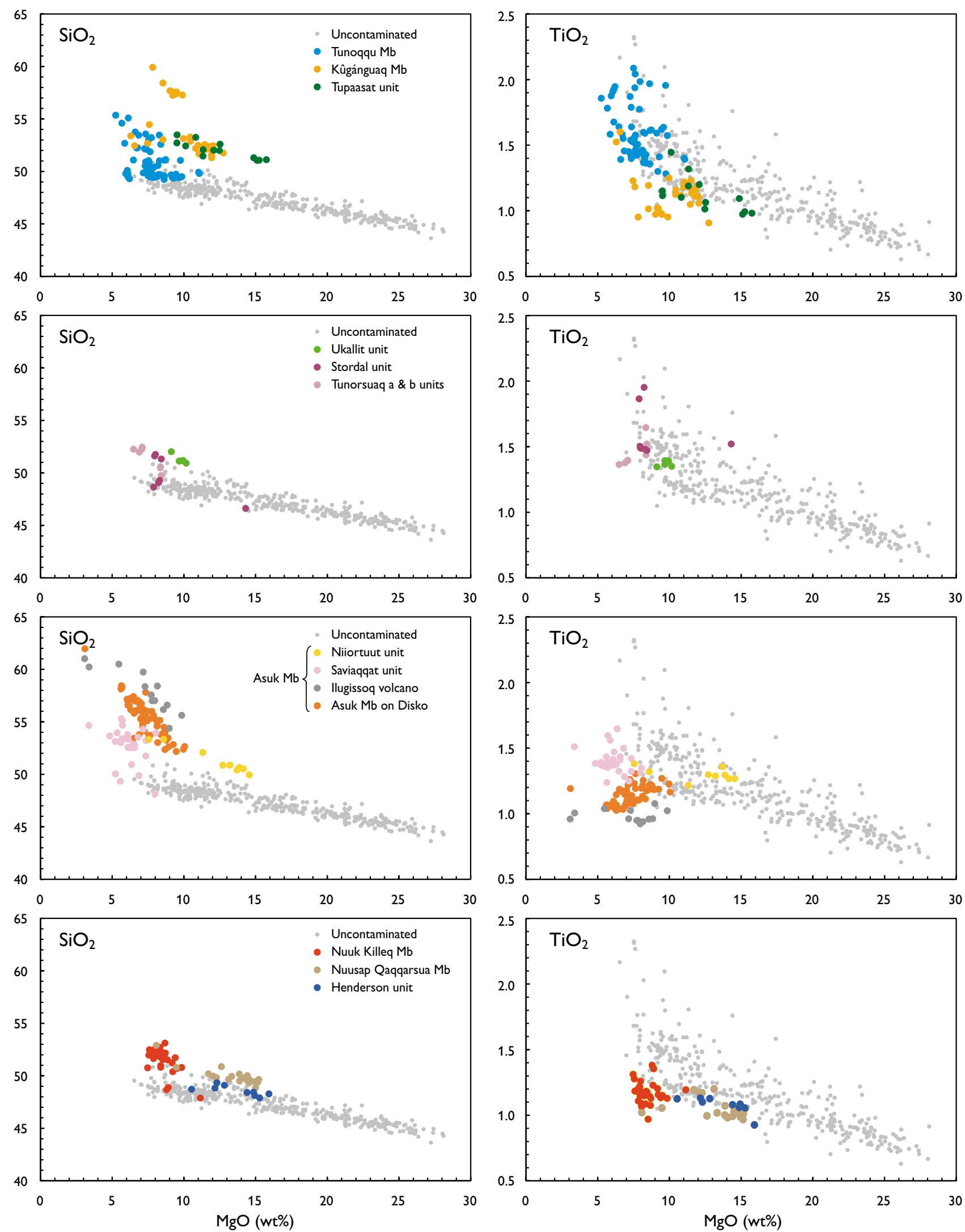

Fig. 156 (first of four parts). Major-element variation diagrams for the crustally contaminated members and units associated with the Naujánguit Member. Data in wt\% oxides calculated volatile-free. Uncontaminated rocks of the Naujánguit and Qordlortorssuaq members are shown as small grey dots for ease of comparison. 

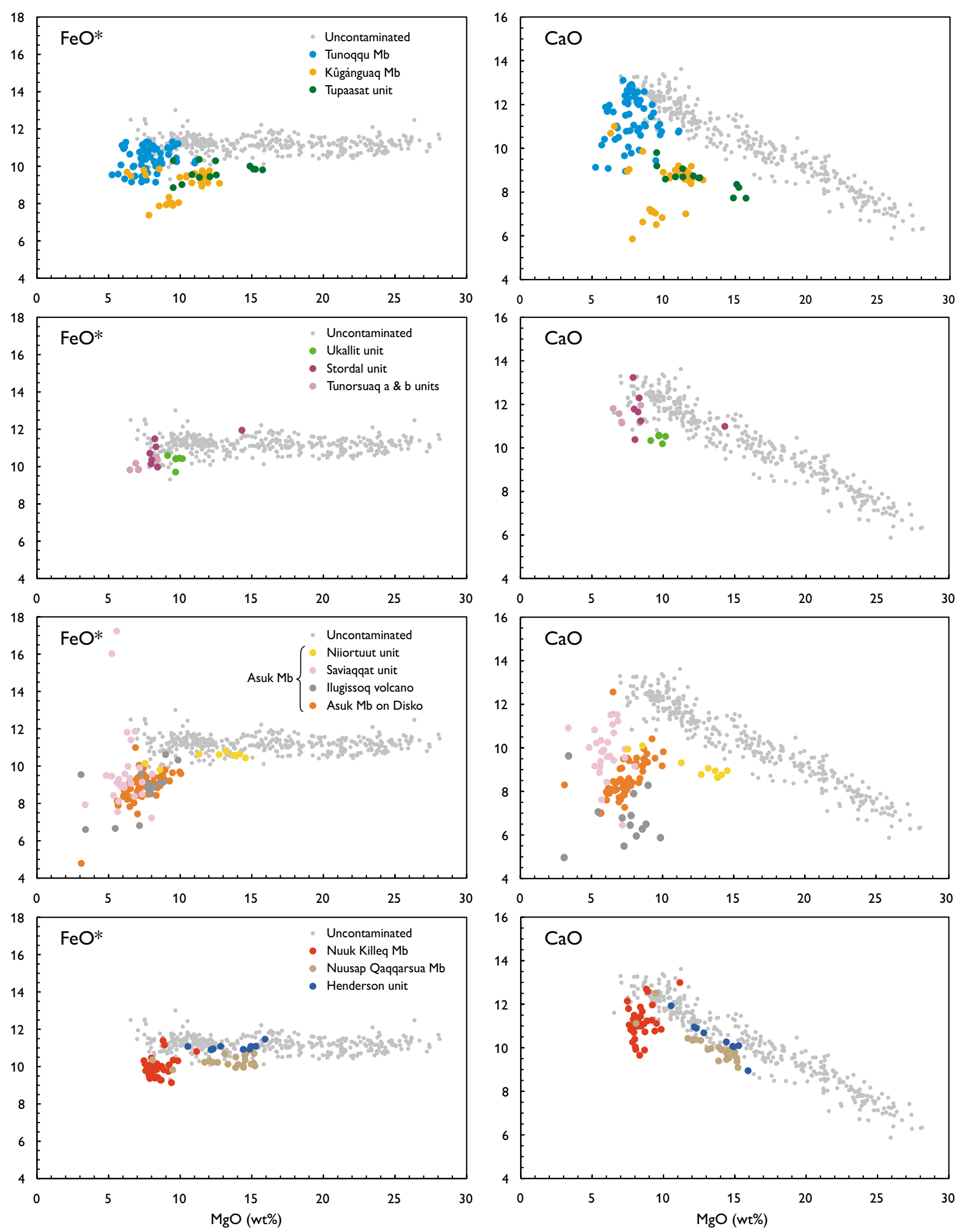

Fig. 156 (second offour parts). Major-element variation diagrams for the crustally contaminated members and units associated with the Naujánguit Member. Data in wt\% oxides calculated volatile-free. FeO* is total iron as FeO. Uncontaminated rocks of the Naujánguit and Qordlortorssuaq members are shown as small grey dots for ease of comparison. 

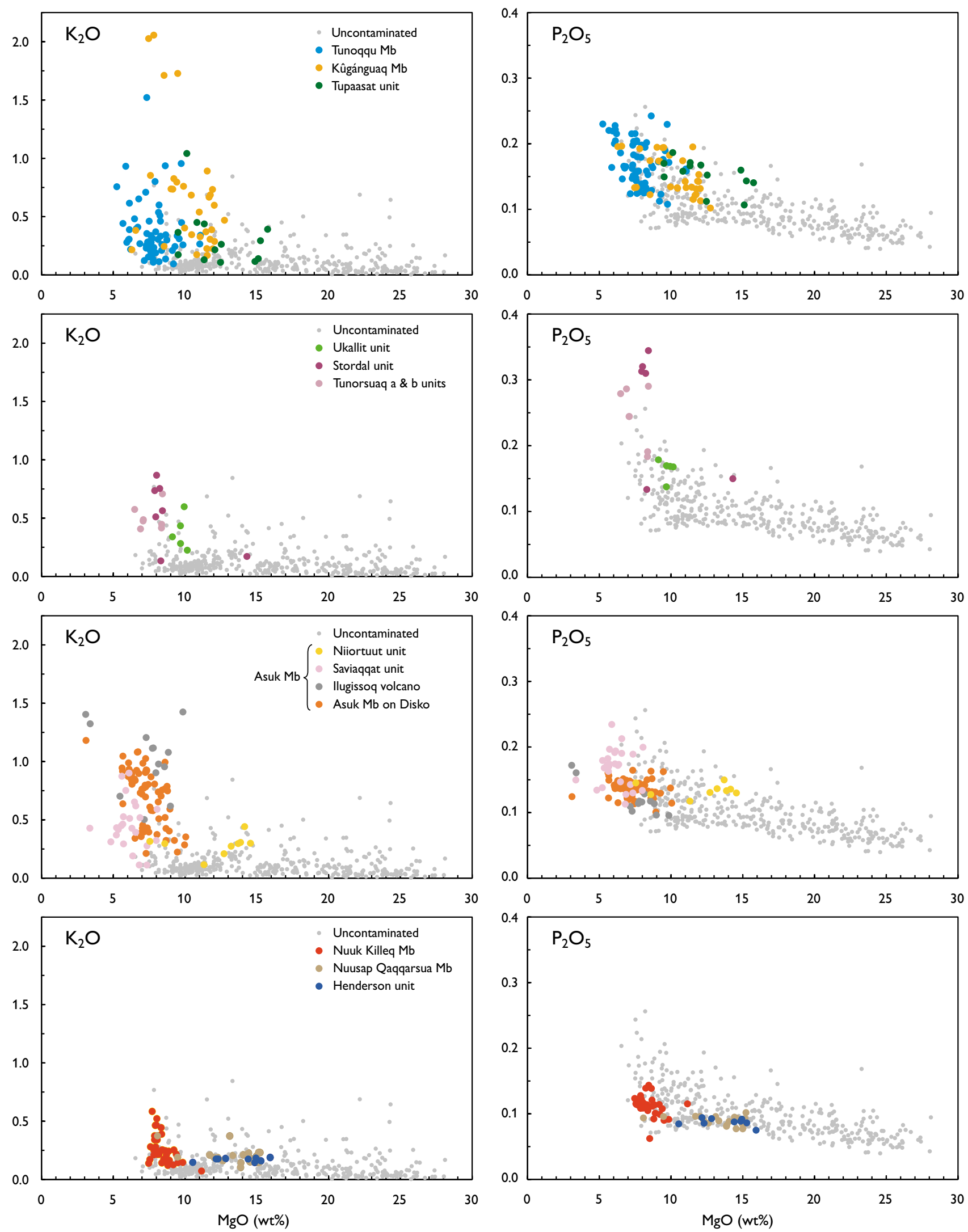

Fig. 156 (third offour parts). Major-element variation diagrams for the crustally contaminated members and units associated with the Naujánguit Member. Data in wt\% oxides calculated volatile-free. Uncontaminated rocks of the Naujánguit and Qordlortorssuaq members are shown as small grey dots for ease of comparison. 

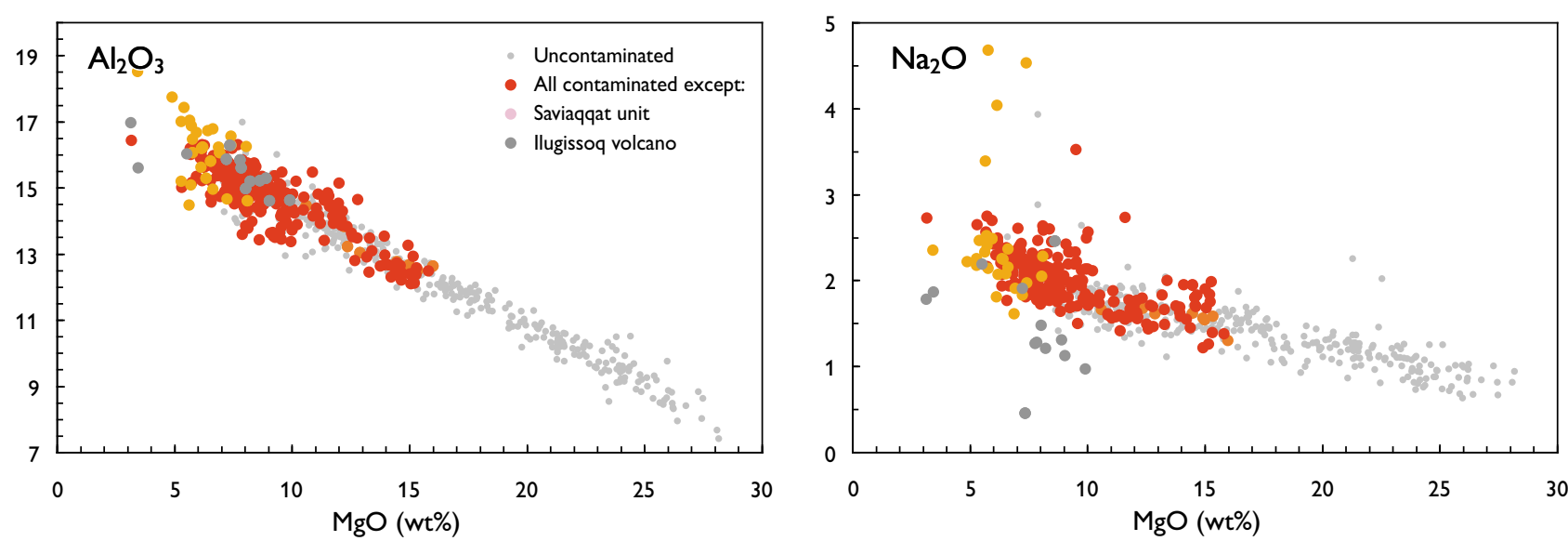

Fig. 156 (fourth offour parts). Major-element variation diagrams for the crustally contaminated members and units associated with the Naujánguit Member. Data in wt\% oxides calculated volatile-free. Uncontaminated rocks of the Naujánguit and Qordlortorssuaq members are shown as small grey dots for ease of comparison.

tion elements, there is a significant loss of $\mathrm{Cu}$ and $\mathrm{Ni}$. A few of the younger flow groups of this member are lithologically brown basalts but are not perceptibly contaminated. One of these is the $4 \mathrm{~m}$ thick, dark, glass-rich, conformable horizon in the hyaloclastites just west of Nuuk Killeq seen in Figs 87-89.

\section{Asuk Member}

This member comprises a number of individual units which occupy the same stratigraphic level and are thus near-simultaneous but produced from separate eruption centres. These are the 'classical' Asuk Member on Disko and, on Nuussuaq, the Ilugissoq volcano, the Saviaqqat unit and the Niiortuut unit. Most of these rocks are highly contaminated and reduced, and some carry native iron.

The Niiortuut unit is the least contaminated. It remains partly picritic, with 7-14.5 wt $\% \mathrm{MgO}$, but $\mathrm{SiO}_{2}$ is distinctly increased and $\mathrm{FeO}^{*}$ and $\mathrm{CaO}$ are decreased. Potassium, $\mathrm{Rb}, \mathrm{Ba}, \mathrm{Th}, \mathrm{Nb}$ and LREE are increased and the multi-element pattern has a $\mathrm{Nb}-\mathrm{Ta}$ trough.

The other units are strongly contaminated, with up to $62 \mathrm{wt} \% \mathrm{SiO}_{2}$, and also fractionated, with $\mathrm{MgO}<10$ $\mathrm{wt} \%$, ranging down to $3 \mathrm{wt} \%$ in the most silicic rocks. In Fig. 160 the Saviaqqat unit forms a separate group (three analyses) with around $15 \%$ contamination, and the Asuk Member on Disko and the Ilugissoq volcano both show variable contamination of $c .22-40 \%$.

The rocks of the Asuk Member on Disko and the Ilugissoq volcano show many chemical similarities despite the large lithological differences between them. They are highly silicic and have lost significant amounts of $\mathrm{FeO}^{*}$,
$\mathrm{CaO}$ and $\mathrm{TiO}_{2}$; because of the high volatile contents in the graphite-rich products of the Ilugissoq volcano, the recalculated plots show higher $\mathrm{SiO}_{2}, \mathrm{~K}, \mathrm{Rb}, \mathrm{Ba}, \mathrm{Zr}$ and $\mathrm{Ce}$ than in the Asuk Member on Disko, whereas the original analyses show similar contents of these elements (Table 5). The lower contents of $\mathrm{TiO}_{2}, \mathrm{CaO}$ and $\mathrm{Y}$ in the Ilugissoq rocks are not an effect of recalculation. The REE patterns are relatively steep and have negative $\mathrm{Eu}$ anomalies (discussed in the chapter on crustal contamination in Pedersen et al. 2018). The multi-element patterns show very elevated $\mathrm{Rb}-\mathrm{U}$ and $\mathrm{K}-\mathrm{Sr}$ levels, with distinct $\mathrm{Nb}-\mathrm{Ta}$ troughs and $\mathrm{Pb}$ peaks.

The lavas of the Saviaqqat unit have lower $\mathrm{SiO}_{2}$ and higher $\mathrm{CaO}$ relative to the other units. Some of the compositional spread within this unit is due to samples that have accumulated iron metal (high $\mathrm{FeO}^{*}$ and low $\mathrm{SiO}_{2}$ ) or have zeolitised plagioclase (high $\mathrm{Na}_{2} \mathrm{O}$ or $\mathrm{K}_{2} \mathrm{O}$ and high volatiles). Two altered samples have 3.5-4 wt $\%$ $\mathrm{K}_{2} \mathrm{O}$ and are off scale in the $\mathrm{K}_{2} \mathrm{O}$ diagram. Despite the high modal content of plagioclase in most rocks of the Saviaqqat unit they do not appear to have accumulated plagioclase because even the most alumina-rich samples do not have lower contents of e.g. $\mathrm{FeO}^{*}$ and $\mathrm{TiO}_{2}$ than the other Asuk Member rocks. Of the minor and trace elements, the Saviaqqat unit shows significantly higher contents of Ti, P, Sr, Y, Nb and LREE than the other units in the Asuk Member, which must be ascribed to a different contaminant. The differences in $\mathrm{Nb}$ and LREE are particularly striking and the rocks do not show $\mathrm{Nb}-$ Ta troughs in their multi-element patterns.

A sample from the strongly contaminated sill at $\mathrm{Tu}-$ paasat is included in the REE- and multi-element dia- 

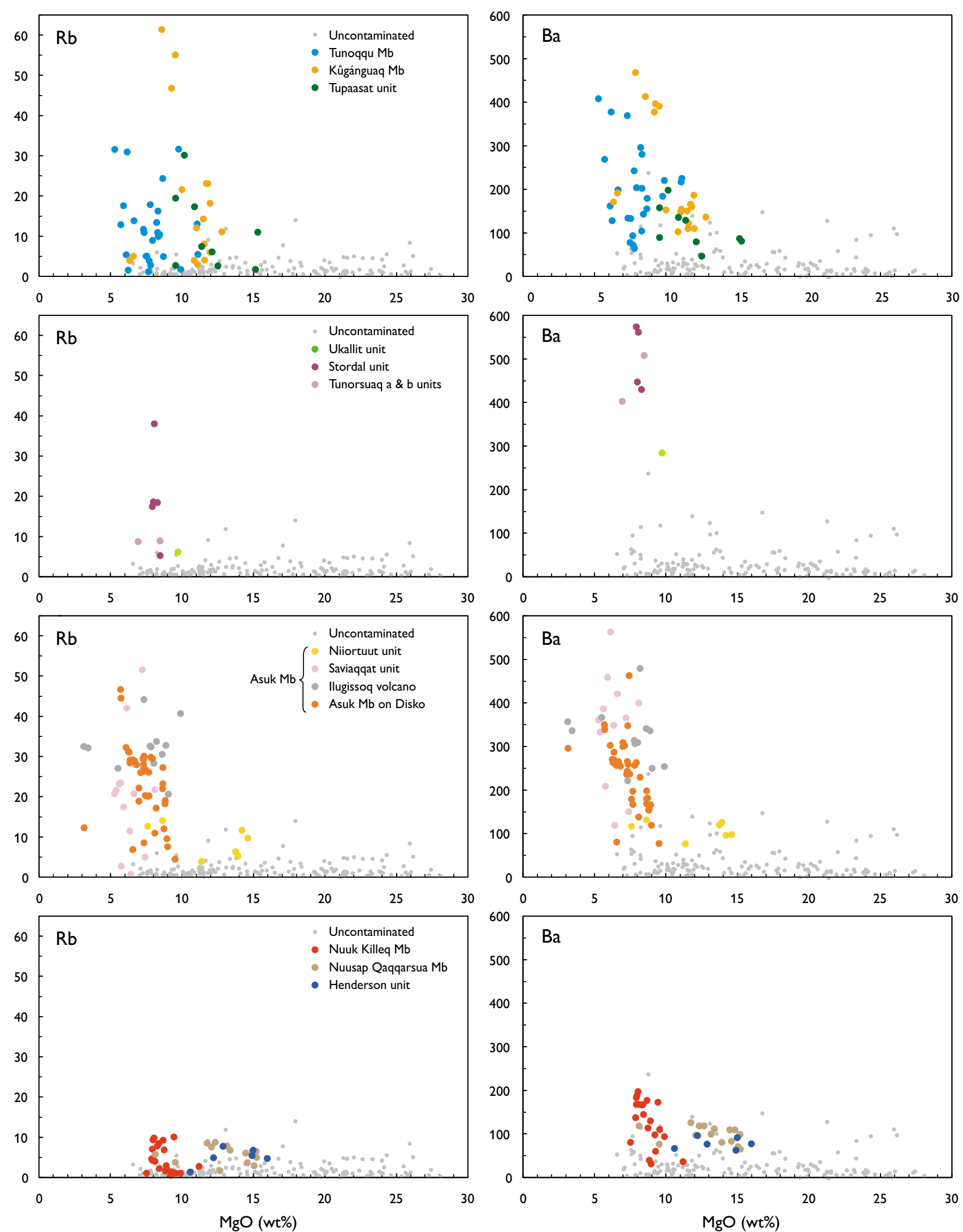

Fig. 157 (first of four parts). Incompatible trace-element variation diagrams for the crustally contaminated members and units associated with the Naujánguit Member. Data in ppm. 

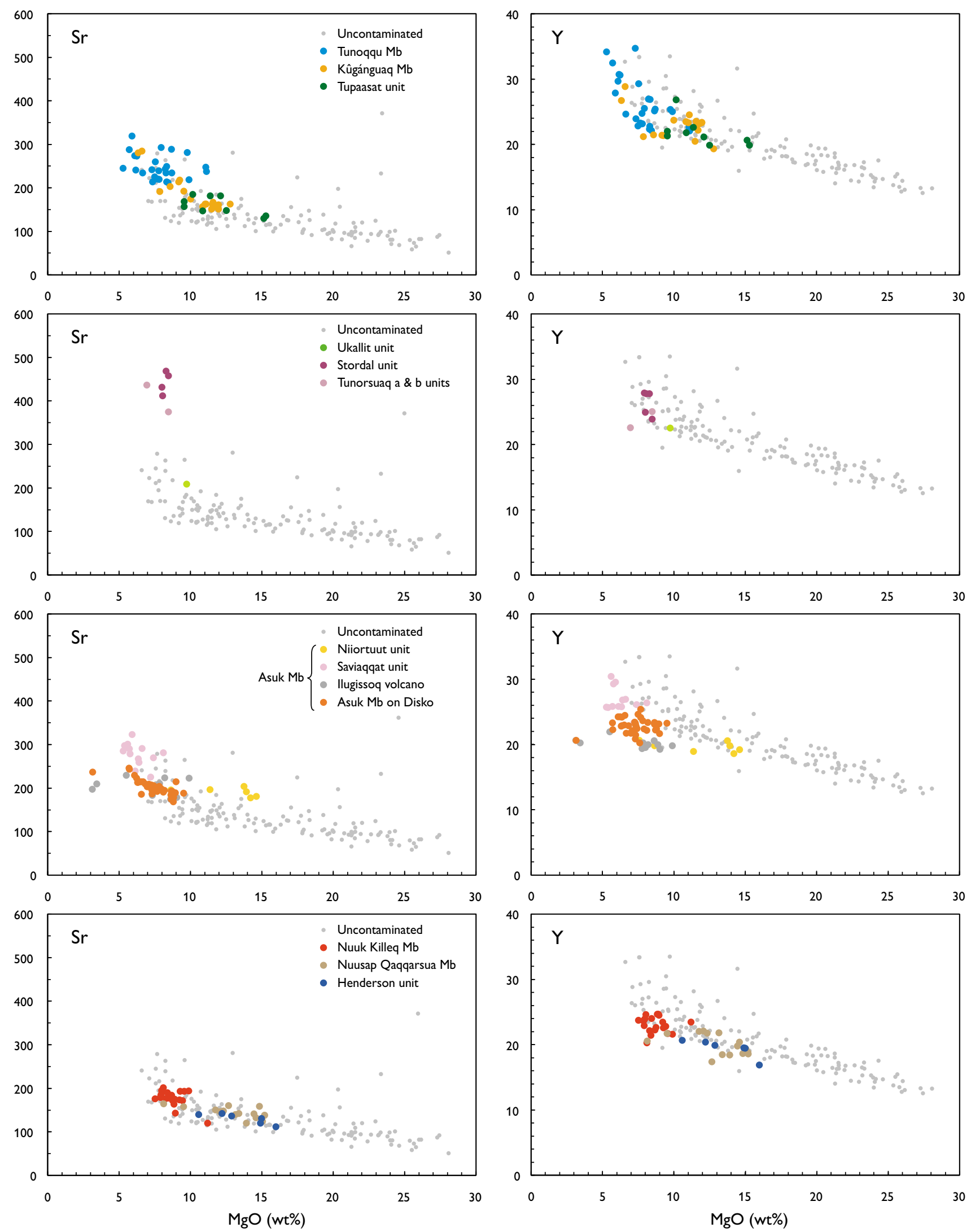

Fig. 157 (second offourparts). Incompatible trace-element variation diagrams for the crustally contaminated members and units associated with the Naujánguit Member. Data in ppm. 

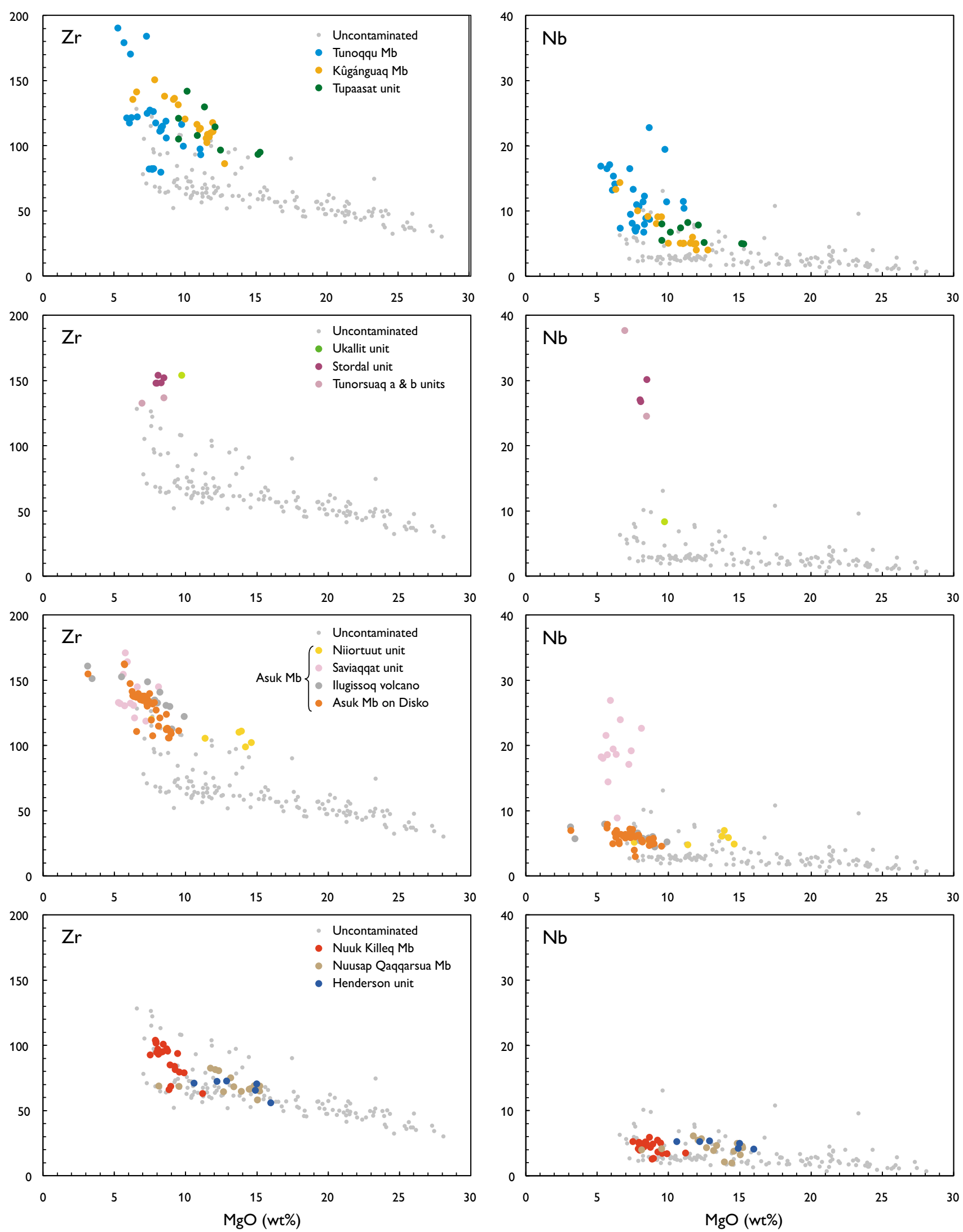

Fig. 157 (third of four parts). Incompatible trace-element variation diagrams for the crustally contaminated members and units associated with the Naujánguit Member. Data in ppm. 

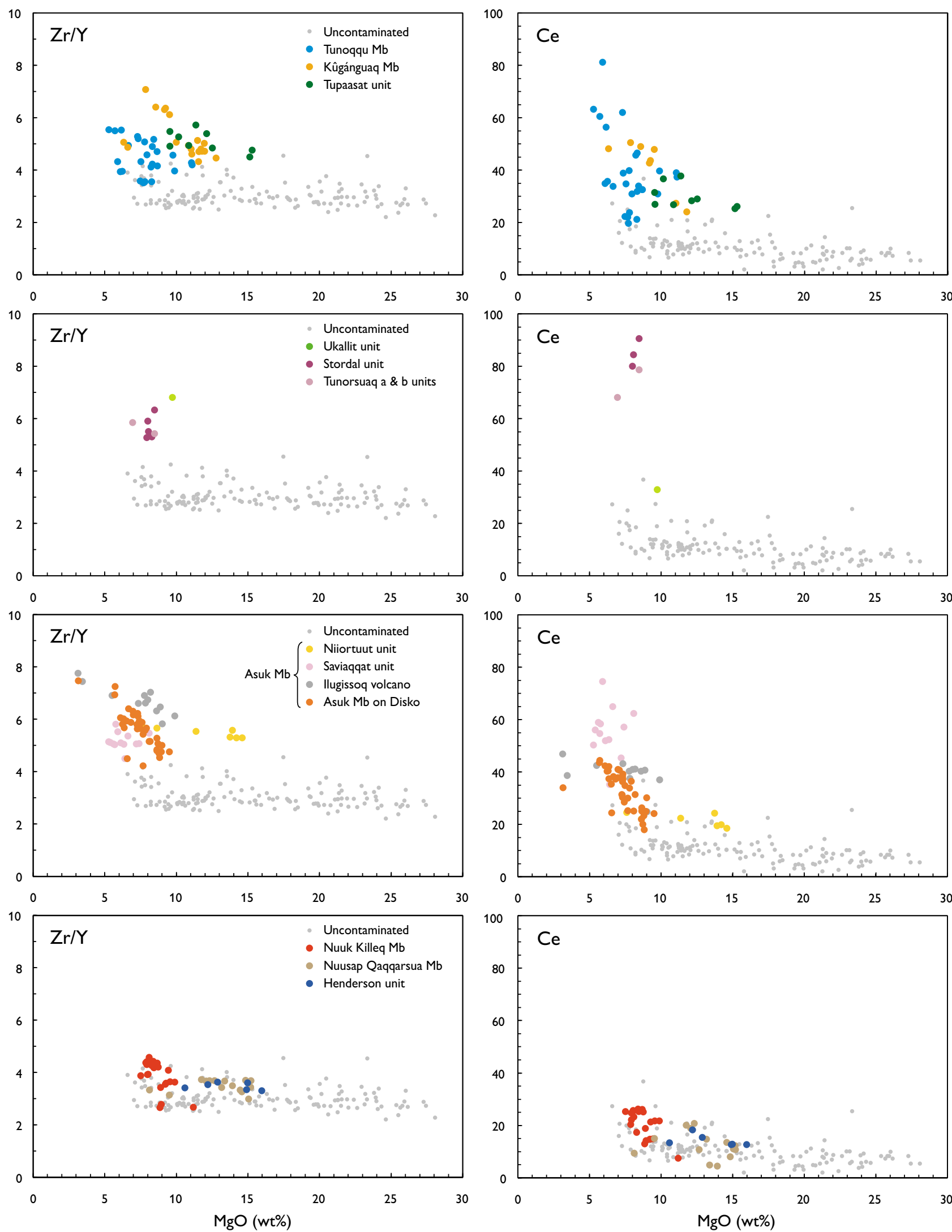

Fig. 157 (fourth of four parts). Incompatible trace-element variation diagrams for the crustally contaminated members and units associated with the Naujánguit Member. Data in ppm. 

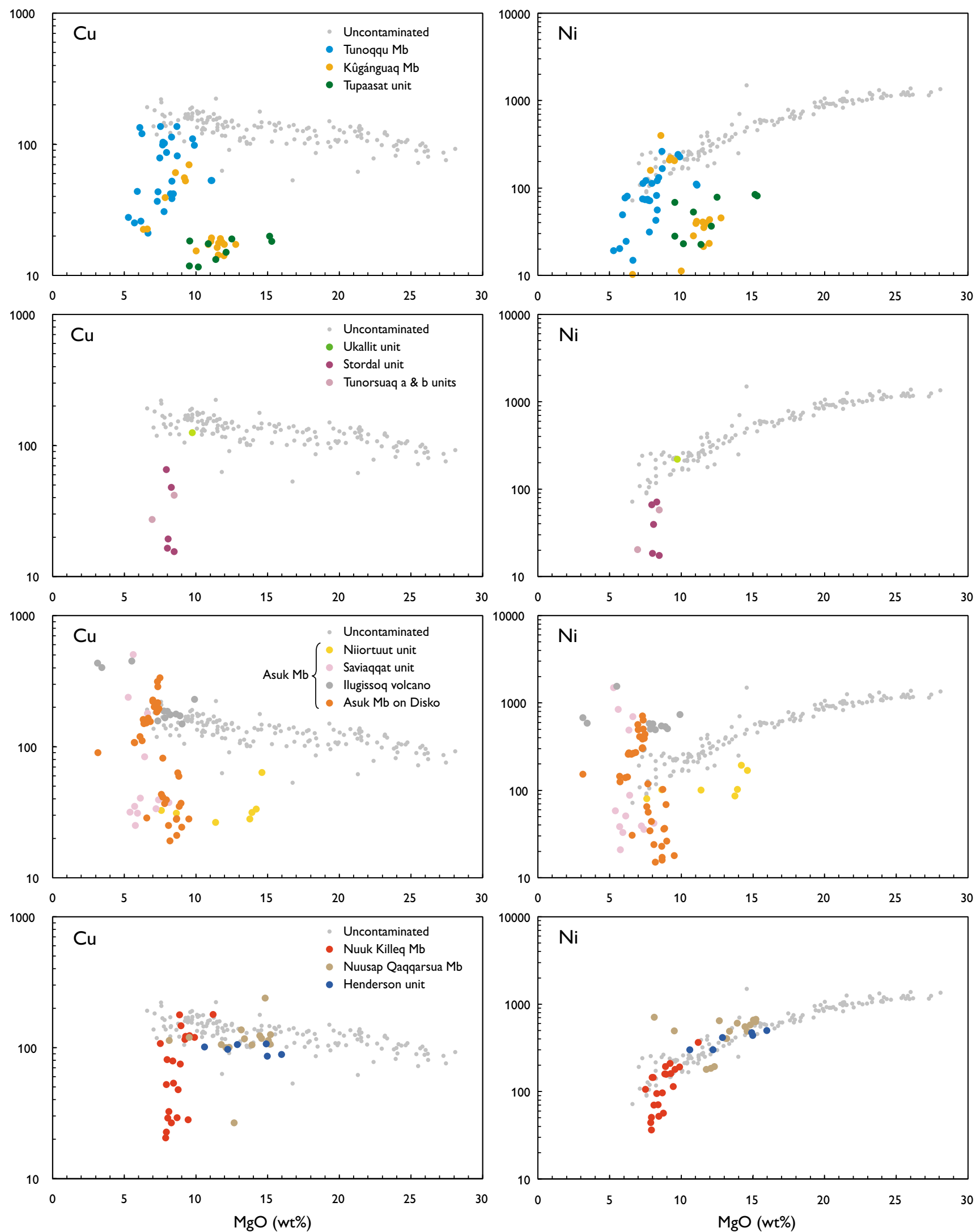

Fig. 158 (first of three parts). Transition-element variation diagrams for the crustally contaminated members and units associated with the Naujánguit Member. Data in ppm. 

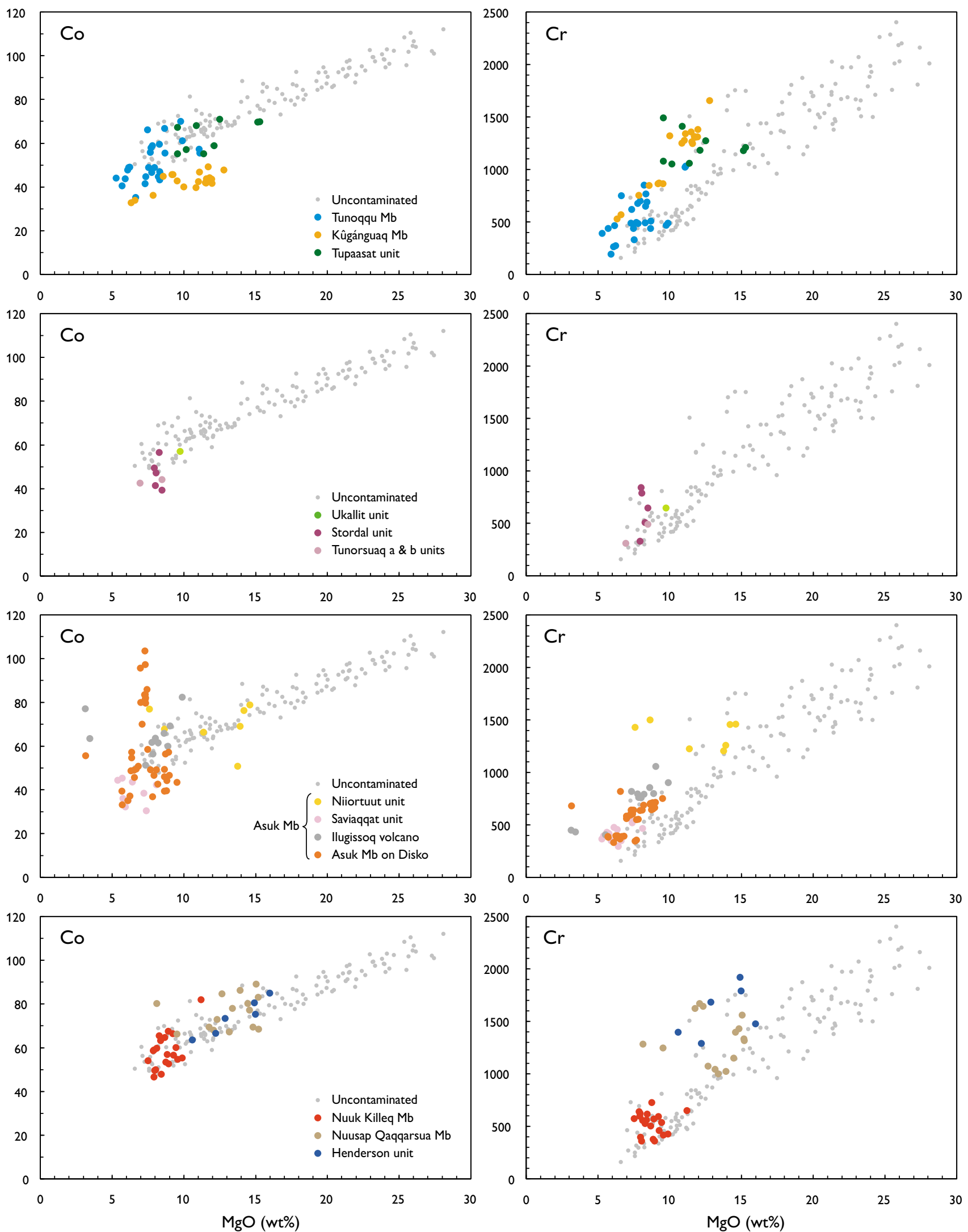

Fig. 158 (second of three parts). Transition-element variation diagrams for the crustally contaminated members and units associated with the Naujánguit Member. Data in ppm. 

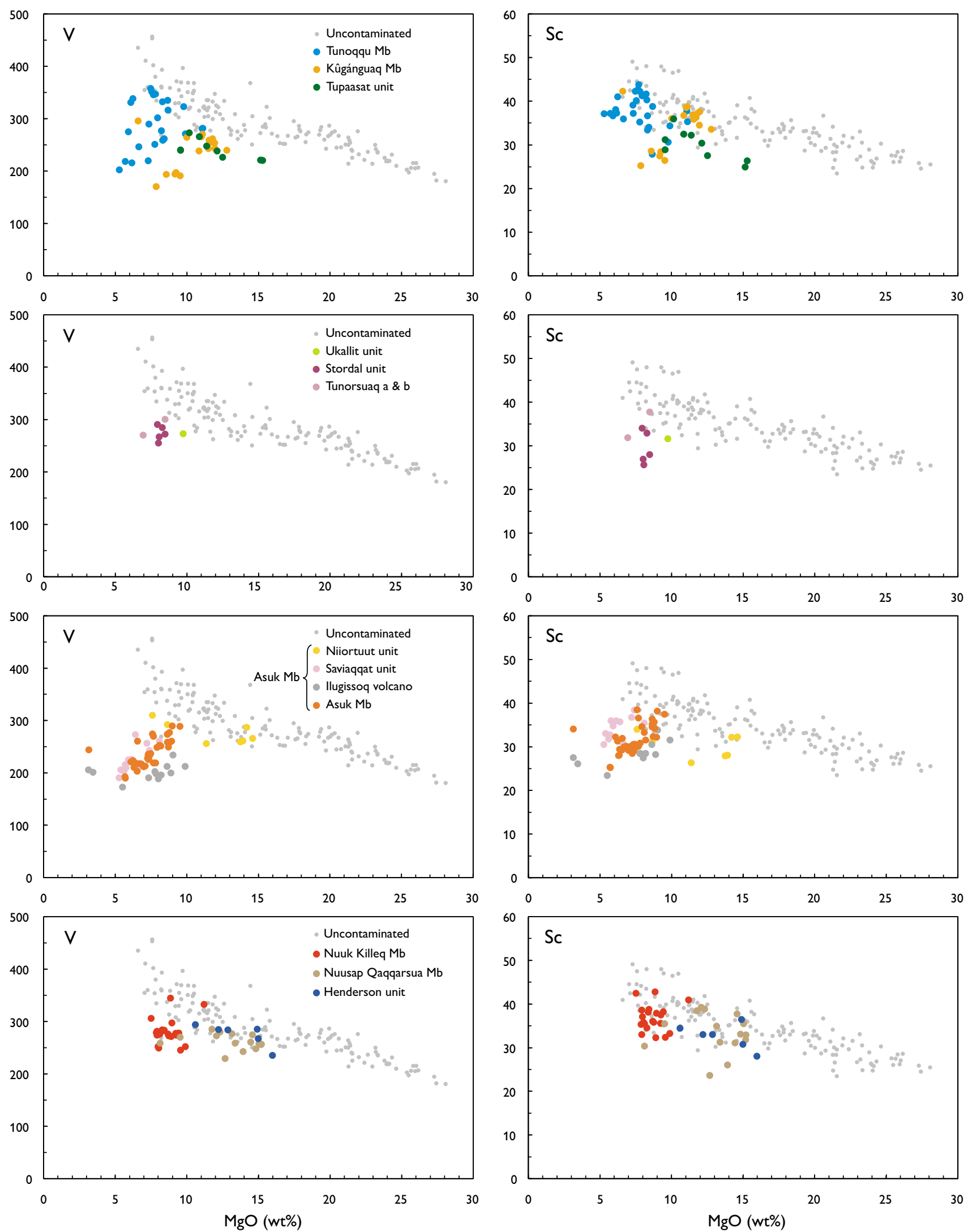

Fig. 158 (third of three parts). Transition-element variation diagrams for the crustally contaminated members and units associated with the Naujánguit Member. Data in ppm. 

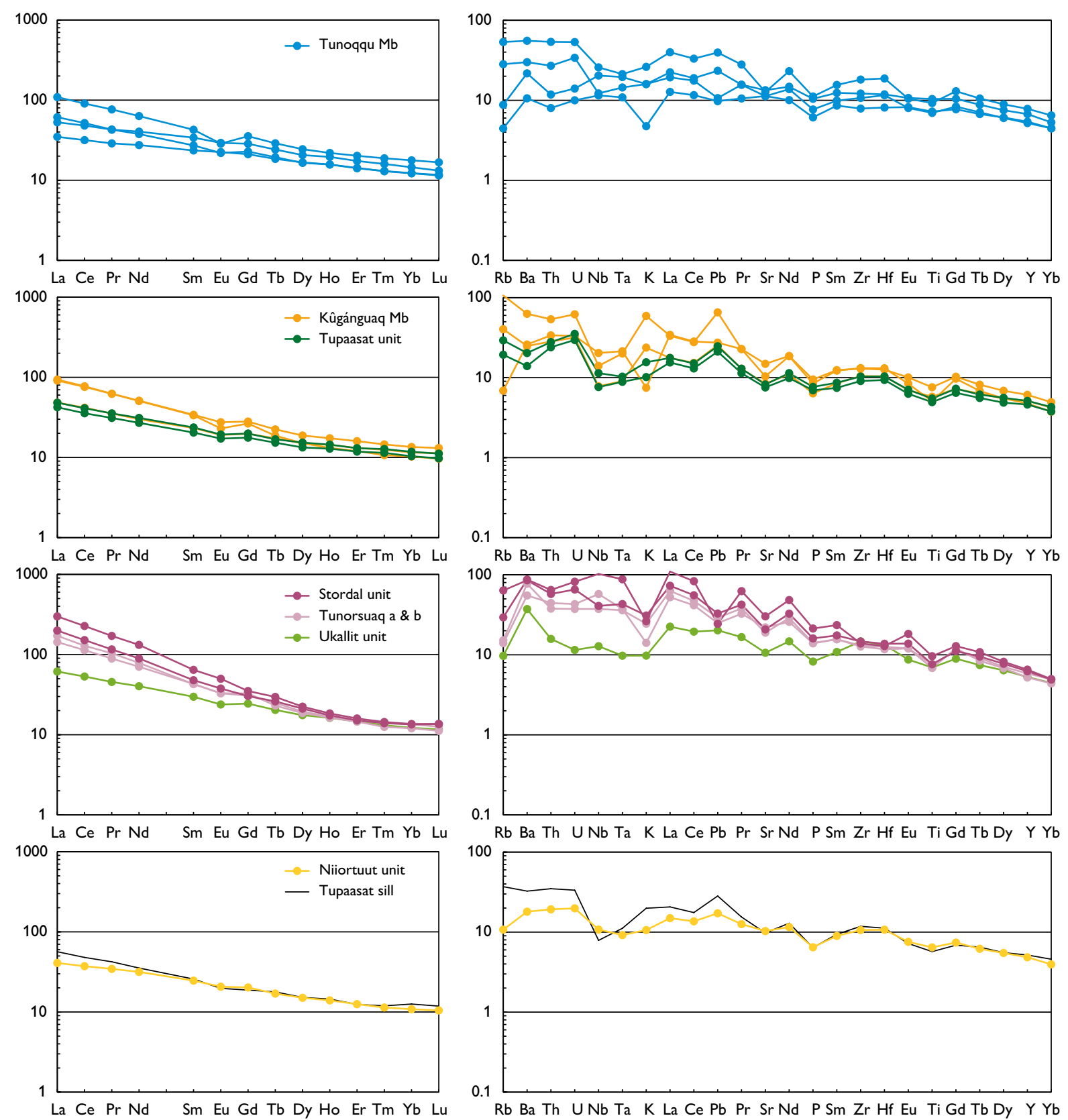

Fig. 159 (first of two parts). REE and multi-element diagrams for representative rocks of the crustally contaminated members and units associated with the Naujánguit Member. Left diagrams, chondrite normalised; right diagrams, primitive mantle normalised; normalisation factors from McDonough \& Sun (1995).

gram for the Niiortuut unit (Fig. 159). The patterns of the sill are most similar to those of the Asuk Member on Disko, and the $\mathrm{Sr}-\mathrm{Nd}$ isotope ratios are also similar ( $\mathrm{Ta}-$ ble 5).

The distribution of the transition metals is complicated and depends on whether the rocks carry native iron and/or graphite or neither. The Niiortuut unit, where the rocks carry neither native iron nor graphite, has lost
$\mathrm{Cu}$ and $\mathrm{Ni}$ but apparently not $\mathrm{Co}$. In the other units, andesites with neither native iron nor graphite have lost $\mathrm{Cu}, \mathrm{Ni}$ and $\mathrm{Co}$, whereas andesites with native iron, and also the metal-free graphite-rich Ilugissoq andesites, have normal or higher-than-normal $\mathrm{Cu}$ and $\mathrm{Co}$, and higher $\mathrm{Ni}$. The groups are clearly distinguished in the diagrams. The Cr contents of the Niiortuut unit indicate parental magmas with 16-19 wt\% MgO; Cr contents in the Asuk 

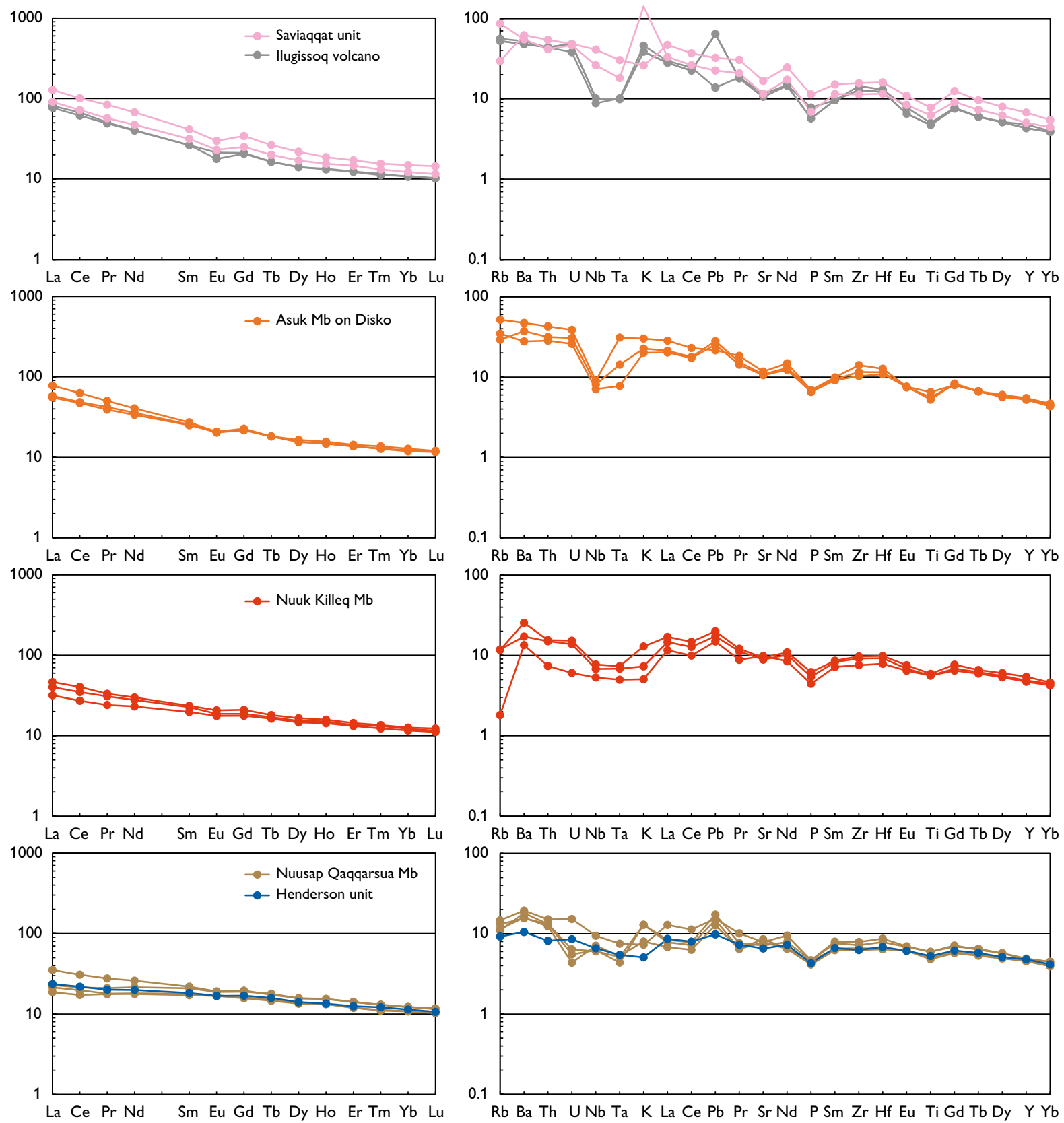

Fig. 159 (second of two parts). REE and multi-element diagrams for representative rocks of the crustally contaminated members and units associated with the Naujánguit Member. Left diagrams, chondrite normalised; right diagrams, primitive mantle normalised; normalisation factors from McDonough \& Sun (1995).

Member on Disko and the Ilugissoq volcano reach to $800-950 \mathrm{ppm}$, indicating parental magmas with at least $13 \mathrm{wt} \% \mathrm{MgO}$; and $\mathrm{Cr}$ contents in the Saviaqqat unit reach to $550 \mathrm{ppm}$, indicating parental magmas with at least $10 \mathrm{wt} \% \mathrm{MgO}$.
Carbon, sulfur and native iron in the Asuk Member as evidence for the nature and location of the highlevel magma chambers

The most contaminated lavas and pyroclastic rocks of the Asuk Member have unusually high contents of carbon (in graphite and cohenite, $\mathrm{Fe}_{3} \mathrm{C}$ ) and sulfur (in troilite, $\mathrm{FeS}$ ) and commonly carry native iron $\left(\mathrm{Fe}^{0}\right)$. Sulfur is normally degassed in basic magmas at low pressures (Moore 


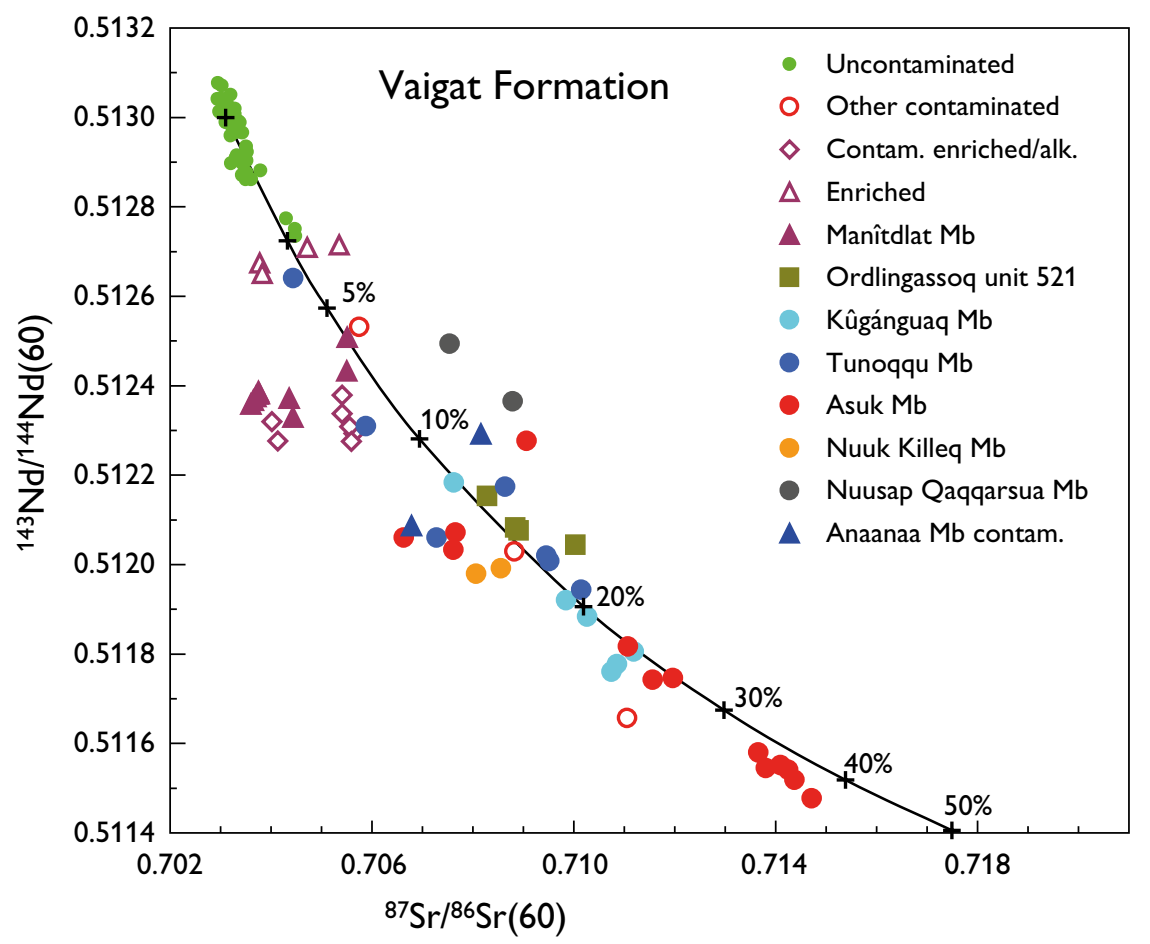

Fig. 160. Sr and Nd isotope plot for the Vaigat Formation, based on data from Larsen \& Pedersen (2009) with some additional data from Lightfoot et al. (1997). Isotope ratios are recalculated to $60 \mathrm{Ma}$. The mixing curve is calculated by bulk mixing of a picrite with $120 \mathrm{ppm}$ $\mathrm{Sr}, 7 \mathrm{ppm} \mathrm{Nd},{ }^{87} \mathrm{Sr} /{ }^{86} \mathrm{Sr}(60)=0.7031$, and ${ }^{143} \mathrm{Nd} /{ }^{144} \mathrm{Nd}(60)=0.5130$ with an average sediment with $230 \mathrm{ppm} \mathrm{Sr}, 39$ ppm Nd, ${ }^{87} \mathrm{Sr} /{ }^{86} \mathrm{Sr}(60)=0.7250$, and ${ }^{143} \mathrm{Nd} /{ }^{144} \mathrm{Nd}(60)=0.5111$. The percentages are percent sediment in the mixture. The group 'Enriched' comprises Ordlingassoq Member units 453 and 455 and an Anaanaa Member picrite. The group 'Contaminated enriched/alkaline' comprises Naujánguit Member units 416, 421 and 425. The group 'Other contaminated' comprises Naujánguit Member units 411, 426 and 464.

\& Fabbi 1971) and is essentially lost during eruptions and lava flowage and crystallisation (e.g. Self et al. 2006). Accordingly, the uncontaminated Vaigat Formation lavas and hyaloclastites have $<0.05 \mathrm{wt} \% \mathrm{~S}$ (AKP, unpublished data). However, in highly reduced environments in the presence of $\mathrm{Fe}^{0}$, the sulfur fugacity is low because it is buffered by a troilite-iron reaction (e.g. Toulmin \& Barton 1964), and degassing of such magmas is limited (e.g. Solovova et al. 2002; Iacono-Marziano et al. 2012). The Asuk Member rocks therefore provide information on the nature and location of their high-level reservoirs.

Table 4 presents analyses of carbon, sulfur and metallic iron in strongly contaminated volcanic rocks of the Ilugissoq volcano on Nuussuaq and from Asuk and Kuugannguaq on Disko. The graphite andesites of the root zone of the Ilugissoq volcano and the native-iron-bearing graphite andesite lava flow at Nuuk Killeq have notably high contents of carbon and sulfur: $2-3 \mathrm{wt} \%$ total organic carbon (TOC) and $0.5-0.9 \mathrm{wt} \% \mathrm{~S}$. In the composite lava flows at Asuk and in Kuugannguaq, the native-ironbearing andesitic and near-andesitic upper parts have similarly high contents of $0.3-2 \mathrm{wt} \%$ TOC and $0.5-1$ wt $\% \mathrm{~S}$, whereas the more basic lower parts with $0.03 \mathrm{wt} \%$ $\mathrm{C}$ and $0.01-0.2 \mathrm{wt} \% \mathrm{~S}$ are variably degassed.

The Asuk Member rocks commonly contain magmamodified mudstone xenoliths, and there is no doubt that mudstone was the dominating contaminant in the high-level magma chambers on both Nuussuaq and Disko (Larsen \& Pedersen 2009). The high S contents in the most contaminated rocks indicate a sulfur-rich mudstone. As non-marine, anoxic mudstones normally contain less than $0.5 \mathrm{wt} \% \mathrm{~S}$, whereas marine anoxic mudstones generally reach higher levels (Berner \& Raiswell 1983, 1984; Raiswell \& Canfield 2012), the contaminants were marine mudstones.

For the Ilugissoq volcano with about $5 \mathrm{~km}^{3}$ of erupted pyroclastic rock, the magma reservoir was situated on central Nuussuaq and was of considerable size. Exposed sediments beneath the volcano are thin mudstones of the Paleocene Eqalulik Formation and sand-dominated delta front deposits of the Santonian-Campanian Atane Formation, none of which are suitable candidates for hosting the magma chambers. A deeper and older mudstone succession is a more realistic candidate.

On Disko, the magma chambers would be situated beneath Asuk and the inner Kuugannguaq valley. The only exposed marine mudstone here is a small occurrence of the Cenomanian Kussinerujuk Member of the Itilli Formation east of Asuk, known for the occurrence of an oil seep (Bojesen-Koefoed et al. 2007). Again, a deeper and older mudstone succession is a more realistic candidate for the contaminant.

This considerably extends the area with marine mudstones as possible source rocks at depth eastwards from the limit around the Kuugannguaq-Qunnilik fault drawn by Bojesen-Koefoed et al. (1999) for Campanian mudstones. 
Table 4. Carbon, sulfur and metallic iron in rocks of the Asuk Member

\begin{tabular}{|c|c|c|c|c|c|}
\hline Volcanic unit & GGU No. & TOC & $\mathrm{S}$ & $\mathrm{Fe}^{0}$ & $\mathrm{SiO}_{2}$ \\
\hline Ilugissoq volcano & & \multicolumn{4}{|c|}{ All concentrations in wt $\%$} \\
\hline Root zone & $400287 *$ & 2.43 & 0.73 & 0 & 56.9 \\
\hline Root zone & 400286 & 2.11 & 0.88 & 0 & 57.5 \\
\hline Root zone & 400285 & 2.11 & 0.57 & 0 & 58.3 \\
\hline Middle part of cone & 400288 & 2.02 & 0.58 & 0 & 56.5 \\
\hline Upper part of cone & $400281 *$ & 1.88 & 0.54 & 0 & 55.5 \\
\hline Lava flow, Nuuk Killeq & $340772 *$ & 2.84 & 0.84 & + & 60.4 \\
\hline $\begin{array}{l}\text { Graphitic scoria, Nuuk Killeq } \\
\text { Asuk (Fig. 94) }\end{array}$ & 113518 & 4.20 & 0.02 & + & 59.7 \\
\hline Subaqueous lava flow & $113291 *$ & 0.07 & 0.42 & 3.0 & 57.8 \\
\hline Composite lava, lower basic part & $113277^{*}$ & 0.03 & 0.10 & trace & 53.7 \\
\hline Same flow, lower andesite part & 136989 & 0.40 & 0.56 & 3.1 & 56.5 \\
\hline same flow, middle andesite part & $113280 *$ & 0.30 & 0.48 & 2.9 & 57.1 \\
\hline \multicolumn{6}{|l|}{ Kuugannguaq (Fig. 98) } \\
\hline Composite lava 1 , lower basic part & $176735^{*}$ & 0.04 & 0.01 & 0 & 53.5 \\
\hline same flow, near-andesitic lower part & 176736 & 1.53 & 0.91 & 2.3 & 55.0 \\
\hline same flow, near-andesitic middle part & 176737 & 1.96 & 0.97 & 0.2 & 56.0 \\
\hline same flow, near-andesitic upper part & $176734 *$ & 1.91 & 0.91 & 0.93 & 56.0 \\
\hline Composite lava 2 , lower part & 176728 & 0.03 & 0.21 & trace & 56.0 \\
\hline same flow, andesitic upper part & 176725 & 0.32 & 0.52 & 2.3 & 58.4 \\
\hline
\end{tabular}

*: Sample included in Table 5 (major and trace element analysis).

TOC: Total organic carbon.

$0:$ Native iron not present.

+ : Native iron present but not analysed for.

$\mathrm{SiO}_{2}$ recalculated on volatile-free basis; total sulfur determined by combustion using a LECO CS-200 induction furnace apparatus; total organic carbon determined similarly after elimination of carbonate-bonded carbon through several stages of prolonged treatment with hot hydrochloric acid ( $\mathrm{HCl}, 2 \mathrm{~N})$. Analyst: J. Bojesen-Koefoed; metallic iron determined by the $\mathrm{HgCl}_{2} \cdot \mathrm{NH}_{4} \mathrm{Cl}$ method. Analyst: M. Mouritzen.

\section{Ukallit unit, Stordal unit and Tunorsuaq $a$ and $b$ units}

Ukallit unit. This small unit is contaminated similarly to the Nuuk Killeq Member (15\%) but has higher P, Nb$\mathrm{Ta}, \mathrm{LREE}$ and $\mathrm{Zr}-\mathrm{Hf}$. It has not lost transition elements.

Stordal unit. The lava flows of the Stordal volcano are distinctly contaminated, with $51-52 \mathrm{wt} \% \mathrm{SiO}_{2}$, whereas samples from the feeder neck are not, or much less, contaminated ( $48.5-49 \mathrm{wt} \% \mathrm{SiO}_{2}$ ). In addition, all the rocks are strongly enriched in incompatible elements and their REE patterns are very steep. The low-silica samples have the highest contents of these elements, particularly of $\mathrm{Nb}-\mathrm{Ta}$ and LREE; these samples have glass chills that are nepheline-normative, i.e., alkali basaltic. The Stordal unit was described in association with the Manîtdlat Member by Larsen et al. (2003) who interpreted the magmas as alkaline melts of enriched lithospheric mantle that subsequently became crustally contaminated en route to the surface.

Tunorsuaq $a$ and Tunorsuaq $b$ units. These two small units located (a) below and (b) above the Saviaqqat unit have increased $\mathrm{SiO}_{2}$ and decreased $\mathrm{FeO}^{*}$ and $\mathrm{CaO}$ relative to uncontaminated rocks. Both units are strongly enriched in incompatible elements, particularly $\mathrm{Ba}, \mathrm{Sr}$, $\mathrm{Nb}$, LREE and P. They have steep REE patterns. Their trace elements and $\mathrm{Sr}-\mathrm{Nd}$ isotope compositions show dis- tinct similarities to the contaminated alkali basalts of the Stordal unit, and despite the $c .80 \mathrm{~km}$ distance between Stordal and Tunorsuaq these three units seem to include a component of similar enriched lithospheric mantle.

\section{Kûgánguaq Member and Tunoqqu Member}

Kùgánguaq Member. The eruption centre in Kuugannguaq produced magnesian basaltic andesites with $9-13 \mathrm{wt} \% \mathrm{MgO}$ and $52-54 \mathrm{wt} \% \mathrm{SiO}_{2}$, and a group of magnesian andesites with 7-10 $\mathrm{wt} \% \mathrm{MgO}$ and 57-60 wt $\% \mathrm{SiO}_{2}$; both rock groups have significantly decreased contents of $\mathrm{TiO}_{2}, \mathrm{FeO}^{*}, \mathrm{CaO}, \mathrm{Cu}$ and $\mathrm{Ni}$. The $\mathrm{Sr}-\mathrm{Nd}$ isotope compositions indicate between $12 \%$ and $25 \%$ contamination. The high $\mathrm{Cr}$ contents (1200-1600 ppm) of the basaltic andesites indicate that the uncontaminated precursor magma had at least $18 \mathrm{wt} \% \mathrm{MgO}$. The combination of high $\mathrm{Cr}$ and low $\mathrm{Cu}$ and $\mathrm{Ni}$ has led to prospecting for Ni-Pt mineral deposits in the Kuugannguaq area.

Tunoqqu Member. The different eruption centres of the Tunoqqu Member produced different magma types which together contribute to the overall large compositional variation within this group of rocks, e.g. the range in $\mathrm{MgO}$ is $5-16 \mathrm{wt} \%$. The Sr-Nd isotope compositions 
Table 5a. Chemical analyses of crustally contaminated rocks, Naujánguit Member and associated members

\begin{tabular}{|c|c|c|c|c|c|c|c|c|c|c|c|c|}
\hline \multirow{2}{*}{$\begin{array}{l}\text { Member } \\
\text { Unit } \\
\text { Lith. code }\end{array}$} & \multirow{2}{*}{$\begin{array}{l}\text { Naujánguit } \\
\text { Henderson } \\
\frac{4112}{4}\end{array}$} & \multicolumn{4}{|c|}{ Nuusap Qaqqarsua } & \multicolumn{3}{|c|}{ Nuuk Killeq } & \multirow{2}{*}{$\begin{array}{l}\text { Naujánguit } \\
\text { Tunorsuaq a } \\
\frac{4161}{4}\end{array}$} & \multicolumn{3}{|c|}{$\begin{array}{c}\text { Asuk } \\
\text { Asuk Mb on Disko }\end{array}$} \\
\hline & & 4122 & 4121 & 4122 & 4121 & 4141 & 4142 & 4141 & & 4201 & 4201 & 4201 \\
\hline GGU No. & 332762 & 362123 & 400176 & 400168 & 362242 & 400197 & 400150 & 362265 & $400108 \quad 1$ & 176735 & 176734 & 113271 \\
\hline Deg.W & 5355.75 & 5348.98 & 5349.61 & 5347.09 & 5349.56 & 5345.49 & 5337.55 & 5350.54 & 5326.56 & 5341.11 & 5341.12 & 5317.48 \\
\hline Deg. $N$ & 7033.36 & 7024.17 & 7029.76 & 7028.78 & 7024.23 & 7030.34 & 7029.24 & 7024.67 & 7042.70 & 7006.49 & 7006.51 & 7011.76 \\
\hline Altitude, $\mathrm{m}$ & 827.3 & 521.2 & 632.9 & 540.6 & 739.4 & 956.2 & 954.4 & 1140.0 & 1136.5 & 355.5 & 374.4 & 14.8 \\
\hline $\mathrm{SiO}_{2}$ & 46.95 & 47.57 & 48.70 & 48.48 & 50.24 & 49.40 & 51.39 & 51.75 & 50.65 & 52.32 & 53.78 & 53.45 \\
\hline $\mathrm{TiO}_{2}$ & 1.03 & 0.93 & 1.18 & 1.15 & 0.97 & 1.10 & 1.11 & 1.17 & 1.34 & 1.18 & 1.04 & 1.11 \\
\hline $\mathrm{Al}_{2} \mathrm{O}_{3}$ & 12.26 & 12.03 & 12.70 & 13.50 & 13.12 & 14.41 & 14.53 & 15.25 & 14.40 & 14.49 & 14.68 & 14.61 \\
\hline $\mathrm{Fe}_{2} \mathrm{O}_{3}$ & 1.98 & 1.33 & 3.43 & 1.26 & 0.78 & 4.49 & 3.07 & 2.17 & 4.54 & 2.99 & 0 & 1.35 \\
\hline $\mathrm{FeO}$ & 8.81 & 8.61 & 7.39 & 8.75 & 9.14 & 5.99 & 7.10 & 7.28 & 5.83 & 6.55 & 8.87 & 7.52 \\
\hline $\mathrm{MnO}$ & 0.19 & 0.16 & 0.17 & 0.16 & 0.14 & 0.16 & 0.19 & 0.18 & 0.17 & 0.14 & 0.13 & 0.15 \\
\hline $\mathrm{MgO}$ & 14.40 & 14.58 & 12.86 & 11.31 & 7.67 & 9.57 & 8.57 & 7.77 & 6.72 & 8.55 & 6.99 & 7.96 \\
\hline $\mathrm{CaO}$ & 9.76 & 9.18 & 9.73 & 10.08 & 10.56 & 10.55 & 10.57 & 10.74 & 11.28 & 9.16 & 7.53 & 8.96 \\
\hline $\mathrm{Na}_{2} \mathrm{O}$ & 1.53 & 1.79 & 1.81 & 1.73 & 1.98 & 1.81 & 1.97 & 2.03 & 2.29 & 1.79 & 1.83 & 2.14 \\
\hline $\mathrm{K}_{2} \mathrm{O}$ & 0.142 & 0.223 & 0.366 & 0.204 & 0.355 & 0.142 & 0.208 & 0.369 & 0.397 & 0.77 & 0.89 & 0.64 \\
\hline $\mathrm{P}_{2} \mathrm{O}_{5}$ & 0.086 & 0.082 & 0.094 & 0.093 & 0.089 & 0.089 & 0.110 & 0.126 & 0.279 & 0.12 & 0.13 & 0.14 \\
\hline Volatiles & 2.89 & 3.41 & 1.37 & 2.83 & 4.30 & 2.39 & 1.64 & 1.23 & 1.78 & 1.41 & 3.69 & 1.92 \\
\hline Sum & 100.02 & 99.89 & 99.79 & 99.57 & 99.34 & 100.10 & 100.45 & 100.07 & 99.67 & 99.47 & 99.56 & 99.95 \\
\hline $\mathrm{Zn}$ & 95 & 74 & 77 & 78 & 74 & 78 & 87 & 75 & 103 & 106 & 24 & 78 \\
\hline $\mathrm{Cu}$ & 105 & 104 & 136 & 103 & 109 & 118 & 48 & 23 & 27 & 59 & 279 & 19 \\
\hline Co & 78 & 80 & 66 & 67 & 76 & 54 & 53 & 58 & 42 & 39 & 79 & 42 \\
\hline $\mathrm{Ni}$ & 465 & 616 & 402 & 177 & 686 & 189 & 57 & 37 & 20 & 36 & 621 & 15 \\
\hline Sc & 36 & 31 & 34 & 37 & 29 & 33 & 35 & 33 & 31 & 35 & 28 & 31 \\
\hline V & 278 & 248 & 273 & 277 & 247 & 246 & 270 & 272 & 265 & 272 & 221 & 247 \\
\hline $\mathrm{Cr}$ & 1867 & 1292 & 1031 & 1573 & 1226 & 423 & 722 & 596 & 309 & 703 & 622 & 681 \\
\hline $\mathrm{Ga}$ & 20 & 13 & 16 & 17 & 14 & 18 & 18 & 19 & 17 & 20 & 16 & 21 \\
\hline $\mathrm{Rb}$ & 5.37 & 6.64 & 7.70 & 8.52 & 6.22 & 1.06 & 7.01 & 6.90 & 8.17 & 19.0 & 28.4 & 17.1 \\
\hline $\mathrm{Sr}$ & 126 & 151 & 140 & 152 & 162 & 190 & 173 & 183 & 427 & 173 & 197 & 210 \\
\hline Y & 19.9 & 19.0 & 20.5 & 20.4 & 18.5 & 19.6 & 20.6 & 23.1 & 21.8 & 22.3 & 20.7 & 22.7 \\
\hline $\mathrm{Zr}$ & 69.3 & 64.6 & 79.3 & 85.5 & 65.8 & 79.8 & 97.9 & 107 & 133 & 110 & 132 & 126 \\
\hline $\mathrm{Nb}$ & 3.64 & 3.14 & 3.66 & 5.22 & 3.39 & 3.03 & 4.24 & 4.50 & 30.96 & 4.58 & 5.89 & 5.07 \\
\hline Cs & 0.133 & 0.054 & 0.061 & 0.230 & 0.038 & 0.003 & 0.198 & 0.140 & 0.185 & 0.217 & 0.760 & 0.448 \\
\hline $\mathrm{Ba}$ & 67.2 & 101 & 101 & 124 & 113 & 86.2 & 112 & 165 & 355 & 175 & 266 & 241 \\
\hline $\mathrm{La}$ & 5.42 & 4.25 & 5.32 & 8.05 & 4.82 & 7.32 & 9.37 & 10.9 & 33.1 & 11.3 & 23.0 & 13.5 \\
\hline $\mathrm{Ce}$ & 13.0 & 10.2 & 12.8 & 18.2 & 11.5 & 16.2 & 21.1 & 24.4 & 67.9 & 25.4 & 42.2 & 29.2 \\
\hline $\operatorname{Pr}$ & 1.80 & 1.58 & 1.91 & 2.48 & 1.58 & 2.18 & 2.82 & 3.04 & 8.07 & 3.28 & 5.46 & 3.83 \\
\hline Nd & 8.80 & 7.80 & 9.64 & 11.5 & 7.82 & 10.3 & 12.5 & 13.5 & 31.4 & 14.3 & 20.4 & 16.0 \\
\hline Sm & 2.61 & 2.44 & 3.03 & 3.13 & 2.52 & 2.84 & 3.30 & 3.44 & 6.20 & 3.50 & 3.87 & 3.71 \\
\hline $\mathrm{Eu}$ & 0.914 & 0.910 & 1.04 & 1.038 & 0.914 & 0.966 & 1.04 & 1.15 & 1.80 & 1.09 & 1.09 & 1.12 \\
\hline Gd & 3.25 & 3.00 & 3.69 & 3.75 & 3.03 & 3.43 & 3.66 & 4.12 & 6.36 & 3.50 & 3.61 & 4.25 \\
\hline Tb & 0.553 & 0.508 & 0.632 & 0.603 & 0.514 & 0.572 & 0.604 & 0.642 & 0.813 & 0.618 & 0.613 & 0.644 \\
\hline Dy & 3.35 & 3.18 & 3.76 & 3.73 & 3.19 & 3.50 & 3.70 & 4.00 & 4.47 & 3.74 & 3.55 & 3.72 \\
\hline Ho & 0.712 & 0.698 & 0.821 & 0.811 & 0.692 & 0.758 & 0.809 & 0.852 & 0.868 & 0.760 & 0.734 & 0.798 \\
\hline $\mathrm{Er}$ & 1.94 & 1.85 & 2.21 & 2.19 & 1.81 & 2.05 & 2.13 & 2.27 & 2.27 & 2.10 & 1.97 & 2.15 \\
\hline $\mathrm{Tm}$ & 0.290 & 0.262 & 0.316 & 0.309 & 0.264 & 0.296 & 0.321 & 0.329 & 0.301 & 0.308 & 0.294 & 0.310 \\
\hline Yb & 1.77 & 1.67 & 1.94 & 1.90 & 1.65 & 1.82 & 1.93 & 2.00 & 1.89 & 1.91 & 1.80 & 1.92 \\
\hline Lu & 0.254 & 0.244 & 0.277 & 0.280 & 0.242 & 0.266 & 0.280 & 0.298 & 0.268 & 0.282 & 0.276 & 0.284 \\
\hline $\mathrm{Hf}$ & 1.88 & 1.75 & 2.19 & 2.37 & 1.75 & 2.16 & 2.57 & 2.74 & 3.24 & 2.86 & 3.36 & 3.18 \\
\hline $\mathrm{Ta}$ & 0.195 & 0.188 & 0.186 & 0.269 & 0.154 & 0.179 & 0.249 & 0.267 & 1.35 & 0.263 & 0.606 & 0.518 \\
\hline $\mathrm{Pb}$ & 1.43 & 1.84 & 2.55 & 2.23 & 2.11 & 2.18 & 2.56 & 2.95 & 3.63 & 3.30 & 3.90 & 4.11 \\
\hline Th & 0.629 & 0.947 & 1.03 & 1.16 & 0.996 & 0.572 & 1.18 & 1.21 & 3.44 & 2.11 & 3.45 & 2.45 \\
\hline U & 0.174 & 0.088 & 0.132 & 0.309 & 0.110 & 0.124 & 0.285 & 0.317 & 0.881 & 0.500 & 0.832 & 0.631 \\
\hline \multicolumn{13}{|c|}{ Isotope ratios calculated at $60 \mathrm{Ma}$} \\
\hline${ }^{87} \mathrm{Sr} /{ }^{86} \mathrm{Sr}_{60}$ & 0.705753 & & & 0.708792 & 220.70754 & & 0.708561 & 0.708067 & $67 \quad 0.704130$ & 0.709812 & 20.713035 & 0.711381 \\
\hline & 17.07 & & & 60.21 & 42.46 & & 56.93 & 49.91 & -5.97 & 74.69 & 120.43 & 96.96 \\
\hline${ }^{143} \mathrm{Nd} /{ }^{144} \mathrm{~N}$ & $\mathrm{Vd}_{60} \quad 0.512531$ & & & 0.512365 & 50.51249 & & 0.511991 & 0.511979 & $79 \quad 0.512277$ & & & \\
\hline$\varepsilon N d$ & -0.58 & & & -3.82 & -1.32 & & -11.11 & -11.35 & -5.54 & & & \\
\hline${ }^{206} \mathrm{~Pb} / 204 \mathrm{~Pb}$ & $b_{60} \quad 17.642$ & & & 17.235 & 15.689 & & 16.030 & 17.059 & 17.442 & & & \\
\hline${ }^{207} \mathrm{~Pb} / 204 \mathrm{~Pb}$ & 15.441 & & & 15.218 & 14.964 & & 14.936 & 15.287 & 15.201 & & & \\
\hline${ }^{208} \mathrm{~Pb} / 204 \mathrm{~Pb}$ & 37.688 & & & 37.613 & 36.143 & & 36.318 & 37.120 & 37.741 & & & \\
\hline
\end{tabular}

For explanation of lithological codes, see Table 1. For petrographical notes on the samples, see Table $5 \mathrm{e}$

Geographical coordinates in WGS 84. First two digits are degrees, then follow minutes in decimal form.

Major elements in wt\% (XRF analyses). Trace elements in PPm ( $\mathrm{Zn}-\mathrm{Ga}$ : XRF analyses; Rb-U: ICP-MS analyses).

The units and members are arranged in ascending stratigraphical order. 
Table 5b. Chemical analyses of crustally contaminated rocks,

Naujánguit Member and associated members

\begin{tabular}{|c|c|c|c|c|c|c|c|c|c|c|c|c|}
\hline \multirow{3}{*}{$\begin{array}{l}\text { Member } \\
\text { Unit } \\
\text { Lith. code }\end{array}$} & \multicolumn{12}{|c|}{ Asuk } \\
\hline & \multicolumn{3}{|c|}{ Asuk Mb on Disko } & \multicolumn{3}{|c|}{ Ilugissoq volcano } & \multicolumn{4}{|c|}{ Saviaqqat unit } & \multicolumn{2}{|c|}{ Niiortuut unit } \\
\hline & 4201 & 4201 & 4202 & 4206 & 4206 & 4201 & 4191 & 4191 & 4191 & 4191 & 4221 & 4222 \\
\hline GGU No. & 113277 & 113280 & 113291 & 400281 & 400287 & 340772 & 402555 & 402596 & 402558 & 402563 & 362161 & 362059 \\
\hline Deg.W & 5317.60 & 5317.92 & 5317.38 & 5329.84 & 5332.06 & 5325.60 & 5316.37 & 5334.88 & 5316.37 & 5316.37 & 5317.37 & 5313.32 \\
\hline Deg. N & 7011.78 & 7011.87 & 7011.74 & 7029.47 & 7030.11 & 7022.96 & 7043.47 & 7036.34 & 7043.47 & 7043.47 & 7022.16 & 7021.72 \\
\hline Altitude, $m$ & 33.7 & 24.3 & 4.3 & 1034.9 & 710.9 & 881.2 & 866.0 & 1320.5 & 870.1 & 873.6 & 784.1 & 653.5 \\
\hline $\mathrm{SiO}_{2}$ & 52.68 & 56.39 & 56.22 & 48.28 & 50.44 & 56.47 & 53.26 & 52.39 & 48.51 & 52.97 & 49.40 & 50.66 \\
\hline $\mathrm{TiO}_{2}$ & 1.28 & 1.04 & 1.06 & 0.89 & 0.84 & 0.97 & 1.23 & 1.53 & 1.34 & 1.34 & 1.26 & 1.31 \\
\hline $\mathrm{Al}_{2} \mathrm{O}_{3}$ & 15.40 & 15.73 & 14.44 & 12.73 & 13.85 & 15.01 & 14.42 & 16.40 & 14.28 & 17.15 & 12.40 & 14.23 \\
\hline $\mathrm{Fe}_{2} \mathrm{O}_{3}$ & 1.14 & 0 & 0 & 9.96 & 8.92 & 0.93 & 3.39 & 1.36 & 9.25 & 1.66 & 2.38 & 2.83 \\
\hline $\mathrm{FeO}$ & 8.02 & 8.26 & 8.14 & 0.00 & 0.00 & 5.38 & 6.67 & 7.52 & 8.63 & 6.78 & 8.17 & 7.10 \\
\hline $\mathrm{MnO}$ & 0.16 & 0.13 & 0.16 & 0.11 & 0.10 & 0.12 & 0.16 & 0.15 & 0.14 & 0.15 & 0.17 & 0.15 \\
\hline $\mathrm{MgO}$ & 7.49 & 5.96 & 7.13 & 8.55 & 6.89 & 5.10 & 7.03 & 5.76 & 5.47 & 5.25 & 13.52 & 7.17 \\
\hline $\mathrm{CaO}$ & 9.23 & 7.87 & 7.07 & 5.10 & 6.10 & 6.59 & 6.33 & 9.72 & 8.72 & 10.04 & 8.42 & 9.45 \\
\hline $\mathrm{Na}_{2} \mathrm{O}$ & 2.09 & 2.28 & 1.97 & 0.86 & 1.15 & 2.06 & 1.81 & 2.46 & 2.31 & 2.44 & 1.60 & 1.95 \\
\hline $\mathrm{K}_{2} \mathrm{O}$ & 0.57 & 0.86 & 0.90 & 1.237 & 0.988 & 0.656 & 3.993 & 0.738 & 0.443 & 0.410 & 0.299 & 0.300 \\
\hline $\mathrm{P}_{2} \mathrm{O}_{5}$ & 0.13 & 0.14 & 0.16 & 0.083 & 0.104 & 0.158 & 0.140 & 0.230 & 0.170 & 0.165 & 0.130 & 0.138 \\
\hline Volatiles & 1.56 & 0.90 & 2.23 & 10.76 & 8.83 & 5.78 & 1.35 & 1.09 & 1.16 & 1.12 & 1.76 & 4.28 \\
\hline Sum & 99.75 & 99.56 & 98.76 & 98.56 & 98.21 & 99.22 & 99.76 & 99.34 & 100.41 & 99.48 & 99.51 & 99.57 \\
\hline $\mathrm{Zn}$ & 21 & 38 & 37 & 67 & 63 & 6 & 82 & 84 & 81 & 74 & 85 & 93 \\
\hline $\mathrm{Cu}$ & 71 & 119 & 143 & 202 & 148 & 426 & 33 & 31 & 501 & 32 & 31 & 31 \\
\hline Co & 40 & 35 & 58 & 72 & 50 & 135 & 38 & 32 & 173 & 44 & 68 & 73 \\
\hline $\mathrm{Ni}$ & 56 & 140 & 328 & 650 & 451 & 1477 & 39 & 33 & 842 & 58 & 101 & 78 \\
\hline Sc & 36 & 32 & 26 & 28 & 25 & 22 & 36 & 34 & 31 & 33 & 28 & 32 \\
\hline V & 266 & 219 & 194 & 185 & 177 & 163 & 253 & 222 & 201 & 203 & 256 & 296 \\
\hline $\mathrm{Cr}$ & 355 & 333 & 558 & 788 & 679 & 387 & 561 & 349 & 430 & 396 & 1235 & 1365 \\
\hline $\mathrm{Ga}$ & 20 & 20 & 19 & 16 & 17 & 18 & 17 & 21 & 25 & 21 & 17 & 19 \\
\hline $\mathrm{Rb}$ & 20.5 & 30.6 & 31.6 & 34.8 & 27.8 & 26.4 & 51.1 & 17.4 & 20.5 & 21.8 & 6.3 & 12.7 \\
\hline $\mathrm{Sr}$ & 206 & 231 & 209 & 185 & 186 & 224 & 225 & 326 & 257 & 297 & 200 & 194 \\
\hline$Y$ & 23.1 & 22.2 & 20.3 & 16.7 & 16.4 & 19.8 & 21.2 & 28.5 & 26.2 & 25.3 & 20.3 & 20.8 \\
\hline $\mathrm{Zr}$ & 117 & 142 & 146 & 108 & 118 & 145 & 120 & 168 & 143 & 140 & 116 & 118 \\
\hline $\mathrm{Nb}$ & 4.57 & 5.86 & 6.29 & 4.33 & 5.06 & 6.25 & 14.8 & 28.7 & 19.1 & 18.3 & 4.76 & 5.43 \\
\hline Cs & 0.463 & 0.775 & 0.803 & 0.634 & 0.851 & 0.637 & 0.500 & 0.408 & 0.657 & 0.589 & 0.210 & 0.413 \\
\hline $\mathrm{Ba}$ & 180 & 308 & 329 & 219 & 279 & 351 & 355 & 401 & 347 & 312 & 116 & 115 \\
\hline La & 12.9 & 18.2 & 18.1 & 12.5 & 16.1 & 18.4 & 21.1 & 29.8 & 44.3 & 24.6 & 9.4 & 10.9 \\
\hline $\mathrm{Ce}$ & 28.4 & 38.0 & 37.8 & 27.0 & 33.2 & 38.3 & 43.2 & 60.6 & 80.1 & 50.9 & 22.3 & 25.5 \\
\hline $\operatorname{Pr}$ & 3.57 & 4.60 & 4.77 & 3.28 & 4.03 & 4.84 & 5.17 & 7.62 & 9.41 & 5.94 & 3.12 & 3.36 \\
\hline Nd & 15.1 & 18.3 & 18.8 & 13.4 & 16.1 & 19.1 & 21.2 & 30.2 & 32.2 & 23.7 & 14.1 & 15.1 \\
\hline Sm & 3.64 & 3.97 & 3.92 & 2.98 & 3.45 & 4.08 & 4.57 & 6.02 & 5.15 & 4.93 & 3.55 & 3.67 \\
\hline Eu & 1.14 & 1.16 & 1.06 & 0.833 & 0.887 & 1.12 & 1.27 & 1.65 & 1.43 & 1.54 & 1.13 & 1.18 \\
\hline Gd & 4.23 & 4.46 & 3.75 & 2.84 & 3.63 & 4.00 & 4.88 & 6.69 & 5.25 & 4.65 & 3.93 & 3.61 \\
\hline Tb & 0.646 & 0.649 & 0.599 & 0.482 & 0.523 & 0.622 & 0.709 & 0.934 & 0.847 & 0.763 & 0.598 & 0.616 \\
\hline Dy & 3.98 & 3.80 & 3.61 & 2.98 & 3.05 & 3.60 & 4.10 & 5.26 & 4.64 & 4.49 & 3.60 & 3.62 \\
\hline $\mathrm{Ho}$ & 0.839 & 0.794 & 0.721 & 0.604 & 0.649 & 0.714 & 0.830 & 1.002 & 0.898 & 0.859 & 0.744 & 0.728 \\
\hline $\mathrm{Er}$ & 2.25 & 2.17 & 1.96 & 1.57 & 1.75 & 2.05 & 2.30 & 2.69 & 2.49 & 2.31 & 1.95 & 1.95 \\
\hline $\mathrm{Tm}$ & 0.332 & 0.311 & 0.288 & 0.249 & 0.254 & 0.283 & 0.318 & 0.376 & 0.350 & 0.344 & 0.274 & 0.294 \\
\hline $\mathrm{Yb}$ & 2.02 & 1.89 & 1.83 & 1.44 & 1.51 & 1.77 & 1.92 & 2.36 & 2.19 & 2.13 & 1.70 & 1.77 \\
\hline Lu & 0.290 & 0.283 & 0.278 & 0.222 & 0.221 & 0.268 & 0.278 & 0.348 & 0.331 & 0.308 & 0.251 & 0.270 \\
\hline $\mathrm{Hf}$ & 3.01 & 3.55 & 3.71 & 2.83 & 3.05 & 3.81 & 3.21 & 4.45 & 3.59 & 3.46 & 2.96 & 3.02 \\
\hline $\mathrm{Ta}$ & 0.281 & 1.13 & 0.534 & 0.251 & 0.323 & 0.386 & 0.658 & 1.102 & 0.767 & 0.735 & 0.332 & 0.390 \\
\hline $\mathrm{Pb}$ & 3.71 & 3.19 & 2.96 & 8.13 & 8.50 & 5.24 & 3.31 & 4.77 & 10.2 & 4.27 & 2.52 & 3.04 \\
\hline Th & 2.22 & 3.36 & 3.74 & 2.63 & 3.08 & 4.16 & 3.24 & 4.23 & 4.11 & 3.93 & 1.49 & 2.04 \\
\hline U & 0.533 & 0.804 & 0.818 & 0.723 & 0.895 & 0.941 & 0.740 & 0.960 & 0.907 & 0.840 & 0.406 & 0.553 \\
\hline \multicolumn{13}{|c|}{ Isotope ratios calculated at $60 \mathrm{Ma}$} \\
\hline${ }^{87} \mathrm{Sr} /{ }^{86} \mathrm{Sr}_{60}$ & & \multicolumn{3}{|c|}{0.714716} & & & & & \multicolumn{2}{|c|}{0.709070} \\
\hline$\varepsilon S r$ & 92.60 & \multicolumn{2}{|c|}{$\begin{array}{c}750.713812 \\
131.45\end{array}$} & \multicolumn{3}{|c|}{144.29} & & & & & 64.15 & \\
\hline${ }^{143} \mathrm{Nd} /{ }^{144} \mathrm{Nd}_{6 \mathrm{C}}$ & $\begin{array}{ll}60 & 0.511817\end{array}$ & $7 \quad 0.5115$ & & & 0.511 & & & & & & 0.5122 & \\
\hline$\varepsilon N d$ & -14.52 & -19.82 & & & -21.15 & & & & & & -5.55 & \\
\hline${ }^{206} \mathrm{~Pb} /{ }^{204} \mathrm{~Pb}_{60}$ & $0 \quad 16.975$ & 16.932 & & & 16.713 & & & & & & 17.427 & \\
\hline${ }^{207} \mathrm{~Pb} /{ }^{204} \mathrm{~Pb}_{60}$ & $0 \quad 15.219$ & 15.188 & & & 15.015 & & & & & & 15.207 & \\
\hline${ }^{208} \mathrm{~Pb} / 204 \mathrm{~Pb}_{60}$ & $0 \quad 37.530$ & 37.325 & & & 37.252 & & & & & & 37.583 & \\
\hline
\end{tabular}


Table 5c. Chemical analyses of crustally contaminated rocks, Naujánguit Member and associated members

\begin{tabular}{|c|c|c|c|c|c|c|c|c|c|c|c|c|}
\hline \multirow{3}{*}{$\begin{array}{l}\text { Member } \\
\text { Unit } \\
\text { Lith. code }\end{array}$} & \multirow{2}{*}{\multicolumn{3}{|c|}{$\begin{array}{c}\text { Asuk (presumed) } \\
\text { Sills on Vaigat coasts }\end{array}$}} & \multicolumn{4}{|c|}{ Naujánguit } & \multicolumn{5}{|c|}{ Tunoqqu } \\
\hline & & & & \multicolumn{2}{|c|}{ Stordal T } & \multicolumn{2}{|c|}{ Tunorsuaq b Ukallit } & \multicolumn{2}{|c|}{ Tupaasat } & \multicolumn{3}{|c|}{ Main Tunoqqu Mb } \\
\hline & 6122 & 6102 & 6222 & 4211 & 4211 & 4251 & $\overline{4261}$ & 4242 & 4242 & 4281 & 4282 & 4281 \\
\hline GGU No. & 362036 & 362054 & 156690 & 264167 & 264165 & 400131 & 332796 & 340711 & 340748 & 400307 & 332703 & 332790 \\
\hline Deg.W & 5314.24 & 5308.10 & 5258.99 & 5402.14 & 5402.16 & 5326.76 & 5339.06 & 5305.14 & 5303.64 & 5344.33 & 5304.09 & 5338.62 \\
\hline Deg. N & 7021.23 & 7020.84 & 7002.46 & 7001.18 & 7001.28 & 7042.94 & 7029.83 & 7021.12 & 7020.97 & 7034.39 & 7030.52 & 7029.95 \\
\hline Altitude, $\mathrm{m}$ & 217.8 & 534.0 & c. 160 & 309.6 & 356.2 & 1400.4 & 1252.3 & 746.2 & 699.5 & 1160.3 & 906.1 & 1344.6 \\
\hline $\mathrm{SiO}_{2}$ & 52.19 & 52.86 & 51.88 & 46.95 & 50.1 & 48.50 & 50.32 & 49.89 & 51.20 & 52.65 & 49.25 & 48.80 \\
\hline $\mathrm{TiO}_{2}^{2}$ & 1.09 & 1.11 & 1.17 & 1.8 & 1.44 & 1.48 & 1.37 & 0.97 & 1.06 & 1.38 & 1.44 & 2.05 \\
\hline $\mathrm{Al}_{2} \mathrm{O}_{3}$ & 13.97 & 14.77 & 15.05 & 13.96 & 13.86 & 14.52 & 13.83 & 12.33 & 13.65 & 14.83 & 14.82 & 14.34 \\
\hline $\mathrm{Fe}_{2} \mathrm{O}_{3}$ & 1.48 & 0.33 & 0 & 4.75 & 3.1 & 5.01 & 2.67 & 1.06 & 1.75 & 2.41 & 2.77 & 5.73 \\
\hline $\mathrm{FeO}$ & 7.71 & 8.24 & 10.07 & 6.06 & 7.24 & 5.59 & 7.84 & 8.66 & 7.61 & 6.84 & 8.19 & 5.87 \\
\hline $\mathrm{MnO}$ & 0.15 & 0.14 & 0.15 & 0.16 & 0.17 & 0.16 & 0.16 & 0.16 & 0.16 & 0.15 & 0.17 & 0.18 \\
\hline $\mathrm{MgO}$ & 9.33 & 7.85 & 7.60 & 7.61 & 7.76 & 8.21 & 9.53 & 14.90 & 10.41 & 8.16 & 7.69 & 7.38 \\
\hline $\mathrm{CaO}$ & 8.95 & 8.78 & 8.74 & 12.77 & 10.05 & 11.66 & 10.42 & 8.02 & 8.36 & 9.77 & 12.80 & 11.84 \\
\hline $\mathrm{Na}_{2} \mathrm{O}$ & 2.05 & 2.15 & 1.89 & 1.8 & 2.24 & 1.88 & 2.10 & 1.38 & 1.55 & 1.92 & 1.96 & 2.14 \\
\hline $\mathrm{K}_{2} \mathrm{O}$ & 0.363 & 0.557 & 0.65 & 0.71 & 0.84 & 0.690 & 0.278 & 0.287 & 0.433 & 0.454 & 0.136 & 0.454 \\
\hline $\mathrm{P}_{2} \mathrm{O}_{5}$ & 0.115 & 0.128 & 0.13 & 0.41 & 0.31 & 0.283 & 0.167 & 0.140 & 0.152 & 0.156 & 0.125 & 0.212 \\
\hline Volatiles & 2.85 & 2.88 & 2.77 & 2.82 & 2.46 & 1.63 & 1.40 & 1.82 & 2.72 & 1.13 & 0.90 & 0.89 \\
\hline Sum & 100.25 & 99.79 & $\overline{100.10}$ & 99.8 & 99.57 & 99.61 & $\overline{100.09}$ & 99.62 & 99.06 & 99.85 & 100.26 & 99.91 \\
\hline $\mathrm{Zn}$ & 74 & 80 & 18 & 76 & 88 & 82 & 107 & 84 & 86 & 85 & 92 & 97 \\
\hline $\mathrm{Cu}$ & 35 & 20 & 222 & 64 & 19 & 41 & 125 & 18 & 17 & 38 & 102 & 136 \\
\hline Co & 40 & 55 & 84 & 48 & 46 & 43 & 57 & 68 & 66 & 47 & 59 & 48 \\
\hline $\mathrm{Ni}$ & 39 & 29 & 412 & 65 & 39 & 57 & 220 & 81 & 52 & 121 & 72 & 121 \\
\hline Sc & 32 & 30 & 31 & 33 & 25 & 37 & 31 & 26 & 31 & 33 & 42 & 40 \\
\hline V & 238 & 239 & 240 & 282 & 260 & 294 & 270 & 216 & 257 & 256 & 345 & 347 \\
\hline $\mathrm{Cr}$ & 677 & 530 & 563 & 326 & 770 & 485 & 642 & 1186 & 1360 & 645 & 484 & 332 \\
\hline $\mathrm{Ga}$ & 18 & 18 & 18 & 20 & 22 & 19 & 18 & 15 & 17 & 20 & 19 & 23 \\
\hline $\mathrm{Rb}$ & 16.7 & 21.5 & 20.7 & 16.6 & 38.9 & 8.9 & 5.7 & 11.3 & 16.9 & 16.7 & 2.65 & 5.18 \\
\hline $\mathrm{Sr}$ & 192 & 188 & 191 & 590 & 410 & 367 & 208 & 147 & 157 & 221 & 223 & 262 \\
\hline Y & 20.87 & 21.6 & 21.58 & 27.1 & 26.0 & 24.5 & 22.3 & 19.4 & 21.2 & 22.0 & 23.0 & 28.5 \\
\hline $\mathrm{Zr}$ & 108 & 120 & 116 & 140 & 149 & 134 & 156 & 98 & 109 & 124 & 85.3 & 132 \\
\hline $\mathrm{Nb}$ & 4.46 & 5.03 & 5.14 & 74.3 & 28.4 & 24.0 & 7.00 & 4.23 & 4.65 & 8.33 & 6.35 & 11.7 \\
\hline Cs & 1.20 & 0.539 & 0.585 & 0.281 & 0.904 & 0.055 & 0.107 & 0.541 & 0.607 & 0.519 & 0.068 & 0.014 \\
\hline $\mathrm{Ba}$ & 156 & 208 & 209 & 530 & 562 & 497 & 242 & 90.0 & 129 & 195 & 69.2 & 141 \\
\hline $\mathrm{La}$ & 11.2 & 13.0 & 13.9 & 68.5 & 45.7 & 39.7 & 14.3 & 9.80 & 11.0 & 14.3 & 8.18 & 12.3 \\
\hline $\mathrm{Ce}$ & 24.9 & 28.5 & 30.2 & 134 & 89.9 & 77.0 & 32.1 & 21.3 & 24.3 & 31.2 & 19.2 & 29.0 \\
\hline $\operatorname{Pr}$ & 3.25 & 3.80 & 3.77 & 15.3 & 10.4 & 9.39 & 4.16 & 2.82 & 3.16 & 3.92 & 2.65 & 3.92 \\
\hline $\mathrm{Nd}$ & 14.0 & 15.7 & 16.0 & 58.2 & 39.6 & 35.1 & 18.1 & 12.1 & 13.7 & 17.0 & 12.5 & 18.2 \\
\hline Sm & 3.41 & 3.69 & 3.62 & 9.21 & 6.86 & 6.18 & 4.34 & 2.96 & 3.37 & 3.96 & 3.45 & 4.95 \\
\hline Eu & 1.04 & 1.07 & 1.11 & 2.71 & 2.06 & 1.81 & 1.32 & 0.946 & 1.05 & 1.21 & 1.25 & 1.62 \\
\hline Gd & 3.81 & 3.62 & 4.04 & 6.74 & 5.86 & 5.96 & 4.79 & 3.43 & 3.80 & 4.47 & 4.16 & 5.59 \\
\hline Tb & 0.606 & 0.623 & 0.655 & 1.03 & 0.911 & 0.876 & 0.725 & 0.539 & 0.585 & 0.690 & 0.661 & 0.859 \\
\hline Dy & 3.67 & 3.62 & 3.56 & 5.32 & 5.04 & 4.65 & 4.25 & 3.21 & 3.63 & 3.99 & 4.08 & 4.99 \\
\hline Ho & 0.728 & 0.767 & 0.737 & 0.972 & 0.922 & 0.901 & 0.872 & 0.686 & 0.760 & 0.846 & 0.850 & 1.05 \\
\hline $\mathrm{Er}$ & 2.04 & 1.93 & 1.96 & 2.46 & 2.34 & 2.33 & 2.30 & 1.85 & 2.01 & 2.22 & 2.26 & 2.74 \\
\hline $\mathrm{Tm}$ & 0.284 & 0.286 & 0.306 & 0.344 & 0.333 & 0.340 & 0.319 & 0.275 & 0.303 & 0.317 & 0.317 & 0.388 \\
\hline $\mathrm{Yb}$ & 1.85 & 1.96 & 1.86 & 2.12 & 2.10 & 2.12 & 1.93 & 1.63 & 1.82 & 1.94 & 1.95 & 2.30 \\
\hline Lu & 0.283 & 0.282 & 0.292 & 0.324 & 0.324 & 0.302 & 0.282 & 0.234 & 0.264 & 0.283 & 0.280 & 0.319 \\
\hline $\mathrm{Hf}$ & 2.85 & 3.07 & 2.99 & 3.51 & 3.77 & 3.47 & 3.72 & 2.59 & 2.82 & 3.22 & 2.28 & 3.30 \\
\hline $\mathrm{Ta}$ & 0.351 & 0.400 & 0.544 & 3.14 & 1.54 & 1.30 & 0.355 & 0.320 & 0.366 & 0.527 & 0.399 & 0.711 \\
\hline $\mathrm{Pb}$ & 2.91 & 4.11 & 1.83 & 3.53 & 4.76 & 4.26 & 2.99 & 3.10 & 3.56 & 3.45 & 1.45 & 1.57 \\
\hline Th & 2.26 & 2.69 & 2.64 & 4.95 & 4.43 & 2.93 & 1.23 & 1.86 & 2.12 & 2.12 & 0.631 & 0.924 \\
\hline$U$ & 0.529 & 0.658 & 0.678 & 1.60 & 1.29 & 0.739 & 0.238 & 0.607 & 0.713 & 0.703 & 0.208 & 0.290 \\
\hline \multicolumn{13}{|c|}{ Isotope ratios calculated at $60 \mathrm{Ma}$} \\
\hline${ }^{87} \mathrm{Sr} / 86 \mathrm{Sr}_{60}$ & \multicolumn{3}{|c|}{0.711042} & \multicolumn{3}{|c|}{$0.704021 \quad 0.705556$} & \multicolumn{3}{|c|}{$0.711057 \quad 0.710148$} & 0.7086 & & \\
\hline$\varepsilon S r$ & & 92.14 & & -7.52 & 14.27 & & 92.35 & 79.45 & & 58.08 & & \\
\hline${ }^{143} \mathrm{Nd} /{ }^{144} \mathrm{~N}$ & & 0.5118 & & $0.51232 C$ & $0 \quad 0.5123$ & & 0.511657 & $7 \quad 0.5119$ & & 0.5121 & & \\
\hline$\varepsilon N d$ & & -14.35 & & -4.70 & -4.93 & & -17.64 & -12.04 & & -7.55 & & \\
\hline${ }^{206} \mathrm{~Pb} / 204 \mathrm{~Pb}$ & & 17.208 & & 19.717 & 18.330 & & 15.632 & 17.452 & & 17.445 & & \\
\hline${ }^{207} \mathrm{~Pb} / 204 \mathrm{~Pb}$ & & 15.280 & & 15.392 & 15.244 & & 14.889 & 15.253 & & 15.240 & & \\
\hline${ }^{208} \mathrm{~Pb} / 204 \mathrm{~Pb}$ & & 37.456 & & 38.724 & 37.995 & & 36.071 & 37.698 & & 37.641 & & \\
\hline
\end{tabular}


Table 5d. Chemical analyses of crustally contaminated rocks, Naujánguit Member and associated members

\begin{tabular}{|c|c|c|c|c|c|}
\hline \multirow{2}{*}{$\begin{array}{l}\text { Member } \\
\text { Lith. code }\end{array}$} & \multirow{2}{*}{$\frac{\text { Tunoqqu }}{4281}$} & \multicolumn{4}{|c|}{ Kûgánguaq } \\
\hline & & 4306 & 6221 & 4301 & 4301 \\
\hline GGU No. & 400239 & 113380 & 138229 & 135927 & 135972 \\
\hline Deg.W & 5307.35 & 5351.73 & 5340.89 & 5348.16 & 5351.81 \\
\hline Deg. $N$ & 7035.56 & 7013.84 & 7013.42 & 7013.08 & 7013.75 \\
\hline Altitude, m & 605.1 & 819.8 & 960.4 & 829.4 & 832.3 \\
\hline $\mathrm{SiO}_{2}$ & 54.14 & 51.67 & 51.35 & 57.01 & 51.84 \\
\hline $\mathrm{TiO}_{2}^{2}$ & 1.82 & 1.15 & 1.16 & 0.99 & 1.48 \\
\hline $\mathrm{Al}_{2} \mathrm{O}_{3}$ & 14.73 & 14.16 & 14.12 & 13.15 & 15.25 \\
\hline $\mathrm{Fe}_{2} \mathrm{O}_{3}$ & 1.68 & 2.04 & 0.71 & 2.32 & 2.10 \\
\hline $\mathrm{FeO}$ & 7.82 & 7.50 & 8.53 & 5.60 & 7.52 \\
\hline $\mathrm{MnO}$ & 0.16 & 0.19 & 0.16 & 0.19 & 0.21 \\
\hline $\mathrm{MgO}$ & 5.13 & 11.65 & 10.28 & 8.33 & 6.11 \\
\hline $\mathrm{CaO}$ & 8.93 & 8.44 & 8.56 & 6.47 & 10.38 \\
\hline $\mathrm{Na}_{2} \mathrm{O}$ & 2.61 & 1.67 & 1.90 & 1.92 & 2.03 \\
\hline $\mathrm{K}_{2} \mathrm{O}$ & 0.740 & 0.68 & 0.37 & 1.67 & 0.21 \\
\hline $\mathrm{P}_{2} \mathrm{O}_{5}$ & 0.225 & 0.13 & 0.13 & 0.17 & 0.19 \\
\hline Volatiles & 1.36 & 1.06 & 2.03 & 1.56 & 1.97 \\
\hline Sum & 99.34 & 100.34 & 99.30 & 99.38 & 99.29 \\
\hline $\mathrm{Zn}$ & 93 & 82 & 82 & 82 & 83 \\
\hline $\mathrm{Cu}$ & 27 & 18 & 18 & 60 & 22 \\
\hline Co & 43 & 44 & 42 & 44 & 32 \\
\hline $\mathrm{Ni}$ & 19 & 40 & 13 & 395 & 9 \\
\hline Sc & 36 & 37 & 35 & 28 & 35 \\
\hline V & 199 & 260 & 255 & 190 & 270 \\
\hline $\mathrm{Cr}$ & 387 & 1300 & 223 & 831 & 518 \\
\hline $\mathrm{Ga}$ & 22 & 18 & 18 & 18 & 20 \\
\hline $\mathrm{Rb}$ & 31.4 & 24.0 & 13.7 & 62.4 & 4.0 \\
\hline $\mathrm{Sr}$ & 247 & 166 & 167 & 201 & 287 \\
\hline$Y$ & 32.9 & 22.0 & 21.0 & 20.0 & 25.5 \\
\hline $\mathrm{Zr}$ & 196 & 114 & 115 & 135 & 136 \\
\hline $\mathrm{Nb}$ & 18.5 & 5.09 & 5.41 & 9.08 & 13.3 \\
\hline Cs & 0.911 & 0.668 & 0.560 & 1.618 & 0.215 \\
\hline $\mathrm{Ba}$ & 358 & 162 & 178 & 405 & 166 \\
\hline $\mathrm{La}$ & 25.3 & 11.3 & 11.6 & 21.1 & 21.6 \\
\hline $\mathrm{Ce}$ & 54.3 & 25.4 & 26.0 & 45.4 & 46.0 \\
\hline $\mathrm{Pr}$ & 6.94 & 3.25 & 3.38 & 5.65 & 5.61 \\
\hline $\mathrm{Nd}$ & 28.3 & 13.6 & 14.7 & 22.6 & 22.7 \\
\hline Sm & 6.18 & 3.42 & 3.45 & 4.85 & 4.89 \\
\hline $\mathrm{Eu}$ & 1.58 & 1.06 & 1.08 & 1.26 & 1.51 \\
\hline Gd & 6.91 & 3.90 & 3.51 & 5.15 & 5.43 \\
\hline $\mathrm{Tb}$ & 1.02 & 0.620 & 0.611 & 0.659 & 0.786 \\
\hline Dy & 5.87 & 3.66 & 3.74 & 3.62 & 4.49 \\
\hline Ho & 1.17 & 0.779 & 0.728 & 0.701 & 0.922 \\
\hline $\mathrm{Er}$ & 3.16 & 2.08 & 2.00 & 1.88 & 2.48 \\
\hline $\mathrm{Tm}$ & 0.454 & 0.305 & 0.299 & 0.258 & 0.349 \\
\hline Yb & 2.79 & 1.84 & 1.83 & 1.61 & 2.11 \\
\hline $\mathrm{Lu}$ & 0.403 & 0.276 & 0.273 & 0.231 & 0.313 \\
\hline $\mathrm{Hf}$ & 5.19 & 2.92 & 3.07 & 3.62 & 3.46 \\
\hline $\mathrm{Ta}$ & 0.769 & 0.331 & 0.374 & 0.724 & 0.768 \\
\hline $\mathrm{Pb}$ & 5.80 & 3.78 & 4.19 & 9.58 & 3.99 \\
\hline Th & 4.18 & 2.23 & 2.59 & 4.16 & 2.61 \\
\hline $\mathrm{U}$ & 1.06 & 0.660 & 0.707 & 1.27 & 0.680 \\
\hline \multicolumn{6}{|c|}{ Isotope ratios calculated at $60 \overline{\mathrm{Ma}}$} \\
\hline${ }^{87} \mathrm{Sr} /{ }^{86} \mathrm{Sr}_{60}$ & 0.707285 & $5 \quad 0.709853$ & 0.709710 & 0.710855 & 0.707626 \\
\hline$\varepsilon S r$ & 38.82 & 75.27 & 73.23 & 89.48 & 43.65 \\
\hline${ }^{143} \mathrm{Nd} /{ }^{144} \mathrm{Nd}_{60}$ & 0.512060 & $0 \quad 0.511920$ & & 0.511777 & 0.512184 \\
\hline$\varepsilon N d$ & -9.77 & -12.50 & & -15.29 & -7.36 \\
\hline${ }^{206} \mathrm{~Pb} /{ }^{204} \mathrm{~Pb}_{60}$ & 17.224 & 17.387 & & 17.110 & 17.650 \\
\hline${ }^{207} \mathrm{~Pb} /{ }^{204} \mathrm{~Pb}_{60}$ & 15.197 & 15.246 & & 15.109 & 15.295 \\
\hline${ }^{208} \mathrm{~Pb} /{ }^{204} \mathrm{~Pb}_{60}$ & 37.531 & 37.495 & & 37.371 & 37.764 \\
\hline
\end{tabular}

Table 5e. Notes on analysed contaminated samples from the Naujánguit Member and associated members

332762 Brown picrite pillow from hyaloclastite, Anariartorfik, western Nuussuaq.

362123 Brown picrite pillow from hyaloclastite, beneath Nuusap Qaqqarsua, south coast of Nuussuaq.

400176 Brown olivine-poor picrite lava flow, Qunnilik-west profile, western side of mouth of Qunnilik valley, western Nuussuaq.

400168 Olivine-phyric basalt pillow from hyaloclastite, western side of mouth of Qunnilik valley, western Nuussuaq.

362242 Olivine-phyric basalt lava flow, Nuusap Qaqqarsua profile, south coast of Nuussuaq.

400197 Aphyric silicic basalt lava flow, Qunnilik-west profile, western side of mouth of Qunnilik valley, western Nuussuaq.

400150 Plagioclase-olivine-clinopyroxene-glomerophyric silicic basalt, feeder body in hyaloclastite heap, Ukallit, eastern side of mouth of Qunnilik valley, western Nuussuaq.

362265 Plagioclase-olivine-clinopyroxene-glomerophyric silicic basalt lava flow, Nuusap Qaqqarsua profile, south coast ofNuussuaq.

400108 Aphyric silicic basalt lava flow with enriched geochemistry, Tunorsuaq profile, Tunorsuaq valley, northern Nuussuaq.

176735 Aphyric to slightly olivine-phyric magnesian basaltic andesite, lower part of composite lava flow, east side of Kuugannguaq valley $17 \mathrm{~km}$ from the coast, northern Disko (Fig. 98, composite lava 1).

176734 Orthopyroxene-phyric magnesian basaltic andesite with graphite and native iron, upper part of composite lava flow, same flow as 176735 .

113271 Orthopyroxene-microphyric magnesian basaltic andesite lava flow, Asuk, north coast of Disko (Figs 94, 95).

113277 Nearly aphyric magnesian basaltic andesite from the lower part of large composite lava flow, Asuk, north coast of Disko (Figs 94, 97).

113280 Slightly orthopyroxene-phyric magnesian andesite with native iron, graphite and sediment xenoliths and xenocrysts, central upper part of composite lava flow at Asuk, same flow as 113277.

113291 Orthopyroxene-phyric magnesian andesite with native iron and sediment xenoliths and xenocrysts, from subaqueous brecciated lava flow at Asuk, north coast of Disko (Figs 94, 95).

400281 Orthopyroxene-microphyric, graphite-rich magnesian basaltic andesite, upper part of cone D, llugissoq volcano, llugissoq valley, Nuussuaq.

400287 Orthopyroxene-microphyric, graphite-rich magnesian andesite from the root zone of the llugissog volcano, Ilugissoq valley, Nuussuaq.

340772 Orthopyroxene-microphyric magnesian andesite with native iron, compact lava flow, Nuuk Killeq, south coast of Nuussuaq (Fig. 112).

402555 Densely plagioclase-clinopyroxene-olivine-glomerophyric magnesian basaltic andesite lava flow, $3 \mathrm{~km}$ south of Saviaqqat, north coast of Nuussuaq (Fig. 123).

402596 Densely plagioclase-clinopyroxene-olivine-glomerophyric, native-iron-bearing basaltic andesite lava flow with segregation patches, Snekuplen, west-central Nuussuaq.

402558 Densely plagioclase-clinopyroxene-olivine-glomerophyric basaltic andesite lava flow with accumulated native iron and sulphides, $3 \mathrm{~km}$ south of Saviaqqat, north coast of Nuussuaq (Fig. 123).

Phenocryst phases are mentioned in order of decreasing abundance.All picrites are strongly olivine-phyric. 
Table 5f. Notes on analysed contaminated samples from the Naujánguit Member and associated members (continued)

402563 Densely plagioclase-clinopyroxene-glomerophyric, native-iron-bearing basaltic andesite lava flow, $3 \mathrm{~km}$ south of Saviaqqat, north coast of Nuussuaq (Fig. 123).

362161 Brown olivine-poor picrite lava flow, below Niiortuut peak, Nuuk Qiterleq, south coast of Nuussuaq.

362059 Olivine-microphyric basalt pillow from hyaloclastite, Niiortuut profile, Nuuk Qiterleq, south coast of Nuussuaq.

362036 Olivine-plagioclase microphyric coarse-grained magnesian basaltic andesite, $30 \mathrm{~m}$ thick sill in sandstones, $2 \mathrm{~km}$ south-east of Nuuk Qiterleq, south coast of Nuussuaq (Fig. 128 at $26-27 \mathrm{~km}$ ).

362054 Nearly aphyric coarse-grained magnesian basaltic andesite, $40 \mathrm{~m}$ thick sill in sandstones, western Tupaasat, south coast of Nuussuaq (Fig. 128 at 29-30 km).

156690 Graphite-rich iron-bearing magnesian basaltic andesite, sill in sediments north of Gamle Qullissat, north coast of Disko (Fig. 161 at c. 1 km).

264167 Aphyric alkali basalt, apparently uncontaminated, volcanic neck, Stordal centre, Stordal, central Disko (Fig. 77).

264165 Olivine-phyric contaminated alkali basalt, lava flow from the Stordal centre, Stordal, central Disko.

400131 Aphyric contaminated basalt lava flow with enriched geochemistry, Tunorsuaq profile, Tunorsuaq valley, northern Nuussuaq.

332796 Olivine-plagioclase-phyric silicic basalt lava flow, Ukallit profile, eastern side of mouth of Qunnilik valley, western Nuussuaq.

340711 Brown picrite pillow from hyaloclastite, Tupaasat profile, Tupaasat, south coast of Nuussuaq.

340748 Olivine-phyric silicic basalt pillow from hyaloclastite, Tupaasat, south coast of Nuussuaq.

400307 Clinopyroxene-olivine-plagioclase-phyric magnesian basaltic andesite, feeder body, west side of Qunnilik valley, western Nuussuaq.

332703 Plagioclase-olivine-clinopyroxene-phyric basalt, subaqueous lava flow, Tunoqqu profile, Tunoqqu mountain, central Nuussuaq.

332790 Aphyric basalt lava flow with slightly enriched geochemistry, Ukallit profile, eastern side of mouth of Qunnilik valley, western Nuussuaq.

400239 Aphyric magnesian basaltic andesite lava flow with slightly enriched geochemistry, Puugutalissuaq profile, Agatdalen, central Nuussuaq (Fig. 171)

113380 Olivine-microphyric magnesian basaltic andesite, welded tuff recrystallised to hornfels, east side of Kuugannguaq valley 6 $\mathrm{km}$ from the coast, northern Disko.

138229 Olivine-microphyric magnesian basaltic andesite, feeder dyke, Kussinikassak gully, north coast of Disko.

135927 Orthopyroxene-olivine-microphyric magnesian andesite lava flow, Harald Molkte Dal, east side of Kuugannguaq valley 7 $\mathrm{km}$ from the coast, northern Disko.

135972 Plagioclase-clinopyroxene-orthopyroxene-phyric magnesian basaltic andesite lava flow, east side of Kuugannguaq valley 7 $\mathrm{km}$ from the coast, northern Disko (Fig. 145 flow E). indicate variable degrees of contamination from around $6 \%$ to $20 \%$.

The Tupaasat centre produced magnesian basaltic andesites and silicic picrites with up to $16 \mathrm{wt} \% \mathrm{MgO}$. The basaltic andesites are chemically so closely similar to the contemporaneous basaltic andesites of the Kûgánguaq Member that they must have formed under near-identical conditions; the magma chambers would also have been situated only few kilometres apart. The similarities include large losses of $\mathrm{Cu}$ and $\mathrm{Ni}$ and relative enrichment in $\mathrm{Cr}$, suggesting a Ni-Pt mineralisation potential for intrusions of this unit as well as for the Kûgánguaq Member.

The Qunnilik centre produced silicic basalts with around $8 \mathrm{wt} \% \mathrm{MgO}$ that have low $\mathrm{FeO}^{*}$ and $\mathrm{CaO}$ but have not lost $\mathrm{Cu}$ and $\mathrm{Ni}$. The $\mathrm{Cr}$ contents indicate a precursor magma with at least $12 \mathrm{wt} \% \mathrm{MgO}$.

The Agatdalen centre produced highly evolved magmas with 5-7 wt $\% \mathrm{MgO}$ and variable $\mathrm{SiO}_{2}, 50-55$ wt $\%$. Their low $\mathrm{Cr}$ and very low $\mathrm{Ni}$ that plot in continuation of the uncontaminated trends for $\mathrm{Cr}$ and $\mathrm{Ni}$ indicate that the uncontaminated precursor magma for this centre was itself highly evolved.

The dispersed lava flows of the Tunoqqu Member are only weakly or very weakly contaminated; the majority of these have $49-50 \mathrm{wt} \% \mathrm{SiO}_{2}$ and are essentially normal, evolved basalts with 6-10 wt\% $\mathrm{MgO}$. Other dispersed lavas have $50-54 \mathrm{wt} \% \mathrm{SiO}_{2}$ and represent contaminated evolved magmas.

Detailed descriptions of the chemistry of the Tunoqqu Member are given by Pedersen et al. (1996) and of the Kûgánguaq Member by Pedersen (1985b). 


\section{Third volcanic episode: Ordlingassoq and Manîtdlat members}

\section{Ordlingassoq Member}

\section{Summary of the main features of the Ordlingassoq Member}

- Main member produced in the third volcanic episode. Thick and widespread; continues north of Nuussuaq.

- Dominated by grey picrite lava flows and associated hyaloclastites.

- Not subdivided on a regional basis. Small informal units on Nuussuaq form local markers.

- One small informal unit on Disko comprises crustally contaminated basalts, some with native iron.

- Lower part on Disko contains intercalations of alkaline picrite and the alkaline Manîtdlat Member.

- Continued the eastward progradation of lava flows and hyaloclastites into the non-marine Naajaat Lake which was filled in. Lava flows and hyaloclastites lapped onto the high gneiss country in the east.

- Eruption sites are widespread, both subaqueous and subaerial, and both small and large.

- Chemically less depleted in incompatible elements than the Naujánguit Member rocks.

- Economic geology: The native-iron-bearing basalts in Stordal have fractionated $\mathrm{Cu}$ and $\mathrm{Ni}$ and have been explored for $\mathrm{Ni}$ and platinum-group elements.

\section{Lithostratigraphy of the Ordlingassoq Member}

Revised member

History. Originally defined by Pedersen (1985a) on Disko. Here extended to also cover Nuussuaq and Hareøen.

Name. After the mountain Orlingasoq (new spelling) on north-east Disko, facing the Vaigat strait.

Distribution. The Ordlingassoq Member extends over large areas on northern Disko and Nuussuaq (Fig. 9). It is also present on Hareøen east of the Itilli Fault. The western extension is below exposure level on Disko whereas it is above exposure level on Nuussuaq. Due to downfaulting the member is again exposed west of the Itilli Fault. The western limit is thus unconstrained. The northern limit at the north coast of Nuussuaq is erosional. The southern and eastern limits are depositional. To the south, on central Disko, the member thins and disappears below exposure level south of Stordal (Pedersen \& UlffMøller 1980, fig. 15). To the east the member thins and stops, on Disko just east of Qullissat (Figs 161, 162), on southern Nuussuaq near Giesecke Monument/Uppalluk (South Nuussuaq section at $c .58 \mathrm{~km}$ ) and on northern Nuussuaq just west of Kuuk (North Nuussuaq section at c. $54 \mathrm{~km})$.

Type area. The Norddalen gully on northern Disko (Fig. 16, profiles 24, 27; Pedersen 1985a, profile 4).

Reference sections. Kussinikassak, Orlingasoq, Point $1100 \mathrm{~m}$ (Fig. 16, profiles 26, 28, 29) on Disko. Sorluut, Tunorsuaq, Vesterfjeld, Aaffarsuaq, Puugutalissuaq (Fig. 14, profiles 11, 12, 14, 15, 16), Niiortuut, Point 1722 m, Paatuut Puiattua (Fig. 15, profiles 17, 18, 19), all on Nuussuaq. Niaqua (Fig. 17, profile 30) on Hareøen.

Thickness. The maximum thickness of the Ordlingassoq Member is $c .800 \mathrm{~m}$ on northern Disko and $c .1100 \mathrm{~m}$ around Ikorfat and Agatdalen on central Nuussuaq. To the south, the member thins gradually to $450 \mathrm{~m}$ in Stordal (c. $200 \mathrm{~m}$ where it laps onto the Disko Gneiss Ridge); it is $\geq 200 \mathrm{~m}$ thick south of Nordfjord before it disappears below exposure level. Towards the east, the member thins to c. $200 \mathrm{~m}$ of hyaloclastites at Qullissat, c. 400 $\mathrm{m}$ of hyaloclastites and lava flows at Paatuut, $800 \mathrm{~m}$ of hyaloclastites and lava flows at Qaarsut and 60-200 m of lava flows on the irregular basement surface at Nunavik on eastern Nuussuaq.

Lithology. The Ordlingassoq Member comprises subaerial lava flows and associated hyaloclastites produced when the lavas flowed into water or were erupted subaqueously. Several eruption sites are known. The lower part of the member also comprises minor mudstone horizons and minor conglomerates.

The dominant rocks are grey picrites; basalts are subordinate. Brown, crustally contaminated basalts occur in 


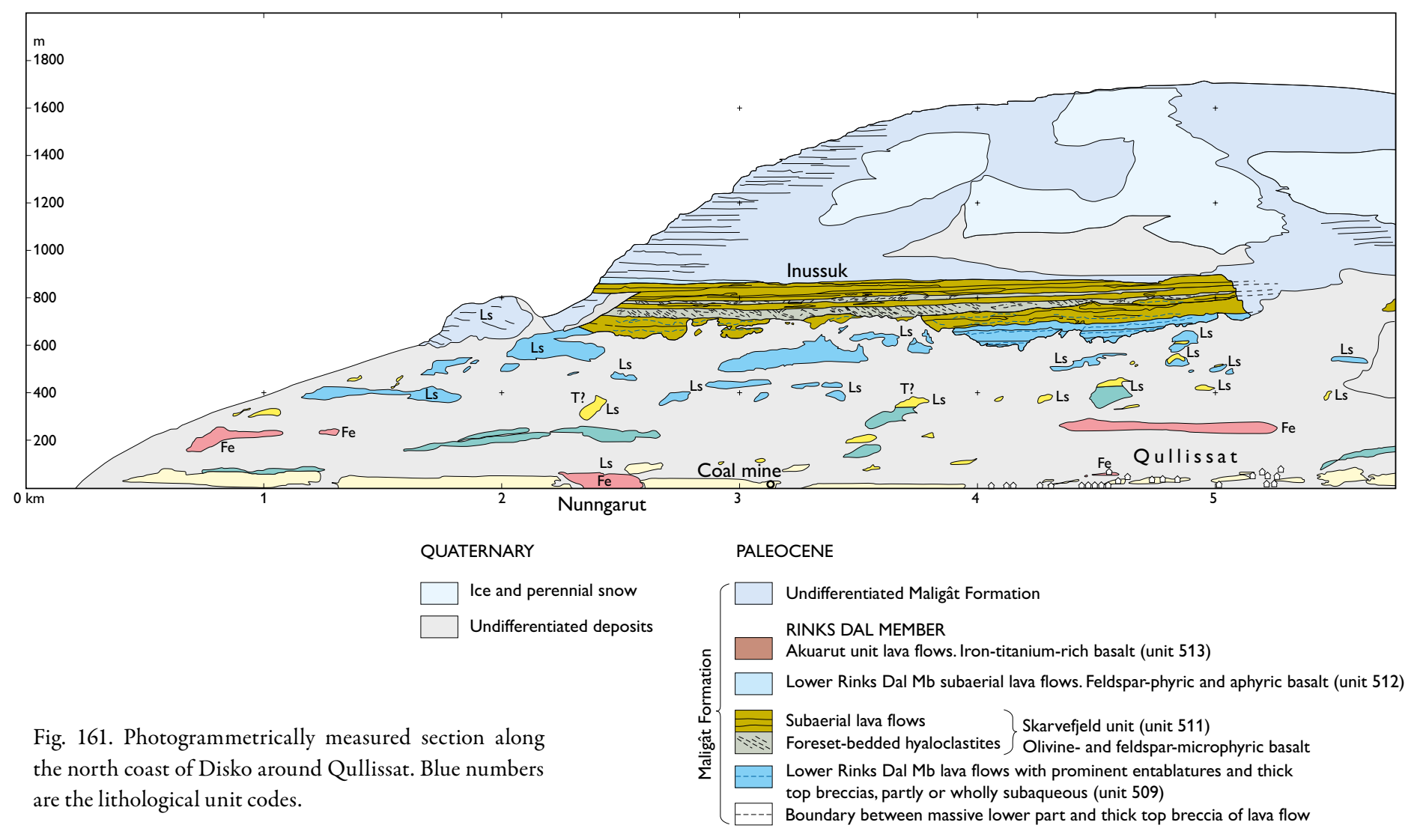

the Stordal area. A small succession of alkaline picrites closely related to the alkaline Manîtdlat Member and described together with this is formally part of the Ordlingassoq Member. On Nuussuaq there are some local horizons of brown basalt lava flows, and near the top of the member there is a small unit of plagioclase-phyric evolved basalt flows.

Subdivisions. Due to a lack of extensive marker horizons it has not been possible to divide the Ordlingassoq Member into regional subunits as was done for the Naujánguit Member. Some small basaltic subunits exist and are mentioned in the lithology section above.

Boundaries. On western Disko, Hareøen and western Nuussuaq, grey, olivine-rich lava flows and hyaloclastites of the Ordlingassoq Member rest on weathered surfaces of lava flows of the Qordlortorssuaq, Kûgánguaq and Tunoqqu members, capped by thin red to grey soil horizons. In parts of northern Disko, there is a very low-angle unconformity at the boundary. East of a line from south to north through Qorlortorsuaq, Tupaasat, Agatdalen and Qaarsut, Ordlingasoq Member hyaloclastites (as well as lava flows on northern Nuussuaq) prograded beyond the

limits of the older volcanic deposits. They rest on grey to black mudstones of the Nâujat Member of the Atanikerluk Formation (G.K. Pedersen et al. 1998; Dam et al. 2009; Fig. 148). The geometry of the boundary between the volcanic rocks and the Naujât Member in the western part of the Naajaat Lake is complicated by the fast subsidence which is a combination of compaction and loading as the front of heavy picritic volcanic rocks prograded eastwards into the lake basin. In minor areas in Stordal (Central Disko section) and in large areas on eastern Nuussuaq (Central Nuussuaq section; Pedersen et al. 2007a), subaerial lava flows and hyaloclastites of the Ordlingassoq Member directly overlie Precambrian gneiss (Fig. 163) which is deeply kaolinised at some localities (Fig. 164).

The upper boundary marks the top of the Vaigat Formation. The uppermost picrite lavas are weathered and may be covered by up to several metres of mudstone, sandstone or claystone. The upper surface of the Vaigat Formation is slightly domed and raises from altitudes of 300-700 m on central and eastern Disko to $c .1500 \mathrm{~m}$ around outer Kuugannguaq on northern Disko, and farther to $c .1000 \mathrm{~m}$ on eastern Nuussuaq (Giesecke Monument) and $1600 \mathrm{~m}$ west of Ataata Kuua, to $c .1600 \mathrm{~m}$ on 

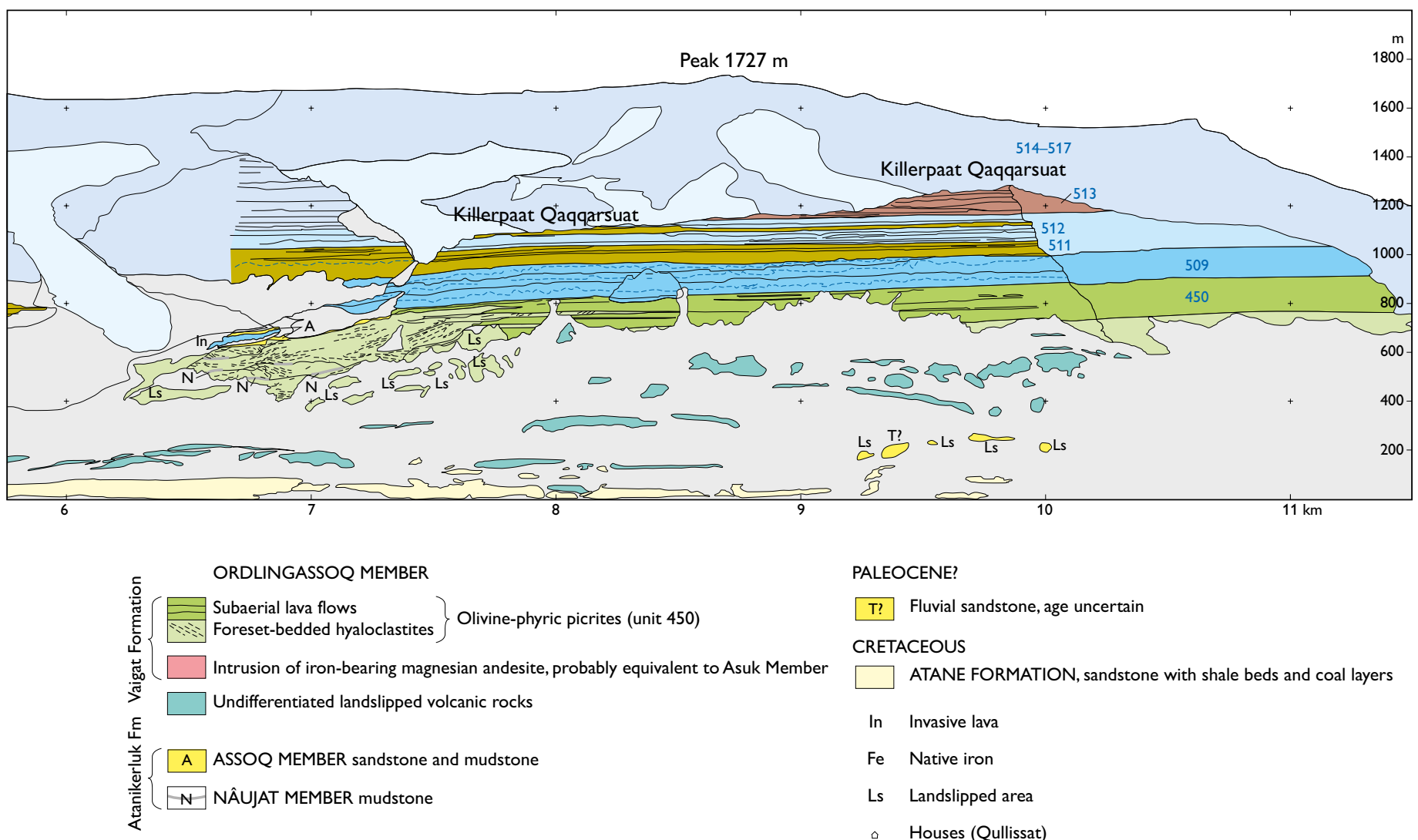

PALEOCENE?

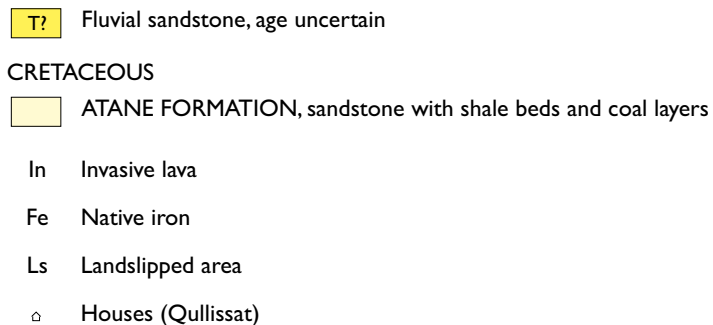

north-eastern Nuussuaq and to $>2000 \mathrm{~m}$ on north-central Nuussuaq. The lava flows of the Maligât Formation lap onto this domed surface, which is particularly clearly seen on exposures on the southern side of the Kuugannguaq valley. Going from south to north on Disko and then to Nuussuaq, the Vaigat Formation is onlapped by successively younger units of the Rinks Dal Member. At Qullissat on Disko, where Ordlingassoq Member lavas and hyaloclastites reached their eastern depositional limit, a c. $20 \mathrm{~m}$ thick lacustrine mudstone and sandstone wedge separates the uppermost picritic hyaloclastites of the Ordlingassoq Member from overlying, strongly columnar-jointed basalt flows of the Maligât Formation (Pedersen 1985a, figs 19, 20; Figs 161, 162, 165). The sediments are tentatively assigned to the Umiussat Member of the Atanikerluk Formation (Figs 6, 15; Dam et al. 2009, fig. 131).

Age. Paleocene, nannoplankton zone NP5-6, c. 60-61 Ma, magnetochron C26r, based on dinoflagellate cysts (Piasecki et al. 1992), radiometric dating (Storey et al. 1998) and palaeomagnetic investigations of the succession (Athavale \& Sharma 1975, Riisager \& Abrahamsen 1999).
Correlation. The picrites of Ubekendt Ejland and the bulk of the picrites on Svartenhuk Halvø are inferred to correlate with the Ordlingassoq Member (Larsen et al. 2016).

\section{Geology of the Ordlingassoq Member}

The Naajaat Lake. At the end of the second volcanic episode, the Tunoqqu Member rocks had reached the gneiss highland on eastern Nuussuaq and blocked the connection between the marine embayment on eastern DiskoNuussuaq and the sea to the north (Fig. 136). The embayment was subsequently transformed into a freshwater lake which, with rising water level, spread westwards over parts of the old subaerial volcanic surface (G.K. Pedersen et al. 1998). The mudstones of the Naujât Member and on eastern Disko the Pingu Member accumulated at the bottom of this lake (Dam et al. 2009; Fig. 6) which was gradually filled in from the west and north-west by the prograding volcanic products of the third volcanic episode.

The Ordlingassoq Member constitutes the major part of the rocks produced during the third volcanic episode. It is the most widespread of the three major volcanic mem- 


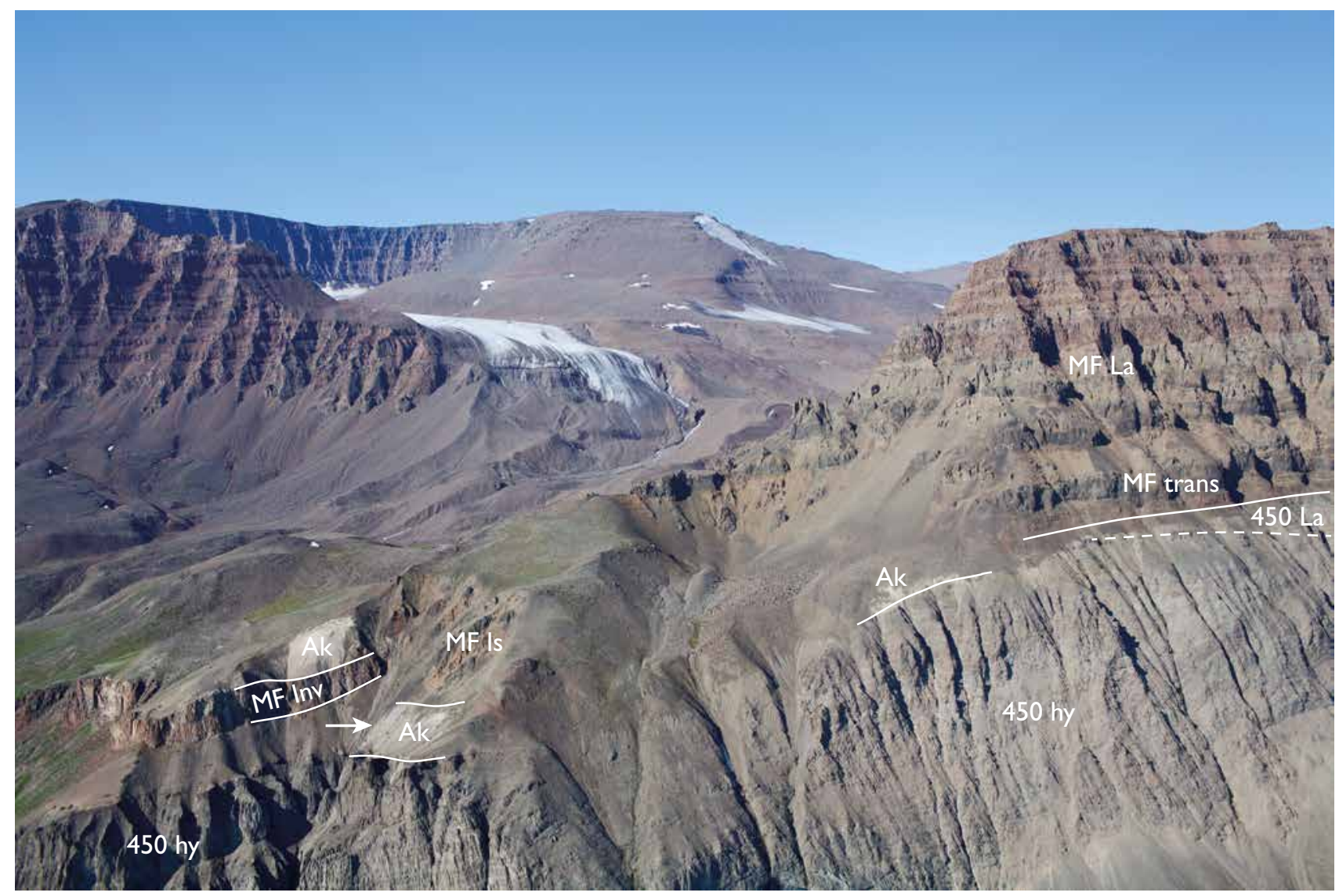

Fig. 162. The easternmost termination of the Vaigat Formation on Disko (Fig. 161 at $6.5-7.5 \mathrm{~km}$ ). The sloping front of the easternmost foresetbedded hyaloclastites of the Ordlingassoq Member ( 450 hy) of the Vaigat Formation is overlain by mudstones and sandstones of the Atanikerluk Formation (Ak), deposited in a successor of the Naajaat Lake (Dam et al. 2009, fig. 131, profile 2). A lava flow of the Maligât Formation has invaded the sediments as a 'sill' (MF inv), and younger subaqueous and transitional flows (MF trans) of the Maligât Formation have covered both sediments and Ordlingassoq Member lava flows. A block of lavas is landslipped (MF 1s). The white arrow points to the locality shown in Fig. 165. Eastern flank of the mountain Killerpaat Qaqqarsuat above Qullissat, northern Disko. Photo: Erik Vest Sørensen.

bers of the Vaigat Formation (Fig. 9). Like the underlying members, it is well exposed in cliffs along the Vaigat strait and along the major valleys such as Kuugannguaq and Stordal on Disko and Aaffarsuaq on Nuussuaq. In contrast to the underlying Naujánguit Member, the Ordlingassoq Member contains only few marker horizons. Furthermore, sampling of the member has been focused on north-eastern Disko and southern, eastern and northern Nuussuaq, with special emphasis on the progradation of hyaloclastites into the Naajaat Lake. This means that the relatively monotonous, high-altitude lava successions on north-western Disko and western to central Nuussuaq have only been scantily sampled.

The small marker horizons within the Ordlingassoq Member are, with one exception, not crustally contaminated but deviate lithologically for other reasons. They comprise some lithologically and chemically characteris- tic horizons described below after the main Ordlingassoq Member. The subdivision is listed in Table 1 with unit codes as used in the following.

The Ordlingassoq Member has an intercalation of an exceptional succession of alkaline rocks on Disko; this is formalised as the Manîtdlat Member and is described separately.

\section{Main Ordlingassoq Member (unit 450)}

The uncontaminated greyish-weathering picrites and subordinate basalts of unit 450 constitute more than $98 \%$ of the total volume of the volcanic rocks of the Ordlingassoq Member. The rocks show a wide variation in $\mathrm{MgO}$ contents with 6-27 wt\% $\mathrm{MgO}$, the majority being picrites ( $84 \%$ of analyses). Due to the eastwardsprograding deposition it is possible to discern some parts 


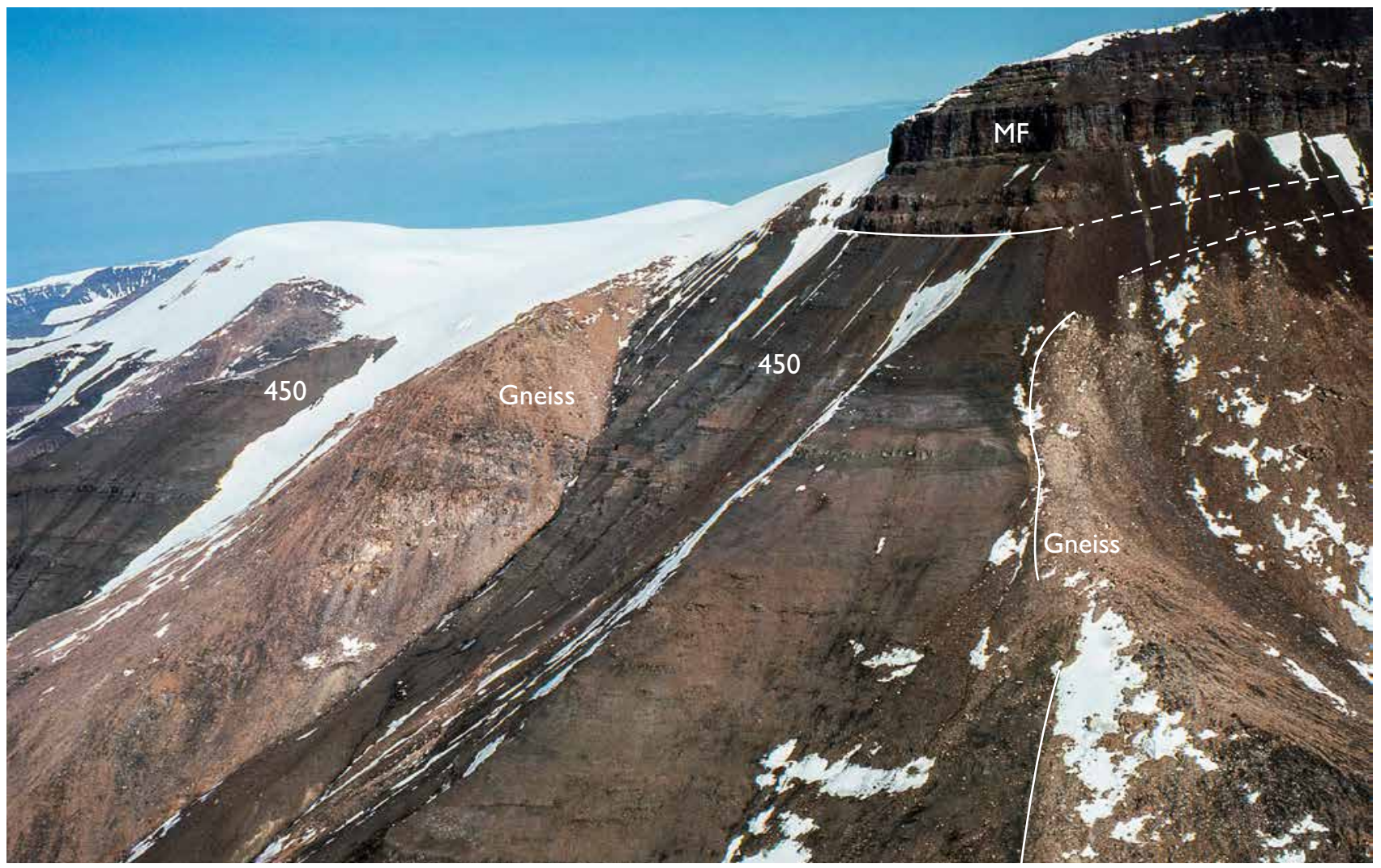

Fig. 163. The boundary between gneiss and onlapping subaerial lava flows of the Ordlingassoq Member (450) demonstrates an extremely steep prevolcanic palaeotopography of several hundred metres on central Nuussuaq between Agatdalen and Nunavik. The boundary between the Vaigat and Maligât (MF) formations is exposed at the top.

that must be relatively old and some that must be the youngest within the member, but large parts are only approximately located in the stratigraphy of the succession. Improved internal correlation may be possible in the future for those parts of the member that are thick and semi-continuous over large areas. By detailed palaeomagnetic investigations it is possible to identify directional flow groups, with the potential to establish a precise and reliable stratigraphical correlation. Such work has been done on the Vaigat Formation on Svartenhuk Halvø (J. Riisager et al. 2003b, 2004, detailed below).

\section{Lithologies}

The Ordlingassoq Member succession appears very monotonous, and the distinct scarcity of tuffs and soil horizons can be taken as an expression of high eruption rates. The member (unit 450) comprises subaerial lava flows and their crater sites, foreset-bedded hyaloclastites and subaqueous lava flows formed when subaerial lava flows entered the Naajaat Lake basin and subaqueous crater sites. The subaqueous crater sites were either formed in single eruptive events or constitute complex sites (with feeders) formed during multiple volcanic events. There are also volcaniclastic sediments. The progradation of the volcanic front across older lava flows, unconsolidated muddy sediments, subaerially eroded Precambrian gneiss hills and across older and re-activated fault systems has resulted in a substantial variation in volcanic lithologies and morphologies, on several scales, despite an apparent chemical monotony of the erupting picrites and basalts.

Subaerial lava flows. There is a considerable range in both thickness and morphology of the uncontaminated lava flows of the Ordlingassoq Member. The typical lava flow is a picritic pahoehoe flow with a fairly massive, vesiclepoor lower part which appears dark grey to dark brown, and a highly vesiculated upper part which appears light grey to whitish due to vesicle filling by zeolites, Ca-hydrosilicates and carbonate (Figs 166, 167). Subhorizontal pegmatitic segregation veins are common in the upper part of the flows and appear white due to mineral infill- 


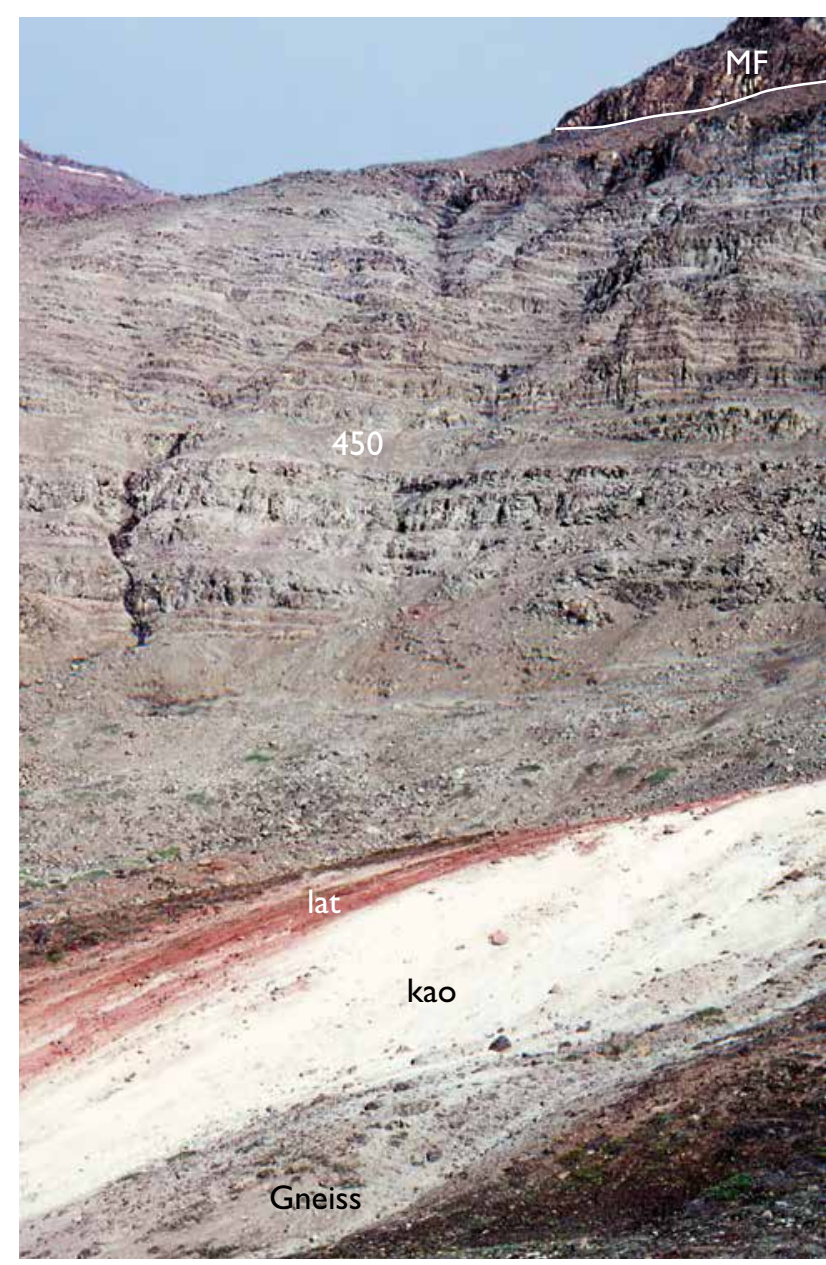

Fig. 164. White kaolinite (kao) and red laterite (lat) formed through deep prevolcanic weathering of the Disko Gneiss Ridge in the north side of Stordal on Disko (Central Disko section at c. $36 \mathrm{~km}$ ). The gneiss is covered by subaerial picrite lava flows of the Ordlingassoq Member (450); on top the base of the Maligât Formation (MF). Height of the Vaigat Formation succession c. $320 \mathrm{~m}$.

ings. These flows tend to crumble easily. Some flows or groups of flows are distinctly less vesiculated and appear as more erosion-resistant lava benches with a crude columnar jointing (Fig. 168). Finally, a few flows of basalt are erosion-resistant and columnar-jointed and form local marker horizons. Lateritic soil at the base and top of such basalt flows indicates that they were erupted during periods with low magma production.

The size offlow fields within the Ordlingassoq Member. Detailed observations on lava successions and a large number of eruption sites have shown that the picrites were emplaced both in very small and in fairly large eruptive events resulting, respectively, in a few lava flow tongues and in large flow fields composed of a multitude of flows emplaced over an extended time period. Extremely wellexposed sections of Ordlingassoq Member lava flows (Figs 166, 167) show monotonous successions of picritic pahoehoe flows on top of each other without interlayered tuffs or soil horizons. Occasionally, horizons of foresetbedded hyaloclastite (Fig. 167) or soil show with certainty the existence of separate flow fields, but otherwise it is difficult to estimate the magnitude of eruptive events or eruption rates. In some sections, flow fields are identified as successions of erosion-resistant, vesicle-poor flows or as successions of high-temperature red-oxidised flows.

An estimate of the size of typical flow fields and the eruption rate within the Ordlingassoq Member may be gained from the Nunavik Member of the Vaigat Formation (correlated with the Ordlingassoq Member) on Svartenhuk Halvø about $100 \mathrm{~km}$ north of Nuussuaq (Fig. 2). Here, high-resolution palaeomagnetic work has been carried out in two long profiles through a succession of picritic pahoehoe flows lithologically very similar to lava flows on Disko and Nuussuaq (J. Riisager $e t$ al. 2003b, 2004). In one profile (Svartenhuk-2), a c. $140 \mathrm{~m}$ thick succession (directional groups 2 to 9 ) was shown to be erupted during a magnetic excursion within geomagnetic Chron C26r (J. Riisager et al. 2004). The duration of a magnetic excursion is estimated to be approximately similar to the duration of a magnetic transition (c. 5000 years), and this implies an eruption rate for the $140 \mathrm{~m}$ succession that was very high and similar to that of the picrites erupted during the $\mathrm{C} 27 \mathrm{n}-\mathrm{C} 26 \mathrm{r}$ transition zone within Naujánguit Member unit 413 on Nuussuaq (Pedersen et al. 2002b).

Within the magnetic excursion zone in the Svartenhuk-2 profile, J. Riisager et al. (2003a, 2004) furthermore recognised a very monotonous succession of thin picrite flows (directional groups 5 and 6), c. $83 \mathrm{~m}$ thick and composed of 31 flows, which is characterised by almost identical magnetisation directions. This was interpreted as a single large flow field erupted within less than about 100 years. The flow field has not been mapped out but can be followed over several kilometres on photographs, and it is likely to cover at least $30 \mathrm{~km}^{2}$ and probably considerable more. With a thickness of $80-90 \mathrm{~m}$, it must have a volume well in excess of $2 \mathrm{~km}^{3}$ which makes it a large eruptive event when compared to recent volcanism.

Based on the Svartenhuk data, we infer similar high eruption rates and large flow fields for the Ordlingassoq Member. Independent evidence for similar large eruptive events within the Ordlingassoq Member comes from the 


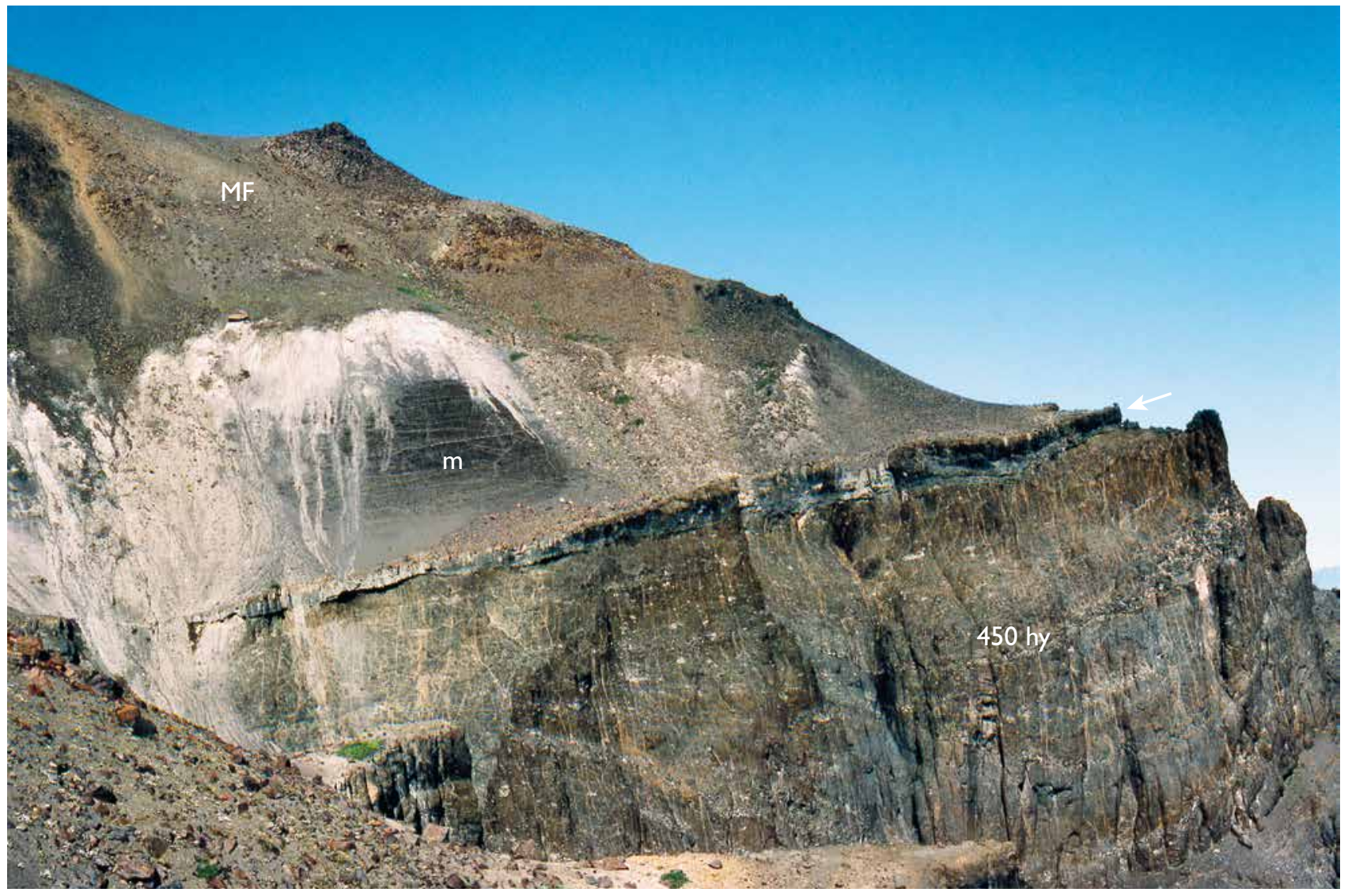

Fig. 165. Sediments between the Vaigat and Maligât Formations in the eastern flank of the mountain Killerpaat Qaqqarsuat above Qullissat, Disko. The easternmost and youngest picritic hyaloclastites of the Ordlingassoq Member ( 450 hy) have a hardened top surface (at arrow) and are overlain by $c .37 \mathrm{~m}$ of dark lacustrine mudstone $(\mathbf{m})$, in the upper part interbedded with fine-grained sandstone, and overlain by basalt lava flows of the lower Maligat Formation (MF). The top part of the sediment is bleached white and washed down over the dark mudstone. The locality is situated on Fig. 161 at $6.9 \mathrm{~km}$ and $650 \mathrm{~m}$ altitude. It is also indicated with a white arrow in Fig. 162.

discovery of large complex picritic subaqueous eruption sites on Nuussuaq, described below.

Subaqueous volcanic rocks. The subaqueous volcanic rocks of unit 450 show a considerable variation in morphology and are the products either of lava flows entering the Naajaat Lake or of eruptions directly into the lake.

The western limit of the Naajaat Lake was not stationary but sometimes transgressed westwards onto the older lava plateau, creating a shallow marginal western lake basin. Where thin picritic lava flows entered this shallow part of the Naajaat Lake basin they were brecciated throughout to form foreset-bedded hyaloclastites (Figs $167,169)$; in contrast, the more massive, vesicle-poor lava flows continued into the lake as subaqueous flows with vesicle-poor, strongly columnar-jointed lower parts and highly brecciated tops (Figs 168, 169). The best exposed example of such differences in subaqueous morphology can be studied in the mountain ridge Puugutalissuaq in the inner Agatdalen and on the neighbouring mountain side north-west of Turritellakløft. Here, flow fields of thin pahoehoe flows alternating with flow fields of more massive flows have entered a $75-150 \mathrm{~m}$ deep part of the lake basin (Figs 170, 171).

Where the Ordlingassoq Member lava flows entered the deeper parts of the Naajaat Lake, the morphology of the volcanic rocks was affected by interaction between the relatively heavy picritic rocks and the underlying unconsolidated, muddy sediments which increase in thickness from west to east. As the volcanic front moved eastwards, a succession of alternating beds of hyaloclastites and subaerial lava flows or shoreline flows in facies transition covered the underlying sediments. These nearshore lava flows and hyaloclastites show evidence of rapid synvolcanic deformation as recorded both by varying dips of originally horizontal subaerial flows and by locally 


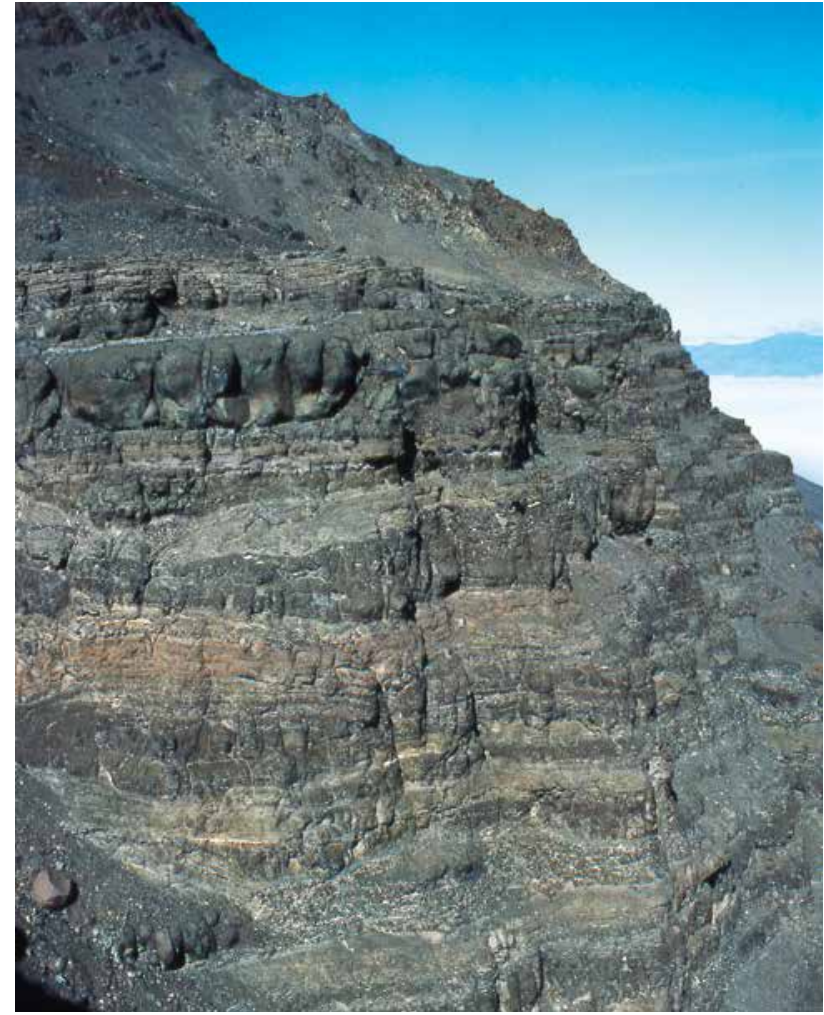

Fig. 166. Typical 1-4 $\mathrm{m}$ thick picritic pahoehoe lava flows in the upper part of the Ordlingassoq Member south of Asuk, Disko. Note the virtual absence of soil between the flows, indicating a high eruption rate. Height of section shown $c .45 \mathrm{~m}$.

varying thicknesses of hyaloclastite beds, which attest to rapid and at times differential subsidence (South Nuussuaq section at 35 to $57 \mathrm{~km}$ ). Such features are exemplified below. The deformed successions are at most a few

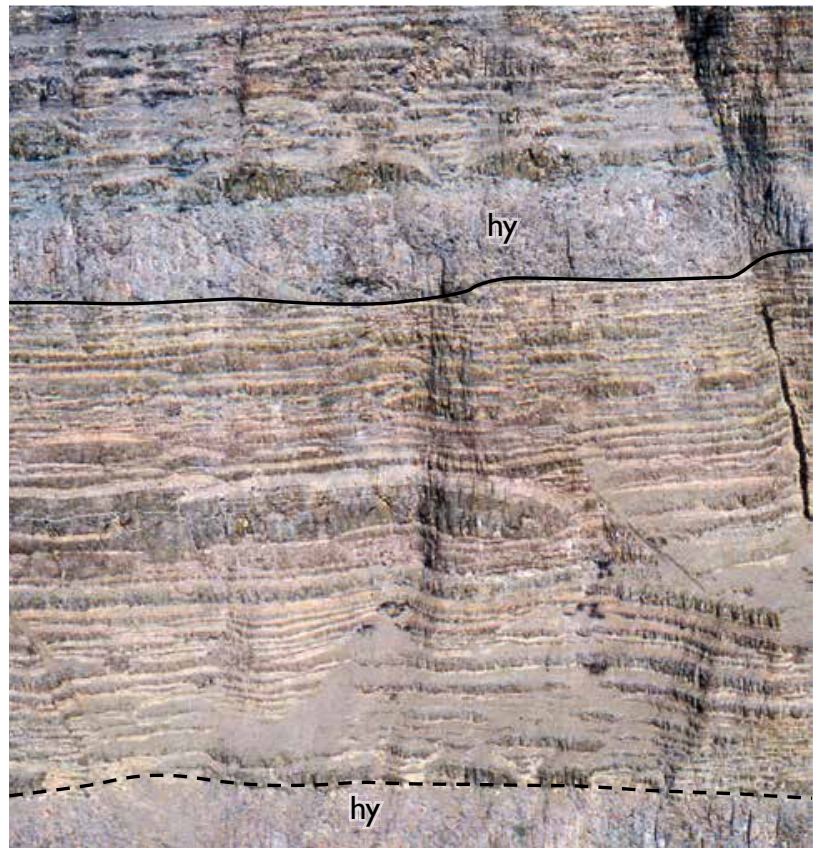

Fig. 167. Picritic pahehoe lava flows and two thin successions of foreset-bedded hyaloclastites (hy) in the lower part of the Ordlingassoq Member. The hyaloclastites represent two transgressions of the Naajaat Lake which were quickly obliterated by volcanic infill. Near-vertical wall on the south coast of Nuussuaq at Nuuk Killeq. Height of section $c .130 \mathrm{~m}$.

hundred metres thick and are covered by successions of subaerial picrite flows which have monotonous dips and were not affected by local deformation.

In the Ataata Kuua valley, a several hundred metres thick succession of hyaloclastites is exposed which records a synvolcanic landslide from the early stage of infill-

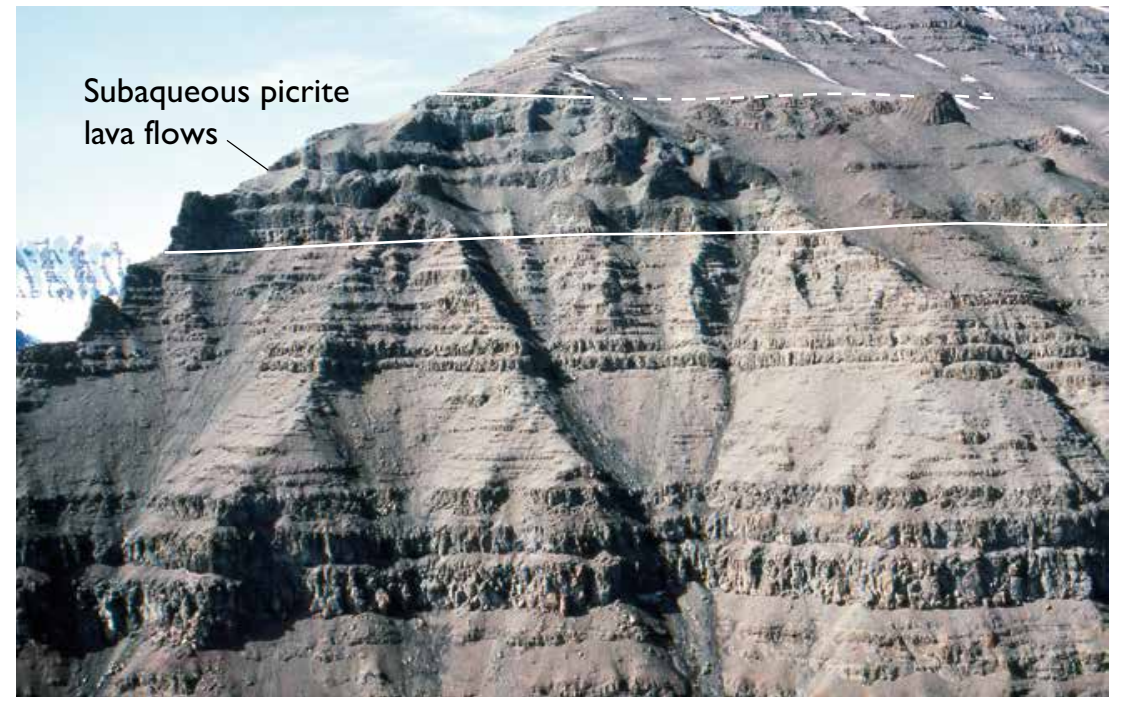

Fig. 168. Flow fields of subaerial and subaqueous picrite lava flows in the lower part of the Ordlingassoq Member. Several flow fields of lavas with different morphologies are seen. In the upper part is a succession of subaqueous picrite lava flows formed when high-volume lavas similar to the three massive picrite flows in the lower part of the picture entered the shallow Naajaat Lake basin. Western wall of Pyramidedal on central Nuussuaq; see also Fig. 171. Height of section c. $200 \mathrm{~m}$. 


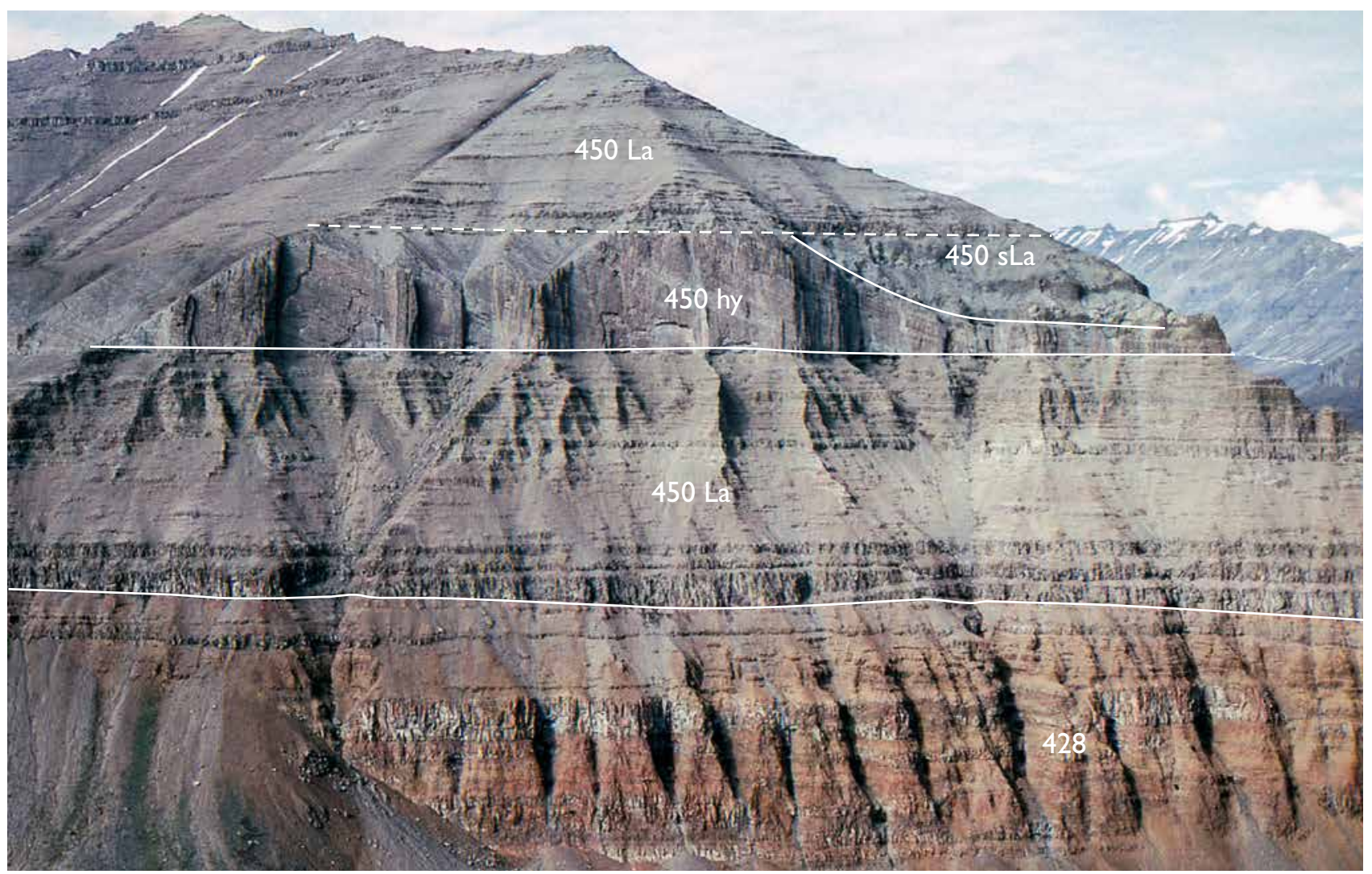

Fig. 169. Ordlingassoq Member picrites (450) in variable facies. At the base, brownish-weathering lava flows of the Tunoqqu Member (428), covered by subaerial Ordlingassoq Member picrite flows ( $450 \mathrm{La}$ ) forming alternating thick-bedded and thin-bedded flow groups. These are overlain by a succession of foreset-bedded hyaloclastites ( $450 \mathrm{hy}$ ) formed from thin pahoehoe lavas, which is covered by a fan of subaqueous flows (sLa) to the right, formed from more massive flows. Part of the succession is seen from another angle in Fig. 168. North wall of Turritelladal, central Nuussuaq. Height of section $c .700 \mathrm{~m}$.

ing of the Naajaat Lake (Fig. 172; Pedersen et al. 2007a, projections $\mathrm{A}-\mathrm{B}$ ).

Farther to the east within the Naajaat Lake basin, $c$. $3 \mathrm{~km}$ south-west of Eqi, a succession of alternating beds of hyaloclastite and picrite lavas is exposed which flowed from the north-west into the lake (Pedersen et al. 2007a, projections $\mathrm{C}-\mathrm{D})$. The thickness variation and the geometry of the beds demonstrate that the succession was undergoing rapid differential subsidence, probably due to compaction of the underlying mud deposited on the Naajaat Lake floor. The overlying picritic lava flows (unit $\mathrm{V}_{\mathrm{o}}$ ) are unaffected by this earlier deformation.

\section{Eruption sites}

A large number of picritic eruption sites have been located within the Ordlingassoq Member on both Disko and Nuussuaq, and many more are likely to be discovered in the future. The eruption sites show a considerable range in both size and morphology. They occur in subaerial as well as subaqueous settings; some are simple structures created in single eruptive events whereas others are complex composite structures created during many eruptive phases.

Due to the crumbling nature of picritic rocks, the verification of eruption sites requires excellent exposures combined with detailed field observations or detailed photographic coverage, or both. In many cases it is difficult to distinguish local strong inflation of pahoehoe flows from true eruption sites; the more so because feeder dykes are rarely exposed. However, eruption sites in the Ordlingassoq Member have been recorded systematically in the area covered by the geological map on a scale of 1:100 000 of southern Nuussuaq (Paatuut map, Pedersen et al. 2007a), and at least in this area they are numerous (Fig. 173). 


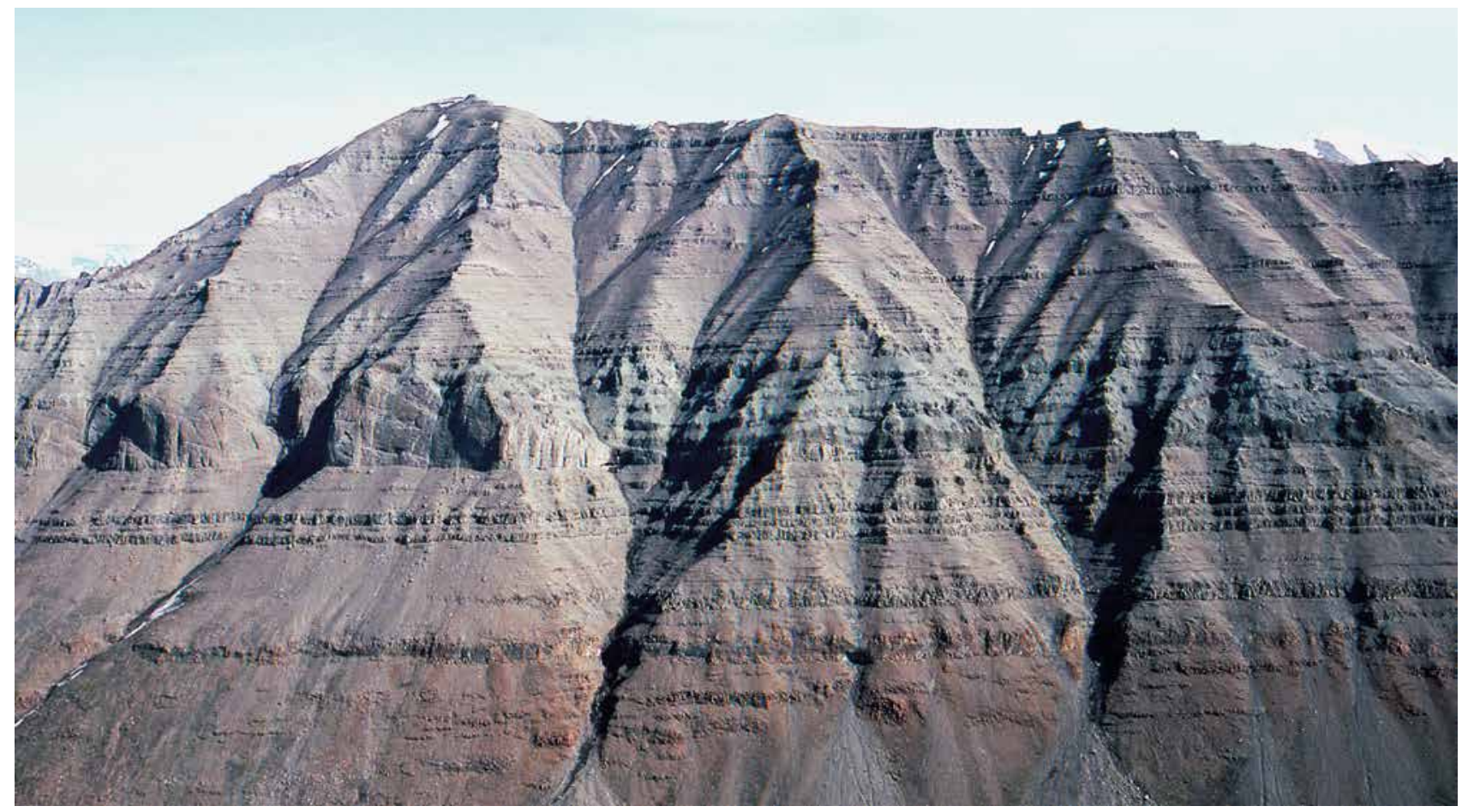

Fig. 170. Ordlingassoq Member picrites in variable facies. In the middle part of the section, a horizon with foreset-bedded hyaloclastites, to the left, and subaqueous lava flow tongues with brecciated tops, to the right, demonstrate the different lithologies developed when low- and high-volume-rate lava flows, respectively, entered the lake basin. Western side of the mountain ridge Puugutalissuaq that forms the west wall of Pyramidedal, inner Agatdalen area, central Nuussuaq. The section is $c .700 \mathrm{~m}$ high and is seen at $c .1 .3-3.7 \mathrm{~km}$ in the interpreted photogrammetric section in Fig. 171.

Simple eruption sites. Some eruption sites of the Ordlingassoq Member are the result of low-volume eruptive events which gave rise to very small flow fields.

An example of a simple eruption site is seen in the south-west facing eastern side of Agatdalen (Fig. 174). Here, a feeder dyke only a few metres thick cuts vertically through picritic lavas and two horizons of foreset-bedded hyaloclastites, and terminates within a subaerial lava succession in an irregular mass of columnar-jointed picrite. The picrite mass constitutes the core of the crater (probably a fissure) and is about $20 \mathrm{~m}$ in width and height; it is surrounded by crumbling picritic gravel which obscures the detailed relations to the onlapping picrite lava flows.

A number of small picritic eruption sites are seen on the south-west facing mountain slope $c .2 \mathrm{~km}$ west of Avataasalissuaq west of Agatdalen (Fig. 175). They are situated within a fairly monotonous, c. $150 \mathrm{~m}$ thick succession of thin, crumbling pahoehoe flows sandwiched between two massive, crudely columnar-jointed lava flows. No feeder dykes are seen. There are three well- defined eruption sites which are horizontally spaced from each other by a few hundred metres and vertically spaced by $10 \mathrm{~m}$ to
$50 \mathrm{~m}$. The lowermost site (A in Fig. 175) is c. $35 \mathrm{~m}$ high and has a $c .50 \mathrm{~m}$ wide core zone of branching, columnarjointed, massive picrite alternating with patches of scoria, resting on a $c .5 \mathrm{~m}$ thick lava flow derived from the site. The structure is onlapped by numerous thin, crumbling pahoehoe tongues. The uppermost site, which is the largest one (B in Fig. 175), is about $35 \mathrm{~m}$ high and has at its base a $c .10 \mathrm{~m}$ thick lava flow derived from the site and extending for at least $200 \mathrm{~m}$ before it tapers out. Extending upwards from the central part of the flow are several columnar-jointed masses of solid picrite alternating with light grey to reddish bodies of high-temperature oxidised scoria. The close association of small picritic eruption sites in space and time indicates that magma was repeatedly channelled upwards within a very limited area over an unconstrained but limited period of time.

An oxidised crater site on Disko. A small picritic eruption site is exposed in the western wall of Norddalen about 6.5 $\mathrm{km}$ south of the Vaigat coast. It is surrounded by subaerial picritic lava flows of the Ordlingassoq Member (Fig. 176). The exposed part of the site forms a mushroom- 


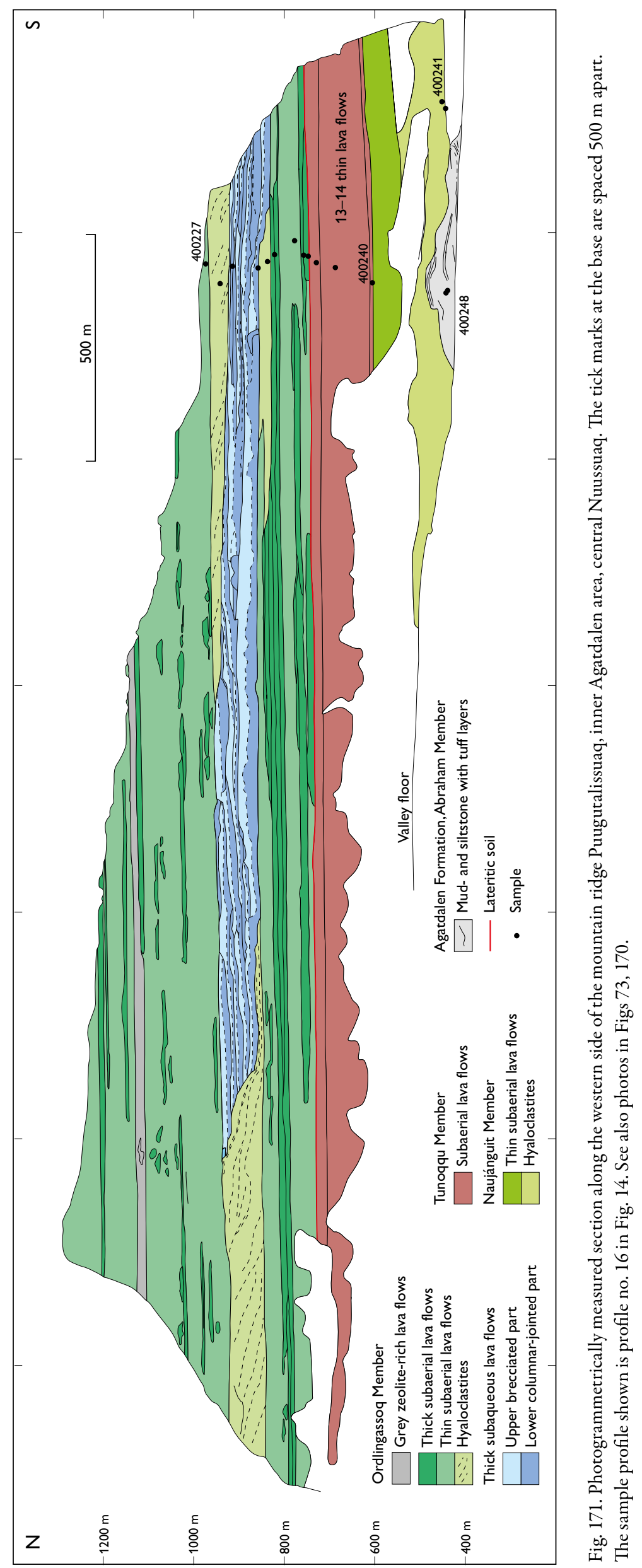




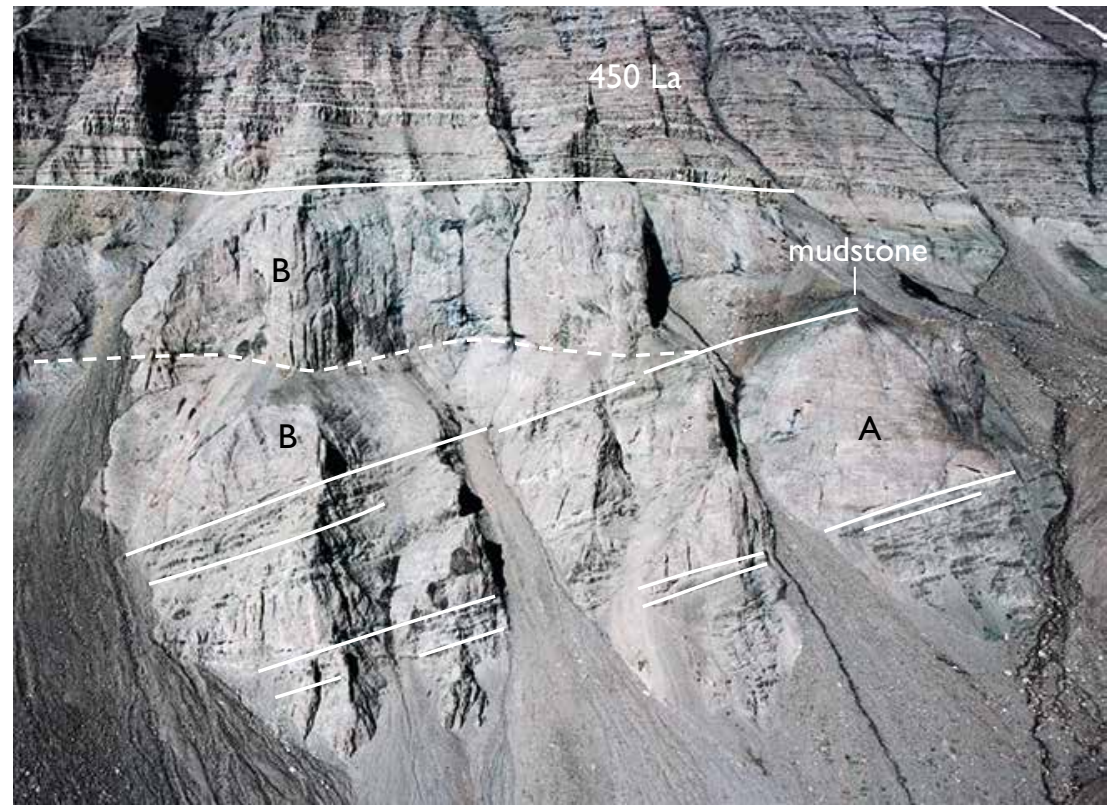

Fig. 172. Remnant of a synvolcanic landslide in the north-western steep-walled part of the Ataata Kuua valley, Nuussuaq. The lower part of the wall is a more than $150 \mathrm{~m}$ thick succession of alternating hyaloclastites and thin picrite lavas in a coherent block (A) which has been rotated along a NW-SE axis. In a short period after the landslide, mudstone of the Naujât Member (mudstone) was deposited on the top of the slide. Thereafter, the slide was covered by two large hyaloclastite beds (B) of which the upper one was formed from and is covered by a succession of subhorizontal picrite lava flows (450 La). See also Pedersen et al. 2007a; section A-B.

shaped crater about 20 to $30 \mathrm{~m}$ wide which is visible from a considerable distance because of strikingly red scoria and reddish-grey lava tongues. It is flanked by about 20 pahoehoe lava tongues which vary in thickness between 0.3 and $2 \mathrm{~m}$, all of which are reddish due to high-tem- perature oxidation and all of which must have issued from the crater site. On the northern flank, the crater is partly covered by a 10 to $15 \mathrm{~m}$ thick lava flow which is also high-temperature oxidised. The top of the crater is covered by a more than $20 \mathrm{~m}$ thick succession of gener-

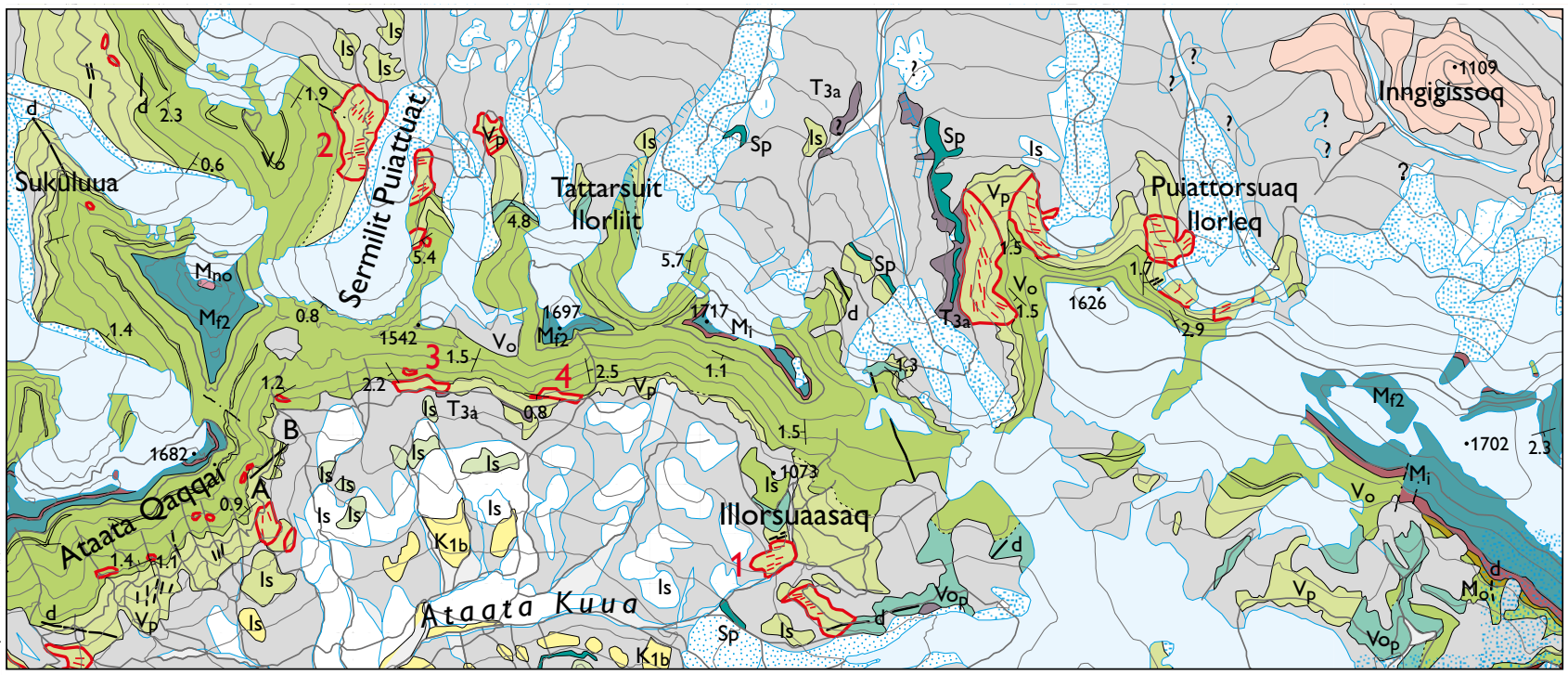

$10 \mathrm{~km}$

Fig. 173. Excerpt from the geological map of the Nuussuaq Basin on southern Nuussuaq on a scale of 1:100 000 (special map Paatuut, Pedersen et al. 2007a), showing eruption sites in the Ordlingassoq Member outlined in red and with feeder dyke patterns in red. Note the high frequency of eruption sites and their large size variation. Eruption sites described here are indicated with large red numbers. 1: Fig. 177. 2: Figs 178, 179. 3: Figs 180A, 181. 4: Figs 180B, 182. Other unit annotations are from the original. 
Fig. 174. A well-exposed, simple small eruption site. A thin, erosion-resistant feeder dyke cuts vertically through picritic lavas and hyaloclastites and terminates within subaerial lava flows in an irregular mass of columnarjointed picrite. The picrite mass is about $20 \mathrm{~m}$ in width and height. South-west-facing eastern wall of Agatdalen, Nuussuaq.

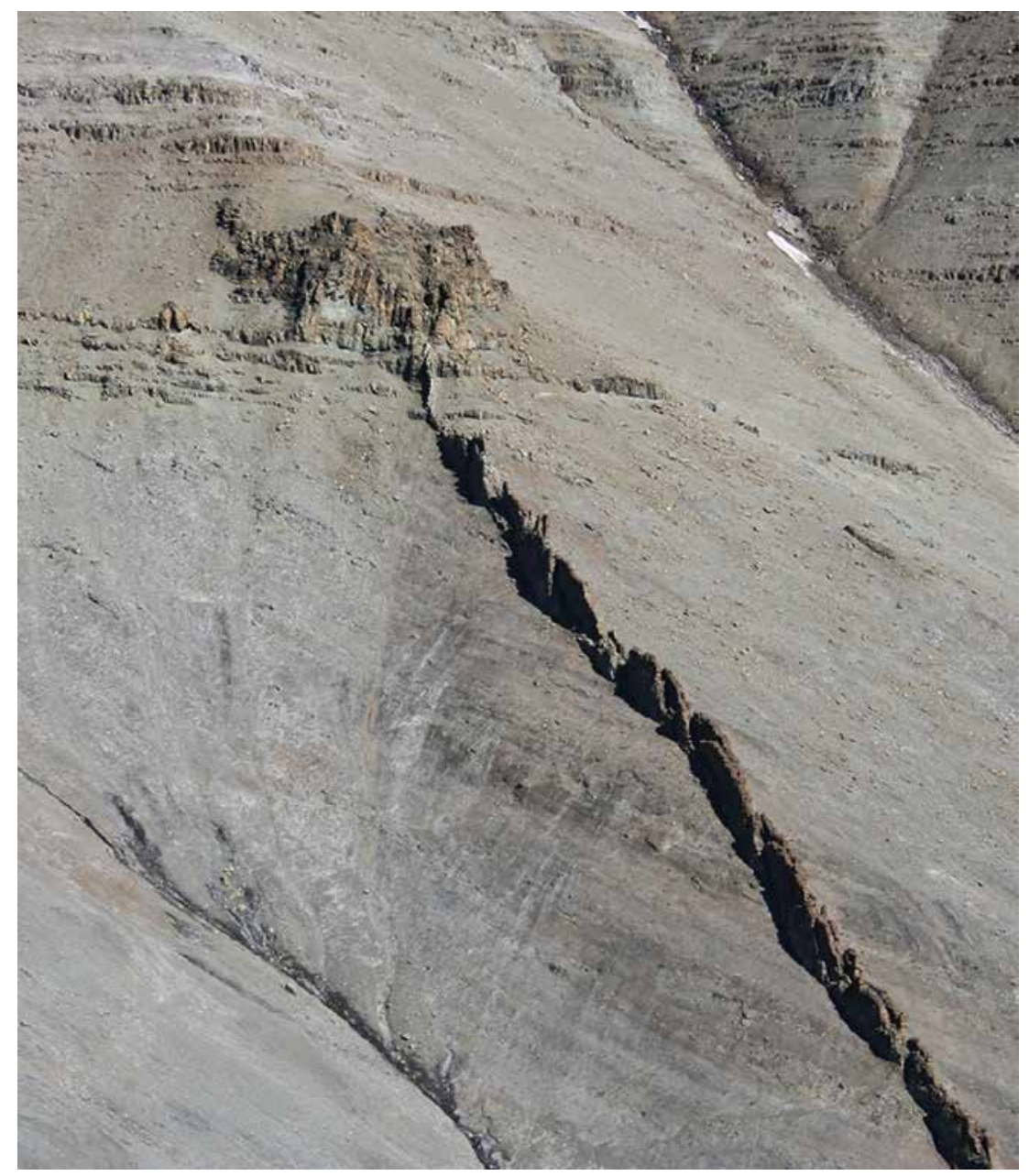

ally thin-bedded lava flows all of which have oxidised top zones. Altogether, the crater was probably the outlet for a considerable flow field composed of high-temperature oxidised picrite lavas. The oxidation is considered to be a local high-level phenomenon.

A small subaqueous eruption site on Disko. In the eastern side of the Kuugannguaq valley about $32 \mathrm{~km}$ from the entrance, a small subaqueous eruption site is exposed just above a large local landslide (see Fig. 200 at $4.8 \mathrm{~km}$ ). The water body was the Naajaat Lake, and the eruption occurred c. $1.5 \mathrm{~km}$ south-east of the shoreline produced by the uppermost lavas of Manîtdlat Member unit 465 which flowed into the lake from the north-west. In contrast, the subsequent lavas of unit 450 entered the lake from the south-east, and the eruption occurred on the gently northerly sloping hyaloclastite shelf. The crater is situated within the succession of foreset-bedded hyaloclastites $c .150 \mathrm{~m}$ below the top. The eruption site is inconspicuous and was only discovered in the field by chance. It consists of a $c .1 \mathrm{~m}$ wide picrite dyke which cuts through underlying hyaloclastites to develop into a convex, mushroom-shaped mass composed of several horizontal to slightly down-sloping brecciated tongues of vesiculated picrite with glass chills. With higher fragmentation the tongues grade into hyaloclastite. The surface of the crater body has a gentle northerly slope. The vertical distance from the lowest part of the feeder dyke to the top of the crater body is $c .30 \mathrm{~m}$.

Large subaqueous eruption sites on Nuussuaq. More than 20 large subaqueous eruption sites are known from the Ordlingassoq Member on Nuussuaq in areas that were covered by the Naajaat Lake complex (Fig. 173; South Nuussuaq section; Pedersen et al. 2002b, 2007a, b). Their size ranges from $100 \mathrm{~m}$ to more than $1.5 \mathrm{~km}$, and they appear as cupolas of hyaloclastite and subaqueous lava tongues invaded by dense but very local swarms of picritic feeder dykes. They may be onlapped and covered by foreset-bedded hyaloclastites fed from subaerial 


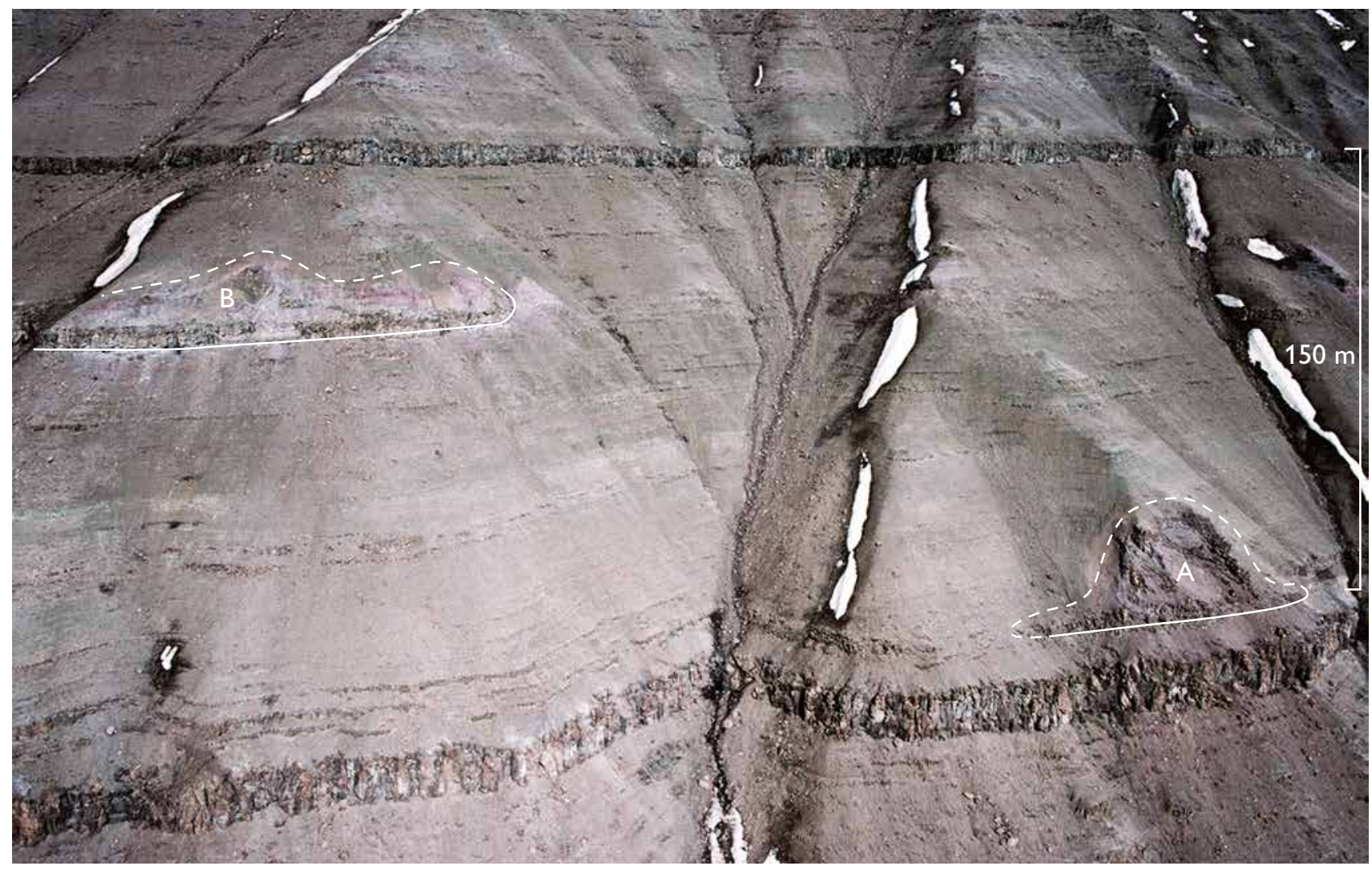

Fig. 175. Two small picritic eruption sites $(\mathbf{A}$ and $\mathbf{B})$ situated within a fairly monotonous succession of thin crumbling pahoehoe flows. The lower site (A) is $c .35 \mathrm{~m}$ high and has a $c .50 \mathrm{~m}$ wide core zone resting on a $c .5 \mathrm{~m}$ thick lava flow derived from the site. The upper site (B) is about $35 \mathrm{~m}$ high and has at its base a c. $10 \mathrm{~m}$ thick lava flow derived from the site and extending for at least $200 \mathrm{~m}$ before it tapers out. South-westfacing mountain slope west of Agatdalen, Nuussuaq.

pahoehoe flows as the volcanic front advanced into the lake, or they may be directly covered by subaerial flows. In steep cliffs large, partially exposed eruption sites can be recognised by their distinctive swarms of feeder dykes which erode less easily and have darker colours than the hyaloclastites which make up most of the sites (Fig. 177).
A large subaqueous eruption site is situated in the south side of the Aaffarsuaq valley at Sermillit Puiattuat just north of Ataata Kuua (Fig. 173); it has been photographed and surveyed using multi-model photogrammetry but never visited on the ground. The exposed parts cover about $0.5 \mathrm{~km}^{2}$; however, additional parts are hid-

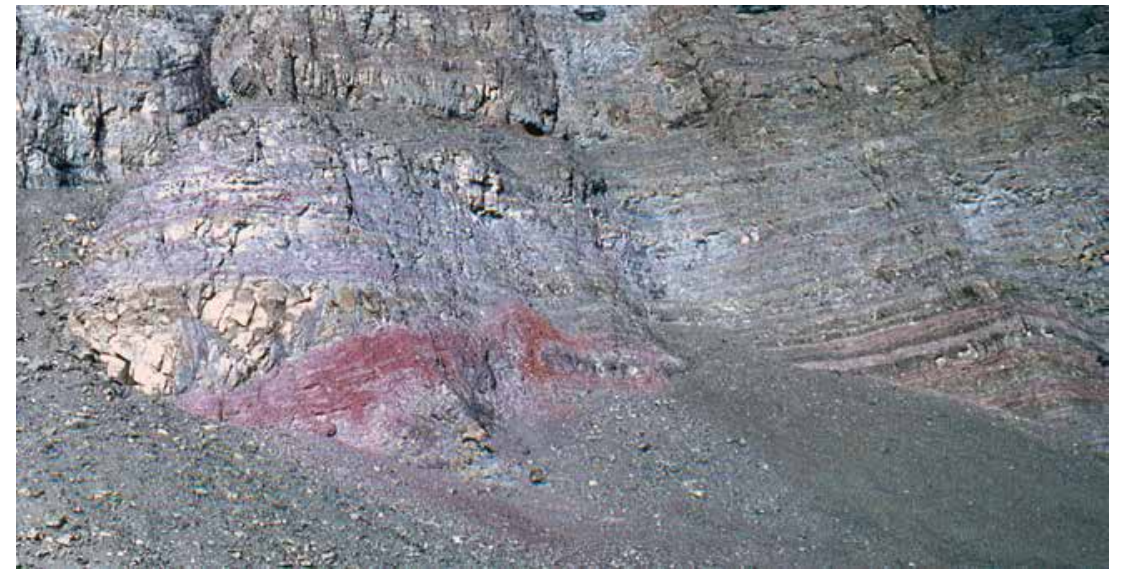

Fig. 176. Small picritic eruption site in the western wall of Norddalen on Disko. The 20-30 m wide crater deposit consists of strikingly red scoria and reddish-grey lava tongues. The surrounding pahoehoe lavas are redoxidised and must have issued from the crater site. The crater deposit is partly covered by a 10 to $15 \mathrm{~m}$ thick lava flow which is likewise high-temperature oxidised. 


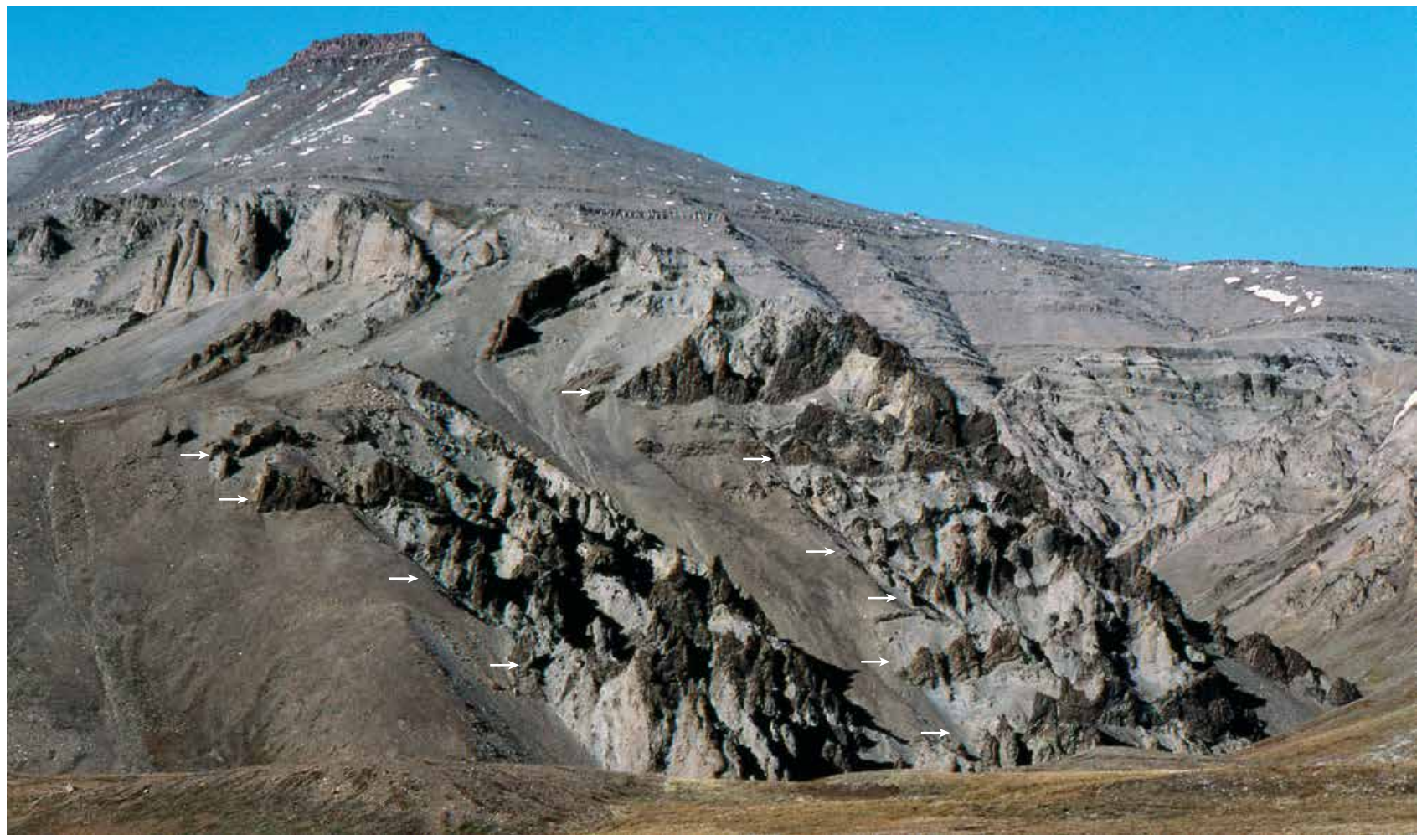

Fig. 177. Large subaqueous eruption site in the Ordlingassoq Member south of Illorsuaasaq in the inner part of Ataataa Kuua on Nuussuaq (Fig. 173, no. 1). The site is a large cupola of hyaloclastite and subaqueous lava tongues invaded by a dense local swarm of picritic feeder dykes which erode less easily and have darker colours than the hyaloclastites. The dykes are mainly oriented left-right in the photo (arrows). The structure rises $c .120 \mathrm{~m}$ above the valley floor.

den towards the west and eroded away towards the east, and the complete site is estimated to cover more than 1 $\mathrm{km}^{2}$ with a volume exceeding $0.3 \mathrm{~km}^{3}$ (Fig. 178). The site is situated within the lower part of the Ordlingassoq Member which in this area is at least $800 \mathrm{~m}$ thick and of which the lower $400 \mathrm{~m}$ is subaqueous facies. The base of the eruption site is below the local level of exposure. The eruption products are at least $250 \mathrm{~m}$ thick and are composed of two overlapping structures centred several hundred metres apart around two slightly overlapping local feeder dyke swarms. Each dyke swarm is at least several hundred metres wide and is composed of up to $8 \mathrm{~m}$ thick dykes. The lower parts of the deposits are composed of hyaloclastites and feeder dykes which grade upwards into a c. $150 \mathrm{~m}$ thick zone of alternating hyaloclastite and subaqueous to shore facies lava tongues many of which were formed as the upper termination of feeder dykes. The older part of the site is centred in its northern end and was fed from a swarm of dykes which tend to strike NE-SW with high and variable dips (Figs 178, 179). The younger part of the site is centred in its southern end and was fed from a swarm of dykes which generally strike E-W with high and variable dips, and which cut the older swarm. The eruption site is covered by a succession of subaerial picrite flows most of which are a few metres thick, but a few up to $10 \mathrm{~m}$ thick massive flows also occur and form local marker horizons. Significantly, none of these flows are cut by the two feeder dyke swarms which were confined in space and time to the eruption site whose products seem just to have reached the surface level of the Naajaat Lake. The local area was probably affected by relatively fast subsidence which kept the upper $c .100 \mathrm{~m}$ close to the lake surface during the relatively short life time of the eruption site.

A crater field in the northern wall of Ataata Kuna. In the steep northern wall of the inner Ataata Kuua valley, a 2.2 $\mathrm{km}$ long section through a crater field is exposed which consists of several composite crater structures in the lower part of the Ordlingassoq Member. The area has been visited in the field at a few accessible localities along the lowermost exposures, but the overall geological analysis presented by Pedersen et al. (2007b) was made using multi-model photogrammetry based on photographs taken 


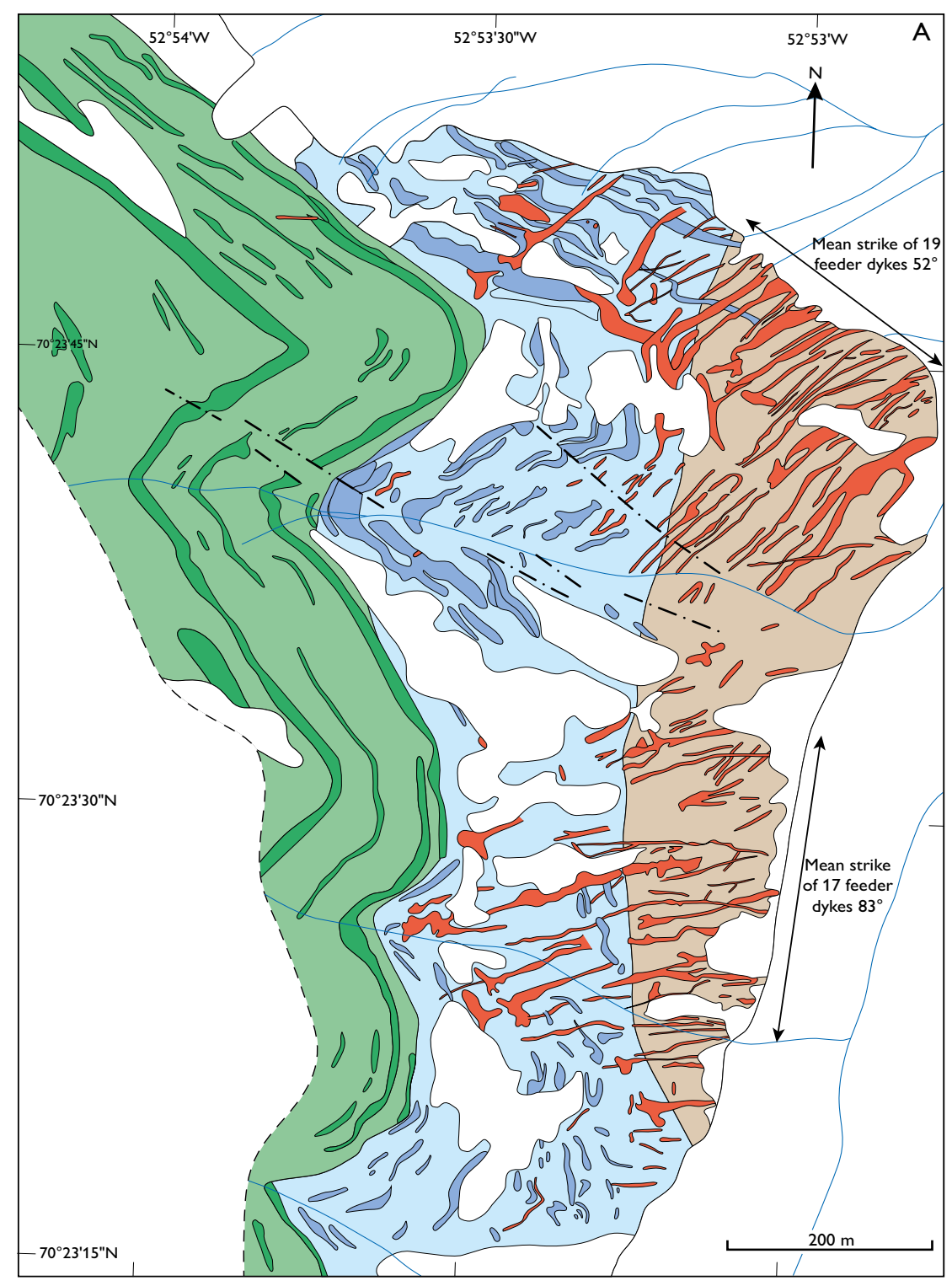

Fig. 178. Large subaqueous eruption site in the south side of the Aaffarsuaq valley at Sermillit Puiattuat (inset map; Fig. 173, no. 2; Fig. 179), photogrammetrically measured. A: Map; the terrain rises from the valley floor in the eastern and northern parts of the map to the high mountain slopes in the western part of the map. The eruption products comprise two overlapping, northern and southern structures with two slightly overlapping local feeder dyke swarms of which the northern one is the older. Both the older and the younger structures have a lower altered zone (pale brown) and an upper unaltered zone (pale blue). The dykes in the northern part strike on average $52^{\circ} \mathrm{N}$, whereas those in the southern part strike on average $83^{\circ} \mathrm{N}$. B: Vertical SE$\mathrm{NW}$ section seen from the north-east. See text for detailed descriptions.
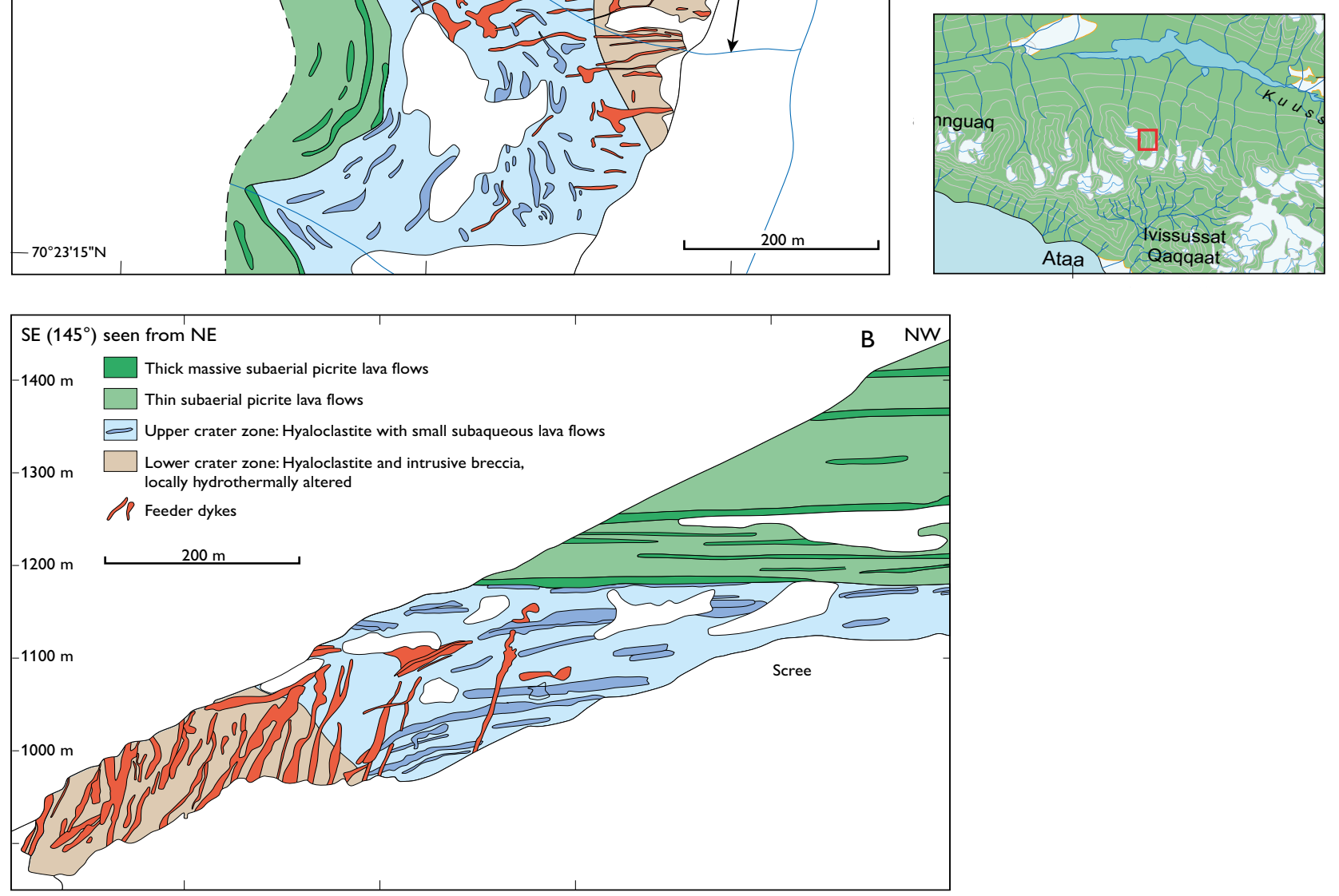


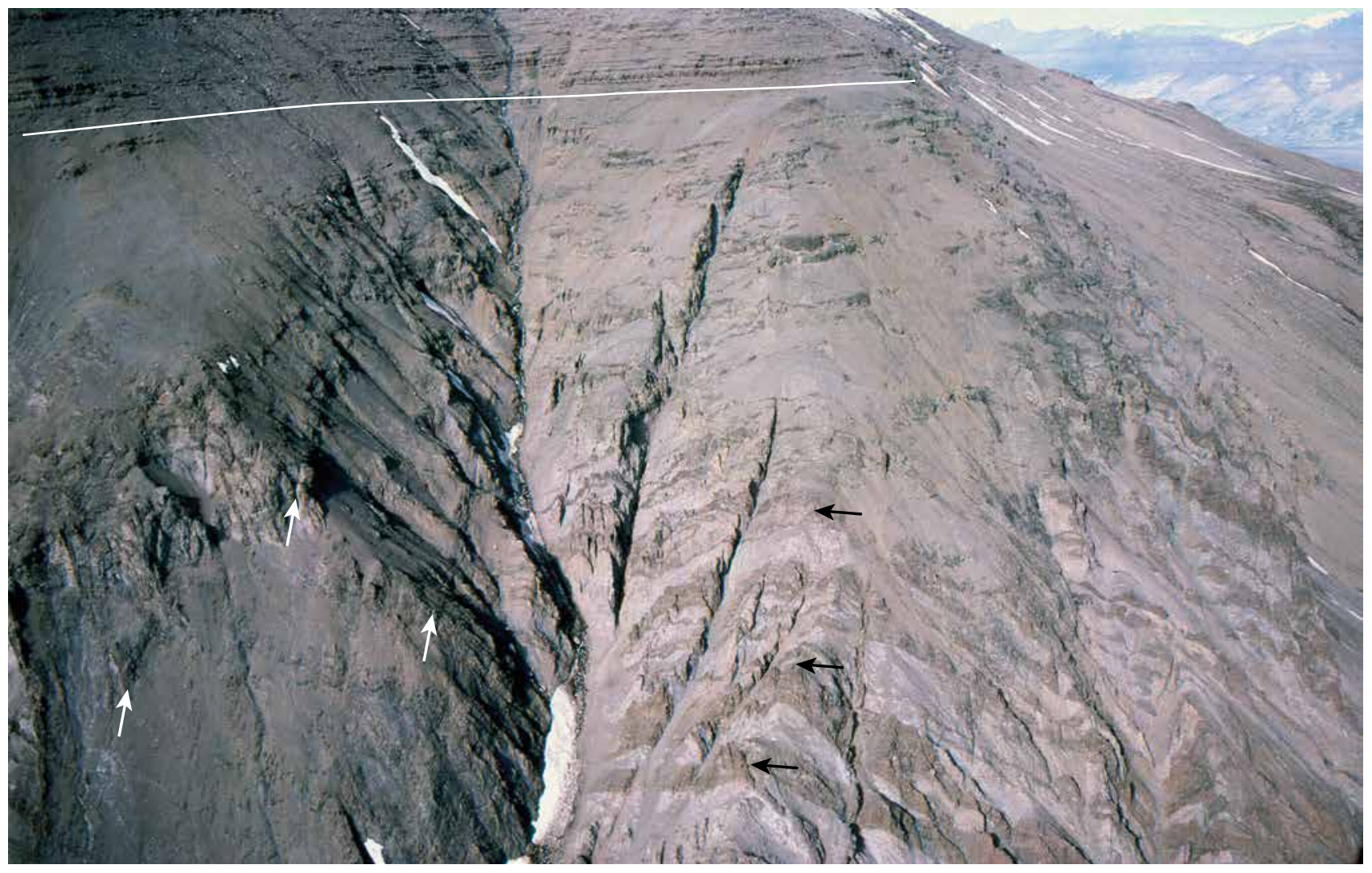

Fig. 179. The northern part of the large subaqueous eruption site in Fig. 178, looking west into a gully with a small stream seen in the upper central part of the map (Fig. 178), showing the close-lying, near-parallel, dark dyke intrusions with screens of light hyaloclastite between them. The two directions of feeder dykes are indicated by white (left) and black (centre) arrows. The overlying, near-horizontal, subaerial lava succession without intrusions is seen in the upper part of the picture. Sermillit Puiattuat, south side of the Aaffarsuaq valley, Nuussuaq.

from a helicopter (Fig. 180). The crater field overlies a succession of dark mudstones of the Naujât Member deposited on the floor of the Naajaat Lake (G.K. Pedersen et al. 1998; Dam et al. 2009). The mudstones are poorly exposed except where they are intruded by feeder dykes and invasive hyaloclastite bodies (Fig. 180 and Pedersen et al. 2007b, sections A-B at $550 \mathrm{~m}, 1300 \mathrm{~m}$ and 1600 $\mathrm{m})$. At some localities, the mudstones contain beds of volcaniclastic debris flows dominated by well-rounded clasts of lava and pillow fragments. The crater area consists of an older part, which had several active phases, centred in the western end (the western Ataata Kuua crater), and a younger part which is centred about $1.4 \mathrm{~km}$ farther to the east (the eastern Ataata Kuua crater).

Western Ataata Kuna crater. The lower part of the western Ataata Kuua crater (Fig. 180A) is composed of a small succession of subaerial picritic lava flows, several of which have high-temperature oxidised top zones; these flows are cut by several irregular feeder dykes which grade upwards into heaps of pyroclastic rocks (units $\mathrm{V}_{\mathrm{W} 1}$,
$\left.\mathrm{V}_{\mathrm{W} 2}\right)$. This part is covered by hyaloclastites and shorefacies lava flows (unit $\mathrm{V}_{\mathrm{p} 3 \mathrm{a}}$ ). The most conspicuous part of the crater is centred at around $600 \mathrm{~m}$ in Fig. 180A and consists of at least three successive phreatic explosion craters superimposed upon each other (units $V_{w 3 a}, V_{w 3 b}$, $\mathrm{V}_{\mathrm{w} 3 \mathrm{c}}, \mathrm{V}_{\mathrm{w} 4}, \mathrm{~V}_{\mathrm{w} 5}$ ) and of which the youngest $\left(\right.$ unit $\mathrm{V}_{\mathrm{w} 5}$ ) has a diameter of $c .900 \mathrm{~m}$. The upper crater unit $\left(\mathrm{V}_{\mathrm{w}}\right)$ is separated in time from the underlying craters by a number of thin picritic lava flows (unit $\mathrm{V}_{\mathrm{o} 3}$ ) and accompanying hyaloclastite succession (Unit $\mathrm{V}_{\mathrm{p} 3 \mathrm{~b}}$ ). The explosions left deep central depressions, and the pyroclastic units $\mathrm{V}_{\mathrm{W} 6}$ and $\mathrm{V}_{\mathrm{W} 7}$ were deposited in the central depression of crater $V_{W 5}$, probably as late parts of the same eruptive event. The craters are covered by a succession of subaerial picritic pahoehoe flows which erupted shortly after the crater formation and which have therefore preserved the upper surface of the $\mathrm{V}_{\mathrm{w} 5}$ crater cone and its floor (Figs $180 \mathrm{~A}, 181)$. Up to $c .150 \mathrm{~m}$ above the crater level the subaerial lava succession contains a number of short and up to 30 to $40 \mathrm{~m}$ thick picrite bodies which are interpreted 


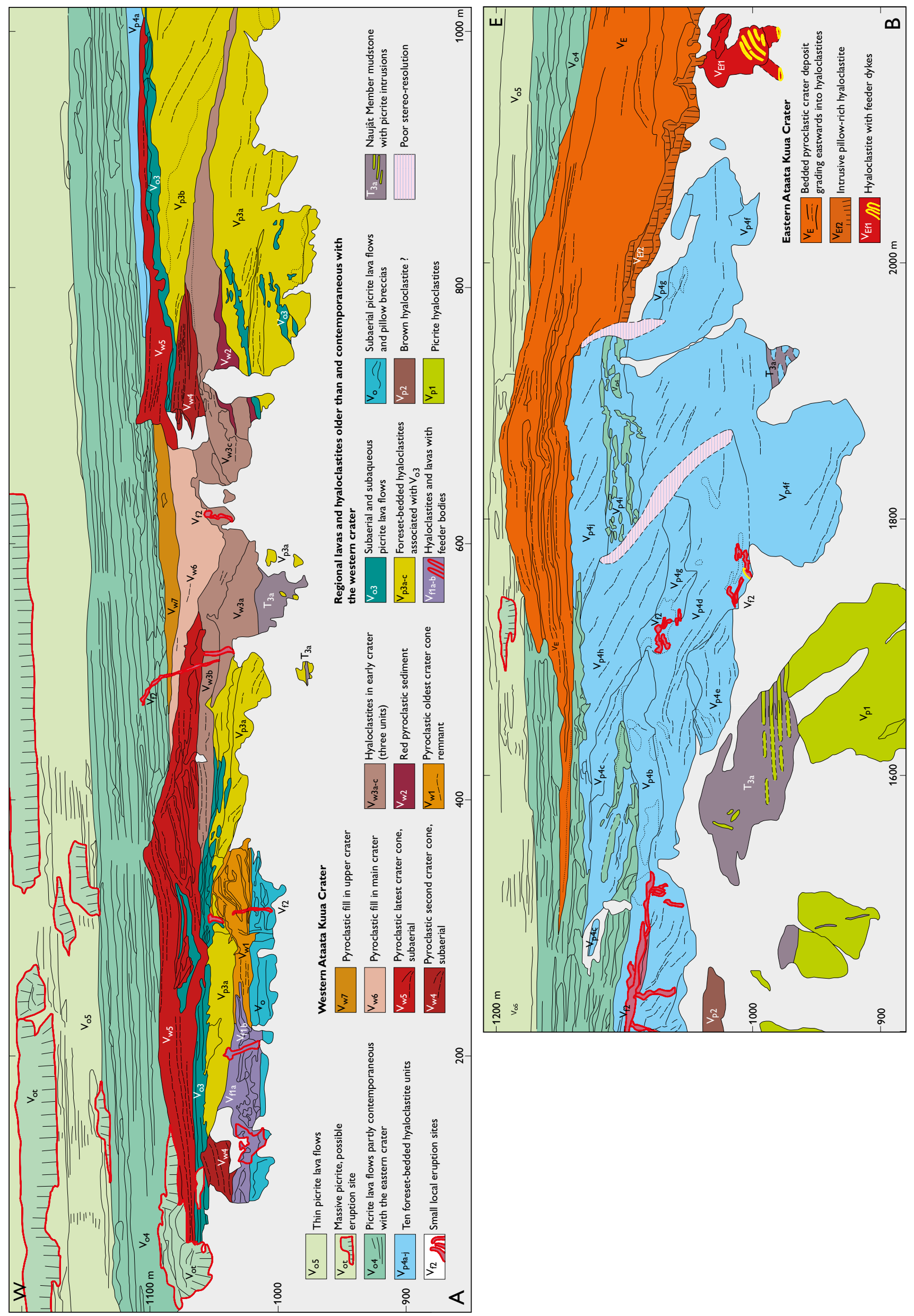


Facing page:

Fig. 180. Photogrammetrically measured section along the northern wall of the inner Ataata Kuua valley: two excerpts from Pedersen $e t$ al. (2007b). The section shows picritic lava flows, hyaloclastites and two phreatic crater structures. A: The western Ataata Kuua crater (at 0-1000 $\mathrm{m}$ along the section) and B: The eastern Ataata Kuua crater (at 1400-2200 m along the section). See Fig. 173 nos 3 and 4 for location. Scattered exposures of mudstone of the Naajaat Lake appear in the lower part of the section. The craters were formed by interaction of erupting picritic magma with water from the lake and from unconsolidated muddy sediment. The craters reached well above the lake surface and were subsequently covered by subaerial picritic lava flows. Several explosive phases can be discerned in the western crater. See text for descriptions.

to be local eruption sites and not just inflated pahoehoe flows (Figs 180A, 181). These sites indicate that the crater area remained an active feeder site, acting as a magma channel during the short, but poorly constrained, time period during which the additional c. $150 \mathrm{~m}$ of lavas were deposited.
Eastern Ataata Kuna crater. The eastern Ataata Kuua crater (Fig. 180B) is a prominent volcanic feature that is visible from a distance of more than $10 \mathrm{~km}$ due to its striking orange brown colour which makes a strong contrast to the surrounding grey picritic lava flows and hyaloclastites (Fig. 182). Despite the colour, feeder dykes and large clasts associated with the crater are picritic and show no signs of crustal contamination at igneous temperatures. However, the pyroclastic parts of the crater site contain numerous millimetre- to centimetre-sized flakes of black mudstones which are only slightly baked and which originated from the underlying mudstones of the Naujât Member. We believe that interaction between the erupting picrite magma and the unconsolidated mud, which provided volatiles, gave rise to the phreatomagmatic activity which created the crater.

The eastern Ataata Kuua crater consists of a feeder system, a subaerial phreatomagmatic cone and a subaqueous deposit. The connection between the feeder system and the centre of the cone is not seen in the otherwise excellent erosional section through the crater. The crater cone

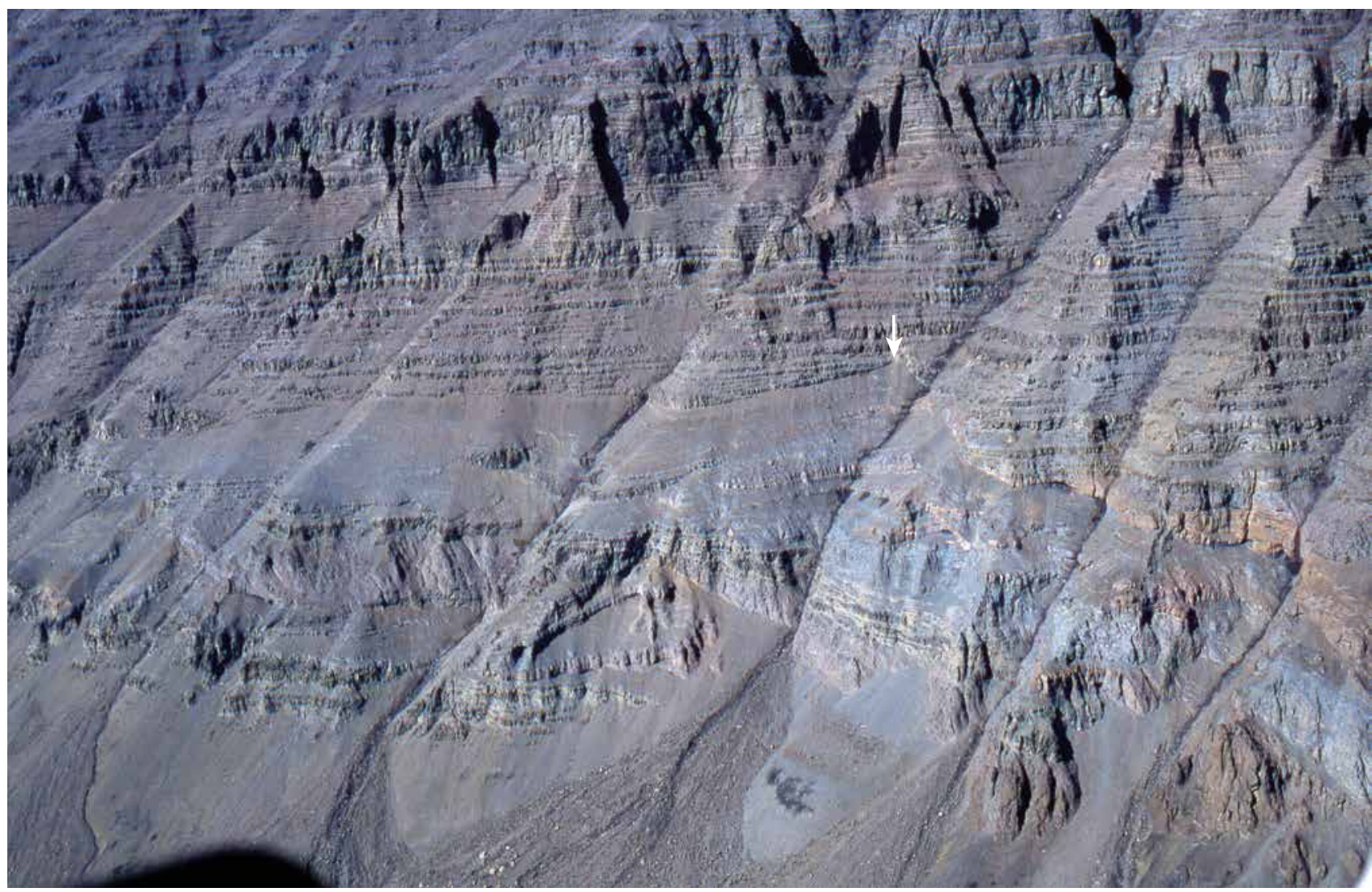

Fig. 181. The western part of the western Ataata Kuua crater; the picture shows the area at $0-600 \mathrm{~m}$ in Fig. 180A. For interpretation and scale, see Fig. 180A. The top of the latest crater cone $\left(\mathbf{V}_{\mathbf{W} 5}\right)$ is indicated by an arrow. 


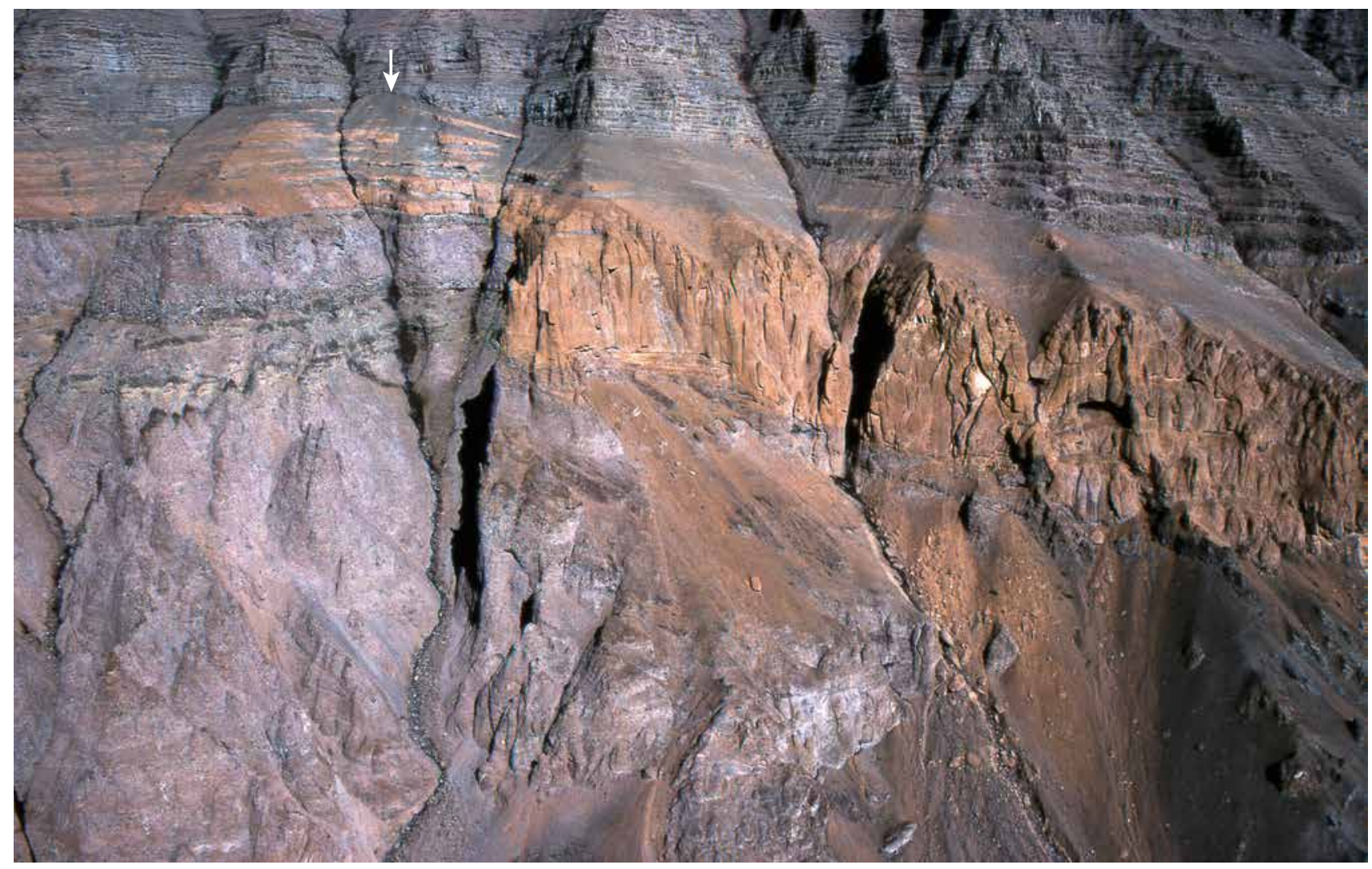

Fig. 182. The eastern Ataata Kuua crater; the picture shows the area at $c .1750-2200 \mathrm{~m}$ in Fig. 180B. For interpretation and scale, see Fig. 180B. The top of the crater deposit $\left(\mathbf{V}_{\mathbf{E}}\right)$ is indicated by an arrow.

is $c .50 \mathrm{~m}$ high and $600 \mathrm{~m}$ wide and is centred at the palaeoshoreline. The central and western parts of the cone overlie three successive units of foreset-bedded hyaloclastites and a few thin subaerial lava tongues. This indicates that the area was undergoing relatively rapid subsidence, part of which may have been caused by compaction of the underlying mud (Fig. 180B). The crater cone is composed of thin beds of volcaniclastic material (unit $V_{E}$ ) and its upper surface is excellently preserved beneath the onlapping and overflowing subaerial picrite lavas (unit $\mathrm{V}_{\mathrm{o} 4}$ and $\mathrm{V}_{\mathrm{0}}$ ). To the east, the volcaniclastic material has been deposited subaqueously downslope into the Naajaat Lake. The exposed part of the feeder system consists of a swarm of 0.5 to $2 \mathrm{~m}$ thick picrite dykes which strike c. NE-SW and rise up through a hyaloclastite that was probably produced from the dykes (unit $\mathrm{V}_{\mathrm{Ef} 1}$ ). Upwards the dykes develop into irregular entablature-jointed masses which develop into mushroom-shaped masses of hyaloclastite (unit $\mathrm{V}_{\mathrm{Ef} 2}$ ) and poorly structured hyaloclastite mixed with volcaniclastic material in the downslope deposit (eastern part of unit $V_{E}$ ), both of which contain picritic pillow fragments and abundant small flakes of mudstone.

\section{Minor units in the Ordlingassoq Member}

Crustally contaminated rocks within the Ordlingassoq Member on Disko comprise a minor succession close to the base of the member in the Stordal area, here described as unit 451 , and a small succession of rocks which are partly interlayered with the Manîtdlat Member in Stordal and Kuugannguaq, here described as unit 464 together with the Manîtdlat Member.

On Nuussuaq, a possible small occurrence of contaminated rocks is inferred from photogrammetry only; it is located in the steep, east-facing mountain wall in the western end of the Kangersooq valley c. $4 \mathrm{~km}$ due north of Qilakitsoq. Here, a $20-40 \mathrm{~m}$ thick succession of rusty brownish-weathering pahoehoe lava flows has a visual similarity to other horizons of contaminated rocks of the Vaigat Formation.

A small succession of alkaline picrite flows (unit 460) at the north coast of Disko in the lower part of the Or- 

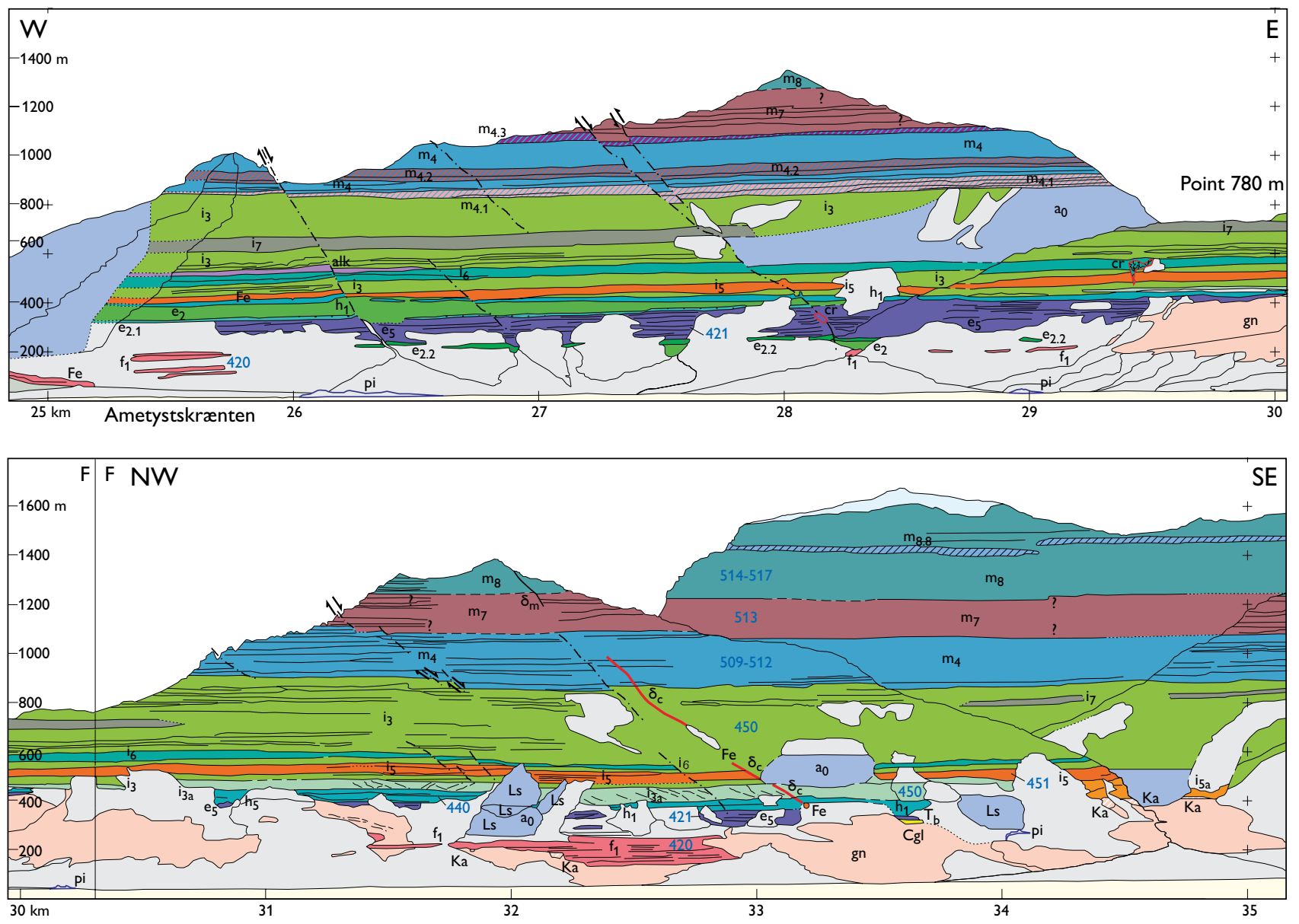

Fig. 183. Photogrammetrically measured section along the northern wall of Stordal, central Disko. Blue numbers are unit codes; other unit annotations are from the original. The unit codes 509-517 denote units of the Rinks Dal Member of the Maligât Formation. Excerpt from the Central Disko section at $25-35 \mathrm{~km}$ (Pedersen et al. 2005), slightly modified.

dlingassoq Member is situated some $30-80 \mathrm{~m}$ below the alkaline Manîtdlat Member (see Fig. 201). As the alkaline rocks are closely related, unit 460 is described together with the Manîtdlat Member.

\section{Crustally contaminated basaltic andesites and picrites in Stordal on Disko (unit 451)}

A distinct marker horizon of light brownish, crustally contaminated rocks has been mapped out close to the base of the Ordlingassoq Member in the northern side of Stordal from Ametystskrænten in the west and $10 \mathrm{~km}$ to the east (Fig. 12; Fig. 183, unit $i_{5}$ and $i_{5 a}$ at $25-35 \mathrm{~km}$ ). The lava succession of unit 451 increases in thickness from $c .15-20 \mathrm{~m}$ in the west to about $50 \mathrm{~m}$ in the east, and the total thickness increases to $120 \mathrm{~m}$ as the lavas prograded into the Naajaat Lake basin to form foresetbedded hyaloclastites and subaqueous lava tongues that ended up ponded against the hills of the Disko Gneiss Ridge. Unit 451 is delimited to the west by the Kuugannguaq-Qunnilik fault system, but may have continued farther west. The unit can be followed for a few kilometres northwards in the east side of Steenstrup Dal. It has not been investigated south of the main river in Stordal. The unit is tentatively estimated to cover $c .40$ $\mathrm{km}^{2}$ with a mean thickness of $c .35-45 \mathrm{~m}$ and a volume between 1.5 and $2 \mathrm{~km}^{3}$.

The lower boundary of unit 451 is marked by lateritic claystone deposited on picritic lava flows of the Ordlingassoq Member or evolved flows of the Qordlortorssuaq Member. Going eastwards, lavas, hyaloclastites and subaqueous flows of unit 451 overlie first subaerial picrite flows and hyaloclastites of the Ordlingasoq Member, and then kaolinised Precambrian gneiss ( $\mathrm{Ka}$ at $34-35 \mathrm{~km}$ in Fig. 183). 


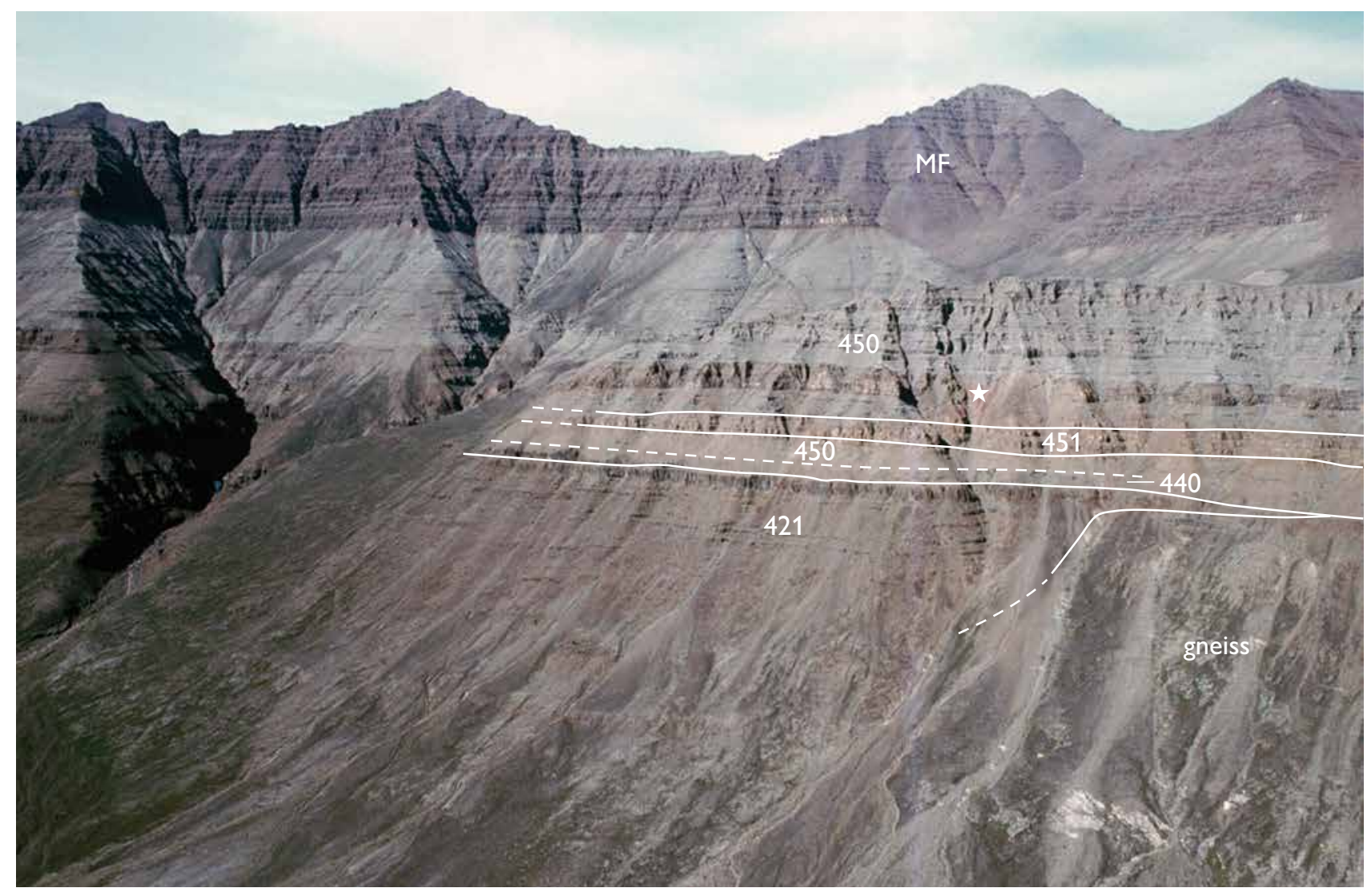

Fig. 184. The northern wall of Stordal, central Disko, showing the various units present. The picture corresponds approximately to the section shown in Fig. 183 at 27-30 km but is seen from a different angle. The units annotated in this picture can also be found in Fig. 183, and the crater site (located at the white star) is a good starting point. The marker unit of crustally contaminated basalts (unit 451) is labelled i in Fig. 183.
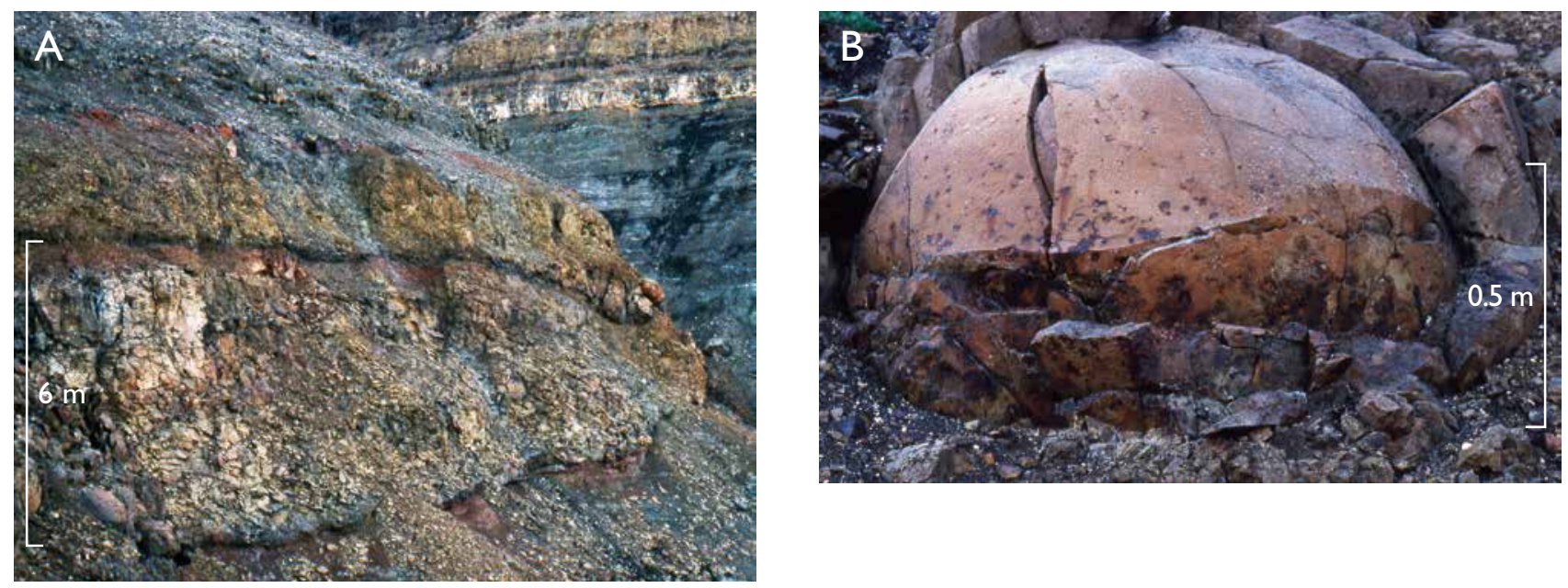

Fig. 185. The most silicic lava flow of unit 451 at Ametystskrænten, with $52.7 \mathrm{wt} \% \mathrm{SiO}_{2}$. A: The 6-8 m thick flow (with scale) which carries native iron and troilite in its lower part. The overlying flow is from the same unit but does not carry native iron. Flow tops are red-oxidised, and flow bases are black. Spheroidal jointing, as in B, is weakly developed in the lower left part of the photo. B: The diffuse zone of accumulation of native iron and troilite about $0.5-1 \mathrm{~m}$ above the base of the flow. The zone is situated at the level of the scale, and the metal and sulfide grains are seen as black specks and patches in the light brown silicate matrix. Note spheriodal jointing in this part of the flow, controlling the rounded shape of the exposure. 


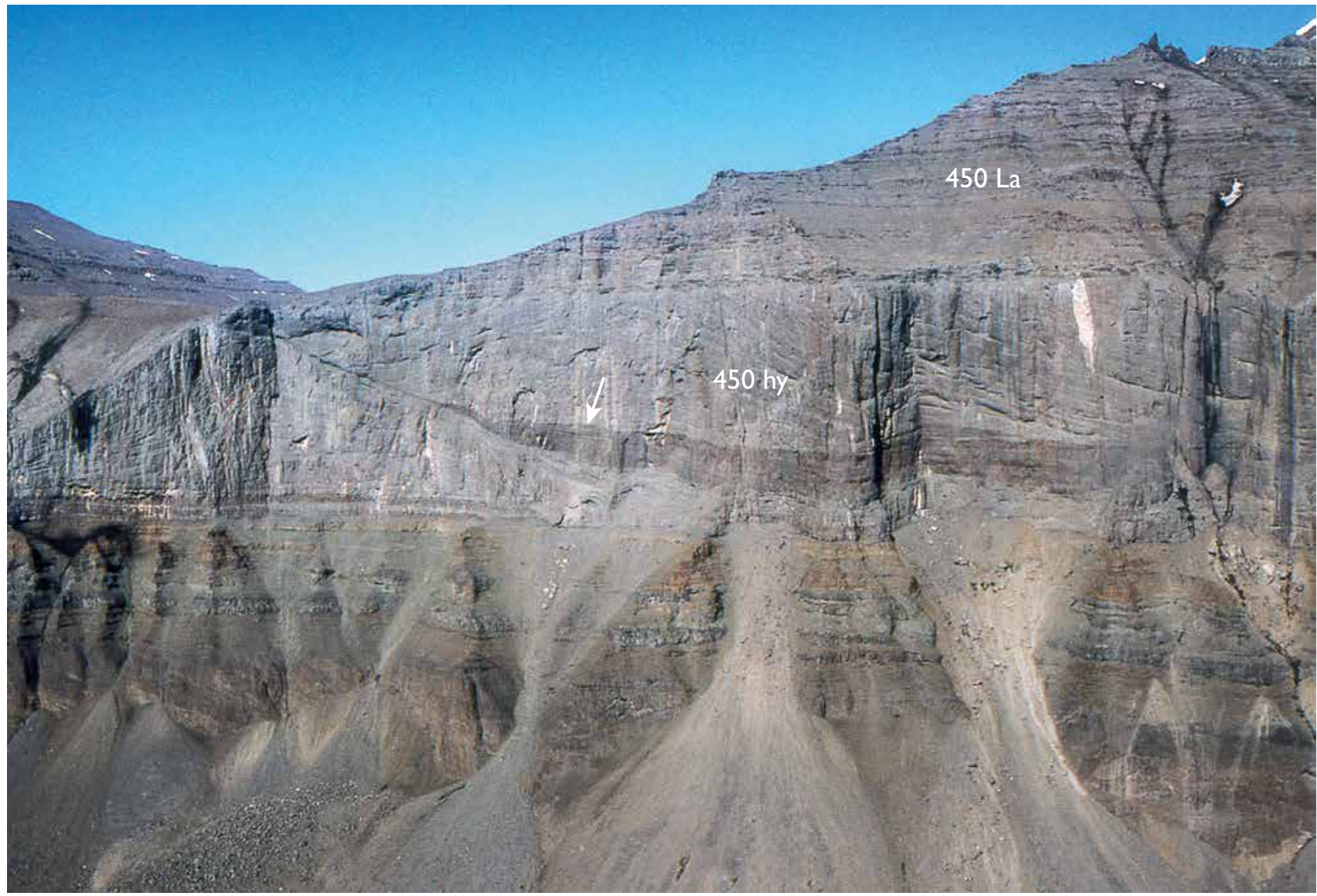

Fig. 186. The steep coastal cliff on the south coast of Nuussuaq between Nuuk Qiterleq and Tupaasat, at 27-29 km on the South Nuussuaq section. The hyaloclastites of the Ordlingassoq Member ( $450 \mathrm{hy}$ ) contain a distinctly brown unit which has not been sampled (at arrow).

The upper boundary is marked by a few decimetres of lateritic claystone covered by picritic lava flows of the main Ordlingassoq Member.

Lithology. Unit 451 is composed of crustally contaminated magnesian basaltic andesites and picrites with $9-15 \mathrm{wt} \% \mathrm{MgO}$. The most common lithology is vesiculated pahoehoe flows which weather with a characteristic light brownish colour (Fig. 184). The rocks are olivine microphyric and the olivine is generally altered. In addition, the rocks have sparse phenocrysts of orthopyroxene and abundant microphenocrysts of the same mineral. There are also a few spongy plagioclase xenocrysts with sieve-textured cores. No sediment xenoliths have been found in unit 451, but lava flows resting on the gneiss ridge contain scattered gneiss xenoliths which have retained their general texture whereas their potassic feldspar has inverted to sanidine. The most silicic lava (52.7 wt $\% \mathrm{SiO}_{2}$ ) is a 6-8 $\mathrm{m}$ thick flow that carries native iron and troilite, most of which is concentrated in a relatively diffuse accumulation zone from about 0.5 to $1 \mathrm{~m}$ above the base of the flow (Fig. 185). With $11 \mathrm{wt} \% \mathrm{MgO}$, this lava flow is the most magnesian native-iron-bearing rock in the Vaigat Formation and hence of particular economic interest. It is only known from Ametystskrænten (Fig. 16 , profile 25).

In the central part of Stordal (Fig. 183 at c. $34 \mathrm{~km}$ ), the lava flows of unit 451 entered the Naajaat Lake basin to form an up to $80 \mathrm{~m}$ thick succession of foreset-bedded hyaloclastites and strongly columnar-jointed subaqueous flow tongues; the two lithologies were produced from respectively thin and thick flows. The flow tongues are locally piled up against the white grey, deeply weathered and kaolinised Precambrian gneiss.

\section{Brown marker horizons}

The Ordlingassoq Member contains a number of brown, commonly erosion-resistant horizons which can be mapped out as local marker horizons against the more greyish-weathering and crumbling picrite flows. These 


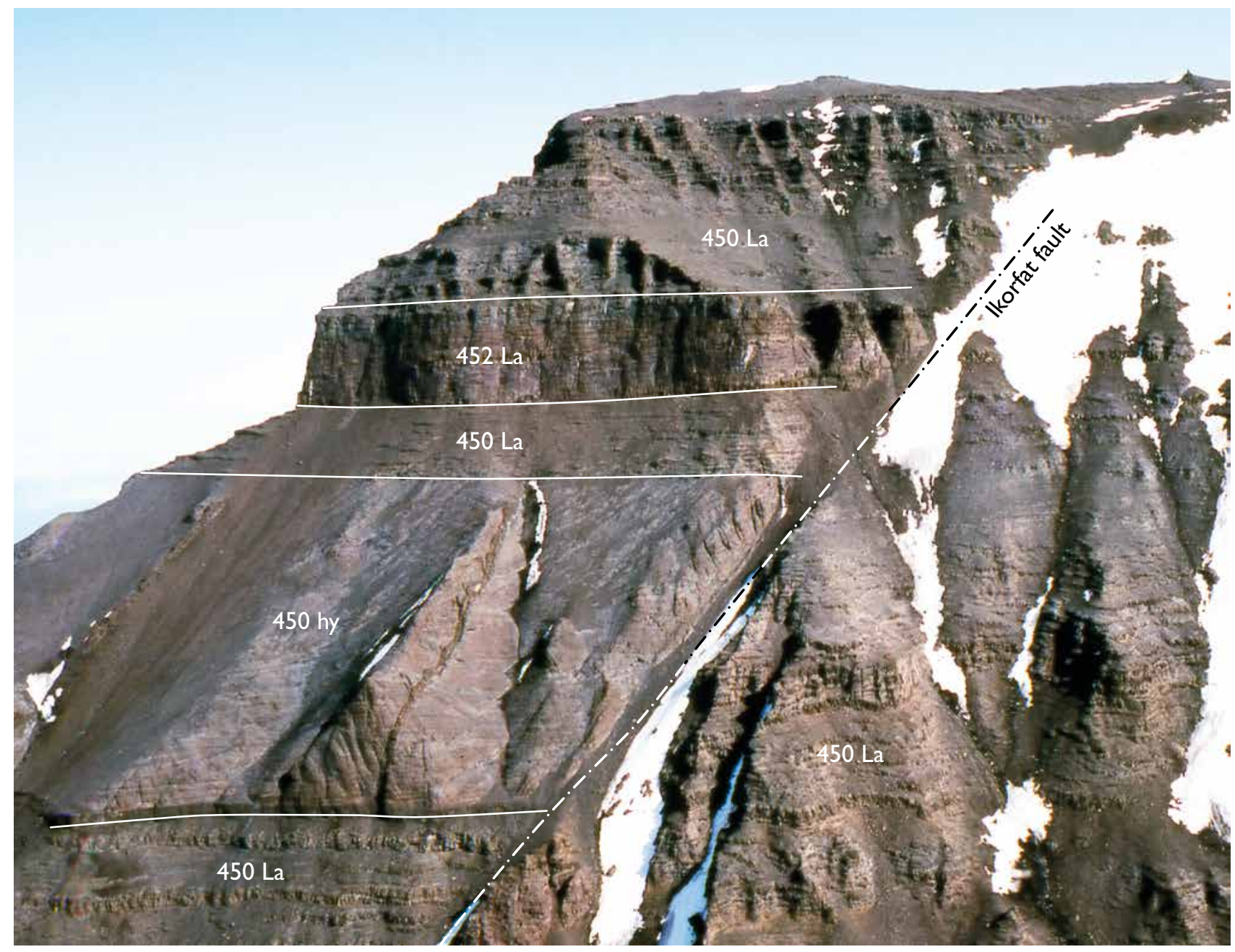

Fig. 187. The volcanic succession on both sides of the Ikorfat fault, northern Nuussuaq, looking east-south-east. Ordlingassoq Member lava flows $(450 \mathrm{La})$ and hyaloclastites $(450 \mathrm{hy})$ are downthrown west of the fault (right side of photo). The succession east of the fault contains a marker horizon ( $452 \mathrm{La}$ ) of erosion-resistant, brownish weathering pahoehoe lava flows in the upper part of the Ordlingassoq Member. The succession is seen in the left part of Fig. 63 and in Fig. 64. Height of the succession left of the fault c. $350 \mathrm{~m}$.

horizons have been sampled at a limited number of localities. They are generally composed of pahoehoe flows of basalt with less than $12 \mathrm{wt} \% \mathrm{MgO}$ but they may also include picrite flows. Some of the brown horizons are compositionally distinct from the main part of the Ordlingassoq Member and have been assigned separate unit codes. Others are not distinct and are coded as the main Ordlingassoq Member (unit 450), whereas still others have not been sampled (Fig. 186). The brown horizons are particularly widespread on Nuussuaq. They are presented in the South Nuussuaq section (several units $i_{M}$ ), the Central Nuussuaq section (units $i_{\mathrm{Ma}}$ and $\mathrm{i}_{\mathrm{Mb}}$ ), the North Nuussuaq section (units $\mathrm{i}_{\mathrm{M}}$ and $\mathrm{i}_{\mathrm{M} 1 \text { to }} 4$; see also Fig. 63) and in Pedersen et al. 2007a (unit $\mathrm{V}_{\text {om }}$ ).
Brown marker horizon in the Stordal area. In Stordal, a grey-brown weathering succession of feldspar-phyric, evolved basalts, some of which are probably slightly contaminated, is situated stratigraphically just below the upper succession of the Manîtdlat Member (Fig. 16, profile 25, samples 264143-144; see also Fig. 203) and 10-60 m above the crustally contaminated basalts of unit 451 (the main succession of the Manitdlat Member is not present here). It is possible that these feldspar-phyric Mg-poor basalts correlate with the non-alkaline, partly contaminated unit 464 that farther north on Disko is intercalated with the Manitdlat Member lava flows (see chapter on the Manitdlat Member), but they are not compositionally similar. The feldspar-phyric basalt succession is about $40 \mathrm{~m}$ thick and has been mapped over a distance of $c .10$ 


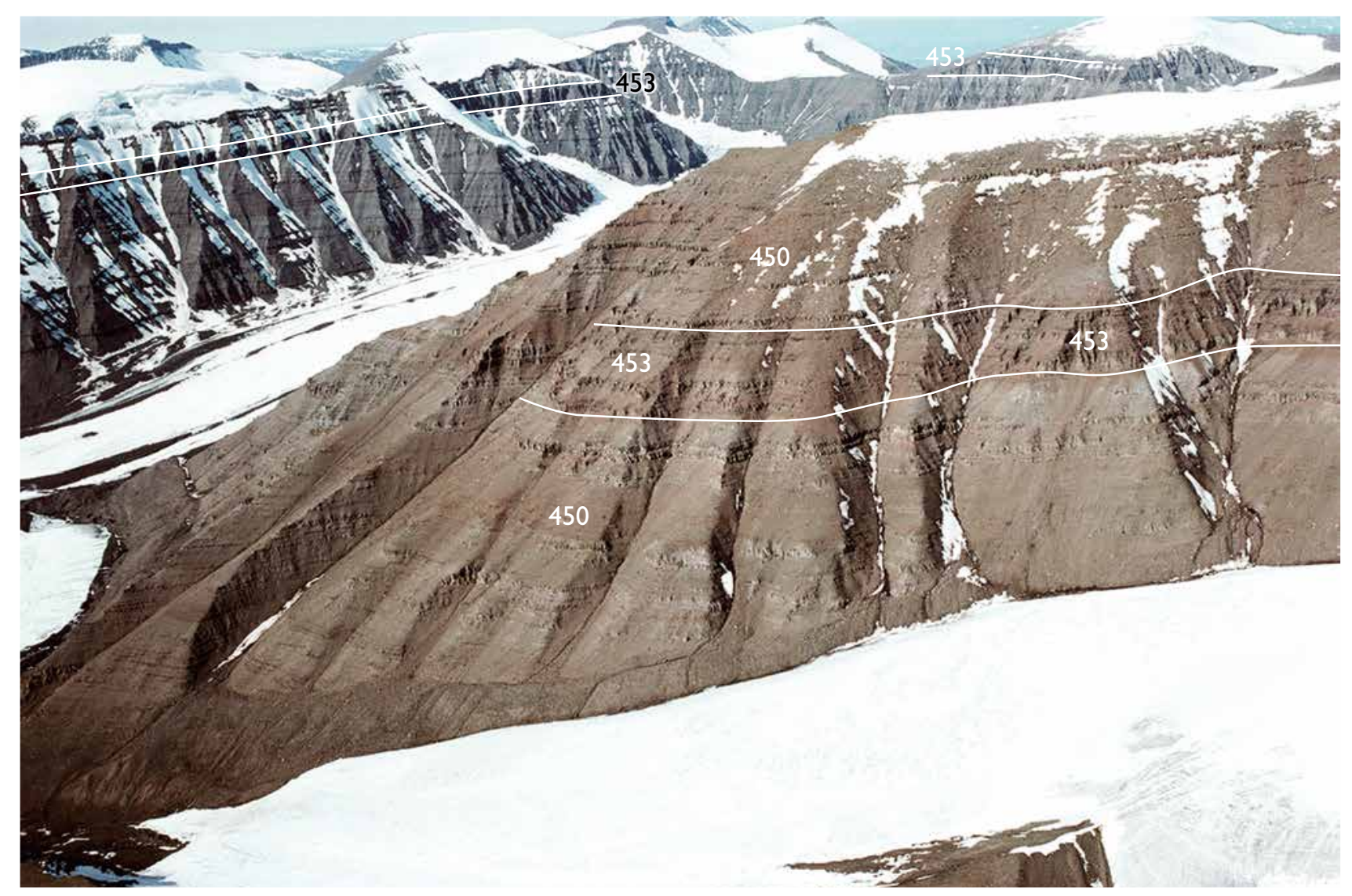

Fig. 188. Marker horizon in the Ordlingassoq Member in the glaciated highland $c .5 \mathrm{~km}$ north-east of Puugutalissuaq, central Nuussuaq, looking north-west. The chemically enriched unit 453 forms a prominent horizon of brown olivine-poor basalts which helps to define the structure of the Ikorfat fault system. The height of the mountain side in the foreground is $c .700 \mathrm{~m}$.

$\mathrm{km}$ in the northern side of Stordal from Ametystskrænten in the west and $10 \mathrm{~km}$ eastwards (Fig. 183 at 25-35 $\mathrm{km}$, unit $\mathrm{i}_{6}$ ). Its extent and volume are estimated to be c. $40 \mathrm{~km}^{2}$ and $c .2 \mathrm{~km}^{3}$, but it may extend much farther to the north-east. At the base of this succession there are traces of claystone. In the lower part there are one or two 10-17 m thick columnar-jointed, fairly massive flows which are covered by several thinner pahoehoe flows all of which are also feldspar-phyric. In Steenstrup Dal and in most of Ametystskrænten, the succession is overlain by the distinctive dark brown pahoehoe lavas of alkaline basalts of unit 465 of the Manîtdlat Member (Fig. 183 at 25-26.5 km; see also Fig. 203). In its eastern part in Stordal, the feldspar-phyric basalt succession is covered by typical picritic flows of unit 450 .

An eruption site within this horizon is seen in Fig. 183 (at $29.5 \mathrm{~km}$ ) and in Fig. 184. It comprises a mass of hightemperature-oxidised pyroclastic rocks and has a vertical extent of $80-100 \mathrm{~m}$. The crater is obscured by later faulting, and the setting of both this crater and the Stordal neck (unit 421) within $1 \mathrm{~km}$ of each other and very close to the steeply rising western margin of the Disko Gneiss Ridge strongly suggests that the older fault zone which created the gneiss ridge was re-activated to channelise the evolved magmas around the end of the Naujánguit Member and the start of Ordlingassoq Member volcanism.

Lower brown marker horizon near Ikorfat (unit 452). Over a distance of about 6 to $7 \mathrm{~km}$ along the north coast of Nuussuaq, from Saviaqqat to just east of Ikorfat, a prominent brownish-weathering lava succession has been sampled and mapped out in the steep mountain wall at a level of about $220 \mathrm{~m}$ above the Tunoqqu Member (North Nuussuaq section, unit $\mathrm{i}_{\mathrm{M} 1}$ at $c .21$ to $31 \mathrm{~km}$; Figs 63, 64). The unit is $40-70 \mathrm{~m}$ thick (Fig. 187) and composed of several flow fields of pahoehoe flows separated by at least one horizon of red lateritic soil. At the eastern side of the glacial valley just south of Ikorfat, unit 452 is underlain by about $40 \mathrm{~m}$ of grey picritic pahoehoe flows above a c. $100 \mathrm{~m}$ thick succession of foreset-bedded grey hyalo- 


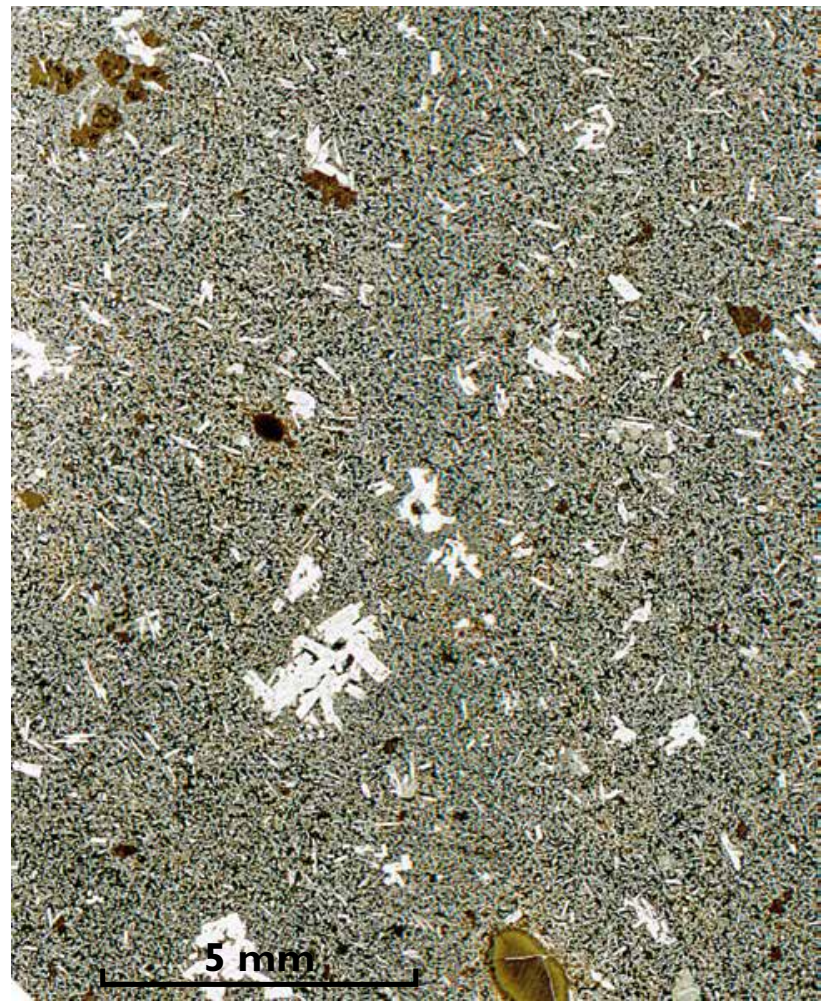

Fig. 189. Thin section (scanned) of evolved basalt from unit 458 near the top of the Vaigat Formation. The rock carries small glomerocrysts of plagioclase, scattered dark brown pseudomorphs of olivine, and small microphenocrysts of clinopyroxene in a fine-grained groundmass. Sample 332820, Paatuut Puiattua, southern Nuussuaq.

clastites created by infilling of a part of the Naajaat Lake basin. It is estimated that the lavas of unit 452 must have entered the lake a few kilometres east of Ikorfat, probably south of Ravn Kløft. Unit 452 is estimated to have covered at least 40 to $50 \mathrm{~km}^{2}$ and to have extended for at least $5 \mathrm{~km}$ to the south of Ikorfat where there are several unsampled brown lava horizons at this level (Fig. 12). The minimum volume of unit 452 is estimated to 2.5 to $3 \mathrm{~km}^{3}$. The unit is composed of basalt with $8-11$ $\mathrm{wt} \% \mathrm{MgO}$ but it also contains a picrite flow with $20 \mathrm{wt} \%$ $\mathrm{MgO}$. Despite their distinctive appearance, the rocks of unit 452 are not compositionally different from the more fractionated parts of the main Ordlingassoq Member. No eruption sites are known.

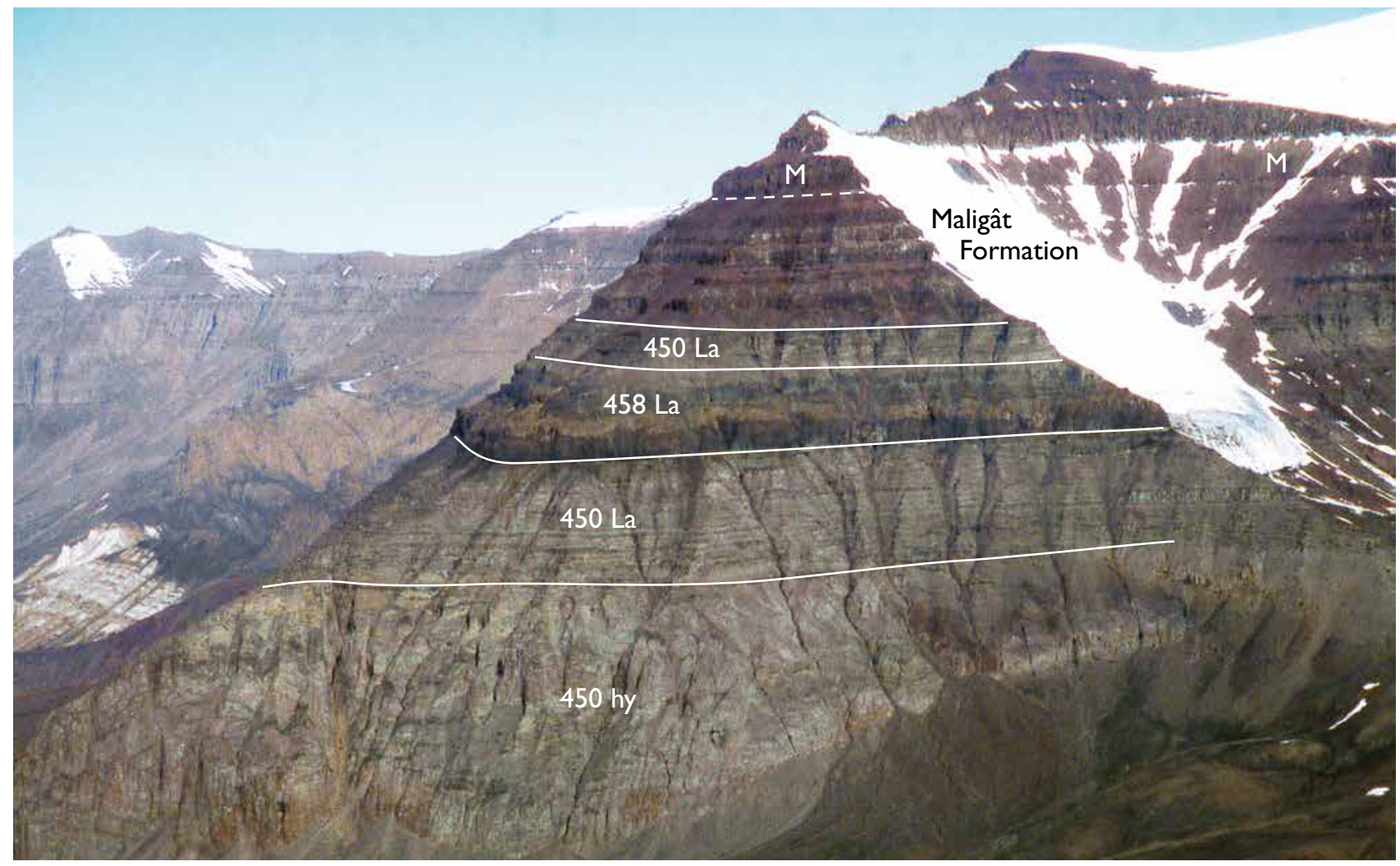

Fig. 190. Evolved basalt lava flows of unit 458 ( $458 \mathrm{La}$ ) near the top of the Ordlingassoq Member just west of Paatuut Puiattua, south-eastern Nuussuaq (South Nuussuaq section at $48-49 \mathrm{~km}$ ). Unit 458 is here $100 \mathrm{~m}$ thick and forms a prominent marker horizon in the upper part of the Vaigat Formation. The Vaigat Formation is overlain by brown lava flows of the Maligât Formation in which a very thick and voluminous flow is labelled M. In the background sediments and volcanic rocks along the south coast of Nuussuaq west of Paatuut Puiattua. 
Upper brown marker horizon around the Ikorfat fault system (unit 453). A lava succession forming a brown marker horizon (unit 453) in the upper part of the Ordlingassoq Member has been sampled and photogrammetrically mapped out along the northern part of the Ikorfat fault system (North Nuussuaq section, unit $\mathrm{i}_{\mathrm{M}}$ at $c .25$ to 28 $\mathrm{km}$; Figs 12, 63, 188). The horizon is situated $500-550$ $\mathrm{m}$ above unit 452 and is separated from the underlying picrites of unit 450 by a few decimetres of lateritic soil. It is $50-75 \mathrm{~m}$ thick and composed of brownish-weathering, erosion-resistant basalts with 9-11 wt $\% \mathrm{MgO}$ and at least one picrite flow with $16 \mathrm{wt} \% \mathrm{MgO}$. The unit has been mapped out over an area of about 150 to $160 \mathrm{~km}^{2}$ in the area between Ikorfat and Agatdalen (Fig. 12) and has an estimated present volume of $c .7 .5 \mathrm{~km}^{3}$. Both extent and volume are minimum estimates as the northern boundary is erosional. The eastern extension is poorly known. Parts of the lavas may be in contact with Precambrian gneiss highs, other parts may have reached their natural limits defined by the erupted volumes, and yet other parts may have entered the Naajaat Lake basin to form hyaloclastites. No eruption sites are known. The lavas of unit 453 are non-alkaline but distinctly geochemically enriched in some trace elements compared to the lavas of the main Ordlingassoq Member (see below). The lavas of unit 453 constitute one of the main marker horizons which can be used to define the structures of the northern part of the Ikorfat fault system, including ramp structures (Fig. 188).

Scattered lavas that deviate compositionally (codes 455 and 456). Geochemically enriched lavas occur sporadically in the Ordlingassoq Member on Nuussuaq; they do not form a regular unit and are not mappable. For the purpose of easy identification, the samples have been assigned a unit code (455). Geochemically depleted lavas also occur sporadically. Some of the most depleted ones occur at the same level at Qilakitsoq and Tunoqqu and probably correlate as a unit; they are not distinguishable lithologically. For the purpose of identification also these have been assigned a unit code (456).

Plagioclase-phyric basalts near the top of the Ordlingassoq Member (unit 458). Near the top of the Ordlingassoq Member on south-eastern Nuussuaq between Ataata Kuua and Paatuut, there is a 50-100 m thick succession of one to three massive, thick entablature lava flows of plagioclase-phyric, evolved basalt with 6-7 wt $\% \mathrm{MgO}$ (unit 458, Fig. 189). The unit forms a prominent marker horizon in the upper part of the Vaigat Formation (Fig.

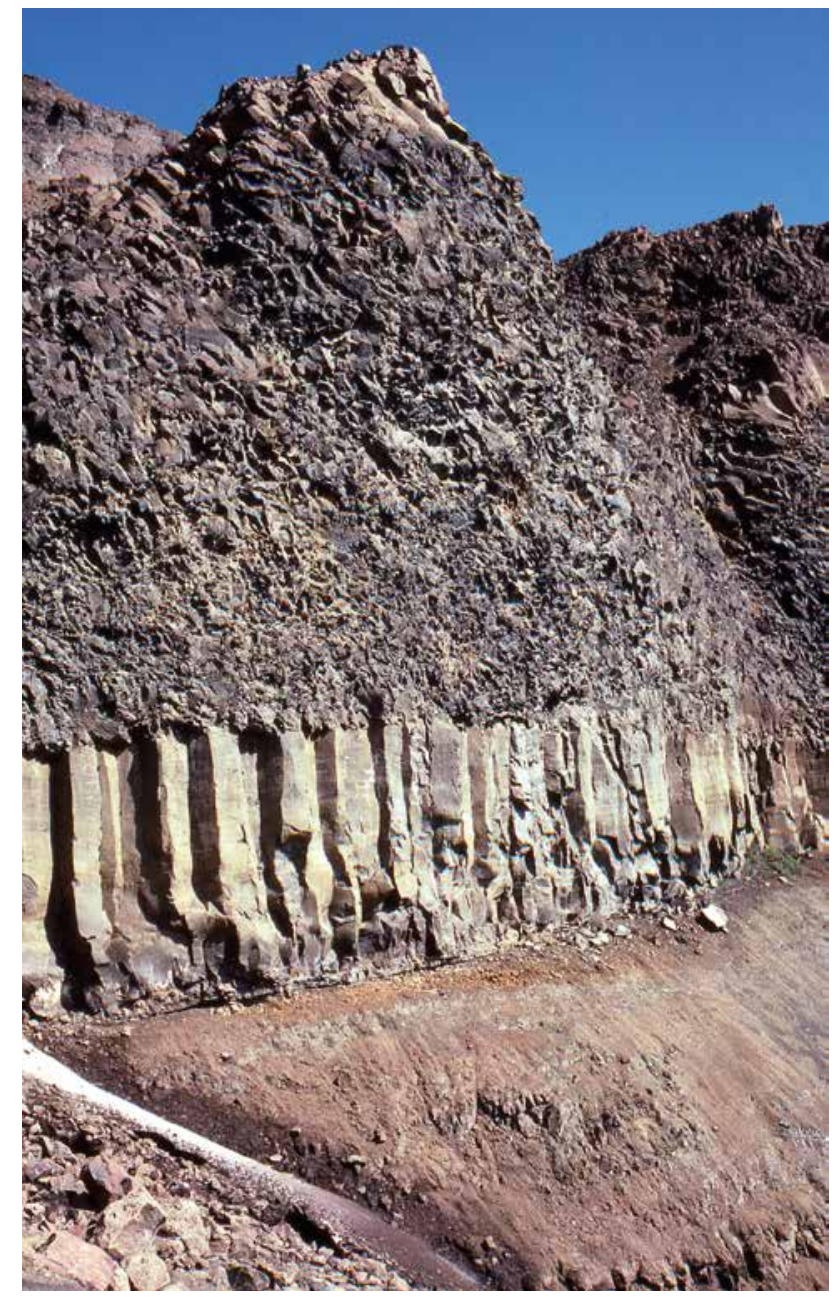

Fig. 191. Feldspar-phyric basalt lava flow with very prominent colonnade and entablature zones from unit 458 in the upper part of the Ordlingassoaq Member at Paatuut Puitattua. The flow rests on thin subaerial picrite flows of unit 450 and is separated from these by $c .40 \mathrm{~cm}$ of light brown claystone with traces of plant fossils. The colonnade is $c .4 \mathrm{~m}$ thick.

$190)$ in the steep mountain wall facing the Vaigat strait (South Nuussuaq section at $42-50.5 \mathrm{~km}$, unit $\mathrm{j}$ ) and has been mapped both along the coast and in the glaciated corries up to $5 \mathrm{~km}$ inland (Pedersen et al. 2007a, b, unit $\mathrm{V}_{\mathrm{f}}$ ). Unit 458 is estimated to have covered more than 60 $\mathrm{km}^{2}$ with an erupted volume in excess of $3.7 \mathrm{~km}^{3}$ (Fig. 12). Eruption sites are not known.

The succession rests on thin, subaerial picrite flows of unit 450 and is separated from these by $c .40 \mathrm{~cm}$ of light brown claystone with traces of plant fossils (Fig. 191).

The upper boundary is eroded and planed and covered by a few centimetres of claystone. In the west unit 458 is overlain by $c .120 \mathrm{~m}$ of grey subaerial picrite flows which 


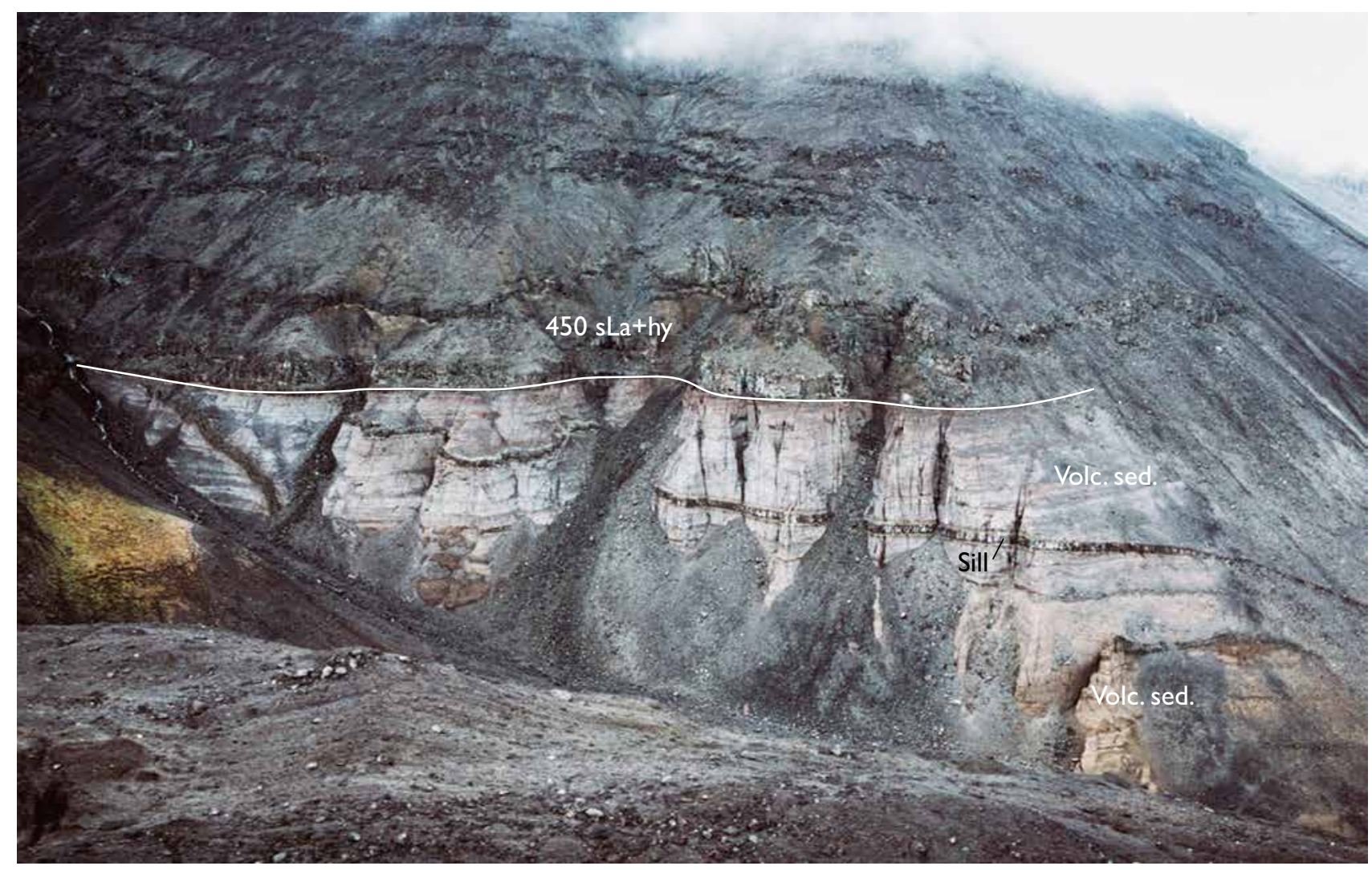

Fig. 192. The upper about two thirds of a c. $200 \mathrm{~m}$ thick succession of volcaniclastic sediments with quartzo-feldspathic beds (Volc. sed.), overlain by picritic subaqueous lava flows and hyaloclastites of the Ordlingassoq Member ( $450 \mathrm{sLa}+\mathrm{hy})$ and cut by dark, Eocene alkali basalt sills. Western side of the gully Qaarsut Kussinersuat about $5 \mathrm{~km}$ south of Qaarsut, north coast of Nuussuaq (North Nuussuaq section at 46-47 km).

in the east around Paatuut Puiattua has decreased to 25 $\mathrm{m}$ of picritic hyaloclastite underlain by claystone. Near its eastern end the upper boundary is covered by scree which may hide mudstone sediments. The eastern end of unit 458 is situated east of Paatuut Puiattua and is completely covered by scree; therefore the exact relation to the basalts of the Maligât Formation is not clear.

Over most of the area, the lava flows of unit 458 are characterised by distinct colonnades and very prominent entablature zones indicative of cooling in a wet environment (Fig. 191). At the only locality investigated in detail (Paatuut Puiattua, Fig. 15, profile 19), there are two lava flows with traces of claystone between them, indicating a time lapse between their emplacements, but otherwise they are chemically and petrographically identical. The basalts of unit 458 carry small glomerocrysts of plagioclase, scattered pseudomorphs of olivine and small microphenocrysts of clinopyroxene (Fig. 189); they are indistinguishable from typical Maligât Formation basalt.

\section{Volcaniclastic and quartzo-feldspathic sediments south of Qaarsut}

A succession of volcaniclastic sediments is exposed between $c .950$ and $1200 \mathrm{~m}$ altitude in the western side of the gully Qaarsut Kussinersuat about $5 \mathrm{~km}$ south of Qaarsut on the north coast of Nuussuaq (North Nuussuaq section at $46-47 \mathrm{~km}$ ). The sediments are light greyish to distinctly brownish in colour and are covered by several hundred metres of subaqueous lava flows and hyaloclastites of Ordlingassoq Member unit 450 (Fig. 192). The succession at $980-1045 \mathrm{~m}$ a.s.l. was visited and sampled during a brief reconnaissance helicopter landing in 2005, and the entire succession was visited during field work in 2017. The volcaniclastic sediments rest on sandstone-dominated Lower Cretaceous deposits overlain by grey mudstones; the age of these mudstones has not yet been established. The lowermost part of the exposures at 980-1045 m (Fig. 193) consists of brownishweathering volcaniclastic sediments composed of fragmented and reworked basalt (some plagioclase-phyric) and dolerite clasts ranging in size from less than $1 \mathrm{~mm}$ to 
Fig. 193. The lower part of a succession of volcaniclastic sediments (Volc. sed.) with Eocene alkali basalt intrusions (Alk. bas. int., black). In the middle part of the sediments shown here, there is a c. $20 \mathrm{~m}$ thick light grey horizon consisting of mixed volcaniclastic beds and siltstone and quartzo-feldspathic beds. Western side of the gully Qaarsut Kussinersuat about $5 \mathrm{~km}$ south of Qaarsut, north coast of Nuussuaq.

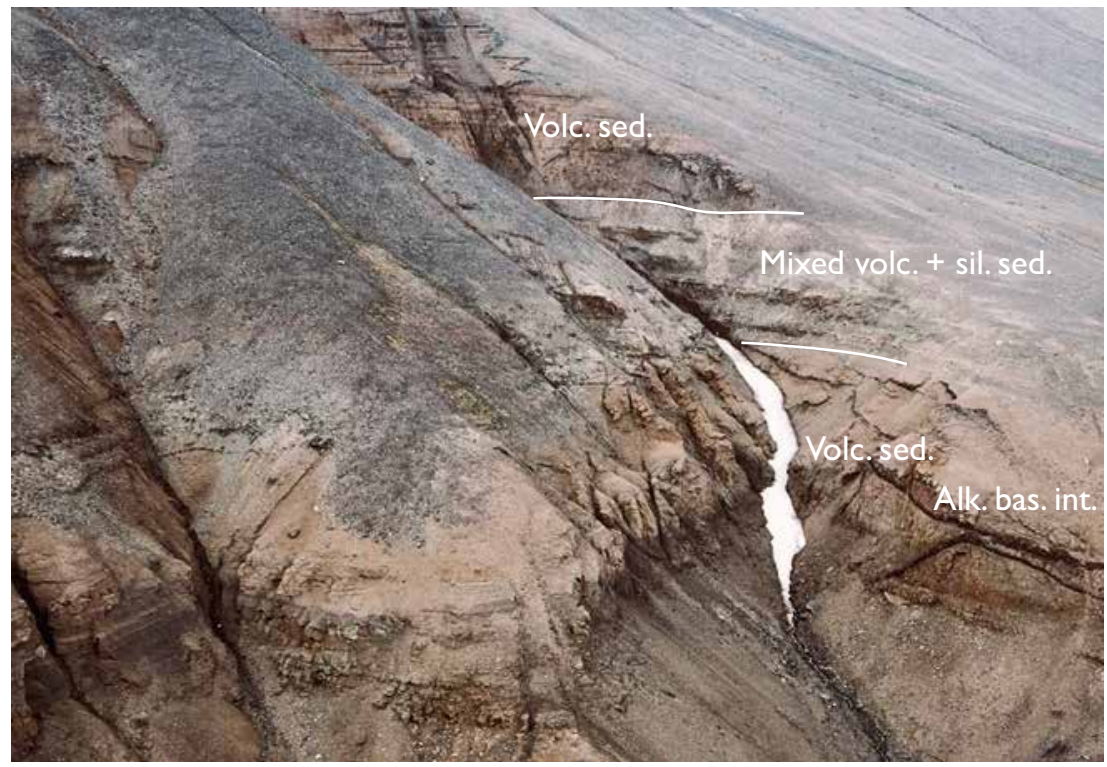

a few centimetres and comprising both sharp-edged and well-rounded forms. In addition the sediment contains millimetre-sized aggregates of quartz and feldspar derived from gneiss. The sediment also contains very wellrounded and polished pebbles of basalt and fragments of silicified wood.

Higher up, a c. $20 \mathrm{~m}$ thick horizon occurs which, in addition to volcaniclastic sediment, also contains intervals almost devoid of a volcanic component (Fig. 193). These intervals consist of interbedded light grey quartzofeldspathic sandstones and dark grey to black mudstones. Thin layers and fragments of coal also occur. Some of these beds can be followed laterally for several hundred metres. The decimetre-thick beds of fine-grained laminated sandstone show very platy weathering (Fig. 194). In the microscope, the mudstones show thin coarseningupward beds.

The horizon with quartzo-feldspathic sediments is overlain by brownish-weathering volcaniclastic debris flows with up to $0.5 \mathrm{~m}$ large lava clasts that comprise both picritic and basaltic lithologies.

Interpretation. The quartzo-feldspathic sandstones and mudstones were deposited in a body of water, presumably the Naajaat Lake. The sandstones are interpreted as storm deposits indicating proximity to the coast. The source area was an uneven terrain comprising exposed Precambrian gneiss as well as lavas, hyaloclastites and conglomerates of, firstly the Tunoqqu Member plagioclase-phyric and aphyric basalts, and later the overlying Ordlingassoq Member picrites and subordinate basalts.

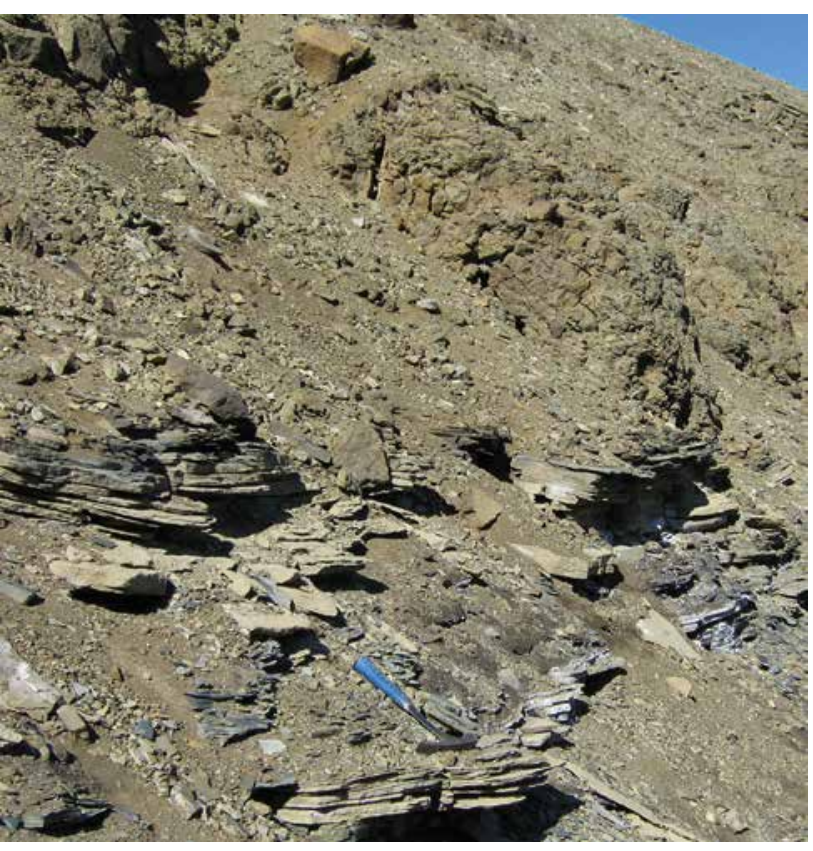

Fig. 194. Volcaniclastic and quartzo-feldspathic sediments south of Qaarsut, Nuussuaq. The sediments comprise decimetre-thick beds of fine-grained, laminated sandstone and mudstone with a distinct platy weathering. The hammer is $32 \mathrm{~cm}$ long. Same locality as Fig. 193, the mixed horizon. 


\section{Chemical composition of the Ordlingassoq Member}

The uncontaminated rocks of the Ordlingassoq Member range from olivine-rich picrites to evolved olivine-plagioclase microphyric, aphyric and distinctly plagioclase-phyric basalts. The rocks are less altered than those of the underlying members, with all volatile contents below 5.5 wt $\%$, mostly below $4 \mathrm{wt} \%$. Mobile elements such as K, Rb and Ba may still be scattered due to alteration, but much of the variation in these elements is of primary origin. Representative chemical analyses are shown in Table 6.

\section{Major elements}

Variation diagrams of the major elements are shown in Fig. 195. The rocks cover a large range in $\mathrm{MgO}, 6-27$ $\mathrm{wt} \%$, which is the same as that seen in the Anaanaa and Naujánguit members, and as in these members there is a strong olivine control. Basalts (with $<12 \mathrm{wt} \% \mathrm{MgO}$ ) are much less frequent in the Ordlingassoq Member than in the earlier members. Although there is some overlap, the $\mathrm{TiO}_{2}$ and $\mathrm{P}_{2} \mathrm{O}_{5}$ contents (at similar $\mathrm{MgO}$ ) are generally higher than in the earlier members, and in this respect they continue the trend towards higher $\mathrm{TiO}_{2}$ and $\mathrm{P}_{2} \mathrm{O}_{5}$ with time seen in the Naujánguit Member (Fig. 152). Some trace-element-enriched rocks shown with a separate symbol in Fig. 195 do not have major-element compositions that deviate significantly from the main suite of rocks, whereas some depleted rocks clearly have low contents of $\mathrm{TiO}_{2}$ and $\mathrm{P}_{2} \mathrm{O}_{5}$.

The two brown marker horizons in the Ikorfat area (units 452 and 453) are mainly basalts with 9-12 wt\% $\mathrm{MgO}$ but each of them also contains a picrite flow. Chemically, the lower horizon is similar to the normal Ordlingassoq Member basalts, whereas the upper horizon has high, but not extreme, $\mathrm{K}_{2} \mathrm{O}$ and $\mathrm{P}_{2} \mathrm{O}_{5}$.

The plagioclase-phyric basalts (unit 458) near the top of the member, with 6-7 wt $\% \mathrm{MgO}$, are the most evolved of all the Ordlingassoq Member rocks. They show evidence of some plagioclase fractionation in their low $\mathrm{CaO}$ and $\mathrm{Al}_{2} \mathrm{O}_{3}$ and high $\mathrm{TiO}_{2}$ and are chemically indistinguishable from many lavas of the Maligât Formation (Pedersen et al. 2018).

The crustally contaminated rocks of unit 451 have increased $\mathrm{SiO}_{2}$ and $\mathrm{K}_{2} \mathrm{O}$ and decreased $\mathrm{CaO}, \mathrm{FeO}^{*}$ and $\mathrm{TiO}_{2}$ similar to the contaminated rocks in the earlier members. The Sr-Nd isotopes indicate between $10 \%$ and $20 \%$ contamination (Fig. 160).

\section{Trace elements}

Variation diagrams for trace elements are shown in Figs 196, 197. As in the earlier members, olivine (and chromite) control is the dominant feature, making all elements except $\mathrm{Ni}, \mathrm{Co}$ and $\mathrm{Cr}$ incompatible and thus increasing with decreasing $\mathrm{MgO}$. Compared to the earlier members, the Ordlingassoq Member shows a greater compositional scatter and in particular includes rocks with higher contents of $\mathrm{Ba}, \mathrm{Sr}, \mathrm{Zr}, \mathrm{Nb}$ and LREE. The scatter does not have any apparent stratigraphic or regional significance.

It is notable that the contaminated rocks of unit 451 have higher contents of $\mathrm{Zr}$ and LREE than the uncontaminated rocks, and $\mathrm{Nb}$ is not decreased. They show considerable fractionation of $\mathrm{Cu}, \mathrm{Ni}$ and $\mathrm{Co}$, and their high $\mathrm{Cr}$ contents suggest uncontaminated precursors with $15-20$ wt $\%$ MgO.

REE and multi-element diagrams are shown in Fig. 198. For the main suite (unit 450), most REE patterns show geochemical depletion in the most incompatible elements, with normalised $\mathrm{La} / \mathrm{Sm}(\mathrm{La} / \mathrm{Sm})_{\mathrm{N}}<1$, similar to the earlier members, with culminations around $\mathrm{Nd}$ or $\mathrm{Sm}$ as in the highest Naujánguit Member unit. The parallel arrangement of the patterns is due to variable degrees of fractionation ( $\mathrm{MgO}$ contents). The scatter at the LREE end is significantly larger than in the earlier members and a number of samples are geochemically enriched and have $(\mathrm{La} / \mathrm{Sm})_{\mathrm{N}}>1$. Similarly, the multielement diagrams show fractionation-induced parallelism in the $\mathrm{Sm}-\mathrm{Yb}$ part and more scatter in the $\mathrm{Rb}-\mathrm{La}$ part. The $P$ troughs vary greatly in size and a few samples even have a $\mathrm{P}$ peak. Similarly, the $\mathrm{K}$ troughs are also of different sizes although the $\mathrm{K}$ peak in one sample is probably due to secondary alteration. The most $\mathrm{Mg}$-rich and trace-element-poor sample has increased $\mathrm{Rb}$, ascribed to alteration, and increased Ta which may be contamination from the grinding mill. The three most evolved samples have higher $\mathrm{Ba}$ than expected from fractionation alone.

The evolved plagioclase-phyric sample (unit 458) has the highest middle to heavy REE, Zr, Hf and Ti contents, but not the highest $\mathrm{Ba}-\mathrm{La}$ contents. In this respect it is more 'depleted' in the most incompatible elements than most samples of the main Ordlingassoq Member and is more like the Maligât Formation basalts. It has not fractionated enough plagioclase to develop a Eu trough. The Ti-depleted unit (456) is also depleted in the middle $\mathrm{REE}, \mathrm{Sr}, \mathrm{P}, \mathrm{Zr}$ and $\mathrm{Hf}$, but not in the most incompatible elements $\mathrm{Rb}-\mathrm{La}$. These two patterns are thus tilted in opposite directions.

Two samples from the lower brown unit (452) near Ikorfat are quite different despite similar $\mathrm{MgO}$ contents 

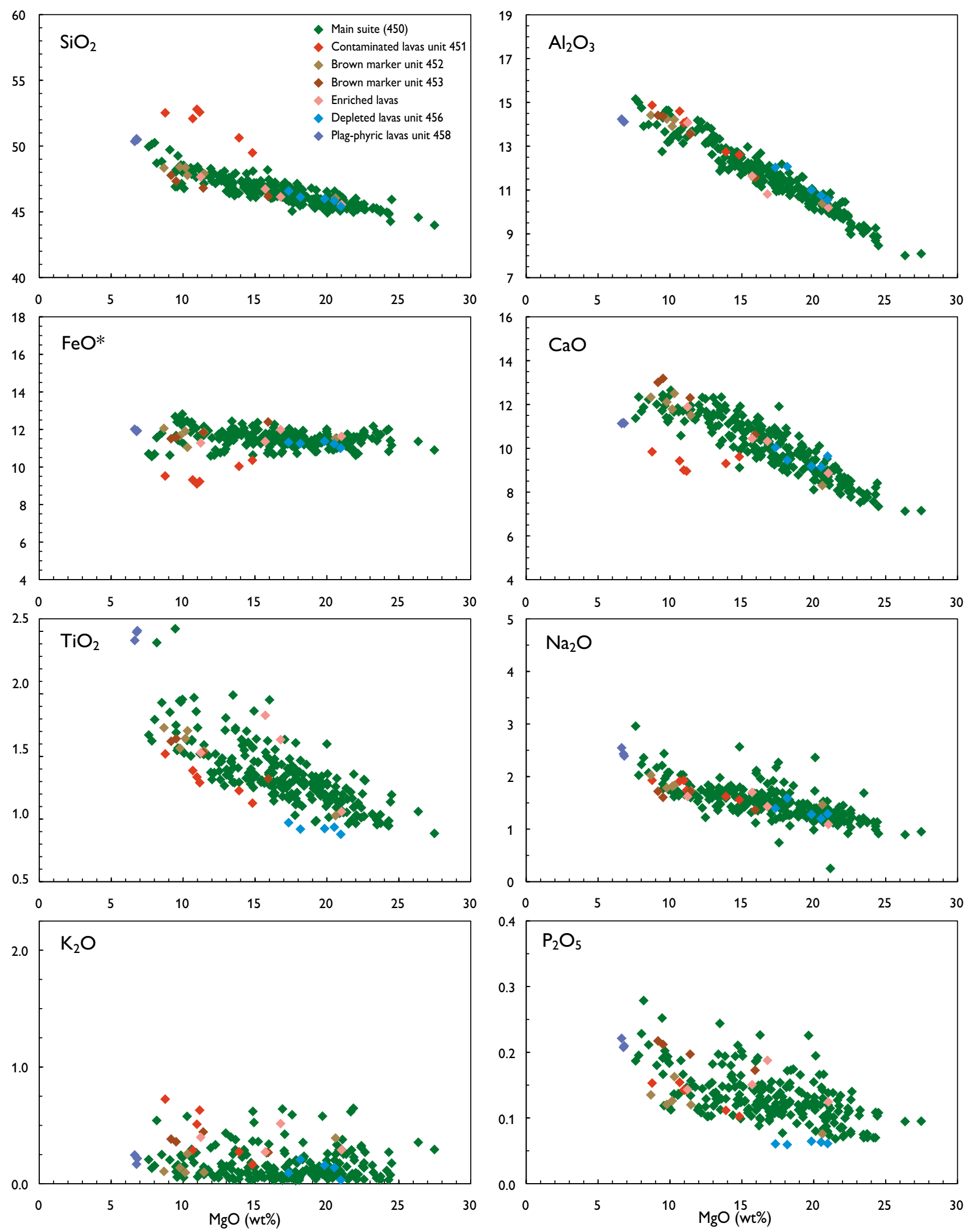

Fig. 195. Major-element variation diagrams for rocks of the Ordlingassoq Member. Data in wt\% oxides calculated volatile-free. FeO* is total iron as $\mathrm{FeO}$. 

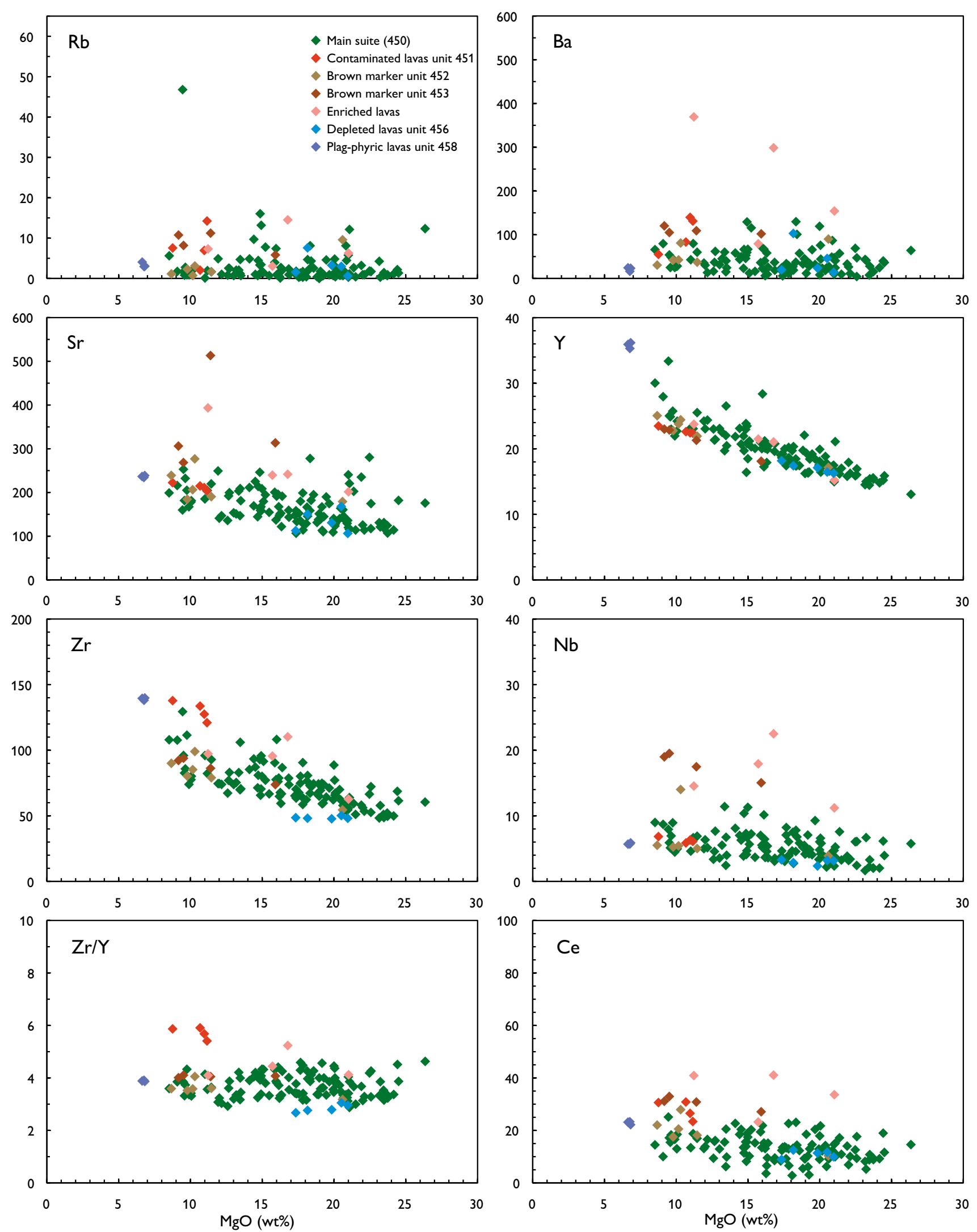

Fig. 196. Incompatible trace-element variation diagrams for rocks of the Ordlingassoq Member. Data in ppm. 

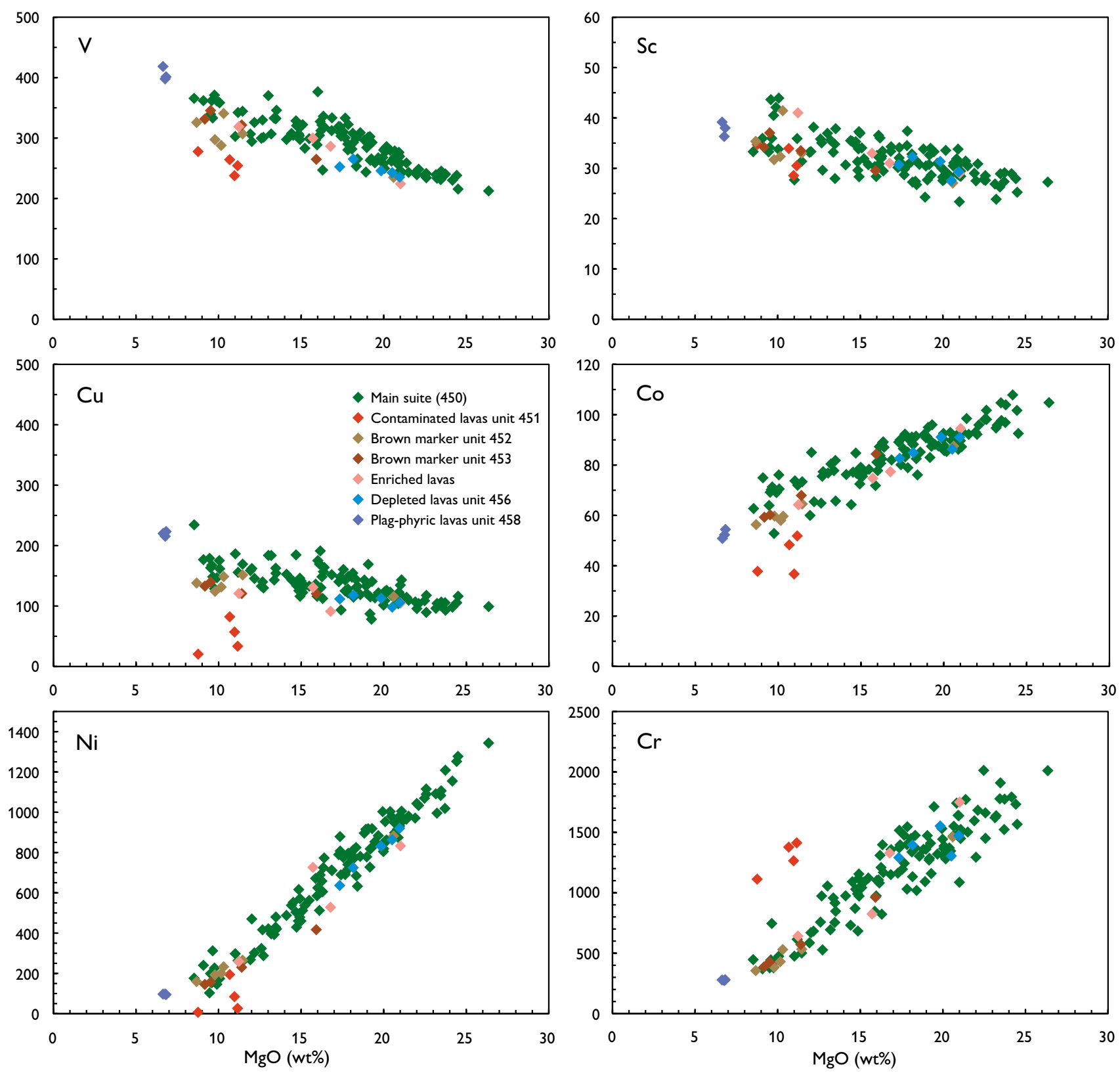

Fig. 197. Transition-element variation diagrams for rocks of the Ordlingassoq Member. Data in ppm.

(10.1 and $10.3 \mathrm{wt} \%)$. One sample is indistinguishable from the main suite whereas the other (400403) is systematically enriched in the most incompatible elements $\mathrm{Ba}-\mathrm{Nd}$ and in particular in $\mathrm{Nb}-\mathrm{Ta}$. It appears to be the only enriched lava in the unit (Fig. 196).

The upper brown unit (453) near Ikorfat is significantly enriched in all trace elements except the least incompatible, and it is particularly enriched in $\mathrm{Nb}-\mathrm{Ta}$.

A brown basaltic hyaloclastite sample from a profile on Mellemfjeld is compositionally indistinguishable from the main Ordlingassoq suite (Fig. 198, sample 400364).
The crustally contaminated rocks in Stordal (unit 451) have increased $\mathrm{Rb}-\mathrm{U}$ and $\mathrm{K}-\mathrm{LREE}$ and ensuing $\mathrm{Nb}-\mathrm{Ta}$ troughs. Also $\mathrm{Pb}$ and $\mathrm{Zr}-\mathrm{Hf}$ are increased. Compared to the contaminated rocks of the second volcanic episode they are most similar to those of the Asuk Member.

Some single lava flows that are not lithologically distinguishable from the main suite of lavas are considerably enriched in incompatible elements. On Disko, some lava flows and hyaloclastites situated immediately above the alkaline Manitdlat Member, and a feeder dyke crossing it, are evidently contaminated by rocks or remain- 

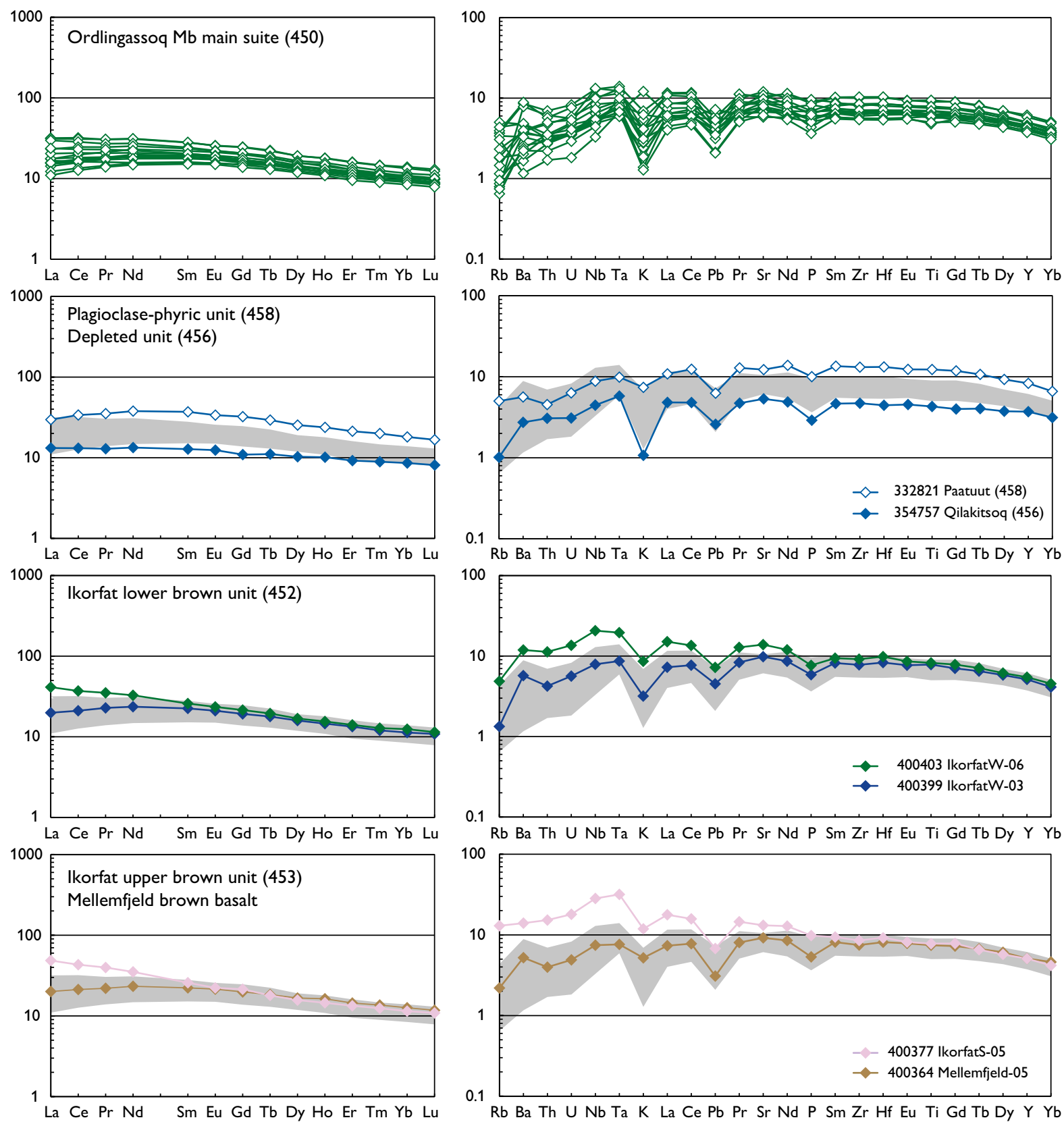

Fig. 198 (first of two parts). REE and multi-element diagrams for representative rocks of the Ordlingassoq Member. Left diagrams, chondrite normalised; right diagrams, primitive mantle normalised; normalisation factors from McDonough \& Sun (1995). The grey fields in the diagrams for the minor units show the fields for the main suite (unit 450) of the Ordlingassoq Member. Note that the brown marker unit 452 comprises rocks of completely 'normal' composition alongside enriched rocks; the brown unit 453 comprises only enriched rocks, and the brown unit in Mellemfjeld is compositionally normal and has not been assigned a separate unit code.

ing magma pools of this member (Fig. 198). The dyke (sample 326785) was modelled by Larsen et al. (2003) as consisting of $85 \%$ tholeiitic magma and 15\% Manittlat Member type 1a component, whereas the lavas (sample 326790 ) contain $1-3 \%$ of the alkaline component. On Nuussuaq, some scattered lava flows are also enriched, but the enrichment patterns are different and there seems to be no direct relation to the magma types of the Manitdlat Member. One flow (332788) is particularly enriched in $\mathrm{Rb}, \mathrm{Ba}$ and $\mathrm{K}$ but only slightly enriched in $\mathrm{Nb}-\mathrm{Ta}$ and LREE. Another flow (400231) is enriched in Nb-Ta and LREE but not in $\mathrm{Rb}, \mathrm{Ba}, \mathrm{K}$ and $\mathrm{P}$ and is the one geo- 

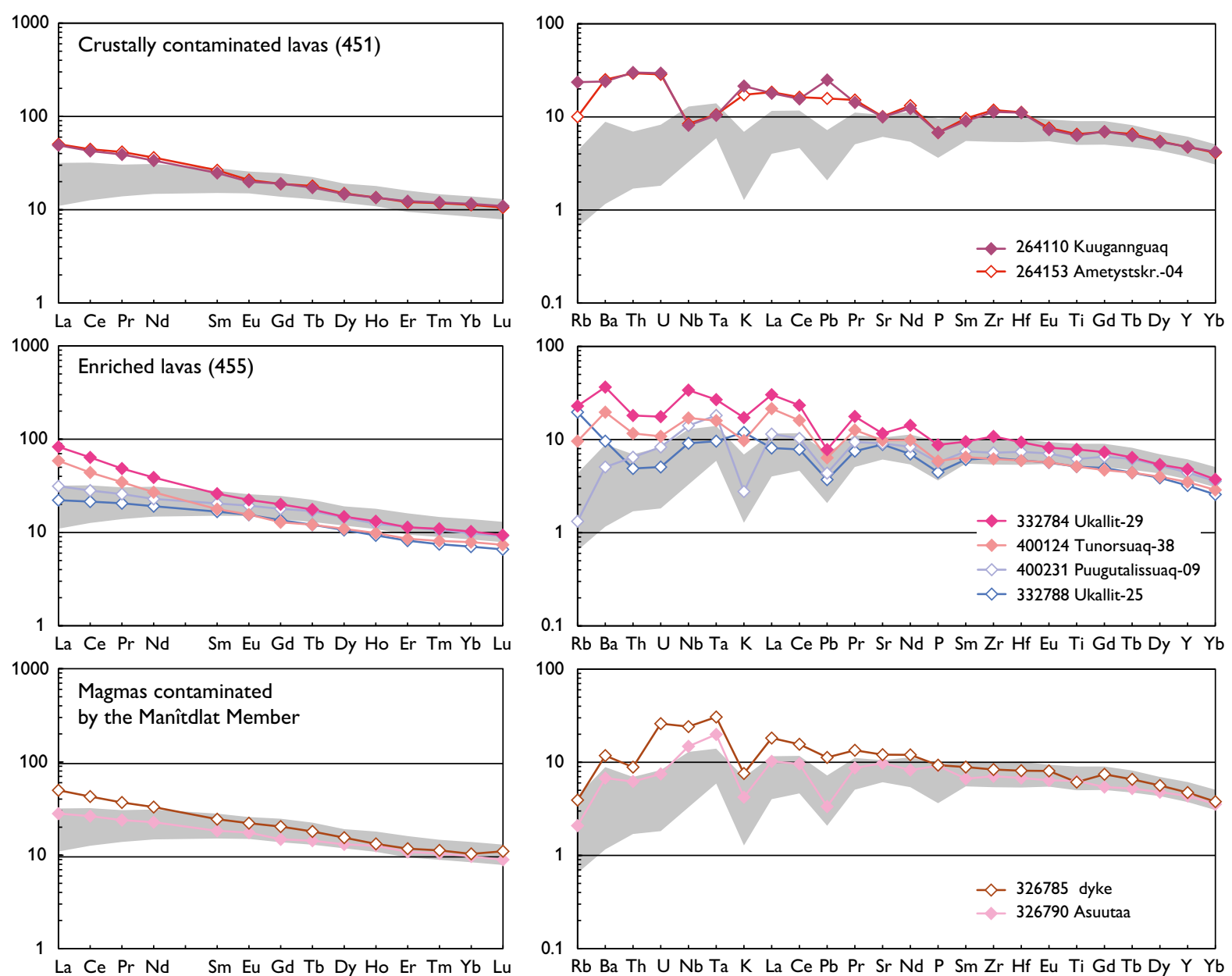

Fig. 198 (second of two parts). REE and multi-element diagrams for representative rocks of the Ordlingassoq Member. Left diagrams, chondrite normalised; right diagrams, primitive mantle normalised; normalisation factors from McDonough \& Sun (1995). The grey fields in the diagrams for the minor units show the fields for the main suite (unit 450) of the Ordlingassoq Member. Note that the brown marker unit 452 comprises rocks of completely 'normal' composition alongside enriched rocks; the brown unit 453 comprises only enriched rocks, and the brown unit in Mellemfjeld is compositionally normal and has not been assigned a separate unit code.

chemically most reminiscent of the Manîtdlat Member. The two most enriched flows $(332784,400124)$ have particularly steep REE patterns.

In summary, the bulk of the Ordlingassoq Member consists of rocks that are slightly more enriched in incompatible elements than the earlier members. In addition, there are scattered occurrences at all levels and locations of rocks with moderate to strong enrichment of incompatible elements and with variable enrichment patterns. These rocks probably represent single small magma batches that became contaminated by spurious reactions with small melt fractions derived from alkaline veins in the sub-crustal lithosphere, as argued by Larsen et al. (2003) for the Manîtdlat Member. 
Table 6a. Chemical analyses of rocks, Ordlingassoq Member

\begin{tabular}{|c|c|c|c|c|c|c|c|c|c|c|c|c|}
\hline \multirow[b]{2}{*}{ Lith. code } & \multicolumn{12}{|c|}{ Main Ordlingassoq Mb samples arranged by MgO; not in stratigraphic order } \\
\hline & 4501 & 4501 & 4502 & 4501 & 4501 & 4501 & 4502 & 4502 & 4502 & 4502 & 4502 & 4502 \\
\hline GGU No. & 332788 & 332901 & 332828 & 400230 & 113333 & 410152 & 340740 & 264137 & 400231 & 326783 & 327100 & 136943 \\
\hline Deg.W & 5338.68 & 5331.14 & 5238.24 & 5306.79 & 5324.61 & 5345.41 & 5258.52 & 5330.41 & 5306.82 & 5325.44 & 5322.63 & 5323.80 \\
\hline Deg. N & 7029.97 & 7022.95 & 7016.48 & 7035.62 & 7001.60 & 7040.28 & 7019.73 & 7004.09 & 7035.60 & 7012.30 & 7010.85 & 7011.55 \\
\hline Altitude, $\mathrm{m}$ & 1370.69 & 1004.03 & 1088.43 & 858.96 & 727.60 & 1098.94 & 698.42 & 574.63 & 837.17 & 421.48 & 817.41 & 729.45 \\
\hline $\mathrm{SiO}_{2}$ & 43.34 & 45.02 & 44.60 & 44.67 & 45.59 & 44.28 & 44.40 & 45.42 & 44.77 & 44.70 & 44.18 & 45.08 \\
\hline $\mathrm{TiO}_{2}$ & 1.03 & 1.14 & 1.01 & 1.05 & 1.19 & 1.23 & 1.18 & 1.14 & 1.24 & 0.96 & 1.25 & 1.17 \\
\hline $\mathrm{Al}_{2} \mathrm{O}_{3}$ & 7.79 & 8.50 & 9.31 & 10.11 & 10.19 & 9.99 & 10.28 & 10.40 & 10.05 & 11.39 & 10.65 & 11.23 \\
\hline $\mathrm{Fe}_{2} \mathrm{O}_{3}$ & 2.45 & 2.72 & 2.88 & 2.68 & 2.96 & 2.92 & 2.24 & 2.36 & 2.72 & 2.84 & 4.46 & 3.63 \\
\hline $\mathrm{FeO}$ & 8.84 & 9.52 & 9.06 & 8.93 & 8.25 & 8.58 & 8.72 & 8.98 & 8.82 & 8.05 & 7.20 & 7.62 \\
\hline $\mathrm{MnO}$ & 0.17 & 0.18 & 0.17 & 0.19 & 0.18 & 0.17 & 0.18 & 0.17 & 0.18 & 0.18 & 0.18 & 0.17 \\
\hline $\mathrm{MgO}$ & 25.62 & 23.17 & 22.23 & 20.61 & 20.30 & 20.06 & 20.03 & 19.84 & 19.29 & 18.81 & 18.70 & 18.48 \\
\hline $\mathrm{CaO}$ & 6.93 & 7.41 & 8.38 & 8.85 & 8.57 & 8.61 & 9.93 & 8.66 & 9.65 & 9.93 & 9.93 & 9.59 \\
\hline $\mathrm{Na}_{2} \mathrm{O}$ & 0.87 & 1.26 & 1.02 & 1.37 & 1.26 & 1.43 & 1.28 & 1.38 & 1.41 & 1.32 & 1.26 & 1.30 \\
\hline $\mathrm{K}_{2} \mathrm{O}$ & 0.345 & 0.154 & 0.037 & 0.062 & 0.090 & 0.245 & 0.048 & 0.12 & 0.080 & 0.054 & 0.082 & 0.18 \\
\hline $\mathrm{P}_{2} \mathrm{O}_{5}$ & 0.092 & 0.103 & 0.075 & 0.078 & 0.128 & 0.139 & 0.163 & 0.12 & 0.117 & 0.104 & 0.135 & 0.09 \\
\hline Volatiles & 2.51 & 0.82 & 1.07 & 0.79 & 1.12 & 2.17 & 1.28 & 1.18 & 1.05 & 2.21 & 2.42 & 1.44 \\
\hline Sum & 99.98 & 100.00 & 99.83 & 99.38 & 99.83 & 99.82 & 99.73 & 99.77 & 99.38 & 100.55 & 100.45 & 99.98 \\
\hline Zn & 77 & 82 & 91 & 76 & 86 & 71 & 84 & 95 & 86 & 86 & 86 & 81 \\
\hline $\mathrm{Cu}$ & 96 & 108 & 88 & 113 & 113 & 107 & 121 & 124 & 120 & 113 & 85 & 141 \\
\hline Co & 102 & 98 & 100 & 90 & 86 & 79 & 91 & 84 & 86 & 88 & 81 & 91 \\
\hline $\mathrm{Ni}$ & 1306 & 1095 & 1098 & 908 & 935 & 769 & 986 & 848 & 867 & 802 & 710 & 880 \\
\hline $\mathrm{Sc}$ & 27 & 25 & 28 & 28 & 30 & 28 & 28 & 33 & 30 & 32 & 30 & 33 \\
\hline V & 207 & 229 & 238 & 254 & 263 & 236 & 275 & 281 & 262 & 258 & 295 & 291 \\
\hline $\mathrm{Cr}$ & 1955 & 1606 & 1636 & 1486 & 1447 & 1688 & 1347 & 1260 & 1295 & 1260 & 1240 & 1334 \\
\hline $\mathrm{Ga}$ & 9 & 12 & 15 & 14 & 14 & 12 & 13 & 17 & 15 & 13 & 19 & 16 \\
\hline $\mathrm{Rb}$ & 11.8 & 1.43 & 1.84 & 0.67 & 0.57 & 10.2 & 0.45 & 2.04 & 0.80 & 0.45 & 1.10 & 0.87 \\
\hline $\mathrm{Sr}$ & 176 & 149.11 & 121 & 134.28 & 158 & 160 & 147 & 135 & 181 & 116 & 170 & 132 \\
\hline$Y$ & 13.8 & 15.0 & 16.1 & 16.8 & 17.0 & 15.9 & 17.7 & 18.0 & 19.0 & 18.7 & 18.1 & 19.3 \\
\hline $\mathrm{Zr}$ & 66.6 & 64.0 & 56.6 & 55.2 & 59.0 & 64.2 & 69.2 & 62.7 & 75.8 & 57.4 & 74.4 & 65.4 \\
\hline $\mathrm{Nb}$ & 6.01 & 4.53 & 2.16 & 3.01 & 2.92 & 5.71 & 5.01 & 3.32 & 9.29 & 3.59 & 6.52 & 3.65 \\
\hline Cs & 0.024 & 0.008 & 0.025 & 0.003 & 0.005 & 0.237 & 0.005 & 0.026 & 0.009 & 0.005 & 0.029 & 0.019 \\
\hline $\mathrm{Ba}$ & 63.5 & 47.3 & 7.66 & 19.5 & 14.7 & 60.1 & 21.8 & 21.7 & 33.5 & 15.7 & 26.3 & 25.1 \\
\hline $\mathrm{La}$ & 5.26 & 4.48 & 2.60 & 2.96 & 2.90 & 5.26 & 4.54 & 3.71 & 7.42 & 3.95 & 5.62 & 3.67 \\
\hline $\mathrm{Ce}$ & 13.1 & 11.9 & 7.75 & 8.41 & 8.26 & 13.3 & 12.0 & 9.98 & 17.3 & 9.92 & 14.13 & 10.1 \\
\hline $\operatorname{Pr}$ & 1.91 & 1.76 & 1.29 & 1.31 & 1.34 & 1.90 & 1.86 & 1.59 & 2.39 & 1.48 & 2.12 & 1.68 \\
\hline $\mathrm{Nd}$ & 8.74 & 8.91 & 6.76 & 7.21 & 7.04 & 9.44 & 9.28 & 8.07 & 10.5 & 7.18 & 10.2 & 8.85 \\
\hline Sm & 2.47 & 2.55 & 2.24 & 2.22 & 2.33 & 2.65 & 2.56 & 2.62 & 3.03 & 2.37 & 3.02 & 2.68 \\
\hline Eu & 0.872 & 0.869 & 0.843 & 0.832 & 0.879 & 0.892 & 0.934 & 0.965 & 1.09 & 0.867 & 1.07 & 0.984 \\
\hline Gd & 2.69 & 2.83 & 2.74 & 2.70 & 2.94 & 2.96 & 3.14 & 3.10 & 3.56 & 2.97 & 3.36 & 3.26 \\
\hline Tb & 0.437 & 0.446 & 0.468 & 0.474 & 0.492 & 0.477 & 0.514 & 0.551 & 0.613 & 0.528 & 0.575 & 0.553 \\
\hline Dy & 2.62 & 2.76 & 2.92 & 2.88 & 3.05 & 2.88 & 3.13 & 3.32 & 3.56 & 3.20 & 3.30 & 3.43 \\
\hline Ho & 0.508 & 0.533 & 0.594 & 0.598 & 0.623 & 0.569 & 0.649 & 0.658 & 0.679 & 0.664 & 0.643 & 0.718 \\
\hline $\mathrm{Er}$ & 1.31 & 1.43 & 1.52 & 1.65 & 1.64 & 1.52 & 1.76 & 1.78 & 1.83 & 1.77 & 1.76 & 1.93 \\
\hline $\mathrm{Tm}$ & 0.185 & 0.200 & 0.221 & 0.229 & 0.235 & 0.224 & 0.242 & 0.242 & 0.262 & 0.263 & 0.245 & 0.275 \\
\hline Yb & 1.13 & 1.26 & 1.35 & 1.50 & 1.45 & 1.42 & 1.63 & 1.55 & 1.58 & 1.68 & 1.44 & 1.66 \\
\hline Lu & 0.162 & 0.189 & 0.194 & 0.224 & 0.207 & 0.207 & 0.254 & 0.214 & 0.225 & 0.232 & 0.213 & 0.248 \\
\hline $\mathrm{Hf}$ & 1.70 & 1.81 & 1.52 & 1.51 & 1.58 & 1.78 & 1.98 & 1.75 & 2.09 & 1.57 & 2.01 & 1.90 \\
\hline $\mathrm{Ta}$ & 0.356 & 0.303 & 0.250 & 0.221 & 0.369 & 0.442 & 0.389 & 0.253 & 0.671 & 0.284 & 0.481 & 0.304 \\
\hline $\mathrm{Pb}$ & 0.557 & 0.523 & 0.312 & 0.545 & 0.320 & 0.569 & 0.531 & 1.08 & 0.654 & 0.801 & 0.894 & 0.525 \\
\hline Th & 0.389 & 0.335 & 0.135 & 0.203 & 0.174 & 0.410 & 0.398 & 0.220 & 0.514 & 0.281 & 0.398 & 0.257 \\
\hline$U$ & 0.103 & 0.098 & 0.037 & 0.057 & 0.059 & 0.099 & 0.112 & 0.074 & 0.169 & 0.083 & 0.109 & 0.075 \\
\hline \multicolumn{13}{|c|}{ Isotope ratios calculated at $60 \mathrm{Ma}$} \\
\hline${ }^{87} \mathrm{Sr}^{8} /{ }^{86} \mathrm{Sr}_{60}$ & \multicolumn{2}{|c|}{0.703315} & \multicolumn{2}{|c|}{0.702943} & \multicolumn{2}{|c|}{0.703261} & \multicolumn{3}{|c|}{0.703262} & 0.703210 & 0.703303 & 0.703198 \\
\hline$\varepsilon S r$ & \multicolumn{2}{|c|}{-17.54} & \multicolumn{2}{|c|}{-22.82} & -18.30 & & & -18.29 & & 19.02 & -17.70 & -19.20 \\
\hline${ }^{143} \mathrm{Nd} /{ }^{144} \mathrm{Nd}_{6}$ & $d_{60} \quad 0.51291$ & & 0.5130 & & 0.5130 & & & 0.513 & & 0.512897 & 0.512909 & 0.512959 \\
\hline$\varepsilon N d$ & 6.84 & & 9.36 & & 8.78 & & & 8.77 & & 6.56 & 6.78 & 7.78 \\
\hline${ }^{206} \mathrm{~Pb} / 204 \mathrm{~Pb}_{60}$ & 17.991 & & 17.891 & & 17.958 & & & 18.489 & & 17.919 & 18.046 & 17.796 \\
\hline${ }^{207} \mathrm{~Pb} / 204 \mathrm{~Pb}_{60}$ & 15.477 & & 15.402 & & 15.408 & & & 15.527 & & 15.350 & 15.339 & 15.526 \\
\hline${ }^{208} \mathrm{~Pb} / 204 \mathrm{~Pb}_{60}$ & 37.893 & & 37.563 & & 37.613 & & & 37.860 & & 37.648 & 37.577 & 37.686 \\
\hline
\end{tabular}

For explanation of lithological codes, see Table 1. For petrographical notes on the samples, see Table 6d.

Geographical coordinates in WGS 84. First two digits are degrees, then follow minutes in decimal form.

Major elements in wt\% (XRF analyses). Trace elements in Ppm (Zn-Ga: XRF analyses; Rb-U: ICP-MS analyses). 
Table 6b. Chemical analyses of rocks, Ordlingassoq Member

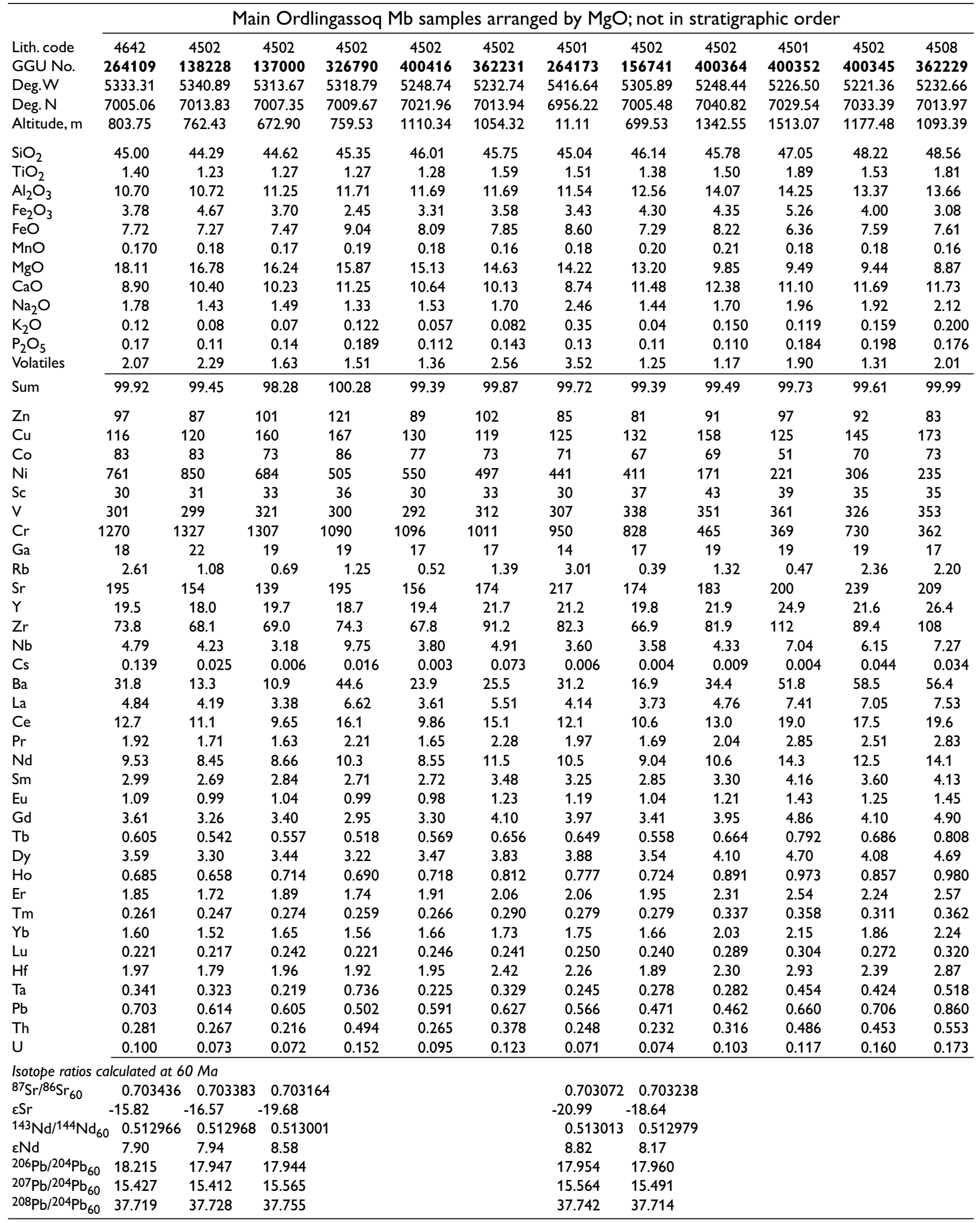


Table 6c. Chemical analyses of rocks in the Ordlingassoq Member (from minor units)

\begin{tabular}{|c|c|c|c|c|c|c|c|c|c|c|}
\hline \multirow{2}{*}{$\begin{array}{l}\text { Unit } \\
\text { Lith. code }\end{array}$} & \multirow{2}{*}{$\frac{\text { Stordal }}{4511}$} & \multirow{2}{*}{$\begin{array}{l}\text { In Manîtdlat } \\
\frac{\mathrm{Mb}}{4642}\end{array}$} & \multicolumn{3}{|c|}{ Brown marker units } & \multicolumn{2}{|c|}{ Enriched lavas } & \multicolumn{2}{|c|}{ Low-Ti lavas } & \multirow{2}{*}{$\begin{array}{l}\begin{array}{l}\text { Plagioclase- } \\
\text { phyric unit }\end{array} \\
\frac{4581}{}\end{array}$} \\
\hline & & & 4521 & 4521 & 4531 & 4551 & 4551 & 4562 & 4561 & \\
\hline GGU No. & 264153 & 264110 & 400403 & 400399 & 400377 & 400124 & 332784 & 354757 & 354754 & 332821 \\
\hline Deg.W & 5405.33 & 5333.45 & 5305.35 & 5305.20 & 5309.47 & 5326.58 & 5338.54 & 5317.42 & 5317.63 & 5239.70 \\
\hline Deg. N & 7001.29 & 7005.06 & 7044.02 & 7044.03 & 7042.02 & 7042.95 & 7030.03 & 7029.49 & 7029.51 & 7017.03 \\
\hline Altitude, m & 449.34 & 760.49 & 1386.88 & 1335.34 & 1597.42 & 1470.39 & 1427.09 & 1091.30 & 1130.38 & 1322.10 \\
\hline $\mathrm{SiO}_{2}$ & 51.77 & 51.71 & 46.36 & 46.37 & 45.11 & 44.30 & 44.49 & 44.64 & 44.89 & 49.82 \\
\hline $\mathrm{TiO}_{2}$ & 1.31 & 1.27 & 1.66 & 1.58 & 1.57 & 1.03 & 1.58 & 0.86 & 0.90 & 2.47 \\
\hline $\mathrm{Al}_{2} \mathrm{O}_{3}$ & 13.79 & 13.90 & 13.80 & 13.34 & 13.69 & 9.92 & 10.43 & 10.37 & 10.74 & 13.93 \\
\hline $\mathrm{Fe}_{2} \mathrm{O}_{3}$ & 1.00 & 1.58 & 3.30 & 6.65 & 6.13 & 2.47 & 3.97 & 2.95 & 2.85 & 3.36 \\
\hline $\mathrm{FeO}$ & 8.02 & 7.65 & 7.75 & 5.43 & 5.53 & 9.09 & 7.99 & 8.17 & 8.53 & 8.75 \\
\hline $\mathrm{MnO}$ & 0.15 & 0.15 & 0.18 & 0.19 & 0.19 & 0.18 & 0.18 & 0.17 & 0.17 & 0.19 \\
\hline $\mathrm{MgO}$ & 10.75 & 10.97 & 10.00 & 9.74 & 9.07 & 20.44 & 16.18 & 20.61 & 19.36 & 6.73 \\
\hline $\mathrm{CaO}$ & 8.83 & 8.81 & 12.13 & 11.30 & 12.57 & 8.62 & 9.95 & 9.48 & 8.96 & 10.99 \\
\hline $\mathrm{Na}_{2} \mathrm{O}$ & 1.89 & 1.71 & 1.78 & 1.74 & 1.53 & 1.06 & 1.38 & 1.27 & 1.25 & 2.36 \\
\hline $\mathrm{K}_{2} \mathrm{O}$ & 0.50 & 0.62 & 0.249 & 0.092 & 0.343 & 0.282 & 0.497 & 0.031 & 0.154 & 0.214 \\
\hline $\mathrm{P}_{2} \mathrm{O}_{5}$ & 0.14 & 0.14 & 0.158 & 0.121 & 0.202 & 0.121 & 0.181 & 0.060 & 0.063 & 0.207 \\
\hline Volatiles & 1.31 & 1.30 & 1.89 & 3.21 & 3.89 & 2.43 & 3.13 & 1.26 & 2.19 & 0.76 \\
\hline Sum & 99.46 & 99.81 & 99.26 & 99.76 & 99.82 & 99.95 & 99.94 & 99.87 & 100.05 & 99.79 \\
\hline $\mathrm{Zn}$ & 61 & 80 & 83 & 88 & 91 & 79 & 95 & 81 & 70 & 102 \\
\hline $\mathrm{Cu}$ & 56 & 33 & 144 & 126 & 133 & 102 & 88 & 104 & 100 & 220 \\
\hline Co & 36 & 51 & 58 & 56 & 57 & 92 & 75 & 90 & 83 & 54 \\
\hline $\mathrm{Ni}$ & 83 & 26 & 226 & 192 & 149 & 810 & 509 & 905 & 796 & 94 \\
\hline Sc & 28 & 30 & 40 & 31 & 35 & 28 & 30 & 29 & 29 & 38 \\
\hline V & 233 & 250 & 331 & 276 & 329 & 218 & 276 & 231 & 247 & 396 \\
\hline $\mathrm{Cr}$ & 1240 & 1390 & 514 & 413 & 408 & 1702 & 1281 & 1449 & 1453 & 277 \\
\hline $\mathrm{Ga}$ & 16 & 21 & 20 & 20 & 20 & 13 & 18 & 15 & 12 & 24 \\
\hline $\mathrm{Rb}$ & 6.02 & 14.2 & 2.92 & 0.80 & 7.78 & 5.77 & 13.7 & 0.61 & 3.25 & 3.01 \\
\hline $\mathrm{Sr}$ & 201 & 199 & 276 & 195 & 261 & 195 & 231 & 106 & 127 & 244 \\
\hline Y & 20.4 & 20.5 & 23.5 & 22.1 & 21.8 & 15.1 & 20.6 & 15.9 & 16.1 & 35.7 \\
\hline $\mathrm{Zr}$ & 124 & 119 & 101 & 85.0 & 95.1 & 65.1 & 113 & 49.5 & 47.7 & 146 \\
\hline $\mathrm{Nb}$ & 5.55 & 5.35 & 14.8 & 5.74 & 20.7 & 11.2 & 22.3 & 2.93 & 2.18 & 5.15 \\
\hline Cs & 0.070 & 0.269 & 0.015 & 0.007 & 0.036 & 0.019 & 0.085 & 0.007 & 0.009 & 0.052 \\
\hline $\mathrm{Ba}$ & 166 & 159 & 78.5 & 37.7 & 92.2 & 130 & 241 & 18.1 & 22.4 & 37.2 \\
\hline $\mathrm{La}$ & 12.0 & 11.6 & 9.78 & 4.71 & 11.5 & 13.9 & 19.6 & 3.13 & 2.39 & 7.04 \\
\hline $\mathrm{Ce}$ & 27.3 & 26.1 & 22.7 & 12.9 & 26.5 & 26.9 & 39.1 & 8.05 & 6.76 & 20.8 \\
\hline $\operatorname{Pr}$ & 3.86 & 3.63 & 3.26 & 2.12 & 3.69 & 3.21 & 4.50 & 1.20 & 1.10 & 3.27 \\
\hline Nd & 16.5 & 15.4 & 14.9 & 10.8 & 16.1 & 12.3 & 17.8 & 6.11 & 5.78 & 17.3 \\
\hline $\mathrm{Sm}$ & 3.92 & 3.67 & 3.83 & 3.33 & 3.82 & 2.63 & 3.86 & 1.89 & 1.931 & 5.49 \\
\hline Eu & 1.17 & 1.12 & 1.32 & 1.18 & 1.25 & 0.877 & 1.26 & 0.700 & 0.740 & 1.90 \\
\hline Gd & 3.77 & 3.78 & 4.27 & 3.83 & 4.26 & 2.56 & 3.99 & 2.18 & 2.52 & 6.43 \\
\hline Tb & 0.648 & 0.623 & 0.702 & 0.643 & 0.649 & 0.437 & 0.636 & 0.400 & 0.413 & 1.06 \\
\hline Dy & 3.68 & 3.62 & 4.15 & 3.91 & 3.86 & 2.69 & 3.63 & 2.53 & 2.674 & 6.25 \\
\hline Ho & 0.738 & 0.736 & 0.845 & 0.795 & 0.795 & 0.538 & 0.720 & 0.554 & 0.594 & 1.30 \\
\hline $\mathrm{Er}$ & 1.93 & 1.97 & 2.25 & 2.14 & 2.14 & 1.37 & 1.82 & 1.47 & 1.57 & 3.41 \\
\hline $\mathrm{Tm}$ & 0.291 & 0.295 & 0.317 & 0.296 & 0.307 & 0.200 & 0.270 & 0.220 & 0.237 & 0.493 \\
\hline $\mathrm{Yb}$ & 1.82 & 1.86 & 2.00 & 1.82 & 1.85 & 1.27 & 1.65 & 1.38 & 1.51 & 2.92 \\
\hline Lu & 0.260 & 0.269 & 0.281 & 0.267 & 0.268 & 0.182 & 0.230 & 0.200 & 0.220 & 0.411 \\
\hline $\mathrm{Hf}$ & 3.17 & 3.14 & 2.79 & 2.35 & 2.62 & 1.68 & 2.65 & 1.26 & 1.41 & 3.74 \\
\hline $\mathrm{Ta}$ & 0.391 & 0.385 & 0.723 & 0.321 & 1.17 & 0.590 & 0.993 & 0.214 & 0.151 & 0.366 \\
\hline $\mathrm{Pb}$ & 2.37 & 3.74 & 1.08 & 0.678 & 1.02 & 0.956 & 1.17 & 0.389 & 0.312 & 0.941 \\
\hline Th & 2.34 & 2.38 & 0.896 & 0.337 & 1.21 & 0.925 & 1.44 & 0.244 & 0.176 & 0.361 \\
\hline $\mathrm{U}$ & 0.581 & 0.599 & 0.276 & 0.114 & 0.365 & 0.220 & 0.357 & 0.063 & 0.050 & 0.133 \\
\hline \multicolumn{11}{|c|}{ Isotope ratios calculated at $60 \mathrm{Ma}$} \\
\hline${ }^{87} \mathrm{Sr} / 86 \mathrm{Sr}_{60}$ & 0.708907 & 0.708821 & & & 0.7053 & & & & & \\
\hline$\varepsilon S r$ & 61.83 & 60.62 & & & 11.31 & & & & & \\
\hline${ }^{143} \mathrm{Nd} /{ }^{144} \mathrm{Nd}_{60}$ & 0.512076 & 0.512029 & & & 0.5127 & & & & & \\
\hline$\varepsilon N d$ & -9.46 & -10.38 & & & 3.00 & & & & & \\
\hline${ }^{206} \mathrm{~Pb} /{ }^{204} \mathrm{~Pb}_{60}$ & 16.960 & 16.979 & & & 18.164 & & & & & \\
\hline${ }^{207} \mathrm{~Pb} /{ }^{204} \mathrm{~Pb}_{60}$ & 15.097 & 15.084 & & & 15.452 & & & & & \\
\hline${ }^{208} \mathrm{~Pb} / 204 \mathrm{~Pb}_{60}$ & 37.304 & 37.236 & & & 38.081 & & & & & \\
\hline
\end{tabular}




\section{Table 6d. Notes on analysed samples from the Ordlingassoq Member}

332788 Olivine-rich picrite lava flow with slightly enriched geochemistry, Ukallit profile, eastern side of mouth of Qunnilik valley, western Nuussuaq.

332901 Olivine-rich picrite lava flow near the boundary to the Naujánguit Nember.Top of mountain wall above Nuuk Killeq, south coast of Nuussuaq.

332828 Olivine-rich picrite pillow in hyaloclastite, Paatuut, south-east Nuussuaq.

400230 Picrite lava flow, Puugutalissuaq profile, Agatdalen, central Nuussuaq (Fig. 171).

113333 Picrite lava flow, north-east side of the inner Kuugannguaq valley $17 \mathrm{~km}$ west-south-west of Qullissat, northern Disko.

410152 Massive picrite lava flow, lowest flow in Ordlingassoq Mb, Sorluut profile, northern Nuussuaq.

340740 Picrite pillow in hyaloclastite, base of mountain wall above Tupaasat, south coast of Nuussuaq.

264137 Picrite pillow in hyaloclastite, north-east side of inner Kuugannguaq valley $19 \mathrm{~km}$ west of Qullissat, northern Disko.

400231 Picrite pillow in hyaloclastite with slightly enriched geochemistry, Puugutalissuaq profile, Agatdalen, central Nuussuaq (Fig. 171).

326783 Picrite pillow in hyaloclastite, Kamaffiaraq c. 5 km west of Asuk, north coast of Disko.

327100 Picrite pillow in hyaloclastite, Orlingasoq $3.5 \mathrm{~km}$ south-west of Asuk, north coast of Disko.

136943 Picrite pillow in hyaloclastite, Orlingasoq profile, $4 \mathrm{~km}$ west-south-west of Asuk, north coast of Disko.

264109 Picrite pillow in hyaloclastite from local tholeitic intercalation within Manîtdlat Member, north-east side of the inner Kuugannguaq valley $18 \mathrm{~km}$ from the coast, northern Disko.

138228 Picrite pillow in hyaloclastite, Kussinikassak profile, gully $2.5 \mathrm{~km}$ from the coast, north coast of Disko.

137000 Picrite pillow in hyaloclastite, south-east side of Qorlortorsuaq gully $5 \mathrm{~km}$ from the coast, north coast of Disko.

326790 Picrite pillow in hyaloclastite with enriched geochemistry due to weak contamination with Manîtdlat Member melts, Asuutaa mountain, north coast of Disko.

400416 Picrite pillow in hyaloclastite, Ataata Kuua, south coast of Nuussuaq.

362231 Picrite pillow in hyaloclastite, Peak $1760 \mathrm{~m}$ profile, south coast of Nuussuaq.

264173 Picrite lava flow, head of Nordfjord, western Disko.

156741 Olivine-poor picrite pillow in hyaloclastite, Killerpaat Qaqqarsuat, Qullissat, north coast of Disko.

400364 Olivine-phyric basalt pillow in hyaloclastite, Mellemfjeld profile, north coast of Nuussuaq.

400352 Olivine-clinopyroxene-plagioclase-phyric basalt lava flow, Nunavik, north-eastern Nuussuaq.

400345 Olivine-plagioclase-clinopyroxene-phyric basalt pillow in hyaloclastite, easternmost Vaigat Formation, west side of Kuuk gully, northern Nuussuaq.

362229 Weakly olivine-plagioclase-phyric basalt, lower chill zone of picrite sill (invasive lava flow) in thin shale between the Vaigat and Maligât Formations, Point $1760 \mathrm{~m}$ profile, south coast of Nuussuaq.

264153 Native-iron-bearing olivine-microphyric basaltic andesite lava flow from contaminated flow group, Ametystskrænten, Stordal, central Disko.

264110 Weakly olivine-phyric basaltic andesite pillow in hyaloclastite from local contaminated tholeiitic intercalation within Manîtdlat Member, north-east side of Kuugannguaq valley $18 \mathrm{~km}$ from the coast, northern Disko.

400403 Olivine-phyric basalt with enriched geochemistry, massive lava flow in lower brown marker, lkorfat, just west of the lkorfat fault, north coast of Nuussuaq (Fig. 63).

400399 Olivine-microphyric basalt, thin pahoehoe lava flow in lower brown marker, lkorfat, just west of the lkorfat fault, north coast of Nuussuaq (Fig. 63).

400377 Olivine-microphyric basalt with enriched geochemistry, lava flow in upper brown marker, Ikorfat-south profile, west of lkorfat fault, north coast of Nuussuaq (Fig. 63).

400124 Picrite lava flow with distinctly enriched geochemistry, Tunorsuaq profile, Tunorsuaq valley, northern Nuussuaq.

332784 Picrite lava flow with distinctly enriched geochemistry, Ukallit profile, eastern side of mouth of Qunnilik valley, western Nuussuaq.

354757 Picrite pillow in hyaloclastite,Ti- and Zr-poor flow group in central Nuussuaq, Aaffarsuaq profile, central Nuussuaq.

354754 Picrite, massive lava flow from Ti- and Zr-poor flow group in central Nuussuaq, Aaffarsuaq profile, central Nuussuaq.

332821 Plagioclase-olivine-clinopyroxene-phyric basalt, thick lava flow from evolved flow group near the upper boundary of the Vaigat Formation, Paatuut Puiattua profile, south coast of Nuussuaq.

Phenocryst phases are mentioned in order of decreasing abundance. All picrites are strongly olivine-phyric. 


\section{Manîtdlat Member}

\section{Summary of the main features of the Manitdlat Member}

- Dark brown to purplish succession of alkaline picrites and basalts on Disko.

- Divided into four units (chemical types) representing at least four eruption areas. (A fifth type is the alkaline picrite unit in the Ordlingassoq Member).

- Most units are separated by thin sediment horizons and at some localities by horizons of Ordlingassoq Member tholeiitic rocks.

- Lava flows and hyaloclastites running into the Naajaat Lake towards the south and south-east.

- Highly unusual geochemistry with different patterns of strong enrichment in incompatible elements indicates melts from metasomatised veins in the lithospheric mantle.

- The only occurrence of strongly alkaline rocks within the Vaigat and Maligât formations on Disko and Nuussuaq.

\section{Lithostratigraphy of the Manîtdlat Member}

History. Originally defined by Pedersen (1985a). No revision is applied here.

Name. After the Maniillat (new spelling) slope just west of Norddalen on northern Disko.

Distribution. The Manîtdlat Member occurs in an area measuring about $20 \times 30 \mathrm{~km}$ on northern and northcentral Disko (Fig. 11). The limits to the east and south, and probably to the west, are depositional. No extension on Nuussuaq has been found despite dedicated search.

Type section. Norddalen (Fig. 16, profile 27) which is also the type section for the Ordlingassoq Member (Pedersen 1985a, profile 4).

Reference sections. Ametystskrænten, Kussinikassak, Orlingasoq (Fig. 16, profiles 25, 26, 28) and the inner Kuugannguaq section (Fig. 200).

Thickness. In subaerial lava facies the Manittdlat Member is up to $75 \mathrm{~m}$ thick. In hyaloclastite facies, a thickness of about $200 \mathrm{~m}$ is reached locally.
Lithology. The Manîtdlat Member comprises dark brown subaerial pahoehoe lava flows and subordinate hyaloclastites. The member terminates to the south and east in a broad zone of hyaloclastites where the lavas have flowed into water several hundred metres deep. Eruption sites are not known but must be local. The alkaline lavas interfinger with tholeiitic lavas from other, contemporaneous eruption sites of the Ordlingassoq Member.

The dominant rocks are alkali picrites and alkali basalts. All rocks are olivine-phyric and many also have clinopyroxene microphenocrysts. The alkali basalts of the latest unit (465) are clinopyroxene-olivine-phyric (ankaramites).

Subdivisions. The alkaline rocks have been subdivided into five chemical types $(0,1 \mathrm{a}, 1 \mathrm{~b}, 2,3)$ based on different element enrichment patterns (Larsen et al. 2003). The unit codes for the types are, respectively, 460, 461, 462,463 and 465 . Unit 464 comprises a few non-alkaline contaminated and picritic flows situated between units 463 and 465 (Fig. 200).

Boundaries. The Manittlat Member is conformably near-enclosed within the lower part of the Ordlingassoq Member. It rests on grey tholeiitic picrite lavas except near its southern limit; in Kuugannguaq the Manîtdlat and Ordlingassoq Member flows reached the Naajaat Lake at the same time and prograded piggyback-wise into the Naajaat Lake so that hyaloclastites of both members rest on thin mudstones and lava flows of the Qordlortorssuaq Member (Fig. 200). In the Stordal area lava flows of unit 465 were dammed up against a shield of slightly contaminated plagioclase-phyric lavas (Fig. 203). The member is partly intercalated with and overlain by grey tholeiitic picrite lava flows and their equivalent hyaloclastites.

Age. Paleocene, nannoplankton zone NP5-6, c. 60-61 $\mathrm{Ma}$, magnetochron C26r, based on dinoflagellate cysts (Piasecki et al. 1992), radiometric dating (Storey et al. 1998) and palaeomagnetic investigations of the succession (Athavale \& Sharma 1975).

\section{Geology of the Manîtdlat Member}

Two units of alkaline rocks occur at close-lying stratigraphic levels within the lower Ordlingassoq Member on 
northern Disko. The main level is that of the Manitdlat Member, whereas a smaller alkaline unit (460) is situated at a lower level in the Ordlingassoq Member. The alkaline rocks are genetically related and are treated together here. Their detailed petrology was presented by Larsen et al. (2003) together with the related alkaline Stordal volcano (unit 421) in the upper part of the Naujánguit Member.

The five alkaline subunits (types $0,1 \mathrm{a}, 1 \mathrm{~b}, 2,3$ ) defined by Larsen et al. (2003) cannot be distinguished from a distance in the field, and their mapping therefore requires a large sampling and analytical effort. The present data set does not cover the full extent of the alkaline rocks.

\section{Alkaline picrites in the lower part of the Ordlingassoq Member on Disko (unit 460, type 0)}

A small succession of alkaline picritic pahoehoe lavas occurs along the north-east coast of Disko over a distance of $c .20 \mathrm{~km}$ between Naajannguit and Asuk. The extent of unit 460 is poorly constrained; it is only known from the coastal areas and neither present in the Kuugannguaq valley nor on Nuussuaq (Fig. 11). Eruption sites are not known but must be situated locally.

The lava flows of unit 460 rest on non-alkaline picritic lava flows of the Ordlingassoq Member (Fig. 16, profiles 26, 27, 28; Pedersen 1985a, fig. 19, profiles 4, 10). The upper boundary is marked by lateritic clay. On top of this follow 30-80 m (up to 25 flow lobes) of non-alkaline picrite lava flows of unit 450 which are in turn overlain by the rocks of the Manittlat Member.

Lithologies. The alkaline succession is $20-35 \mathrm{~m}$ thick and comprises up to 20 lava lobes. About 1-1.5 km west of Point $860 \mathrm{~m}$ south-west of Asuk the succession enters the Naajaat Lake basin over a distance of about $1 \mathrm{~km}$ to form foreset-bedded hyaloclastites more than $50 \mathrm{~m}$ thick. The alkaline picrites are darker in colour than the nonalkaline picrites of the Ordlingassoq Member but they do not form a distinctive lithological marker horizon. On the other hand, the petrography of the subaerial lavas is quite distinctive. Compared to the non-alkaline rocks, the alkaline picrites are characterised by a higher clinopyroxene to feldspar ratio in the basaltic groundmass and in particular by the presence of zoned, purplish titanaugite; this identifies even extensively hydrothermally metamorphosed rocks. In general, the alkaline rocks are more susceptible to zeolite facies alteration than the non-

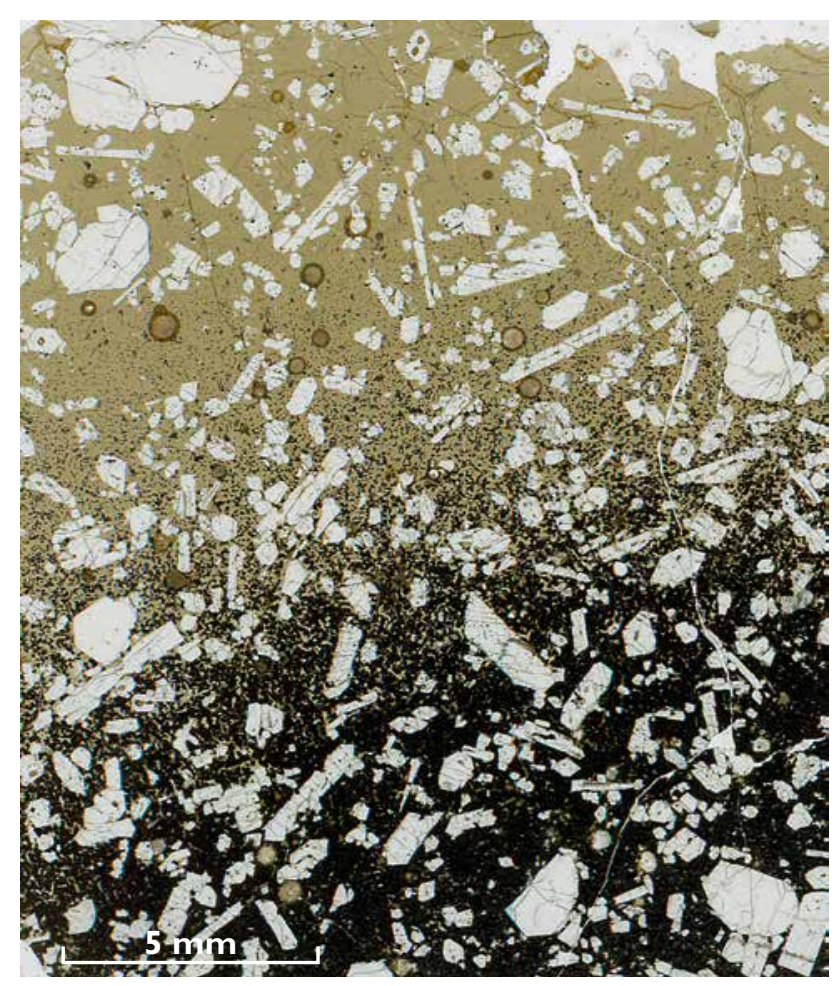

Fig. 199. Thin section (scanned) of a pillow rim from an alkaline picrite of unit 460. Numerous olivine crystals with shapes varying from equant to elongate to skeletal are embedded in fresh pale brown glass at the outer rim (top of photo) and in an aphanitic groundmass farther inside the pillow (lower part of photo). Sample GGU 327096, Maniillat. The glass of a twin sample (327097) was dated by Storey et al. (1998).

alkaline ones. In hyaloclastite facies, the alkaline picrites of unit 460 tend to have a very zeolite-rich matrix. However, fresh pillow fragments have been recovered and these may have up to $2 \mathrm{~cm}$ thick glassy rims (Fig. 199) with preserved olivine and very fresh non-hydrated alkali basalt glass (Larsen et al. 2003) which has been successfully dated by the Ar/Ar method (Storey et al. 1998).

\section{Manîtdlat Member (units 461, 462, 463, 465, types 1a, 1b, 2, 3)}

The alkaline rocks of the Manîtdlat Member form a purplish-brown marker horizon that extends over c. $20 \times$ $30 \mathrm{~km}$ on northern Disko where it covers approximately $600 \mathrm{~km}^{2}$ (Fig. 11). In subaerial lava facies it is on average about $50 \mathrm{~m}$ thick and may be up to $120 \mathrm{~m}$. The member reaches a maximum thickness of about $200 \mathrm{~m}$ where it formed hyaloclastites upon entering the Naajaat Lake ba$\sin$. The total estimated volume of alkaline rocks is about 


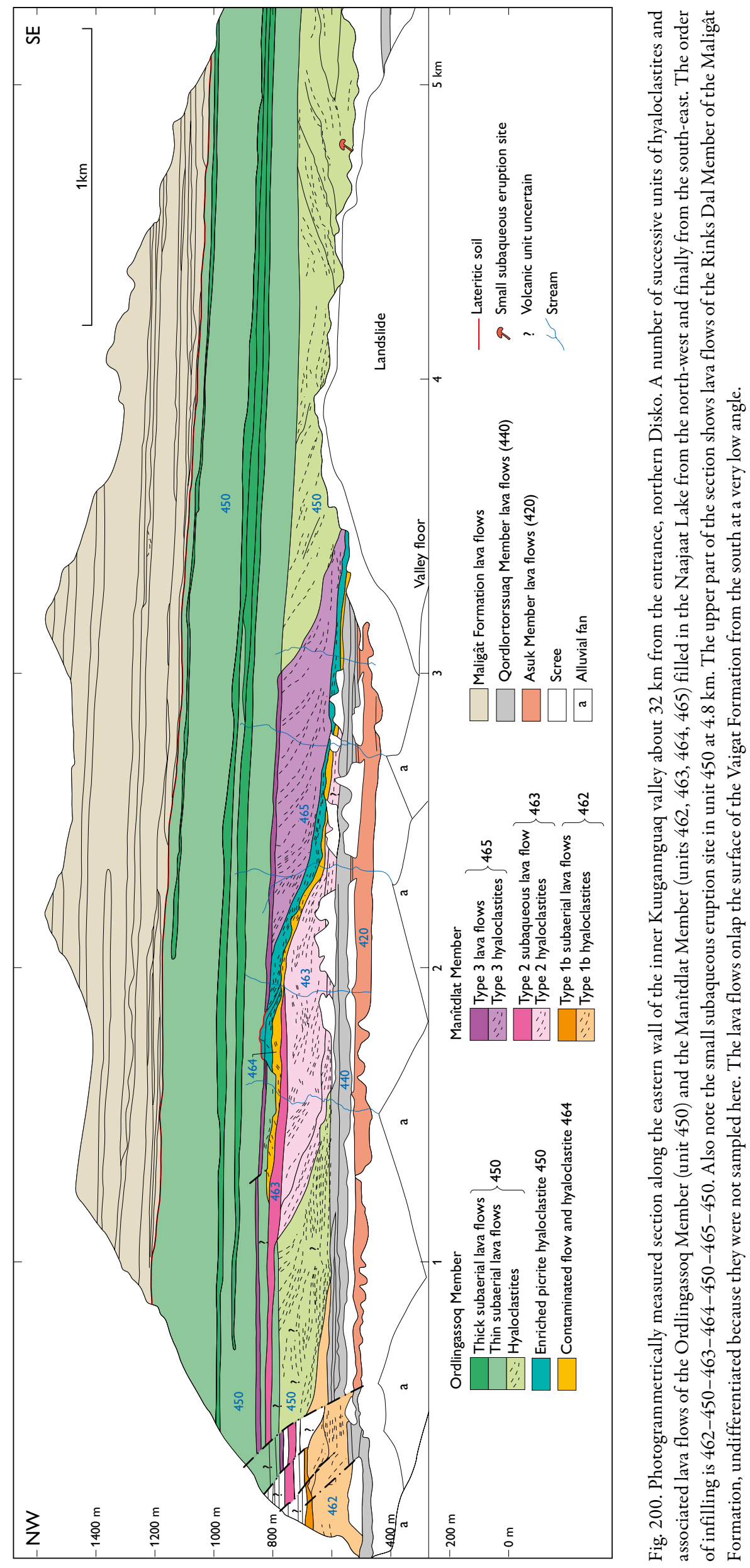




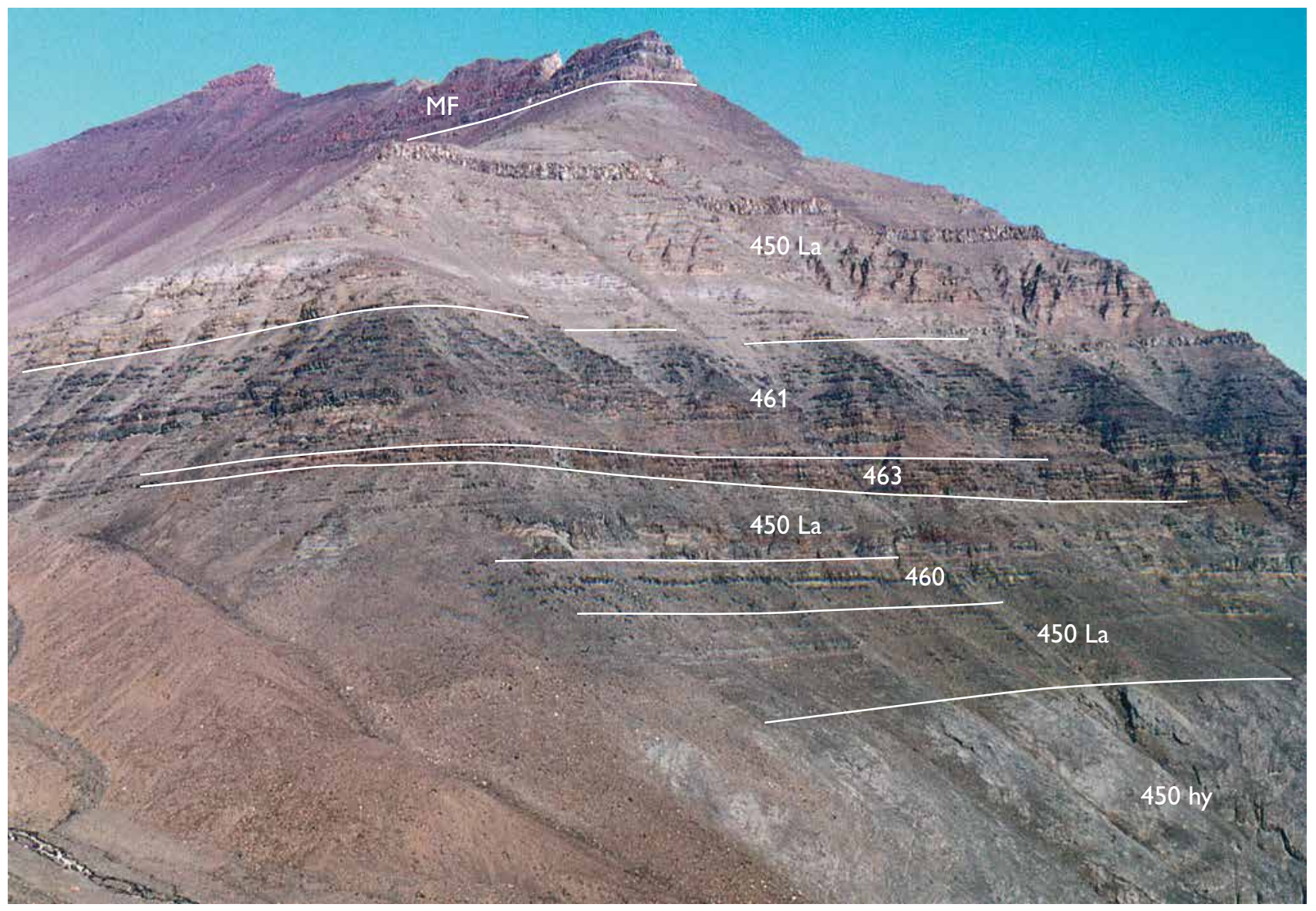

Fig. 201. Along the north coast of Disko, the alkaline Manîtdlat Member in subaerial facies forms a $80 \mathrm{~m}$ thick succession of dark purplish lava flows (461: type 1a and 463: type 2) within Ordlingassoq Member picrites ( $450 \mathrm{La}$ ), here at the type locality in the valley Norddalen $c .4 \mathrm{~km}$ south of the Vaigat coast. Beneath the main alkaline succession there are $c .15 \mathrm{~m}$ of alkaline picrite lava flows of type 0 (unit 460). See Fig. 16, profile 27 and Pedersen 1985a, fig 19, profile 4. Above the Manîtdlat Member, grey picritic lava flows of the Ordlingassoq Member are capped by basalt of the Maligât Formation (MF). The section is about $750 \mathrm{~m}$ thick.

$30 \mathrm{~km}^{3}$, and with possible extensions to the north and west the original volume may have exceeded $50 \mathrm{~km}^{3}$. In the north, the underlying lavas and hyaloclastites of unit 450 are $200-300 \mathrm{~m}$ thick, but this succession thins towards south-east until the alkaline lavas are the first to enter the Naajaat Lake basin (Fig. 200). They prograde 2-6 $\mathrm{km}$ into the lake over a $25-30 \mathrm{~km}$ wide zone that extends from south-west of Asuk to the inner part of Kuugannguaq.

\section{Units of the Manitdlat Member}

The Manitdlat Member was erupted from at least four alkaline volcanic centres that produced rocks with four distinctly different patterns of geochemical enrichment (units 461, 462, 463, 465). The four units are in some places separated from each other by thin intervals of unit
450 or by crustally contaminated basalt and non-alkaline picrite (unit 464). Thin sediment horizons indicate significant time gaps between the emplacement of the various parts. Figure 11 shows the general distribution of the four units; the picture is tentative due to incomplete knowledge. No eruption sites are known but they must be local. Eruptions were most probably from fissures because all the lava flows are of pahoehoe type and no traces of volcanic edifices or explosive activity have been found.

Unit 462 (type 1b) is the oldest and smallest unit. It constitutes only about $5 \%$ of the member and occurs exclusively in the Kuugannguaq valley (Fig. 200 at $0-1$ $\mathrm{km})$. It is composed of lava flows and hyaloclastites of alkaline picrites and basalts with 11-13 wt $\% \mathrm{MgO}$. The lavas form one or more flow fields of thin pahoehoe flows which are 15-25 m thick; they entered the Naajaat Lake basin from the north-west to form up to $125 \mathrm{~m}$ thick 


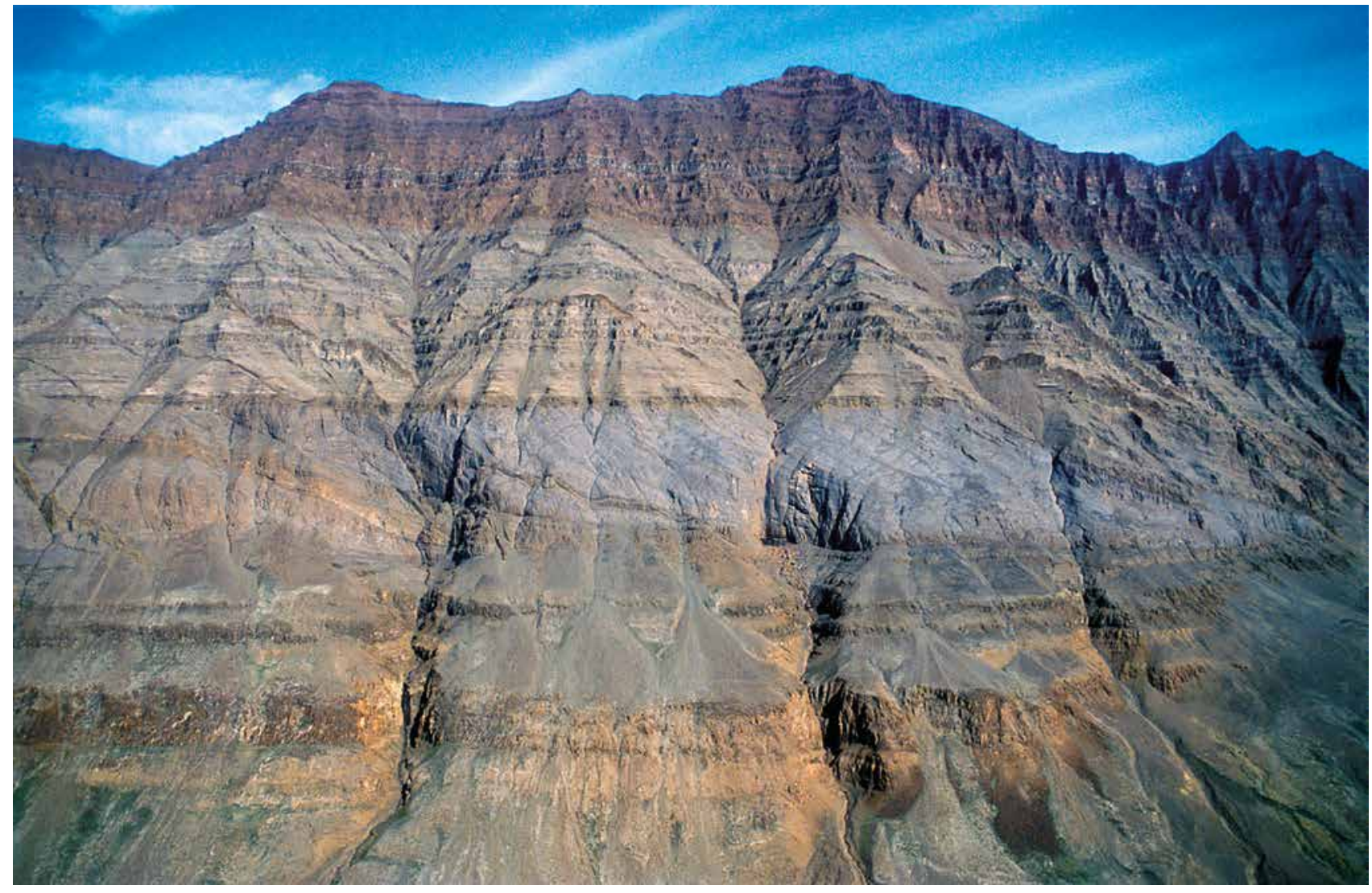

Fig. 202. Light purple hyaloclastites and associated brown alkali basalt (ankaramite) lava flows of Manitdlat Member unit 465 infilling the Naajaat Lake in Kuugannguaq. The picture corresponds to the photogrammetric section in Fig. 200 at 1.9-3.5 km, see this for interpretation. Height of section $c .1100 \mathrm{~m}$.

foreset-bedded hyaloclastites prograding 4 to $5 \mathrm{~km}$ into the lake. The unit is separated from the main succession by $10-15 \mathrm{~m}$ of non-alkaline picrite flows of the Ordlingassoq Member (unit 450).
The main succession (units 461, 463, types 1a, 2) constitutes around $80 \%$ of the member and consists of alkaline picrites and basalts with 9-21 wt\% $\mathrm{MgO}$ for type $1 \mathrm{a}$ and $10-16 \mathrm{wt} \% \mathrm{MgO}$ for type 2. It is present along the

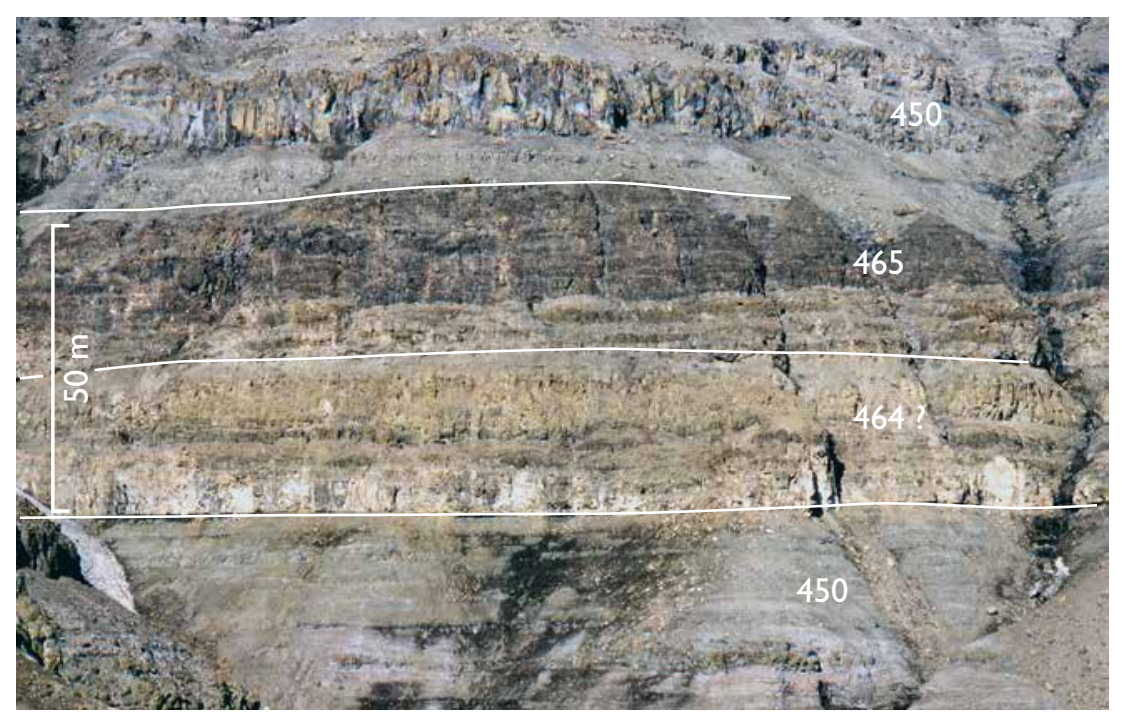

Fig. 203. Dark lava flows of Manîtdlat Member unit 465 (type 3) in Ametystskrænten in Stordal. The light brown lava flows beneath unit 465 are part of a brown marker horizon in the Stordal area (Fig. 184) and are possibly, but not certainly, correlated with unit 464 . 
Fig. 204. Details of the facies transition from subaerial alkali basaltic pahoehoe lava flows to foreset-bedded hyaloclastites. Unit 465 , gully in Kuugannguaq (Fig. 200 at $2.3 \mathrm{~km}$; Fig. 205), seen towards north-west; the flow direction had a south-western component. Height of section $c .70 \mathrm{~m}$.

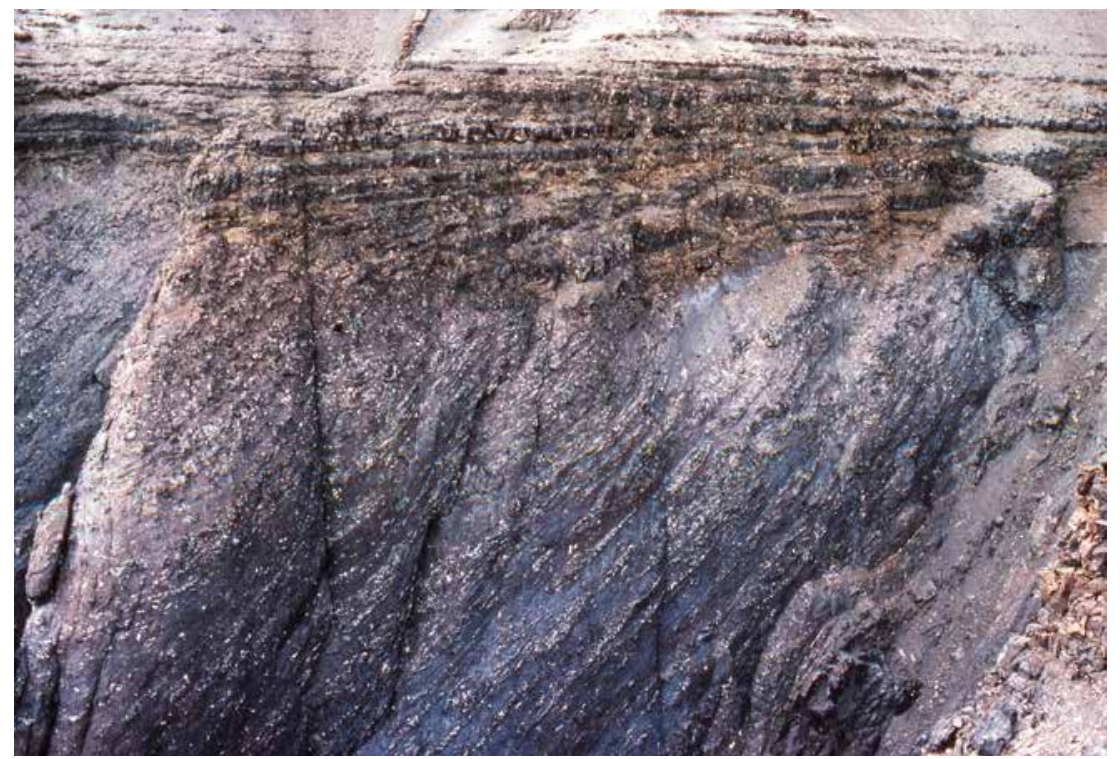

north coast of Disko between the outlet of Kuugannguaq and Asuutaa (Fig. 201), and in the middle Kuugannguaq valley where it is well exposed over a distance of $25 \mathrm{~km}$ in the eastern side of the valley (Fig. 200). On the north coast, the thickness is $55-95 \mathrm{~m}$ in lava facies, increasing to $140 \mathrm{~m}$ just west of Asuutaa where the lavas entered the Naajaat Lake to form hyaloclastites. On the north coast, about the lower third is composed of alkaline basalts and picrites of type 2 , whereas the upper two thirds are composed of alkaline basalts and picrites of type 1a (Fig. 201). In Kuugannguaq, the main succession is up to $60 \mathrm{~m}$ thick but has only been sampled at a single locality where lava flows of type 2 entered the basin to form hyaloclastites (Fig. 200). Rocks of type 1a are very likely to be present as the upper part of the main succession over large areas.

In Kuugannguaq unit 463 (type 2) lavas and hyaloclastites are separated from the younger unit 465 (type 3) lavas and hyaloclastites by about $10 \mathrm{~m}$ of non-alkaline picrite flows of the Ordlingassoq Member unit 450 and crustally contaminated basalt of unit 464 (Fig. 200).

Unit 465 (type 3) is the youngest part of the Manitdlat Member. It constitutes around $15 \%$ of the member and consists of alkali basalts (ankaramites) with 7-11 wt\% $\mathrm{MgO}$. It has a southern depocentre (Fig. 11) and is not present at the north coast. It is present in Kuugannguaq over a distance of around $4 \mathrm{~km}$ in the well-exposed eastern valley side from $c .25 \mathrm{~km}$ from the outlet. It forms an up to $20 \mathrm{~m}$ thick succession of pahoehoe lava flows which entered the Naajaat Lake basin to form up to 160 $\mathrm{m}$ thick foreset-bedded hyaloclastites (Figs 200, 202). The lava flows are missing in a small area where a hya- loclastite heap of non-alkaline picrite has formed a local topographic high (see below, unit 464). Unit 465 is also present in Ametystskrænten in Stordal as a c. $25 \mathrm{~m}$ thick series of pahoehoe flows (Fig. 183 at $25-26.5 \mathrm{~km}$, unit 'alk'; Figs 16, 203). Presumably it once covered the area between the two known localities which are about $20 \mathrm{~km}$ apart.

Lithologies. In subaerial facies the alkaline basalts and picrites of the Manittlat Member form flow fields of thin pahoehoe lavas which have a characteristic dark brownish to almost black weathering colour when seen from a distance, in contrast to the greyish weathering picrite flows of the Ordlingassoq Member (Figs 201-203). The individual flows are mostly 1 to $4 \mathrm{~m}$ thick but may locally reach a thickness of 20-25 m. At Maniillat, several very thick flows on top of each other may indicate proximity to an eruption site.

The transition from subaerial lava flows to hyaloclastites is excellently exposed at many localities in the northeastern side of the Kuugannguaq valley (Figs 202, 204). Downslope, the hyaloclastite foresets vary from crude pillow breccia beds with lava fragments several decimetres in size to fine-grained well-bedded sediments. Some beds are separated by millimetre- to centimetre-thick mudstones, and where the overlying bed includes basalt clasts the top of the underlying bed may be deformed. The transition zone and hyaloclastites are also present just north-west of Asuutaa but the exposures are less continuous and affected by landslides. 


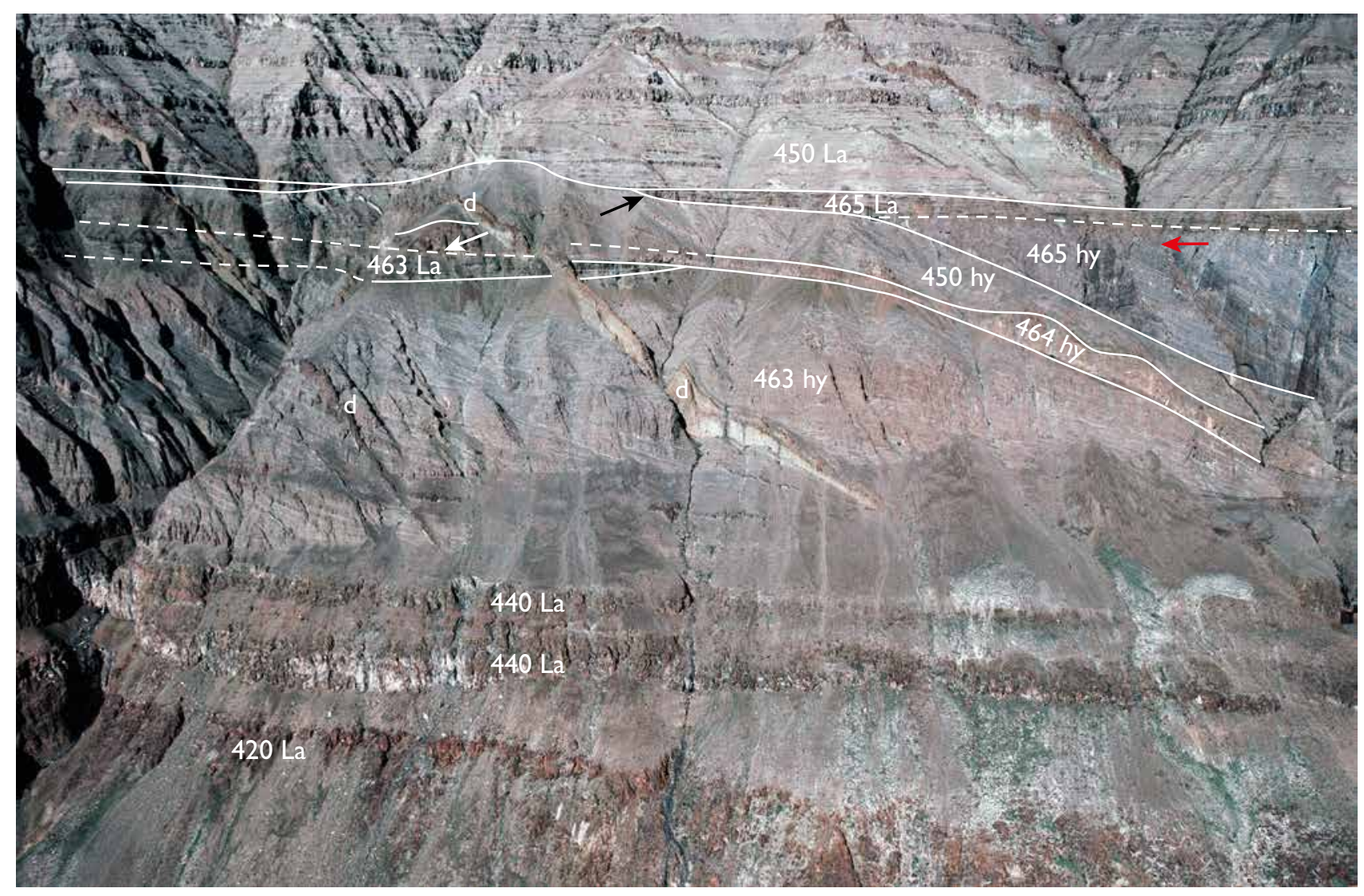

Fig. 205. The geological relations interpreted in Fig. 200 at $1.5-2.3 \mathrm{~km}$ and $440-890 \mathrm{~m}$ altitude in the eastern wall of the Kuugannguaq valley; for legend, see Fig. 200 (the cross-cutting dykes (d) are not shown in Fig. 200). The red arrow shows the location and viewing direction of Fig. 204, the white arrow shows the location of Fig. 206, and the black arrow shows the location of Fig. 207. The same area is also seen in the left centre of Fig. 202.

Boundaries. Subaerial lava flows of all three parts of the Manitdlat Member are deposited on thin layers of lateritic claystone, indicating repeated interruptions in the volcanic activity. Where the oldest unit (462) enters the Naajaat Lake in Kuugannguaq, there are patches of redcoloured sediment deposited on the shelf-slope on top of the underlying Ordlingassoq Member hyaloclastites.

The upper boundaries have only been investigated in detail at a few localities. Along the north coast of Disko, lava flows of unit 461 form the upper part of the Manitdlat Member and are covered by picritic pahoehoe flows of the Ordlingassoq Member. In an area north-west of Asuutaa, the alkaline succession thins gradually eastwards as the flows are transformed into hyaloclastites, whereas the overlying horizon of Ordlingassoq Member picritic hyaloclastite thickens gradually eastwards. In a small waterfall just where the last unit 461 lava flow has entered the basin, a 2-3 m thick sediment layer is situated between the alkaline and non-alkaline hyaloclastites. The sediment has a several decimetres thick basal layer of volcaniclastic sand deposited on a slightly eroded hyaloclastite surface, followed by up to $2 \mathrm{~m}$ of basaltic conglomerate composed mostly of well-abraded basalt lava clasts in a finer-grained volcaniclastic matrix. The conglomerate is covered by $5-30 \mathrm{~cm}$ of siltstone or mudstone with traces of plant fossils. The sediment is considered to be a shore deposit at the Naajaat Lake.

In Kuugannguaq (Fig. 200 at 3-3.5 km) foreset-bedded hyaloclastites of the youngest unit (465) are separated from the overlying Ordlingassoq Member hyaloclastites by a few decimetres of deformed schlieren of mudstone.

\section{Non-alkaline rocks between the main alkaline succession and unit 465 (unit 464)}

Kuugannguaq. In Kuugannguaq a crustally contaminated basalt flow and some picritic hyaloclastites separate Manîtdlat Member units 463 (type 2) and 465 (type 3 ). Exposures are located in the eastern side of the Kuugannguaq valley over a distance of $2.4 \mathrm{~km}$ (Fig. 200 at 
Fig. 206. Contaminated basalt flow from unit 464 erupted in a shallow near-shore part of the Naajaat Lake basin in Kuugannguaq (Fig. 200 at 1.75 km; Fig. 205). The columnar- and entablature-jointed flow is a subaqueous to transitional lava flow and pillow lava and has a few decimetres of claystone at the base. The picture shows the lower $c .10 \mathrm{~m}$ of the $20 \mathrm{~m}$ thick flow.

1.1-3.5 km, Fig. 205), but the total extent is unknown (the western valley side has not been visited). The distinctly contaminated basalt $\left(52.5 \mathrm{wt} \% \mathrm{SiO}_{2}\right)$ covers subaerial lava flows of unit 463 and is separated from these by a few decimetres of claystone. The basalt was erupted in a shallow, near-shore part of the Naajaat Lake basin and forms a columnar-jointed, subaqueous to transitional lava flow and pillow lava (Fig. 200 at $1.3-2$ km, Fig. 206); the flow continues downslope on top of unit 463 hyaloclastites as subaqueous lava, pillow tongues and pillow breccias to form the local base of the Naajaat Lake basin at $2.4 \mathrm{~km}$.

The contaminated basalt is overlain by non-alkaline picrites. In subaerial facies, these form a thin succession of pahoehoe flows that separate flows of units 463 and 465 (Fig. 200 at $0.4-1.5 \mathrm{~km}$ ). The picrite flows entered the shallow shore zone of the Naajaat Lake basin to form foreset-bedded hyaloclastites which overlie the crustally

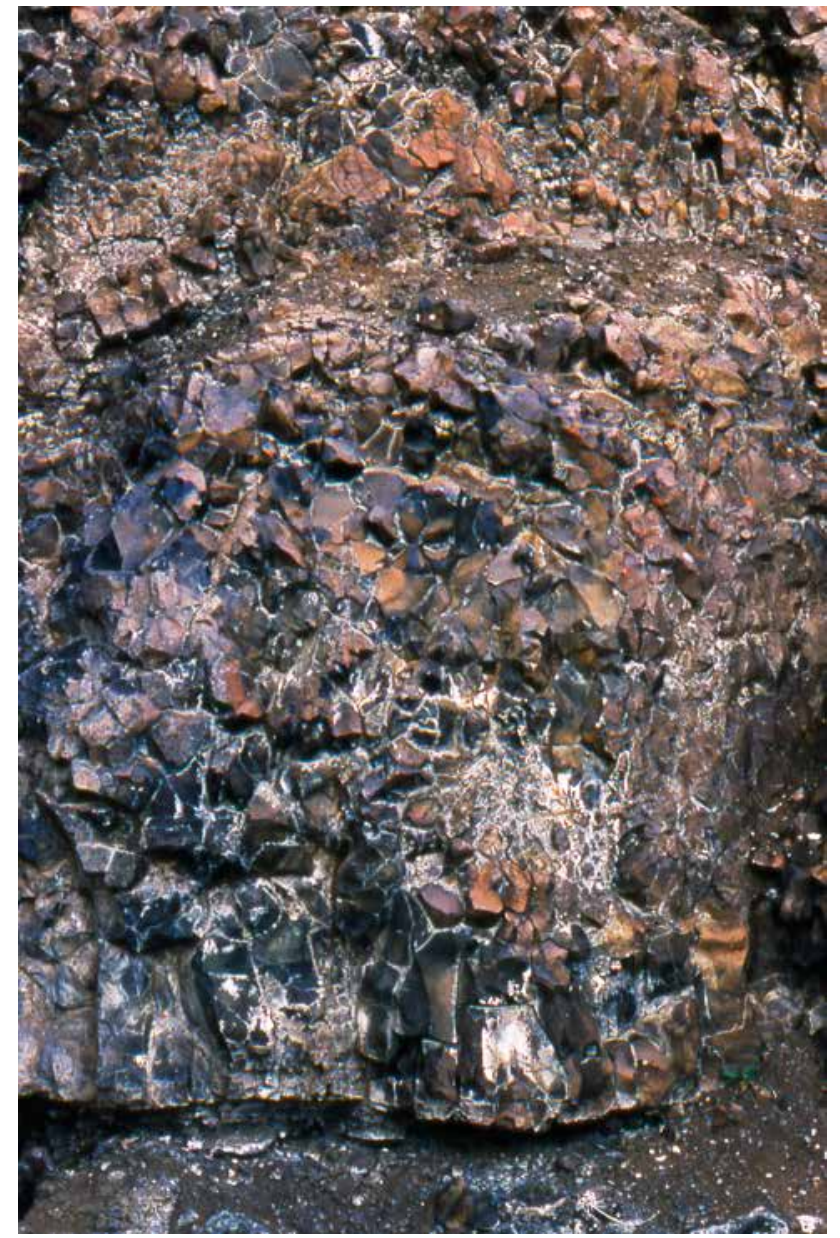

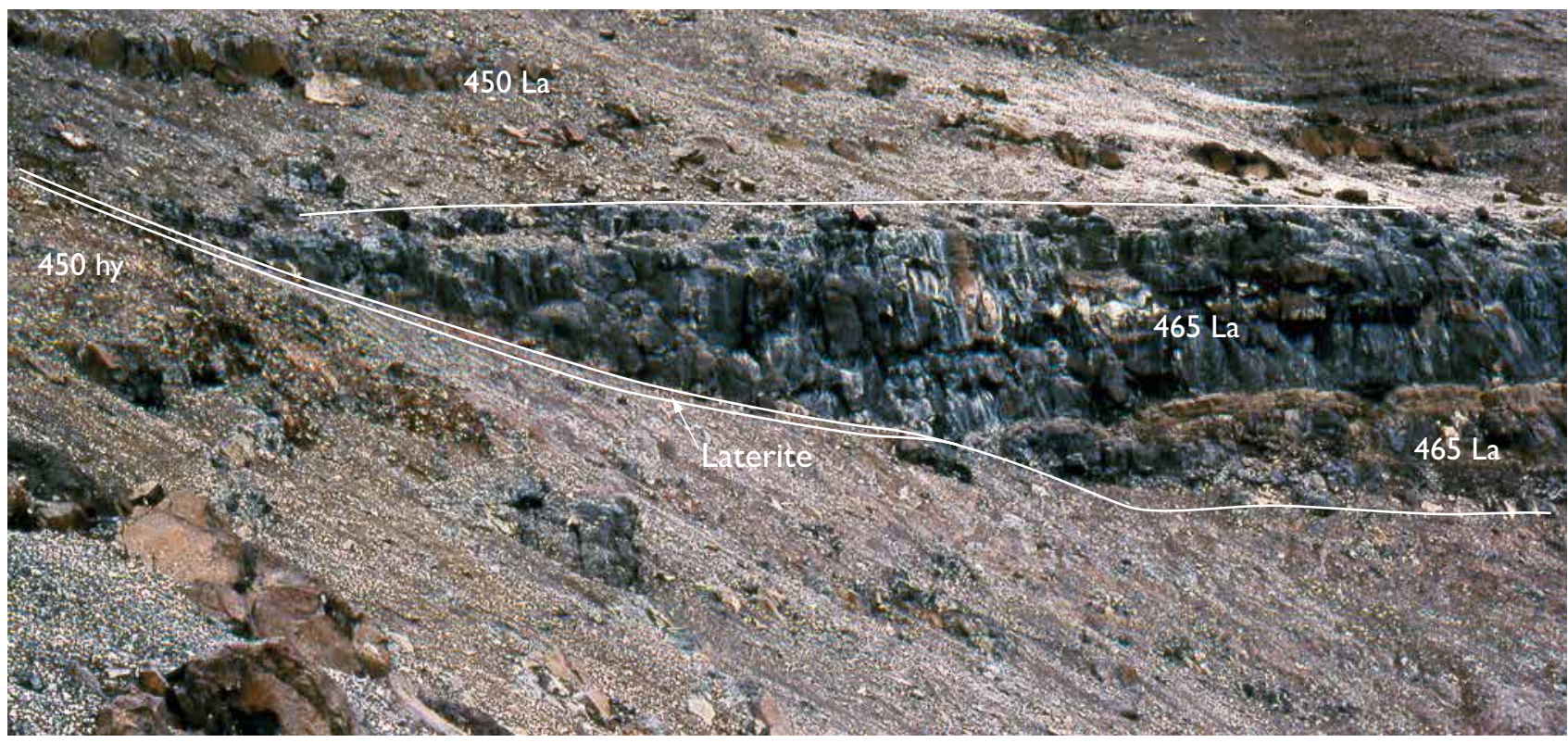

Fig. 207. The flank of a picritic pillow breccia heap ( $450 \mathrm{hy}$ ) that rose about $25 \mathrm{~m}$ above the surface of the Naajaat Lake. The surface of the heap is eroded, oxidised, covered by laterite, partly onlapped by subaerial alkali basalt lava flows of Manîtdlat Member unit 465 (465 La) and buried by picrite flows of Ordlingassoq Member unit 450 ( $450 \mathrm{La})$. The pillow heap may indicate proximity to a feeder site. The locality is indicated by a black arrow in Fig. 205. 
contaminated basalt (Fig. 200 at $1.5-3.5 \mathrm{~km}$ ). The picritic hyaloclastites are about $20 \mathrm{~m}$ thick but increase very locally to a thickness of about $50 \mathrm{~m}$ (Fig. 200 at around $1.7 \mathrm{~km}$ ) to form a pillow breccia heap which rose about $25 \mathrm{~m}$ above the lake surface (Fig. 205). The surface of the heap is oxidised and eroded by subaerial weathering. It was subsequently partly covered by subaerial alkaline lava flows of unit 465 and later buried by non-alkaline picrite flows of Ordlingassoq Member unit 450 (Fig. 207). The heap may indicate the proximity of a feeder site.

From the hyaloclastite heap, the non-alkaline hyaloclastites continue downslope the lake shelf to form a number of approximately horizontal hyaloclastite beds which have covered parts of the lake floor as a $40-50 \mathrm{~m}$ thick layer. The uppermost hyaloclastite bed is a coherent, brownish-weathering bed composed of many subbeds; this must have been produced from a single flow field with many small individual flows. The most finegrained sub-beds may show internal, small-scale crossbedding. Several centimetre- to decimetre-thick beds of mudstone and siltstone separate the larger hyaloclastite beds. These sediments must be time-equivalent to the erosion and oxidation surface which separates the hyaloclastite heap from the subaerial unit 465 lavas (Fig. 207), indicating a significant time interval between the eruption of the alkaline units 463 and 465 .

\section{Chemical composition of the Manîtdlat Member}

The compositional variations within the Manitdlat Member and the related unit of alkali picrites below it were described and interpreted by Larsen $e t$ al. 2003 and are briefly summarised here. Representative chemical analyses are shown in Table 7.

\section{Major elements}

Variation diagrams of the major elements are shown in Fig. 208. Compared to the tholeiitic rocks, the alkaline rocks have slightly lower $\mathrm{SiO}_{2}$ and $\mathrm{Al}_{2} \mathrm{O}_{3}$ and similar $\mathrm{FeO}^{*}$; however, compared to alkaline rocks elsewhere with similar degrees of trace-element enrichment (basanites and nephelinites), they have much higher $\mathrm{SiO}_{2}$ and $\mathrm{Al}_{2} \mathrm{O}_{3}$. Rocks of types 0,1 and 3 have significantly higher $\mathrm{CaO}$ than the tholeiites but similar $\mathrm{TiO}_{2}$. In contrast, type 2 rocks have similar $\mathrm{CaO}$ but higher $\mathrm{TiO}_{2}$. All rocks have high $\mathrm{P}_{2} \mathrm{O}_{5}$, particularly type $3 . \mathrm{Na}_{2} \mathrm{O}$ and in some samples $\mathrm{K}_{2} \mathrm{O}$ are low, and all the bulk rock analyses are hypersthene normative. However, fresh glasses in all the types have somewhat higher $\mathrm{Na}_{2} \mathrm{O}\left(2.0-2.8\right.$ wt $\% \mathrm{Na}_{2} \mathrm{O}$ at $7-8 \mathrm{wt} \% \mathrm{MgO}$ ) and are nepheline normative, and the crystalline lava samples appear to have lost $\mathrm{Na}_{2} \mathrm{O}$, and in some cases $\mathrm{K}_{2} \mathrm{O}$, by circulation of hydrothermal fluids.

Four samples of type 1a have increased $\mathrm{SiO}_{2}$ and decreased $\mathrm{CaO}$ and $\mathrm{P}_{2} \mathrm{O}_{5}$ and are most probably crustally contaminated.

\section{Trace elements}

Variation diagrams for trace elements are shown in Figs 209,210 . The high levels of incompatible elements are striking, particularly the high $\mathrm{Ba}, \mathrm{Sr}$ and LREE in types $1 \mathrm{~b}$ and 3 and high $\mathrm{Zr}$ in type 2 . Of the compatible elements, $\mathrm{Ni}$ and $\mathrm{Co}$ are lower than in the tholeiites, indicating lesser amounts of olivine in the melting assemblages than for the tholeiites.

REE and multi-element diagrams are shown in Fig. 211 (one sample for each type). The REE patterns are steep, with extremely high light REE and low heavy REE. The different enrichment patterns are clearly apparent in the multi-element diagrams; types $0,1 \mathrm{a}, 1 \mathrm{~b}$ and 3 all have peaks at $\mathrm{Ba}, \mathrm{U}, \mathrm{Nb}-\mathrm{Ta}$ and LREE, and troughs at $\mathrm{Rb}$, Th, K, P, Zr-Hf and Ti, but different element ratios, e.g. $(\mathrm{Nb} / \mathrm{La})_{\mathrm{N}}<1$ in types 0 and $1 \mathrm{~b}$ and $(\mathrm{Nb} / \mathrm{La})_{\mathrm{N}} \sim 1$ in types $1 \mathrm{a}, 3$. The strong and unusual $\mathrm{Th} / \mathrm{U}$ fractionation in all of these types is characteristic. In contrast, type 2 has peaks at $\mathrm{Rb}, \mathrm{Nb}-\mathrm{Ta}$ and $\mathrm{Zr}-\mathrm{Hf}$, a smaller $\mathrm{K}$ trough, $(\mathrm{Nb} / \mathrm{La})_{\mathrm{N}}>1$, and much lower degrees of enrichment in $\mathrm{Ba}, \mathrm{U}, \mathrm{LREE}$ and Sr.

The peculiar characteristics of the Manîtdlat Member magmas were interpreted by Larsen $e t$ al. (2003) to be caused by melting of amphibole- and apatite-rich, metasomatised parts of the local lithospheric mantle. The source for types $0,1 \mathrm{a}, 1 \mathrm{~b}$ and 3 also contained small amounts of exotic Ba-U-LREE-Sr-rich oxide, and the source for type 2 contained mica.

The existence of trace element enriched metasomatic veins in the lithospheric mantle beneath the Nuussuaq Basin, as indicated by the geochemistry of the Manittlat Member, provides a straightforward explanation for the previously noted, scattered occurrences of rocks that are enriched in incompatible elements. These rocks probably represent single, small magma batches that became contaminated by chance reactions with small melt fractions derived from such veins. 

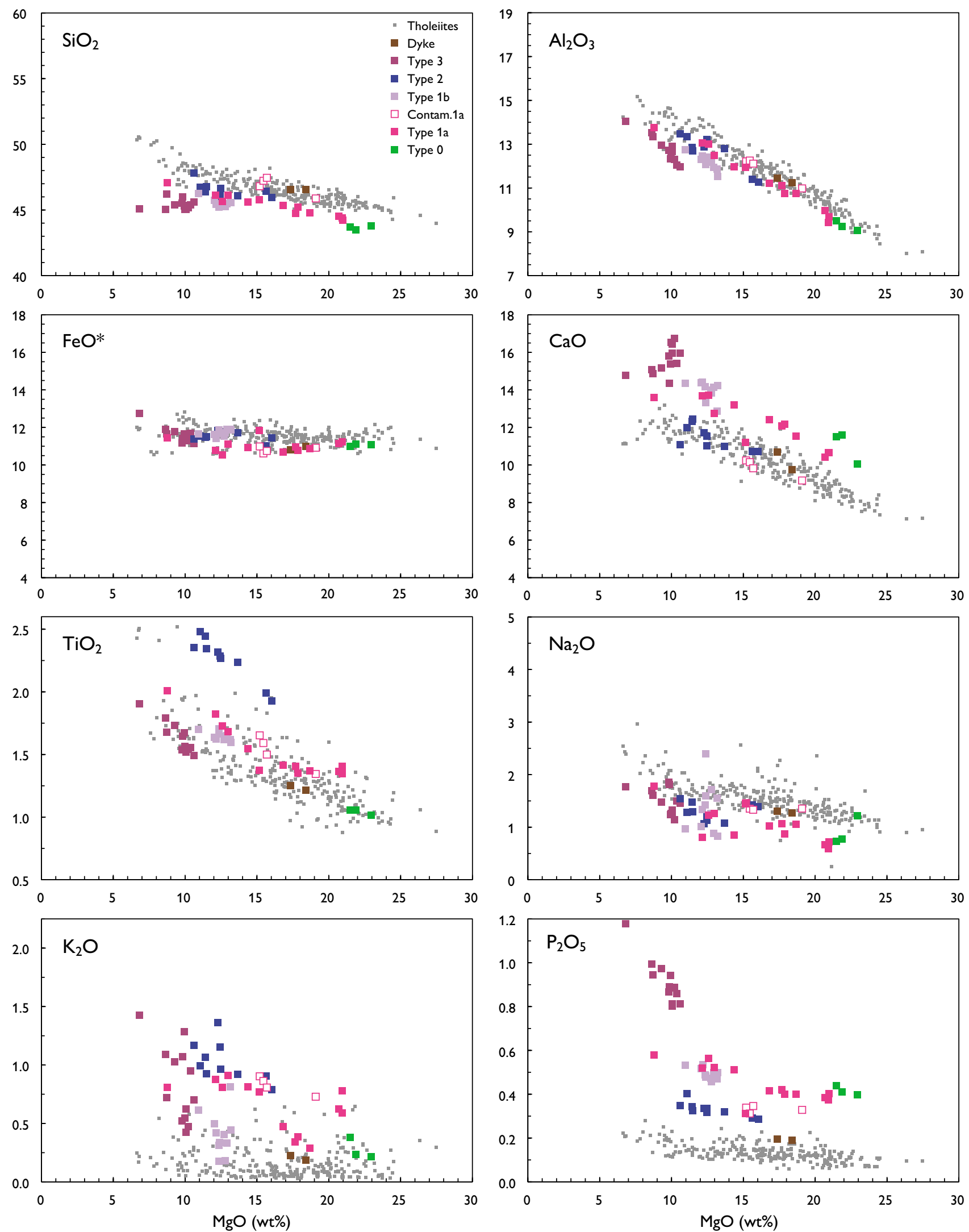

Fig. 208. Major-element variation diagrams for rocks of the Manitdlat Member. Data in wt\% oxides calculated volatile-free. FeO* is total iron as $\mathrm{FeO}$. 

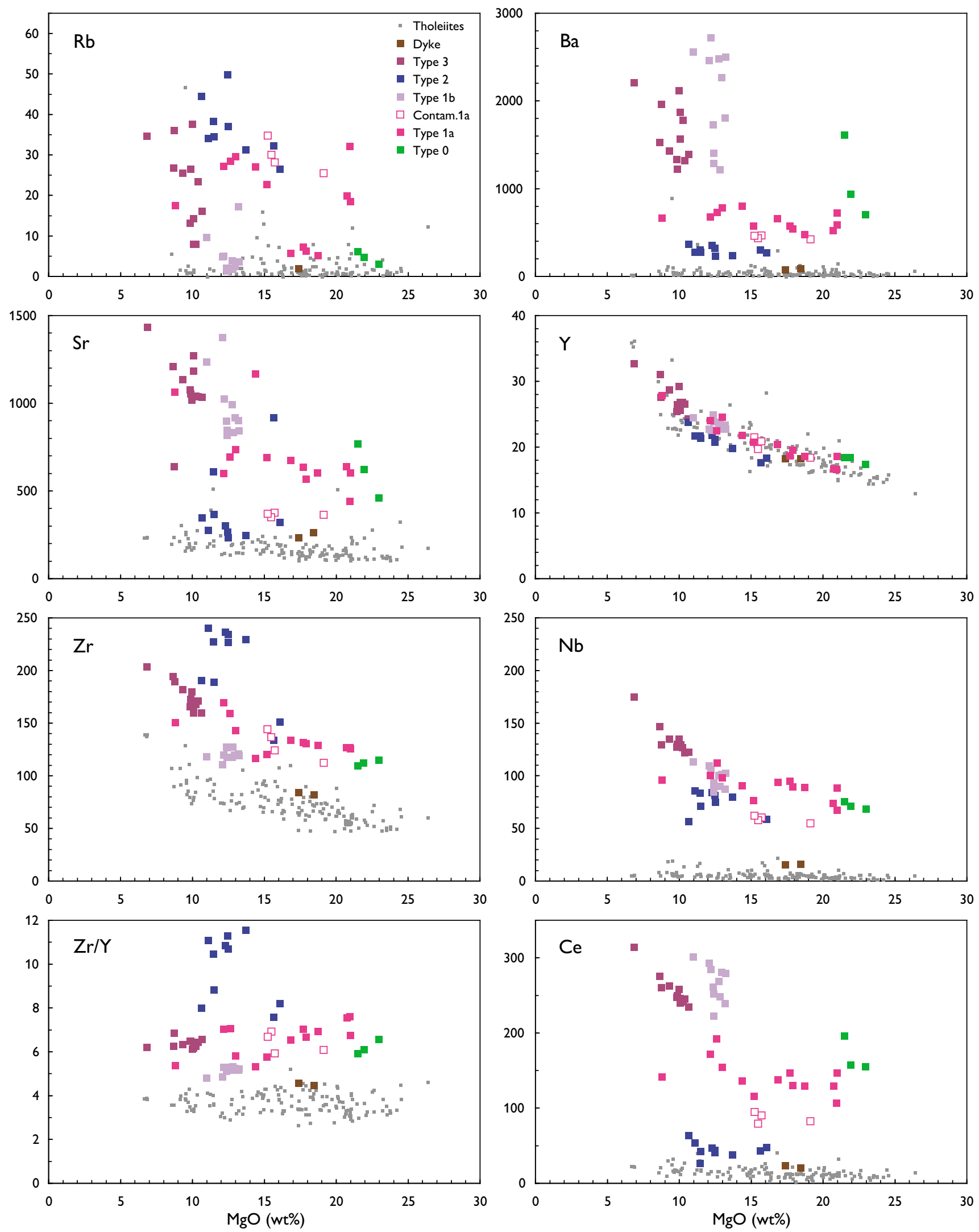

Fig. 209. Incompatible trace-element variation diagrams for rocks of the Manîtdlat Member. Data in ppm. 

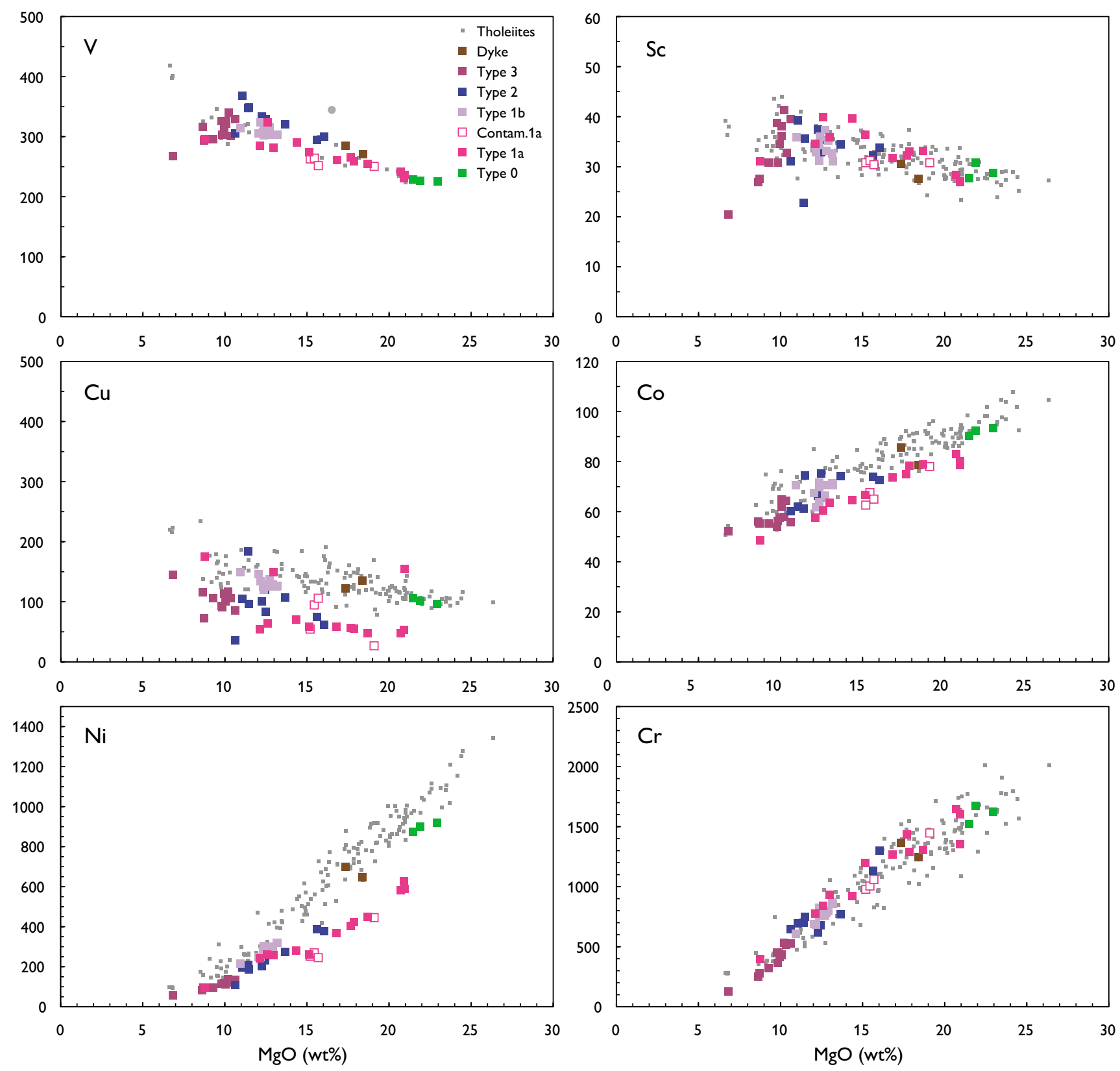

Fig. 210. Transition-element variation diagrams for rocks of the Manîtdlat Member. Data in ppm. 
Table 7a. Chemical analyses of rocks from the Manîtdlat Member

\begin{tabular}{|c|c|c|c|c|c|c|c|c|c|c|c|}
\hline \multirow[b]{3}{*}{ Lith. code } & \multirow{2}{*}{\multicolumn{2}{|c|}{$\frac{\begin{array}{c}\text { Embedded in } \\
\text { Ordlingassoq } \mathrm{Mb}\end{array}}{\text { Type } 0}$}} & \multicolumn{9}{|c|}{ Main Manîtdlat Mb } \\
\hline & & & \multicolumn{2}{|c|}{ Type 1a } & \multicolumn{2}{|c|}{ Type 1b } & \multicolumn{2}{|c|}{ Type 2} & \multicolumn{2}{|c|}{ Type 3} & \multirow{2}{*}{$\frac{\text { Mix-dyke }}{6211}$} \\
\hline & 4602 & 4602 & 4612 & 4612 & 4622 & 4622 & 4632 & 4632 & 4642 & 4641 & \\
\hline GGU No. & 327099 & 327097 & 326788 & 326787 & 264124 & 264122 & 264113 & 264114 & 264093 & 264106 & 326785 \\
\hline Deg.W & 5325.12 & 5325.33 & 5320.42 & 5320.42 & 5335.29 & 5335.28 & 5333.55 & 5333.65 & 5331.51 & 5332.59 & 5320.59 \\
\hline Deg. $N$ & 7011.02 & 7011.12 & 7009.75 & 7009.75 & 7005.56 & 7005.58 & 7005.04 & 7004.97 & 7004.38 & 7004.77 & 7009.87 \\
\hline Altitude, $\mathrm{m}$ & 816.94 & 796.87 & 734.68 & 734.68 & 565.77 & 585.10 & 709.63 & 605.06 & 573.57 & 777.08 & 693.16 \\
\hline $\mathrm{SiO}_{2}$ & 42.64 & 42.37 & 43.04 & 44.27 & 43.79 & 45.20 & 44.85 & 45.92 & 43.92 & 44.03 & 45.71 \\
\hline $\mathrm{TiO}_{2}$ & 0.99 & 1.03 & 1.35 & 1.38 & 1.56 & 1.66 & 1.88 & 2.30 & 1.47 & 1.86 & 1.23 \\
\hline $\mathrm{Al}_{2} \mathrm{O}_{3}$ & 8.82 & 9.02 & 10.68 & 10.96 & 11.96 & 12.46 & 11.01 & 12.46 & 12.50 & 13.72 & 11.25 \\
\hline $\mathrm{Fe}_{2} \mathrm{O}_{3}$ & 2.52 & 2.18 & 2.04 & 2.10 & 2.59 & 2.33 & 2.49 & 2.79 & 2.05 & 4.93 & 1.96 \\
\hline $\mathrm{FeO}$ & 8.53 & 8.87 & 8.72 & 8.56 & 8.79 & 9.29 & 8.92 & 8.79 & 9.16 & 8.00 & 8.85 \\
\hline $\mathrm{MnO}$ & 0.20 & 0.19 & 0.19 & 0.19 & 0.21 & 0.20 & 0.18 & 0.18 & 0.21 & 0.23 & 0.18 \\
\hline $\mathrm{MgO}$ & 22.34 & 21.33 & 17.00 & 16.42 & 12.28 & 10.70 & 15.66 & 11.26 & 9.74 & 6.66 & 17.04 \\
\hline $\mathrm{CaO}$ & 9.80 & 11.31 & 11.61 & 12.12 & 13.49 & 14.04 & 10.48 & 12.22 & 15.45 & 14.44 & 10.49 \\
\hline $\mathrm{Na}_{2} \mathrm{O}$ & 1.19 & 0.75 & 1.03 & 1.00 & 1.22 & 0.95 & 1.36 & 1.27 & 1.22 & 1.73 & 1.28 \\
\hline $\mathrm{K}_{2} \mathrm{O}$ & 0.209 & 0.228 & 0.327 & 0.463 & 0.39 & 0.60 & 0.77 & 0.91 & 0.603 & 1.39 & 0.219 \\
\hline $\mathrm{P}_{2} \mathrm{O}_{5}$ & 0.386 & 0.400 & 0.404 & 0.407 & 0.46 & 0.52 & 0.28 & 0.32 & 0.778 & 1.15 & 0.192 \\
\hline Volatiles & 2.63 & 2.54 & 3.66 & 2.27 & 2.66 & 1.06 & 1.59 & 1.32 & 2.75 & 0.89 & 1.78 \\
\hline Sum & 100.26 & 100.22 & $\overline{100.06}$ & 100.14 & 99.40 & 99.01 & 99.47 & 99.74 & 99.85 & 99.03 & 100.18 \\
\hline $\mathrm{Zn}$ & 91 & 86 & 88 & 87 & 94 & 94 & 87 & 91 & 107 & 112 & 91 \\
\hline $\mathrm{Cu}$ & 94 & 99 & 54 & 57 & 133 & 146 & 60 & 94 & 97 & 142 & 120 \\
\hline Co & 91 & 90 & 72 & 72 & 64 & 69 & 71 & 73 & 60 & 51 & 84 \\
\hline $\mathrm{Ni}$ & 896 & 876 & 387 & 360 & 258 & 210 & 368 & 183 & 114 & 56 & 688 \\
\hline $\mathrm{Sc}$ & 28 & 30 & 31 & 31 & 36 & 35 & 33 & 35 & 35 & 20 & 30 \\
\hline V & 219 & 221 & 255 & 255 & 305 & 307 & 293 & 342 & 312 & 261 & 280 \\
\hline $\mathrm{Cr}$ & 1580 & 1630 & 1380 & 1240 & 734 & 596 & 1270 & 733 & 418 & 123 & 1340 \\
\hline $\mathrm{Ga}$ & 12 & 14 & 13 & 16 & 13 & 18 & 15 & 31 & 23 & 20 & 15 \\
\hline $\mathrm{Rb}$ & 3.53 & 5.60 & 7.34 & 6.49 & 5.09 & 12.0 & 29.3 & 36.6 & 31.0 & 37.9 & 2.28 \\
\hline $\mathrm{Sr}$ & 458 & 629 & 647 & 695 & 1001 & 1281 & 335 & 374 & 1161 & 1481 & 240 \\
\hline$Y$ & 18.8 & 19.4 & 21.4 & 21.9 & 25.3 & 27.3 & 20.7 & 23.5 & 31.1 & 35.9 & 20.3 \\
\hline $\mathrm{Zr}$ & 122 & 125 & 147 & 152 & 142 & 155 & 161 & 197 & 215 & 255 & 87.7 \\
\hline $\mathrm{Nb}$ & 70 & 73 & 99 & 99 & 104 & 121 & 64 & 72 & 148 & 195 & 15.9 \\
\hline Cs & 0.515 & 0.228 & 0.503 & 0.169 & 0.114 & 0.163 & 0.389 & 0.361 & 0.393 & 0.365 & 0.164 \\
\hline $\mathrm{Ba}$ & 577 & 865 & 534 & 643 & 2286 & 2380 & 266 & 267 & 1241 & 1896 & 71.4 \\
\hline $\mathrm{La}$ & 92 & 98 & 88 & 87 & 170 & 191 & 25 & 25 & 154 & 198 & 11.8 \\
\hline $\mathrm{Ce}$ & 157 & 169 & 156 & 154 & 290 & 327 & 52 & 53 & 284 & 360 & 26.1 \\
\hline $\operatorname{Pr}$ & 16.5 & 17.7 & 16.5 & 16.4 & 29.9 & 33.6 & 6.35 & 6.49 & 30.8 & 38.6 & 3.42 \\
\hline Nd & 58.0 & 61.2 & 58.3 & 57.9 & 102 & 114 & 25.6 & 27.2 & 111 & 135 & 14.3 \\
\hline $\mathrm{Sm}$ & 7.85 & 8.30 & 8.43 & 8.41 & 13.0 & 14.4 & 4.93 & 5.55 & 15.3 & 18.2 & 3.60 \\
\hline $\mathrm{Eu}$ & 2.15 & 2.27 & 2.28 & 2.31 & 3.49 & 3.81 & 1.53 & 1.72 & 4.22 & 4.96 & 1.24 \\
\hline Gd & 4.87 & 4.91 & 5.21 & 5.58 & 6.92 & 7.51 & 4.70 & 5.17 & 9.53 & 10.3 & 3.80 \\
\hline $\mathrm{Tb}$ & 0.759 & 0.789 & 0.846 & 0.851 & 1.10 & 1.18 & 0.702 & 0.815 & 1.36 & 1.61 & 0.649 \\
\hline Dy & 3.86 & 3.89 & 4.21 & 4.33 & 5.35 & 5.78 & 3.90 & 4.45 & 6.59 & 7.73 & 3.80 \\
\hline Ho & 0.675 & 0.696 & 0.761 & 0.775 & 0.926 & 0.980 & 0.735 & 0.839 & 1.13 & 1.33 & 0.723 \\
\hline $\mathrm{Er}$ & 1.64 & 1.70 & 1.90 & 1.98 & 2.19 & 2.34 & 1.84 & 2.11 & 2.60 & 3.08 & 1.94 \\
\hline $\mathrm{Tm}$ & 0.234 & 0.236 & 0.269 & 0.277 & 0.316 & 0.335 & 0.268 & 0.305 & 0.361 & 0.439 & 0.280 \\
\hline $\mathrm{Yb}$ & 1.41 & 1.39 & 1.67 & 1.66 & 1.93 & 2.03 & 1.62 & 1.92 & 2.22 & 2.65 & 1.67 \\
\hline Lu & 0.220 & 0.234 & 0.257 & 0.268 & 0.290 & 0.314 & 0.260 & 0.293 & 0.330 & 0.400 & 0.244 \\
\hline $\mathrm{Hf}$ & 2.84 & 2.98 & 3.61 & 3.74 & 3.61 & 3.84 & 4.39 & 5.35 & 4.75 & 5.37 & 2.30 \\
\hline $\mathrm{Ta}$ & 3.31 & 3.44 & 5.11 & 5.09 & 5.06 & 5.79 & 4.26 & 4.99 & 7.17 & 9.58 & 1.02 \\
\hline $\mathrm{Pb}$ & 4.45 & 4.94 & 3.72 & 3.68 & 9.77 & 10.4 & 2.71 & 3.64 & 5.32 & 7.30 & 1.86 \\
\hline Th & 2.54 & 2.66 & 3.25 & 3.26 & 4.86 & 5.35 & 2.12 & 2.20 & 5.55 & 7.45 & 0.648 \\
\hline $\mathrm{U}$ & 1.72 & 1.75 & 2.61 & 2.60 & 2.59 & 3.02 & 0.799 & 0.690 & 4.14 & 5.66 & 0.475 \\
\hline \multicolumn{12}{|c|}{ Isotope ratios calculated at $60 \mathrm{Ma}$} \\
\hline${ }^{87} \mathrm{Sr} /{ }^{86} \mathrm{Sr}_{60}$ & 0.703701 & 0.703738 & 0.704432 & 0.704357 & 0.703747 & 0.703767 & 0.705504 & 0.705508 & 0.703604 & $\begin{array}{l}4 \quad 0.703647 \\
\end{array}$ & 0.703996 \\
\hline$\varepsilon S r$ & -12.06 & -11.53 & -1.68 & -2.75 & -11.40 & -11.12 & 13.54 & 13.60 & -13.43 & -12.82 & -7.87 \\
\hline${ }^{143} \mathrm{Nd} /{ }^{144} \mathrm{Nd}_{60}$ & 0.512375 & 0.512381 & 0.512329 & 0.512372 & $2 \quad 0.512387$ & 0.512382 & 0.512432 & 0.512508 & $8 \quad 0.512358$ & $3 \quad 0.512367$ & 0.512658 \\
\hline$\varepsilon N d$ & -3.62 & -3.51 & -4.53 & -3.69 & -3.39 & -3.49 & -2.50 & -1.03 & -3.95 & -3.78 & 1.90 \\
\hline${ }^{206} \mathrm{~Pb} /{ }^{204} \mathrm{~Pb}_{60}$ & 19.998 & 19.962 & 20.620 & 20.570 & 19.689 & 19.693 & 18.648 & 18.921 & 21.238 & 21.258 & 19.619 \\
\hline${ }^{207} \mathrm{~Pb} /{ }^{204} \mathrm{~Pb}_{60}$ & 15.547 & 15.564 & 15.530 & 15.492 & 15.553 & 15.541 & 15.299 & 15.321 & 15.572 & 15.599 & 15.554 \\
\hline${ }^{208} \mathrm{~Pb} /{ }^{204} \mathrm{~Pb}_{60}$ & 38.446 & 38.453 & 38.442 & 38.341 & 38.425 & 38.394 & 38.143 & 38.372 & 38.732 & 38.806 & 38.646 \\
\hline
\end{tabular}

For explanation of lithological codes, see Table 1. For petrographical notes on the samples, see Table 7b.

Geographical coordinates in WGS 84. First two digits are degrees, then follow minutes in decimal form.

Major elements in wt\% (XRF analyses). Trace elements in PPm (Zn-Ga: XRF analyses; Rb-U: ICP-MS analyses). 
Table 7b. Notes on analysed samples from the Manîtdlat Member and associated rocks

327099 Picrite pillow in hyaloclastite, Orlingassoq profile, $5 \mathrm{~km}$ west-south-west of Asuk, north coast of Disko.

327097 Picrite pillow in hyaloclastite, Orlingassoq profile, $5 \mathrm{~km}$ west-south-west of Asuk, north coast of Disko.

326788 Picrite pillow in hyaloclastite, west side of Asuutaa mountain, north coast of Disko.

326787 Picrite pillow in hyaloclastite, west side of Asuutaa mountain, north coast of Disko.

264124 Olivine-poor picrite pillow in hyaloclastite, east side of Kuugannguaq valley 17 km from the coast, northern Disko (Fig. 200).

264122 Olivine-phyric basalt pillow in hyaloclastite, east side of Kuugannguaq valley $17 \mathrm{~km}$ from the coast, northern Disko.

264113 Picrite pillow breccia, east side of Kuugannguaq valley $18 \mathrm{~km}$ from the coast, northern Disko.

264114 Olivine-phyric basalt pillow in hyaloclastite, east side of Kuugannguaq valley $18 \mathrm{~km}$ from the coast, northern Disko.

264093 Olivine-clinopyroxene-phyric basalt pillow in hyaloclastite, east side of Kuugannguaq valley $19 \mathrm{~km}$ from the coast, northern Disko.

264106 Clinopyroxene-microphyric basalt lava flow, east side of Kuugannguaq valley $19 \mathrm{~km}$ from the coast, northern Disko.

326785 Picrite dyke, tholeiitic magma contaminated with c. 15\% Manîtdlat Member Type 1a melt. The dyke fed a lava flow in the Ordlingassoq Member immediately above the Manîtdlat Member, $2 \mathrm{~km}$ west of Asuutaa mountain, north coast of Disko.

Phenocryst phases are mentioned in order of decreasing abundance. All picrites are strongly olivine-phyric.
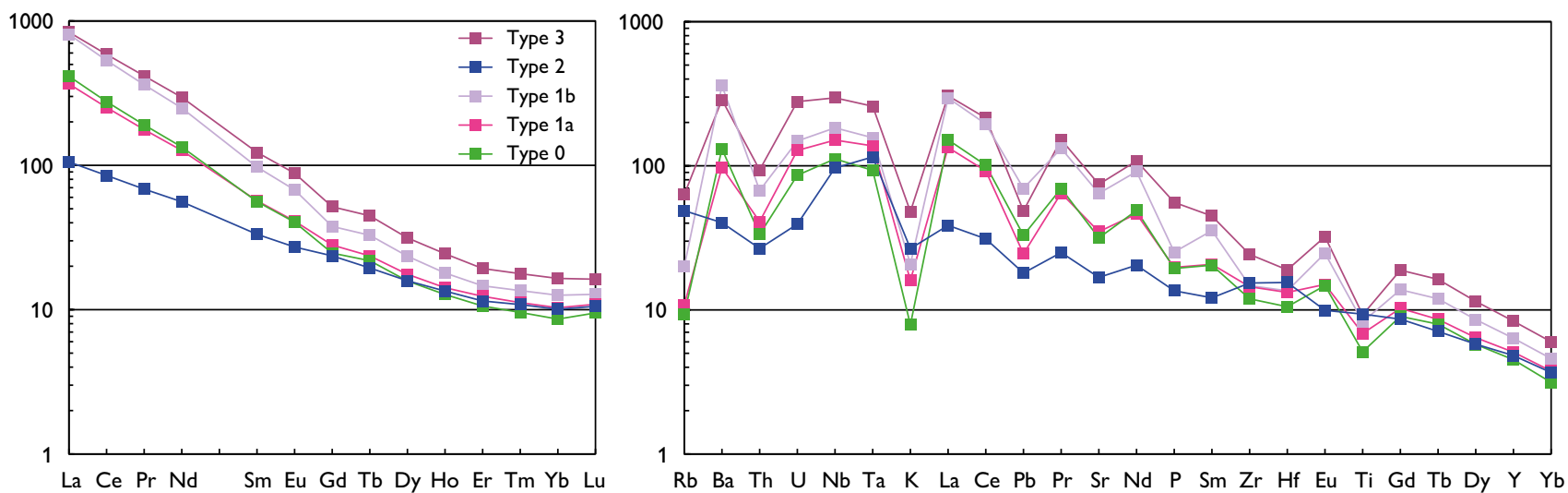

Fig. 211. REE and multi-element diagrams for representative rocks of the Manîtdlat Member. Left diagram, chondrite normalised; right diagram, primitive mantle normalised; normalisation factors from McDonough \& Sun (1995). 


\section{Intrusions of the Vaigat Formation}

Dykes and sills with picritic compositions $(\mathrm{MgO}>12$ wt\%) are common within the area of the Vaigat Formation, and, except for some sills in mudstones on southeastern Nuussuaq which are invasive lava flows of the Ordlingassoq Member (unit 450), they do not occur outside it; this demonstrates a close connection between the extrusive and intrusive rocks. Some intrusions form feeders at, or close to, eruption sites and samples of these have been grouped together with the volcanic units to which they belong. For most intrusions there is no direct physical connection with eruption sites, yet the picritic dykes must be considered as feeders for the volcanic rocks, whereas the sills may be offshoots from the feeder systems.

It is commonly not possible to correlate intrusions situated in sediments or low in the volcanic succession with any volcanic unit with absolute certainty. However, in some cases a correlation or association can be suggested with confidence, as follows.

The picrite sill intrusions in the sediments below the volcanics in the drill cores GANW\#1, Marraat-1 and GANE\#1, all on western Nuussuaq, belong to the Anaanaa Member; their chemistry suggests units 402 or 404.

Two contaminated basalt dykes in the Sikillingi area on western Nuussuaq are considered to be feeders for the contaminated lavas of unit 408 in the Anaanaa Member.

A slightly contaminated picrite dyke in Anariartorfik, western Nuussuaq, is probably a feeder to the lava flows of the contaminated Henderson unit (411) of the Naujánguit Member in the same small area.

Prominent sill intrusions are seen in the Atane Formation sandstones at Gamle Qullissat on northern Disko and along the south coast of Nuussuaq from Nuuk Killeq to Ataata Kuua. These sills are strongly contaminated, with 54-55 wt\% $\mathrm{SiO}_{2}$, 7.5-9.5 wt\% $\mathrm{MgO}$ and strong depletion in $\mathrm{Cu}$ and $\mathrm{Ni}$. The sills on Disko are native- iron- and graphite-bearing, whereas those on Nuussuaq are not. None of them show the relative $\mathrm{Cr}$ enrichment characteristic of the Kûgánguaq Member. The sills are tentatively correlated with the Asuk Member, although they occur outside the reaches of the extrusive rocks of this member. A sill with similar composition just below the mudstones of the Naujât Member at Kingittoq, just east of Giesecke Monument, is situated completely outside the south-eastern extension of the extrusives of the Vaigat Formation.

A number of highly contaminated dykes with 51-55 wt $\% \mathrm{SiO}_{2}$ and 7-10 wt\% $\mathrm{MgO}$ within a small area on northern Disko are clearly associated with the Kûgánguaq Member in the same area; one dyke is an observed feeder dyke. Their chemical compositions are in accordance with this, including increased $\mathrm{Cr}$ relative to the uncontaminated trend and strong depletions in $\mathrm{Cu}$ and $\mathrm{Ni}$.

Some enriched picrite dykes on Nuussuaq are most probably feeders for the enriched picrite flows in the Ordlingassoq Member in the same area; some of the dykes cut flows of this member. A few enriched picrite dykes in a small area on Disko occur in the same area as the Manitdlat Member and cut this member; they are interpreted to have mixed with the alkaline magmas during their passage to the surface (Larsen et al. (2003).

Uncontaminated basalt dykes with 8-12 wt\% $\mathrm{MgO}$ (more than in the uncontaminated basalts of the Maligât Formation) occur only on western Nuussuaq, Hareøen and northern Disko. Some of the dykes on western Nuussuaq are probably feeders for the low-Mg units of the Anaanaa Member (units 405, 407), but in the other areas these dykes cut higher levels and could have fed Mg-poor lavas in the higher units of the Vaigat Formation; others have a somewhat enriched chemistry and could be very much younger. None of them have been dated radiometrically. 


\section{Volumes of the Vaigat Formation}

Estimates of the volumes of the various units of the Vaigat Formation (Table 8) have been made within an area delimited by the north coast of Nuussuaq to the north, the Itilli fault to the north-west, a N-S line skirting the western edge of Disko to the west and the depositional limits (Figs 9-11) to the south and east. The Vaigat Formation certainly continues west and north of the chosen area as shown on Fig. 9, but there is not enough data to warrant similar estimates there.

The volume estimates for the volcanic rocks of the three major episodes involve considerable extrapolation of thicknesses to the west. This comprises estimates of the thicknesses in the succession removed by erosion on western Nuussuaq and similar estimates for the succession below the level of exposure west of the Disko Gneiss Ridge. The overall volumes produced in the three main episodes (Table 8 ) are therefore fairly rough estimates. The volumes of the contaminated units are estimated based on their distribution (Figs 10, 12, 18), and although some extrapolation was also necessary for some of these, we consider that the volumes of the contaminated units are reasonably well constrained.

The results in Table 8 show that the volume of the contaminated units is $5.7 \%$ of the total Vaigat Formation and highlight the differences between the second (Naujánguit) episode with $14.2 \%$ contaminated rocks and the third (Ordlingassoq) episode with only $0.03 \%$ contaminated rocks. Additional contaminated units may exist in the extrapolated parts of the succession, and there are some minor occurrences of slightly contaminated rocks, but the overall picture is considered to be robust.

The close to $10000 \mathrm{~km}^{3}$ large volume of the Vaigat Formation on Disko and Nuussuaq, of which the major part is picritic with an average $\mathrm{MgO}$ content of $16.6 \mathrm{wt} \%$ (Larsen \& Pedersen 2009), is unique. Addition of the volumes of the Vaigat Formation on Ubekendt Ejland and Svartenhuk Halvø probably increases the total picrite volume in West Greenland to more than $20000 \mathrm{~km}^{3}$. This is, to our knowledge, the most voluminous picrite succession on Earth.

Table 8. Volumes of different parts of the Vaigat Formation

\begin{tabular}{|c|c|c|c|c|c|}
\hline Volcanic episode & code & Area $\left(\mathrm{km}^{2}\right)$ & Average thickness (m) & Volume $\left(\mathrm{km}^{3}\right)$ & $\%$ of total \\
\hline Ordlingassoq Mb episode & & 7630 & 700 & 5300 & 56 \\
\hline Naujánguit Mb episode & & 5240 & 700 & 3700 & 38 \\
\hline Anaanaa Mb episode & & 630 & 850 & 500 & 6 \\
\hline Vaigat Formation, total volume & & & & 9500 & \\
\hline \multicolumn{6}{|l|}{ Contaminated units } \\
\hline Ordlingassoq Mb, contaminated & 451 & 40 & 40 & 2 & 0.02 \\
\hline Kûgànguaq Mb & 430 & 680 & 30 & 20 & 0.2 \\
\hline Tunoqqu Mb & $424+428$ & 2700 & 70 & 189 & 2.0 \\
\hline Ukallit unit & 426 & 20 & 15 & 0.3 & $<0.01$ \\
\hline Tunorsuaq $b$ unit & 425 & 20 & 30 & 0.6 & 0.01 \\
\hline Stordal unit & 421 & 60 & 70 & 4 & 0.04 \\
\hline Niiortuut unit & 422 & 50 & 80 & 4 & 0.04 \\
\hline Asuk Mb on Disko & 420 & 630 & 30 & 19 & 0.2 \\
\hline Ilugissoq volcano & 420 & 20 & 200 & 4 & 0.04 \\
\hline Saviaqqat unit & 419 & 630 & 30 & 19 & 0.2 \\
\hline Tunorsuaq a unit & 416 & 50 & 20 & 1 & 0.01 \\
\hline Nuuk Killeq Member & 414 & 1500 & 120 & 180 & 1.9 \\
\hline Nuusap Qaqqarsua Mb & 412 & 330 & 250 & 83 & 0.9 \\
\hline Henderson unit & 411 & 30 & 30 & 0.9 & 0.01 \\
\hline Anaanaa Mb, Marraat unit & 408 & 600 & 30 & 18 & 0.2 \\
\hline Anaanaa Mb, lower contam. unit & 406 & 30 & 20 & 0.6 & 0.01 \\
\hline \multicolumn{3}{|c|}{ Contaminated rocks: volume and percent of total volume } & & 545 & 5.7 \\
\hline \multicolumn{6}{|c|}{ Contaminated volumes in each episode (\%) } \\
\hline Ordlingassoq Member episode & 0.03 & & & & \\
\hline Naujánguit Member episode & 14.3 & & & & \\
\hline Anaanaa Member episode & 3.5 & & & & \\
\hline
\end{tabular}

Areas of the three major members are extrapolated to the west as described in the text. Supplementary thickness information was extracted from vertical profiles. Areas of the contaminated units are delimited based on maps and photogrammetric sections.

Thicknesses were measured in $1 \mathrm{~km}$-steps in the photogrammetric sections and averaged. Results for the three major episodes are in rounded figures. 


\section{Concluding remarks}

The Vaigat Formation is the most voluminous picrite succession known on Earth and as such unique. It reflects a history of $\mathrm{Mg}$-rich magmas that were produced in the asthenosphere and rose from the melting areas to the surface with only little modification on the way and were erupted over wide areas. Only during some brief periods were magma batches trapped in magma chambers in sediments and became contaminated and fractionated. The formation must be the result of a highly unusual combination of conditions, most importantly a tectonic setting that prevented the establishment of permanent magma chambers.

At the end of the Vaigat Formation activity, the Mgrich volcanic rocks formed a $\mathrm{N}-\mathrm{S}$ elongate dome with tapering southern and south-eastern margins on central Disko and eastern Nuussuaq, surrounded by non-marine sediments and gneiss hills to the east and south. West of the Disko Gneiss Ridge relations are unknown, and it is in this area that the oldest known part of the Maligât Formation was deposited.

The transition from the picrites of the Vaigat Formation to the basalts of the Maligat Formation must be tied to fundamental changes in the conditions in the lithosphere that led to establishment of large and deep, longlived magma chambers where the magmas fractionated to basalt, and eruption sites were mainly confined to west of the Disko Gneiss Ridge. It is an unanswered question as to whether the two formations were completely separated in time or the activities were partly overlapping.

\section{Acknowledgements}

The results described in this bulletin are based on field work carried out under the auspices of GGU and subsequently GEUS, and with support from the Bureau of
Minerals and Petroleum, Government of Greenland. Arktisk Station (University of Copenhagen) in Qeqertarsuaq (Godhavn) also provided generous field support. Starting in 1968 (AKP) at the suggestion of professor Arne Noe-Nygaard, we are indebted to many persons over the years, in particular to the expedition leaders Gilroy Henderson, Feiko Kalsbeek and Flemming Getreuer Christiansen, and also to Heads of Department Niels Henriksen and Christian Knudsen for general GEUS support. Special thanks go to our late friend and colleague Finn Ulff-Møller who took part in the field work during several years and who later, during work for the mining company Greenex, collected invaluable information in areas not visited by us. Some of his photographs and field sketches are used in this bulletin.

The photogrammetric work was mainly carried out at the Technical University of Denmark in close cooperation with Keld S. Dueholm and with generous support from Ole Mærsk-Møller and Ole Jacobi. We are also grateful for support from Hans Jepsen and Erik Vest Sørensen from the GGU/GEUS photogrammetrical laboratory, to Jakob Lautrup for reproduction of countless photographs in the pre-digital age and to Annette Hindø and Willy Weng for technical and geodetic help in the design and production of the geological maps and sections. Jørgen Kystol and Ib Sørensen at GGU/GEUS' rock geochemical laboratory, and John Bailey at the XRF laboratory of the Geological Institute, University of Copenhagen, maintained the constantly high quality of the chemical analyses of the rocks. Jørgen Bojesen-Koefoed at GEUS kindly made the carbon and sulfur analyses. Jette Halskov prepared the drawings and she and Susanne Rømer annotated the photographs in this bulletin. Finally, we thank the reviewers Henry Emeleus and Richard Wilson for their helpful and constructive reviews. 


\section{References}

Athavale, R.N. \& Sharma, P.V. 1975: Paleomagnetic results on Early Tertiary lava flows from West Greenland and their bearing on the evolution history of the Baffin Bay-Labrador Sea region. Canadian Journal of Earth Sciences 12, 1-18.

Auclair, M., Gauthier, M., Trottier, J., Jebrak, M. \& Chartrand, F. 1993: Mineralogy, geochemistry, and paragenesis of the Eastern Metals serpentinite-associated Ni-Cu-Zn deposit, Quebec Appalachians. Economic Geology 88, 123-138.

Berner, R.A. \& Raiswell, R. 1983: Burial of organic carbon and pyrite sulfur in sediments over Phanerozoic time: a new theory. Geochimica et Cosmochimica Acta 47, 855-862.

Berner, R.A. \& Raiswell, R. 1984: C/S method for distinguishing freshwater from marine sedimentary rocks. Geology 12, 365-368.

Binzer, K. \& Karup-Møller, S. 1974: Ferri-sepiolite in hydrothermal calcite-quartz-chalcedony veins on Nûgssuaq in West Grenland. Bulletin Grønlands Geologiske Undersøgelse 114, 16 pp. + plates.

Bøggild, O.B. 1953: The mineralogy of Greenland. Meddelelser om Grønland 149(3), 442 pp.

Bojesen-Koefoed, J.A., Christiansen, F.G., Nytoft, H.P. \& Pedersen, A.K. 1999: Oil seepage onshore West Greenland: evidence of multiple source rocks and oil mixing. In: Fleet, A.J. \& Boldy, S.A.R. (eds): Petroleum geology of Northwest Europe: Proceedings of the 5th conference, 305-314. London: Geological Society.

Bojesen-Koefoed, J.A., Bidstrup, T., Christiansen, F.G., Dalhoff, F., Gregersen, U., Nytoft, H.P., Nøhr-Hansen, H. \& Pedersen, A.K. \& Sønderholm, M. 2007: Petroleum seepages at Asuk, Disko, West Greenland: implications for regional petroleum exploration. Journal of Petroleum Geology 30, 219-236.

Bonow, J.M. 2005: Re-exposed basement landforms in the Disko region, West Greenland - disregarded data for estimation of glacial erosion and uplift modelling. Geomorphology 72, 106-127.

Buchwald, V.F. \& Mosdal, G. 1985: Meteoritic iron, telluric iron and wrought iron in Greenland. Meddelelser om Grønland, Man and Society 9, 52 pp.

Chalmers, J A. \& Pulvertaft, T.C.R. 2001: Development of the continental margins of the Labrador Sea: a review. In: Wilson, R.C.L. et al. (eds): Non-volcanic rifting of continental margins: a comparison of evidence from land and sea. Geological Society (London) Special Publication 187, 77-105.

Chalmers, J.A., Dahl-Jensen, T., Bate, K.J. \& Whittaker, R.C. 1995: Geology and petroleum prospectivity of the region offshore southern West Greenland - a summary. Rapport Grønlands Geologiske Undersøgelse 165, 13-21.

Chalmers, J.A., Pulvertaft, T.C.R., Marcussen, C. \& Pedersen, A.K. 1999a: New insight into the structure of the Nuussuaq Basin, central West Greenland. Marine and Petroleum Geology 16, 197-224.

Chalmers, J.A., Whittaker, R.C., Skaarup, N. \& Pulvertaft, T.C.R. 1999b: Discussion on the coastal flexure of Disko (West Greenland), onshore expression of the 'oblique reflectors'. Journal of the Geological Society (London) 156, 1051-1055.
Christiansen, F.G., Dam, G. \& Pedersen, A.K. 1994: Discovery of live oil at Marraat, Nuussuaq, West Greenland: field work, drilling and logging. Rapport Grønlands Geologiske Undersøgelse 160, 57-63. Christiansen, F.G., Marcussen, C. \& Chalmers, J.A. 1995a: Geophysical and petroleum geological activities in the Nuussuaq - Svartenhuk Halvø area 1994: promising results for an onshore exploration potential. Rapport Grønlands Geologiske Undersøgelse 165, 30-39.

Christiansen, F.G., Dam, G., Larsen, L.M., Nøhr-Hansen, H., Pedersen, A.K., Boserup, J., Bojesen-Koefoed, J., Laier, T. \& Pulvertaft, T.C.R. 1995b: Stratigraphy, sedimentology and geochemistry of cores and other samples from the GANW\#1 well, Nuussuaq, West Greenland. Confidential Report prepared for grønArctic Energy Inc., Regina, Saskatchewan, Canada. Released April 1997. Danmarks og Grønlands Geologiske Undersøgelse Rapport 1997/36, $52 \mathrm{pp}$.

Christiansen, F.G., Bojesen-Koefoed, J. \& Laier, T. 1997: Organic geochemistry of sediments and gases in the borehole Umiivik-1, Svartenhuk Halvø, West Greenland. Geological Survey of Denmark and Greenland Report 1997/33, 14 pp. + figures and tables.

Clarke, D.B. 1970: Tertiary basalts of the Baffin Bay: possible primary magma from the mantle. Contributions to Mineralogy and Petrology 25, 203-224.

Clarke, D.B. \& Pedersen, A.K. 1976: Tertiary volcanic province of West Greenland. In: Escher, A. \& Watt, W.S. (eds): Geology of Greenland, 364-385. Copenhagen: Geological Survey of Greenland.

Clarke, D.B. \& Upton, B.G.J. 1971: Tertiary basalts of Baffin Island: field relations and tectonic setting. Canadian Journal of Earth Science 8, 248-258.

Dahl-Jensen, T., Larsen, L.M., Pedersen, S.A.S., Pedersen, J., Jepsen, H.F., Pedersen, G.K., Nielsen, T., Pedersen, A.K., von PlatenHallermund, F. \& Weng, W. 2004: Landslide and tsunami 21 November 2000 at Paatuut, West Greenland. Natural Hazards 31, 277-287.

Dam, G. 1996: Sedimentology of the GANE\#1 and GANE\#1A cores drilled by grønArctic Energy Inc., Eqalulik, Nuussuaq, West Greenland. Rapport Danmarks og Grønlands Geologiske Undersøgelse 1996/82, 18 pp. + app.

Dam, G. 2002: Sedimentology of magmatically and structurally controlled outburst valleys along rifted volcanic margins; examples from the Nuussuaq Basin, West Greenland. Sedimentology 49, 505-532.

Dam, G. \& Sønderholm, M. 1994: Lowstand slope channels of the Itilli succession (Maastrichtian-Lower Paleocene), Nuussuaq, West Greenland. Sedimentary Geology 94, 49-71.

Dam, G. \& Sønderholm, M. 1998: Sedimentological evolution of a fault-controlled Early Paleocene incised valley system, Nuussuaq Basin, West Greenland. In: Shanley, K.W. \& McCabe, P.J. (eds): Relative role of eustacy, climate, and tectonism in continental rocks. Society of Economic Palaeontologists and Mineralogists, Special Publication 59, 109-121. 
Dam, G., Nøhr-Hansen, H., Pedersen, G.K. \& Sønderholm, M. 2000: Sedimentary and structural evidence of a new early Campanian rift phase in the Nuussuaq Basin, West Greenland. Cretaceous Research 21, 127-154.

Dam, G., Pedersen, G.K., Sønderholm, M.S., Midtgaard, H.H., Larsen, L.M., Nøhr-Hansen, H. \& Pedersen, A.K. 2009: Lithostratigraphy of the Cretaceous-Paleocene Nuussuaq Group, Nuussuaq Basin, West Greenland. Geological Survey of Denmark and Greenland Bulletin 19, 171 pp.

Deutsch, E.R. \& Kristjansson, L.G. 1974: Palaeomagnetism of the Late Cretaceous-Tertiary volcanics from Disko Island, West Greenland. Geophysical Journal of the Royal Astronomical Society 39, 343-360.

Drever, H.I. 1953: The origin of some ultramafic rocks: a preliminary survey of the evidence for and against gravitative accumulation of olivine. Meddelelser fra Dansk Geologisk Forening 12, 227-229.

Drever, H.I. 1956: The geology of Ubekendt Ejland, West Greenland. Part II. The picritic sheets and dykes of the east coast. Meddelelser om Grønland 137(4), 41 pp.

Drever, H.I. \& Game, P.M. 1948: The geology of Ubekendt Ejland, West Greenland. Part I. A preliminary review. Meddelelser om Grønland 134(8), 1-35.

Drever, H.I. \& Johnston, R. 1957: Crystal growth of forsteritic olivine in magmas and melts. Transactions of the Royal Society of Edinburgh 63, 289-315.

Dueholm, K.S. 1976: New instruments for geological photo-interpretation and mapping. Rapport Grønlands Geologiske Undersøgelse 80, 144-148.

Dueholm, K.S. 1979: Geologic and topographic mapping from aerial photographs. Meddelelse Instituttet for Landmåling og Fotogrammetri, Technical University of Denmark 10, 9-146.

Dueholm, K.S. 1990: Multi-model stereo restitution. Photogrammetric Engineering and Remote Sensing 56, 239-242.

Dueholm, K.S. 1992: Geological photogrammetry using standard small-frame cameras. In: Dueholm, K.S. \& Pedersen, A.K. (eds): Geological analysis and mapping using multi-model photogrammetry. Rapport Grønlands Geologiske Undersøgelse 156, 7-17.

Dueholm, K.S. \& Coe, J.A. 1989: Geoprogram. Program for geologic photogrammetry. Compass 66, 59-64.

Dueholm, K.S. \& Olsen, T. 1993: Reservoir analog studies using multimodel photogrammetry: A new tool for the petroleum industry. AAPG Bulletin 77, 2023-2031.

Dueholm, K.S. \& Pedersen, A.K. 1988: Geological photogrammetry using oblique aerial photographs. Rapport Grønlands Geologiske Undersøgelse 140, 33-38.

Dueholm, K.S. \& Pedersen, A.K. 1990: Multi-model photogrammetry applied to Arctic terrains using colour slides from Greenland. Proceedings of the 3rd International Conference on Development and Commercial Utilization of Technologies in Polar Regions, Copenhagen, Denmark, 14-16 August 1990, 151-160.

Dueholm, K.S. \& Pedersen, A.K. 1992: The application of multimodel photogrammetry in geology - status and development trends. In: Dueholm, K.S. \& Pedersen, A.K. (eds): Geological analysis and mapping using multi-model photogrammetry. Rapport Grønlands Geologiske Undersøgelse 156, 69-72.
Dueholm, K.S \& Pillmore, C.L. 1989: Computer-assisted geologic photogrammetry. Photogrammetrical Engineering and Remote Sensing 55, 1191-1196.

Dueholm, K.S., Pedersen, A.K. \& Ulff-Møller, F. 1977: High precision photogrammetric methods used in geological mapping. Rapport Grønlands Geologiske Undersøgelse 81, 51-54.

Dueholm, K.S., Garde, A.A. \& Pedersen, A.K. 1993: Preparation of accurate geological and structural maps, cross-sections and block diagrams from colour slides, using multi-model photogrammetry. Journal of Structural Geology 15, 933-937.

Eldholm, O. \& Grue, K. 1994: North Atlantic volcanic margins: dimensions and production rates. Journal of Geophysical Research 99, B2, 2955-2968.

Floris, S. 1972: Scleractinian corals from the Upper Cretaceous and Lower Tertiary of Nûgssuaq, West Greenland. Bulletin Grønlands Geologiske Undersøgelse 100, 132 pp. (also Meddelelser om Grønland 196(1).

Funck, T., Gohl, K., Damm, V. \& Heyde, I. 2012: Tectonic evolution of southern Baffin Bay and Davis Strait: Results from a seismic refraction transect between Canada and Greenland. Journal of Geophysical Research 117, B04107, 24 pp. http://dx.doi. org/10.1029/2011JB009110

Garde, A.A. 1992: Close-range geological photogrammetry studies: field and laboratory procedures with examples from prograde granulite facies orthogneisses, Kerala, South India. In: Dueholm, K.S. \& Pedersen, A.K. (eds): Geological analysis and mapping using multi-model photogrammetry. Rapport Grønlands Geologiske Undersøgelse 156, 53-62.

Geoffroy, L., Gelard, J.P., Lepvrier, C. \& Olivier, P. 1998: The coastal flexure of Disko (West Greenland), onshore expression of the 'oblique reflectors'. Journal of the Geological Society (London) 155, 463-473.

Geoffroy, L., Skuce, A.G., Angelier, J., Gelard, J.P., Lepvrier, C. \& Olivier, P. 1999: Reply to Chalmers et al. 1999. Journal of the Geological Society (London) 156, 1051-1055.

Geoffroy, L., Callot, J-P., Scaillet, S., Skuce, A., Gélard, J.P., Ravilly, M., Angelier, J., Bonin, B., Cayet, C., Perrot, K. \& Lepvrier, C. 2001: Southeast Baffin volcanic margin and the North AmericanGreenland plate separation. Tectonics 20, 566-584.

Giesecke, K.L. 1821: Mineralogy of Disko Island. Transactions of the Royal Society of Edinburgh 9, 263-272.

[Giesecke, K.L.] 1910: Karl Ludwig Gieseckes Mineralogisches Reisejournal über Grönland 1806-1813. Meddelelser om Grønland 35, 1-478.

Goodrich, C.A. 1984: Phosphoran pyroxene and olivine in silicate inclusions in natural iron-carbon alloy, Disko Island, Greenland. Geochimica et Cosmochimica Acta 48, 1115-1126.

Goodrich, C.A. \& Patchett, P.J. 1991: Nd and Sr isotope chemistry of metallic iron-bearing, sediment-contaminated Tertiary volcanics from Disko Island, Greenland. Lithos 27, 13-27.

Govindaraju, K. 1994: 1994 compilation of working values and sample descriptions for 383 geostandards. Geostandards Newsletter 18, Special Issue 1, 1-158.

Gregersen, U. \& Bidstrup, T. 2008: Structures and hydrocarbon prospectivity in the northern Davis Strait area, offshore West Greenland. Petroleum Geoscience 14, 151-166. 
Gregersen, U., Hopper, J.R. \& Knutz, P.C. 2013: Basin seismic stratigraphy and aspects of prospectivity in the NE Baffin Bay, Northwest Greenland. Marine and Petroleum Geology 46, 1-18.

Hald, N. 1977a: Normally magnetized lower Tertiary lavas on Nûgssuaq, central West Greenland. Rapport Grønlands Geologiske Undersøgelse 79, 5-7.

Hald, N. 1977b: Lithostratigraphy of the Maligât and Hareøen Formations, West Greenland Basalt Group, on Hareøen and western Nûgssuaq. Rapport Grønlands Geologiske Undersøgelse 79, 9-16.

Hald, N. \& Pedersen, A.K. 1975: Lithostratigraphy of the Early Tertiary volcanic rocks of central West Greenland. Rapport Grønlands Geologiske Undersøgelse 69, 17-24.

Hart, S.R. \& Davis, K.E. 1978: Nickel partitioning between olivine and silicate melt. Earth and Planetary Science Letters 40, 203-219.

Heim, A. 1910: Über die Petrographie und Geologie der Umgebungen von Karsuarsuk, Nordseite der Halbinsel Nugsuak, W. Grönland. Meddelelser om Grønland 47(3), 173-228.

Henderson, G. 1973: The geological setting of the West Greenland basin in the Baffin Bay region. Earth Science Symposium on Offshore Eastern Canada. Geological Survey of Canada, Paper 71-23, 521-544.

Henderson, G. 1975: Stratigraphy and structure of the Tertiary volcanic rocks of the Marrait kitdlit area, Nûgssuaq. Rapport Grønlands geologiske Undersøgelse 69, 11-16.

Henderson, G., Rosenkrantz, A. \& Schiener, E.J. 1976: CretaceousTertiary sedimentary rocks of West Greenland. In: Escher, A. \& Watt, W.S. (eds): Geology of Greenland, 340-362. Copenhagen: Geological Survey of Greenland.

Henderson, G., Schiener, E.J., Risum, J.B., Croxton, C.A. \& Andersen, B.B. 1981: The West Greenland Basin. In: Kerr, J.W. (ed.): Geology of the North Atlantic Borderlands. Memoir, Canadian Society of Petroleum Geologists 7, 399-428.

Holm, P.M., Gill, R.C.O., Pedersen, A.K., Larsen, J.G., Hald, N., Nielsen, T.F.D. \& Thirlwall, M.F. 1993: The Tertiary picrites of West Greenland: contributions from 'Icelandic' and other sources. Earth and Planetary Science Letters 115, 227-244.

Holmes, A. 1918: The basaltic rocks of the Arctic region. Mineralogical Magazine 18, 180-223.

Hougaard, G., Jepsen, H.F. \& Neve, J.K. 1991: GGU's photogeological laboratory: aerial photogrammetry - a valuable geological mapping tool in Greenland. Rapport Grønlands Geologiske Undersøgelse 90, 146-150.

Iacono-Marziano, G., Gaillard, F., Scaillet, B., Polozov, A.G., Marecal, V., Pirre, M. \& Arndt, N.T. 2012: Extremely reducing conditions reached during basaltic intrusion in organic matter-bearing sediments. Earth and Planetary Science Letters 357, 319-326.

Jepsen, H.F. \& Dueholm, K.S. 1978: Computer supported geological photo-interpretation. Rapport Grønlands Geologiske Undersøgelse 90, 146-150.

Jones, A.P., Kearsley, A.T., Friend, C.R.L., Robin, E., Beard, A.,Tamura, A., Trickett, S. \& Claeys, P. 2005: Are there signs of a large Paleocene impact preserved around Disko Bay, West Greenland? Nuussuaq spherule beds origin by impact instead of volcanic eruption? In: Kenkmann, T., Hörz, F. \& Deutsch, A. (eds): Large meteorite impacts III. Geological Society of America, Special Paper 384, 281-298.
Jürgensen, T. \& Mikkelsen, N. 1974: Coccoliths from volcanic sediments (Danian) in Nûgssuaq, West Greenland. Bulletin of the Geological Society of Denmark 23, 225-230.

Kilburn, C.R.J. 2000: Lava flows and flow fields. In: Sigurdsson, H. (ed.): Encyklopedia of volcanoes, 291-305. London: Academic Press.

Koch, B.E. 1959: Contribution to the stratigraphy of the non-marine Tertiary deposits on the south coast of the Nûgssuaq peninsula, northwest Greenland, with remarks on the fossil flora. Meddelelser om Grønland 162, 100 pp.

Koch, L. 1929: Stratigraphy of Greenland. Meddelelser om Grønland 73, 205-320.

Kystol, J. \& Larsen, L.M. 1999: Analytical procedures in the Rock Geochemical Laboratory of the Geological Survey of Denmark and Greenland. Geology of Greenland Survey Bulletin 184, 59-62.

Larsen, H.C. \& Saunders, A.D. 1998: Tectonism and volcanism at the Southeast Greenland rifted margin: a record of plume impact and later continental rupture. In: Saunders, A.D., Larsen, H.C. \& Wise, S.W., Jr. (eds): Proceedings of the Ocean Drilling Program, Scientific Results 152, 503-534. College Station, TX.

Larsen, J.G. 1977: Transition from low potassium olivine tholeiites to alkali basalts on Ubekendt Ejland. Meddelelser om Grønland 200(1), 42 pp.

Larsen, J.G. \& Grocott, J. 1991: Geological Map of Greenland, 1:100 000, Svartenhuk 71 V.1 Nord. Copenhagen: Geological Survey of Denmark and Greenland.

Larsen, L.M. \& Pedersen, A.K. 1988: Investigations of Tertiary volcanic rocks along the south coast of Nûgssuaq and in eastern Disko, 1987. Rapport Grønlands geologiske Undersøgelse 140, 28-32.

Larsen, L.M. \& Pedersen, A.K. 1997: The volcanic succession in the West Greenland drill holes GANE-1 and GANK-1, with notes on trapped hydrocarbons. Rapport Danmarks og Grønlands Geologiske Undersøgelse 97/120, 10 pp.

Larsen, L.M. \& Pedersen, A.K. 2000: Processes in high-Mg, high-T magmas: Evidence from olivine, chromite and glass in Palaeogene picrites from West Greenland. Journal of Petrology 41, 10711098.

Larsen, L.M. \& Pedersen, A.K. 2009: Petrology of the Paleocene picrites and flood basalts on Disko and Nuussuaq, West Greenland. Journal of Petrology 50, 1667-1711.

Larsen, L.M., Pedersen, A.K., Sundvoll, B. \& Frei, R. 2003: Alkali picrites formed by melting of old metasomatised lithospheric mantle: Manîtdlat Member, Paleocene of West Greenland. Journal of Petrology 44, 3-38.

Larsen, L.M., Pedersen, A.K., Tegner, C., Duncan, R.A., Hald, N. \& Larsen, J.G. 2016: Age of Tertiary volcanic rocks on the West Greenland continental margin: volcanic evolution and event correlation to other parts of the North Atlantic Igneous Province. Geological Magazine 153, 487-511, http://dx.doi.org/10.1017/ S0016756815000515

Le Maitre, R.W. (ed.) 2002: Igneous Rocks, a classification and glossary of terms. 2nd edition. Recommendations of the IUGS subcommission on the systematics of igneous rocks, 236 pp. Cambridge: Cambridge University Press. 
Lightfoot, P.C., Hawkesworth, C.J., Olshevsky, K., Green, A., Doherty, W. \& Keays, R.R. 1997: Geochemistry of Tertiary tholeiites and picrites from Qeqertarssuaq (Disko Island) and Nuussuaq, West Greenland with implications for the mineral potential of comagmatic intrusions. Contributions to Mineralogy and Petrology 128, 139-163.

Lorenzen, J. 1882: Kemisk Undersøgelse af det metalliske jern fra Grønland samt nogle af de dermed følgende bjergarter. Meddelelser om Grønland 4(4), 133-172.

Margolis, S.V., Swinburne, N.H.M., Asaro, F., Swisher, C.C., McWilliams, M., Hansen, H.J. \& Pedersen, A.K. 1991: Possible impact ejecta in the Paleocene flood basalt province of West Greenland. Eos Transactions, American Geophysical Union 72, 278 only.

McDonough, W.F. \& Sun, S.-S. 1995: The composition of the Earth. Chemical Geology 120, 223-253.

Melson, W.G. \& Switzer, G. 1966: Plagioclase-spinel-graphite xenoliths in metallic iron-bearing basalts, Disko Island, Greenland. American Mineralogist 51, 664-676.

Midtgaard, H.H. 1996: Inner-shelf to lower-shoreface hummocky sandstone bodies with evidence for geostrophic influenced combined flow, Lower Cretaceous, West Greenland. Journal of Sedimentary Research 66, 343-353.

Moore, J.G. \& Fabbi, B.P. 1971: An estimate of the juvenile sulfur content of basalt. Contributions to Mineralogy and Petrology 33, $118-127$.

Moore, J.G., Clague, D.A., Holcomb, R.B., Lipman, P.W. \& Normark, W.P. 1989: Prodigious submarine landslides from the Hawaiian Ridge. Journal of Geophysical Research 94, 17465-17484.

Munck, S. 1945: On the geology and petrography of the West Greenland basalt province. Part V. Two major doleritic intrusions of the Nûgssuaq peninsula. Meddelelser om Grønland 137(5), 61 pp.

Murphy, M.A. \& Salvador, A. (eds) 1999: International Stratigraphic Guide - an abridged version. International Subcommission on Stratigraphic Classification of IUGS, International Commission on Stratigraphy. Episodes 22(4), 255-271.

Neuhoff, P.S., Rogers, K.L., Stannius, L.S., Bird, D.K. \& Pedersen, A.K. 2006: Regional very low-grade metamorphism of basaltic lavas, Disko-Nuussuaq region, West Greenland. Lithos 92, 33-54.

Nicolau, T. 1900: Untersuchungen an den eisenführenden Gesteinen der Insel Disko. Meddelelser om Grønland 24, 215-248.

Noe-Nygaard, A. 1942: On the geology and petrography of the West Greenland basalt province. Part III. The plateaubasalts of Svartenhuk peninsula. Meddelelser om Grønland 137(3), 78 pp.

Noe-Nygaard, A. 1974: Cenozoic to recent volcanism in and around the North Atlantic basin. In: Nairn, A.E.M. \& Stehli, F.G. (eds): The ocean basins and margins 2, 391-443. New York: Plenum.

Nøhr-Hansen, H., Sheldon, E. \& Dam, G. 2002: A new stratigraphic scheme for the Paleocene onshore West Greenland and its implications for the timing of the pre-volcanic evolution. In: Jolley, D.W. $\&$ Bell, B.R. (eds): The North Atlantic Igneous Province: stratigraphy, tectonics, volcanic and magmatic processes. Geological Society Special Publication (London) 197, 111-156.

Nordenskiöld, N.A.E. 1871: Redogörelse för en expedition till Grönland år 1870. Öfversigt af Kungl. Vetenskapsakademiens förhandlingar, Stockholm 27(10), 923-1082.
Oakey, G.N. \& Chalmers, J.A. 2012: A new model for the Paleogene motion of Greenland relative to North America: Plate reconstructions of the Davis Strait and Nares Strait regions between Canada and Greenland. Journal of Geophysical Research 117, B10401, 28 pp., http://dx.doi.org/ 10.1029/2011JB008942

Ottley, C.J., Pearson, D.G. \& Irvine, G.J. 2003: A routine method for the dissolution of geological samples for the analysis of REE and trace elements via ICP-MS. In: Holland, J.G. \& Tanner, S.D. (eds): Plasma source mass spectrometry: applications and emerging technologies, 221-230. Cambridge: Royal Society of Chemistry.

Pálmason, G. 1981: Crustal rifting, and related thermo-mechanical processes in the lithosphere beneath Iceland. Geologische Rundschau 70, 244-260.

Pauly, H. 1958: Igdlukúnguaq nickeliferous pyrrhotite. Meddelelser om Grønland 157(3), 169 pp. (also Bulletin of the Geological Survey of Greenland 17).

Pauly, H. 1969: White cast iron with cohenite, schreibersite and sulphides from Tertiary basalts on Disko, Greenland. Meddelelser fra Dansk Geologisk Forening 19, 8-26.

Pedersen, A.K. 1969: Preliminary notes on the Tertiary volcanic lavas of northern Disko. Rapport Grønlands Geologiske Undersøgelse 19, 21-24.

Pedersen, A.K. 1973: Report on field work along the north coast of Disko, 1971. Rapport Grønlands geologiske Undersøgelse 53, 21-27.

Pedersen, A.K. 1975: New mapping in north-western Disko 1972. Rapport Grønlands Geologiske Undersøgelse 69, 25-32.

Pedersen, A.K. 1977a: Iron-bearing and related volcanic rocks in the area between Gieseckes Dal and Hammers Dal, north-west Disko. Rapport Grønlands Geologiske Undersøgelse 81, 5-14.

Pedersen, A.K. 1977b: Tertiary volcanic geology of the Mellemfjord area, south-west Disko. Rapport Grønlands Geologiske Undersøgelse 81, 35-51.

Pedersen, A.K. 1978a: Non-stoichiometric magnesian spinels in shale xenoliths from a native iron bearing andesite at Asuk, Disko, Central West Greenland. Contributions to Mineralogy and Petrology 67, 331-340.

Pedersen, A.K. 1978b: Graphite andesite tuffs resulting from high$\mathrm{Mg}$ tholeiite and sediment interaction; Nûgssuaq, West Greenland. Bulletin Geological Society of Denmark 27, Special Issue, 117-130.

Pedersen, A.K. 1979a: A shale buchite xenolith with armalcolite and native iron in a lava from Asuk, Disko, central West Greenland. Contributions to Mineralogy and Petrology 69, 83-94.

Pedersen, A.K. 1979b: Basaltic glass with high-temperature equilibrated immiscible sulphide bodies with native iron from Disko, central West Greenland. Contributions to Mineralogy and Petrology 69, 397-407.

Pedersen, A.K. 1981: Armalcolite-bearing Fe-Ti oxide assemblages in graphite-equilibrated salic volcanic rocks with native iron from Disko, central West Greenland. Contributions to Mineralogy and Petrology 77, 307-324.

Pedersen, A.K. 1985a: Lithostratigraphy of the Tertiary Vaigat Formation on Disko, central West Greenland. Rapport Grønlands Geologiske Undersøgelse 124, 30 pp. 
Pedersen, A.K. 1985b: Reaction between picrite magma and continental crust: early Tertiary silicic basalts and magnesian andesites from Disko, West Greenland. Bulletin Grønlands Geologiske Undersøgelse 152, $126 \mathrm{pp}$.

Pedersen, A.K. \& Dueholm, K.S. 1992: New methods for the geological analysis of Tertiary volcanic formations on Nuussuaq and Disko, central West Greenland, using multi-model photogrammetry. In: Dueholm, K.S. \& Pedersen, A.K. (eds): Geological analysis and mapping using multi-model photogrammetry. Rapport Grønlands Geologiske Undersøgelse 156, 19-34.

Pedersen, A.K. \& Larsen, L.M. 2006: The Ilugissoq graphite andesite volcano, Nuussuaq, central West Greenland. Lithos 92, 1-19.

Pedersen, A.K. \& Pedersen, S. 1987: Sr isotope chemistry of contaminated Tertiary volcanic rocks from Disko, central West Greenland. Bulletin Geological Society of Denmark 36, 315-336.

Pedersen, A.K. \& Rønsbo, J.G. 1987: Oxygen deficient Ti oxides (natural magnéli phases) from mudstone xenoliths with native iron from Disko, central West Greenland. Contributions to Mineralogy and Petrology 96, 35-46.

Pedersen, A.K. \& Ulff-Møller, F. 1980: Field work in central West Disko. Rapport Grønlands Geologiske Undersøgelse 100, 51-55.

Pedersen, A.K. \& Ulff-Møller, F. 1987: Geological Map of Greenland, 1:100 000, Mellemfjord 69 V.1 Nord. Copenhagen: Geological Survey of Greenland.

Pedersen, A.K., Larsen, L.M. \& Ulff-Møller, F. 1989: Discovery of andesite tuffs with graphite from the Vaigat Formation of south central Nûgssuaq: stratigraphical implications. Rapport Grønlands Geologiske Undersøgelse 145, 42-45.

Pedersen, A.K., Larsen, L.M. \& Dueholm, K.S. 1993: Geological section along the south coast of Nuussuaq, central West Greenland. 1:20 000 coloured geological sheet. Copenhagen: Geological Survey of Greenland.

Pedersen, A.K., Larsen, L. M. \& Pedersen, G.K. 1996: Filling and plugging of a marine basin by volcanic rocks: the Tunoqqu Member of the Lower Tertiary Vaigat Formation on Nuussuaq, central West Greenland. Bulletin Grønlands Geologiske Undersøgelse 171, 5-28.

Pedersen, A.K., Ulff-Møller, F., Larsen, L.M., Pedersen, G.K. \& Dueholm, K.S. 2000: Geological Map of Greenland, 1:100 000, Uiffaq 69 V.1 Syd. Copenhagen: Geological Survey of Denmark and Greenland.

Pedersen, A.K., Larsen, L.M., Ulff-Møller, F., Pedersen, G.K. \& Dueholm, K.S. 2001: Geological Map of Greenland, 1:100 000, Pingu 69 V.2 Nord. Copenhagen: Geological Survey of Denmark and Greenland.

Pedersen, A.K., Larsen, L.M. \& Dueholm, K.S. 2002a: Geological section along the north side of the Aaffarsuaq valley and central Nuussuaq, central West Greenland. 1:20 000 coloured geological sheet. Copenhagen: Geological Survey of Denmark and Greenland.

Pedersen, A.K., Larsen, L.M., Riisager, P. \& Dueholm, K.S. 2002b: Rates of volcanic deposition, facies changes and movements in a dynamic basin: the Nuussuaq Basin, West Greenland, around the C27n-C26r transition. In: Jolley, D.W. \& Bell, B.R. (eds): The North Atlantic Igneous Province: stratigraphy, tectonics, volcanic and magmatic processes. Geological Society (London) Special Publication 197, 157-181.

Pedersen, A.K., Larsen, L.M., Pedersen, G.K., Heinesen, M.V. \& Dueholm, K.S. 2003: Geological section along the south and southwest coast of Disko, central West Greenland. 1:20 000 coloured geological sheet. Copenhagen: Geological Survey of Denmark and Greenland.

Pedersen, A.K., Larsen, L.M., Pedersen, G.K. \& Dueholm, K.S. 2005: Geological section across north central Disko from Nordfjord to Pingu, central West Greenland. 1:20 000 coloured geological sheet. Copenhagen: Geological Survey of Denmark and Greenland.

Pedersen, A.K., Larsen, L.M., Pedersen, G.K., Sønderholm, M., Midtgaard, H.H., Pulvertaft. T.C.R. \& Dueholm, K.S. 2006a: Geological section along the north coast of the Nuussuaq peninsula, central West Greenland. 1:20 000 coloured geological sheet. Copenhagen: Geological Survey of Denmark and Greenland.

Pedersen, A.K., Larsen, L.M., Pedersen, G.K. \& Dueholm, K.S. 2006b: Five slices through the Nuussuaq Basin. Geological Survey of Denmark and Greenland Bulletin 10, 53-56.

Pedersen, A.K., Pedersen, G.K., Larsen, L.M., Pulvertaft. T.C.R., Sønderholm, M. \& Dueholm, K.S. 2007a: Geological map of the Nuussuaq Basin in southern Nuussuaq, 1:100 000, special map Paatuut, with detailed sections. Copenhagen: Geological Survey of Denmark and Greenland.

Pedersen, A.K., Pedersen, G.K., Larsen, L.M., Pulvertaft. T.C.R., Sønderholm, M. \& Dueholm, K.S. 2007b: Geological map of the southeast coast of Nuussuaq between Ataata Kuua and Saqqaqdalen, central West Greenland, 1:50 000, with detailed sections. Copenhagen: Geological Survey of Denmark and Greenland.

Pedersen, A.K., Larsen, L.M., Pedersen, G.K. \& Dueholm, K.S. 2008: Geological map of the area around Sikillingi, western Nuussuaq, central West Greenland, 1:20 000. Copenhagen: Geological Survey of Denmark and Greenland.

Pedersen, A.K., Larsen, L.M. \& Pedersen, G.K. 2018: Lithostratigraphy, geology and geochemistry of the volcanic rocks of the Maligât Formation and associated intrusions on Disko and Nuussuaq, Paleocene of West Greenland. Geological Survey of Denmark and Greenland Bulletin 40, in press.

Pedersen, G.K. 1992: An application of multi-model photogrammetry in the study of a Tertiary shale unit, north-east Disko, West Greenland. In: Dueholm, K.S. \& Pedersen, A.K. (eds): Geological analysis and mapping using multi-model photogrammetry. Rapport Grønlands Geologiske Undersøgelse 165, 47-52.

Pedersen, G.K. \& Pulvertaft, T.C.R. 1992: The non-marine Cretaceous of the West Greenland Basin, onshore West Greenland. Cretaceous Research 13, 263-272.

Pedersen, G.K., Larsen, L.M., Pedersen, A.K. \& Hjortkjær, B.F. 1998: The syn-volcanic Naajaat lake, Paleocene of West Greenland. Palaeogeography, Palaeoclimatology, Palaeoecology 140, 271-287.

Pedersen, G.K., Andersen, L.A., Lundsteen, E.B., Petersen, H.I., Bojesen-Koefoed, J.A. \& Nytoft, H.P. 2006: Depositional environments, organic maturity and petroleum potential of the Cretaceous coal-bearing Atane Formation at Qullissat, Nuussuaq Basin, West Greenland. Journal of Petroleum Geology 29, 3-26. 
Piasecki, S., Larsen, L.M., Pedersen, A.K. \& Pedersen, G.K. 1992: Palynostratigraphy of the Lower Tertiary volcanics and marine clastic sediments in the southern part of the West Greenland Basin: Implications for the timing and duration of the volcanism. Rapport Grønlands Geologiske Undersøgelse 154, 13-31.

Pillmore, C.L., Dueholm, K.S., Jepsen, H.S. \& Schuch, C.H. 1981: Computer-assisted photogrammetric mapping systems for geologic studies - a progress report. Photogrammetria 36, 159-171.

Pulvertaft, T.C.R. 1979: Lower Cretaceous fluvial-deltaic sediments at Kûk, Nûgssuaq, West Greenland. Bulletin Geological Society of Denmark 28, 57-72.

Raiswell, R. \& Canfield, D.E. 2012: Iron diagenesis and the C-S-Fe geochemical indicators. Geochemical Perspectives 1(1), 19-41.

Riisager, J., Riisager, P. \& Perrin, M. 1999: Palaeodirectional and palaeointensity results of Paleocene and Eocene basalts from West Greenland. Bulletin Geological Society of Denmark 46, 69-78.

Riisager, J., Riisager, P. \& Pedersen, A.K. 2003a: The C27n-C26r geomagnetic polarity reversal recorded in the west Greenland flood basalt province: How complex is the transitional field? Journal of Geophysical Research 108 (B3) 2155, 11 pp., http://dx.doi. org/10.1029/2002JB002124

Riisager, J., Riisager, P. \& Pedersen, A.K. 2003b: Paleomagnetism of large igneous provinces: case-study from West Greenland, North Atlantic igneous province. Earth and Planetary Science Letters 214, 409-425.

Riisager, J., Riisager, P., Zhao, X., Coe, R.S. \& Pedersen, A.K. 2004: Paleointensity during a chron C26r excursion recorded in West Greenland lava flows. Journal of Geophysical Research 109, B04107, 12 pp., http://dx.doi.org/10.1029/2003JB002887

Riisager, P. \& Abrahamsen, N. 1999: Magnetostratigraphy of Paleocene basalts from the Vaigat Formation of West Greenland. Geophysical Journal International 137, 774-782.

Riisager, P. \& Abrahamsen, N. 2000: Palaeointensity of West Greenland Paleocene basalts: asymmetric intensity around the C27n-C26r transition. Physics of the Earth and Planetary Interiors 118, 53-64.

Rink, H. 1852: Om den geographiske Beskaffenhed af de danske Handelsdistrikter i Nordgrönland tilligemed en Udsigt over Nordgrönlands Geognosi. Kongelige Danske Videnskabernes Selskabs Skrifter, 5te række (3) 62 pp.

Robin, E., Swinburne, N.H.M., Froget, L., Rocchia, R. \& Gayraud, J. 1996: Characteristics and origin of the glass spherules from the Paleocene flood basalt province of western Greenland. Geochimica et Cosmochimica Acta 60, 815-830.

Rosenkrantz, A. 1970: Marine Upper Cretaceous and lowermost Tertiary deposits in West Greenland. Bulletin Geological Society of Denmark 19, 406-453.

Rosenkrantz, A. \& Pulvertaft, T.C.R. 1969: Cretaceous-Tertiary stratigraphy and tectonics in northern West Greenland. AAPG Memoir 12, 883-898.

Rosenkrantz, A., Münther, V. \& Henderson, G. 1974: Geological map of Greenland, 1:100 000, Agatdal 70 V.1 Nord. Copenhagen: Geological Survey of Greenland.

Rosenkrantz, A., Münther, V., Henderson, G., Pedersen, A.K. \& Hald, N. 1976: Geological map of Greenland, 1:100 000, Qutdligssat 70 V.1 Syd. Copenhagen: Geological Survey of Greenland.
Saunders, A.D., Fitton, J.G., Kerr, A.C., Norry, M.J. \& Kent, R.W. 1997: The North Atlantic Igneous Province. In: Mahoney, J.J. \& Coffin, M.L. (eds): Large Igneous Provinces. Geophysical Monograph 100, 45-93. Washington, D.C.: American Geophysical Union.

Schmid, R. 1981: Descriptive nomenclature and classification of pyroclastic deposits and fragments: recommendations of the IUGS Subcommission on the Systematics of Igneous Rocks. Geology 9, 41-43.

Self, S., Widdowson, M., Thordarson, T. \& Jay, A.E. 2006: Volatile fluxes during flood basalt eruptions and potential effects on the global environment: A Deccan perspective. Earth and Planetary Science Letters 248, 517-531.

Skaarup, N. 2002: Evidence for continental crust in the offshore Palaeogene volcanic province, central West Greenland. Geology of Greenland Survey Bulletin 191, 97-102.

Skaarup, N. \& Pulvertaft, T.C.R. 2007: Aspects of the structure on the coast of the West Greenland volcanic province revealed in seismic data. Bulletin Geological Society of Denmark 55, 65-80.

Solovova, I.P., Ryabchikov, I.D., Girnis, A.V., Pedersen, A. \& Hansteen, T. 2002: Reduced magmatic fluids in basalt from the island of Disko, central West Greenland. Chemical Geology 183, 365371.

Sørensen, E.V., Pedersen, A.K., García-Sellés, D. \& Strunck, M.N. 2015a: Point clouds from oblique stereo-imagery: Two outcrop case studies across scales and accessibility. European Journal of Remote Sensing 48, 593-614.

Sørensen, E.V., Bjerager, M. \& Citterio, M. 2015b: Digital models based on images taken with handheld cameras - examples on land, from the sea and on ice. Geological Survey of Denmark and Greenland Bulletin 33, 73-76.

Sørensen, E.V., Hopper, J.R., Pedersen, G.K., Nøhr-Hansen, H., Guarnieri, P., Pedersen, A.K. \& Christiansen, F.G. 2017: Inversion structures as potential petroleum exploration targets on Nuussuaq and northern Disko, onshore West Greenland. Geological Survey of Denmark and Greenland Bulletin 38, 45-48.

Starkey, N.A., Stuart, F.M., Ellam, R.M., Fitton, J.G., Basu, S. \& Larsen, L.M. 2009. Helium isotopes in early Iceland plume picrites: Constraints on the composition of high ${ }^{3} \mathrm{He} /{ }^{4} \mathrm{He}$ mantle. Earth and Planetary Science Letters 277, 91-100.

Steenstrup, K.J.V. 1875: Om de Nordenskiöldske Jærnmasser og om Forekomsten af gedigent Jærn i Basalt. Videnskabelige Meddelelser fra den naturhistoriske Forening i Kjöbenhavn for Aaret 1875, 284-306 + 2 plates.

Steenstrup, K.J.V. 1877: On the non-meteoric origin of the masses of metallic iron in the basalt of Disko in Greenland. Mineralogical Magazine 1, 143-148.

Steenstrup, K.J.V. 1882: Om Forekomsten af Nikkeljern med Widmannstättenske Figurer i Basalten i Nord-Grønland. Meddelelser om Grønland 4(3), 113-131.

Steenstrup, K.J.V. 1883: Bidrag til Kjendskab til de geognostiske og geographiske Forhold i en Del af Nord-Grønland. Meddelelser om Grønland 4(5), 173-242.

Steenstrup, K.J.V. 1884: On the existence of nickel-iron with Widmannstätten's Figures in the basalt of north Greenland. Mineralogical Magazine 6, 1-13. 
Steenstrup, K.J.V. 1900: Beretning om en Undersøgelsesrejse til Øen Disko i Sommeren 1898. Meddelelser om Grønland 24, 249-306.

Storey, M., Duncan, R.A., Pedersen, A.K., Larsen, L.M. \& Larsen, H.C. 1998: ${ }^{40} \mathrm{Ar} /{ }^{39} \mathrm{Ar}$ geochronology of the West Greenland Tertiary volcanic province. Earth and Planetary Science Letters 160, 569-586.

Törnebohm, A.E. 1878: Über die eisenführenden Gesteine von Ovifaq und Assuk in Grönland. Bihang till Kungliga Vetenskapsakademiens Handlingar 4(10), 1-22.

Toulmin, P. \& Barton, P.B. 1964: A thermodynamic study of pyrite and pyrrhotite. Geochimica et Cosmochimica Acta 28, 641-671.

Turner, S.P., Platt, J.P., George, R.M.M., Kelly, S.P., Pearson, D.G. \& Nowell, G.M. 1999: Magmatism associated with orogenic collapse of the Beltic-Alboran domain, SE Spain. Journal of Petrology 40 , 1011-1036.

Ulff-Møller, F. 1977: Native iron bearing intrusions of the Hammers Dal Complex, north-west Disko. Rapport Grønlands Geologiske Undersøgelse 81, 15-33.

Ulff-Møller, F. 1985: Solidification history of the Kitdlit lens: immiscible metal and sulphide liquids from a basaltic dyke on Disko, central West Greenland. Journal of Petrology 26, 64-91.

Ulff-Møller, F. 1989: Exsolution of metallic Pb liquid in a magmatic sulfide - metal lens from Disko, central West Greenland. Neues Jahrbuch für Mineralogie Abhandlungen 160, 193-206.

Ulff-Møller, F. 1990: Formation of native iron in sediment-contaminated magma. I. A case study of the Hanekammen Complex on Disko Island, West Greenland. Geochimica et Cosmochimica Acta 54, 57-70.

Ulff-Møller, F. 1991: Magmatic platinum-nickel occurrences in the Tertiary West Greenland Basalt Province: prospecting by Greenex A/S in 1985-1988. Open File Series Grønlands Geologiske Undersøgelse 91/1, $37 \mathrm{pp}$.

Upton, B.G.J. 1988: History of Tertiary igneous activity in the N Atlantic borderlands. In: Morton, A. C. \& Parson, L.M. (eds): Early Tertiary volcanism and the opening of the NE Atlantic. Geological Society (London) Special Publication 39, 429-453.

Vaasjoki, O. 1965: On basalt rocks with native iron in Disko, West Greenland. Comptes Rendus de la Société géologique de Finlande 37, 85-97.

Vandenberghe, N., Hilgen, F.J. \& Speijer, R.P. 2012: The Paleogene period. In: Gradstein, F.M. et al. (eds): The geologic time scale 2012, 855-921. Amsterdam: Elsevier, http://dx.doi.org/ 10.1016/ B978-0-444-59425-9.00028-7

White, J.D.L. \& Houghton, B.F. 2006: Primary volcaniclastic rocks. Geology 34, 677-680.

White, R. \& Mckenzie, D. 1989: Magmatism at rift zones: The generation of volcanic continental margins and flood basalts. Journal of Geophysical Research 94(B6), 7685-7729.

\section{List of geological map sheets and sections covering the volcanic rocks of Disko and Nuussuaq}

Outlines of maps and traces of sections are shown in Fig. 3. All except Pulvertaft (1987) are also included in the reference list because they are referred to in the main text.

Pedersen, A.K. \& Ulff-Møller, F. 1987: Geological Map of Greenland, 1:100 000, Mellemfjord 69 V.1 Nord. Copenhagen: Geological Survey of Greenland.

Pedersen, A.K., Larsen, L.M. \& Dueholm, K.S. 1993: Geological section along the south coast of Nuussuaq, central West Greenland. 1:20 000 coloured geological sheet. Copenhagen: Geological Survey of Greenland.

Pedersen, A.K., Ulff-Møller, F., Larsen, L.M., Pedersen, G.K. \& Dueholm, K.S. 2000: Geological Map of Greenland, 1:100 000, Uiffaq 69 V.1 Syd. Copenhagen: Geological Survey of Denmark and Greenland.

Pedersen, A.K., Larsen, L.M., Ulff-Møller, F., Pedersen, G.K. \& Dueholm, K.S. 2001: Geological Map of Greenland, 1:100 000, Pingu 69 V.2 Nord. Copenhagen: Geological Survey of Denmark and Greenland.

Pedersen, A.K., Larsen, L.M. \& Dueholm, K.S. 2002: Geological section along the north side of the Aaffarsuaq valley and central Nuussuaq, central West Greenland. 1:20 000 coloured geological sheet. Copenhagen: Geological Survey of Denmark and Greenland.

Pedersen, A.K., Larsen, L.M., Pedersen, G.K., Heinesen, M.V. \& Dueholm, K.S. 2003: Geological section along the south and southwest coast of Disko, central West Greenland. 1:20 000 coloured geological sheet. Copenhagen: Geological Survey of Denmark and Greenland.

Pedersen, A.K., Larsen, L.M., Pedersen, G.K. \& Dueholm, K.S. 2005: Geological section across north central Disko from Nordfjord to Pingu, central West Greenland. 1:20 000 coloured geological sheet. Copenhagen: Geological Survey of Denmark and Greenland.

Pedersen, A.K., Larsen, L.M., Pedersen, G.K., Sønderholm, M., Midtgaard, H.H., Pulvertaft. T.C.R. \& Dueholm, K.S. 2006: Geological section along the north coast of the Nuussuaq peninsula, central West Greenland. 1:20 000 coloured geological sheet. Copenhagen: Geological Survey of Denmark and Greenland.

Pedersen, A.K., Pedersen, G.K., Larsen, L.M., Pulvertaft. T.C.R., Sønderholm, M., \& Dueholm, K.S. 2007: Geological map of the Nuussuaq Basin in southern Nuussuaq, 1:100 000, special map Paatuut, with detailed sections. Copenhagen: Geological Survey of Denmark and Greenland.

Pedersen, A.K., Pedersen, G.K., Larsen, L.M., Pulvertaft. T.C.R., Sønderholm, M., \& Dueholm, K.S. 2007: Geological map of the southeast coast of Nuussuaq between Ataata Kuua and Saqqaqdalen, central West Greenland, 1:50 000, with detailed sections. Copenhagen: Geological Survey of Denmark and Greenland.

Pedersen, A.K., Larsen, L.M., Pedersen, G.K. \& Dueholm, K.S. 2008: Geological map of the area around Sikillingi, western Nuussuaq, central West Greenland, 1:20 000. Copenhagen: Geological Survey of Denmark and Greenland. 
Pulvertaft, T.C.R. 1987: Geological Map of Greenland, 1:100 000, Agpat 70 V.2 Nord. Copenhagen: Geological Survey of Greenland. Rosenkrantz, A., Münther, V. \& Henderson, G. 1974: Geological map of Greenland, 1:100 000, Agatdal 70 V.1 Nord. Copenhagen: Geological Survey of Greenland.

Rosenkrantz, A., Münther, V., Henderson, G., Pedersen, A.K. \& Hald, N. 1976: Geological map of Greenland, 1:100 000, Qutdligssat 70 V.1 Syd. Copenhagen: Geological Survey of Greenland. 


\section{Appendix: Place names}

The place names mentioned in the text and listed below are shown on the maps in Figs 1 and 2 (regional names) and Figs 4, 5 and 18 (local names and localities).

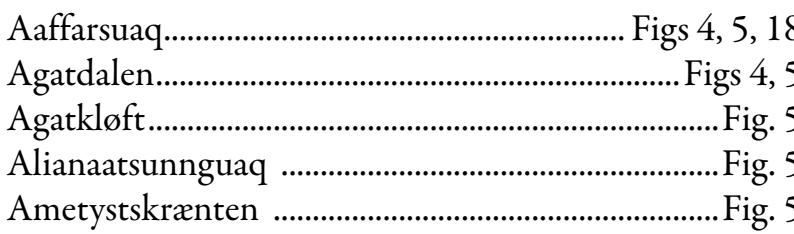

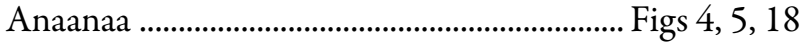

Anariartorfik..........................................................Figs 5, 18

Arnold Heim Dal ............................................................. Fig. 5

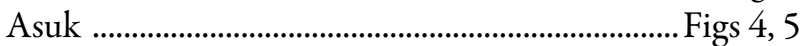

Asuup Innartaa ............................................................... Fig. 5

Asuutaa ............................................................................... Fig. 5

Ataata Kuua ……………………………………....... Figs 4, 5

Avataasalissuaq ……………………………………....Fig. 5

Cape Dyer......................................................................... Fig. 1

Davis Strait ....................................................................... Fig. 1

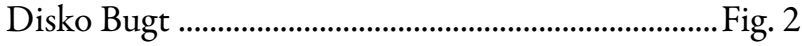

Eqalulik .......................................................................... Fig. 18

Eqi ……...................................................................... Fig. 5

Gamle Qullissat ................................................................ 5

Gassøen ............................................................................ 18

Giesecke Monument ....................................................... Fig. 5

Hammer Dal ............................................................. Figs 4, 5

Harald Moltke Dal ........................................................ Fig. 5

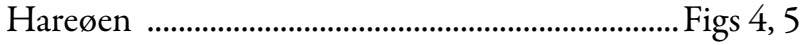

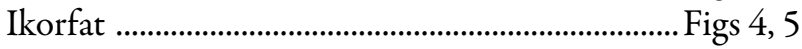

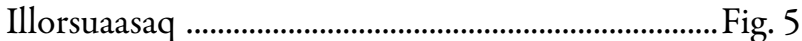

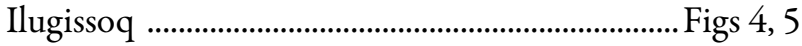

Innerit .............................................................................. Fig. 2

Ippiarsuk ....................................................................Fig. 18

Itilli.......................................................................... Figs 5, 18

Jens Vahl Dal .................................................................... Fig. 5

Kamaffiaraq......................................................................... Fig. 5

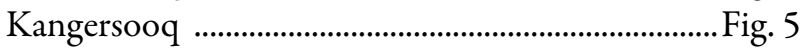

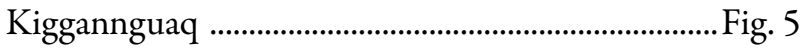

Killerpaat Qaqqarsuat ..................................................Fig. 5

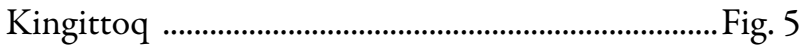

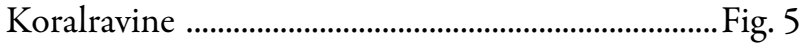

Kussinikassak ................................................................... Fig. 5

Kuugannguaq …………………………………..... Figs 4, 5

Kuugannguup Innartaa .................................................. Fig. 5

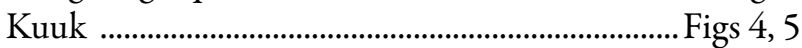

Maniillat
Marraat Killiit

Figs 4, 5, 18

Mellemfjeld

Figs 4, 5

Mellemfjord

Fig. 4

Naajannguit .

Figs 4, 5

Niaqornaarsuk ……………………………………........ 18

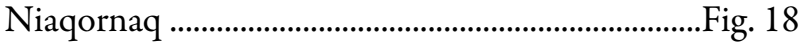

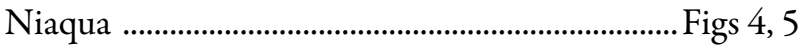

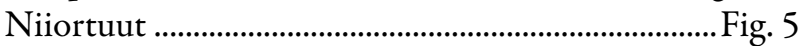

Norddalen ................................................................. Figs 4, 5

Nordfjord ................................................................ Figs 4, 5

Nunavik .................................................................... Figs 4, 5

Nuungarut .....................................................................Fig. 5

Nuuk Killeq ............................................................... Figs 4, 5

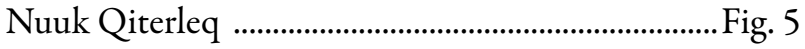

Nuusap Qaqqarsua ......................................... Figs 4, 5, 18

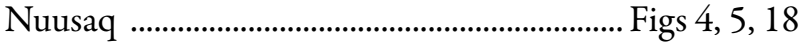

Orlingasoq ……………………………………...... Figs 4, 5

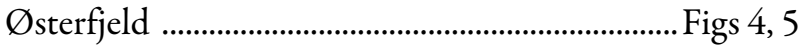

Paatuut ............................................................... Figs 4, 5

Paatuut Puiattua ………………………………….......... Fig. 5

Pingunnguaq .................................................................... 18

Pingunnguup Tunulikassaa .......................................Fig. 18

Point $860 \mathrm{~m}$..................................................................... Fig. 5

Point $1100 \mathrm{~m}$.................................................................Fig. 5

Point $1589 \mathrm{~m}$.................................................................Fig. 5

point $1640 \mathrm{~m}$............................................................... Fig. 5

Point $1722 \mathrm{~m}$.............................................................Fig. 5

Point $1756 \mathrm{~m}$................................................................... Fig. 5

Point $1908 \mathrm{~m}$...................................................................... 5

Puugutalissuaq ………………………….........................Fig. 5

Pyramidedal .................................................................... Fig. 5

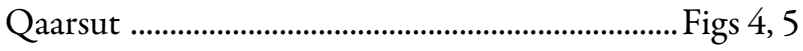

Qaarsut Kussinersuat .................................................... Fig. 5

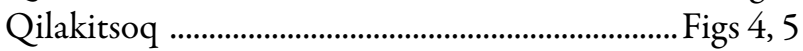

Qorlortorsuaq ………………………..........................Fig. 5

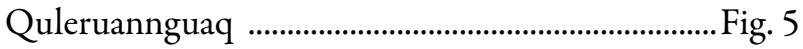

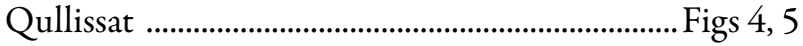

Qunnileeraasakkassak ...............................................Fig. 18

Qunnileeraq …………………………………........

Qunnilik ............................................................... Figs 4, 5

Ravn Kløft ...................................................................... Fig. 5

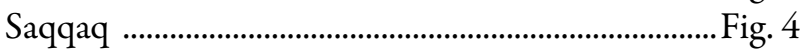


Saviaqqat Figs 4, 5

Serfarsuit Figs 4, 5

Sermillit Puiattuat

Fig. 173

Sikillingi

Figs 4, 5, 18

Siorarsuit Figs 5, 18

Snekuplen ... Fig. 5

Sorluut Figs 4, 5

Steenstrup Dal Fig. 5

Stordal Figs 4, 5

Svartenhuk Halvø

Fig. 2

Timiusartorfik Fig. 5

Tufdalen Fig. 18

Tunoqqu Figs 4, 5

Tunorsuaq Figs 4, 5

Tupaasat .. Fig. 5

Turritellakløft Fig. 5

Ubekendt Ejland ..Fig. 2

Ukallit ... Fig. 5 Uppalluk see Giesecke Monument Vaigat Vesterfjeld .Figs 2, 4, 5 ... Figs 4, 5 


\section{De Nationale Geologiske Undersøgelser for Danmark og Grønland (GEUS) Geological Survey of Denmark and Greenland Øster Voldgade 10, DK-1350 Copenhagen K}

Denmark

The series Geological Survey of Denmark and Greenland Bulletin started in 2003 and replaced the two former bulletin series of the Survey, viz. Geology of Greenland Survey Bulletin and Geology of Denmark Survey Bulletin. The twenty-one volumes published since 1997 in those two series are listed on the following pages. The present series, together with Geological Survey of Denmark and Greenland Map Series, now form the peer-reviewed scientific series of the Survey. The below listed bulletins can be downloaded (open access) from www.geus.dk/UK/publications/pages/default.aspx.

\section{Geological Survey of Denmark and Greenland Bulletin}

1 The Jurassic of Denmark and Greenland, 948 pp. (28 articles), 2003. Edited by J.R. Ineson \& F. Surlyk.

500.00

2 Fish otoliths from the Paleocene of Denmark, 94 pp., 2003. By W. Schwarzhans.

100.00

3 Late Quaternary environmental changes recorded in the Danish marine molluscan faunas, 268 pp., 2004. By K.S. Petersen.

200.00

4 Review of Survey activities 2003, 100 pp. (24 articles), 2004. Edited by M. Sønderholm \& A.K. Higgins.

180.00

5 The Jurassic of North-East Greenland, 112 pp. (7 articles), 2004. Edited by L. Stemmerik \& S. Stouge.

160.00

6 East Greenland Caledonides: stratigraphy, structure and geochronology, 93 pp. (6 articles), 2004.

Edited by A.K. Higgins \& F. Kalsbeek.

160.00

7 Review of Survey activities 2004, 80 pp. (19 articles), 2005. Edited by M. Sønderholm \& A.K. Higgins.

180.00

8 Structural analysis of the Rubjerg Knude Glaciotectonic Complex, Vendsyssel, northern Denmark, 192 pp., 2005. By S.A.S. Pedersen.

300.00

9 Scientific results from the deepened Lopra-1 borehole, Faroe Islands, 156 pp. (11 articles), 2006.

Edited by J.A. Chalmers \& R. Waagstein.

240.00

10 Review of Survey activities 2005, 68 pp. (15 articles), 2006. Edited by M. Sønderholm \& A.K. Higgins.

180.00

11 Precambrian crustal evolution and Cretaceous-Palaeogene faulting in West Greenland, 204 pp.

(12 articles), 2006. Edited by A.A. Garde \& F. Kalsbeek.

240.00

12 Lithostratigraphy of the Palaeogene - Lower Neogene succession of the Danish North Sea, 77 pp., 2007.

By P. Schiøler, J. Andsbjerg, O.R. Clausen, G. Dam, K. Dybkjær, L. Hamberg, C. Heilmann-Clausen,

E.P. Johannessen, L.E. Kristensen, I. Prince \& J.A. Rasmussen.

240.00

13 Review of Survey activities 2006, 76 pp. (17 articles), 2007. Edited by M. Sønderholm \& A.K. Higgins.

180.00

14 Quaternary glaciation history and glaciology of Jakobshavn Isbræ and the Disko Bugt region,

West Greenland: a review, 78 pp., 2007. By A. Weidick \& O. Bennike.

200.00

15 Review of Survey activities 2007, 96 pp. (22 articles), 2008. Edited by O. Bennike \& A.K. Higgins. 200.00

16 Evaluation of the quality, thermal maturity and distribution of potential source rocks in the Danish part of the Norwegian-

Danish Basin, 66 pp., 2008. By H.I. Petersen, L.H. Nielsen, J.A. Bojesen-Koefoed, A. Mathiesen, L. Kristensen \& F. Dalhoff. 200.00

17 Review of Survey activities 2008, 84 pp. (19 articles), 2009. Edited by O. Bennike, A.A. Garde \& W.S. Watt.

200.00

18 Greenland from Archaean to Quaternary. Descriptive text to the 1995 Geological map of Greenland, 1:2 500 000. 2nd edition, 126 pp., 2009. By N. Henriksen, A.K. Higgins, F. Kalsbeek \& T.C.R. Pulvertaft.

19 Lithostratigraphy of the Cretaceous-Paleocene Nuussuaq Group, Nuussuaq Basin, West Greenland, 171 pp., 2009.

By G. Dam, G.K. Pedersen, M. Sønderholm, H.H. Midtgaard, L.M. Larsen, H. Nøhr-Hansen \& A.K. Pedersen.

20 Review of Survey activities 2009, 106 pp. (23 articles), 2010. Edited by O. Bennike, A.A. Garde \& W.S. Watt.

21 Exploration history and place names of northern East Greenland, 368 pp., 2010. By A.K. Higgins.

22 Lithostratigraphy of the Upper Oligocene - Miocene succession of Denmark, 92 pp., 2010.

By E.S. Rasmussen,K. Dybkjær \& S. Piasecki.

23 Review of Survey activities 2010, 84 pp. (19 articles), 2011. Edited by O. Bennike, A.A. Garde \& W.S. Watt. 
24 The East Greenland rifted volcanic margin, 96 pp., 2011. By C.K. Brooks.

25 Upper Cretaceous chalk facies and depositional history recorded in the Mona- 1 core, Mona Ridge,

Danish North Sea. 2011. By K. Anderskouv \& F. Surlyk.

200.00

26 Review of Survey activities 2011, 88 pp. (21 articles), 2012. Edited by O. Bennike, A.A. Garde \& W.S. Watt.

200.00

27 Neoglacial and historical glacier changes around Kangersuneq fjord in southern West Greenland, 68 pp., 2012.

By A. Weidick, O. Bennike, M. Citterio \& N. Nørgaard-Pedersen.

200.00

28 Review of Survey activities 2012,76 pp. (17 articles), 2013. Edited by O. Bennike, A.A. Garde \& W.S. Watt.

200.00

29 Tectono-magmatic evolution of the younger Gardar southern rift, South Greenland, 124 pp., 2013. By B.G.J. Upton.

240.00

30 Stratigraphic landscape analysis, thermochronology and the episodic development of elevated, passive continental margins, 150 pp., 2014. By Paul F. Green, Karna Lidmar-Bergström, Peter Japsen, Johan M. Bonow and James A. Chalmers.

250.00

31 Review of Survey activities 2013, 98 pp., 2014. Edited by O. Bennike, A.A. Garde \& W.S. Watt

200.00

32 A catalogue of Danian gastropods from the Baunekule facies, Faxe Formation, Denmark, 117 pp., 2014

By B.W. Lauridsen \& K.I. Schnetler.

240.00

33 Review of Survey activities 2014, 88 pp. (20 articles), 2015. Edited by O. Bennike, A.A. Garde \& W.S. Watt.

200.00

34 The ammonites of the Middle Jurassic Cranocephalites beds of East Greenland, 145 pp., 2015.

By J.H. Callomon, P. Alsen \& F. Surlyk.

250.00

35 Review of Survey activities 2015, 106 pp. (24 articles), 2015. Edited by A.A Garde, O. Bennike, K. Thrane \& W.S. Watt.

200.00

36 Cretaceous and Cenozoic dinoflagellate cysts and other palynomorphs from the western and eastern margins of

the Labrador-Baffin Seaway, 143 pp., 2016. By R.A. Fensome, H. Nøhr-Hansen \& G.L. Williams.

250.00

37 Biostratigraphic correlation of the western and eastern margins of the Labrador-Baffin Seaway and implications for the regional geology, 75 pp., 2016. By H. Nøhr-Hansen, G.L. Williams \& R.A. Fensome.

200.00

38 Review of Survey activities 2016,76 pp. (18 articles), 2017. Edited by A.A Garde, and O. Bennike.

200.00

39 Lithostratigraphy, geology and geochemistry of the volcanic rocks of the Vaigat Formation on Disko and Nuussuaq, Paleocene of West Greenland, 244 pp., 2017. By Asger Ken Pedersen, Lotte Melchior Larsen and Gunver Krarup Pedersen

250.00

\section{Geological Survey of Denmark and Greenland Map Series}

1 Explanatory notes to the Geological map of Greenland, 1:500 000, Humboldt Gletscher, Sheet 6,

48 pp. + map, 2004. By P.R. Dawes.

280.00

2 Explanatory notes to the Geological map of Greenland, 1:500 000, Thule, Sheet 5 (1991),

97 pp. + map, 2006. By P.R. Dawes.

300.00

3 Explanatory notes to the Geological map of Greenland, 1:100 000, Ussuit 67 V.2 Nord,

40 pp. + map, 2007. By J.A.M. van Gool \& M. Marker.

280.00

4 Descriptive text to the Geological map of Greenland, 1:500 000, Dove Bugt, Sheet 10,

32 pp. + map, 2009. By N. Henriksen \& A.K. Higgins.

240.00

5 Descriptive text to the Geological map of Greenland, 1:100 000, Kangaatsiaq 68 V.1 Syd

and Ikamiut 68 V.1 Nord, 41 pp. +2 maps, 2010. By A.A. Garde \& J.A. Hollis.

280.00

\section{Geology of Greenland Survey Bulletin (173-191; discontinued)}

173 Cambrian shelf stratigraphy of North Greenland, 120 pp., 1997. By J.R. Ineson \& J.S. Peel

174 The Proterozoic Thule Supergroup, Greenland and Canada: history, lithostratigraphy and development, 150 pp., 1997. By P.R. Dawes

175 Stratigraphy of the Neill Klinter Group; a Lower - lower Middle Jurassic tidal embayment succession, Jameson Land, East Greenland, 80 pp., 1998. By G. Dam \& F. Surlyk.

177 Accretion and evolution of an Archaean high-grade grey gneiss - amphibolite complex: the Fiskefjord area, southern West Greenland, 115 pp., 1997. By A.A. Garde. 
178 Lithostratigraphy, sedimentary evolution and sequence stratigraphy of the Upper Proterozoic Lyell Land Group (Eleonore Bay Supergroup) of East and North-East Greenland, 60 pp., 1997. By H. Tirsgaard \& M. Sønderholm.

179 The Citronen Fjord massive sulphide deposit, Peary Land, North Greenland: discovery, stratigraphy, mineralization and structural setting, 40 pp., 1998. By F.W. van der Stijl \& G.Z. Mosher.

180 Review of Greenland activities 1997, 176 pp. (26 articles), 1998. Edited by A.K. Higgins \& W.S. Watt.

181 Precambrian geology of the Disko Bugt region, West Greenland, 179 pp. (15 articles), 1999. Edited by F. Kalsbeek.

182 Vertebrate remains from Upper Silurian - Lower Devonian beds of Hall Land, North Greenland,

80 pp., 1999. By H. Blom.

183 Review of Greenland activities 1998, 81 pp. (10 articles), 1999. Edited by A.K. Higgins \& W.S. Watt.

184 Collected research papers: palaeontology, geochronology, geochemistry, 62 pp. (6 articles), 1999.

Edited by W. Stuart Watt.

185 Greenland from Archaean to Quaternary. Descriptive text to the Geological map of Greenland, 1:2 500 000, 93 pp., 2000. By N. Henriksen, A.K. Higgins, F. Kalsbeek \& T.C.R. Pulvertaft.

186 Review of Greenland activities 1999, 105 pp. (13 articles), 2000. Edited by P.R. Dawes \& A.K. Higgins.

187 Palynology and deposition in the Wandel Sea Basin, eastern North Greenland, 101 pp. (6 articles), 2000. Edited by L. Stemmerik.

188 The structure of the Cretaceous-Palaeogene sedimentary-volcanic area of Svartenhuk Halvø, central West Greenland, 40 pp., 2000. By J. Gutzon Larsen \& T.C.R. Pulvertaft.

189 Review of Greenland activities 2000, 131 pp. (17 articles), 2001. Edited by A.K. Higgins \& K. Secher.

190 The Ilímaussaq alkaline complex, South Greenland: status of mineralogical research with new results, 167 pp. (19 articles), 2001. Edited by H. Sørensen.

\section{Geology of Denmark Survey Bulletin (36-37; discontinued)}

36 Petroleum potential and depositional environments of Middle Jurassic coals and non-marine deposits, Danish Central Graben, with special reference to the Søgne Basin, 78 pp., 1998.

By H.I. Petersen, J. Andsbjerg, J.A. Bojesen-Koefoed, H.P. Nytoft \& P. Rosenberg.

37 The Selandian (Paleocene) mollusc fauna from Copenhagen, Denmark: the Poul Harder 1920 collection,

Prices are in Danish kroner exclusive of local taxes, postage and handling

Note that information on the publications of the former Geological Survey of Denmark and the former Geological Survey of Greenland (amalgamated in 1995 to form the present Geological Survey of Denmark and Greenland) can be found on www.geus.dk 
Danish Ministry

of Energy, Utilities and and Climate

GEUS is a research and advisory institution in the

Danish Ministry of Energy, Utilities and Climate
GEOCENTER

Geocenter Denmark is a formalised cooperation between Geological Survey of Denmark and Greenland (GEUS) Department of Geoscience at Aarhus University and the Geological Museum and Department of Geosciences and Natural Resource Management at the University of Copenhagen.

Lithostratigraphy, geology and geochemistry of the volcanic rocks of the Vaigat Formation on Disko and Nuussuaq, Paleocene of West Greenland

The upper Cretaceous-Tertiary Nuussuaq Basin in West Greenland contains a many kilometres thick succession of siliciclastic sediments and overlying volcanic rocks. The first studies in the early 19th century centred on the coal and fossils in the sediments and the minerals in the volcanic rocks, including famous occurrences of native iron. The present focus of interest includes modern stratigraphic and volcanological studies to decipher the basin evolution and support hydrocarbon exploration.

The Nuussuaq Basin is the only onshore analogue for the sedimentary and volcanic basins offshore West Greenland primarily known from seismic data. The excellently exposed volcanic rocks, in particular giant foreset-bedded hyaloclastite deposits, are of a size comparable to seismic sections and therefore directly applicable to their interpretation.

This bulletin presents the lithostratigraphy, geology and geochemistry of the Paleocene volcanic rocks of the Vaigat Formation on Disko and the major part of the Nuussuaq peninsula. The Vaigat Formation in this area is up to $1600 \mathrm{~m}$ thick and composed mainly of olivine-rich picrites, with ten formally defined members and 20 informal units. The comprehensive descriptions and analyses of each member and unit represent a synthesis of many years of work and are intended to serve as a guide for future studies, including exploration for mineral deposits associated with some units of the formation.

A companion bulletin on the volcanic rocks of the Maligât Formation overlying the Vaigat Formation is scheduled for publication in 2018.

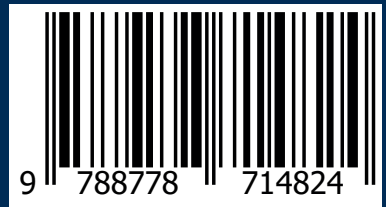

